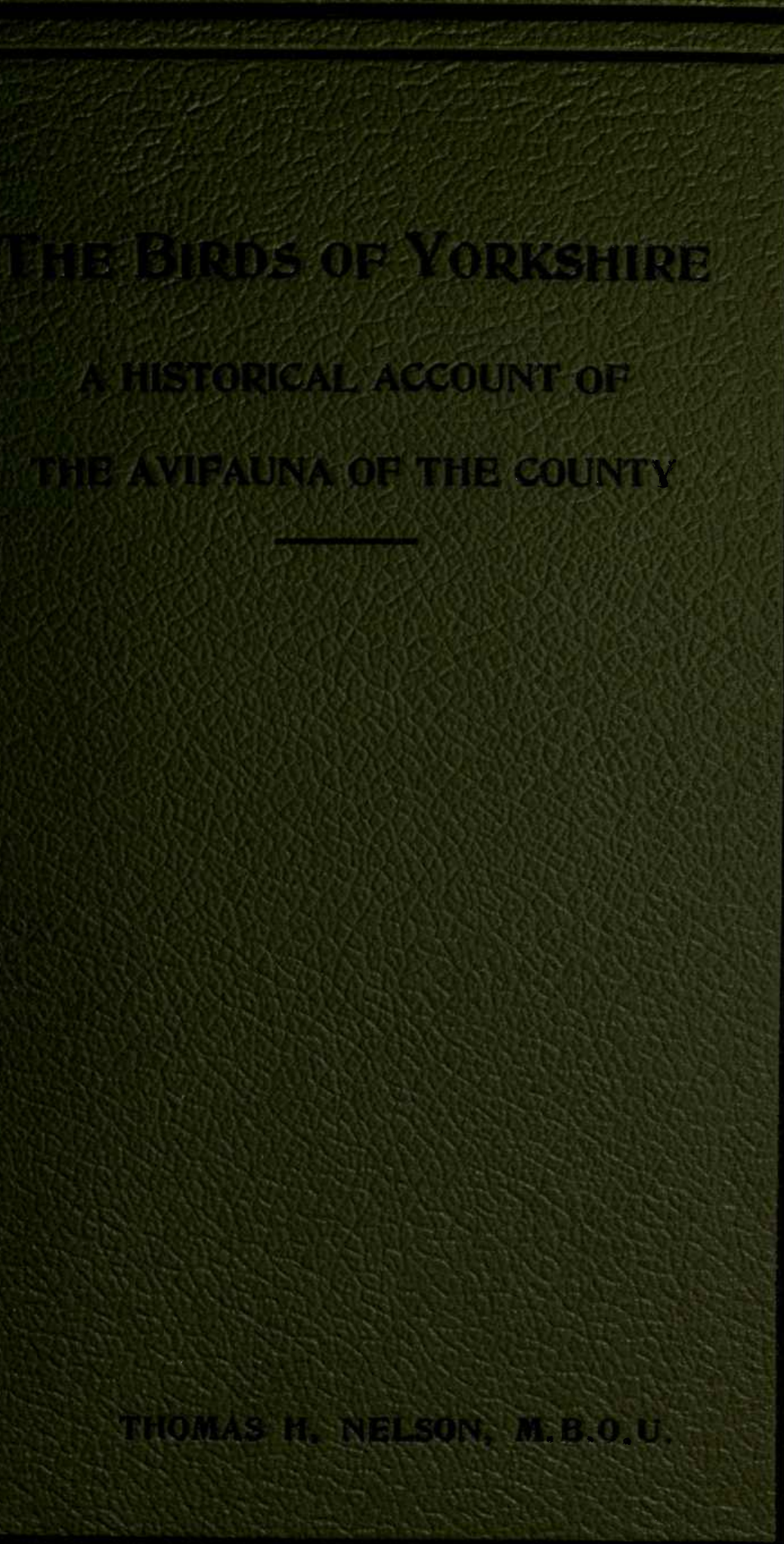


$2 \mathrm{~m}$
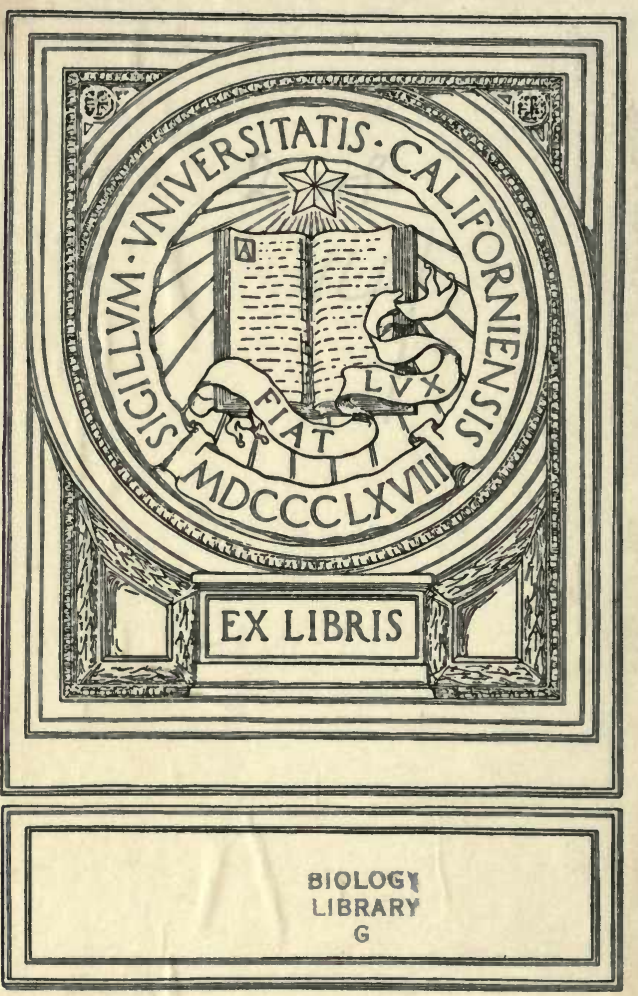
THE BIRDS OF YORKSHIRE 



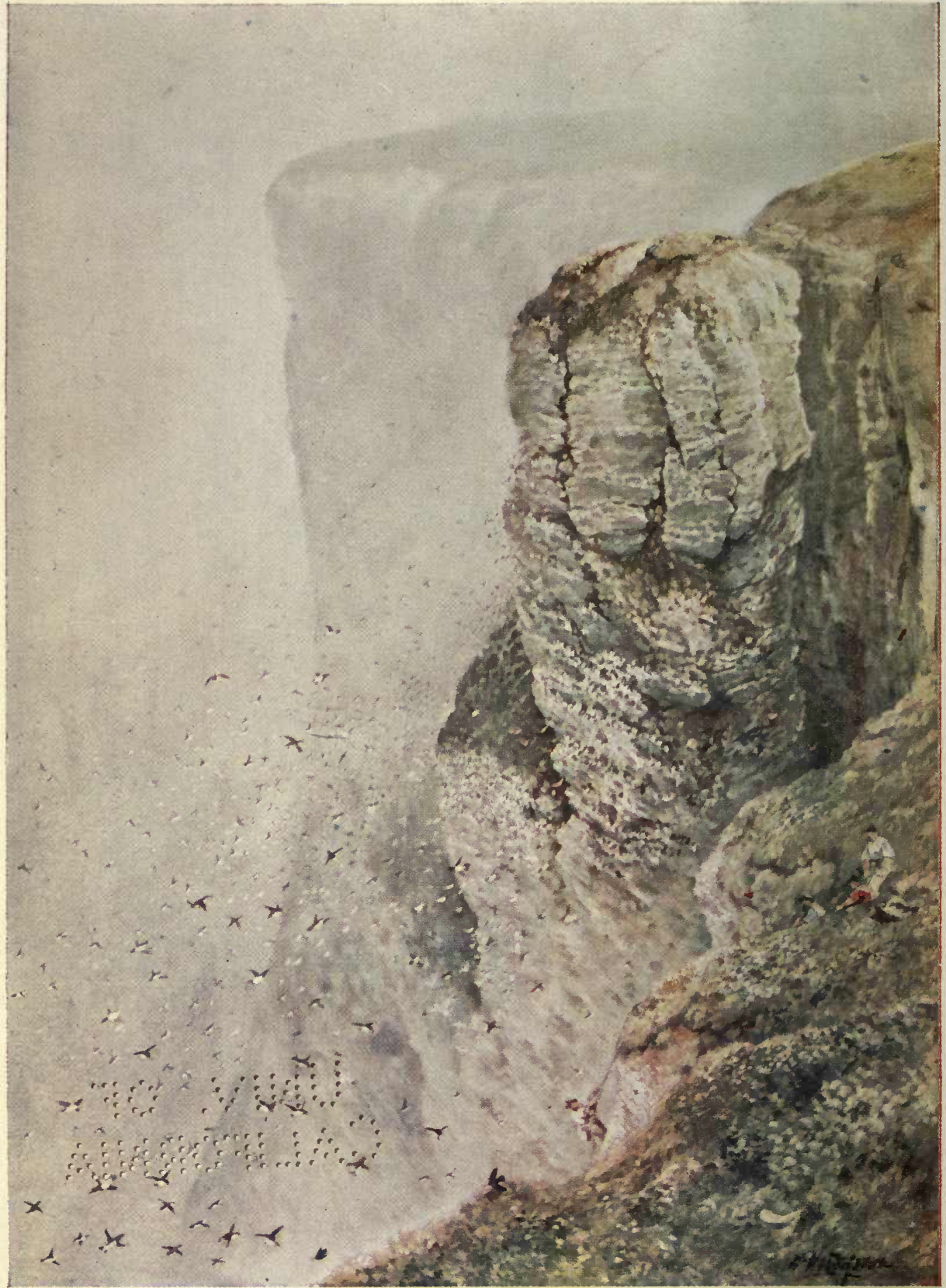

From an Oil Painting by $\mathrm{W}$. Woodhouse.

A Misty Morning on the Bempton Cliffs, at "Hateley Shoot."

Frontispiece, Vol. I. 


\section{THE BIRDS \\ OF YORKSHIRE.}

Being a Historical Account of the Avi-Fauna of the County,

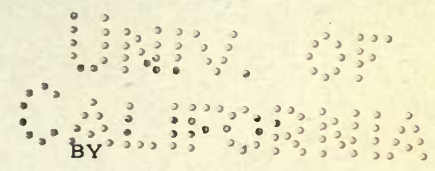

T. H. NELSON. M.B.O.U.

WITH THE CO-OPERATION OF

W. Eagle Clarke. F.R.S. E., F.l S.

AN D

F. BOYES.

IN TWO VOLUMES.

VOL. I.

LONDON :

A. BROWN \& SONS, LIMITED,

5 Farringdon Avenue, E.C.

* ANit hull and york.
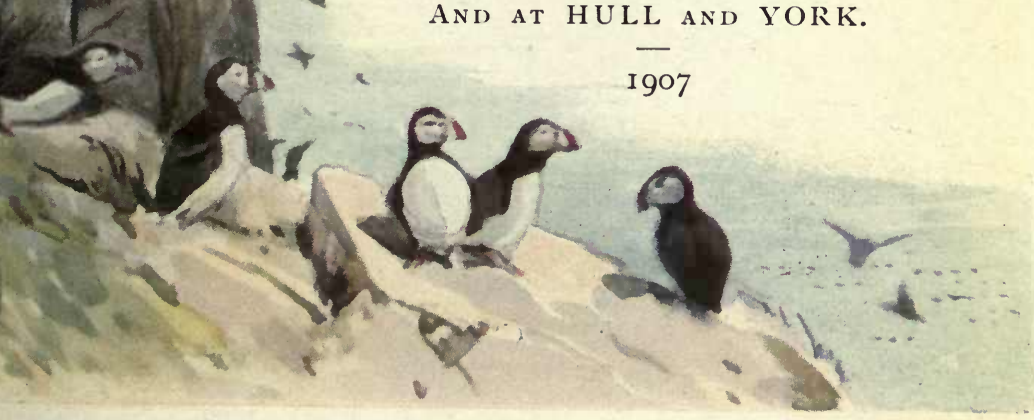
$\because \because \because: \quad \therefore \because \vdots \because: \vdots \vdots:$

$\therefore: \because \because \because \because \because \because: \vdots \therefore: \therefore \circ:$

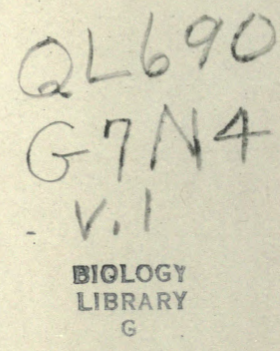

BIOLOGY

LIBRARY 


\section{YORKSHIRE NATURALISTS' UNION EDITORIAL.}

IN the present work the Yorkshire Naturalists' Union has completed still another county monograph, the "Birds of Yorkshire." In the first part of the Union's Transactions, published so long ago as 1877, Mr. W. Eagle Clarke, the Secretary of the Vertebrate Section, gave the first part of a monograph of the avifauna of the county. Subsequent Transactions contained further instalments. It was found, however, that to publish the work piecemeal would be very unsatisfactory, and eventually it was decided to commence de novo. Mr. Eagle Clarke having left the county, Mr. T. H. Nelson kindly undertook the task of preparing the work for the press, and the Union is indebted to him for the way in which he has done the work. For this purpose the whole of the MS. and lists in the possession of Messrs. Eagle Clarke and Roebuck were handed over to him, and Mr. F. Boyes has also greatly assisted by supplying many notes on East Yorkshire birds.

Record should here be made of the generous way in which Messrs. A. Brown \& Sons, Ltd., have met the Union with regard to the publication of the work, and of the care they have taken in connection with its production.

T. SHEPPARD, F.G.S.,

Hon. Secretary.

The Museum, Hull,

June $30 t h, 1907$. 



\section{PREFACE.}

$7 \mathrm{HE}$ history of the Birds of Yorkshire is based upon an unrivalled and exceptionally complete mass of material, which, in addition to my own observations for many years past, comprises the voluminous notes collected by Mr. W. Eagle Clarke and Mr. W. Denison Roebuck, which include the MSS. of the late John Cordeaux, intended for a new edition of his "Birds of the Humber District," together with lists, notes, and observations from nearly all the leading ornithologists of the county; indeed, there has scarcely been a Yorkshire naturalist living within the past thirty-five years who has not contributed manuscript notes or lists to the store available for reference.

The scope of the work is comprehensive, and in the account of each species includes particulars of faunistic position, distribution, migration, nidification, , folk-lore, varieties, and vernacular names, whilst at the commencement of each is given the verbatim account from the Report of Thomas Allis, the earliest Yorkshire one, now published for the first time, which, up to the year I88r, when Mr. W. Eagle Clarke's contribution on the Birds of the County to the "Vertebrate Fauna of Yorkshire" appeared, was the only complete list.

It is necessary to explain that this work was commenced by Mr. Eagle Clarke, published in the Vertebrate Fauna section of the Transactions of the Yorkshire Naturalists' Union, and discontinued owing to his removal from Yorkshire to Edinburgh in I888. The 
parts written by him are the Thrushes, Shrikes, Flycatchers, Dipper, and birds of prey (Accipitres and Striges), which have now been re-written and brought down to date.

I take this opportunity of expressing my grateful thanks for the valuable assistance he has rendered me during the past six years, and for placing at my disposal the whole of his collected information up to the year I888.

I am also indebted to Mr. W. Denison Roebuck, joint author with Mr. Eagle Clarke of the "Vertebrate Fauna of Yorkshire," who has placed unreservedly at my disposal the ornithological portion of his collection of printed records, the result of many years' bibliographical examination of the literature of Yorkshire zoology, and to Mr. F. Boyes, who has supplied many notes on the East Riding.

My sincere thanks are tendered to Professor Alfred Newton, Messrs. Howard Saunders, J. E. Harting, W. Denison Roebuck, J. H. Gurney, T. Southwell, C. E. Millburn, and to my veteran taxidermist, George Mussell; also to the naturalists whose names appear on $\mathrm{p}$. xxx., and to my friends who have most generously presented me with materials for the purposes of illustrations: Mr. W. Woodhouse, who designed the sketch on the title-page and granted the privilege of using two oil paintings of Bempton Cliffs, in addition to several sketches; Mr. John Charlton, who has contributed a sketch; whilst numerous photographs have been supplied by Messrs. Riley Fortune, E. W. Wade, H. Lazenby, E. G. Potter, and S. Smith. Other illustrations have been added by Messrs. J. Backhouse, W. B. Tegetmeier, T. A. Lofthouse, and T. Sheppard.

As it has been found inconvenient to mention authorities in the text in every case, a general acknowledgment is made by stating, after the contributor's name in the appended list, the district to which his notes refer. Those marked $(*)$ have furnished lists of birds :- 
Thomas Altham (Forest of Bowland); * Major W. B. Arundel (Ackworth); Rev. G. D. Armitage; * F. Atkinson (Glaisdale and Great Ayton); * Thos. Audas; * F. Boyes ; * G. Swailes ; *E. W. Wade (Holderness, East Riding) ; James Backhouse, * Matthew Bailey (Flamborough); R. Blakeborough, H. B. Booth (Shipley); Thos. Boynton (Bridlington); * E. P. Butterfield (Wilsden); Rosse Butterfield ; Thos. Bunker (Goole); *H. W. Carson (Knaresborough); * James Carter (Masham); *R. Clarke ; $*$ F. C. Stevens (Lower Wharfedale); *W. J. Clarke (Scarborough); *A. Crabtree, (Halifax) ; * Riley Fortune (Nidd Valley);* F. S. Graves (Sedbergh district); *W. Gyngell (Scarborough) ; Rev. J. A. Haydyn; *W. Hewett ; * Rev. H. N. Hind (Liversedge); H. K. Horsfield ; A. S. Hutchinson ; * James Ingleby (Eavestone, Ripon); Rev. E. P. Knubley; * F. Lawton (Skelmanthorpe); Robert Lee (Thirsk); P. W. Loten (Easington, Spurn); * Kenneth MacLean (Loftus and Staithes); *G. B. Milne-Redhead ; *W. Morris (Sedbergh); *S. L. Mosley (Huddersfield) ; G. W. Murdoch (Bentham) ; * G. Parkin (Wakefield) ; L. Parsey ; * M. N. Peel (Forest of Bowland) ; *T. Petch (South Holderness); E. G. Potter ; *T. Raine (Chapel Allerton); *W. H. St. Quintin, (Scampston); *W. Storey (Fewston); * G. Steels (Pocklington); * Thos. Stephenson (Whitby) ; * Rev. R. A. Summerfield (North Stainley, Ripon); * J. T. Thomasson (Valley of the Hodder); J. Thwaite; Lord Walsingham; *W. Walton (Upper Teesdale); * A. Ward (Malham); *W. E. L. Wattam (Huddersfield district); * J. A. Wheldon (Northallerton and York); T. Whitwell; G. A. Widdas (Bradford); W. Wilson; * J. J. Baldwin-Young (Sheffield).

The Introduction has, with the permission of Messrs. Clarke and Roebuck, been adopted from their "Vertebrate Fauna of Yorkshire," with such modifications as are rendered necessary in a work of this nature, by the events which have occurred during the past twenty-five years. 
I also desire to thank Mr. T. Sheppard, F.G.S., of Hull, the editor of the publications of the Yorkshire Naturalists' Union, for his assistance in the matter of proof reading, preparing the Index of personal and place-names, and seeing the work through the press.

The Cliffe, REDCAR. 


\title{
CONTENTS
}

\author{
VOL. I
}

Preface . . . . . . . . . . vii

List of Illustrations . . . . . . .

INTRODUCTION $. \quad . \quad . \quad . \quad . \quad . \quad$. $x i x-x l v$

Genus Turdus (Thrush, \&c.) . . . . I I-2 I

Monticola (Rock Thrush, \&c.) . . 21-22

Saxicola (Wheatear, \&c.) . . . 22-26

Pratincola (Whinchat, \&c.) . . . 26-32

Ruticilla (Redstart, \&c.) . . . 33-37

Cyanecula (Bluethroat, \&c.) . . . 38-4I

ERithacus (Redbreast) . . . . 42-47

Philomela (Nightingale) . . . . 47-65

Sylvia (Whitethroat, \&c.) . . . 65-75

Regulus (Golden-Crested Wren, \&c.) • 75-80

Phylloscopus (Yellow-Browed Warbler, \&c.) 8o-88

Hypolais (Icterine Warbler) . . . 88-89

Acrocephalus (Reed Warbler, \&c.). 89-93

Locustella (Grasshopper Warbler) . 93-97

ACCEntor (Hedge Accentor, \&c.) . . 97-101

Cinclus (Dipper, \&c.) . . . . ror-104

Panurus (Bearded Titmouse) . . . 104-105

Acredula (Long-Tailed Titmouse) . . 106-107

Parus (Great Titmouse, \&c.) . . . ro8-115

Sitta (Nuthatch) . . . . . II5-II8

Troglodytes (Wren). . . . . II8-120

Certhia (Creeper) . . . . . 120-121

Motacilla (Pied Wagtail, \&c.) . . 121-130

Anthus (Tree Pipit, \&c.) . . . . 130-136 
Genus Oriolus (Golden Oriole) . . . . 136-1 38

LANiUs (Great Grey Shrike, \&c.) . . I38-145

Ampelis (Waxwing) • . . . . $145-148$

Muscicapa (Spotted Flycatcher, \&c.) . I48-I 53

Hirundo (Swallow) • • • . . $153^{-1} 5^{8}$

Chelidon (House Martin). . . . $15^{8-161}$

Cotile (Sand Martin) . . . . 16 $1-163$

Ligurinus (Greenfinch) . . . . $16_{3}-16_{5}$

Coccothraustes (Hawfinch) . . . 165-168

Carduelis (Goldfinch, \&c.) • . I69-I 74

Serinus (Șerin) . . . . . . I74-175

Passer (House Sparrow, \&c.) . . . $175^{-180}$

Fringilla (Chaffinch, \&c.) . . . I80-184

Linota (Linnet, \&c.) • . . . 185-193

Pyrrhula (Bullfinch, \&c.) . . . 193-195

Pinicola (Pin Grosbeak) • . . . 195-196

Loxia (Common Crossbill, \&c.) . . 197-201

Emberiza (Corn Bunting, \&c.). . . 20I-2 Io

Calcarius (Lapland Bunting) . . . 2 IO-2 I I

Plectrophanes (Snow Bunting) • . 212-215

Sturnus (Starling) . . . . . 2I 5-22I

Pastor (Rose Coloured Pastor) . . $221-223$

Pyrrhocorax (Chough) . . . . 223-224

Nucifraga (Nutcracker) • • . . 224-225

Garrulus (Jay) . . . . . $225-227$

PICA (Magpie) • . . . . . 228-232

Corvus (Crow, \&c.). • . . . 232-254

Alauda (Skylark, \&c.) . . . . $255^{-2} 5^{8}$

OTOCORYS (Shorelark) • . . . 259-26I

Cypselus (Swift, \&c.) . . . . 261-265

Caprimulgus (Nightjar) . . . . $265-269$

Jynx (Wryneck) • • • . . 269-27I

Gecinus (Green Woodpecker) • • . 272-274

Dendrocopus (Great Spotted Woodpecker,

\&c.) • . . . . . $274-278$

Alcedo (Kingfisher) . . . . . 278-28r 
Genus Coracias (Roller)

MERops (Bee-Eater).

- $28 \mathrm{I}-283$

UPUPA (Hoopoe)

Cuculus (Cuckoo) . $\quad$. $\quad . \quad$. $\quad$ 287-292

Strix (Barn Owl, \&c.) . . . . 292-295

, " . . . . 30I-303

Asio (Long-Eared Owl, \&c. . . . 295-30 I

Nyctala (Tengmalm's Owl, \&c.) . . 303-306

Athene (Little Owl) . . . . . 306-308

Nyctea (Snowy Owl) . . . . 309-310

Scops (Scops Owl) . . . . . 310-3 I 2

Bubo (Eagle Owl) . . . . . 312-315

Circus (Marsh Harrier, \&c.) . . . 315-325

Buteo (Common Buzzard, \&c.) . . 325-33I

Aquila (Golden Eagle) . . . . 331-334

Haliaetus (White-Tailed Eagle) . . 334-338

Astur (Goshawk) • . . . . 339-342

Accipter (Sparrowhawk) . . . . 343-344

Milvus (Kite) • • • . • . 344-347

Elanoides (Swallow-Tailed Kite) • • 347-350

Pernis (Honey Buzzard) . . . . 350-352

Falco (Greenland Falcon, \&c.) . . 352-373

Pandion (Osprey) . . . . . $373-374$ 



\title{
LIST OF ILLUSTRATIONS
}

\author{
VOL. I
}

A Misty Morning on the Bempton Cliffs, at "Hateley Shoot". . . . Frontispiece Flamborough Lighthouse . . . . Introduction Spurn Lighthouse . • • . . . ",

Snowden Sleights, the last of the Yorkshire Wildfowlers, with his armoury

TO FACE PAGE

Mistle Thrush on nest in standard plum tree, four feet from the ground . . . . . 2

Mistle Thrush at nest, feeding young . . . . 4

Song Thrush on nest . . . . . . . 6

Nest of Song Thrush . . . . . . . 6

Nest of Song Thrush without usual lining . . 8

White's Thrush, taken near Halifax, Dec. 1902 . 12

Ring Ouzel's nest, North West Yorkshire . . . 20

Whinchat's nest . • . . . . . . 32

Stonechat's nest . . . . . . . . 32

Nesting haunt of Nightingale, near Harrogate . $\quad 5^{\circ}$

Nesting place of Nightingale, near Knaresborough . $5^{6}$

Whitethroat feeding its young . . . . 66

Nest of Whitethroat, near Harrogate . . . 66

Nest of Nightingale, near Harrogate . . . 68

Nest of Lesser Whitethroat, near Ripon . . . 68

Nest of Black Cap . . . . . . 70

Nest of Garden Warbler . . . . . 70

Nest of Goldcrest suspended on branch of fir . $\quad 78$

Nest of Chiff Chaff, near Harrogate . . . 82

Nest of Willow Warbler . . . . . 82

Wood Warbler's Nest . . . . . . 86

Reed Warbler's nest, Hornsea Mere . . . $\quad 88$ 
Reed Warbler's nest, Hornsea Mere

Sedge Warbler feeding young • • • • $\quad 9^{2}$

Nests of Grasshopper Warbler, near Harrogate • . 96

Nest of Hedge Accentor with a Cuckoo's Egg (top on

left), near Harrogate . . . . . . 100

Dipper's nest, in usual situation . . . . . 102

Unusual site for a Dipper's nest, on the River Nidd . 104

Long-Tailed Tit at nest, near Pickering . . . 106

Nest of Long-Tailed Tit, near Harrogate . . . 106

Great Tit's in old wall . . . . . . . ro8

Open nest of Great Tit, built on an old Song Thrush's

nest in a clump of woodbine . . . . . I Io

Cole Tit's nest in old wall . . . . . . II 2

Marsh Tit's nest in sunk fence . . . . . II

Blue Tit's nest in tree stump . . . . . II4

Blue Tit taking food to its young . . . . . II4

Whale's jaw bones near Bempton, nesting place of

Blue Tit . . . . . . . . I I6

Young Tree Creeper . . . . . . . . 120

Tree Creeper's nest $\quad . \quad$. . . . . I 20

Nest of Pied Wagtail . . . . . . . 122

Nest of Grey Wagtail • . . . . . . 122

Young Grey Wagtail in nest . . . . . 124

Tree Pipit's nest . . . . . . . . I30

Meadow Pipit's nest with Cuckoo's egg . . . I30

Male Meadow Pipit feeding female at nest . . . 132

Nest of Red-Backed Shrike in north-west Yorkshire . I40

Spotted Flycatcher on nest . . . . . 148

Pied Flycatcher taking food to young . . . . I50

Swallow's nest . . . . . . . . 156

Cup-shaped Swallow's nest, near Harrogate . . 156

Old Cottage at Hartwith, under the eaves of which forty-six Martin's nests have been found at one time

Greenfinch's nest .

Hawfinch 
Nest of Hawfinch .

Nests of Goldfinch .

Nest of Linnet in gorse bush

Nest of Twite placed amongst heather, north-west

Yorkshire

Nest of Lesser Redpoll .

Nest of Bullfinch in fir tree

Nest of Corn Bunting .

Nest of Reed Bunting . . . . . . . 202

Nest of Cirl Bunting, near Harrogate . . . 204

Siberian Meadow Bunting . . . . . 206

Raven's nest, north-west Yorkshire . . . $\quad 234$

Cronkley Scar, Upper Teesdale. Nesting site of Raven and Peregrine . . . . . . 236

Young Raven after its first flight from nest, northwest Yorkshire . . . . . . 238

Nest of Carrion Crow (exterior), north-west Yorkshire. 240 Nest of Carrion Crow (interior), north-west Yorkshire . 242 Nest of Rook

An Ancient Domicile. Rooks' nests near Pannal . $\quad 25^{2}$

Skylark's nest . . . . . . . . 256

Skylark feeding young . . . . . . 256

Nest and eggs of Nightjar . . . . . 266

Young Nightjar, found near York • . • . 266

Home of Green Woodpecker • . . . 272

Green Woodpecker at nesting hole . . . 274

Young Green Woodpeckers . • . • • 274

Lesser Spotted Woodpecker taking food to its young . 27ó

Kingfisher . . . . . . , . 280

Brood of young Kingfishers . • . . . 280

Young Cuckoo in nest of Pied Wagtail, Sutton-onForest, York . . . . . . 286

Young Cuckoo in Pied Wagtail's nest, near Harrogate. 288

Young Cuckoo from Yellow Wagtail's nest, near Harrogate . . . . . . 288

Barn Owl's nest in old oak tree . . . . . 294 
xviii

Long-Eared Owl's nest . . . . . . . $\quad . \quad 296$

Tawny Owl's nest . $\quad$. . . . . . . . 296

Tawny Owl (sleepy) . $\quad . \quad . \quad . \quad . \quad . \quad 302$

Tawny Owl (awake) . $\quad . \quad \cdot \quad \cdot \quad \cdot \quad \cdot 302$

Ancient nesting place of Buzzard, in north-west Yorkshire . . . . . . 326

Sparrowhawk's nest . . . . . . . 342

Sparrowhawk (female) • • . . . • 342

Telephoto picture of a Wild Peregrine, taken in northwest Yorkshire. . . . . . . 358

Cautley Crag, ancient nesting site of Raven, Peregrine, and Buzzard . . . . . . 360

Peregrine Falcon's eyries, north-west Yorkshire • . $\quad 362$

Nest of Merlin, north-west Yorkshire . . . . 366

Merlin . . . . . . . . . . 366

Kestrel's nest $\quad . \quad$. $\quad . \quad$. , . . 370

Kestrel (female) . . . . . . . . 370 


\section{INTRODUCTION.}

\section{ERRATA.}

Page xxxvii., line 5-For ' 1889 ' read ' 1899 '

,, xlii., line 9-For 'Two' read 'Three.' And add the 'Liberian Meadow Bunting ' before 'the Cuneate-tailed Gull.'

" 38, line 2-For 'leucocyana,' read 'wolfii.'

" +1, headline--For 'Redbreast,' read 'Red-spotted Bluethroat.'

", 41, line 4-This example, obtained at Kilnsea, 8th October, 1903, may possibly be referable to $C$. wolfi.

, 560, 3rd line from bottom-For 'Houbraas' read 'Houbarats.

" 717 , inth line from bottom-For' 130,000 ' read ' $80,000$.

\section{ILLUSTRATIONS.}

Plats facing page $108-A d d$ 'Nest' after ' Great Tit's.

" , 6ro- 'Nests of Dunlin, north-west Yorkshire,' omit

tract of mountainous country, ascending to 2,590 reet at the extreme north-western angle of the county, and nowhere descending to a lower elevation than about four hundred feet. A district of lofty hills, thirty-six of which attain an altitude of two thousand feet or more, of extensive stretches of heathery moorlands, of grassy slopes and grey limestone VOL. I. 
xviii

LIST OF ILLUSTRATIONS

Long-Eared Owl's nest .

Tawny Owl's nest .

Tawny Owl (sleepy)

Tawny Owl (awake)

Ancient nesting place of Buzzard, in north-west Yorkshire

Sparrowhawk's nest
TO FACE PAGE

- 296

. 296

- 302

- 302

- 326

242 


\section{INTRODUCTION.}

\section{YORKSHIRE: ITS PHYSICAL ASPECT AND AVI-FAUNA.}

$\mathrm{Y}^{\mathrm{o}}$

ORKSHIRE, the largest county in the British Isles, containing an area of $3,936,242$ statute acres, or 6,150 square miles, and situate between $53^{\circ} \mathrm{I} 8^{\prime}$ and $54^{\circ} 40^{\prime} \mathrm{N}$. latitude and about $9^{\prime} \mathrm{E}$. and $2^{\circ} 36^{\prime} \mathrm{W}$. longitude of the meridian of Greenwich, is also one of the most compact in form, the most varied in geological structure, soil, climate, and physical aspect.

The lands of Yorkshire rise in masses from S.E. to N.W., in a direction which corresponds with that of the age of the underlying rocks, the oldest or palæozoic formations constituting the high mountains of the north-west, whilst the newest or tertiary deposits of Holderness occupy the opposite or south-east angle. Thus a line drawn from the beach at Spurn to the highest summit of Yorkshire-Mickle Fell, 2,596 feet-marks not only the general slope of the high lands but their succession in geological time, and is moreover the longest line (I20 miles) that it is possible to draw within the county.

Broadly speaking, the most salient features of its physical configuration are the great central depression and the flanking masses of hills to the east and west.

The NORTh-Western Fells is a wild and picturesque tract of mountainous country, ascending to 2,596 feet at the extreme north-western angle of the county, and nowhere descending to a lower elevation than about four hundred feet. A district of lofty hills, thirty-six of which attain an altitude of two thousand feet or more, of extensive stretches of heathery moorlands, of grassy slopes and grey limestone vol. I. 
scars, diversified by waterfalls, caves, clear and sparkling streams, and beautiful and romantic dales, this elevated region includes the main watershed of the North of England, and within its limits and upon Yorkshire soil rise all the great rivers of the north-Tyne and Wear alone excepted. The steep western slopes are drained into the Irish Sea by the Eden, the Lune, the Ribble, and their tributary streams; while down the broader valleys and more gentle inclines of the eastern slopes flow the Aire, the Wharfe, the Nidd, the Ure, the Swale, and the Tees, into the North Sea.

The gritstone summits and limestone scars of this region are the last refuge in Yorkshire of the Buzzard, and amongst the last of the Raven and the Peregrine; the high moors are inhabited by the Red Grouse, Ring Ousel, Merlin, Twite, Curlew, Dunlin, Snipe, and Golden Plover, while the Dipper, Grey Wagtail, and Sandpiper are abundant on the mountain becks.

Of the very few natural sheets of water in Yorkshire this district possesses three of the most important, Malham Tarn, Semerwater, and Birkdale Tarn, besides a few others of smaller size. Malham Tarn, I53 acres in extent, and I,250 feet above the level of the sea, together with the limestone plateau on which it is situate, is of special interest as illustrating the altitude to which certain species will ascend, and its fauna has therefore been made a special feature in this work. Here the Wood-wren, Redshank, Teal, Coot, and Dabchick nest annually, and it is one of the few localities in Yorkshire where the Tufted Duck has been known to breed.

The Craven Pasture-Lands.-Immediately below the North-western Fells, which are abruptly terminated to the south by the steep and occasionally precipitous descents of the Craven and Pennine faults, succeeds a comparatively low region, under 600 feet in elevation, with an undulating grassy surface and low rounded hills, in places rising into fells which reproduce on a smaller scale the leading physical characteristics of those of the north-west. Through the green pastures of this uninteresting country, of which the Peewit is the characteristic bird, the Ribble and the Hodder 


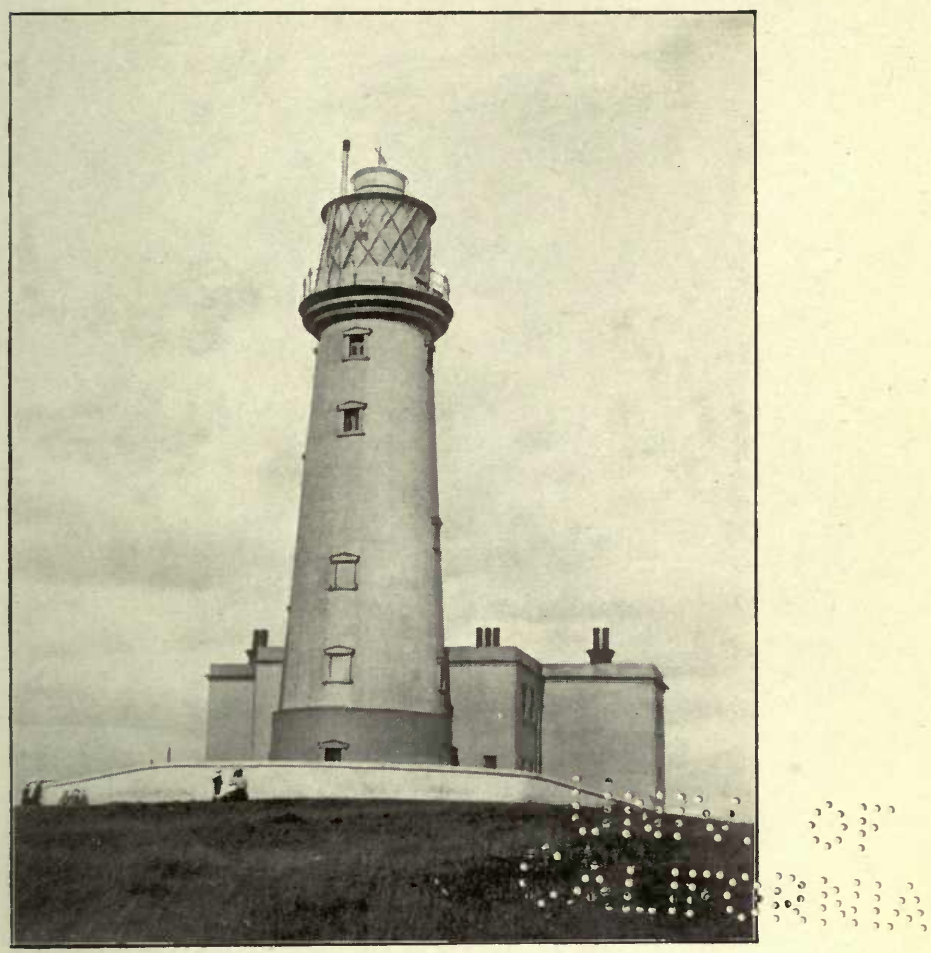

Flamborough Lighthouse. 

cut their way in the form of narrow, well-wooded, sheltered and productive ravines, giving some charm to this otherwise monotonous country, which formerly constituted the famous Forest of Bowland.

The South-Western Moorlands.-The summit ridge, broken and irregular among the fells of the north-west, and interrupted by comparatively low ground south of them, begins again near Keighley and Ilkley, and is carried southward by a broad and continuous band of elevated and monotonous rolling heatherland, which extends along the county boundary as far as Derbyshire, and attains its greatest elevation-I,859 feet-at Holme Moss. These unbroken stretches of dreary moorlands-unrelieved save by deep and narrow "cloughs" or ravines, are, in comparison with the Fells of the north-west, of but slight interest to the naturalist. Homogeneous in their geological structure, and presenting no other soils than the barren and unproductive peat-laden and heather-covered millstone grit, they afford little variety in their fauna. The high moors are inhabited by Grouse-more strictly preserved here than elsewhereand by occasional pairs of Curlew, Golden Plover, Snipe, Black Grouse, Ring Ousel, and less frequent still an odd pair of Dunlin; the streams are the haunt of the Dipper, the Grey Wagtail, and Sandpiper, while the lower parts of the valleys are inhabited by such birds as are able to maintain their ground against man and his works. For the south-western moorlands are situate between the two great coal-fields and manufacturing districts of Yorkshire and Lancashire, and are not only of easy access to a vast population, but within the direct influence of the clouds of smoke which accompany the manufacture of cotton upon the one side, and wollens and worsteds upon the other.

The Manufacturing District.-At the foot of the south-western moorlands, and to the east of them, the great Yorkshire coalfield stretches from Leeds and Bradford to Halifax, Huddersfield, Wakefield, Barnsley, and Sheffield. Within this comparatively limited area is congregated the great mass of the population of Yorkshire, for here the presence 
of coal and ironstone has determined the location of some of the world's greatest industries; and the coal-mining districts of the West Riding afford one of the clearest demonstrations of the transforming influence of human agencies upon the surface of a country. The air is laden with smoke above, vegetation is checked and stunted, while the foulness and inky blackness of the rivers can only be paralleled by that of the streams of the neighbouring county palatine of Lancaster.

Naturally well-wooded, the district still retains that characteristic in parts, more especially in the southern portion, where the noble Chase of Wharncliffe, overlooking an extensive prospect in the Don valley, and the fine parks about Barnsley and Wakefield, still afford a shelter to woodland species of birds, some of considerable interest-such as the Nightingale and the Pied Flycatcher-though the inimical influence of smoke has long told upon the trees. The district is also interesting as within it is situated Walton Park-the sylvan domain wherein for many years Charles Waterton extended complete protection to living things of all kinds. In an old ivy tower there nested in one spring seven pairs of Jackdaws, twenty-four pairs of Starlings, four pairs of Ring-doves, the Barn Owl, the Blackbird, the Redbreast, the Redstart, the House Sparrow, and the Chaffinch. A walled bank, in the naturalist's garden, was fitted with drain-pipes, intended for nestingholes of Sand Martins, which took advantage of the hospitality offered them, and upwards of fifty pairs nested there. Large numbers of Magpies, Jays, and Carrion Crows bred in the Park; an extract from one of Waterton's note books states that on $5_{5}$ th December I 863 he counted more than a hundred of the latter birds preparing to go to roost. Here flourished a famous Heronry, which after the death of Waterton was disturbed and finally dispersed. But the continued presence of so dense a population and the ever-increasing demands of modern commerce are gradually breaking up and destroying what suitable habitats the district still possesses, hastening the process of extinction which is continually going on, and thus diminishing a fauna which was never at any time a very rich one. 
The Central Plain, including under this name not only the entire vale of York, but also the lowlands of Cleveland and the Tees valley, is a broad fertile tract of agricultural land, for the most part below 300 feet in elevation, traversed by the middle and lower portions of most of the Yorkshire rivers, and stretching from the banks of the Tees to the borders of Nottinghamshire. Its light and sandy soils support ordinary lowland and woodland types of vegetation, the fauna partaking of the same character.

In former times the famous forest of Galtres stretched for many miles in extent from beneath the very walls of York. Parts of the district still remain to some extent in their pristine condition; and such places as Pilmoor, and Strensall and Riccall Commons-the breeding places of the Redshank, Teal, Snipe, Black-headed Gull, etc., and some of them formerly of the Ruff and other birds-with some boggy carrs and wet heaths of the North and East Ridings, and Askham Bog, still display their primitive characteristics. At Hornby Castle, near Catterick, is to be found one of the two decoys now existing in the county. There is no lack of woodland, especially towards the south, where at Edlington Wood one of the last Yorkshire nests of the Kite was taken, while that of the Hobby has been found at Rossington and in the woods at Cawood, and in the latter, which were the largest in the county, the Raven and Buzzard reared their young till within comparativery recent times.

In the extreme south the flat marsh-lands which lie between the present and the old channels of the river Don, including the carrs near Doncaster, and the famed levels of Hatfield Chase and Thorne Waste, once ornithologically rich, even now present an avifauna of considerable interest. Formerly the three Harriers, the Black-tailed Godwit, and the Ruff were among the species breeding annually, and an island at the mouth of the Trent afforded the last British nest and eggs of the Avocet. On Thorne Waste was also the site of a small decoy fairly productive of Mallard, Wigeon, and Teal, especially the latter. Until quite recently Thorne Waste, which is about 6,000 acres in extent, was the breeding haunt of the 
Mallard, Teal, Redshank, Black-headed Gull, and occasionally of the Short-eared Owl and the Curlew. On the intersecting drains the Reed Warbler and species of minor interest nest abundantly.

The Cleveland Hills, occupying the north-eastern portion of the county, though inferior to the North-western Fells in extent and in elevation-reaching only to $I, 485$ feet at Burton Head-are no less picturesque and interesting. Like them also it is a region of high moorlands-frequented by Red Grouse and Twite, and in the spring and early summer by Curlew and Golden Plover, with, occasionally, a pair of Stone Curlews, which here find the northern limit of their breeding range in Britain-and intersected by the ramified, well-wooded, and beautiful dales drained by the Esk and by numerous branches of the Derwent.

The high lands of Cleveland present bold escarpments towards the Tees valley and the central plain, and a lofty line of cliffs towards the sea, reaching 680 feet in elevation at Boulby. The Howardian hills, below 520 feet in elevation, which separate the vale of Pickering from the central plain, must be considered as a southern spur or continuation of the Hambleton hills, as the western escarpment of the Cleveland range is called.

The Cleveland avi-fauna is highly interesting. The Raven was fairly common in the district, and a pair have been observed comparatively recently in the vicinity of the coast. This region was also the resort of the Hen Harrier until I850, to which date a few pairs nested annually. The Short-eared Owl has also on several occasions bred on the moors, and until some few years ago a pair of Peregrines nested annually. On the moors the Twite breeds sparingly, and the Curlew and Golden Plover not uncommonly. The district has on various occasions been visited by rare stragglers, such as the Pine Grosbeak, Lapland Bunting, and Ruffed Bustard; while Tengmalm's Owl has occurred no fewer than four times.

VALE OF Pickering.- South of the Cleveland hills is a small tract of low-lying cultivated land, below a hundred feet in elevation, possessing a rich soil, and including a con- 
siderable extent of carrs and low marsh-land. This district, drained by the Derwent and Rye, is shut in on all sides by high lands, and was, in all probability, formerly a lake, the outlet for its drainage even now being at times inadequate, and in rainy seasons the lower portions are liable to be flooded for miles in extent.

ThE Chalk Wolds.-A semi-circular range of rounded undulating chalk hills commences near the Humber at Ferriby, and sweeping first in a northerly and then in an easterly direction, terminates in a line of stupendous sea-cliffs at Flamborough Head. Culminating at its north-west corner in Wilton Beacon, at an altitude of 805 feet, they present a bold front to the central plain on the west and to the vale of Pickering on the north, while by more gentle inclines their south-eastern or inner aspect merges into the low country of Holderness.

Originally a desolate, grassy, and stony sheepwalkover which a horseman might ride for thirty miles at a stretch without meeting with a fence or other obstruction, and the resort of the Great Bustard and the Stone Curlew-this district is now ranked amongst the best and most highly-farmed agricultural land of England. The deeply excavated hollows in the Wolds are remarkable for the absence of streams, the only rivulets to which they give rise being the variable and intermittent ones called "gypseys." This deficiency of permanent streams decidedly affects the vertebrate fauna, probably accounting for the absence of such birds as the Dipper, the Sandpiper, and the Grey Wagtail, which occur and breed in corresponding altitudes amongst the hills of the north and west. The characteristic fauna of the Wolds must now be regarded as a thing of the past. The Great Bustard, which here found its northern limit in Britain, has long been driven out by cultivation, and the Stone Curlew is in danger of extinction, the chief bird now to be noted being the Lapwing, which occurs in great abundance.

HOLDERNESS. - A flat, low-lying district of triangular outline interposed between the North Sea and the Humber, and separated from the rest of Yorkshire by the green Wold 
hills-is under an elevation of one hundred feet, with the exception of Dimlington Height, which is but one hundred and fifty-nine; and of all districts in the county is probably the one which has undergone the most decided physical transformation. There can be little doubt that the aboriginal condition of the district, now rich and fertile corn-land, was that of a vast fen or swamp-the haunt of the Crane, the Wild Goose, the Bittern, the "Sholarde," and the Ruff. The sheets of water which formerly diversified the surface were made use of for the establishment of decoys for the capture of Wild Duck, and consequently we find that the greater numberfour out of seven-of the decoys known to have existed in East Yorkshire were here, at Holme on the Wolds, Meaux, Watton, and Scorborough.

The impetus given to agriculture about the close of the eighteenth century, and the rapid development of high farming, proved fatal to much of the ornithological wealth of Holderness. The decoys were destroyed by the Holderness (I762) and the Beverley and Barmston (I800) drainage schemes; and many haunts were broken up by the general revival of agriculture.

Holderness, even now, is a rich ornithological district, the Turtle-dove and the Quail being regular summer visitants, and the Hawfinch breeds annually in some abundance. Hornsea Mere-the largest natural sheet of water in Yorkshire-was formerly resorted to in the nesting season by large numbers of Terns, ${ }^{*}$ as is shewn by an entry in the diary of the Rev. Abraham de la Pryme, dated "Hornsey, Dec. 2Ist I693," and which runs as follows :- "The marr is a mile and a half in length, and in one place a mile in breadth .... there are three hills (islands we call them) in the marr, two of them, at the season of the year, are so full of tern eggs and birds as can be imagined. A man must be very careful if he tread not on them " ("Publications of Surtees Society"). The Reed Warbler, the Pochard, and the Great Crested Grebe breed regularly; and it has produced some of the rarest

* Query, Black-headed Gulls. See chapters on Common Tern and Black-headed Gulls. 
Yorkshire visitants, such as the Great White Heron, the Broad-billed Sandpiper, and others. The Mere is inhabited by pike, which attain to a great size, and are exceedingly destructive to the birds which frequent the water, especially the young ones, a circumstance probably explaining the absence of the Little Grebe.

THE YoRKSHIRE COAST-LINE-commencing at the mouth of the Tees, and extending II 7 miles in length to Spurn Pointis one of the most diversified possessed by any English county.

The estuary of the Tees-though by no means comparable in size or attractiveness to that of the Humber-is yet of considerable extent. That there was formerly an extensive breeding colony of sea-birds is proved by the following extract from the Cottonian MS. (about I604):-"Neere unto Dobhoome (the port in the mouth of Tease soe named) the shore lyes flatt, where a shelfe of sand raised above the highe water marke enterteines an infynite number of sea-fowle, which lay their egges here and there scatteringlie, in such sorte that in tyme of breedinge one can hardlye sett his foote soe warelye that he spoyle not many of their nests." The species nesting there would probably include the OysterCatcher and several kinds of Terns; old inhabitants of the district are now (I906) living who can remember Terns breeding near the estuary.* This area includes vast stretches of sands, which afforded the last breeding haunt of the seal in Yorkshire (one sandbank indeed bearing the name of "Seal Sand "); also a series of low salt marshes bordered by sand-hills, and intersected by pools and salt-water ditches-formerly the habitat of shore fishes, and an attractive resort for such migratory birds as the Waders, Ducks, and Geese. But, as so often has happened in the north of England, the development of trade has here sadly interfered with the natural productiveness of the district. The discovery of Cleveland ironstone-and consequent rapid rise of Middlesbrough as a manufacturing and sea-port town-has involved a train of

- Dobhoome is on the Yorkshire side, near Tod Point ; it is now no longer a port, and is called Dabholme Beck, or in the fisherman's vernacular, "Dabbing Gut." 
consequences which have done much to render the zoological riches of the Teesmouth almost a tale of the past. The navigation has been improved, foreshores embanked and reclaimed, docks and harbours built, breakwaters projected, and blast furnaces erected along the Coatham Marsh.

One of these furnaces, built within five hundred yards of the site of a decoy, caused-and no wonder-its discontinuance, about I872. Formerly this decoy was fairly productive, and on one occasion yielded a haul estimated at five hundred. At any rate, so great was the number enclosed in the net, that it broke, and most of the Ducks escaped, only ninety and nine being actually secured. Amongst the most interesting birds of this area are the Sheld-duck, Redshank, and Dunlin, which nest sparingly in the vicinity of the Tees estuary.

The first ten or twelve miles of the Yorkshire coast, commencing from the mouth of the Tees, is low and fronted by a reach of firm sandy beach, but at Marske and Saltburn begins to rise. Beyond Saltburn is Huntcliffe, thus quaintly referred to in the Cottonian MS. (I604):- "Huntley Nabbe, where the coaste beginnes to rise Highe, full of craggs and steepe Rockes, wherein Meawes, pidgeons, and Sea-fowle breed plentifullye." Here the Cleveland hills present towards the sea a line of liassic and oolitic cliffs extending for forty-four miles, and terminating at the Castle Hill of Scarborough. These Cleveland sea-cliffs-amongst the loftiest in England, and attaining their maximum height of 680 feet at Boulbyafford several breeding stations for the Cormorant and the Herring Gull, whilst along their range the Raven formerly bred in scattered pairs in suitable stations. The Scarborough Castle Hill-the outlying mass of rock which marks the southward termination of the Cleveland cliffs-was also in former times a breeding station of this bird, and it is recorded to have nested there for the last time about I850.

The coast-now the eastern termination of the vale of Pickering-is comparatively low from Scarborough southward, and mostly composed of soft rocks which offer but slight resistance to the destructive action of the waves, save where 
the hard sandstone reef of Filey Brig projects into the sea. The shores are here composed of sandy beaches. On the diluvial cliffs near Filey a few Herring Gulls breed annually.

Some distance S.S.E. of Filey the chalk deposits of England reach their northern termination in a lofty range of tide-washed mural precipices, the well-known cliffs of Speeton, Buckton, Bempton, and Flamborough, the most extensive and densely inhabited breeding resort of sea-fowl in England. The earliest known account of this "loomery" was written by Thomas Pennant, who, in the course of his journey to Scotland, visited Flamborough on 3rd July I769, and thus recorded his impressions of that place :- "Went to Flamborough Head . . . . Put myself under the direction of William Camidge, ciceroni of the place, who conducted me to a little creek, at that time covered with fish, a fleet of cobles having just put in. Went out in one of these little boats to view the Head, coasting it for upwards of two miles. The cliffs are of a tremendous height, and amazing grandeur; beneath are several vast caverns, some closed at the end, others are pervious, formed with a natural arch, giving a romantic passage to the boat, different from that we entered. In some places the rocks are insulated, are of a pyramidical figure, and soar up to a vast height; the bases of most are solid, but in some pierced thro', and arched; the color of all these rocks is white, from the dung of the innumerable flocks of migratory birds, which quite cover the face of them, filling every little projection, every little hole that will give them leave to rest; multitudes swarmed in the air, and almost stunned us with the variety of their croaks and screams; I observed among them corvorants, shags in small flocks, guillemots, a few black guillemots very shy and wild, auks, puffins, Kittiwakes,* and herring gulls" ("A Tour in Scotland," I77I, pp. I4-I5). Here Guillemots, Puffins, Razorbills, and Kittiwakes breed in countless multitudes, the Guillemots being by far the most numerous ; and there are also a pair or two of Herring Gulls. In a cave in Buckton cliff called "The Cote" the

"Called here Petrels. "Br. Zool. Supplt." (Tab. xxiii., p. 26). 
Rock Dove breeds in great numbers, and its congener the Stock Dove is particularly numerous, breeding in the cliffs both north and south of the North Landing at Flamborough. The House Martins have their nests under the ledges of the cliffs, and a few Swifts in the crevices, whilst on the broken ground at the summit the Rock Pipit breeds somewhat commonly. Mingled with the sea-fowl breed innumerable Starlings and Jackdaws, and a pair or two of Carrion Crows nest annually, the sable hues of this bird, and of its congener the Jackdaw, forming a striking contrast to the delicate plumage of the Kittiwakes. The Hooded Crow has also occasionally remained to nest; and the highest portions of the cliffs are frequented by the Peregrine, but, although the birds are generally present in the season, one of them usually falls a victim to the gun, and they have nt succeeded in breeding for upwards of a quarter of a century until I906, when a pair brought off three young in June.

The immense abundance of sea-fowl on these cliffs, and the ease with which they can be approached by means of boats, formerly led to their merciless slaughter for so-called sport and to supply the exigencies of fashion, and for years the locality was the scene of so much destruction that some of the species were at last utterly driven away, and others greatly diminished in number. This wanton cruelty was-as a matter of fact-the direct cause of the passing of the Sea Birds Preservation Act of I869. The effects of that salutary measure have been most marked. The Kittiwakes, which had become extremely scarce, are now quite numerous. Among the species which formerly bred at Flamborough may be mentioned the Shag, the Black Guillemot, and the Raven, the former of which some few years prior to I844 used to nest annually on the rocks, but now it breeds no nearer than the Farne Islands, and there only singly and irregularly.

The chalk cliffs attain their highest elevation of 436 feet at Buckton Cliffs, declining thence eastward to 250 feet at the point of the Headland, where the lighthouse is situated.

From its favourable geographical situation and bold physical aspect, the Headland of Flamborough is famed as 
affording in the autumn a shelter to the neighbouring bay, thus providing a resting-place for many uncommon birdssuch as the Long-tailed Duck, Common, Pomatorhine, and Richardson's Skuas, the Shearwaters, Grebes, and Petrels occurring annually.

The chalk terminates below Sewerby Hall, and is succeeded by the low diluvial cliffs and sandy beach of Bridlington Bay, stretching for forty-two miles in a bold concave sweep, which terminates in the marram-covered sand-hills of Spurn. This line of coast, the eastern border of Holderness, composed of soft strata which are being steadily wasted away by the action of the sea, is comparatively uninteresting, and offers but little that is worthy of special note until Spurn is reached. Spurn Point, the southern termination of the Yorkshire coast, is connected with the mainland of Holderness by a narrow neck of sand-hills overgrown with marram-grass, a few yards in width, and preserved intact only by constant supervision, and at considerable expense. Were these intermitted the sea would speedily break through the isthmus and join the Humber, as it has done on several occasions. Spurn is ornithologically rich. Birds migrating along the coast, or arriving from the east, find many temptations to linger. The miles of mudflats left bare on the Humber side of the isthmus by every receding tide offer great attractions and a never failing supply of food to various shore birds, and in the spring and autumn are frequented by great numbers of birds of this class. Many of these winter here-such as the Bar-tailed Godwit, Grey Plover, Knot, Turnstone, Sanderling, and others. It is fortunate that Spurn is very strictly preserved, and equally so that this part of the coast is unsuitable for " punting." In winter thousands of duck and many Brent Geese are to be noted on the Humber; while Woodcocks are sometimes observed in very great numbers on their arrival during their migration in the latter days of October.

The Geographical Position of Yorkshire, viewed from a faunistic standpoint, must be regarded as singularly favourable, as it presents a combination of advantages seldom equalled, both as regards the actual geographical range of 
the breeding species and the arrival of migrants and stragglers.

Situate about midway on the eastern seaboard of the British Isles, and directly opposite the European continent, Yorkshire is sufficiently far south to include species whose distribution is of the southern type-such as the Nuthatch and the Nightingale, which find in it the northern limit of their range, while it is sufficiently far north to admit of the inclusion of such species as the Curlew, Dunlin, etc., which here meet with their southern breeding limits.

As regards the influx of migratory birds, a glance at the map of Europe will at once show the advantageous position of the county. Not only does its coast lie opposite that of the Continent, but Flamborough is on the same parallel of latitude as Heligoland, the island which is so renowned for the myriads of migrants which pass and repass it every spring and autumn. The observations made there for many years by the late $\mathrm{H}$. Gätke show that most of the birds passing over Heligoland in the autumn do so in a direction due E. and W. Such a line of flight, if sustained, would land the stream of immigrants upon the Yorkshire coast, and especially upon the prominent Headland of Flamborough, which as a locality productive of rare birds has few equals.

The configuration of the coast materially increases the advantage of the position, which is still more enhanced by the possession of two such points as Flamborough and Spurn. From the Teesmouth the coast-line trends in a gracefully convex sweep in a south-easterly direction to the Headland of Flamborough-a promontory which stands boldly out in the North Sea forty-three miles in advance of the Teesmouth, and fully fifty miles $\mathrm{E}$. of the mean longitude of the coast of Durham. South of Flamborough the coast-line recedes, and after the concave sweep of Bridlington Bay, again advances terminating in the long narrow spit of Spurn, which-projecting sixty-two miles $\mathrm{E}$. of the Teesmouth-overlaps to a considerable extent the coast of Lincolnshire. Those birdsmostly waders and marine species-which pursue a north and south course in their migrations, are in the habit of following 


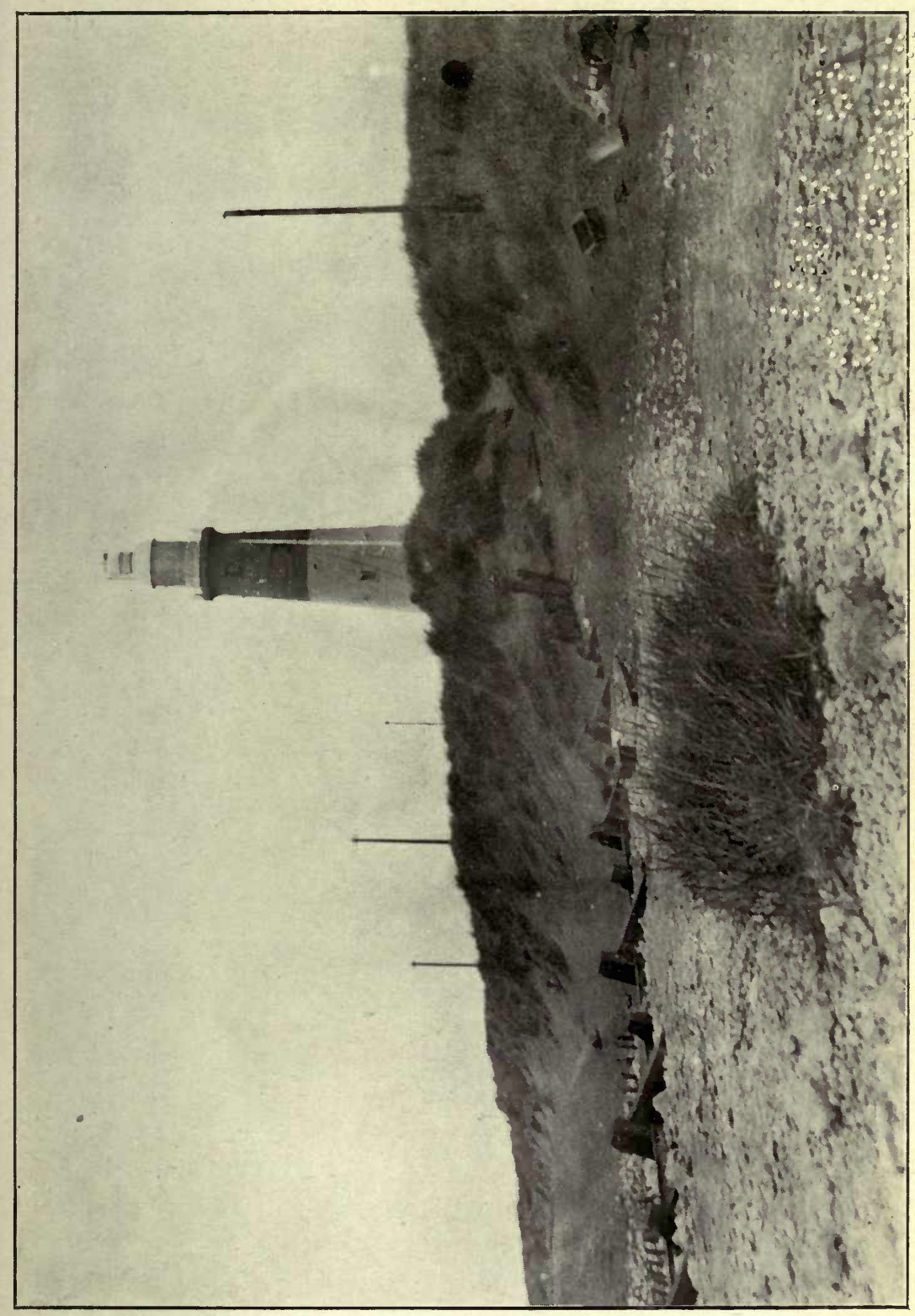

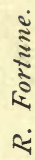

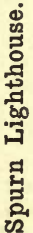



coast-lines, even though the latter keep well out to sea. Such species making their way down the east coast would probably pass the shores of Northumberland and Durham, meeting with no obstruction till their progress is arrested by the promontory of Flamborough, where they are observed-and very often shot. On leaving Flamborough they cross Bridlington Bay, and are either seen at Spurn, or, skirting Lincolnshire, pass on for the north coast of Norfolk-a well situated and rich ornithological county.

Flamborough and Spurn are by far the most favourable points for observing the arrivals of immigrants; and Spurn is considered far to surpass any portion of the Lincolnshire coast, though the tall cliffs of Cleveland probably offer attractions from their height and the secluded nature of the coast. The winds which bring immigrant birds in the greatest numbers in the autumn are those not favourable to their passage. When worn out by a long and adverse journey against contrary winds they drop on the first shore they reach, and the presence of Woodcocks at Spurn and elsewhere on the coast depends on the prevalence of the strong N. or N.E. winds during their passage, which tire them out, and after which they are to be found on the Point in great numbers. On the contrary, should the winds be light and favourable, they simply pass on, dispersing themselves over the country in suitable situations, and very few would be observed on the coast.

\section{MIGRATION.}

For this important section, I have, with his kind permission, adopted Mr. Eagle Clarke's views regarding the movements for the east coast of England, as set forth in his " Digest of Observations," published in the "Report of the British Association," Liverpool Meeting, I896.

Between Britain and Continental Europe travel a host of migrants which are either birds of passage on, or winter visitors to, our shores. The former visit our eastern coastline in spring when journeying to their northern summer haunts lying to the north-east of Britain, and again in autumn 
when returning to their winter quarters to the south of our Islands. The winter visitors are chiefly individuals from the ranks of certain species of the birds of passage which winter in the British area, and emigrate to the north-east in the spring.

In the autumn these numerous migrants cross the North Sea and arrive on the east shores of Britain at points between the Shetland Isles and the Humber or the northern seaboard of Norfolk. All the movements do not cover this stretch of coast-line, but not infrequently such is the case, and as a rule they are recorded from the greater part of the region indicated. Observations prove that these migrants pass to the northward or westward of the Outer Dowsing Lightship, which is situated 38 miles E.S.E. of the mouth of the Humber.

After long and careful study it is decided that these immigrants and emigrants from and to Northern Europe pass and repass between this portion of the Continent and Britain by crossing the North Sea in autumn in a south-westerly direction, and in spring in a north-easterly one,* and that while the limit of their flight in the'north is the Shetland Isles, that on the south extends to the coast of Norfolk. $\dagger$

It is to be remarked, also, as bearing upon this point, that all the species occur on migration in the Orkney and Shetland Islands, but not in the Faroes. $\$$ And, further, all the British birds of passage to Northern Europe are either summer visitors to Scandinavia or are regular migrants along the western shores of that peninsula.

After arriving on our eastern shores, these immigrants from

* The direction varies. It is probably more westerly (in autumn) or easterly (in spring) at the most northern British stations, and southsouth-westerly (in autumn) or north-north-easterly (in spring) at the stations on the east coast of England.

t The formation adopted by the migrants during passage would seem to be an extended line-perhaps a series of lines-whose right wing extends to the Northern Islands and its left wing to the coast of Norfolk.

$\ddagger$ A few species occur in the Faroes on migration, but they are also summer visitors to those Islands and to Iceland. 
the north-some of them after resting for a while-move either down the east coast, en route for more southern winter quarters, or, if winter visitors, to their accustomed haunts in Britain and Ireland. A few occur as birds of passage on the west, which they reach by overland routes across Britain, and then pass southward to their winter quarters.

Intermigration between the South-East Coast of England and the Coast of Western Europe- "East and West Route."

This is one of the discoveries of the inquiry. It has already been shown that the more southern section of the East coast of England does not receive immigrants direct from Northern Europe. There is, however, a considerable amount of migration observed at the lightships south of the Wash. During the autumn, day after day, a stream of migrants, often of great volume, is observed off the coast, flowing chiefly from the south-east to the north-west at the more northerly stations (and this is what particularly affects Yorkshire), and from east to west at the southerly ones, across the southernmost waters of the North Sea. This is called the "East and West Route." From the stations off the mouth of the Thames as a centre, the birds either sweep up the east coast, sometimes to and beyond the Tees (many proceeding inland as they go), or pass to the west along the southern shores of England. These important immigrations set in during the latter days of September, reach their maximum in October, and continue at intervals until November. They are chronicled with wonderful precision and regularity in the returns from stations on the south-east coast of England. They are renewed during winter on occasions of exceptionally severe cold, but the birds then pass to the westward along the south coast.

There are some remarkable features associated with these movements :-

(I) They are frequently observed for several or many consecutive days;

(2) They often occur when there is an almost entire absence of bird-migration on other parts of our shores ; 
(3) The movements appear to be entirely confined to the day-time-usually from daylight to I p.m., sometimes until 3 p.m., thus indicating, probably, the shortness of the passage;

(4) The autumn migratory flocks are chiefly composed of Larks in vast numbers, "Black Crows" (Rooks), Grey Crows, Redbreasts, Goldcrests, Chaffinches, Greenfinches, Tree Sparrows, Starlings, and Woodcock; and during the winter Larks, various Thrushes, and Lapwings ;

(5) And lastly, on certain occasions these immigrants, while passing northward along the English eastern seaboard, actually cross the movements of "coasting" emigrants proceeding southward. At Redcar and the Teesmouth these immigrants are frequently observed coming in direct from the north or north-east (as well as from the east). The arrivals from the north and north-east usually comprise Pipits, Snow Buntings, Finches, and Starlings, and these occur generally in calm weather or during the prevalence of light northerly or north-easterly breezes. In some seasons continuous flights of various Thrushes are seen coming in direct from the sea.

These conclusions have been chiefly based upon autumn data, because the information for that season is more complete and voluminous. When, however, we come to examine the information relating to spring movements, with a view to ascertain how far they corroborate the conclusions so clearly indicated by the autumn chronicles, it is satisfactory to find decided evidence that the birds retrace their flight to the north and east along precisely the same lines as those along which the autumnal south and west journeys were performed. Thus in the spring these birds depart from the same sections of our eastern seaboard as witnessed their arrival in the autumn.

Nearly every season possesses some remarkable feature connected with migration:-thus, for instance, in October I879, Pomatorhine Skuas were reported in enormous numbers ; in I887, Little Stints and Pygmy Curlews were unusually abundant; Grebes were the chief features in I892; Scaup Ducks and Little Auks in I895; Rough-legged Buzzards in Ig03, and so on. 
The system of classification followed in this work is chiefly in agreement with the List of British Birds compiled by the Committee of the British Ornithological Union in 1885 , modified in accordance with Mr. Howard Saunders' Manual (and Ed. I889).

The most important requirements in the compilation of a local fauna are a careful definition of the true faunistic position occupied by each species, and of its distribution and relative numbers within the area treated of, together with some notice of its migratory movements. To these should be added-in the case of the rare species-lists of all the occurrences, with dates, localities, authorities, and such other details as are likely to be of service.

For the purpose of defining the faunistic position of the Birds of Yorkshire, the following terms are employed :-

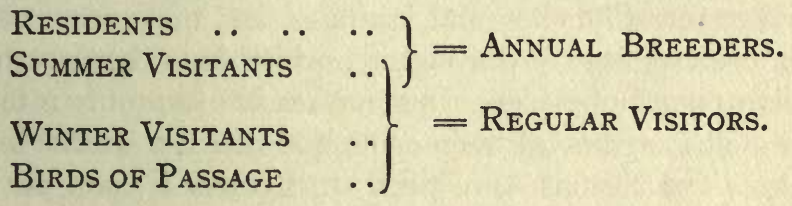

OCCASIONAL OR ACCIDENTAL VisitaNTS ... .. $\}=$ IRREgULAR Visitors.

RESIDENTS are species which are found in some district or other of the county throughout the year, and therein breed annualiy.

SUMmer Visitants are species which appear annually in the spring, remain through the summer for the purpose of rearing their young, and afterwards depart in the autumn.

WINTER VISITANTS are species which appear annually in the autumn, and remain in more or less numbers throughout the winter, departing in the spring for their breeding haunts.

BIRDS OF PASSAGE are species which are observed in the county only on their annual passage to and from their breeding haunts in spring or autumn, or both.

OcCasional Visitants include the species whose appearance in the county is uncertain, but whose occurrencethey being resident in, or more or less regular visitants to, 
other parts of the British Isles-is not improbable, even though their visits may be very few and far between ; and also

Accidental Visitants, mere waifs and strays-species whose geographical range renders their occurrence in Britain quite exceptional and more or less remarkable.

These definitions have been carefully framed, and will, it is believed, be found applicable to all cases. A few general remarks upon them, illustrated by characteristic examples, desirable in order to make their meaning perfectly unmistakable, will be given in proceeding to analyse the Yorkshire fauna.

The avifauna of Yorkshire, compared with that of other counties, stands unrivalled, not only in its numerical extent, but also-a circumstance of much greater significance-in the inherent richness which is shown by the number of species breeding annually within its limits.

Excluding twenty-one species, which have been recorded on the strength of evidence more or less insufficient to establish their claims, the total number of birds on the Yorkshire list is 325. The Norfolk list, given in "Trans. N. and N. Nat. Soc." (I885, I886, I887), included 288 species-to which must be added 27 which have occurred in the county since that time, for the names of which I am indebted to Messrs. J. H. Gurney and Thomas Southwell of Norwich, making a total of $3 \mathbf{1 5}$. The list given in Hancock's "Birds of Northumberland and Durham," published in I874, comprises 268 species. But applying the same rules as are employed for the exclusion of doubtful species from the Yorkshire list, the total is reduced to 266 for Northumberland and Durham.

Since the publication of Hancock's catalogue, however, the following species must be omitted from the list:-the Purple Gallinule, Vi.ginian Colin, Egyptian and Canada Geese, and the Blue-tailed Bee-eater (which latter occurred in Yorkshire, see p. 284). Eleven additional species which have occurred in Northumberland and Durham are:- the Tree Warbler, Icterine Warbler, White Wagtail, Rustic Bunting, Little Bunting, Alpine Swift, Spotted Eagle, Crane, Red- 


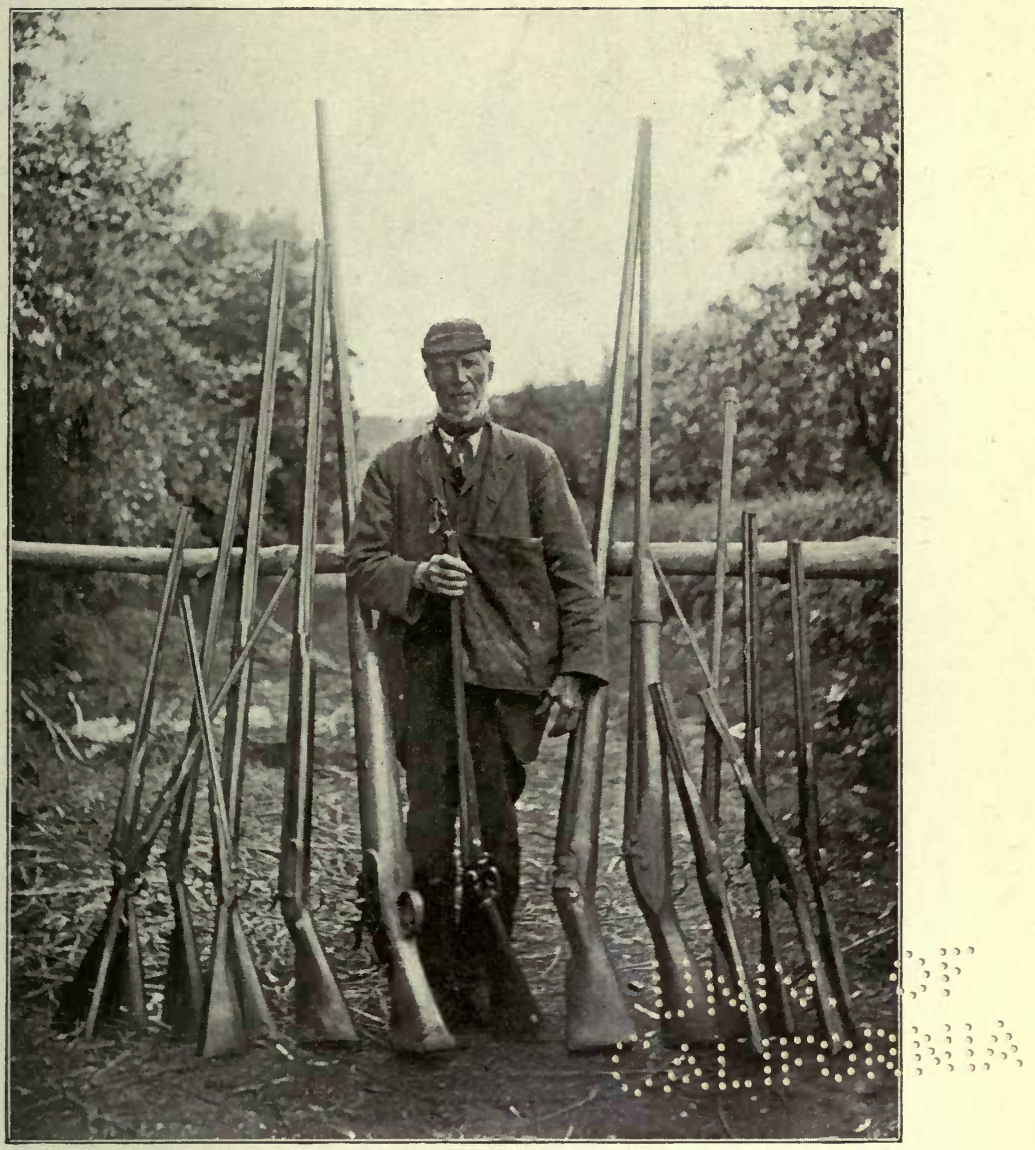

Snowden Sleights, the last of the Yorkshire wildfowlers, with his armoury.

S. H. Smith. 
पदि

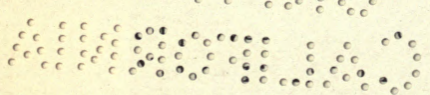


necked Phalarope, Kentish Dotterel, Sabine's Gull. The Mute Swan may also be added to the residents, making a total of 275 .

The species excluded from the Norfolk list are:-Pallas's Shrike, Grey-headed Yellow Wagtail, Red-barred Crossbill (L. rubifasciata), Eagle Owl, Pelican, Great White Heron, Little Egret, Buff-backed Heron, Canada Goose, Egyptian Goose, Harlequin Duck, Rock Dove, Hooded Merganser, Virginian Colin, Green-backed Gallinule, Cream-coloured Courser, Eastern Golden Plover, Sabine's Snipe (variety), Wilson's Petrel, Ringed Guillemot (variety), all admitted on insufficient evidence.

The species which have been added to the Norfolk fauna during the past twenty years include:-Siberian Stonechat, Aquatic Warbler, Pallas's Warbler, Yellow-browed Warbler, White Wagtail, Tawny Pipit, Water Pipit, Red-breasted Flycatcher, Citril Finch, Holboell's Redpoll, Northern or Russian Bullfinch, Two-barred Crossbill, Yellow-breasted Bunting, Great Spotted Cuckoo, Flamingo, Lesser Whitefronted Goose, Ruddy Sheld-duck, King Eider, Allen's Gallinule, Caspian Plover, Siberian Pectoral Sandpiper, Sooty Tern, Mediterranean Herring Gull, White-billed Northern Diver, Great Shearwater.

A comparison of the three avifaunas-based upon a careful analysis in accordance with the faunistic definitions given on page xxxvii-yields the following results :-

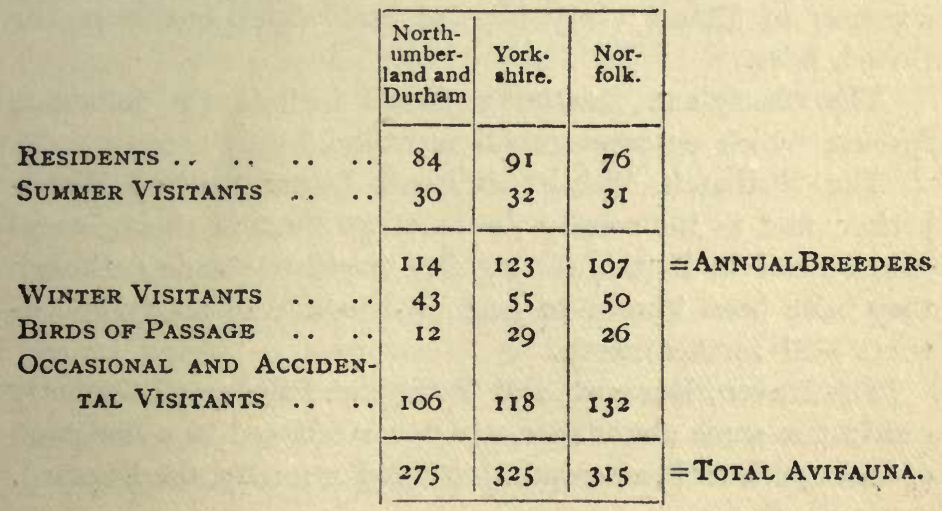


The Capercaillie, although not placed between square brackets, is not included in the list of county birds; if this species is added, the total number is 326 .

This decided superiority of the avifauna of Yorkshire over those of the two maritime districts with which alone it is fair to institute comparisons, is to be accounted for by a combination of advantages. In Yorkshire the favourable geographical position of Norfolk is associated with its physical advantages and those of Northumberland and Durham, and when it is further considered that Yorkshire possesses in addition a much greater diversity of surface, soil, and climate than either, there remains little reason for surprise at the numerical excellence of its fauna. The superiority is not merely one of numerical extent. Casual and accidental visitants cannot be regarded as true members of any fauna, and the ornithological richness or poverty of a district can only be gauged by a comparison of the number of its residents and regular visitants, and more especially of that of the species which breed annually. In this respect too-as the table shows-the superiority of Yorkshire is well marked, demonstrating still more forcibly the advantages possessed by the county which contains the greatest diversity of surface, a diversity ranging in this case from the low carr lands of the E.S.E. to the mountains of the W.N.W., with a coast-line affording both lofty and rugged cliffs and sandy flats, thus presenting every kind of habitat necessary for the presence of almost every type of bird which breeds in the British Isles.

The ninety-one RESIDENT BIRDS include the following species, which deserve special mention:-

The Nuthatch, Wood-Lark, and Lesser Spotted Woodpecker, find in the county the northern limit of their general distribution in Britain during the breeding season; though they have been known to nest occasionally or singly in districts still further north.

The Raven, Buzzard, and Peregrine Falcon, all formerly resident in some abundance, are now restricted to a few pairs of each species still attempting to breed annually, the Buzzard, 
once so common among the crags of the Yorkshire fells, being now the rarest of the three, though it is highly gratifying to announce that it succeeded in rearing young during 1906 . The elegant little Goldfinch, although widely distributed in the county, is extremely local and nowhere numerous. The Sheld-duck is one of the most local birds which nest in Yorkshire, only two breeding haunts being known.

Yorkshire Heronries have greatly decreased during the past century. Those now in existence are enumerated when treating of the Heron.

Of the thirty-two Summer Visitants, the Nightingale, Reed Warbler, Wryneck, Turtle-Dove, and Stone Curlew reach in Yorkshire the northern limit of their annual distribution during the nesting season. The Wryneck and TurtleDove have, however, been known in isolated instances to rear their young in localities further north.

The local and interesting bird, the Pied Flycatcher, is probably more abundant than in any other British county, its breeding haunts being numerous and widely diffused.

The Lesser Tern has a single breeding station. It is somewhat singular that Yorkshire, having this species and the Ringed Plover in abundance, should not be able to include among its breeding birds the larger species of Terns, though it is possible they formerly bred at the Teesmouth.

The fifty-five Winter Visitants do not include many species which merit special mention, but the following are uncommon birds of annual occurrence:-The Great Grey Shrike, Shore Lark, and Rough-legged Buzzard. Some birds of this class, as the Hooded Crow, Crossbill, and Short-eared Owl, have in isolated instances been known to breed in the county; whilst the Tufted Duck may now be classed as breeding regularly.

None of the twenty-nine BIRDS OF PASSAGE admit of much comment. The Pgymy Curlew, Common and Buffon's Skuas, are amongst the least numerous; while the Dotterel still visits the county annually as of old, but in gradually decreasing numbers.

Of the hundred and eighteen Occasional and ACcIDENTAL 
Visitants, the Bearded Reedling, Crested Titmouse, Lesser Grey Shrike, Ortolan Bunting, Chough, and Golden Eagle are noticeable as of exceptionally rare occurrence.

The species excluded from the Yorkshire list are placed between square brackets, in their proper order, and although their claims to a place in the county fauna must be regarded as inadequate, it is quite possible that further investigation may show some of them to have been genuine occurrences.

Two species which have occurred in Yorkshire-the Cuneate-tailed Gull, and Bulwer's Petrel-have not been known to visit any other British locality, and the one last named, until the year I903, had not even occurred elsewhere in Europe.

The Cuneate-tailed Gull is specially interesting from its extreme rarity; and although there is a discrepancy of dates in the two versions published at the time of the occurrence, there is no ground for doubting its genuineness.

[The Blue-tailed Bee-eater, hitherto recorded as a Durham specimen, actually occurred in Yorkshire; no other instance is known of its appearance in Europe.]

Amongst the species which have occurred in this county, of which very few British examples are known, may be cited the Rock-Thrush, Orphean Warbler, White-spotted Bluethroat, Lesser Grey Shrike, Tawny Pipit, Pine Grosbeak, White-winged Crossbill, Eagle Owl, American Bittern, Redbreasted Goose, Ruddy Sheld-duck, Buffel-headed Duck, KingEider, Steller's Duck, Broad-billed Sandpiper, Gullbilled Tern, and White-winged Black Tern.

Treating of Yorkshire birds generally, it may be remarked that many resident birds are to a greater or less extent migratory, shifting their quarters from one locality to another according to the season, as for example the Curlew, which breeds on the high moors in the summer and retires to the shores during the winter, while the Thrush, Pied Wagtail, and others remain through that season in much reduced numbers. Such a circumstance, however, would not in the least militate against the claim of the species to be considered as resident. On the other hand, there are species-true winter visitants, 
though ranked in some county lists as residents-of which a few are found in the district throughout the year, but they cannot be regarded as "residents" in the true sense of the term, for the individuals remaining through the summer are immature and non-breeding birds. These remarks are applicable to (amongst other species) the Turnstone (of which about a score remain at Spurn and Teesmouth throughout the summer), Common Scoter, Common Gull, and Redthroated Diver, all of which are to be found in more or less numbers on or off the coast at all seasons. The fact of individuals remaining in this way is but an exceptional one, not affecting the faunistic location of the species.

In addition to the species at the present time regularly breeding in the county, others must be mentioned as having formerly nested annually, but which are now entirely banished in consequence of persecution, or of the great changes wrought in their former haunts; and instead of being claimable as members of the two classes which furnish the breeding species, they can now only be ranked as Occasional or as Accidental Visitants, of more or less rare occurrence.

Such species include the Kite, which there can be no doubt was once very abundant, but of whose breeding the information is so meagre that only two actual instances can be cited. The three Harriers, though local, were once fairly abundant, the Hen Harrier perhaps, being the least so, though it is now the most frequent as a casual visitant. The Marsh Harrier, on the contrary, is now one of the rarest, whilst Montagu's Harrier was the most widely distributed and the last to linger on the Yorkshire Heaths. The Hobby, eailier in the past century, was regarded as far from uncommon in South Yorkshire, but it is now seldom seen, and only three instances of its breeding in the county can be cited. Although the Bittern was formerly abundant, and doubtless bred in the county, there is no positive record in existence of a nest or eggs having been found. Regarding the Bustard, which formerly had its most northern residence in Britain on the Wolds of Eastern Yorkshire, all the information obtainable has been amassed. The Shag, though now quite unknown 
even as a casual breeder, once nested in some abundance on the cliffs at Flamborough. It is satisfactory to have information so interesting on the high authority of Arthur Strickland. The former breeding of such birds as the Black Guillemot, Grey-lag Goose, Avocet, Ruff, Black-tailed Godwit, and Black Tern, is mentioned under the head of the respective species.

Such are the principal losses which Yorkshire has sustained in breeding birds, the result chiefly of the changes which have taken place in the physical aspect of the county.

To all rules there are, of course, exceptions; and it is therefore not surprising to find that winter visitants, like the Short-eared Owl, Hooded Crow, and Tufted Duck; casual visitants, as the Bearded Reedling, Siskin, Crossbill, Cirl Bunting, and Goshawk, have occasionally, and in isolated instances, remained to breed.

With respect to migratory species, the dates of arrival and departure quoted are mainly those observed on the coast, as more likely to be reliable than observations made in inland localities.

It is of interest to note that in addition to the Cuneatetailed Gull, and Bulwer's Petrel-which are unique as British specimens-there are several other species whose first mentioned occurrence in Britain was in this county. Amongst these are the Waxwing (I68I), Red-breasted Goose (I766, one also occurring near London about the same time), Scops Owl (I805), Red-footed Falcon (April I830), Orphean Warbler (I849), and Lesser Kestrel (I867); and probably also the Eagle Owl, mentioned by Pennant in I768 as having once been shot in Yorkshire.

The species added to the Yorkshire list in recent years are the Desert Wheatear, Barred Warbler, Yellow-browed Warbler, Icterine Warbler, Blue-headed Wagtail, Blueheaded Yellow Wagtail, Lesser Grey Shrike, Red-breasted Flycatcher, Serin, Coues' Redpoll, Greenland Redpoll, Northern or Russian Bullfinch, Siberian Meadow Bunting, [Blue-tailed Bee-eater], Snow Goose, American Wigeon, Redcrested Pochard, Rufous Turtle Dove, Capercaillie, McQueen's 
Bustard, Red-breasted Snipe, Whiskered Tern, Mediterranean Black-headed Gull, Brunnich's Guillemot, White-billed Northern Diver, Levantine Shearwater. It may also be remarked of Tengmalm's Owl that out of the twenty known British specimens no fewer than twelve have occurred in this county, and three of these Mr. Clarke has had the personal pleasure of adding on the most unquestionable authority. In addition to this, numerous occurrences of rare species-which have hitherto remained unpublished-now appear for the first time in print.

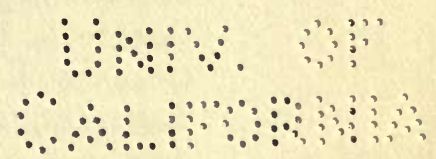





\title{
THE BIRDS OF YORKSHIRE.
}

\author{
M I S T L E - T H R U S H.
}

Turdus viscivorus $(L$.$) .$

Common resident, generally distributed. An influx of arrivals from the north occurs in autumn, some of which move further south, while others winter.

The earliest mention of this as a Yorkshire bird is contained in the Appendix to the Rev. John Graves's " History of Cleveland," dated 1808.

Thomas Allis, in his "Report on the Birds of Yorkshire," prepared for the York Meeting of the British Association, in I844, wrote of this species as follows :-

Turdus viscivorus.-Missel Thrush-Common over the county.

In addition to being a very generally distributed and abundant resident, flocks of immigrant Mistle-Thrushes arrive on our coasts in the autumn from Northern Europe, where the bird is to some extent a summer visitan $:$ at Redcar on 4 th October $\mathrm{I} 884$, at 8 a.m., flocki were "coming in," the wind being N.W. and fresh (Sixth Migitation Report, p. 4I); and on IIth October I885, there occurred a great "rush" at Teesmouth (Seventh Migration Report, p. 38). They are less noticed at the Light Stations than any other of the genus, being frequently confounded with Fieldfares, and both species indifferently designated as "large grey thrushes." Some of these immigrants no doubt remain with us during the winter months, and may leave us for a more southerly clime on the first really severe weather. 
Our indigenous birds however seem to be of a strictly resident turn, frequenting as a rule the vicinity of their chosen haunts, except in very severe seasons, when they are compelled to migrate southward. In the exceptional winters of 1878-79 and $1879-80$, their numbers were very materially reduced, and for the following year or two their diminished ranks were the theme of many notes. They quickly recovered, however, and in two or three years' time were again plentiful. Again in 1894-95 they perished in thousands, and were almost exterminated in the East Riding. Now they are quite as numerous as ever.

This bird nests in a variety of situations, being equally at home and well-known in the more secluded gardens around our large towns, in orchards and woodlands, in the alders bordering our upland streams, in the fir plantations which so frequently fringe the moors, while in some instances nests have been found on the very moorlands themselves, occupying a place in a stone fence (Nat. I888, p. 264, and 1889, p. 52). In May I903, Mr. James Backhouse noted a nest on Penyghent at $135^{\circ}$ feet elevation, and on the I4th of the same month, Mr. H. Lazenby reported one on the ground on a Wensleydale fell side; on 6th April I897, I saw one containing three eggs, in a low branch of a holly tree at Potto Grange, in Cleveland, within five feet of the ground; in I903 a nest, with young, was found in a standard plum tree in the Harrogate Hydro gardens, four feet from the ground; several were seenne in that locality, and also at Beverley, in even lower situations, some being at no greater elevation than two feet. Theispecies is certainly double brooded, and, in an orchard at Beverley, the same nest has been used for both broods; in the last week of March I87r, an old bird was found sitting on four eggs, which hatched early in April, and on the Igth of May the nest again contained four more young birds. The earliest nest known to me had eggs in the first week of March, though at Beverley a hen bird was sitting on eggs on 27th February I903.

The gizzards of young birds examined by Mr. George 


$$
\begin{aligned}
& \text { נa }
\end{aligned}
$$

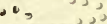

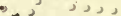

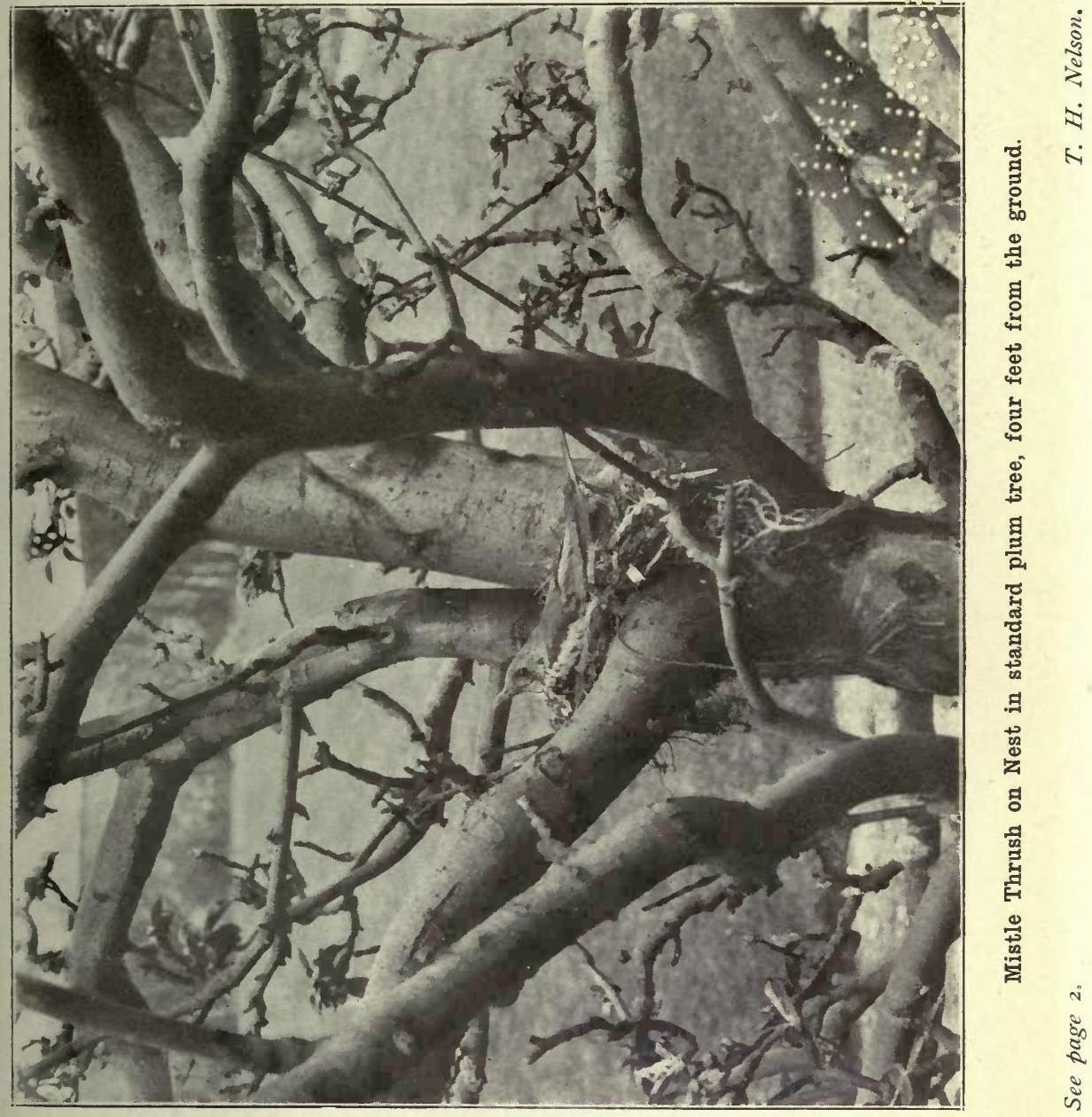



Roberts of Lofthouse, near Wakefield, contained caterpillars, flies, elytra of beetles, and numerous "minute white round bodies resembling the eggs of insects." After the breeding season the birds pack, and on the occasion of the Hawes Meeting of the Yorkshire Naturalists' Union on 28th June I884, a large party was observed swooping down the fell side, uttering their characteristic "churring" note. These gatherings have, in not a few instances, no doubt been reported a : early Fieldfares.

A variety obtained near Patrington, some few years ago, formerly in the possession of Mr. Philip W. Loten, and now in the collection of Mr. Marshall of Taunton, has the ground colour of the feathers white, while the spots and other markings are of the usual tint.

This bird is very generally known as the Storm-cock, or Stormy. In Cleveland, from its early song, it is dubbed Jeremy Joy (January Joy), and in some parts Wood Throstle, Rattle Thrush, and Golden Thrush; in parts of the East Riding it is Charlie Cock; in Craven it is called Churcock and Charlie Cock; at Sedbergh, Shercock; and in Teesdale, Pickie. Old Yorkshire names are Hollin Cock (Zool. I848, p. 2290), and Norman Thrush (Swainson).

\section{SONG THRUSH.}

\section{Turdus musicus $(L$.).}

Resident, common, generally distributed; less numerous in winter. In autumn there is an influx of migrants from the Continent, some of which move southward later.

Probably the earliest mention of the Thrush, as a Yorkshire bird, was made by Marmaduke Tunstall, F.R.S., a Yorkshireman and an ornithologist of repute, who resided at Wycliffe-on-the-Tees, in the I8th century (I743-I790), and 
who mentioned this species as "singing in the north in December."

Thomas Allis, in 1844 , wrote :-

Turdus musicus.-Song Thrush-Generally diffused.

The Thrush is a resident species, abundant in most districts in the summer months, quite the reverse during the winter, and though the numbers were markedly reduced by the Arctic winters of $1878-79$, and I879-8o, and again in $1894-95$, it is now quite as numerous as before. In the wilder portions of the county it becomes scarcer, and while it is almost unknown on the moorlands, its occurrence in Nidderdale has been recorded up to at least twelve hundred feet. The Yorkshire Thrushes are partially migratory; on the approach of autumn the great majority move south, many, however, stay with us during the drear months, along with immigrants from the north. The resident birds enliven us by their cheery song during the finer days of winter, and until the main body returns in the earliest days of spring.

This bird, being a summer visitant to Scandinavia, migrants from the north, as we might naturally expect, arrive on our shores during October and November (see British Association Report), along with Fieldfares and Redwings. Two were captured on a vessel, fourteen miles off Whitby, on 7 th October 1833 (Edward Blyth). The British Association Migration Reports contain many entries, too numerous for recapitulation here, respecting this autumn movement, from which it may be gathered that the great "rushes" of these birds occur in October, and generally about the middle of that month. At this season they are sometimes found dead below the lighthouses; several were killed against Flamborough light in the autumn of I88S. The winter migration, due to the severity of the weather, occasionally extends beyond the usual period, and almost overlaps the return passage; thus in I892 I noticed Thrushes migrating from N.E. on the $24^{\text {th }}$ of January. In the spring these hyperborean Thrushes again visit us on their northward passage, and at Flamborough Lighthouse, on the early 


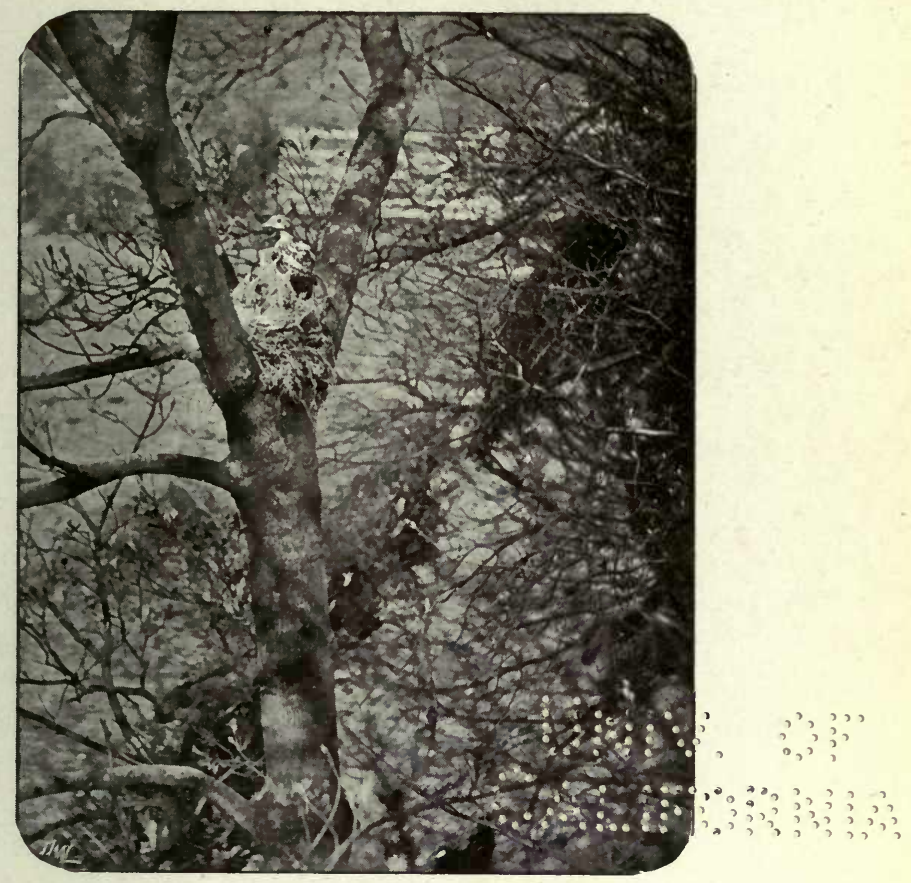

Mistle Thrush at Nest, feeding young.

H. Lazenby.

See page 3. 
at $\because 4$

aीmo 
morning of I2th March IS77, the weather being hazy, several struck the lantern; again on 27 th April I883, one was killed; on the 7 th May of the same season four more were immolated, while on 7-8th February I899, many perished at the same light station.*

Nidification commences early, for it is not an uncommon event to find young birds some days old early in April, and nests and eggs have been seen in the county much earlier, while during the abnormally mild winter of 1843 , a nest with three eggs was found near Campsall, in South Yorkshire, on Christmas Day (Schroeder's “ Annals of Yorkshire," I85I, p. 350); in I900, one with two eggs was recorded at Pannal, near Harrogate, on $I 7$ th December; and another, containing a complement of four, was discovered at Yearby, near Redcar, on I8th February I904. The latest date known to me for eggs is the $27^{\text {th }}$ July; though young ones, about ten days old, were noted near Bradford on 28th August 1905. Occasionally eggs marked with large red spots, or rather blotches, are obtained; spotless examples are frequently found, and a clutch of the unusual number of eight, was described by Mr. Leonard Gaunt of Farsley (in litt. 2Ist April Igor).

The Throstle, as it is locally called, is double-brooded, and sometimes rears both broods in the same home. This species, like the Blackbird, has been known to nest on the ground, and several instances of this departure from its usual habit are known in Yorkshire; a most unusual number was found in the spring of I903, the long continuance of gales in the early part of the year having probably induced the birds to select low situations. A curious nesting site is described in the Naturalist (I876, p. I55), an old tea-kettle hung on a branch in a plantation near Huddersfield having been selected; but a yet more unusual position was chosen at Netherton, near Huddersfield, on a ledge of an iron pillar,

* Mr. W. Eagle Clarke has published a very complete account of the migration of this species in the Report of the British Association for I 900, pp. 404-409. 
in the front of the Station, where trains and passengers were continually moving by; here a brood was reared in I900, and the birds built again in the following year, and succeeded in again rearing young (op. cit. r900, pp. I64, 240, and I90I, p. 352). The late Canon J. C. Atkinson of Danby, gave an instance in the Zoologist (1875, p. 4456), of a Thrush's nest lined like that of a Blackbird.

A variety obtained in Holderness had the markings normal, but the general colour of a " rusty-buff or yellowish sandy hue throughout" (op. cit. 1877, p. 256); and in the Burton Agnes collection there is a similarly coloured example shot by $\mathrm{Sir} \mathrm{H}$. Boynton at Barmston, in 1876 .

The local names are not many or varied-Throlly, Throstle, Thrushie, and Mavis being the only ones in use.

\section{REDWING. \\ Turdus iliacus (L.).}

Regular winter visitant, but variable in numbers; generally arrives from early in October to the end of November.

The earliest mention of this species, as a Yorkshire bird, appears to be in I79I, in the Allan MS. in connection with the Tunstall Museum, where it is stated that Wind Thrush is a name given to the bird in this county. ("Fox's Synopsis," p. 63.)

Thomas Allis, in 1844, wrote :-

Turdus iliacus.-Redwing-Frequent in winter.

Though there are not a few records of parties of Redwings arriving in the county during the latter days of September, the early part or middle of the following month must be regarded as the usual date for its advent; many appear in October and in November, along with Fieldfares; later in the year, owing to adverse climatic conditions, emigrations take place in December and in January. On the $7^{\text {th }}$ 


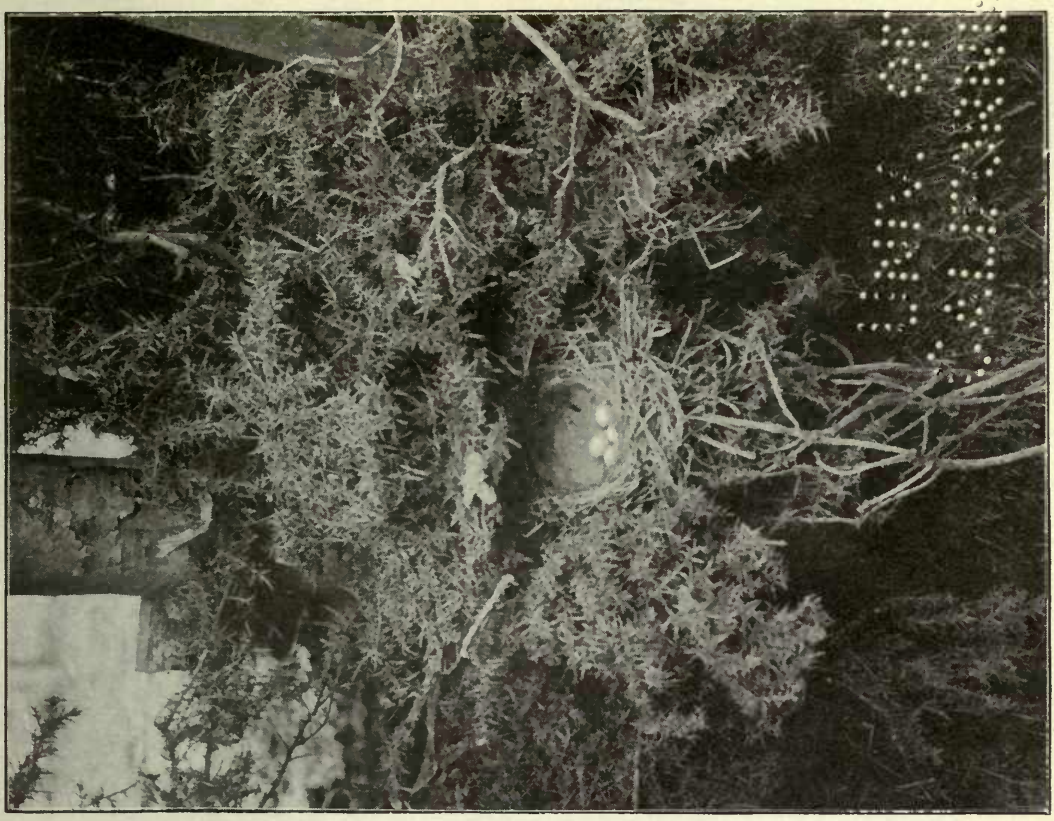

$\frac{0}{3}$
$\frac{1}{3}$
2
2

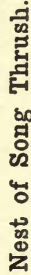

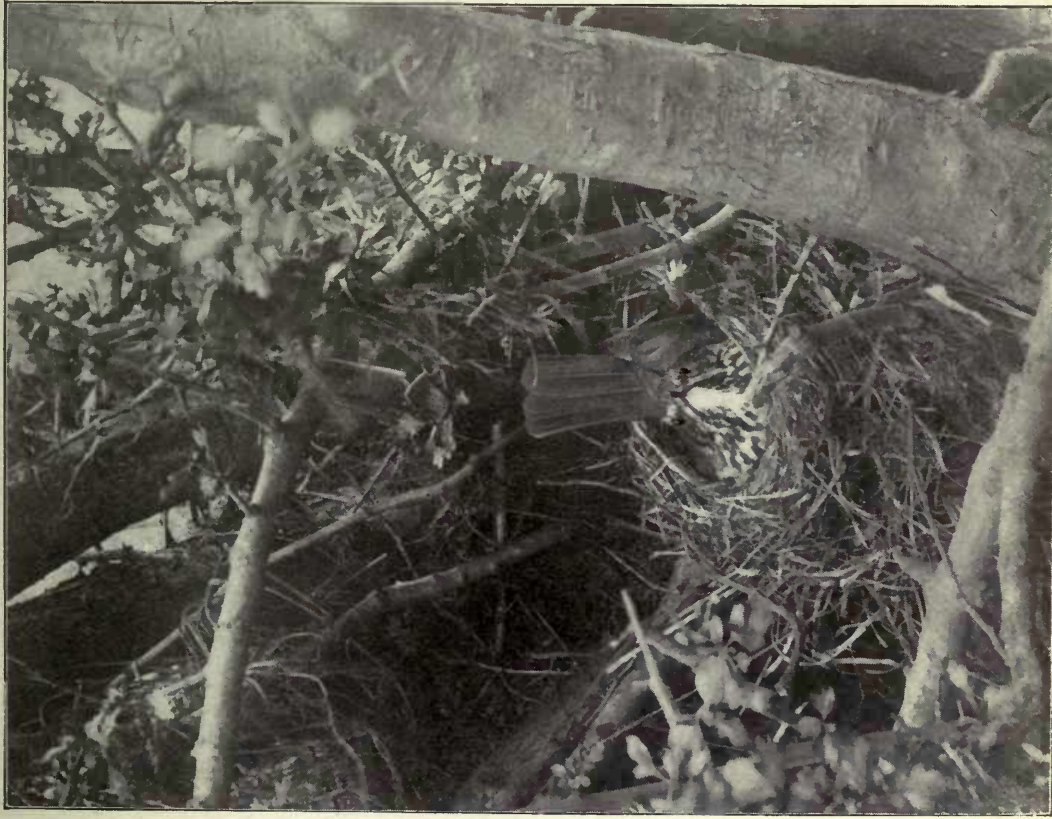

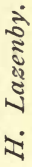

总

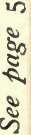




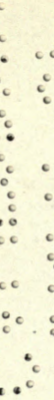


of the latter month, in 1892 , I noticed a passage of Redwings at Redcar, during a north-east gale, with heavy snow, and many were reported at Flamborough light on the 7 th and 8th February 1899. In 1879 the various migrations of the Redwing extended on the east coast over 65 days, from the Irth September to the 2nd December; in I880, from the 6 th September to the 29th October 54 days; and in I88I it extended over three months. There were great flights with other small birds in October $\mathbf{1 8 8 2}$, but in the year 1885 the greatest " rush" ever known occurred. It took place in two flights, from the I5th to the I7th October, night and day, and again from the 7 th to the I7th November (Sixth Migration Report). At Redcar, on 21st to 23rd October I884, there was an incessant day and night migration. I heard flocks passing overhead during the small hours of morning on each of these dates, and saw many crossing between 9 a.m. and dusk. Rushes took place also at Spurn and Flamborough in October 1896 and 1898 . Like others of their genus, they are sometimes killed by striking against the lanterns at the lighthouses. After their arrival they become generally distributed and common over the county throughout the winter, save in very severe seasons, when they either move further south or perish in great numbersthis species being the first to feel the pangs of hungerand become conspicuous by their absence.

During the excessively severe weather in December 1878 , there was an immense migration of these birds on the Cleveland coast. A heavy snowstorm, with a gale from the northeast, commenced on the 9th, and flocks of Redwings, with a few Fieldfares and other small birds, passed over all day, going north-west, both along shore and over the sand-hills. This passage continued almost without intermission, while daylight prevailed, until the I2th, when the Redwings became fewer, and Fieldfares predominated until the 2Ist, then the migration ceased. Thousands succumbed, or were so pinched by hunger that they actually entered the busy thoroughfares of Leeds and other towns in search of food. 
At Flamborough they were noticed daily resorting to the shore at low water to search for food among the seaweed and refuse fish, and when the tide rose they sought shelter at the base of the cliffs, where scores perished.

Their sojourn extends until April, and the 27 th of that month is my latest date for their departure. The Redwing is reported to have nested in the county on several occasions, and although it is to be regretted that the evidence is not conclusive, it is yet of such a nature as to be worthy of recapitulation. John Hogg, in his "Catalogue of Birds of N.W. Cleveland and S.E. Durham" (Zool. I845, p. I056), stated, "Mr. J. W. Ord has informed me that a Redwing's nest with four eggs was found at Kildale in I840. John Bell, Esq., M.P., has two of those eggs, and the other two are at Kildale Hall, in the possession of E. H. Turton, Esq."

Under the heading of "Nesting of the Redwing in North Yorkshire," Major H. W. Feilden wrote (op. cit. I873, pp. 34II-I2): "The following note to an article on Natural History, by the Rev. J. C. Atkinson, appears in the People's Magazine for December I872, p. 379: 'I obtained four eggs about ten years ago from a nest in Commondale (North Yorkshire), about which, from the circumstances connected with bird, nest, and eggs, there could be no reasonable ground of doubt as to their origin. Only I did not see the bird myself.* I received the eggs and the account from a person whose father had been a gamekeeper, and whose own habits have led him to act often as amateur keeper, and had made him familiar with various birds and animals. Hence the eggs, when shown to some metropolitan egg authorities, were pronounced not Redwing's but Ring Ouzel's eggs. However, during the past spring a Redwing's nest and eggs, together with the parent bird herself, have been obtained at Glaisdale, another district (originally of the same parish to which the Commondale mentioned above belongs); the person meeting with them being a very competent ornithologist and ex- 


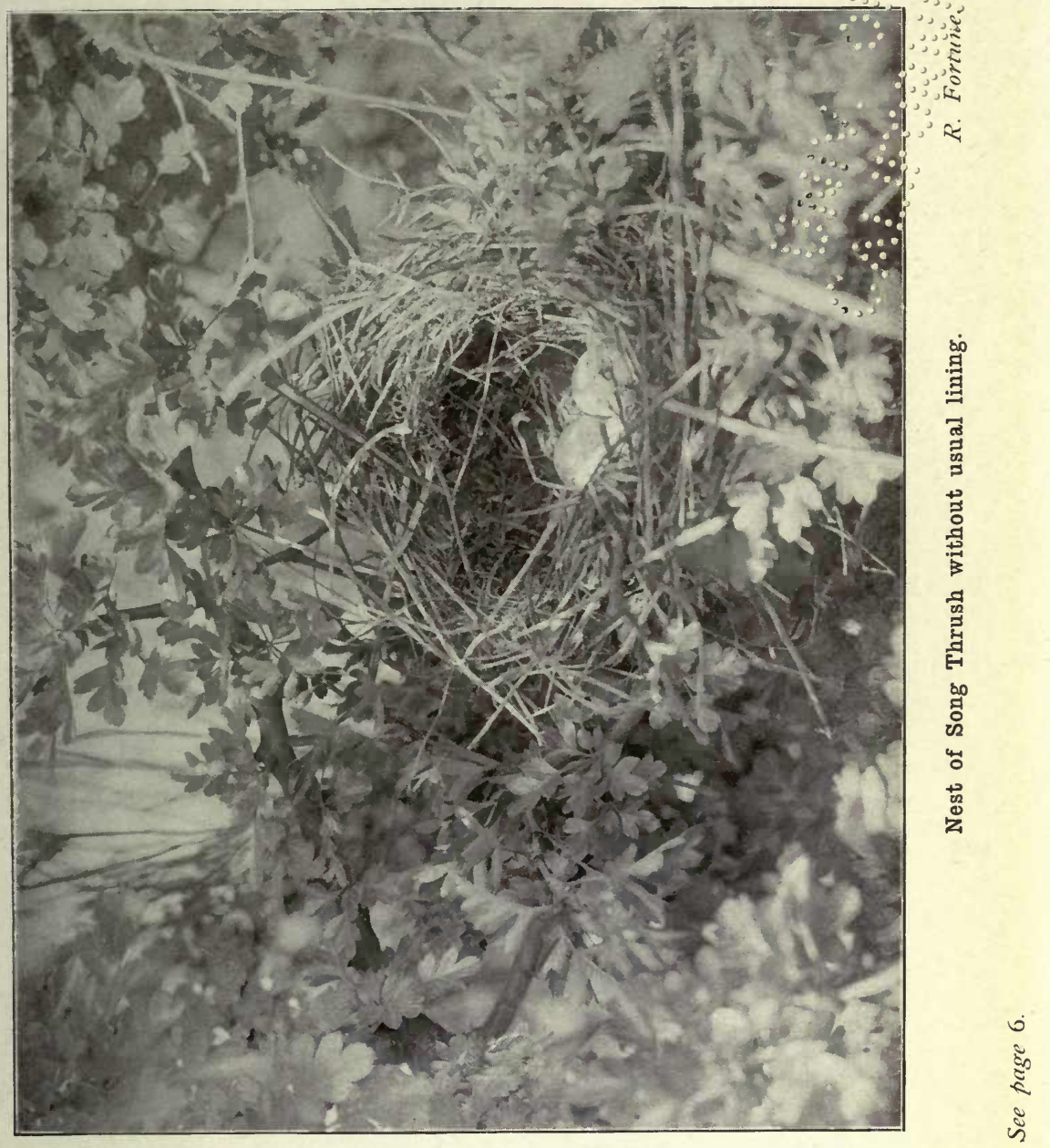




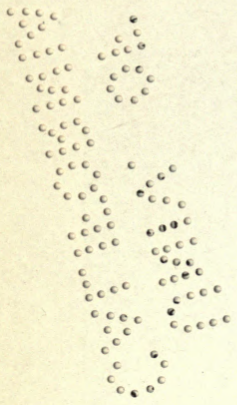


perienced egg-collector. The fact that the Redwing does occasionally breed in North Yorkshire, and I think not so very unfrequently, is an interesting one, and therefore not unworthy of record here.'"

A buff variety, with light grey markings, and the red patch of a paler shade, was procured by Mr. Alwin S. Bell, near Scarborough, about I855 (Zool. I870, p. 2343), a white one, with red flanks and axillaries, about $I 89 \mathrm{I}-92$, is recorded at Ackworth; a pied specimen at Monckton (Nidd.), and a white one in the Beverley district in October 1903.

In Cleveland it is locally known as Swinepipe, from its note. Wind Thrush is a Yorkshire name given by Allan in I79I (Fox's "Synopsis," p. 63) ; in the Western Ainsty Redwing Felfer is in use; and Felfer at Ackworth and Scarborough, being, doubtless, confused with the Fieldfare. In Staithes and Loftus district it is called Redwing Throlly.

\section{FIELDFARE.}

Turdus pilaris (L.).

Winter visitant, common ; generally arrives in October and November, and remains in spring until April, or, occasionally, the middle of May. Its numbers vary greatly in different seasons.

Historically, as a Yorkshire bird, the Fieldfare claims ancestry of great antiquity, for we find in the ordinances as to the price of food in the city of York in the year 1393the I6th year of the reign of King Richard the Second-that the "price for twelve Fieldfares be twopence."

Thomas Allis, in I844, wrote :-

Turdus pilaris.-Fieldfare-W. Eddison says: "I am well assured that both this winter visitant and Iliacus very frequently stay the year round in several places near Huddersfield, and that he has many times seen them in the summer months; mention is also made of its breeding in Yorkshire by W. Yarrell. It bred last year at Lepton, near Huddersfield." 
It is hardly necessary to remark that there is not a particle of evidence as to the Fieldfare ever having nested in the county; indeed, all we know on the subject is contained in Allis's statements, quoted above; so that what Tunstall said of this species one hundred and twenty years ago is true to-day-namely, "I have known them in the north as far as the latter end of March, yet never heard them sing, or that they built there" (Tunst. MS. I784, p. 63).

As an abundant and widely distributed winter visitant, it arrives in flocks, usually during the latter half of October and in November, and remains until April. The young of the year come first, the old birds in separate flocks, and later in the season. In some years the autumn immigration commences as early as the end of September, as in 1875 for instance, and occasionally odd birds are noted early in that month. In I903 I saw one crossing the Tees Breakwater on the 22nd September, while Mr. Boyes has seen one in summer, though this was probably a bird unable to migrate with its fellows in spring. Passages southward in search of retreats from severe cold take place in December, January, and even in February. On 24th January I880, numbers arrived on the Holderness coast; nor was this late movement confined to the east coast of Britain, for Herr Gatke informed Mr. Cordeaux that from the 2 Ist to the 24 th of that month quantities crossed Heligoland from the east. Like its congeners, those which remain with us over severe seasons suffer much, and during the winter of $1879-80$ it was very scarce after the Arctic weather of the preceding year, when there occurred a most extensive immigration from more northern latitudes, which I was fortunate enough to witness. It commenced on 9th December, with a snowstorm and N.E. gale of exceptional severity; a few flocks of Fieldfares passed with Redwings (see p. 6), and increased in numbers day by day, until the I2th, when the Redwings became fewer and the Fieldfares predominated; this movement along shore and over the sand-hills continued daily, and all day, gradually 
becoming less, until the 2 Ist, when the immigration ceased (Zool. 1879, p. 212).

Several references to this bird are contained in the Migration Reports which need not be enumerated here, though it may be mentioned that in I 880 migration extended over eighty days, from $9^{\text {th }}$ September to $27^{\text {th }}$ November, and in the following year from I4th September to 30th November. Extraordinary " rushes" took place on $5_{5}$ th to 16 th October and 8 th to I2th November I885; 27 th to 28 th October I89I, both at Spurn and Flamborough; on Ioth November 1899 at Redcar and Flamborough, when hundreds of thousands came in large flocks; and I4th November I900. Late movements, since I880, were noted on IIth to I4th December I882; I3th to I5th January I883; 4th February I893, when they swarmed at night round the lantern at Flamborough; January I894; and, on 23rd December I9oo, there was an enormous immigration at Redcar, in flocks of from five to eight in number, with a strong S.W. wind and keen frost; they were passing from daylight to dark, evidently fleeing before a severe snowstorm, which broke over Cleveland the same night.*

Prior to leaving for its breeding haunts, the Fieldfare in some districts assembles in great numbers, and there is a small plantation bordering the stream traversing a secluded dell in Washburndale where in mid-April Mr. W. Eagle Clarke has seen hundreds, and heard them incessantly chattering for several days before departure. During this conclave they are very restless, taking short flights en masse, but returning after a short absence. There are many instances of this bird's stay during May, some up to the middle of that month.

In hard winters this species feeds on Swede turnips on the high Wolds of the East Riding.

Several records exist of pied specimens having been

* A very complete history of the Fieldfare's migratory movements is written by Mr. W. Eagle Clarke (see Rep. Brit. Assoc., 1902). 
seen or captured in the county. A light buff variety at Wakefield was noted by the late William Talbot in 1873 , and an example of a mottled plumage, as though sprinkled with snow, was obtained at Easington, Holderness, in December 1894 .

A general vernacular name is Fellfer, Felfer, or Fellfor; on the East Riding Wolds it is Blueback; in Teesdale, Feldy; at Sedbergh, Felfit; in Cleveland, Fenty, or Felty Fare; at Redcar it is known as Tom Piper ; in Staithes and Loftus district it is Slate-backed Throstle; while Bluetail is a local name in vogue in several west and North Riding districts; Bluerump about Doncaster; and Chucker is a term applied to it in Nidderdale.

\section{WHITE'S THRUSH.}

Turdus varius (Pallas).

Accidental visitant from Eastern Asia, of extremely rare occurrence.

The peregrinations by which this species reaches Britain are very remarkable. A summer visitant to, and breeding in, Central and Eastern Siberia and Northern China, White's Thrush winters in South-Western China, Southern Japan, and the Philippine Islands. And since we have chiefly authentic evidence of its occurrence in Yorkshire in the fall and winter, we may conclude that this species has journeyed very far west during the autumn passage, crossing half Asia and the whole of Europe, instead of undertaking the normal and much shorter south-east route.

This bird has been recorded to have occurred on six occasions in Yorkshire. One of these is considered to be open to doubt-namely, that mentioned by the late Canon 


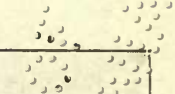

jo

,3, के,

15

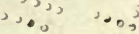
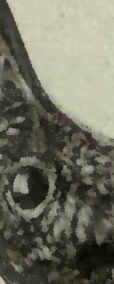

Qxy
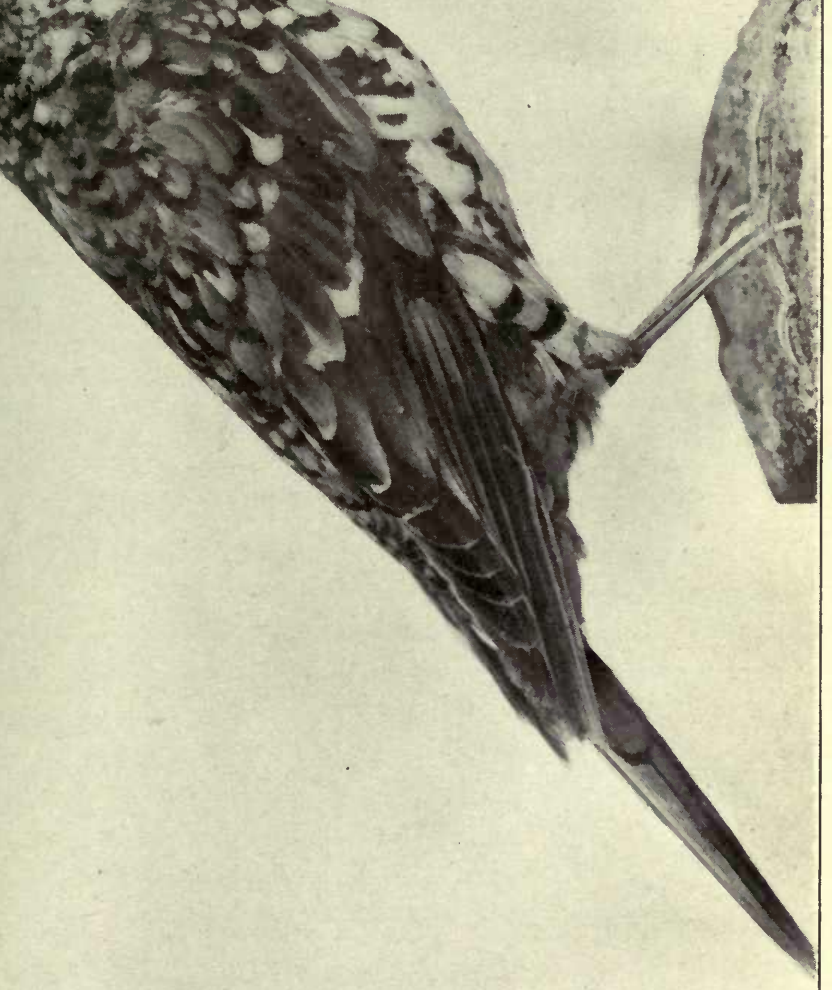

8ั

ڤั 

Atkinson as observed in the spring of $I 870$ on his. lawn at Danby-in-Cleveland, which he carefully examined on two occasions with a binocular glass, and mentioned in the Zoologist (1870, p. 2142), and at greater length in "Forty Years in a Moorland Parish" (p. 328), as this species. We may, however, agree with Professor Newton in his opinion (Yarrell"British Birds," i. p. 252), that "this well-known observer is hardly likely to have been mistaken."

There is evidence that an example, said to have been shot at Almondbury Bank, near Huddersfield, in I864, was not a genuine Yorkshire bird.

In the latter part of November 1878 , the late Martin Simpson, curator of the Whitby Museum, received a bird of this species, which had been killed by coming in contact with the telegraph wires near that town (Zool. I880, p. 68). The specimen is now in the Whitby Museum, where I have seen it.

During the first week in November I88r, a White's Thrush was shot at Rimswell, near Withernsea, in Holderness, by Mr. W. J. Tuton, who mistook it for a Woodcock as it rose from a low, thick hedge close to him. This individual was formerly in the collection of Mr. R. T. Burnham of Rimswell, who supplied Mr. W. Eagle Clarke with these particulars, and gave him several opportunities of examining his beautiful specimen, which is now in the York Museum.

One was obtained at Waplington Manor, near Pocklington, early in January I882, by Mr. Frank Leeman, in whose. possession it is, being recorded by Mr. J. Backhouse (Field, I882, p. 20r, and Zool. I882, p. 74).

Finally, on the I8th December I902, one was taken at Luddenden Dean, Halifax, and brought in the flesh to the curator of the Belle Vue Museum, the late Mr. J. Cunningham, whose opinion as to its identity was confirmed by Mr. A. Crabtree, F.L.S., and the particulars thereof communicated by him to the Halifax Naturalist, February I903. The specimen is now in the Halifax Museum.

A peculiarity of this species which may serve to distinguish 
it from other allied forms, is that it possesses fourteen tail feathers, instead of twelve, which is the normal number in birds of this genus.

\section{BLACKBIRD.}

Turdus merula (L.).

Resident, common, generally distributed. An influx of immigrants ozcurs in autumn.

The first allusion to this species in Yorkshire is by the celebrated Marmaduke Tunstall ( 1783 ), who referred to pied specimens of Blackbirds in his possession. (See varieties at end of this chapter.)

Thomas Allis, r844, wrote:-

Turdus merula.-Blackbird-Equally common with the above (Song Thrush). A male Blackbird paired this season with a female Thrush in my own aviary (York). The Thrush built the nest and laid o re egg, when things were put a stop to by a Wood Pigeon, which had $f$ ormerly built its nest in precisely the same place.

The Blackbird is a common and generally distributed resident, occurring at a considerable elevation in the moorland and fell districts. The late Canon J. C. Atkinson observed that foraging parties of these birds go up from the dales to the moors in autumn, and picnic there for ten days or a fortnight, while the bilberries are ripe ("Moorland Parish," p. 32I). In addition to this it is a winter visitant, or an autumn bird of passage, immigrant Blackbirds arriving on our coast at dates varying from late September to the end of November; but they are usually most abundant during the last fortnight of October, when, along with Fieldfares and Redwings, they frequently perish during fog at the 1:nterns of our sea-marks, for their migrations are chiefly 
undertaken during the hours of darkness, though, on Igth October I903, a continuous passage took place from daylight to dusk, the birds coming direct from the north-east. The great majority of these migratory birds are young males of the year, with dark coloured bills, but on 24th January I880, there arrived on the Holderness coast many fine old cocks, with great numbers of Fieldfares, probably from Northern Europe. After their arrival, these birds appear to be much more fatigued by their passage than their congeners, and shooters on the coast have on several occasions had to avoid treading them under foot. On their return passage in the spring they are not often reported, but during the early morning of I2th March 1877 , a few were killed against the Flamborough Beacon, together with several Fieldfares. These birds had, no doubt, wintered to the southward of these Islands, and were on migration to their native haunts; the evidence in favour of this supposition is strengthened by the fact that every spring a similar movement is observed in the Teesmouth area early in March; on the I5th of that month, I904, a cock Blackbird came in from eastward at Redcar, early in the morning, whistling merrily as he flew, and examples are occasionally picked up dead on the beach, having probably perished at sea and been washed ashore. Observations from the East Coast, communicated to the British Association Migration Committee, prove that unusual "rushes" took place in I880, on 20th November; in I883, on 2Ist September, 28 th to 3 Ist October, and 2nd to 8 th November; and in I886, on $4^{\text {th }}$ to 8 th November. In addition to these, I noticed in 1889 a constant stream of immigrants passing Redcar from midOctober to mid-November, and great numbers arrived in October I895, I898, and I903, in the last instance coming directly off the sea. Other evidence indicates that they usually leave us during February and March.

In the exceptionally severe winters of $1878-79$, I879-80, and in $1894-95$, their ranks were greatly thinned, thousands perishing of hunger, and in the springs succeeding these years the absence of Blackbirds from their usual haunts 
was very noticeable. They quickly recovered, however, and are now quite plentiful again.

An interesting note on the nidification of this bird appears in Neville Wood's Naturalist (1837, ii. p. I66), where a pair is recorded as having the nest beneath the leaves of a large brocoli in the garden at Wentworth Castle, near Barnsley. This nest was completely buried by the snow, which fell during the first week of April 1837, but the parent birds formed a tunnel beneath the snow over two feet in length, and through this gained access to their young. A nest at Masham, in I883, was found in a tuft of grass in a boggy field, and in the spring of 1903 an unusual number of nests of both this bird and the Song Thrush were built on the ground, a probable explanation being that, owing to the gales which prevailed in March, the birds sought low situations. Many other instances of extraordinary breeding sites might be quoted, this species being of an aberrant nature as regards nesting; but perhaps of more interest is a case of dual occupation at Firby, near Kirkham Abbey, where a Blackbird was discovered sitting on four of her own eggs and three belonging to a Thrush (Field, IIth May I90I). A yet more extraordinary departure from the ordinary nesting habits is related by the late Canon Atkinson, who found a nest, which to all intents and purposes was that of a Thrush, with eggs of an undoubted Blackbird type, and it was not till the fourth egg was laid that the mother bird began to line the nest, that then became typical of its owner ("Moorland Parish," p. 342). In the last week of December, in the unusually mild season of 1854 , a nest with four eggs was found at Sneaton Thorpe, near Whitby; and curiously enough, at Loftus-in-Cleveland, a nest and three young were seen on Christmas Eve, I865 ; while near Hawsker, in the last week of December I902, a Blackbird was disturbed while incubating three eggs; both these latter places being in the vicinity of Whitby, one on the north and the other to the south. Spotless eggs and others of a very pale colour are sometimes noted, and a clutch resembling those of a Song Thrush was discovered at Danby (tom. cit. p. 343); 
two in my collection are heavily marked with a zone of blotches at the broad end, the remainder of the shell being almost without spots.

The records relating to pied Blackbirds are very numerous, this species being more subject to variation of plumage than almost any other British bird except the House-sparrow. Marmaduke Tunstall of Wycliffe, in the North Riding, writing in 1783 , remarked: "Have had many pied Blackbirds, which seemed healthy, stout birds, and sung lavishly; had once one quite white, but always appeared sickly and cramped, and lived not long ; have it now set up." Albinos are reported at Sedbergh in I900, and at Harrogate on 2nd June 1890 ; white examples at York in October I882, and at Pateley on 2nd October I886; a perfectly white specimen was seen at large at Harewood, near Leeds, in November 1885 ; while one observed on Strensall Common, near York, in April I88o, had a creamy white head, which was sharply defined from the remaining black plumage; and lastly, I examined a peculiar cinnamon-coloured bird, caught near Yarm on 6th January I903.

Local names: Ouzell or Ouizle (West Riding); Black Ouzel (Craven); Black Uzzle (Cleveland); Blackie (general among schoolboys).

There is a saying among Cleveland folk that "Cleveland Blackies are the best in Yorkshire."

\section{RING OUZEL. \\ Turdus torquatus $(L$.$) .$}

Summer visitant, locally distributed; also a transient visitant in spring and autumn.

Historically speaking, the earliest reference to this species was made by the erudite Martin Lister of York, who wrote

vol. 1 . 
to his celebrated friend, John Ray, under date of and July r676, as follows: "As to that question of a Heath Throstle, $I$ find that the Ring Ouzel is so called with us in Craven, where there is everywhere on the moors plenty of them." ("Correspondence of John Ray," p. 125.)

Thomas Allis, in his Report, 1844, wrote :-

Turdus torquatus.-Ring Ouzel-Common on high moorlands; according to Dr. Farrar, they are sometimes met with in the more frequented lowlands. R. Leyland on one occasion saw a flock of more than twenty feeding on the berries of a mountain ash, in a garden near Halifax, in the month of September. Arthur Strickland has once or twice met with considerable flights of this bird when shooting in turnips in the autumn, probably collecting for emigration, and apparently consisting for the most part of birds of imperfect plumage, probably birds of the year.

In addition to being a summer visitant to the broad belt of moorland and the heather-clad fells which range along the entire west of the county and to the Cleveland moors, the Ring Ouzel occurs with great regularity as a transient visitor in the autumn, from Northern Europe, when on its way to more southern winter quarters, and again in the spring on its return journey, but its movements at the latter season are much mixed up with those of our immigrant summer visitants.

It occurs nearly every autumn, together with the migrant Blackbirds, in the neighbourhood of Beverley, sometimes coming into the gardens, but makes only a short stay, and, after a few days, passes on southward. It is much rarer as a spring migrant, the males at this period singing loudly from the bare ash trees.

A considerable flight which arrived at Spurn on 6th May I 888 may have been referable to the Northern race. They are occasionally at this season noted at other coast stations, and are sometimes killed by striking against the lanterns of our lighthouses; one met its death at Spurn on 7 th May r883, and at Flamborough, on 20th April r897, another was immolated. The information supplied to the British Association Migration Committee shews that in $\mathrm{r} 882$ there were 
"rushes" on I2th-I3th October, between Teesmouth and Spurn, during a N.E. wind, with fog; at Redcar they were associated with Thrushes and other small birds, and again, in 1885 , on 6th October; while later observations prove that large flights occurred in I889, on 23rd October, and in I89r and 1893 in the middle of that month.

As a summer visitant in the wide area occupied by its habitat, it is as numerous as it was two centuries ago, at the time when Martin Lister wrote (ante). It is perhaps most abundant on the rolling heather-lands of the south-west, where the late William Talbot found no fewer than thirteen nests during a walk from Hebden Bridge to Todmorden, a distance of but little over two miles.

The Ring Ouzel has on two occasions been observed as early as 25th February; in I893, at Kilnsea, and in I90r, when Mr. C. E. Milburn saw one on the lawn of Marton Hall, Cleveland, and watched it for half-an-hour. It arrives at some of its breeding haunts during the latter part of March; at Fewston it has been known as early as the $I 5$ th, but is usually seen between the 17 th and the 23 rd of that month; in many parts it does not appear till the first week in April, sometimes in flocks; the cock is then very noisy, and is heard pouring forth vehemently his stunted song from every prominent crag or other coign of vantage.

These summer visitants quit the moors in September, even early in that month visiting the lowlands and the coast, and, as a rule, they leave the country before October, though a pair was observed at Arthington, in Wharfedale, on 2nd November I884.

In the late autumn, usually during the closing days of October, considerable numbers of these birds arrive on the coast, and linger in its immediate vicinity for some days (in 1882 a couple of weeks), frequenting tall old hedgerows of whitethorn, where they feast upon the haws, the gizzards of those examined containing no other food. The late J. Cordeaux stated that they are also very partial to the acid fruit of the sea-buckthorn, a shrub which grows plentifully 
at Spurn; and the late Canon Atkinson frequently observed large numbers in autumn, after bilberries on the moors are exhausted, come into his garden at Danby to feed on what fruit may be available ("Moorland Parish," p. 32r).

The majority of the earlier immigrants are young of both sexes and old females-these are often difficult to distinguish amongst a hedgeful of Blackbirds, except by their note and greyer look-the old cocks generally come later, at the end of October. The numerous specimens then obtained and examined have been in winter plumage, the males, which largely predominate, having the gorget dull white, the feathers of the throat, breast, and abdomen edged with greyish white.

On several occasions single birds have been obtained in the county in mid-winter, namely, at Holmfirth on $25^{\text {th }}$ December I855 (Morris's Nat. I856, iv. p. 93) ; at Oxenhope, near Keighley, on and February 1856 (tom. cit. p. 92); at Leeds, in December I88I, and Mr. Smurthwaite of Richmond, stated (op. cit. $\mathrm{I} 854$, iv. p. $8 \mathrm{I}$ ) that it is sometimes obtained in December and January. I have once met with it on the Bilsdale Moors as late as 25th October in 1886 . Regarding these birds, it would seem most probable that they are autumn visitants attempting to winter with us, rather than laggard summer visitants or their young.

Towards the end of April the nest may be found either on the ground on a flat expanse or sloping bank of heather, or else in the heather fringing the brink of a dell or moorland beck, or concealed in a solitary tuft on a rocky hill side, and it has also been found placed between the stem of a whin bush and the face of the crag. Clutches, consisting of five eggs, are occasionally met with, but four seems to be the usual number. The bird has nested under Cross Fell, in Cumberland, at 2000 feet elevation, and in Wilsden district nests have been known placed upon the lateral branches of firs, and also in the face of stone walls at the edge of the moors. A Ring Ouzel was recorded by John Heppenstall (Zool. I843, p. I44), to have nested on the bank of a peat drain on Thorne Waste, 
;, 3,

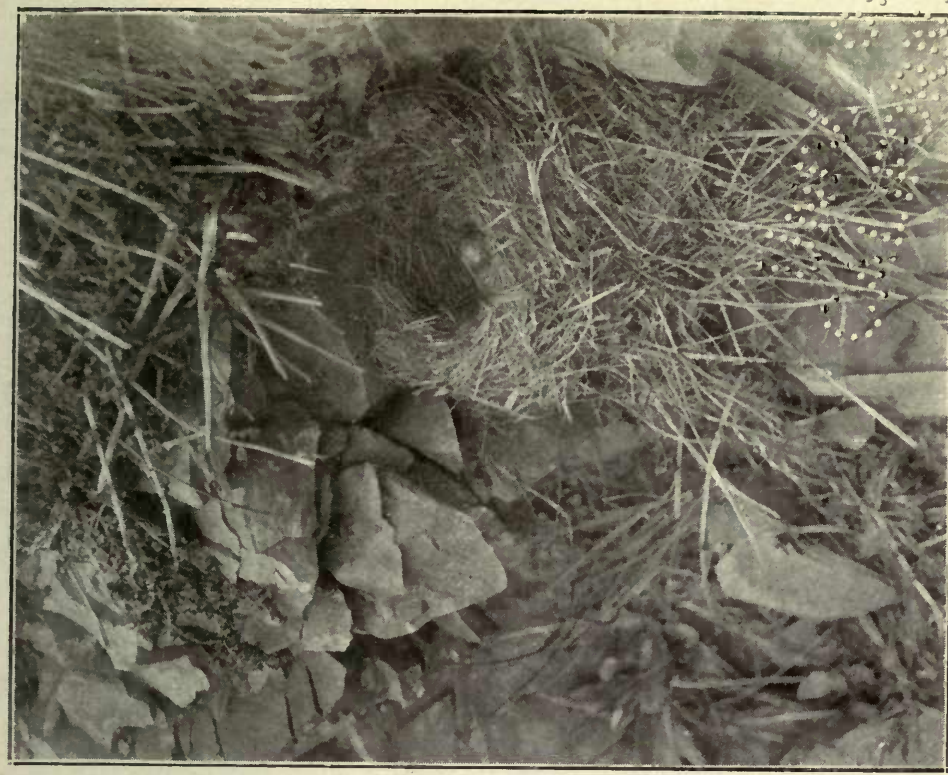

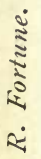

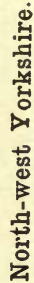

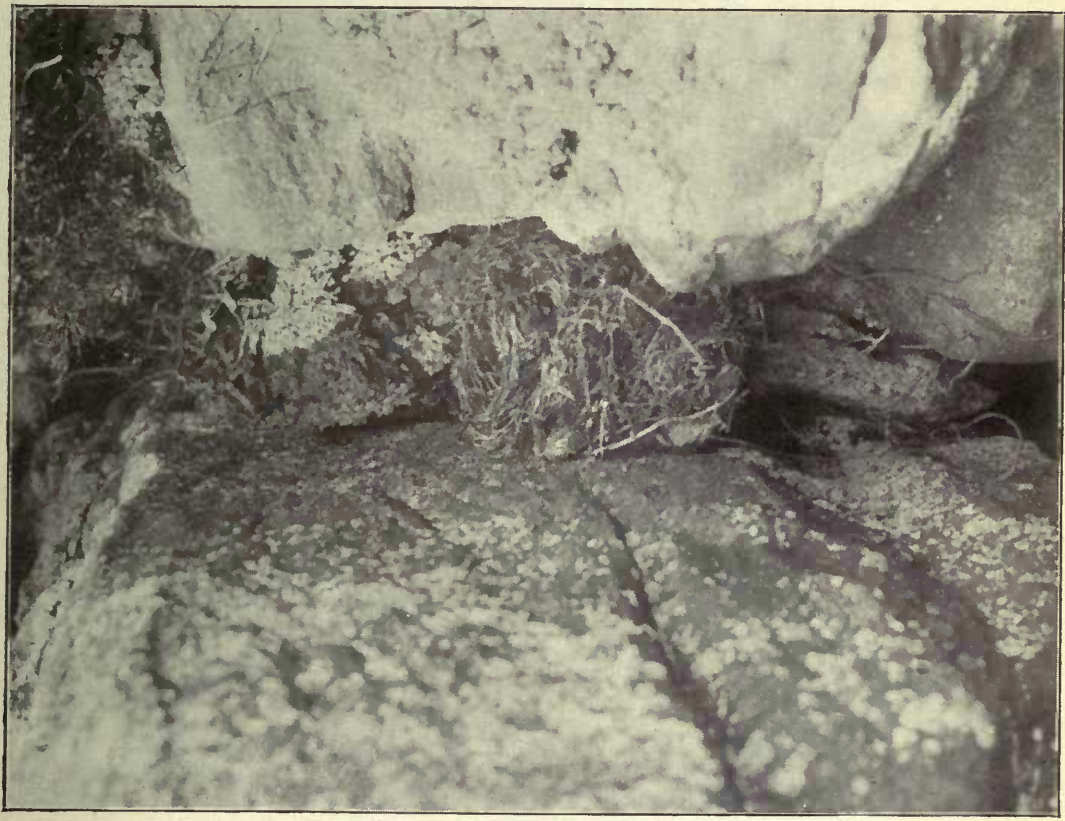

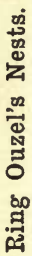



a low-lying tract of heath on the Lincolnshire border of the county, and only a few feet above sea level; but the reported instance of its nesting near Beverley (op. cit. I865, p. 9592), is not to be accepted.

The Ring Ouzel is not subject to great variation in plumage, the only instance of which I am aware being a beautifully marked specimen variegated with white, grey and black, noted on the moors near Whitby on I3th August I889 (Field, I7th August I889).

Local names are as follows:- Heath Throstle (Craven r676); Moor Thrush (Sedbergh); Crag Ouzel (Craven); Moor Blackbird (Sheffield, Craven, and Scarborough); Mountain Blackbird and Fell Blackie (Sedbergh); Ring Uzzle and Moor Blackie (Cleveland); Collared Blackie (Staithes); Rock Ouzel and Ring Whistle (Teesdale).

\section{ROCK THRUSH.}

\section{Monticola saxatilis (L.).}

Accidental visitant from Central or Southern Europe.

This species is a summer visitant to the mountainous districts of Central and Southern Europe, and winters in Arabia and Africa. As a straggler it has occurred at Heligoland, and, perhaps on three occasions, in Britain, once in our county.

Regarding its occurrence near Whitby, Mr. Thomas Bedlington of Middlesbrough, writes as follows in Morris's Nat. for 1856, p. 21 : "In June 1852 I saw a bird in the neighbourhood of Robin Hood's Bay that I was not acquainted with. I followed it for about two miles, and often got within 
a dozen yards of it by creeping behind hedges. In its movements it was very like a Thrush, but it was rather smaller in size. I had no gun with me, or I could very easily have shot it. The bird got very shy at last, I having followed it up very closely. It finally disappeared in a plantation. The bird was a Rock Thrush. I was able to identify the species in a moment after seeing the coloured figure in Morris"British Birds." "

The specimen figured by Morris is an adult male, a bird which is, perhaps, the most unmistakable from its being the most showy of European species, and thus it appears there can be no reasonable doubt as to Mr. Bedlington's identification of it.

\section{WHEATEAR. \\ Saxicola œnanthe $(L)$.}

Regular and early spring migrant ; fairly common where it occurs. A great influx from the north takes places in autumn.

The earliest published reference to this, as a Yorkshire species, is by Ed. Blyth, who stated (Rennie's Field Nat., Nov. 1837, p. 467 ), that when on the voyage from London, northward, and about ten or twelve miles from Redcliff, on the coast of Yorkshire, on I 7 th September, several Wheatears (with other small birds) alighted on the vessel, and they all left on the first night after their appearance.

Thomas Allis, in 1844, wrote as follows :-

Saxicola ananthe.-Wheatear-One of our earlier summer visitants : common about Halifax; and is met with in exposed situations in most parts of the county, but is becoming scarcer than it was formerly.

The Wheatear is one of the earliest spring migrants, the first comers generally arriving in March or early April ; in 
the south of the county the 28 th of March is the average date of its first appearance; in Cleveland and the north it arrives about the end of the month or the first week in April. In the year I870 it was reported as early as 6th March; in I882 several were at Spurn on the Igth; some arrived at Redcar on the $23 \mathrm{rd}$, and on the same date in 1890 ; in 1893 it was noted on the Igth, and in I902 on 8th March. There is a second, or supplementary, arrival in May, usually in the first or second week, and very noticeable on the coast-line.

This lively bird is essentially an inhabitant of the wilds, and as regards its distribution may be described as somewhat local, being chiefly confined to the open downs, moors, commons, and other barren and uncultivated tracts, although at the migratory period it is observed in most parts of the county. On the sea-coast it is found among the sand-hills and rough banks, a few pairs remaining to nest; in the dales and on the moorlands it is fairly common, ascending to the summits of the highest hill, where it breeds, as, for instance, at an elevation of 1200 feet, on Mickle Fell. It occasionally nests in the low country, and has been met with near Skelmanthorpe, York, and at Eccup, near Leeds (Nat. I900, p. 224). There is a large race or variety, of a richer buff colour and with longer legs, which is more arboreal in its habits than the ordinary form, that occasionally passes through in spring; it was noticed in great numbers both at Spurn and Flamborough in $\mathrm{r} 893$, and Mr. E. P. Butterfield has seen it on the high moors near Bradford after the nesting birds arrive.

About the middle of August the return migration from the north commences. For many seasons I have seen immense numbers travelling along the coast in this month and in September, when they are often associated with Redstarts, and the sand-dunes both at the Tees and Humber estuaries are sometimes swarming with them, whilst a few occasionally linger until the end of October; at Spurn, in $I 880$, one was seen as late as the 27 th, and in $I 883$ the last is recorded on the 23 rd of that month. For greater knowledge of its movements we are indebted to the researches of 
the Migration Committee, whose reports furnish abundant evidence of the frequency of this bird's presence at the Light stations, where it often figures amongst the casualities; great influxes have been recorded at Flamborough, both in spring and autumn, and these "rushes" have taken place in nine different years since 1879 .

Although not generally credited with imitative powers the Wheatear has, according to Saxby (" Birds of Shetland," p. 68), and Mr. J. E. Harting (Field, and April I898), been known to imitate the songs of other birds, and in Yorkshire it has been detected in the act of mimicing the song of a Skylark, near Wilsden (E. P. Butterfield, in litt. and Field, roth May Ig02).

Sometimes a curious position is chosen for the nesting site where it would scarcely be suspected. Among these may be mentioned one in the rough slag forming the sloping front of the sea-wall opposite my house at Redcar, where many people passed to and fro daily; one in Teesdale, in a hole on a hillside, whence four eggs of a Wheatear and one of a Cuckoo were taken; another in a hole in a bank overlooking a stream at Adel, the hole being the nesting-place of a Sand Martin (Zool. I880, p. 30I); and lastly, one found in I 886 by Mr. R. Fortune, placed two or three feet below a Peregrine's eyrie in north-west Yorkshire.

Of variations in plumage there are several instances, but it is unnecessary to cite more than the following: One at Filey, with back, shoulders, neck, and top of head white, here and there speckled with minute grey spots (op. cit. I883, p. 79). Near Harrogate, on I6th April I900, Mr. K. McLean saw one all white, except the shoulders, which were terra-cotta coloured; and near Settle, as Mr. F. Atkinson informs me, there were, in June 1896 , four albinos out of a brood of five, with whitish yellow legs and feet, the hairs around the mouth black, and the bills yellowish; the feathers which are white in normal examples, were brown, as also were the tips of the primaries.

This species is the object of various superstitious ideas, 
and bears a bad reputation in the North of England; to hear its note is a token of approaching death, the bird's habit of frequenting old churchyards, ruins, and sepulchral cairns may be the origin of this superstition (op. cit. $I 867$, p. 1007). Its presence is considered in some localities to foretell the death of the spectator; in others the evil fortune is only considered likely to ensue if the bird be first seen on a stone; but should its appearance be first observed whilst sitting on turf or grass good luck may be expected (Swainson).

The vernacular names are :-Stonechat, in general use; Chetstone, Chatty, Barrow-chat, used in Cleveland; Stonechopper, in Teesdale; White-rump, at Barnsley, Doncaster, Sedbergh, and in Cleveland; Wall-chat, in the West Riding ; Stoney-crop, at Barnsley; and Walley is given in "Billy Roberts's " Leeds list.

\section{DESERT WHEATEAR.}

Saxicola deserti $($ Temm).

Accidental visitant in autumn from Northern Africa, of extremely rare occurrence.

As its name indicates, this Wheatear, also called the Desert Chat, is found in dry, sandy regions; Northern Africa, Persia, Afghanistan, and the plains of Turkistan and Kashmir are its summer haunts, and in winter it migrates to NorthWest India, Scinde, Beluchistan, and, according to Mr. (now Sir) A. E. Pease, Somaliland and Abyssinia.

The only Yorkshire specimen is also the second British example: it was obtained between Easington and Kilnsea on I7th October I885, and was sent to Mr. Wm. Eagle Clarke for identification. Mr. Dresser afterwards exhibited it at the Zoological Society's meeting, and stated that it was 
a female (P.Z.S. I885, pp. 835-6; Ibis, x886, p. I00; Zool. 1885, p. 479; Field, 28th November I885; Nat. I885, p. 387 ; r897, p. 20I). This bird is now in the collection of Mr. J. H. Gurney.

[The late J. Cordeaux stated that he was of opinion Mr. H. B. Hewetson saw an example of the Black-throated Wheatear (S. stapazina) at Spurn on I8th September 1892 (Zool. I892, p. 424; I895, p. 57 ; Nat. I893, p. 7 ; I897, p. 20I ; "Birds of Humber District," I899, p. 2). This record is merely quoted for what it is worth.]

\section{WHINCHAT. \\ Pratincola rubetra (L.).}

Summer visitant, common and generally distributed.

The first reference to this species as a county bird is, apparently, that given by Tunstall under the heading of "Stonechat." "It builds in whins, and is perpetually flying up and down when anyone approaches, repeating a cry like 'Eutic,' by which I judged it to be the Whin Chat" (Tunst. MS. 1784, p. 74).

Thomas Allis, I844, wrote:-

Saxicola rubetra.-Whinchat-One of the most common summer visitants.

The earliest date for the appearance of the Whinchat of which I am aware, is the 28th March 1906, when I saw two on the Redcar sand-hills. The average for the south of the county is given as the 2oth April, and, generally speaking, from that date until the end of the month may be considered the usual time for its arrival, and it is often the first week in May before it makes its appearance in Cleveland. It leaves again in September or 
October, the young departing before the old ones, a few of which linger until the end of the latter month.

It is distributed generally and abundantly in rough pastures, meadows, railway banks, and hillsides up to the very edge of the moors; in Nidderdale it reaches an altitude of 1000 feet, in Teesdale it nests at 1200 feet elevation, and it is one of the characteristic birds of the roadsides and grasslands in the dales, its familiar cry of "Yewtic" being heard the summer through. Near the large towns it is less numerous, though the nest has been seen within the city boundaries of Leeds. In the Beverley district, where the species is unaccountably becoming scarce, the males arrive first in spring, mount the tallest trees, and sing until the arrival of the females.

As a migrant, it does not appear to be often recognized by the light-keepers, being referred to only once in the Migration Reports, viz., in I882, "Spurn, October $1_{5}$ th, All day." It has been noticed on arrival at Flamborough in the spring migration, and towards the end of August, or early in September, there is a large influx, on the return journey, of immature birds, with occasionally a few old females ; the adults generally appear later, early in October, but seldom remain more than a few days.

An early reference to the autumn movements of the Whinchat is that of Edward Blyth, who remarked (Rennie's Field Nat., November 1833, p. 467), that when on the voyage from London, northward, on the r6th of September, off the coast of Yorkshire, and about ten or twelve miles from Redcliff, several birds, amongst which were Whinchats, alighted on the vessel.

The imitative powers of this bird have been noticed by Mr. E. P. Butterfield, who detected one in the act of mimicing the Wren, Song Thrush, Chaffinch, Corn Bunting, Tree Pipit, Greenfinch, Ray's Wagtail, and other birds; and on a recent occasion he heard one imitate the Blackcap. The songster, which was perched on an old wall, allowed an approach within a few yards, and continued for some time 
to pour out such a flood of song as to entrance the listener. The attitude of the bird whilst singing, every muscle indicating intense excitement, was no less strange than its song (Zool. I889, p. 369 ; and in litt. I902).

The vernacular names are :-Whinchacker, used in Craven and Cleveland; Bush-chat in the West Riding; Grass-chat and Hay-chat in the North and West Ridings; Hay-bird in Ryedale; Stone-chat in the Nidd Valley; and Utic or Yewtic (from its call) in the East and West Ridings.

\section{STONECHAT. \\ Pratincola rubicola $(L$.$) .$}

Resident ; also summer visitant ; locally distributed. The majority leave in autumn, only a few remaining, chiefly near the sea-coast.

The earliest reference to this as a Yorkshire bird, is, a)parently, that in Part 2 of Willughby's "Ornithology," $\mathrm{I} 578$, where it is called "Stone smich."

Thomas Allis, in I844, wrote:-

Saxicola rubicola.-Stonechat-Occurs, but not numerously, on the moors and high lands in most parts of the county; it is much scarcer than in some of the more southern counties.

The Stonechat is frequently spoken of as a common Yorkshire bird, though it cannot be considered as abundant anywhere, and in its distribution is an eccentric and puzzling species, being very local and often absent from the very places where its presence might confidently be expected; its history, therefore, requires careful treatment, for in some parts where it was formerly met with it has now become extremely rare, or died out, as a breeding species. Commencing with the extreme south of the West Riding, it used, 
until I880, to breed annually near Sheffield on the wild wastes and commons bordering the moors, though only one or two pairs were to be seen in a large tract of country, and recent information tends to prove that it has ceased to frequent the neighbourhood; near Barnsley and Wakefield it is an occasional visitor on passage through the district, and has been known to nest on one occasion; in the Huddersfield area it remains during the year near the moorlands, but is evidently far from common; at Almondbury a pair was seen in 1887 , and one was shot the following year; near Skelmanthorpe it is reported as nesting, and has been seen in winter at Ingbirchworth; in the Wilsden locality there are two instances of its breeding many years ago, and none for more than thirty years past, which is strange, as gorse flourishes up to a thousand feet elevation; a reported instance of the finding of a nest near Halifax is doubtful ; at Hebden Bridge and Keighley it is a rare spring migrant; at Saltaire the old and young have been once discovered, and near Liversedge a small family party was noticed on 5 th October 1899 .

In the extreme north-west it is met with frequently in Craven, and at Settle the nest has been found so recently as I900, also at Malham; further north, near Clapham, the bird is a fairly common summer visitant ; in Upper Wharfedale Mr. W. Eagle Clarke noted one at Grassington, and lower down the Valley, at Ilkley, in May $187 \mathrm{r}$, he found three nests with eggs on the banks of the Wharfe, but diligent search failed to reveal either nests or birds there since that year, though in $\mathrm{r} 886$ he observed two at Linton; near Leeds it is scarce, but is said to have bred occasionally, once at Adel Moor, where a pair with food in their bills was seen in Ig00 and I90I; it has also been noticed on the Otley Road within a mile of the city, and near Headingly one was seen on $24^{\text {th }}$ February 1890 ; it is a rare species in Nidderdale, but two instances are known of its nesting in the upper portions of the dale, at Guyscliffe in 1884 and at Fellbeck in 1885 ; it formerly bred in the Washburn Valley, but is now only a 
casual visitant; near Harrogate it is very scarce, and the same remark applies to its status at Staveley and Ripon; at Selby and at Hatfield it occasionally occurs, and the late $\mathrm{J}$. Cordeaux found a nest on Thorne Waste ; it is also recorded from the neighbourhood of Goole, and is a summer visitant in Ackworth district, breeding in limited numbers.

In the East Riding it has been more frequently noticed on migration than as a nester, and more particularly on the Spurn promontory and at Flamborough than elsewhere; it was reported to the late J. Cordeaux as nesting at Kilnsea in 1888 ; it is occasionally met with at Aldborough; near Beverley it is scarce, the late W. W. Boulton mentioning one instance only of its having come under his observation, and recent information stating that it was never plentiful and is fast dying out; it was always a scarce and local bird and nested only in one or two localities; at Market Weighton and Bridlington it has only been observed as a straggler, also at Fraisthorpe, but at Flamborough it is resident, though not plentiful, except on the spring and autumn passages; it has been noticed migrating as early as February, and there was a great rush in May I89r; it has been observed in the breeding season on the cliff tops at Reighton, Bempton, and Speeton, and was found by Mr. R. Fortune to be nesting there in June 1905 ; at Knapton it is a scarce breeding bird, and a nest near Pocklington " a few years ago" is reported.

In the North Riding the Stonechat is alluded to as early as the year I79I, in the Allan MS. of the Tunstall Museum (Fox's "Synopsis," p. 207), where it is described as "Common in summer on the heaths; in winter in the marshes..... Makes nest early, at foot of some low bush." The nest is recorded in recent years at Hackness and Scalby, near Scarborough, in which locality the bird is rare and oftener met with in winter than in summer; at Whitby a few odd pairs are scattered along the cliffs, and one instance, at least, is on record of its nesting in 1872 near Upgang; at Goathland the nest and young have been found near the moors; it is 
rare at Helmsley, though numerous in a certain valley seven or eight miles west of that place, where it breeds, and it occasionally occurs near Pickering; at Hovingham it is noted, and also from the York district, where it was known to nest up to early in the "eighties" ; in Wensleydale it is scarce, and has been observed very rarely at Leyburn Shawl, and in Bedale neighbourhood, while one instance is known of the nest being reported at Northallerton, in May 1882 ; it is fairly abundant at Hawes; it nests regularly near Sedbergh, but is seldom seen near Richmond and Thirsk. In Upper Teesdale it is a scarce species, though it has nested on Crossthwaite, and odd birds remain in winter, one so recently as February I9or. In Cleveland, John Hogg in his list (Zool. I845, p. I058), remarked that it is local and somewhat rare. I formerly observed it almost annually, and often on the sea banks during the migratory period in spring, but it is now extremely scarce as a resident; it breeds sparingly in several localities on the Cleveland hills, where, after patient watching, the nest was found in gorse bushes; it is, however, not uncommon in some years on the southward passage in autumn; it is perhaps more abundant in the Staithes and Loftus districts than in other parts of Cleveland, and has frequently been noticed on the sea-cliffs in the breeding season; nests have been found on the edge of the Waupley and Lingdale Moors, and at Ugthorpe it also receives a place in the list of local birds.

From the information supplied to the British Association Migration Committee we obtain abundant evidence as to the spring and autumn movements of the Stonechat; at the latter period young birds are usually reported, occasionally an old female, but adult males are always scarce and are more frequently met with in October than at other times; it was very plentiful at Spurn in 1880 , and there was a considerable immigration of immature birds at the latter end of August I884; in I886 it was quite numerous at Spurn on 28th August, and for ten days afterwards, parties of six being often seen together; it was common in the autumn of 
I888, and both old and young birds were noted in October $\mathbf{r 8 9 2}$, and again in $\mathbf{1 8 9 4}$. The most recent migration of this species which calls for special comment occurred between the 20th and 23rd September 1903, when it was very plentiful at the Teesmouth, and all along the Yorkshire coast, in company with Pied Flycatchers, Wheatears, Redstarts, Goldcrests, and Pipits; the slag walls and sand banks at the Tees Breakwater were swarming with small immigrants, at this time, Stonechats being unusually abundant, and they had all moved on by the $24^{\text {th }}$ of the month. An early reference to this bird's migration is mentioned by Edward Blyth (Rennie's Field Nat., November 1837, p. 467), to the effect that during a voyage from London, and when about ten or twelve miles from Redcliff on the Yorkshire coast, on I6th September, several migrants came on board the vessel, amongst them being one Stonechat.

In the breeding season it frequents, as a rule, the rough wastes on the edges of moorlands of low altitude, and particularly affects gorse covers, though sometimes the nest is met with almost on the sea level; near Whitby one was found amongst long benty grass in a cliff side and built of dried grass, moss, wool, feathers, etc., lined with hair; it contained four eggs, one nearly white, the others normal.

The vernacular names are many and varied, though it should be borne in mind that in many parts of the county the Wheatear is known as Stonechat and Stone-chatter. Stone smich is used by Willughby; Stone-smith, Stonesmick, Stone-chatter, Stone-clink, and Stone-chack are all used in Cleveland; Stone-chacker in Cleveland and Craven; Stone-check near Sedbergh; Chick-stone in Cleveland; Whin-chat near Doncaster; Black-cap at Sedbergh and in Cleveland; Moor Titling and Moor Tit in Cleveland; and Red-breasted Moor Tit in East Cleveland. 

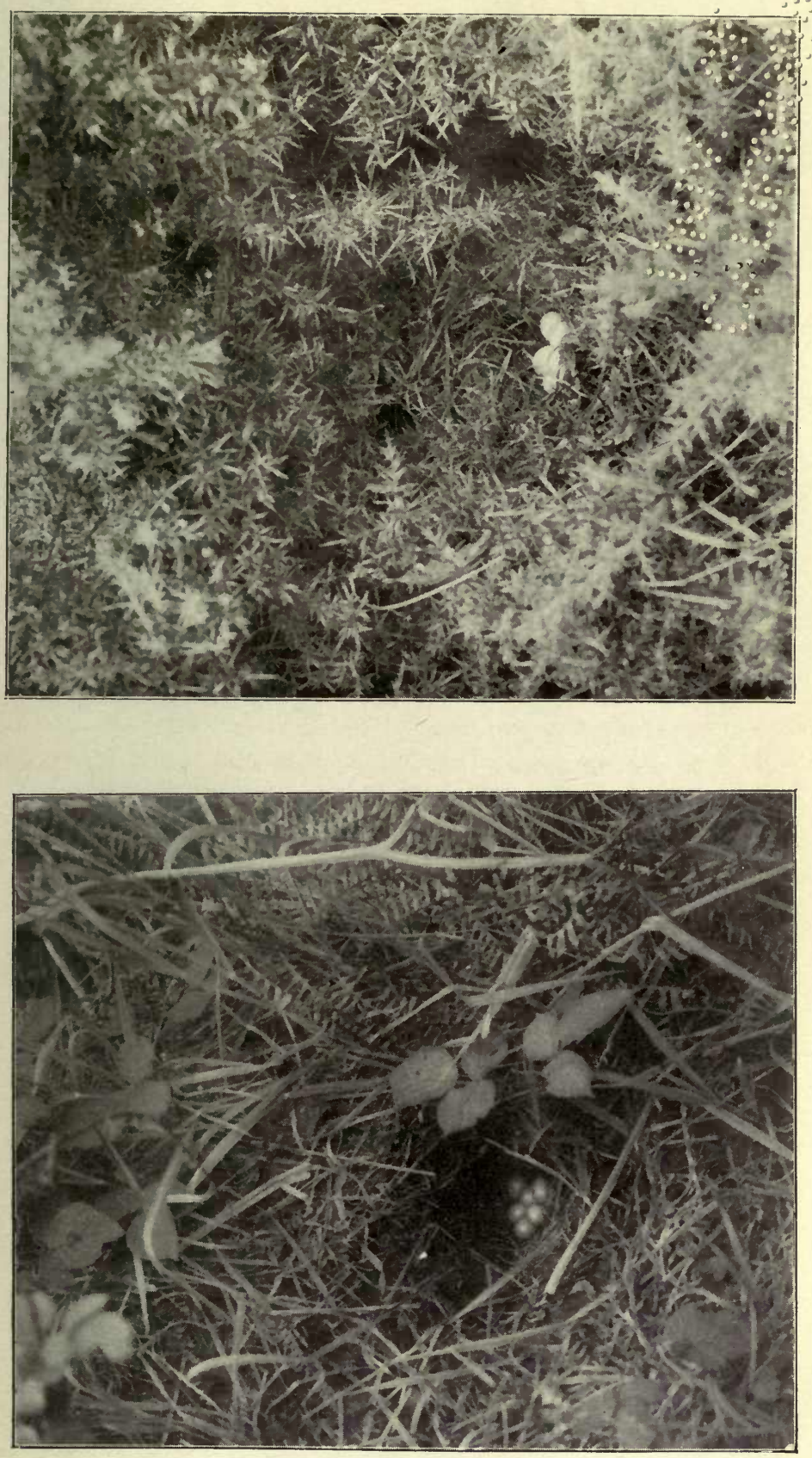


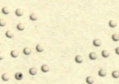

a 


\section{REDSTART.}

\section{Ruticilla phœenicurus $(L$.).}

Regular summer visitant, somewhat locally and thinly distributed. Great numbers observed in autumn passing southward on migration.

This bird's earliest association with Yorkshire history is contained in Marmaduke Tunstall's MS., 1783, thus :"Redstart, pretty common here [Wycliffe-on-Tees]. I never could get any to live in a cage for any time, though I have tried both old and young." (Fox's "Synopsis," p. 72.)

Thomas Allis, in I844, wrote as follows :-

Phoenicurus ruticilla.-Redstart-Appears to be general, though much fewer in numbers than in the South of England.

This is decidedly one of the most beautiful of the summer migrants which visit our shores; its boldly marked plumage and red tail render it a conspicuous object as it darts out in front of the intruder on its domains, whisking along and flirting its tail as if in defiance.

The middle of April is the usual time for its arrival in this county, at Hovingham it has been noted as early as the 6th, while in Cleveland it may be expected about the 22nd of the month; and the time of its departure is stated to be the 2oth September. The Redstart is generally distributed, though as a rule only in small numbers, or scattered pairs, where suitable localities are existing, such as the banks of country lanes, gardens, orchards, the edges of large woods, ivy-clad ruins, and dry stone walls on the borders of moorlands. Though a constant and characteristic bird in the dales of the north and north-west, it is usually absent from the barren and desolate tracts; it is frequent in Craven, Nidderdale, ascending to an elevation of Iooo feet; and to II5O feet at Buckden in Wharfedale; Swaledale; Wensleydale; Ryedale, and Teesdale, where it is found to 800 feet elevation, and is not uncommon in the Plain of York, and in the fir

VOL. I. 
woods of the oolite hills in the East Riding. In Cleveland it is not to be called an abundant species; the late Canon Atkinson ("British Birds' Eggs," I86r, p. 54), deplored its decrease in the Danby district, still in favourable situations it may always be found in summer if looked for, and it is particularly numerous in Bilsdale and the neighbouring valleys; its numbers, however, have decreased of late years, especially in the vicinity of the large towns; it appears to be much scarcer than formerly in Holderness, though more have nested in Boynton Park than in an equal area anywhere else in the county.

During the vernal migration it frequently arrives in company with Pied Flycatchers, as at Flamborough on 3 rd May I885, and 26th April, and I3th to I5th May I886 (Seventh and Eighth Migration Reports, pp. $4 \mathrm{I}$ and 3I); it is also recorded so long ago as 1877 amongst those birds that are killed by striking against the lantern, and other cases have occurred since that year. But, although the Redstart is well known as a regular spring migrant and is often seen at the light-stations in large numbers at that season, it is only the close attention paid to migration in recent years that has been the means of making us acquainted, in common with many hitherto unknown phases of bird life, with its annual autumnal movements, and as is shewn, it comes in August, September, and October from more northerly latitudes on its passage southward to Africa, being then associated with the Wheatear to such an extent that it is difficult to disconnect the two. Probably the earliest mention of its autumn migration was recorded by Edward Blyth in Rennie's Field Naturalist (November I833), and referred to one of these birds coming on board ship whilst off the Yorkshire coast, ten or twelve miles from Redcliff.

The Reports issued by the British Association Migration Committee contain numerous entries connected with the Redstart's autumnal passage; the first of these is from Redcar, dated I5th September I880, when I noted great numbers at the Tees Breakwater, and remarked that the 
bird was not previously reported from that locality; at Flamborough and Spurn great flights were seen at the same time. In the following year at the Humber and Tees estuaries a great "rush" was reported early in September, which continued up to the $25^{\text {th }}$ of that month, and I saw a single bird during a gale as late as the $24^{\text {th }}$ October ; similar flights also occurred in September I884, at intervals from the $4^{\text {th }}$ to the I7th; and on many occasions between this date and I887 Redstarts and Wheatears were recorded as migrating in company, the entries covering the months of August, September, and October; large arrivals were seen at Spurn and Flamborough in September and October 1889, and again at Spurn on 22nd September I892, whilst at the latter place, in September I9or, every hedge was swarming with them; in the same month of the year I903 many were observed at the Teesmouth, and along the sea-board to Spurn, associated with Wheatears, Pied Flycatchers, Stonechats, and other small migrants. It has been remarked that larger numbers land annually at Flamborough Head than elsewhere.

At Linton-upon-Ouse a pair of these birds was kept under observation while the young required their attention, when it was calculated they destroyed at least six hundred grubs and caterpillars for food in one day (Zool. r863, p. 8680). The colour of the throat in the adult male Redstart, while living, is of a deep, dark blue, which changes after death to black. A female assuming the plumage of the male, was caught while sitting upon her eggs, by Mr. W. Eagle Clarke at Wike, near Leeds, in June I886 (J. H. Gurney, Ibis, I888, p. 229).

Occasionally a departure from the customary nesting site is made, and instances are known where the bird has chosen the branch of a trained pear tree (Zool. I869, p. I80r), an inverted flower pot, and even a depression under a sleeper on a railway; the late $W$. W. Boulton also recorded a nest in Beverley Minster, to which the bird gained access through a broken pane of glass (op. cit. 1865, p. 9527). 
The local names are numerous :-Redster, Red-tail, Firetail, are in general use; Redstare at Skelmanthorpe, near Huddersfield; Wrenny in the Nidd Valley; Wrenny Red-tail in the Nidd Valley and in Wharfedale; Jenny Redtail about York and in the North Riding ; Jenny Wrentail about York ; Nanny Redtail in Cleveland; Fanny Redtail near Doncaster ; Red-rump in East Cleveland ; Flirt-tail at Ackworth ; Brandtail about York and in the North Riding; and White-cap at Farnley, Leeds ("Billy Roberts's List").

\section{BLACK REDSTART. \\ Ruticilla titys (Scopoli).}

Irregular visitant on the coast in spring and autumn ; very rare indeed.

Thomas Allis, in his Report on the Birds of Yorkshire, I844, wrote as follows:-

Phonicura tithys. - Black Redstart-The only notice of this bird in Yorkshire is from my friend H. Denny, who informs me that two or three were caught by some bird-catchers last year at Osmondthorpe.

The reference here given by Allis is the first mention of the Black Redstart in connection with the county, and to him is accorded the honour of having made this addition to the avifauna of Yorkshire.

The Black Redstart is usually considered to be an irregular winter visitant, though it is now known as being chiefly observed on migration in spring and autumn; Mr. M. Bailey drew attention to its visits to the Headland of Flamborough in April and May, when he has often observed it, and has noted it amongst those species which strike the lantern in thick, foggy weather, with the wind at north- 
east; he has also reported it in September, and again when the Woodcock make their appearance in October and November.

As it is mainly confined to the coast-line, its distribution may best be defined as limited to that area ; it is not recorded from the Yorkshire side of the Teesmouth, but Mr. C. Milburn shewed me an immature male example which he shot on the north bank of the river on 28th October I903; it has twice been reported at Loftus-in-Cleveland-once in winter, and once in spring-(Nat. 1899, p. 132); at Scarborough it has occurred at intervals : several were on the rocks at low tide in autumn I879; on Christmas Day, I888, one was shot in Cayton Bay; on I2th December I899, one was seen on the sill of a window at the Alexandra Hotel, and another was observed in September 1903. Further south it has been recorded from Filey in October I853; from Flamborough there have been frequent records since 1878 - when some were noted on the I 7 th April-down to the present time; in I89I they were first seen on the 6th April, and on May Ioth and IIth there was a great " rush," described as " something astonishing " (op. cit. I891, p. 82 ; Zool. I893, p. 224); at Spurn also, there have been many instances of its occurrence, both in spring and autumn, too numerous to mention in detail; Mr. W. Eagle Clarke obtained an example in October I883, and it may probably be a regular visitant, though overlooked amongst the crowds of small birds which are in movement at the migration seasons.

Inland it is extremely rare, but has been recorded from the neighbourhood of Leeds, at Osmondthorpe in 1843 (Allis), also at Bingley in May I877 (Varley MS.). 


\section{WHITE-SPOTTED BLUETHROAT.}

Cyanecula leucocyana (Brehm).

Accidental visitant from Central and Western Europe, of extremely rare occurrence.

This species breeds in France, Belgium, Holland, North Germany, and so throughout temperate Europe as far as the west of Russia. Its winter quarters are in the western and northern parts of Africa, Armenia, and southwards to Afghanistan.

The first known instance of the visitation of this rare migrant to Yorkshire, and to Britain, is that communicated by the late Afred Roberts of Scarborough. Writing to Mr. W. Eagle Clarke on Ist January I880, he stated that "a fine female specimen of the Blue-throated Warbler was found dead under the telegraph wires, near Scarborough, by the late John Young, gamekeeper to Lord Londesborough (April I876). The ovary contained eggs in a forward state. It had a white satiny spot in the centre of the blue throat. The specimen is in the possession of Mrs. Young."

This example was recorded at the time by the Rev. Julian G. Tuck (Zool. I876, p. 4956; and Field, 6th May I876), thus: "I have much pleasure in recording for the first time in Yorkshire, the occurrence of the Bluethroat, or Bluethroated Warbler. A specimen of this rare little bird, which had been picked up dead under the telegraph wires at Seamer, near Scarborough, was taken to Mr. Roberts of Scarborough, on the I2th April. Its head and neck had been consideraby damaged from coming in contact with the wires; in addition to which, the man who found it kept it several days, and then carried it to Scarborough in his pocket. Mr. Roberts thought, when he first saw it, that it would be impossible to mount it, but with skilful handling and great patience he has now managed to make it into a very presentable 
specimen. It is a female bird, in good plumage, and Mr. Roberts told me it contained well-developed eggs. The occurrence of this specimen is the more interesting as it is an example of the type which possesses a white spot in the centre of the blue on the throat." (Cf. Yarrell, "Brit. Birds," 4th Ed. Vol. I. p. 323.)

This interesting record has been overlooked by the authors of the various recent treatises on British ornithology ; why, it is difficult to comprehend. The account furnished to Mr. W. Eagle Clarke by Mr. Roberts leaves, however, no doubt as to the identification of the species nor as to the authenticity of the record.

More recent investigation has resulted in my obtaining further confirmatory evidence with regard to this specimen, which is now in the possession of Mr. D. Young (son of the original owner of the bird), gamekeeper to the Earl of Londesborough, at Blankney, Lincs., who describes the specimen as having " a white spot on the breast, extending about half an inch in length." (Cf. Zool. I902, p. 464 ; I903, pp. 23, 43I, 455 ; I904, pp. 3I, 263.)

\section{RED-SPOTTED BLUETHROAT.}

\section{Cyanecula suecica $(L$.$) .$}

Rare visitant on migration in autumn from Northern Europe.

This bird nests in the northern portions of Scandinavia and the Russian Empire, and from there to the far east of Siberia and Kamchatka. In winter it migrates to India and the north-east of Africa as far as Abyssinia; it also occurs throughout China. 
The Spurn promontory appears to be the only district where the Red-spotted or Arctic, Bluethroat can be said to have been actually obtained, and there no fewer than six examples have been procured, whilst several others were identified; it will be noticed that the majority of these appeared in the month of September. The situation of the headland of Spurn is well adapted for attracting the small over-sea migrants, and the wonder is that this rare warbler has for so long escaped detection.

The credit for first recording its occurrence belongs to my esteemed friend, and predecessor in this work, Mr. W. Eagle Clarke, who saw two near the Spurn Lighthouse on the IIth September I882. One of these was shot in Mr. Clarke's presence, and was sent to the late Henry Seebohm, who declared it to be a bird of the year, of this species, just moulted out of the young into first plumage, and probably a female (Fourth Migration Report, p. 3I, and Zool. I884, p. I74).

The other instances are:-Spurn-One in the second week of September 1883 (Thos. Winson in litt., and Fifth Migration Report, p. 38). Spurn-Two seen, adult and immature one obtained on I5th September I884; on the I8th three more were procured (and others seen), one a male of the second year, the other two birds of the year. "These were all feeding on insects amongst the bent grass covering the headland. They could hop very fast. I sometimes put them up thirty or forty yards away from the spot where I had marked them down." (Theo. Fisher, Zool. I884, p. 430, and Sixth Migration Report, p. 44.) Spurn-One in the autumn of 1892 (Cordeaux, Nat. I893, p. 9).

From the Migration Reports the following additional entries are extracted :-

1885. Spurn, October 7 th. Two (Red-spotted Bluethroats) (p. 4I). 1886. Spurn, September 14th. One young bird (Bluethroat). This was seen by Mr. Winson, who knows the bird well (p. 31). (See also Zool. 1891, p. 362).

Easington-One on roth September I90r. Seen by the 
late G. W. Jalland; it was on a hedge, and the observer approached to within two or three yards' distance (Jalland, in litt.).

Kilnsea, 8th October I903-A young male example was "telegraphed," and taken to Mr. P. Loten, in whose possession I saw it a few days afterwards; on the same day Mr. Badcock, of the Spurn Lighthouse, informed me he saw one in the garden at Spurn. The Kilnsea specimen is now in the York Museum.

The only other part of the county which can lay claim to this species figuring in its list, is the low-lying tract between the Teesmouth and Redcar, where I have positive information as to its occurrence on more than one occasion in the month of September; I noted one on the Breakwater at the Teesmouth on 2oth September I883 (this is mentioned by $\mathrm{Mr}$. J. H. Gurney, Transactions of Norfolk and Norwich Naturalists Society, I884, iii. 579-60I, and Fifth Migration Report, p. 38).

It is quite possible, even probable, that this Bluethroat may be a regular autumn migrant to our shores when on passage from its summer haunts in Scandinavia, though often overlooked in the crowds of other birds which pass along the coast, or mistaken, from its red tail, for a Redstart, a species which it closely resembles in habits as well as plumage. It has hitherto escaped notice in the spring on its return to its breeding quarters in N.W. Europe.

Herr Gätke stated that it is common on Heligoland, both in spring and autumn. The White-spotted form "comes very rarely so far north, and when it turns up it always does so four to six weeks earlier than the suecica in the spring." 


\section{REDBREAST.}

\section{Erithacus rubecula (L.).}

Resident, widely distributed and abundant. A regular spring and sutumn migrant.

Thomas Allis, in 1844 , wrote :-

Erithaca rubicula.-Redbreast.

The earliest reference to the Redbreast as a county bird is, perhaps, contained in the following interesting letter from Dr. Martin Lister to the renowned John Ray. This epistle is indited from York, and is dated 8th of February 1675, running as follows :- "Dear Sir, . . . . the Robin Redbreast will not touch a hairy caterpillar, but will gladly take and eat any sort of smooth one that I have given to him, and there is no better way speedily to tame or make wild birds sing than to give them a pleasing insect or two daily; neither this nor the thick-billed birds but will gladly eat spiders as I have experienced in some kinds."

Though generally distributed in the county, the Robin is, in the dale and moorland districts, much less abundant, though by no means absent, save in the wilder and uninhabited localities where suitable haunts do not exist. In the populous manufacturing towns its presence is most familiar in the autumn and winter, for during the spring and summer months many retire to nest in the more secluded parts of their immediate neighbourhood. Usually described and considered a resident species, this bird can only partially be considered as such. True it is that we always have it with us, but the increased attention paid to that interesting and important branch of ornithology-migration-has made us aware of the fact that the Redbreast is undoubtedly a migrant to and from our shores. In the autumn months, from August to November, many migratory Robins are observed on our 
coast line, and often in very large numbers. As the bird is strictly a summer visitant to northern Europe, as well as migratory in the central countries of the Continent, no doubt these immigrants are continental birds en route to their accustomed winter quarters, some of them probably remaining with us until the spring. It is not unlikely, however, that many of these migrants among the Robins are home-bred birds on the move to more genial climes, whose absence we scarcely notice, since their places are soon afterwards filled by the arrival of individuals from more northern British and, as stated, continental localities. In fact, the Robin is to a greater or lesser degree a summer and winter migrant.

In connection with the migratory movements of this species on the Yorkshire coast, the following remarks, by Ed. Blyth, from Rennie's Field Naturalist (November I833, p. 467), may be quoted :- "On the voyage from London northward, on the I6th of September, when off the coast of Yorkshire, and about ten or twelve miles from Redcliff, several small birds alighted on the vessel ; they were of different species. On the following day others made their appearance, several ... Robins, all .... . left the vessel on the first night after their appearance, except two Robins, which remained for some time, and which, with the characteristic effrontery of their species, stationed themselves, the one on the front of the vessel and the other at the stern, and fought at the least intrusion into each other's territory."

Mr. F. Boyes, writing in the Zoologist for February 1877 (p. 42), remarked on the great number of Robins at Spurn on October 23rd 1876 ; he noticed several hundreds of new arrivals amongst the long grass and on the sands, and in all the ditches and hedgerows away from the coast. He states that " this migration of the Robin is not new, but, I believe, an annual occurrence; last year at this spot they were even more numerous."

It may be useful here to detail the information respecting this bird which is furnished by the various Migration Reports issued by the British Association Committee :- 
1879. Very numerous at Spurn on October 3oth, wind blowing very fresh from N.E. (p. I 76$)$.

1880. March 1st. At Whitby L.H., daylight, a flock of Robins.

September 27th. At Whitby L.H., at Io a.m., “ a large flock of small birds containing many Robins, remained a few hours and then went south" (pp. 27 and 37).

1881. March 5th. Whitby L.H., at daybreak, many Redbreasts.

October 2nd to 8 th. At Spurn head in large numbers; on the $3 \mathrm{rd}$, so worn out by a N.E. gale that they might be caught by the hand (p. 20).

1882. October 6th to 25th. Between the Longstone L.H. (Farne Islands) and the East Goodwin L.V. in great numbers (p. 30).

1883. September Ioth to October 14th. Occurred on the "main migration" covering the entire [east of England] coast line ; rushes on September 2 Ist and 30 th, October 6th and 7 th (p. $3^{8)}$.

1984. Autumn. At stations between the Farnes and the mouth of the Thames ; first at Shipwash L.V. [Essex] on the I 4th August, in large numbers, at noon; lastly at the Hasborough L.V., November I 2 th, "one at night on deck" (p. 44).

1885. Autumn. Considerable immigration between the Farne Islands and Guernsey, from September 8 th to November I2th ; rush on October 16 th observed at Spurn L.H., Lincolnshire coast (very large numbers) and other stations to south (p. 4I).

1886. Autumn. First at Whitby L.H., August I6th .... a heavy rush is indicated between the 3 rd and 7 th of October at Teesmouth and Spurn; again on the 16 th at Teesmouth, and 18 th and igth at Spurn (p. 31).

1887. March 26th. Whitby L.H., Robins, Io a.m.

April 5th. Spurn L.H. four Redbreasts, 9 a.m.

September I6th. Spurn, several Redbreasts, 9 a.m.

September 29th. Spurn L.H., great migration of Redbreasts.

November 6th. Spurn L.H., Redbreasts, 9 a.m. (pp. 22-50).

I have for many years known the Robin as a regular autumn migrant between September and November to the Teesmouth district; at Redcar I noted a considerable number in mid-October, and again in mid-November 1887 , in company with a constant stream of other migrants, and many were also observed in the autumns of 1896 and 1898 . In the Naturalist for 1893 (p. 9), the late J. Cordeaux, in his notes from the Humber, wrote, "Robin, October I4th, I5th, I6th. An immense arrival in the Spurn district. Thousands 
in the hedges and gardens. I counted up to fifty in one part of the Warren House garden. Many dropped in the long seagrass on the sand-hills, and some caution was necessary to avoid stepping on them, so reluctant were they to move. The movement extended also to Lincolnshire and Norfolk. The arrivals on the Holderness coast had all of them very pale coloured breasts. From Heligoland Herr Gätke also reported a great migration." Mr. Cordeaux further wrote (MS.): "At Spurn Point I have watched them coming in direct from the sea, on a bright sunny day, their red breasts being very conspicuous as they passed overhead. Along with other small migrants Robins frequently strike the lanterns of our light-vessels and lighthouses during the night, or alighting on the former, leave again after a few hours' rest. They cross Heligoland also by thousands in the autumn and again in the spring; this return migration in the spring is early, compared with that of some other birds, commencing by the first week in March." The vernal passage is not so pronounced as that in autumn; a bird seen at the Teesmouth on $25^{\text {th }}$ April I 902 was evidently a returning migrant.

On the coast, during the autum migratory period, Mr. W. Eagle Clarke has frequently observed this bird in considerable numbers in the most unsuitable localities, such as sand-hills, where food of a congenial nature is almost unprocurable, and it often has to resort to a marine "omnium gatherum" at high-water mark in search of a meal. In such places and at such times if often falls a prey to the marauding Great Grey Shrike, which seems to have a penchant for a dish of Redbreast.

There are very many recorded instances of this bird selecting unusual, nay extraordinary, nesting sites within the county, but I will allude to only two of these :-One, in which the nest, of the usual materials, was placed in the curtains of the drawing-room at Gilling Castle, where three eggs were laid and one young bird reared (Land and Water, 25th May 1878, p. 478). The other is recorded in the Field for 17 th May 1884 , and refers to a nest built in a pot of maiden- 
hair fern in a conservatory at Hull. Early nesting, too, is very frequent in this species, but a single instance only need be mentioned, the earliest I find noted, namely, a nest with five eggs near York, on I8th January I848 (Zool. I848, p. 20I9). Mid-March is the usual period on which nidification may be said to commence, and occasionally unspotted eggs are recorded.

The tameness, or sociability, of the Robin is proverbial, and I may here be permitted to recall an incident which occurred when I was out in a N.E. gale, during the autumn migration, waiting for wildfowl on the sand-hills near Redcar, of a Robin, doubtless a migrant, perching on the end of my gun barrels and remaining there for nearly a minute. Mr. P. Loten of Easington had a brood reared in his garden which would follow him about.

Of interesting Yorkshire varieties the following may be mentioned :-A white one in the Tunstall Museum (Fox's "Synopsis," p. 206); one, a bird of the year, procured on 5 th October 1848 , near Knaresborough, which had the whole of the primaries and secondaries white, and the whole of the tail feathers the same with the exception of the tips, which were dirty grey or smoke colour (Zool. I848, p. 2298); a pale rufous example at Beverley (op. cit. 1877, p. 256), and another, a female, in the collection of Mr. P. Loten, of a light fawn colour, with a breast a shade lighter than usual, obtained near Patrington on 27th February 1884. Other varieties in Yorkshire include a pied example at Easington, at the latter end of $\mathrm{I884}$, also in Mr. Loten's collection, and another at Harrogate (Nat. I887, p. 78). An albino specimen, captured at Sedbergh in 1897 , was kept alive for two years. White, or creamy white, examples were noted at Malton on 5 th January 1885 ; Egton Bridge, near Whitby, December I895; Selby, I897; and a tame one in the gardens at Cliffe Castle, Keighley, which paired with a bird of the normal colour (Yorkshire Weekly Post, I7th December I903).

Various superstitions are prevalent among country farm folks in some parts of Yorkshire as regards this bird; the 
strangest being that if a Robin is killed one of the cows belonging to the person guilty of the offence will give bloody milk. At Staveley, near Knaresborough, a saying goes that "when a Robin sings on the ridge of a roof it foretells fine weather." This idea exists also in the East Riding, with the additional notion that if the bird chirps mournfully the weather will be wet. In Cleveland it is considered to be unlucky to take the eggs from a Robin's nest, a distich in common use running, "Rob a Robin, go a sobbing"; and in the East Riding the following couplet is called out against nest-robbers:"Robin takker, Robin takker, Sin, Sin, Sin !" At Skelmanthorpe the idea was formerly prevalent that young Robins, as soon as they are able to fly, will peck their parents to death. In some parts of mid-Yorkshire it was supposed that the Robin loses his red breast when he retires for the summer, and regains it before returning to his winter quarters. In the North Riding it is said that to cast your eye upon the first Robin through glass, after the winter quarter has set in, is unlucky.

Local names:-Robin; Robin Redbreast (general), Ruddock in North and mid-Yorkshire, and Ploughman's Bird (Lofthouse, near Wakefield) are the only vernacular appellations known.

\section{NIGHTINGALE.}

\section{Philomela luscinia (L.).}

Summer visitor, local in its distribution, and entirely absent from the western side of the county.

The earliest allusion to this species, as a Yorkshire bird, with which $I$ am acquainted is the one made by Pennant in 
I766, where he tells us "it is not found in North Wales, or in any of the English counties north of it, except Yorkshire, where they are met with in great plenty about Doncaster." (" Br. Zool." Ist Ed., I766, p. I0o.)

Thomas Allis reported as follows in 1844 :-

Philomela luscinia.-Nightingale-was heard in the immediate suburbs of York last spring; has been met with at Skelton about five miles north of the city some years ago ; it breeds every year in the wood at Cawood, near York; near Huddersfield ; at Cinderfield Dyke Wood in Bradley ; a few pairs are met with near Barnsley every year, where, as in some other places, they soon fall a prey to the bird-catchers; it is occasionally heard near Sheffield; it occurs at Walton Hall and Bramham Park; and near Doncaster is common in Edlington and other woods.

The Nightingale as a Yorkshire bird has peculiar attractions. To the ornithologist it possesses special interest, since it attains in the county the northernmost limit of its British range; while to the public generally quite a halo of romance surrounds the bird, probably because to many localities its visits are like those of the proverbial angels, few and far between.

In the closing years of the eighteenth century, and in the earlier decades of the one just passed away (the nineteenth), Doncaster was regarded by the recognised writers on British ornithology as the most northern locality visited in England. In I844, Thomas Allis, in his oft alluded-to report, stated that it occurred with some regularity much further north, and informed the naturalists of his day that it had been heard in the suburbs of York in the spring of that year, and that it had been met with at Skelton, about five miles north of that city - a statement that has been reproduced in almost every book treating on British birds down to the present time.

In I88I, when Mr. W. Eagle Clarke came to investigate the dates and make further inquiries regarding the haunts of this species for the bird portion of Mr. Roebuck's and his joint work on the Yorkshire Vertebrata, he found that there was evidence of its occurrence and breeding in localities 
considerably further north of the ancient city referred to. This led to the supposition that this species may be regarded as one of those which has gradually extended its range northward in the county during the past hundred years. Further research, however, into Yorkshire ornithology made known that such has really not been the case, as may be gathered from the statement, made at least a century ago, of Marmaduke Tunstall, F.R.S. - a Yorkshire naturalist and one of the best ornithologists of his day-which appears for some not easily explainable reason to have escaped notice. Writing to Dr. Latham, presumably about the year 1783 , Tunstall remarked that "The Nightingale is never heard or seen here [Wycliffe-on-the-Tees]. It is frequently heard near Boroughbridge,* about 37 miles farther south ; and a few miles farther, near Abberford, particularly at Hazlewood, the seat of Sir Walter Vavasour, is extremely lavish in song. ..." This statement of Tunstall's is true to-day, for the Rev. E. P. Knubley, M.A., late rector of Staveley, near Boroughbridge, stated that a pair nested in Gibbet Wood, two miles from Staveley, in I870; that in I88I a pair nested and reared its young in his rectory garden; and that he was told on reliable authority that a pair nested in Loftus Fox Cover in the parish, a mile from his house, in I883. Boroughbridge, it may be remarked, is ten miles north of the latitude of York, and lies sixteen miles north-west of that city.

In occasional instances, however, it has been known to visit during recent years slightly more hyperborean districts, but it is possible, and even probable, that these exceptional visits were also made in the far past, when, as it is important to remember, ornithology was not the popular study it now is, and when, too, there did not exist the numerous natural history journals wherein to record observations and hand down to us much information which would now be invaluable, and enable us to make more just comparisons between our present knowledge and that of the past.

\section{* The italics are ours.}

VOL. I. 
Within the area of its regular summer range in the county, the Nightingale usually occurs in limited numbers only. Indeed it is only in the neighbourhood of Doncaster and on the southern fringe of the county bordering Nottingham. shire that it can be described as fairly abundant. To certain secluded but more or less smoke-begrimed woodlands of the Yorkshire Coalfield, in some instances scarcely beyond the hum and "racket" of the pit-bank, as in the neighbourhood of Barnsley, Wakefield, and Ackworth, this bird is an annual visitant; as also to pleasanter habitats in the neighbourhood of the picturesque Abbey of Roche. In the central plain it is regularly noted in the districts of Selby, Goole, York, Harrogate, and Boroughbridge; and in Holderness in localities between Patrington and the Humber northward and eastward to Beverley.

Thus a line passing north by Rotherham and Barnsley, and east of Wakefield, Leeds, and Harrogate to near Boroughbridge, and then east through Skelton (five miles north of York), and sweeping round the southern spur of the Wolds up to Beverley, and finally reaching the North Sea about Hornsea, circumscribes the portion of the county within which the Nightingale is an annual summer visitor, while an outer line from Sheffield, by Huddersfield, Bradford, Otley, Ripon, and Thirsk, to Normanby-in-Cleveland, thence south . east to Scarborough, includes all the localities for which there is satisfactory evidence of the bird's ever having bred or occurred; and, moreover, accurately defines, according to our present knowledge, the extreme northern and north. western boundary of its distribution in the British Isles.

It is interesting to note that the whole Yorkshire distribu. tion of the Nightingale lies strictly within the lowlands, and nowhere exceeds 250 feet above sea-level, except in the single instance of its breeding in the Spa Gardens at Harrogate. Indeed, the foot-hills of the Pennine Range, of the Cleveland Hills, and even those of the Chalk Wolds, form fringing barriers of the bird's range, and this, perhaps, accounts for its rarity about Sheffield. These facts in the 


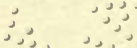

$$
\begin{aligned}
& \text { נק, }
\end{aligned}
$$

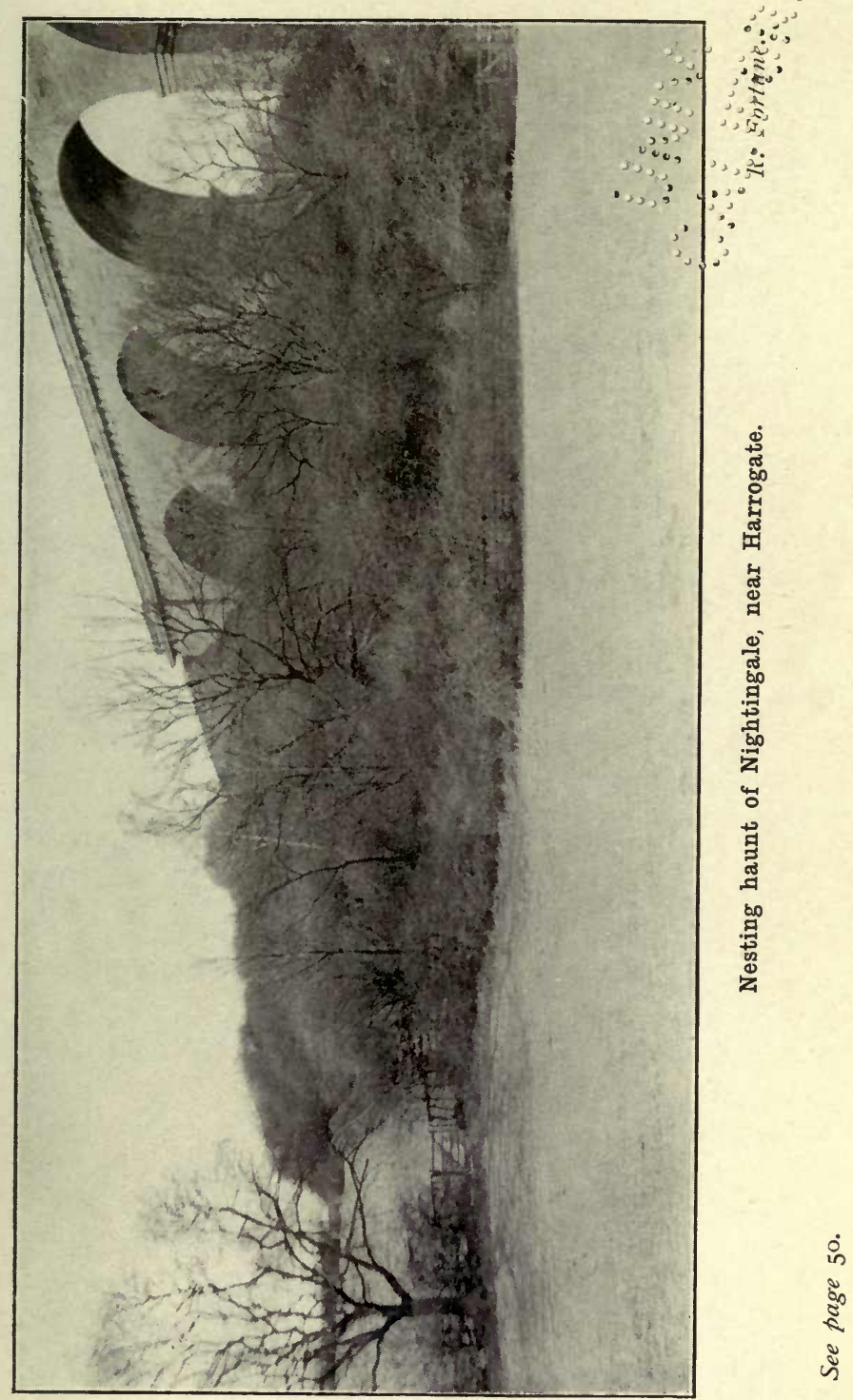




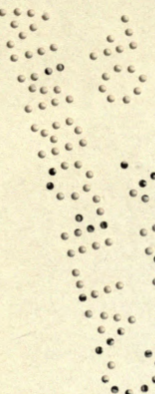


Yorkshire distribution of the Nightingale may throw some light on the conditions which determine the singular range of the bird in England.

On the fringe of its range in Yorkshire, the Nightingale is not at all constant to one particular haunt, but would seem to divide its affections between several in the neighbourhood, and this, too, when it has succeeded in rearing its young in safety, and without receiving that undesirable attention from the "madding crowd" so often attracted by its song. In some seasons it is more abundant in Yorkshire than in others. Thus in 1876 it was noted as absent from its accustomed haunts in the East Riding; while in 1879 it was particularly abundant in the county. This varying abundance may to some extent account for its intermittent appearance in the more northern and outlying districts within its range.

Regarding the dates of the bird's arrival and departure in the county, we have but few reliable data, for the species has hitherto escaped notice during the periods of its migrations. Its appearance may be expected in the last week in April, but the average date of arrival for South Yorkshire has been given as the 8th of May. A pair nesting at Brough, in I880, departed with its young in August.

We will now proceed to discuss the distribution of the Nightingale in the county, historically and in detail, commencing with the localities on the Yorkshire Coalfield. In the Barnsley district, Thomas Allis mentioned, in his report already quoted, that a few pairs are met with every year; and Thomas Lister wrote: "I scarcely remember a year since I842 that I have not heard one or two pairs of Nightingales. In the valleys of Dearne and Dove, in Cliff Wood, Day House, and Keresforth Woods-all three within a mile of Barnsley - they have been heard in various years." He also mentioned Oscar Wood, Cobcar Wood, Kitroyd Jump, Ethersley Wood, Needle Eye Wood, Dodwoth Bottom, Sunny Bank, New Hall, Dark Lane, and Tivy Dale at Cawthorne, Norroyd and Thornhill, as localities 
in the neighbourhood where he had noted the bird from time to time.

In the neighbourhood of Wakefield, Neville Wood mentioned it (Nat. 1838, p. 437), on the authority of Charles Waterton, as an annual visitor to Walton Hall, a statement that has been repeated by various writers to the present date. William Talbot, in his "Birds of Wakefield," tells us he first made its acquaintance in I84I at Burnt Wood, about ten miles from Wakefield; and he noted it in 1870 at Coxley Valley; in $187 \mathrm{I}$ at New Park Spring, Great Houghton, where they were nesting; in may 1873 a pair made its appearance at Haw Park, but unfortunately its career was cut short ; in 1874 two others visited this neighbourhood, and in May 1875 he heard three singing within eight miles of Wakefield. About Lofthouse, George Roberts stated that one was heard about the year I836, and again in 1869, none occurring to his knowledge between these dates. In 1884 one appeared at Stanley.

Regarding the Leeds district, the occurrence of a specimen is recorded (Morris's Nat., I85I, i. 46), at Killingbeck, near Leeds, early in May I849, which was, at that time, in the possession of Thomas Russell of York Road, Leeds. In I879 a Nightingale was heard singing in Mosley Wood, Horsforth, some ten or twelve years before; it was shot by the keeper a short time after. Mr. W. C. Horsfall of Horsforth stated in I 866 that " The Nightingale visits us, but only at intervals; I know of only four instances of its having done so in fifteen years." In the Zoologist (I879, p. 4I3), Mr. Joseph Lucas wrote as follows: "I venture to record two localities in which I have seen these birds-Esholt Woods, in Airedale, in the summer of 1868 , and on May the 8th in Jonas Wood, near Farnley Hall, Wharfedale." In the same periodical (I869, pp. I800-I), Geo. Roberts observed that " on the I3th of May one commenced singing in a small wood called Bushy Cliff, situate about five miles south-east of Leeds ..... and began to sing each evening about half-past ten, and continued in song till four in the morning. I, along with several others, 
walked about in the adjacent meadows most of the nights of the $15^{\text {th }}$ and 16 th listening to it. ... I was somewhat surprised at its tameness; on the third evening many boys and young men from villages round about assembled, and created some uproar, without, however, disturbing it from its perch, and the game-watchers got within a few yards of it. Early in the morning of the 17 th, four days after its appearance, it was captured with limed twigs by two Leeds bird fanciers : a few meal-worms were thrown down among the twigs, and in less than five minutes after the bait was laid, the bird was secured."

At Shipley, near Bradford, in 1850 , one was reported (Morris's Nat. I85I, p. I65), singing last season in a wood about one mile from Shipley. It is said to have occurred at Apperley Bridge.

In the Huddersfield district, Allis (I844) quoted Cinderfield Dyke Wood in Bradley as a locality for it. We are told in Hobkirk's " Hist. and Nat. Hist. of Huddersfield," I859, that two of these birds were noticed at the Grove, Dalton, in 1846. One commenced to sing in Mollicar Wood, Huddersfield, on $5^{\text {th }}$ May 1875, and continued until June $5^{\text {th }}$ (Varley, Nat. 1875, p. 52 ; Palmer, Zool. I875, p. 4499). The late James Varley only knew of three occurrences in this district, one in Lockwood, and those at Grove and Mollicar Woods above mentioned.

Mr. S. L. Mosley (Nat. I889, p. 225), mentions that his daughter and he had heard a nightingale singing near Anston Stones, adding that they "had heard one on a previous visit, and were told that it is a regular visitor."

It appears regularly within a few miles of Ackworth; and has frequently been heard to sing in the vicinity of the town; it has bred on the Stapleton estate since 1870 ; since I 890 it has regularly bred at Brock-o'-dale; as many as six pairs were there in I892. It has also been heard at Upton Beacon. A pair bred at Hogg Wood in I8gI, and the bird has nested there every year since. In I895 a pair nested in Bingley Spring Wood. It also bred at Ackworth Moor top 
in 1862. Its song was heard for a few evenings at Castle Syke Hill in 1868 , the bird being eventually captured by a bird-catcher, who used a glow-worm as bait. In the Rotherham district it occurs in all the woods, and is far from uncommon in the delightful vicinity of Roche Abbey, which is just on the fringe of the Coalfield, and only a few miles from the Nottinghamshire border of the county.

Around Sheffield, Allis reported in 1844 that it was occasionally heard near the town, and Mr. J. J. Baldwin Young, writing from Richmond Park, Sheffield, on 3oth December 1900, states that " Two or three pairs usually nest every year near, and there are other pairs in the same district. This bird is extending its range northward."

In the Halifax district it is said to have formerly visited Elland Woods, while in Ainley Wood, one was said to have occurred in 1845 .

It has not been recorded to my knowledge from elsewhere on the Coalfield save in the columns of the daily press, which, in matters of this kind, cannot be regarded as reliable.

In the Central Plain, about York and district, Allis reported in 1844 that it " was heard in the immediate suburbs of York last spring; has been met with at Skelton, about five miles north of the city, some years ago ; it breeds every year in the wood at Caywood .... it occurs at .... Bramham Park." Regarding its occurrence within the city, my friend, Mr. James Backhouse, informs me that it has nested once in his garden at Holgate. The Rev. F. W. Hayden writes in 1880 that "the Nightingale is plentiful, comparatively speaking, in Skelton. I possess several eggs of that species taken here, and have had nests in my hand, but, as I have made no record, I can give no dates. ... I know that it resorts to Mr. Dawnay's wood, called Skelton Springs, half a mile from my house on the north, and to a wood called Nova Scotia in this parish, one mile to the east of my house. .... The Nightingale has been noticed in Skelton from of old. I have no reason to believe otherwise than that it 
is of annual occurrence. I only once knew of two pair.s at the same time, but I have not sought for them." To the Hon. Payan Dawnay we are indebted for the following interesting communication relating to the Nightingale at Beningborough and other places in the neighbourhood; writing in November I880, he says "I have not heard a Nightingale at Beningborough [eight miles N.W. of York] for some years. The instance of one being heard for two years here, some few years ago, arose from one being caught in a small wood close to the railroad near Shipton, and being brought to me as an unknown bird by the captor; I found it answered the description of a Nightingale, and turned it out into the garden [at Beningborough]. The next year [1867], one of the last days of May, 28th or 29th, I forget which, I heard a Nightingale singing in a plantation about 300 yards from the place I turned out the one brought to me the year previous. This bird continued singing in June, for part of that month; other people heard it as well as myself. The next year [1868] after this I heard a Nightingale in a small wood, perhaps 100 yards from the place it sang in the year before, but it did not sing long, or was taken or frightened. This shows that they come to the same place again if it suits them. One year we had three Nightingales singing, two in Skelton Spring, and one in Overton Wood, but I have not heard of any lately..... I find out on inquiry that the Nightingale was brought to me in I866, and was heard the two following years, but never since that I am aware of close to this place..... There was one at Clifton, a suburb of York, in Mrs. Cattle's garden somewhat about the same time, and she was so annoyed at the lot of people who came late to hear it, that she got some birdcatcher to take it; at least this is what I was told; I cannot say whether it is true or not. The Rev. J. Overton told me of one in Sessay Wood [eighteen miles N.W. of York], a few years ago [1875], that people went to hear in the evening from Easingwold and the neighbourhood. Mr. Overton is now dead, so he cannot be appealed to, but he knew the note of the Nightingale well, 
and was a very fair ornithologist. Sessay is five miles south of Thirsk. I cannot help thinking that a few Nightingales come north more frequently than is thought to be the case, but so many don't know the note, and if they did, do not care." In Gill's "Vallis Eboracensis," published in I852, p. $4 \mathrm{I} 2$, the occurrence of the Nightingale near Easingwold is thus alluded to: "About half-a-mile from Huby, near the road leading to Tollerton, are the fragments of a ruined mansion or monastery, called the Mote, presenting an area of about 600 square yards, surrounded by a deep dyke or fosse, twelve feet in width and seven feet deep. It is now overgrown with Oak and Ash, and for the last four years has been the solitary but favourite retreat, where, in summer evenings the Nightingale

' Sings darkling: and in shadiest covert hid, Tunes her nocturnal note." "

The following information relating to the districts of Wetherby and Boston Spa was supplied by the late Rev. J. W. Chaloner of Newton Kyme, who wrote in I886: "As far as I can remember-and that is sixty years ago-the appearance of the Nightingale in this district is very rare; the first was at Woodhall many years ago, the next time was at Stockeld Park. In I846, one at Colonel Gunter's, Wetherby Grange, where, alas, I saw a blackguard at two o'clock in the morning with a cage, and two or three nights afterwards its song ceased, so I presume he caught it. The next I heard here was in I866. The last here this spring." A pair was reported to have built in the vicarage hedge at Thorparch a number of years ago, but the nest was taken. Its nesting near Bramham has already been alluded to prior to I844, and in more recent years it has been known to resort to that place, and to Skewkirk. Tunstall, one hundred years ago, informed Latham that " near Abberford, particularly near Hazlewood, the seat of Sir Walter Vavasour, it is extremely lavish in song."

Near Harrogate, the Nightingale was first noticed on 


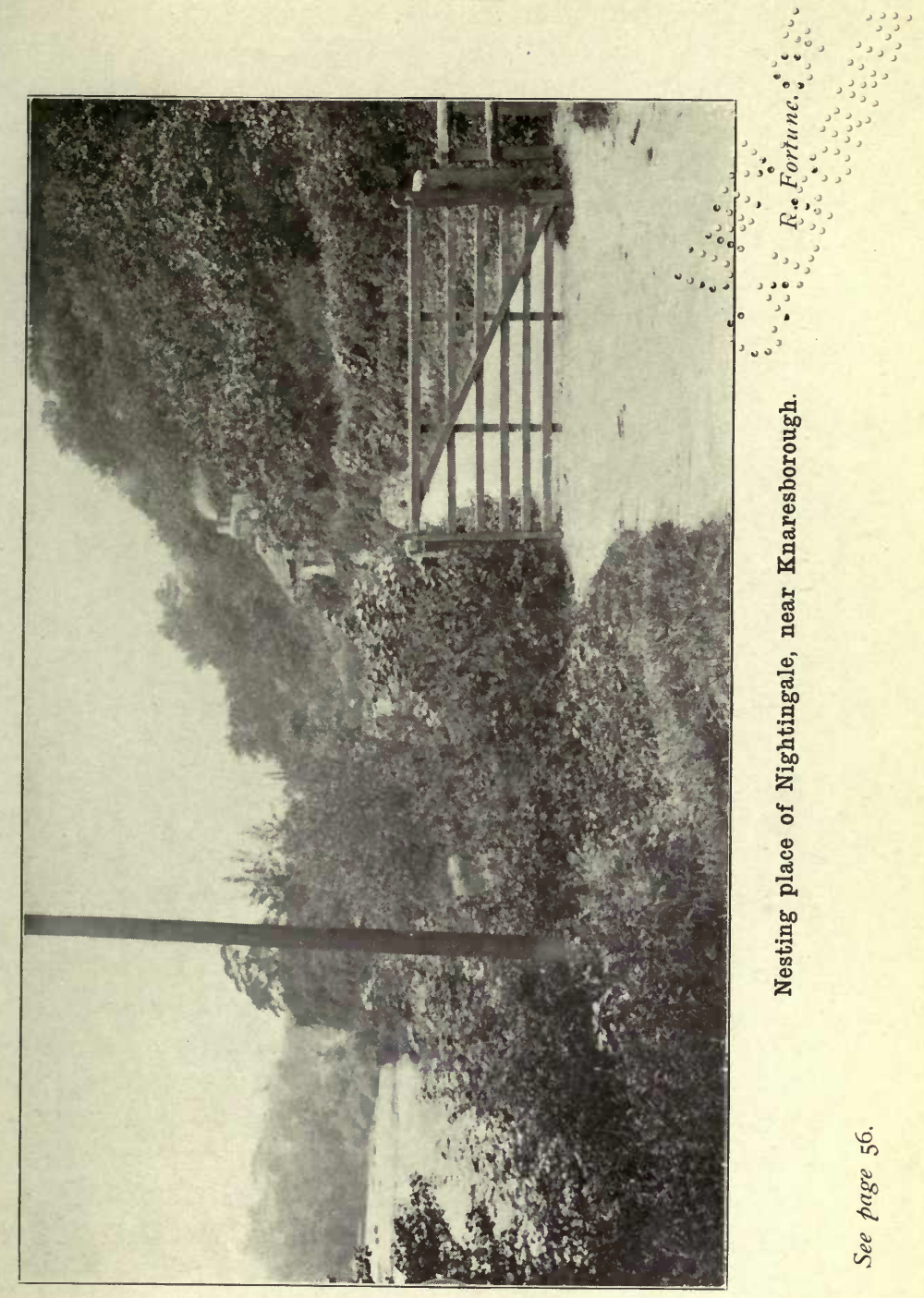



2Ist April I883, and for three consecutive years it made its appearance in the same copse in which it first nested. The same pair of birds was believed to come back year after year. The nest, a remarkably flimsy structure, was built in a tuft of nettles, and contained four eggs. The young were fully fledged on the I6th of June, and left the nest the next day, one egg remaining unhatched. Some days before they left the nest, the notes of the male bird were changed into a call-note, and an angry jarring croak, which it uttered on a near approach. The next year (1884) they appeared again on the 2oth April; this year they were evidently disturbed in their nesting operations by the crowds of people that visited the copse nightly. In 1885 the male bird only was seen, and he disappeared early in June. In I886 no Nightingale appeared, nor was any heard in the neighbourhood. In 1882 a pair attempted to nest in the Spa grounds in Harrogate, and attracted much attention. Its fate is shrouded in mystery.

In 1887 two pairs of Nightingales appeared at Knaresborough, about two miles from Harrogate, during the month of April. They were first heard about the 28th, and took up their summer home at Scriven Park, and on the banks of the River Nidd. The estate belongs to Capt. Slingsby. So far as was ascertained, this was their first visit to Knaresborough.

In the Naturalist (1889, p. 356), corroborative evidence of the appearance of the songsters at Knaresborough in I889, is given as follows: "I have pleasure in being able to put on record the occurrence and nesting of two pairs of Nightingales in some woods within a short distance of Knaresborough. I am not at liberty to be more precise as to the locality, as I have given an undertaking not to do so."

The latest information I have been able to procure as to the Knaresborough district is dated 2Ist February I90I; "A pair of Nightingales was here in the summer of 1892 or I893. They settled in a bank of blackthorn and garden 
orchards below St. Robert's Chapel, on the banks of the River Nidd. Numbers of people went out at night to hear the male bird sing; I went one night. ... A number of rough lads then threw stones at the birds, and they disappeared." A male was heard singing on the banks of the Nidd, half-a-mile below Knaresborough, in May rg02, and in 1903 it was reported near the Crimple, where a nest was found.

At Ripley, two or three miles N.W. of Knaresborough, a Nightingale was heard singing in 1889 .

In the district about Staveley, I have already quoted the evidence bearing upon the three occurrences which have come under notice; and Tunstall has told us that in his day it was "frequently heard near Boroughbridge," but a more recent record is the following: "In the spring of I889 a pair of Nightingales took up their residence in a small wood about a mile from the village of Staveley. The song could be heard on a still evening when more than half-a-mile from the bird's haunt" (Nat. I889, p. I76).

Near Ripon, Mr. J. F. Pratt has in his collection an egg of this species which was taken at Bishopton, about a mile [west] from Ripon, on May 22nd 1878, and was brought him by some lads who wished to know what kind of eggs they were. The nest was built in a bush about two or three feet from the ground, and at the first glance had the appearance of an untidy Blackbird's.

The Nightingale has, however, occurred and bred more than once in the neighbourhood of Thirsk, the most northern limit of its range, save one, or perhaps two, exceptional instances to which allusion will be duly made.

Regarding its occurrence at Baldersby Park, the Hon. Francis H. Dawnay says that in the summer of 1868 a Nightingale was constantly heard to sing, and attracted a large number of people in the evenings, some driving many miles to hear it. It always sang in the same part of the woods, and it is thought it had a nest near. But this gentle- 
man says this is not the first time he has heard of its appear. ance here. In May and June I88I one frequented a wood near Bagby, about three miles from Thirsk.

Sir Ralph Payne Gallwey, Bart., observes that a Nightingale frequented the home wood at Thirkleby Park about 1874. He heard it himself, and the fact is particularly impressed upon his memory, for the people from Thirsk, three-and-a-half miles distant, used to make excursions to hear the bird.

An instance of a pair of these birds nesting at Normanby House in Cleveland, some seven miles west of Redcar, in a locality much further north (indeed, in almost the extreme N.E. corner of the county) than any recorded at the period referred to by Mr. Eagle Clarke, has been known to me for some time; I am indebted to the well-known veteran Yorkshire sportsman, Mr. Thomas Parrington, for a circumstantial account of the occurrence, which was in the early " forties."

The supposed instance of a Nightingale at Tollesby, in Cleveland (op. cit. I89o, p. 27r), is doubtful. A closer investigation of the subject shews that, although Mr. Emerson frequently heard the bird sing after dark in a high thorn hedge, and had little doubt in his own mind as to its identity, he never obtained a view of it. I cannot, therefore, accept it as a true record.

In the extreme southern-eastern position of the Central Plain, at the foot of the Wolds at Market Weighton, in June I880, one had been singing every night in the wood at Harswell Rectory for a week or ten days, which was an unusual occurrence so far north, though not without precedent in this neighbourhood. This last remark is correct, for the Hon. Francis H. Dawnay communicated the information that one was heard at Everingham Park, the seat of Lord Herries, a few years before 1880 ; while at Brough in 1880 a pair nested, brought up their young safely, and left in August. Near the same place a pair bred for four years previous to I900. The nest was found on two occasions, and Mr. L. West shewed me an egg 
which had been taken. At North Cave, the Nightingale appeared in 1896 , and in 1897 was heard on the I6th April, and the young were seen on the 2nd June in a large bush near the ground. In 1898 it was again heard, on April the 29th. At South Cave a Nightingale was heard singing in the Vicarage grounds.

The bird is only an irregular visitant to the eastern part of central Yorkshire, and I am only acquainted with the following instances :-One was heard at Castle Howard on the I3th May 1875, and at Stillingfleet about the same date. The Rev. F. O. Morris (Nat. I85I, p. 216), said he "plainly heard it, ' ni fallor' about a mile south of Malton, namely, seventeen miles north-east of York. It was about eight years ago, when I was walking home one moonlight night." There is most satisfactory evidence of its occurrence at Scarborough, the most northern record, within recent years, for Britain. Mr. William Robinson of West Bank, Scarborough writes as follows in the Naturalist (1882, p. 185): "It will interest ornithologists in Yorkshire to hear that we really have the Nightingale at Scarborough this year. On the Ioth and IIth of May, near Oliver's Mount, I listened to its unmistakable 'jug, jug,' and piping and other liquid notes for about half-an-hour between II p.m. and midnight. I lived many years ago, in Surrey, and became very familiar with these notes, so can speak with confidence as to its not being a "peggy' this time." A later record for this district is that on May the 8th I896, in Raincliffe Wood, it was heard on the I3th, near Throxenby Mere; and it was also seen and heard up to the 29th of the month, on which day it was reported to have been shot (Zool. I896, p. 304).

The late John Cordeaux mentioned (op. cit. I897, p. 332 , and Nat. I897, p. 240), that he saw a Nightingale, in the second week of June I897, within two miles of Filey, in a thicket near the roadside with a caterpillar in its beak, and, within a few feet, a bird of the year.

Passing now to the southern portion of central York- 
shire, Pennant's remarks have been already quoted at the commencement of this chapter. Miller, in his "History of Doncaster" (I804), remarked that this "most delightful songster visits us about the middle of May." Allis, and others down to the present time, mentioned it as common in Edlington and other woods, and in the neighbourhood north of this town the editor of Nevile Wood's Naturalist (I838, p. 437), said: "We have ourselves heard it near Campsall, and in a wood adjoining Owston Hall. .... Wm. H. Rudston Read, Esq., of Frickley Hall, . . . . informs us that several of these nocturnal choristers visit Hooton Pagnall Common."

One was recorded as singing in Regent Square, Doncaster (Nat. I899, p. 292).

About Goole it has been repeatedly heard in the district; at Cowick in 1879 , and at Rawcliffe in 1880 and $188 \mathrm{I}$; it appeared again at Rawcliffe in 1888 and $\mathrm{I} 889$; also at Hook in 1893 and 1894 .

In Holderness, in the southern portion near the Humber estuary, it occurs annually, but in varying numbers. The Rev. H. C. Casson (Field, 21st June 1879), writes as follows on the extension of the range of this species in the neighbourhood of Patrington, and tells us that "Last Monday night, June 9th, I sat on a gate listening to four Nightingales at once, which sang against one another continuously during that time ; and during a walk of a mile I heard three other Nightingales singing, besides the four together. Two years ago a single Nightingale was heard in the same lane, but none was noticed last year." Mr. Casson, in reply to inquiries in I88I, kindly communicated the following additional and interesting information: "On 24th May 1880, and again on the 27th of the same month, I heard (on each occasion), two Nightingales singing in pretty much the same spot each evening. The evenings were both warm ones. On several other occasions I listened for them, but never heard them except on the nights mentioned. However, I have often noticed, when I lived in Cambridgeshire, where Nightingales are very 
plentiful, that when the wind was in a cold quarter I seldom heard their song, and when I did so, it was rather to be called a chirping and twittering than a song. And here in Yorkshire, both last year and this, when I have heard the song it has been on an exceptionally warm evening, for here we have seldom any wind but an E. or N.E. from the first of April to the middle of June. I am inclined to think, therefore, that the Nightingale may be much more common in these parts than is usually supposed, but that the evenings are rarely warm enough to induce them to sing before the beginning or middle of June, by which time I imagine they have young, and the parents have ceased singing. I was struck with this idea especially one evening in June I879. I heard, about 9 p.m., a Nightingale singing very clearly in a tree by the road side, and listened to it for some ten minutes; I then went to a friend's house in order to bring other persons to listen to it; however, I stayed in the friend's house about an hour or more before we set off to listen to our songster, and by this time, i.e. II or II-30 p.m., the wind had changed into a cold quarter, and not even a chirp or a twitter could we hear."

In mid-Holderness, in the neighbourhood of Beverley, Beverley R. Morris, writing in the Zoologist (1846, p. 1298), stated, on the authority of a friend, that five or six years before (about I840), some half-a-dozen specimens were shot or trapped in a thickety wood near this town, called Burton Bushes. There could be no doubt about the identity of the species, as the birds were heard singing when alive, and examined when dead, by persons well acquainted with them. The recorder concluded with the remark, "I am sorry to say, it has never, as far as I can learn, appeared here since." Mr. F. Boyes has furnished the following interesting notes on its occurrence in the Beverley district. "The Nighingale, as you know, is an irregular summer visitor to this part of the county, in some years spread over a considerable area, and at other times entirely absent. I scarcely know how to account for this uncertainty in occupying its previous 
haunts, unless it be that, as we are on the extreme limit of its northern range, we are dependent on the weather in tha spring whether we have them or not. Should the spring be mild and genial at the time of their migration, they probably push further north, whilst should the weather at that time be cold and cheerless, they are kept more within their ordinary limits. We know the mildness or severity of the seasons has much to do with the movements of birds. The Nightingale has visited this district as far back as anyone can remember, but always has been looked on as a rarity, often two, but seldom more, within the precincts of this borough. The first note I can find is in I868, where I have put down that I went to hear a Nightingale sing on Ist May. In I874 I have a note that two sang nightly in our public common, where they bred, and I was told a pair of old ones and the young were taken. In I875 one bird came to the same common (but not exactly to the same place), where it also bred, as I saw the old bird on the nest myself, which had five eggs. It was afterwards taken. It has appeared at uncertain intervals since, but I have not been able to find my note books. It has visited many places in the Riding, but I believe always singly, and generally uncertainly. At North Cliffe, Market Weighton, I was told by old Reynolds that it had appeared there several years in succession, and he pointed out to me the particular wood where it came."

With regard to the present status of the species, Mr. Boyes' opinion, as expressed to me at Beverley, in March I90I, may be summed up in these words:- "Time was when the Nightingale was pretty well known as a summer visitor to Beverley, but I fear the bird-catchers gave them very little peace; of late years its visits have been few and far between, and always intermittent. I have known some instances of the birds taking up their quarters in copses, etc., where they have not been molested, and yet have not returned to them in the following summer ; in fact, I never once knew a Nightingale to come the following year to a spot which 
had been occupied by one the previous season. This is strange when we remember that many birds return to their old haunts. In some seasons I have heard Nightingales sing for an evening or two in a particular spot, and then never be heard again; not having found mates, they have gone elsewhere probably."

Other instances in the Beverley district are at Cherry Burton in 1889 ; at Walkington in 1892 ; at Middleton in I898, and at Boynton in 1890 .

In the extreme north of Holderness, at the foot almost of the Wolds, a pair nested at Littlethorpe, in 1876 , in a plantation on the farm of Mr. W. F. Forster, and not one hundred yards from his house. The nest was taken on the 26th of May, and an egg kindly sent for inspection. The birds built a second time in the same wood, but the nest was unfortunately destroyed. The male used to sing in Mr. Forster's garden continually, and was both seen and heard by him and his friends. Mr. Forster's son afterwards lived at High Caythorpe, near Bridlington, and he found a Nightingale's nest in the garden hedge there in 1887.

There is no satisfactory evidence regarding the occurrence of the Nightingale in north-west Yorkshire, but the following references to it for the district may be quoted as being on record. "The Nightingale is a very rare visitor in Wharfedale, for I have constantly asked this question. A woodman told me that he once heard one when working at Grassington Wood, it was towards evening, and many years since." F. Montagu, "Gleanings in Craven," I838, p. 57). From "Whitaker's Craven" (2nd Ed., I8I2, footnote p. 49I), I transcribe the following passage, which is perhaps worthy of quotation here : "As a trait of old ornithology, I must inform the reader that Craven had formerly two very different birds, long since extinct, the Eagle and the Nightingale. The existence of the first .... is proved by .... that of the latter, in Ribblesdale, by Nichtgaleriding, the name of a place in the parish of Bolton, mentioned in the Coucher 'Book of Sallay.' 
The Nightingale has, within recent years, been reported at Welbeck Wath in Yorkshire (Nat. I899, p. 279).

\section{WHITETHROAT. \\ Sylvia cinerea (Bechstein).}

Summer visitant, common, and generally distributed.

The earliest known reference to the Whitethroat's connection with Yorkshire was made by $\mathrm{R}$. Johnson of Brignall, near Greta Bridge, in a letter to John Ray, dated 29th March I672:- " Honoured Sir . . . I It is like enough our Whitethroat (curruca cinerea) is of the Ficedulæ, for it is her manner with us to fall upon a fair and ripe cherry, whose skin when she hath broken with a chirp she invites her young brood, who devour it in a moment " " Correspondence of John Ray," p. 96).

Thomas Allis, in 1844, wrote:-

Currucca cinerea.-Whitethroat-Abundant in most districts.

This species arrives about the middle of April, sometimes in the third week: the mean date for ten years at Barnsley was the 25 th, though in 1883 it was recorded as early as the I6th, and in I90I it was noted at Newsome on the 3 rd. It takes its departure in September.

In all the wooded and cultivated districts it is commonly met with, and has occasionally nested on the moors; at Buckden, in Upper Wharfedale, it was found at an elevation of rooo feet in Raikes' Wood. In the East Riding it is frequent in the lanes and by-ways of the higher ground, such

vol. 1 . 
as Bempton and Flamborough, as also in the woods and in the low country.

As a migrant at the light-stations it figures in the Reports on several occasions, and appears in the list of birds killed by flying against the Flamborough lighthouse, at which place it is recorded as of annual occurrence; there was a "rush" on 28th April I893, and on I9th April I894 it was plentiful at both Flamborough and Spurn, as again in the same month in 1897 .

The pink variety of egg is occasionally found in Yorkshire ; my collection contains one of a clutch of seven taken in June I894 by Mr. C. Milburn, and a clutch of a similar character is in the possession of Mr. W. Gyngell of Scarborough, found by him near that place.

In 1877 a brood was reared near Masham in the nest of a Sedge Warbler, after the latter bird had brought off its young.

Its vernacular names are varied and numerous; Greater Prettychaps and White-throated Fauvet are fancy book names used in Neville Wood's Naturalist, I837; Winnel or Windle Straw, Peggy, Peggy Whitethroat, and Nettle Creeper are in general use; Small-Straw at Huddersfield and in the West Riding, and Straw-Small at Wilsden and in the West Riding are terms applied to the nest; Muggie or Meggie, and Nettle Monger are used in the North Riding; Big Peggy and Big Peggy Whitethroat in Nidderdale; Peggy Chatter in the East Riding; and Nettle Wren in East Cleveland; while Mock Nightingale is a name formerly used at Redcar. 


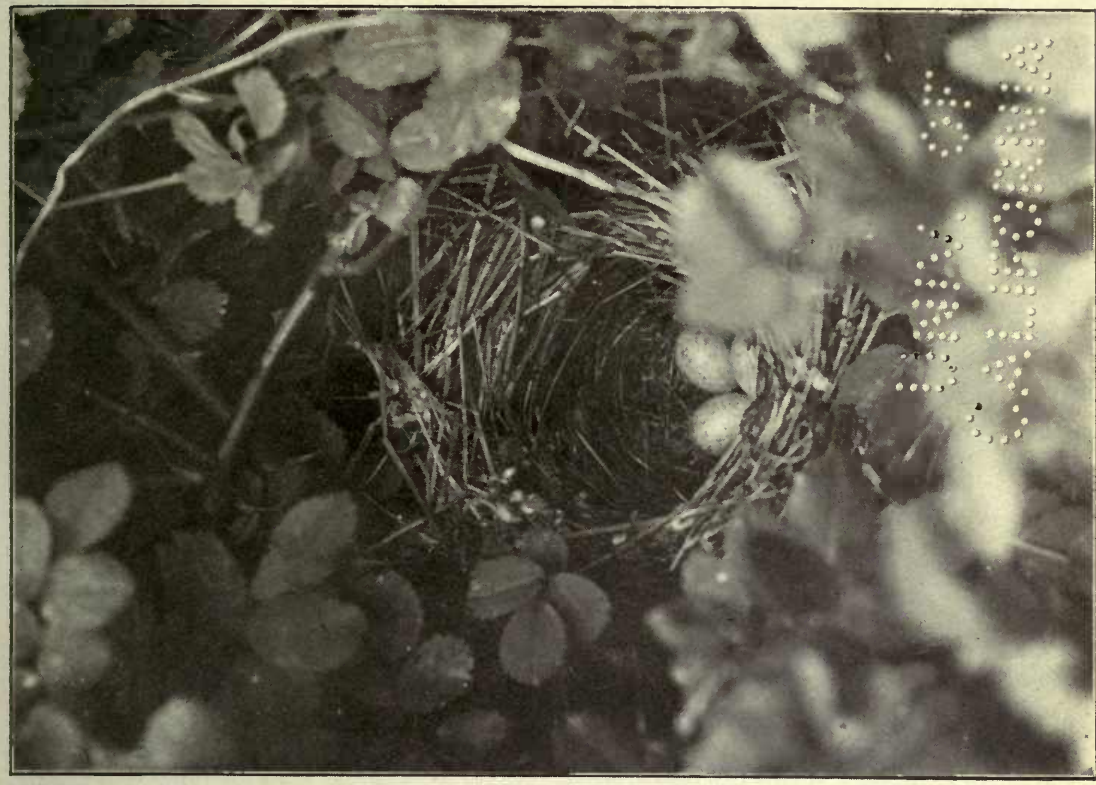

年

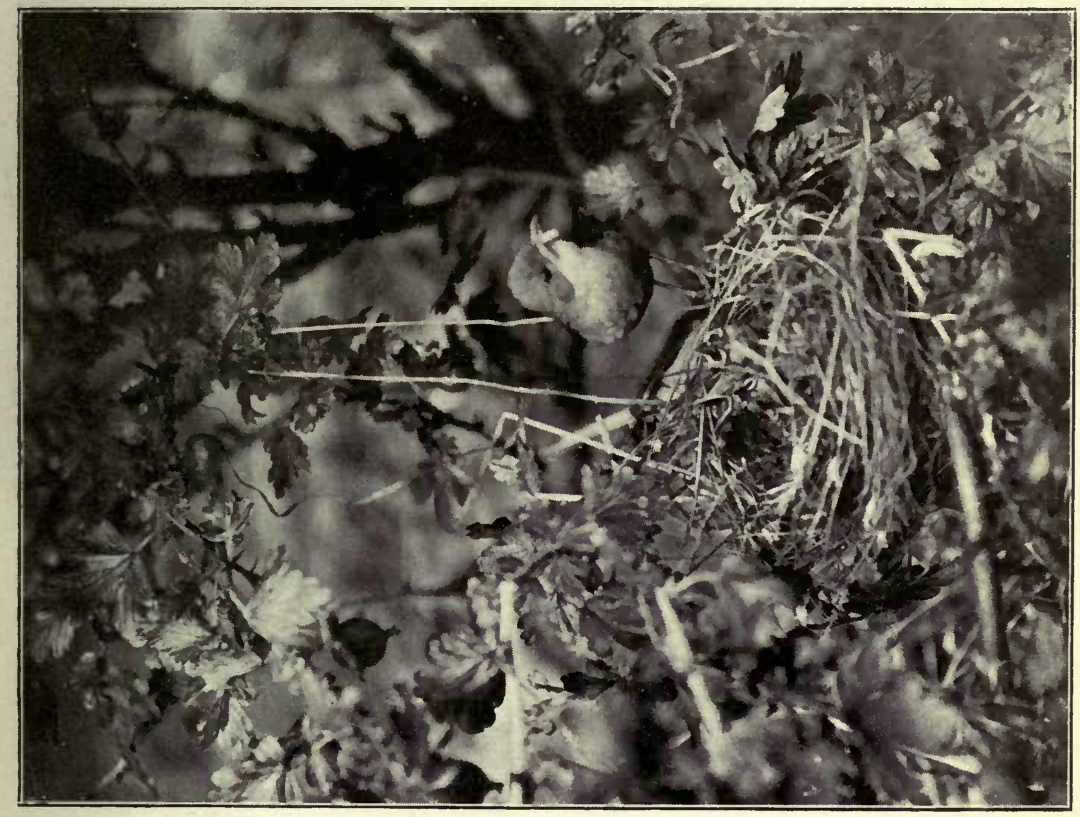

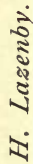

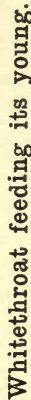




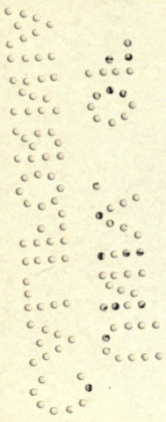




\section{LESSER WHITETHROAT. \\ Sylvia curruca $(L$.$) .$}

Summer visitant, generally but thinly distributed; not so abundant as the preceding species.

The first mention of this as a Yorkshire bird is, apparently, in Loudon's Magazine for July I832, where it is chronicled as occurring in Wensleydale in I83I.

Thomas Allis, in I844, wrote:-

Curruca garrula.-Lesser Whitethroat. Met with near Doncaster, Huddersfield, Hebden Bridge, and Halifax, and is common near Sheffield and York; is seldom seen near Bridlington, and then only in spring and autumn ; it is not known to breed there.*

The general time for the appearance of the Lesser Whitethroat is about the end of April or early in May; at Barnsley the average date, calculated over a period of twenty years between 1854 and 1874 , was the 28th April ; and for ten years afterwards it was the $4^{\text {th }}$ May. The earliest recorded arrival was at Halifax, where one was noted on the I 7 th April, and in 1883 , at Barnsley, it was seen on the I8th of that month.

It usually leaves in September, occasionally lingering until late in the succeeding month: the latest occurrence noted at Spurn is 17 th October 1896.

It is more locally and thinly distributed than its congener, though it may be met with in most localities suitable to its requirements ; it has not been noticed in the Sheffield district, though it breeds regularly near Halifax; and in the Wilsden neighbourhood there are only two instances of its occurrence ; it is not uncommon near Ackworth; at Spofforth and Wetherby it is fairly numerous; and at Beverley it is moderately, and in some seasons plentifully, distributed; while near York it is more abundant than S. cinerea. Though not a common species in the central and north-western dales, yet it may be overlooked owing to its skulking habits; it

* Allis was misinformed as regards its presence near Bridlington. 
is, however, fairly abundant near Bedale; it nests near Malham; and in the Nidd Valley it is found to $\mathrm{r}, 000$ feet elevation and up to the borders of the moors; it occurs also in Lower Swaledale, and is a regular visitant at North Stainley and Ripon.

On the coast line it is known chiefly as a spring and autumn migrant, but nests sparingly in suitable localities in the Esk Valley and in Cleveland. It visits Holderness regularly, but not in great numbers, as a nester, and more frequently on both the spring and autumn migration.

It has often been reported from Flamborough at the period of the vernal passage, and in 1877 one was killed by flying against the lantern of the lighthouse. The Migration Reports contain only the following entries, all of which refer to the autumnal movement :-

" I88I. September 3rd. Spurn. Lesser Whitethroats abounded.

September 22nd. At Teesmouth-Several.

I887. September 2Ist. Spurn. Lesser Whitethroat."

Its local names are: Small Straw in Nidderdale and the West Riding; Whitestraw at Ackworth, and Mealymouth at Helmsley and Thirsk in the North Riding. The name Lesser Pettychaps has been conferred on it by some of the old writers, but it is confused with other small warblers, such as the Chiff-chaff. The title of Beam Bird (Latham Syn. p. 4I3), is also a mistake ; see Garden Warbler.

\section{ORPHEAN WARBLER.}

Sylvia orphea (Temm.).

Accidental visitant from Central and Southern Europe, and Northern. Africa, of extremely rare occurrence.

This warbler nests freely in France and the south-west of Europe, and occurs regularly along the eastern seaboard 


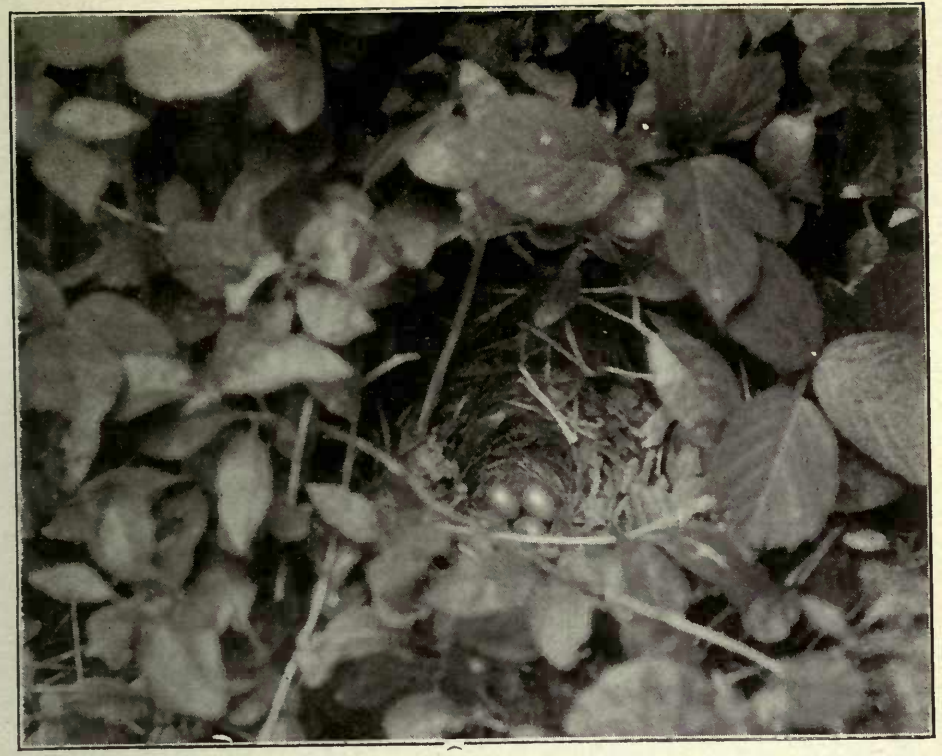

Nest of Nightingale, near Harrogate.

$R$. Fortune.

See page 57.

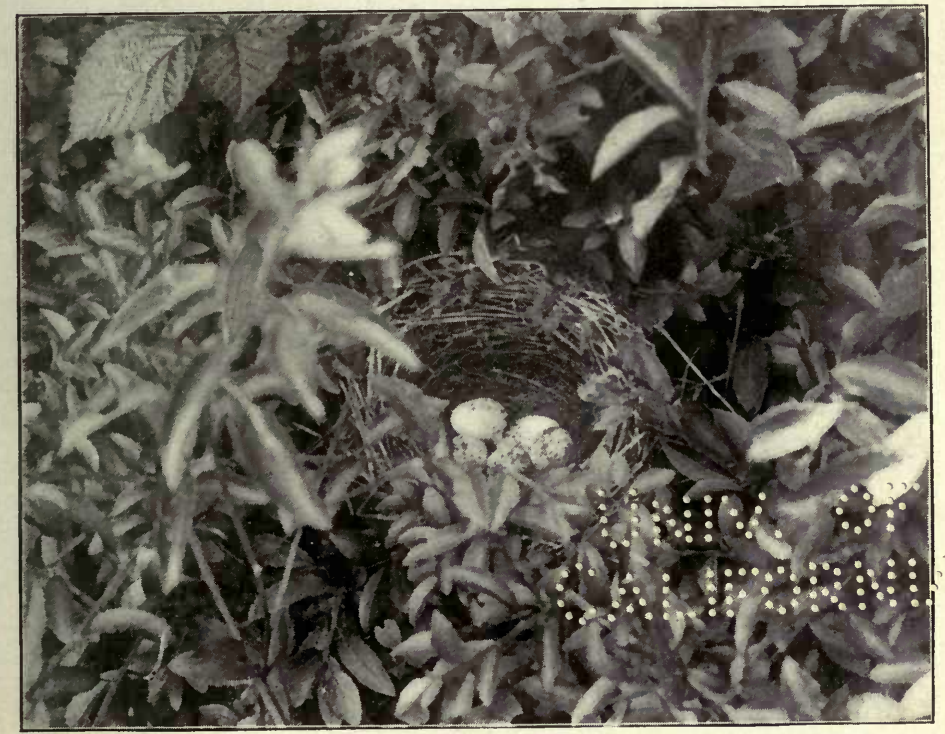

Nest of Lesser Whitethroat, near Ripon.

R. Fortune. 

of the Mediterranean as far as Turkey; in winter it migrates to Egypt and Nubia.

There are but two authenticated records of its occurrence in the British Islands, the first being in this county, where one, out of two seen, was killed on 6th July I848, and came into the possession of the late Sir Wm. Milner, who stated that "it was shot in a small plantation near Wetherby, and was, unfortunately, very ill set up by the man who obtained it; it had the appearance of having been engaged in incubation from the state of its plumage. Mr. Graham, my bird-stuffer at York, having heard that a very uncommon bird had been shot, went over to Wetherby and, fortunately, obtained the specimen for my collection. It has the beak black and very strong, eight lines in length, the upper mandible very much grooved. The whole upper part of the plumage dark ash-coloured brown. The outer feather of the tail white, the rest of a brownish black. Chin dirty white; throat and belly brownish white; under surface of the wings and vent light brown. Legs very strong; toes and claws black. Total length 6 inches 3 lines." (Milner, Zool. I849, p. 2588; I85I, pp. 3107, 3III. Yarrell's “British Birds," Vol. I. p. 343 ; Dresser, Vol. II. p. 4I2.)

This specimen, on the strength of which the species was admitted to the British list, is now in the Milner collection in the Leeds Museum.

The nest and eggs of the Orphean Warbler are said to have been taken at two localities in Yorkshire, viz. : Penny Spring Wood, near Almondbury, in June I856 (Varley MS., $9^{\text {th }}$ November I879), and Notton Wood, Wakefield, in June I864 (Harting's Handbook, 2nd Ed., p. 356), but, as the birds were not identified in either case, these records cannot be accepted as reliable. 


\section{0 \\ BLACKCAP. \\ Sylvia atricapilla $(L$.$) .$}

Summer visitant, somewhat irregularly distributed, and not very numerous. Has occasionally occurred in winter.

The earliest allusion to this species as a Yorkshire bird is, apparently, that contained in the Rev. J. Graves's " History of Cleveland," I808, where it is styled " Motacilla atricapilla.'

Thomas Allis, in I844, wrote :-

Euvruca atricapilla.-Blackcap Warbler. Is frequently met with in most parts of the county; not very common near Huddersfield, where it is stated to remain the year through.

This charming songster arrives late in April, the average date in the south of the county being the 22nd, and the I8th in the central plain; an early date is noted at North Stainley, near Ripon, where two were seen on 3Ist March I892, and at Masham it has been reported as early as the 9 th of April. The time for its departure is September or early October; at Barnsley the approximate date is the roth of the latter month, though it has been known to occur in mid-winter at the following places: Almondbury, on 26th January I866; near Holmfirth Reservoir, on 29th November r873; and near Sheffield on 3rd December I882.

The Blackcap is a bird of rather irregular and local distribution, and appears to be more frequent in the south than in the north, but it varies in numbers in different years. In the Sheffield district it is tolerably common; about Halifax it has been found nesting; and in the north-west and most other parts of the West Riding it may be considered as a regular but, generally speaking, not abundant visitant, though in localities where there is plenty of cover, thick hedgerows, gardens or plantations, it may usually be met with. Allis's Report requires some modification as regards Huddersfield, for various observers state the Blackcap is not uncommon in that district, and the remark respecting its wintering may be qualified by the use of the adverb 


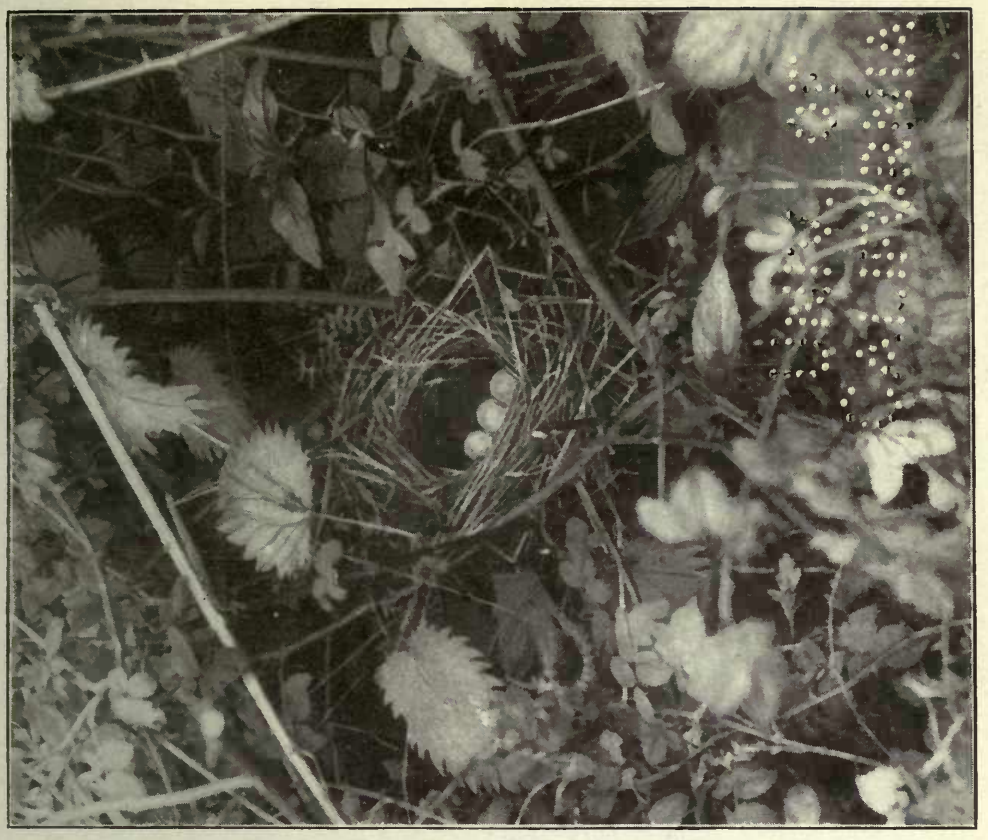

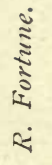

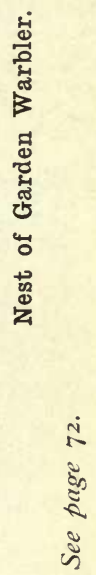

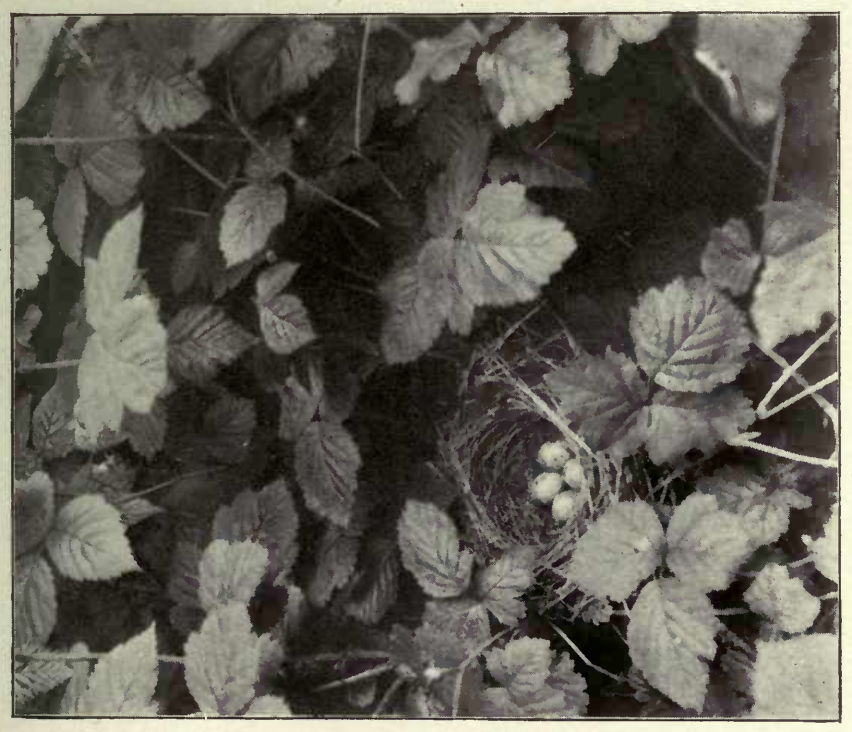

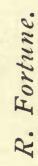

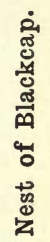

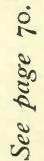



"occasionally" before "remain." In the East Riding it is fairly distributed in suitable places, woods, copses, and gardens, where its loud song is to be heard all day long, and in the autumn it comes to feed on the soft fruits. In the North Riding it is a regular, but cannot be described as a very numerous, visitant. J. Hogg (Zool. I845, p. I058), remarked that "it is the best and most melodious of our northern songsters, as the Nightingale is unknown here [Cleveland] ; it is not infrequent in the gardens and plantations where it nidificates."

During the migration periods it has been reported on several occasions at the light stations on the coast; it occurs pretty regularly at Spurn in spring, and is not uncommon in September and early in October amongst the crowds of warblers then passing southward. The information supplied to the British Association Migration Committee shows that there was a "rush" on 3rd September I88I, and several were noticed at Redcar on the 22nd; one was killed at Spurn on Igth October I886, whilst Mr. W. Eagle Clarke shot a female at Kilnsea as late as 28 th October, I880.

The late P. Inchbald (Zool. I850, p. 2849), noted the powers of mimicry possessed by this bird, which he heard giving accurate imitations of the alarm notes of the Blackbird and Robin ; and Mr. E. L. Gill (in litt.) informs me he has heard it mimicing the Garden Warbler (op. cit. I9or, p. 450).

The scarce pink variety of the Blackcap's egg has occasionally been taken in Yorkshire; my collection contains a clutch of four, found near Whitby, in the "sixties," and formerly in the possession of Mr. J. Braim ; a similar clutch was reported on I8th May I894, at Boston Spa, by Mr. Stevens. In June I876, a nest was found suspended after the manner of a Goldcrest's, in a fir tree near Beverley (op. cit. I877, p. 258).

The local names are: Peggy in the Barnsley district; Black-capped Peggy near Doncaster; and Coal Hoodie in the North Riding (Swainson). At Wilsden the nest is called Straw small. 


\section{GARDEN WARBLER. Sylvia hortensis (Bechstein).}

Summer visitant; generally distributed; more abundant in the south and middle of the county than further north.

This species was first made known as a British bird by Willughby, to whom a specimen was sent from Yorkshire by Mr. Jessop, Broom Hall, Sheffield, who called it "Pettychaps" (Will. "Orn.," I676, p. 26).

Thomas Allis, in 1844, wrote as follows :-

Curruca hortensis. - Garden Warbler. Met with near Huddersfield and Hebden Bridge ; frequent in gardens and shrubberies near Halifax; more frequent than atricapilla near Sheffield; and less so near Leeds and York. In the East Riding in its [passage] in the spring, but seldom breed there.*

This sober plumaged warbler arrives late in April or early in May, generally in the first week of the latter month, its earliest appearance being in 1885 , when one was noted on 28th April, at Scarborough. It usually takes its departure in August or September, at which period a coast migration is sometimes noticed passing south.

Where its favourite gardens and copses are to be found it is pretty generally distributed, most abundantly in the south and south-west, and it may be described as fairly common in the Central Plain, but further to the north-west it is somewhat scarce, yet not infrequent in the Forest of Bowland, and it is not uncommon in the Lower Wharfe and Nidd districts.

It is moderately, still not uncommonly, diffused in the East Riding, and is more frequently observed on its passage in spring and autumn than as a nesting species, though it breeds in several localities, noticeably about Beverley. Near Scarborough it is fairly abundant, and so up the coast to Whitby, Loftus, and in Cleveland; the same remark may also be applied to its status in Teesdale.

* Allis was misinformed as to its status in the East Riding. 
This species does not figure in the Migration Reports on its spring passage, nor has it been noted in autumn so often as the Blackcap. The only entries are :-

I88I, p. 20. At Spurn, 3rd September, and at Redcar on 22nd September, several were noted.

I884, p. 44. At Spurn, I7th September, one struck the lantern and was killed, and several were seen on the following day.

I885, p. 42. At Spurn, 22nd August, one recorded.

The Garden Warbler's partiality for the fruit of the cherry is alluded to in Rennie's Field Naturalist (February I833) as follows:- "I have never seen the Pettychaps in Yorkshire until the cherries are ripe, when they immediately make their appearance and attack the Kentish cherry particularly, being so greedy that I have often taken them with a fishing rod tipped with birdlime while they were pulling at the fruit. The moment they have finished the last Kentish cherries they disappear for the season. If they finish the cherries in the morning they are gone before noon ..... in Yorkshire they do not even wait for the later cherries. The number of these visitants depends upon the crop of early cherries. This year the crop having nearly failed, I saw but two of them, which appeared on the I5th of July, and were not seen after the I7th."

A departure from the usual choice of a nesting site has been reported on several occasions, amongst the places selected being the centre of a large fern; a pear-tree ten feet above the ground, at Beverley, in I903; and in Bolton Woods a nest was found on Whit Monday I876, within four feet of a road.

The vernacular names are: Small Straw in the West Riding; and Straw Small at Wilsden; Nettle Creeper in Craven; Peggy near Barnsley and in the West Riding; Hair-tail in the Nidd Valley. Great Pettychaps is given by Swainson; Willughby called it Pettychaps and Beccafigo, or Fig-eater.

Pennant ("British Zoology," vol. ii. p. 264, Ist Ed.) said this is called in Yorkshire Beambird, but he was evidently mistaken (cf. Montagu's " Ornithological Dictionary," p. 234, and Yarrell's "Brit. Birds," 4th Ed., Vol. i. p. 4I5). 


\section{BARRED WARBLER.}

\section{Sy:via nisoria (Bcchsteir.)}

Rare autumn visitant on migration southward, from North-west Europe.

The Barred Warbler nests in the north-west provinces of the Continent, as also in central Europe, Turkey, South Russia, Persia, and Turkestan, where it attains an altitude of I0,000 feet. It winters in Central and North-east Africa.

Of the twelve examples of this rare visitant which have been recorded in the British Islands, four are from East Yorkshire, and that portion, between Hull and the promontory of Spurn, is the only district in the county which can lay claim to its occurrence.

The first Yorkshire specimen was a female in immature plumage, obtained at Spurn by the Rev. H. H. Slater, on 28th August I884, in an elder hedge by a potato garden on the sand-hills, where it was very shy and difficult to observe. This bird was exhibited at a meeting of the Zoological Society on the $4^{\text {th }}$ November following (P.Z.S. I884, p. 447 ; Zool. I884, p. 489; Nat. I884, p. 9I).

The second example, also from Spurn, was shot on Igth October I892, by the late G. W. Jalland of Hull, who thought it might be a Bluethroat; it was afterwards acquired by $\mathrm{Mr}$. W. Eagle Clarke for the Royal Scottish Museum (A. Newton, P.Z.S. Ist November I892; J. Cordeaux, Zool. I892, p. 424 ; Nat. I893, p. I4).

The third occurrence was at Kilnsea, near Spurn, where one was taken by G. E. Clubly on I3th November I893 (J. E. Harting, Zool. I894, p. 58; Nat. I894, p. I5). This specimen is in Mr. J. H. Gurney's collection.

And the fourth, an immature female, was shot by $\mathrm{Mr}$. Darley of Hull, in his garden at Skirlaugh, on 3rd September I894; his attention was first called to it by his wife, who noticed it was a strange bird. (F. Boyes, Field, 29th December I894; Zool. I895, p. 57; Nat. I896, p. I96; 
1897, p. 20I). This specimen is now in the York Museum.* Mr. L. Harwood, the naturalist who accompanied Mr. (now Sir) A. E. Pease on his Abyssinian expedition in I900-or, has kindly shewn me a skin of a male Barred Warbler, which he shot on 4th March Igor, at Taddasha Malka, Abyssini, the most southern limit of its range as at present ascertainea, in stony, hilly country, the only vegetation being tall grass and mimosa bush, on which it was actively searching, always on the outer twigs; the colour of its eyes, a bright yellow, was quite noticeable at twenty-five yards' distance.

\section{GOLDEN-CRESTED WREN. Regulus cristatus (Koch.)}

Resident; generally distributed in suitable localities. A great influx of winter visitants and birds of passage in autumn.

The first mention of the Golden-crested Wren as a Yorkshire bird is contained in Ray's "Synopsis," dated I7I3, p. I9, where it is alluded to in a few words thus :- "Regulus cristatus -Mr. Francis Jessop [found it] in Yorkshire." An early reference is also found in a communication from Dr. Sherard of North Bierley (a celebrated botanist and a correspondent of John Ray) to Walter Moyle, dated London, Jan. I2th I7 $\frac{1}{2} \frac{9}{9}$, which is as follows:- "I carry'd him two Birds he had not before, sent me out of Yorkshire by Dr. Richardson .... . and Regulus Christatus, well preserv'd" (Works of Walter Moyle, Esqre., London I726). (Dr. Richardson's observation in Philosophical Transactions I7I3, on the alleged nest of a Goldcrest, is evidently a mistake, and is referable to the Long-tailed Tit.)

Thomas Allis, in I844, wrote:-

Regulus vulgaris.-Golden-crested Regulus. Frequent in most of the wooded districts; it breeds and remains throughout the year.

This, the smallest of our British birds, is resident where

* See Nat., I888, p. I, for comparison between England and Heligoland as regards migration. 
it can find suitable nesting haunts ; it breeds in most of the wooded dales even up to the edge of the moorlands, as well as in the low country, where fir plantations exist, also occasionally in shrubberies and gardens, and in some cases its nest may be found within a mile or two of our largest manufacturing towns.

The tiny Goldcrest is one of the best known migrants at the light stations on the coast, and in the autumn incredible numbers of these fragile looking voyagers brave the dangers of the North Sea to land on our shores during the early part of October; they generally arrive simultaneously with the Short-eared Owl and Woodcock, hence one of their local names-"Woodcock Pilot." In I88I these three species appeared about the 5 th September, fully a month in advance of the time when they may usually be expected, being observed at Spurn and also at Redcar, where they sometimes come into the fishermen's cottages, and remain as long as there are sufficient flies to support them. The Humber fishermen have remarked that at this season they frequently alight on the smacks in the North Sea, and in thick foggy weather hundreds perish; as they become quite bewildered, their instinct apparently forsaking them, they do not know what direction to take; they often rest on larger vessels also, and so long ago as I833 Edward Blyth wrote that on the 7 th October, when fourteen miles off Whitby on the voyage to London, a flock of Goldcrests settled on the ship's tackle (Rennie's Field Naturalist, November I833). They have been seen on the sand-hills at Spurn in hundreds about the middle of October, and so exhausted that they could have been easily caught in a butterfly net. If the records relating to migration are searched it will be found that, since Selby's time down to the present date, the Goldcrest has attracted the attention of naturalists; in some years it has arrived in what are termed " rushes," and in other seasons in only small numbers ; Selby recorded a great flight on 24th and 25th October I822, covering the coast from Berwick to Whitby; in 1864 there were great numbers at Spurn and in Holderness; in 1875 
a large flight was reported at Flamborough and Scarborough (Zool. I876, pp. 4778, 4923), and the following year at Spurn (op. cit. 1877 , p. 42$)$, at the same time many large flocks were seen at Redcar; immense quantities were noted at Spurn again on I6th October I878 (op. cit. I879, p. 43); then, coming to the period when the British Association Migration Committee commenced its work, numerous entries are noted in the Reports, which are too voluminous for recapitulation, but the great rush of I 882 may be alluded to when " they covered the entire length of the east coast and the migration extended over ninety-two days, commencing 6th August; near Redcar on the I 3 th of that month about fifty were seen at the Teesmouth; they arrived somewhat sparingly in August and September, and day after day in enormous numbers in October: in this month they are recorded at twenty-one stations between the Farne Islands and Guernsey; two great rushes took place, one on the 7 th and 8th October, and again on the I2th and I3th, the latter with Woodcock, and great numbers are supposed to have perished on passage." (Fourth Report, p. 32.) They arrived at Spurn daily during October until all the hedges and the grass on the sand-dunes positively swarmed with them ; on the sand-hills near Redcar a huge flock, like a swarm of bees, came directly off the sea and settled amongst the hedgerows near where I was watching for wildfowl ; one of the oldest fishermen remarked to me on the I3th October that he had " never seen so many hummingbirds" (as they are locally termed). The years I886 and r889 were also noticeable for unusually large numbers on migration. Subsequent to the Reports of the Migration Committee, rushes occurred in 1892 , on the I4th to I6th October, at Spurn and Flamborough, and again in 1898 from the 6 th to the 15 th October, and in 1906 at the end of October.

The vernal passage takes place in March or April when they are seen near the coast in small parties and are occasionally killed by striking against the lighthouses; two met their death in this manner at Flamborough on $4^{\text {th }}$ April I899, and, on 30th March I890, a swarm was observed in the hedges near the lighthouse. In I 898 some were seen at 
Spurn on the return migration as early as the I6th March, and in I89I they were noticed on the IIth April.

A very remarkable incident connected with this little bird's migratory habits occurred near Redcar some years ago, the facts of which were communicated to me at the time by the late J. Wilson, contractor for the work of constructing the Tees Breakwater. $\mathrm{He}$ was at the end of the "gare" on the morning of I6th October I88I, when he saw a Shorteared Owl " flopping" across the sea, and noticed, as it drew near, that there was some small object between its shoulders; it alighted on the Breakwater close to where he was standing and immediately a little bird flew off its back; one of his men and he followed it up and caught it, when it was found to be a Goldcrest, as I had ocular proof. The fact of " small birds being assisted on migration by larger ones" has long been known to travellers, both in the East and also in America, and most important corroborative evidence was unexpectedly supplied by Mr. Thos. Gibbons of Liverpool, a ship captain, who, in going up the Mediterranean for the Straits of Gibraltar, sighted a flock of birds crossing from the European to the African shore; they were accompanied by smaller birds which frequently settled on the backs of the large ones and, with the aid of marine glasses, could easily be distinguished nestling in between the shoulders of those on the wing; occasionally the small birds would start up from their resting places, and stretch their wings for a short distance. (See Zool. I882, pp. 72, 73; and Field, 3Ist March I888.)

A departure from the ordinary nidification habits of this bird is sometimes made; the nest has been met with at Danby on the top of a branch (not underneath) where it emerged from the trunk (Zool. I863, p. 8680); Mr. W. Eagle Clarke found one in a whin bush in Pollard's Woods, near Leeds, and Mr. F. Boyes has seen the nests amongst the ivy on trees in woods where there were no spruce or firs.

Three Goldcrests, shot in February 1882, weighed exactly sixty grains each.

The vernacular names in use are numerous. Golden Crested Kinglet is used at Sheffield; Fire Crown at Thirsk 


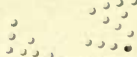

$$
\begin{aligned}
& \text { ע, } \\
& \therefore \\
& \therefore
\end{aligned}
$$

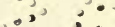

$$
\begin{aligned}
& \ldots
\end{aligned}
$$

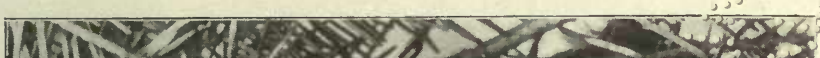

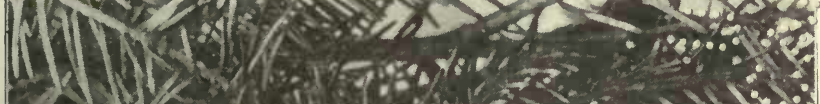

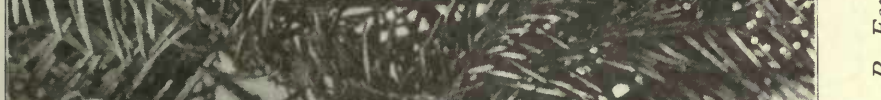
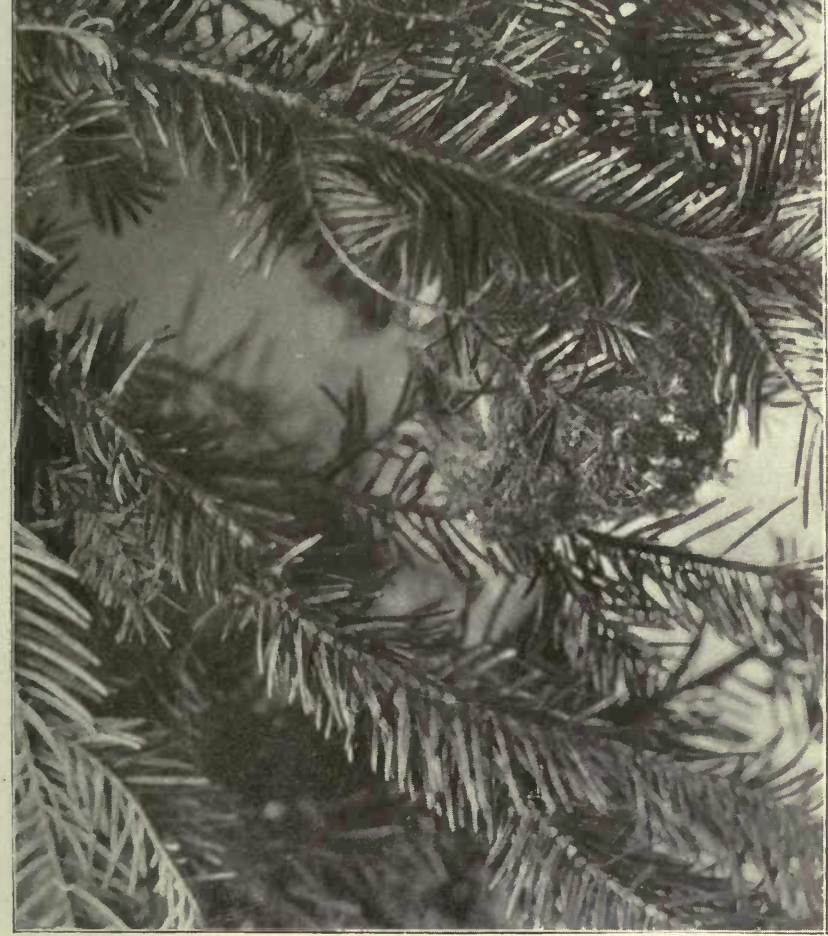

म

$\infty$

8

๘ँ 

and in the North Riding; Jinny Wren in Teesdale; Woodcock Pilot at Flamborough; Herring Spink at Filey and Flamborough ; Humming Bird at Redcar ; Little Wren at Loftusin-Cleveland; and Tot-o'er-seas is a term placed on record by Swainson.

\section{FIRE-CRESTED WREN. \\ Regulus ignicapillus (Brehm).}

Rare autumn visitant, on migration southward.

The range of the Fire-crested Wren is less extended than that of its congener, the Goldcrest; it is unknown in Scandinavia, and to the north-east of the Baltic Provinces of Germany; it breeds in the southern countries of Europe, in some of which, as also the forest region of Algeria, it is a resident throughout the year.

Its first appearance in the county was noted by Thomas Allis, who, in his Report on Yorkshire Birds, 1844, wrote :-

Regulus ignicapillus.-Fire-crested Regulus. Bartholomew Smith reports its occurrence at Woodend, near Thirsk.

It may be well to place on record the individual instances of its occurrence, as it is but a casual visitant in autumn to this country, and is frequently confounded with its near relation, the Goldcrest, from which, however, it may be distinguished by the black streak in which the eye is placed, and which is lacking in the latter species.

The first is that referred to in Allis's Report, at Woodend, near Thirsk, and quoted above.

One was found in an exhausted state in a planting at Armitage Bridge, near Huddersfield, on 3rd September 1874 (J. Varley, in litt. 2oth November I879).

One was obtained at Endcliff Woods, near Sheffield, in I878, as I am informed by Mr. A. S. Hutchinson of Derby, who preserved the specimen.

* Mr. J. H. Gurney's article in the Zoologist (1889, p. 172), may be usefully consulted by those who are interested in this species as a British bird. 
At Clifton, near York, a pair were reported, and one shot in December I880 (W. Hewett, Zool. I882, p. 268).

On $4^{\text {th }}$ November I889, an adult male was killed by a boy at Easington; this specimen was acquired by the late J. Cordeaux (Nat. I89o, p. II).

Another, probably an adult male, was seen by Cordeaux. at Spurn on I5th October I892 (Zool. I892, p. 4I8; Nat. I893, p. II).

The following records are unreliable and are, doubtless, referable to $R$. cristatus :-

One at Whitby (Zool. I850, p. 2699).

One in Whitby local collection (Vertebrate Fauna of Yorkshire, p. 22).

One at Flamborough (Cordeaux, Zool. I89I, p. II).

\section{YELLOW-BROWED WARBLER.}

Phylloscopus superciliosus (Gmelin).

Accidental visitant in autumn from Asia, of rare occurrence.

This little wanderer has its summer home in north-east Siberia, and migrates in winter to southern China, Assam, Burma, and north-east India.

It has been but seldom noticed in the British Islands, and was first reported by the late J. Hancock, who shot an example which is now in the Newcastle Museum. In this county one is said to have been seen by the late H. B. Hewetson at Easington, near Spurn, in October I889 (Cordeaux, Nat. I89o, p. 38), though considerable doubt exists as to the reliability of this record; whilst three were obtained by $\mathrm{Mr}$. Swailes at Beverley on the 2Ist October and following days, r894. One of these specimens is now in the Royal Scottish Museum (Boyes, Zool. 1894, p. 459; I895, p. 58 ; Field, 27 th October 1894). Mr. Boyes believes this bird is not so very uncommon on migration during easterly winds; he has several times noticed it in his garden at Beverley, being attracted to it by the note. 


\section{CHIFF CHAFF. \\ Phylloscopus rufus (Bechstein).}

Summer visitant; common, and generally distributed in wooded localities of the central and eastern districts; less numerous in the south-west, and rare or exceptional in the north-west.

The earliest mention of the Chiff Chaff as a Yorkshire bird is contained in a communication to William Fothergill, dated I6th August I799, from Charles Fothergill, stating that he had seen several Willow Wrens in Askham Bogs, near York, and on shooting some discovered he had procured all three species; the "large," "middle," and "small" Willow Wrens of Gilbert White [Wood Wren, Willow Wren, and Chiff Chaff]. (Morris's Nat. I854, iv., p. I67.)

Thomas Allis, in I844, wrote :-

Sylvia hippolais. - Chiff Chaff-Rather scarce in the neighbourhood of Halifax, Huddersfield, and Hebden Bridge; common in most other parts.

One of the very earliest of our summer migrants, the Chiff Chaff arrives about the same time as the Wheatear, viz. : from the middle to the end of March or the first week in April, and generally appears in the southern and central portions of the county a few days before it is noted in the north. It has, however, been heard and seen much earlier in isolated cases : on 7 th March I866, on the banks of the Don as recorded by P. Inchbald; at Barnsley on the I2th of the same month in $\mathrm{r} 882$; at Hovingham on I4th March I872; on the same date in 1880 at Barnsley and Ripon; and at Meanwood, near Leeds, on 23rd March 1879; the earliest known in Cleveland was on 28th March I902, and in the East Riding on the IIth. Its time of departure is from the end of September to early October, though it sometimes lingers until late in the latter month.

This species is peculiar in its distribution in Yorkshire, being somewhat uncommon in the extreme south about Sheffield, Wakefield, and in the Aire Valley, though a few

vOL. I. 
pairs are found in wooded districts, and for a few miles round Huddersfield it is moderately distributed ; but on approaching the north-west it is decidedly rare, if not altogether absent, in most places : then, coming to the Central Plain, it is more common; it is very numerous near Ackworth, at Knaresborough, and in the lower Wharfe and Nidd Valleys, while at Ripon it is extremely abundant in the woodlands, more so than the Willow Wren. In the East Riding it is rather local, not a very plentiful species, and variable in numbers in different years; unlike the Willow Warbler, seldom found away from woods or trees; its notes, uttered from the top of some tall tree, are unmistakeable and cannot be associated with any other species.

In the North Riding, from York onward to Thirsk and Northallerton, it is quite common in some seasons ; moderately abundant at Scarborough and northward up the coast, and in the little wooded valleys in Cleveland; rare and uncertain in Wensleydale and Teesdale, but not uncommon in Swaledale ; and it breeds sparingly in the Sedbergh district.

On its southward passage in autumn the Chiff Chaff does not appear to attract the attention of the light-keepers to the same extent as the Willow Warbler, or possibly it may be confused with that species; the Migration Reports contain but four entries concerning it, all of which are from Spurn, two of these being on the 2Ist and the 29th March, and the other two in August; it has also been noticed at Redcar on its autumn passage in September. In connection with the migration of this bird the following observation by Ed. Blyth is of interest:- "When off Whitby, about fourteen miles from land, on the 7 th October, a Chiff Chaff came on board with some Goldcrests. It was attempted to keep them alive, but they died on the passage." (Rennie's Field Naturalist, November I833.)

The Chiff Chaff ceases to sing late in May or early in June, and in the autumn migration appears in gardens and orchards, having then resumed its song. One was heard in Claremont Road, Leeds, on Igth September I886, and several instances of its late singing are reported in different 


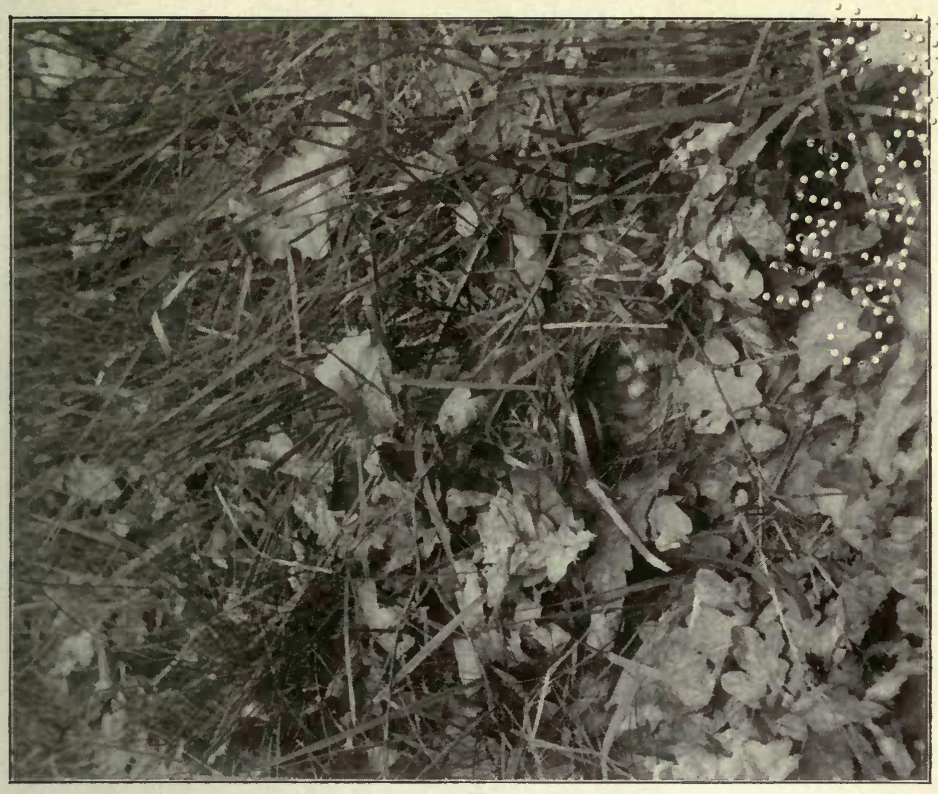

वे

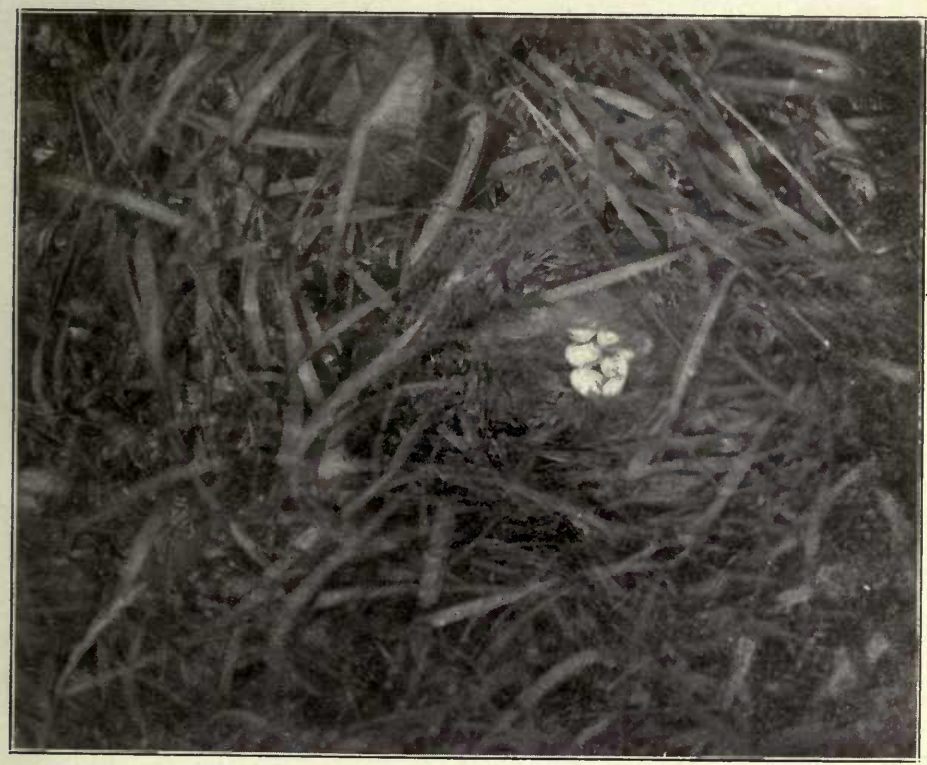

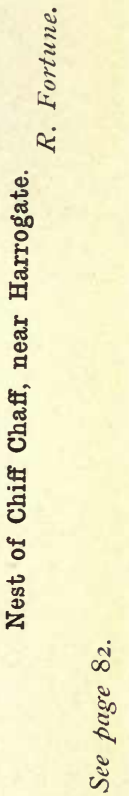



parts of the county: at Hovingham on the 26th October, and at Danby on the 2Ist of the same month in I879; at Ripon on 7 th October I88I ; at Richmond Park, Sheffield, on 3 rd September I900; and as late as 3rd October I879, and 4th October I895, at Ackworth (Zool. Igor, p. 452). Mr. J. Ranson (Nat. I864, p. 87), comments on the partiality of this species for the fruit of the cherry and currant.

Numerous instances in Yorkshire are known where the nest has been met with in elevated situations; of these the following may be cited :- one at York at the end of a branch of an Austrian pine nine feet from the ground, and another in a clump of pinks (Zool. I892, p. 150), and one at Masham in a yew tree four feet above the ground. Spotless eggs are occasionally found.

Of vernacular names Featherpoke is general; Peggy is a West Riding appellation; Jim Jam is used in the Nidd Valley; Ground Wren, Grass Wren, Grass Warbler, in east Cleveland, are used for both the Willow Warbler and this bird; while Miller's Thumb is, in some parts, as at Sedbergh, applied indiscriminately to the Chiff Chaff, Willow Warbler, and Wood Warbler. In Cleveland the nest is called Tom Tit's nest. Lesser Pettychaps and Least Willow Wren are old book-names used by Tunstall.

Several examples of the Chiff Chaff shot at Easington, near Spurn, on I7th October I896, have been referred by Mr. Dresser to an eastern form known as P. brehmi (Nat. I897, p. I7).

\section{WILLOW WARBLER.}

Phylloscopus trochilus (L.).

Summer visitant; abundant, and generally distributed.

The earliest mention of the occurrence of this species in Yorkshire is contained in a communication, dated I6th August I799, from Charles Fothergill to William Fothergill, to the effect that he had seen and shot several Willow Wrens 
in Askham Bogs, near York. (Morris's Naturalist, I854, iv., p. I67.)

Thomas Allis, in his Report on Yorkshire Birds, I844, wrote as follows:-

Sylvia trochilus.-Willow Warbler-Abundant. J. Heppenstall remarks that the eggs of this bird are liable to vary, some specimens. being very beautifully marked.

The arrival of this little songster may be expected from the first to the second week in April ; in some districts of the south and central portions it is noticed earlier than in the north, though, generally speaking, it is not observed until the time first stated; exceptionally early records are 29th March I880, at Hovingham; the IIth of the same month I894, at Middlesbrough ; 2nd April I886, at Masham, and the same date in 1887 at Harrogate; while what may be termed an example wintering in the county is mentioned from Grinkle, where one was shot in January I878. As it is one of the first to arrive so it is amongst the latest in leaving us, and departs in late August or September, often lingering into October, those observed at the latter period being in all probability migrants from more northerly latitudes.

It is the most numerous and generally distributed of all our summer warblers; its cheery song is heard throughout the whole summer, "from early morn to dewy eve," and it is ever on the move searching for food, the attitudes it assumes when stretching upward to pick off an aphis insect or larva being most graceful, and all the while it is incessantly singing. In the dales it often ascends to the borders of the moors ; in Nidderdale to a height of 1200 feet ; in Wharfedale and Wensleydale to rooo feet, and in Teesdale to I500 feet elevation, while it has been found breeding on the moors in the Sheffield neighbourhood.

On its migratory passage southward it has frequently been reported from the light stations on the coast and, according to the information supplied to the British Association Migration Committee, the greatest numbers are observed in August and September; it was unusually abundant at Spurn during the last week in August I88I, in the autumn 
of 1886 , and on the I4th and 15 th October 1892 ; in 1886 a final " rush" occurred as late as the Igth October, and in 1892 it was associated with Goldcrests, Redstarts, Grey Shrikes, and other small migrants. At Flamborough one was caught on the morning after the great storm of 28th October I880, while in I893 an example was seen at the same station as late as the 27 th November; at Spurn this species has been noted in company with Goldcrests in the buckthorn hedges during the last week in October, while so long ago as 1833 this little warbler was the subject of notice by Ed. Blyth, who stated that one came on board ship off the Yorkshire coast, in company with Pipits, Wheatears, and other small birds. (Rennie's Field Naturalist, November 1833.)

The Willow Warbler has occasionally been observed hanging under boughs of trees when searching for food; and the fact of one of these birds singing as late as 8-20 p.m. is reported from Sedbergh; one was heard about the same hour in the Washburn Valley on 2Ist May I887; and at Ackworth it has been heard singing during the day, in a hot autumn, right up to the end of September. (Zool. Igor, p. 452.)

An instance of early nidification is communicated from Aysgarth, where eggs were found on 3oth April 1887. The site chosen for the nest is usually on the ground, though many departures from this habit are known, and a varied selection of such places might be cited, but it is not necessary to make more than a casual reference to these, viz. :-

One built three feet above the ground and placed between two rocks at an angle of $40^{\circ}$ from each other, near Wilsden; one in a clump of whins, in the Goit Stock Valley, two feet from the ground; another in a thick thorn bush at four feet elevation in thick underwood, near Masham; one built on the top of a newly completed Flycatcher's nest, four feet above the ground, in the ivy on a wall, near Settle (Nat. I896, p. 37); another in the ivy covering of a post used as a stretcher for fruit trees in a garden, at Beverley; and yet another built against the bole of a tree, at a height of six feet, in Cottingley Wood (E. P. Butterfield, in litt. I90I). 
Mr. Milne-Redhead of Bolton-by-Bowland, states that this bird is very partial to currants, and comes into his garden in autumn for the purpose of feeding on fruit.

Variation in plumage is not often met with, the only example being a pied specimen recorded by the late $\mathrm{P}$. Inchbald, who saw it at Fulwith, near Harrogate, in 1887.

The vernacular names by which the Willow Warbler is known are numerous; and as this species, the Wood Wren, and Chiff Chaff, are frequently confused by local folk, the same names are in some districts applied to all three. Willow Wren is used at Ackworth, Sheffield, and other parts of the West Riding; Yellow Wren at Scarcroft, Huddersfield, and other West Riding districts; Peggy and Peggy Whitethroat are West Riding terms, though probably mistaken for the Whitethroat; Bank Wren is used in southern Holderness; Featherpoke in the North and West Ridings, and Ground Featherpoke at Doncaster; Grass Warbler, Grass Wren, and Ground Wren in eastern Cleveland; Mealymouth at Danby-inCleveland and in Craven; Miller's Thumb (in some places, as at Sedbergh, where it is also used for Wood Wren and Chiff Chaff) ; and Tom Tit's is applied to the nest in Cleveland. Willow Sparrow is mentioned by Swainson as a West Riding term.

The late J. Cordeaux saw what at the time he supposed to be an example of the Siberian Willow Warbler (Phylloscopus borealis) at Flamborough on 2Ist November I894 (Zool. I894, p. I25; I895, p. 58); though, in a later communication (Nat. I897, p. 20I), he threw a doubt on this, and thought it may have been referable to some other leaf warbler.

\section{WOOD WARBLER. Phylloscopus sibilatrix (Bechstein).}

Summer visitant; local, but not uncommon in suitable localities.

The first mention of the Wood Wren as a Yorkshire bird is contained in the "Ornithology" of Francis Willughby, as follows - 


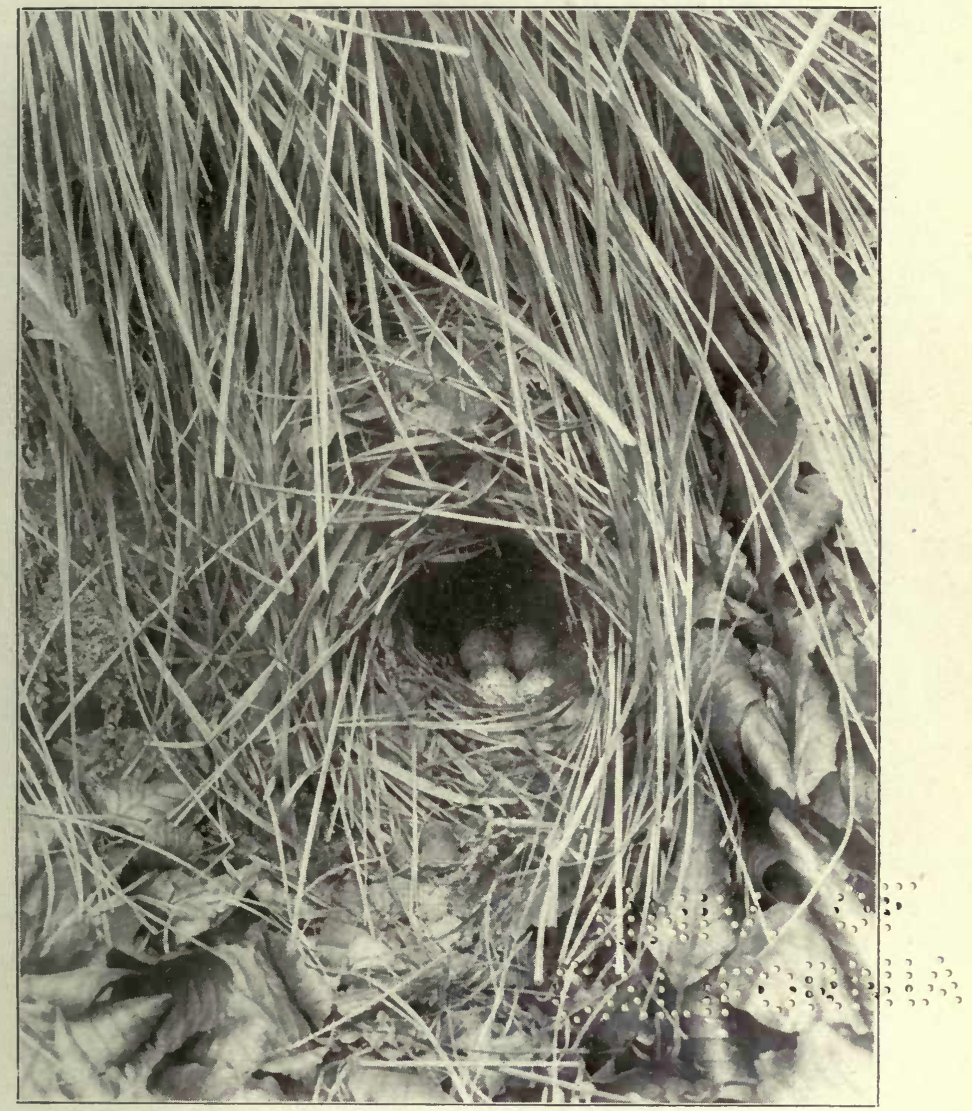

Wood Warbler's Nest.

R. Fortune.

See page 87 . 

"A little yellowish bird without name, called by Aldrovandus, Regulus non cristatus, perchance the Asilus of Ballonius, or the Luteola of Turner."

"This is equal to, or somewhat bigger than, the Crested Wren. ... It sings like a grasshopper and doth much frequent willow trees. Mr. Jessop sent us a bird [presumably from Sheffield] in all points exactly like that here described, and whose note resembled the noise of a grasshopper, but twice as big." (Will. "Orn." I676, p. 228.) See also Montagu's "Ornithological Dictionary."

Thomas Allis, in I844, wrote :-

Sylvia sibillatrix. - Wood Warbler-Not infrequent in most districts.

In the south of the county this little warbler generally arrives about the third or fourth week in April, the average date being the 3oth; though in Cleveland, the north and north-west portions of the shire, it is not noted until the first week in May. Exceptionally early instances are 8th April 1879, at Barnsley, and in I880 Mr. W. Eagle Clarke heard its note at Spurn on the 9th. As it is often silent on first arrival it may well be that its presence is not remarked for a few days : it first utters its single note "twee," and afterwards greets us with its cricket-like shivering trill.

It departs on its southward journey in August.

It is somewhat local in its distribution, but its presence may be expected in those districts where there are woods and copses suited to its requirements. In many localities it affects old woods and forest trees, one of its favourite haunts being Rudding Park; it is rather scarce in Lower Wharfedale, though fairly common in most of the sheltered valleys, in the woods on the fell sides, and up to the edge of the moors; in Nidderdale it is met with to an elevation of 1000 feet, and in the woods about Sedbergh, Bowland, and Malham; at the latter place as high as 1350 feet elevation.

In the East Riding it is common in a few places, but always local; it comes annually to certain woods of a dry peaty or sandy nature where the common bracken flourishes.

The only entry in the Migration Reports in connection with its autumn movements is one in 1885, p. 42 , when it 
was reported from Spurn on August I4th, though it is possible it may be confused with the Willow Wren by the light-keepers.

The Wood Wren is sometimes accused of stealing fruit, and was observed by Mr. J. Ranson coming into his garden at Linton-on-Ouse for the purpose of tasting the cherries and currants.

Local names: Wood Wren is general; Yellow Wren is used at Linton-on-Ouse (J. Ranson, I864); other names are Yellow Warbler and Twittering Wren; Small Straw is in use at Huddersfield, in the Nidd Valley, and other parts of the West Riding, and Hay-bird is given as a West Riding name by Swainson. In some districts, as at Sedbergh, it is, together with the Willow Warbler and Chiff Chaff, known as Miller's Thumb.

\section{ICTERINE WARBLER.}

\section{Hypolais icterina (Vieillot).}

Extremely rare summer visitant from Continental Europe.

The Icterine Warbler nests in Central and Northern Europe, being very abundant in north-east France ; it occurs regularly in the Baltic Provinces and as far north as the Arctic Circle in Norway, while to the eastward the Ural Valley is its limit. In winter it migrates as far as $25^{\circ}$ south latitude.

There are but eight instances of its capture chronicled within the British Islands, one of these being at Easington, near Spurn, as mentioned by the late J. Cordeaux, who informed me that Mr. P. Loten of Easington sent him an adult male example which had been killed with a catapult, and was brought in by some boys, on 28th May I89I. Mr. Loten skinned it, thinking it might be a Wood Wren, but with grave doubts on the subject. The specimen was afterwards sent to Mr. W. Eagle Clarke, and was purchased for the Royal Scottish Museum. (Zool. I89I, p. 308; Nat. I8gI, p. 24I ; I897, p. 20I.) 


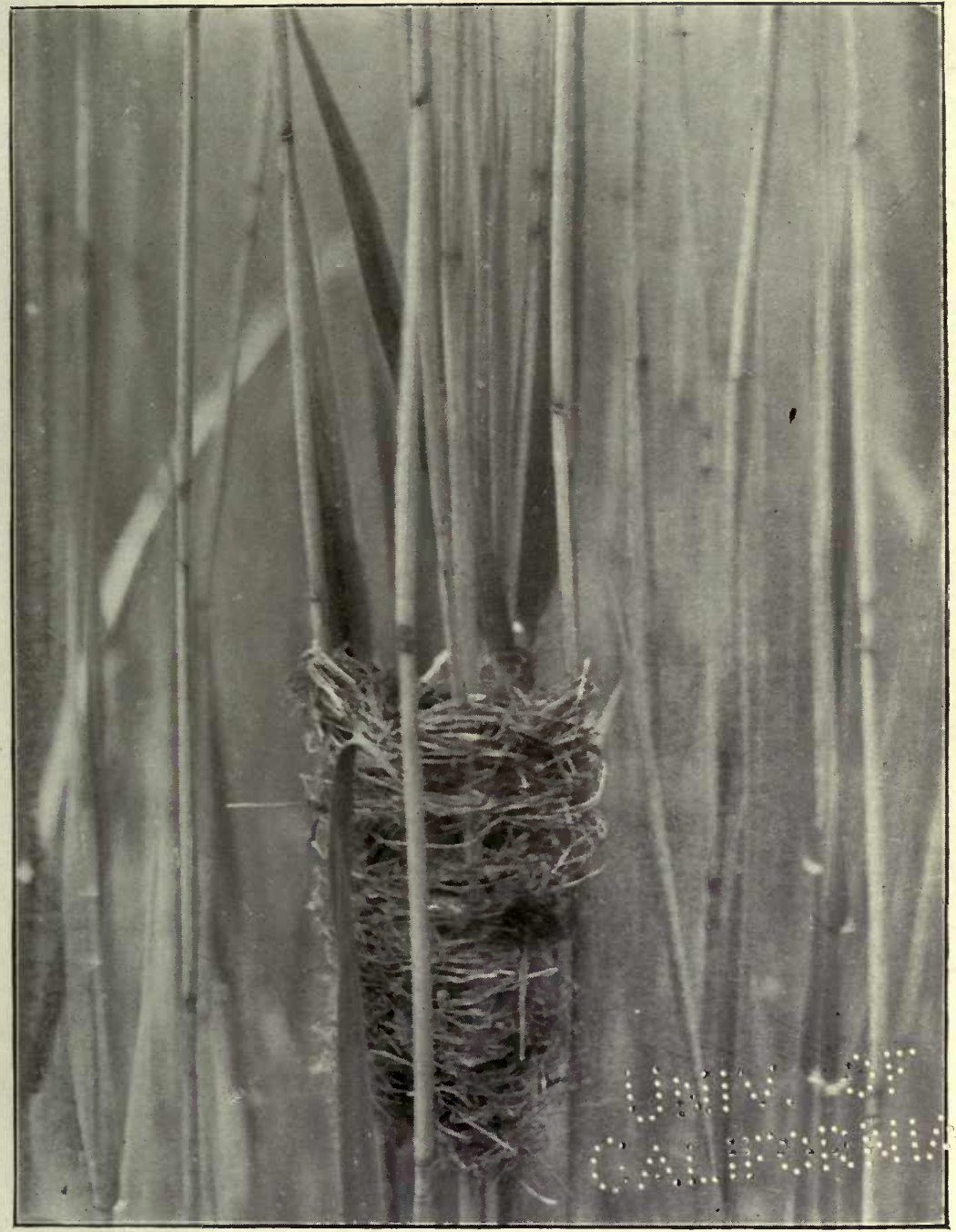

Reed Warbler's nest, Hornsca Mere.

R. Fortune.

See page 90. 

Messrs. W. Eagle Clarke and T. Laidlaw watched an undoubted example of this species for some time, at only a few yards' distance, in the garden at Kilnsea Warren, in September 1897 .

\section{REED WARBLER. \\ Acrocephalus streperus (Vieillot).}

Summer visitant; very locally distributed.

Thomas Allis's Report on Yorkshire Birds, I844, contains the first known county reference to this species, thus :-

Salicaria arundinacea.-Reed Warbler. Arthur Strickland says : "I have no doubt this species would be found in this [the East] Riding if properly sought, but I am not aware I ever did see it here; but in the West Riding I found it many years ago in the neighbourhood of Ripon. I have still in my collection a nest from that neighbourhood, in which a young Cuckoo was brought up." Wm. Eddison remarks that it is occasionally met with near Huddersfield, though but little is known of its history; B. Smith informs me that it is found near Thirsk.

This warbler's northern range was, like that of the Nightingale, until recently considered to be bounded by the line dividing the West and East Ridings of Yorkshire from the North, and its occurrence north of the county is not proven. A summer visitant, it arrives early in May, and owing to the peculiar nature of its habitat, is very local in its distribution, so that only patient and persistent investigation reveals its whereabouts, and it is to be feared its numbers are decreasing, owing chiefly to the drainage of its accustomed haunts. In the West Riding it is not very numerous in any locality, though it is met with near Sheffield, Wakefield, the Craven district, Doncaster, Ackworth, Askern, Goole, along the drain channels at Swinefleet, and other suitable places, and it also occurs, but less abundantly, in Lower Wharfedale and the Washburn and Nidd Valleys; near Knaresborough it was formerly plentiful, but is now 
only occasionally found; it is fairly common near Staveley, and nests sparingly near Harrogate and Ripon. In June I880, it was found particularly abundant at a place just outside the City boundary of Leeds, no less than seven nests containing eggs being discovered (W. Eagle Clarke, Zool. I88o, p. 444). Dr. Steward of Harrogate tells me (Ig04) that this place is now protected, and the bird still nests there.

In the East Riding it is perhaps more numerous than elsewhere in the county, the presence of its favourite reed-beds conducing to its protection; at Pocklington it is common and breeds annually; near Hull it was formerly plentiful as a nesting species (op. cit. I86r, p. 7643-4), and it is found there where the conditions are suitable; at Hornsea Mere it is numerous ; in the Beverley district it has been met with, breeding in gardens, the nest being placed in lilac bushes and snowberry, and also in some numbers in the osier-beds in the Driffield trout-streams and in the reeds bordering on the River Hull ; the nest is also reported from Scampston, Knapton, and near Bridlington, though only rarely. In the North Riding it was fairly abundant at Castle Howard, but has greatly decreased there of late years, and it occasionally occurs at Malton; it was formerly frequent on the Mere at Scarborough before the place was drained; now it is seldom found there, and the same remark may be applied to the north part of the county, though it is noted as nesting near Whitby and Grinkle. In Cleveland I have for some years been aware of its existence as a nesting species at a locality a few miles distant from Redcar, where it breeds annually, and I have an egg taken there in 1896 by $\mathrm{Mr}$. C. Milburn of Middlesbrough; it is scarce near Bedale, and has once been reported from Carperby in Wensleydale.

Though the Reed Warbler is occasionally noticed on migration it is not mentioned in the Reports from the light stations excepting in the year I88I, when two were killed by striking against the Spurn lantern on the 29th May, at II p.m., and on the 2oth August in the same year three old males were killed. (Fourth Report, p. 33.)

In its nidification the bird sometimes departs from its 


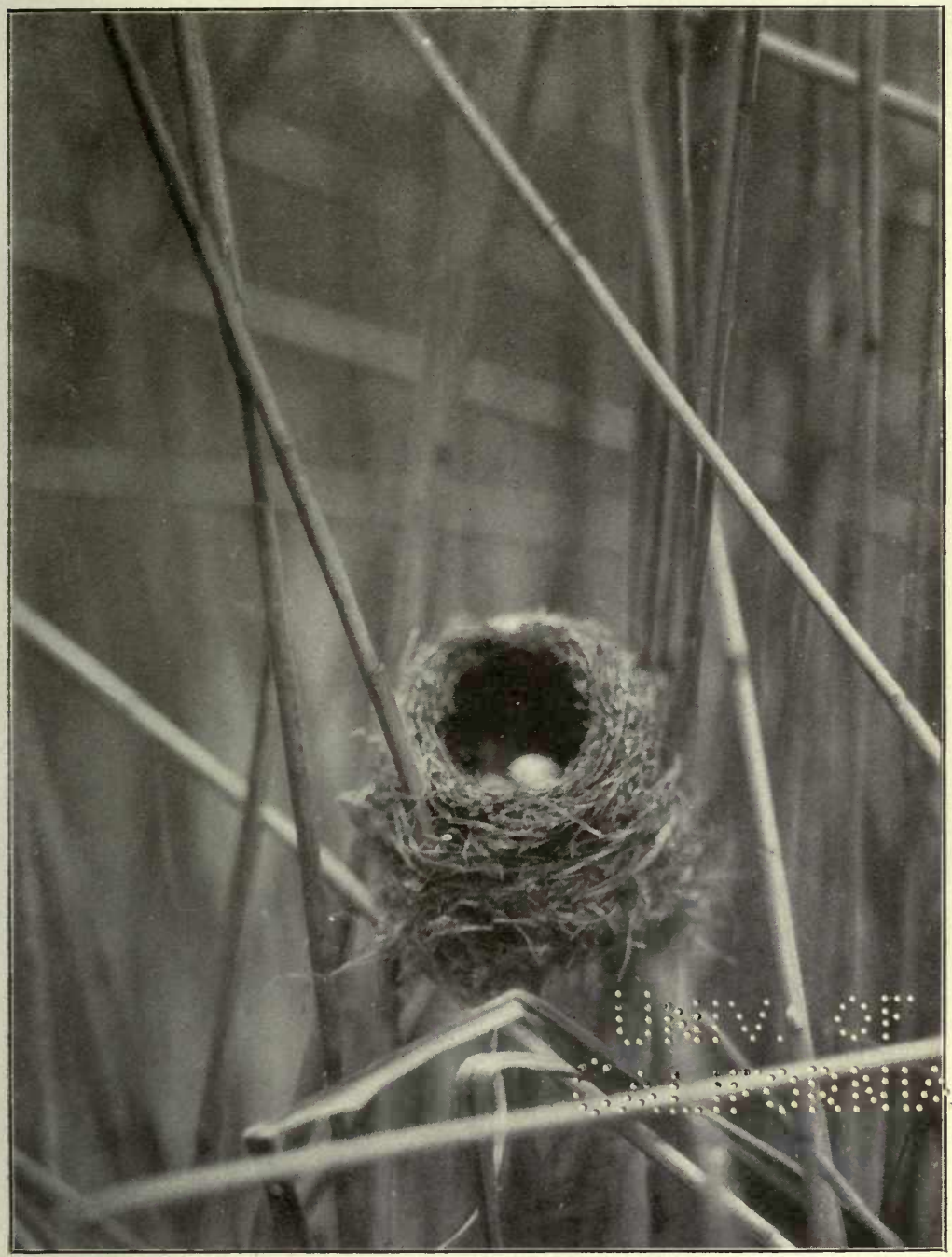

Reed Warbler's nest, Hornsea Mere.

R. Fortune.

See page 91. 

usual custom and builds in extraordinary situations, such as in a yew tree at Malton, presumably its first nest had been destroyed (J. E. Harting's Summer Migrants, p. 85) ; the late Col. Haworth-Booth found one in a black-currant bush at Hullbank House, near Hull (Nat. I896, p. 24); and in the Washburn Valley a nest and young were noted on the bank of a reservoir in long grass (op. cit. r888, p. 330).

In the report of its nesting near Leeds, above referred to, it is stated that four nests were amongst willow bushes and were placed at heights varying from five to seven and a half feet above the ground, whilst others were hidden amongst nettles, about two feet from the ground, and supported by their stems and dead twigs of willows; the eggs were unlike the ordinary type, being white with markings of a clear greenish grey tint. The young have been seen on the rath of June, which is an exceptionally early date.

The late G. Roberts of Lofthouse, near Wakefield, writing in I886, stated that a specimen of the Great Reed Warbler (Acrocephalus turdoides, Meyer), a species that is common on the Continent of Europe, is in the possession of J. Ward of Lofthouse, which G. Lumb got " a good many years since" from someone at Wakefield. "It is said to have been found dead at Methley."

\section{SEDGE WARBLER. Acrocephalus phragmitis (Bechstein).}

Summer visitant; common, and generally distributed.

The first reference to this bird in Yorkshire is contained in the Rev. John Graves's " History of Cleveland," r8o8, where it is mentioned under the name of "Sedge Bird (Motacilla salicaria)," and enumerated amongst the migrants.

Thomas Allis, 1844, wrote :-

Salicaria phragmitis. - Sedge Warbler-is met with near Doncaster and Barnsley; it is scarce near Huddersfield, and not numerous at Halifax ; near Sheffield and at Hobmoor, York, it is frequent ; it also occurs at Swillington and Brotherton. 
This merry little warbler arrives about the latter end of April or early in May; the average date in the south of the county is the 24th of April ; at Lofthouse, near Wakefield, the 2nd of May, and near Halifax a week later; in midYorkshire and in the Spurn district it may be looked for in the first week of May, while in Cleveland I have taken the mean date as the 29th of April ; in 1883 it was reported on the I8th of April at Barnsley, which is earlier than usual, and in 1869 on the Igth of the same month at Tadcaster. The majority take their departure in September, a few stragglers lingering until early in the following month.

It is, as a rule, commonly distributed in localities suitable to its requirements, viz. : gardens, copses, hedgerows, willowbeds, and the margins of streams, and is also frequently met with in places far removed from the vicinity of water; it is fairly abundant in most parts of the county except on the moorlands and waste tracts, though it has been found near the edge of the moors, and it is frequent on the East Riding Wolds. In the neighbourhood of some of the large manufacturing towns, and within the City boundaries of Sheffield and Leeds, the nest has been recorded. Strange to say it is a scarce species near Wilsden, and is not common in the Forest of Bowland, although the surroundings are eminently suited to its habits.

It has been noticed at the light-stations on the coast on several occasions whilst on passage, as is recorded in the Migration Reports, and individuals have been killed by striking against the lanterns at Spurn and Withernsea.

The Sedge Warbler has been heard to imitate the mewing of a cat (Birds of Ackworth, p. 50); it is also well known as a mimic of other birds, and as it often sings late at night it is mistaken for the queen of songsters, the Nightingale ; doubtless many of the reported occurrences of the latter bird which appear in provincial papers may be referable to the species under notice. The Rev. E. Peake, late of Settle, relates an amusing anecdote of the local folk in Craven being deceived by this bird's late singing: crowds of people went nightly to hear the sweet strains, and imagined they 


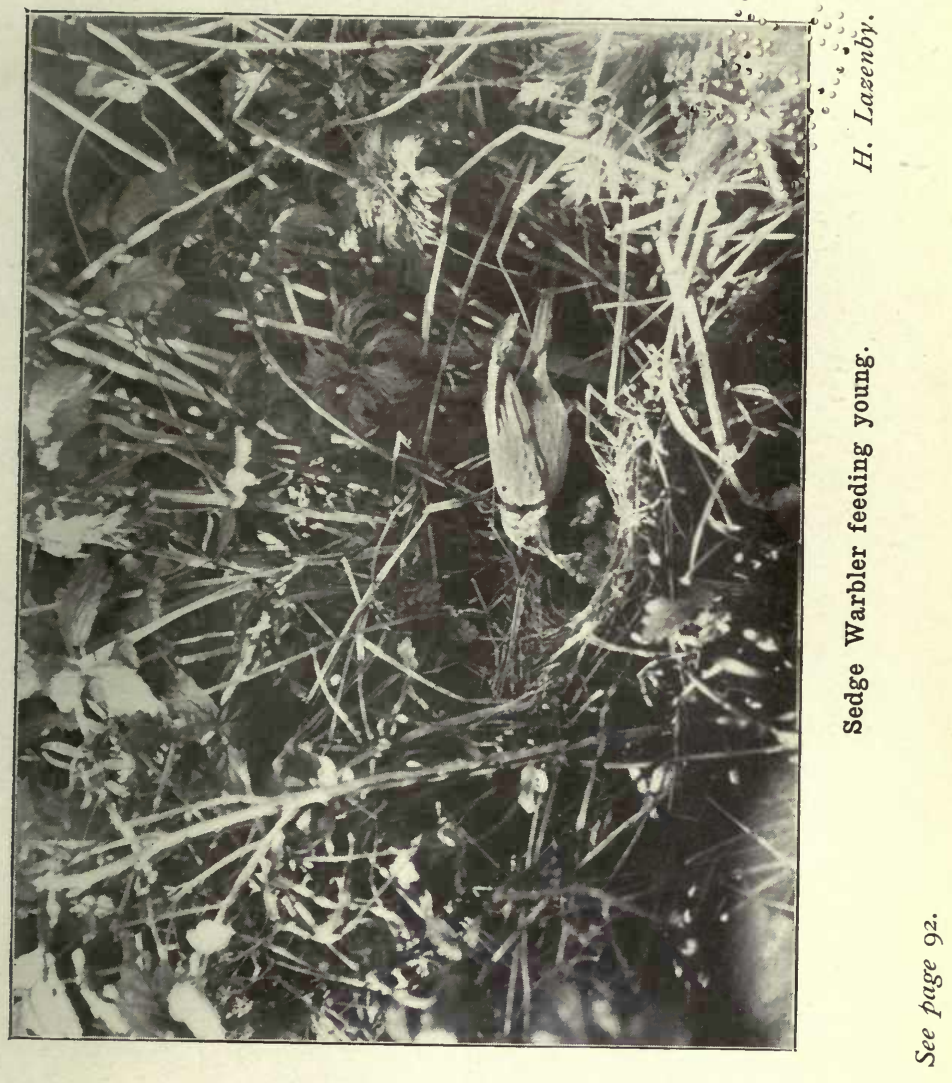



were listening to a Nightingale, until a local naturalist scathingly remarked "It were nobbut a bothering Betty!"

The sites chosen for the nest are as frequently removed from, as in the neighbourhood of, water: I have found it in hedges and shrubs several feet above the ground, while there is one instance of a nest at an elevation of ten feet, and the experience of other county naturalists is similar; eggs at Rempton have been reported as late as August; and a nest at Harome, near Helmsley, contained young on the 4th August I888. In the Natural History Journal I877, there is mention of a nest in a long swinging piece of bramble, far from any water; in the same Journal a clutch of eggs is described, three being white with scarcely traceable black spots, and a fourth much paler than usual. Mr. Harold Watson of Redcar has a clutch of the scarce salmon pink variety, found in the Esk Valley in the first week of June I892.

The vernacular names are numerous: Seg Bird in the Huddersfield neighbourhood (Zool. I848, p. 2290); Sedge Bird in Cleveland (Graves, I808) ; Sedge Chat, Sedgechatter, and Windlestraw, at Ackworth; Willow Wren at Huddersfield; Willow Sparrow at Wilsden and in the West Riding; Grey Bird in Arkengarthdale; Betty near Settle; Nightsinger near Sedbergh; Mock Nightingale in Cleveland and the North Riding; Thorn Warbler in east Cleveland; Willow Chit in the western Ainsty; Chitty Prat in southern Holderness. While Small Straw at Skelmanthorpe, Huddersfield, and Straw Small at Wilsden and in the Aire Valley, are terms applied to the nest.

\section{GRASSHOPPER WARBLER.}

Locustella nævia (Boddaert).

Summer visitant; local; thinly distributed, and varying in numbers in different years.

In considering the question of the earliest reference to the Grasshopper Warbler as a county bird, priority of 
claim is to be accorded to 'Willughby's description contained in a communication, dated 1672 , from $R$. Johnson to the renowned John Ray, which is as follows :-

"The Titlark that sings like a Grasshopper-Locustella. D. Johnson."

"It is lesser than the regulus non cristatus, hath a pretty long straight bill, yet having a little declivity above, the upper chap black, the nether of a horn colour. The upper side of the body is of a dusky yellow, besprinkled with blackish spots, the under side of a pale yellow. The tail is of the longest, of a brown or dusky colour, when spread ending in a circular circumference. On the lower Belly, the Thighs, and under the Tail it hath brown spots tending downwards. It hath long slender dusky coloured Legs, crooked claws and a very long spur, or heel. It feeds upon flies; it hath a note like a Grasshopper, but louder and shriller. When it sings it commonly sits upon a bush, with its mouth open, and straight (sic) up and its wings dishevelled." (Will. "Orn." I676, p. 207.)

In connection with this matter Professor Newton remarks (Yarrell's “British Birds," 4th Ed., Vol. i., p. 386), that Gilbert White asserted Ray had no personal knowledge of this bird, and Mr. Johnson's specimen was referable to the Wood Wren. There can be no question, however, that the description given agrees with that of the Grasshopper Warbler and is totally unlike the Wood Wren.

Thomas Allis, in 1844, wrote :-

Salicaria locustella.-Grasshopper Warbler. I have heard of but one specimen from near Barnsley, shot by Dr. Farrar, now of Bradford. At Hebden Bridge it is met with rarely; it is frequent about Sheffield, and sings between eleven and twelve at night, as mentioned by my Friend, J. Heppenstall. Near Halifax a few pairs breed every summer ; it is rather rare near Leeds; it breeds in several localities near Doncaster, as at Wadsworth, Hutmoor, and Rossington. Near Bridlington it breeds in a few favoured localities, and near York it is found in Buttercrambe Woods, and in the woods at Langwith.

This species arrives from about the middle to the third week of April, although instances are known of its appearance a few days earlier; at Barnsley the mean date of arrival, 
calculated from a series of ten years' records, was the 3oth of April, but in the Knaresborough and Harrogate district the average time is the I8th; in Cleveland it does not, as a rule, makes its presence known until the end of the month. It departs in August and onward to mid-September.

It is thinly distributed, local, and varying in numbers in different seasons. Near Sheffield there are generally a few pairs in the wooded districts; in the Barnsley area it occurs regularly, and nests annually within seven or eight miles of Halifax; at Liversedge it has been noted twice, in 1895 and 1896 ; in the neighbourhood of Huddersfield it breeds in several localities, and is fairly common at Storthes Hall and Skelmanthorpe ; at Almondbury it is not numerous, yet a regular visitant; near Wakefield there are one or two places where it is found nesting; in the Aire Valley it has bred near Leeds, at Roundhay Park, and at Adel, though the bird is scarce and irregular in its visits, as it also is near Doncaster, Selby, and Goole; at Ackworth and Hemsworth it has frequently been known to nest. In the north-west it is reported at Skipton-in-Craven, and in small numbers near Settle, where the eggs were taken on a moor in 1896 ; in Nidderdale it occurs sparingly, as also in the Washburn Valley, and in Upper Wharfedale, being occasionally met with to an altitude of Iooo feet on the Ilkley Moors; near Pateley Bridge it has twice occurred, the last occasion being in 1886 ; in the Harrogate district it was not uncommon (I879-I885), though it is now very irregular and uncertain; the same remark is applicable to the Wetherby, Boston Spa, Ripon and Eavestone districts, but at Cowthorpe, Wilstrop, and Askham Bogs it is fairly numerous. In the East Riding it is reported from near Hull and Sproatley in South Holderness ; it is scarce and uncertain at Beverley, and has occurred a good many times, but irregularly ; it is rare at Flamborough where one was killed against the lantern during the night migration in 1877 , and a nest has been found on the cliff tops. It occurs in most districts of the North Riding, not a common nesting species, yet hardly to be considered very rare; near Pickering it is perhaps most abundant, and 
is fairly common at Malton; near Bedale it was formerly numerous, but has decreased during the past two or three years, and this state of things obtains in some other places; one or two pairs nest in the Sedbergh district, on the moor edges; in the Scarborough neighbourhood it is moderately plentiful, and a few pairs breed near Whitby; in Cleveland it nests scatteringly in a good many localities and has been found within two or three miles of the town of Middlesbrough; formerly it was frequently heard along the hedgerows bordering the sand-hills near Redcar; of late, however, it appears to have discontinued its visits to that part and has not been noted for several years past. In Tunstall's time it was known at Wycliffe-on-Tees, for he states (MS. p. IO7), "This bird is sometimes found in this neighbourhood." Yy]

The Reports of the British Association Migration Committee do not furnish much information respecting the movements of this species, the only entry referring to this county being the following:-

"On I2th September I88I, two were killed in the night against the lantern of Spurn Lighthouse." (Fourth Report, p. 33.)

The nest of the Grasshopper Warbler is generally most craftily concealed and difficult to discover, so that perhaps it may be commoner than is supposed to be the case ; the late W. Talbot found one on the ground amongst rough grass, the tops of which were drawn together so as to form a dome, with an arched passage leading to the nest, and he states that the bird ran amongst the grass like a rat. On 6 th August I884, a nest was discovered with four eggs, evidently a second clutch, in a tuft of tussock grass, overshadowed with bracken fern which hid it entirely from view, and the owner threaded its way in and out in a similar manner to that described by Talbot. In Wensleydale it has been found on the moors near Carperby, and, as stated above, it has been met with on the Ilkley and Sedbergh Moors.

There do not appear to be any truly vernacular names used in Yorkshire, and the term, Sibilous Brakehopper, 


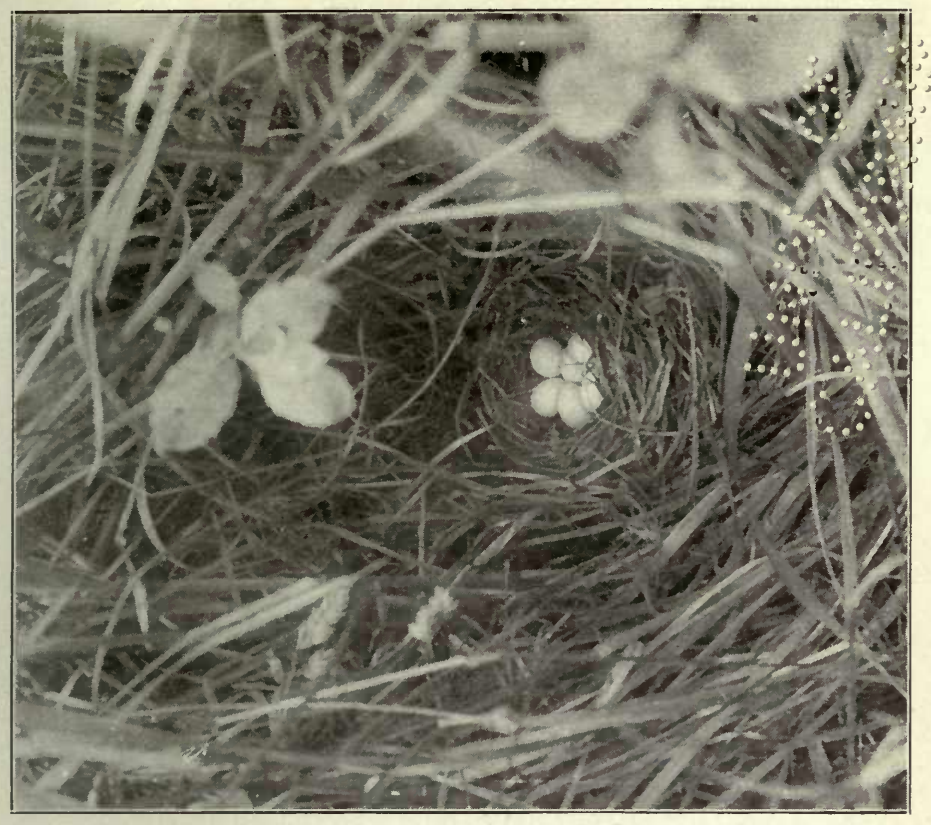

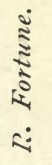

(5)

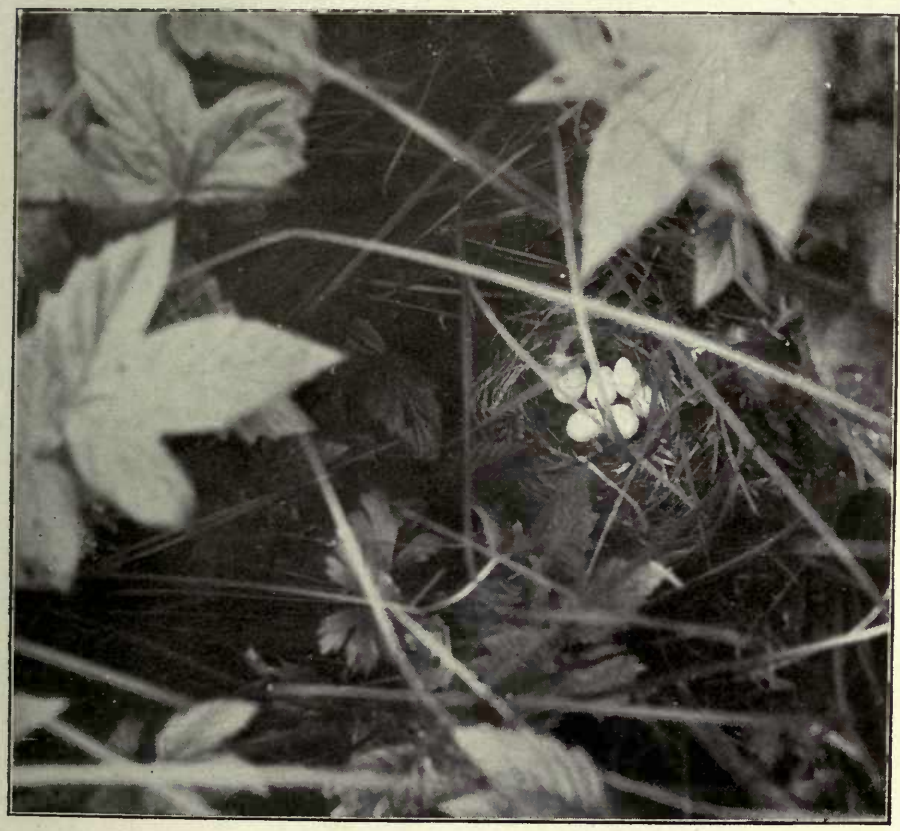

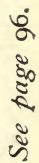



said to be used at Doncaster (Neville Wood's Naturalist, I837), is but one of that author's fancy book-names.

[DARTFORD WARBLER. Sylvia undata (Boddaert).

In Thomas Allis's Report, I844, the following occurs :-

Melizophilus provincialis-Dartford Warbler. Said by W. Edison to occur near Huddersfield, the only Yorkshire locality.

(But it is crossed out.)

No faith is to be placed in the record of this species in the Rivelin Valley by Dixon, quoted in the "Handbook of Yorkshire Vertebrata," p. 2I ; and the alleged discovery of a nest and eggs in Cleveland (Nat. I8g6, p. 240), is, as Mr. Charles Milburn tells me, open to the very gravest doubt; therefore, until more satisfactory evidence is forthcoming, the bird must be expunged from the Yorkshire list.]

\section{HEDGE ACCENTOR. Accentor modularis (L.).}

Resident; generally distributed, there not being a district in the county from which it is not reported; common, except in moorland localities. A spring and autumn migrant.

An early allusion, perhaps the earliest, to this species as a Yorkshire bird is contained in the communication addressed by Dr. Martin Lister to John Ray and dated York, February 8th I675, where it is thus alluded to: "The Currucca or Hedge Sparrow, which I have often seen, lays sea-green or pale blue eggs, which neatly emptied and wired, fair ladies wear at their ears for pendants." ("Correspondence of John Ray," p. II7.)

Thomas Allis, in I844, wrote :-

Accentor modularis.-Hedge Sparrow.

As an abundant and familiar resident, the Hedge Sparrow, for as such it is best known to Yorkshiremen, demands but little attention. It is common or general in the widespread localities affording the usual simple haunts of the bird, namely gardens, shrubberies, and hedgerows; though

vOL. I. 
in the dale and moorland districts of the county, where stone walls are in vogue, and the habitations of man are few and far between, it is not very abundant; but it is usually to be found where its requirements are existing; a great increase has been noted south of Sheffield during the last few years.

As an immigrant from the Continent, however, it is worthy of further consideration at our hands. A summer visitant to northern Europe, seeking a southern winter abode, the bird occurs, though in varying numbers, on our sea-board in the autumn season, remaining through the winter, thus making it much more numerous in localities near the coast during these seasons than at other times.

In autumn it is often very common in the bean and turnip fields near the coast; sometimes solitary or in pairs, but more frequently in small parties of twenty to thirty together. Respecting the migratory movements of this species I feel I cannot do better than quote the information bearing thereon contained in the Reports of the Migration Committee of the British Association :-

I880. October I7th. Very abundant at Spurn Head (p. 37) 1882. At Spurn and in east Lincolnshire great numbers were observed during the first fortnight of September.

Spurn, October 8th. Most abundant and on the Lincolnshire coast at the same date in extraordinary numbers. . . It may be stated that their extraordinary abundance at Spurn and in east Lincolnshire on October 8th corresponds with the enormous flights which crossed Heligoland at the same period, October 6th, 7 th, and 8 th, as reported to $\mathrm{Mr}$. Cordeaux by Herr Gätke (p. 33).

1884. Spurn, August 2oth and through September. Abundant at intervals. Tees L.V., 2Ist August. Two, with a Linnet, Redbreast, and Titlark, on board; leaving to N.W. at 7 a.m. Spurn and Great Cotes 25th and 26th. Swarming (p. 46). 
Further observations indicate that in the years 1892 , 1894 , and 1898 great numbers were noted on migration.

From the above records it is to be inferred that the movements of this species, both as regards numbers and constancy, are somewhat irregular; it is possible, however, that on some occasions this unobtrusive bird may escape observation; but that it varies considerably numerically is beyond question. A return passage is sometimes observed in March.

The ordinary period of nidification in Yorkshire usually commences early in April, and the young are hatched before the end of that month. Instances are recorded of the nest and eggs being found in December and January, the earliest being on the I2th December 1879, near Stokesley, as noted by Mr. H. Kerr. A nest at Beverley (Zool. I863, p. 8445), contained four eggs on $4^{\text {th January }}$ I863. Mr. W. Eagle Clarke has found eggs on the 15 th of March, and a nest with eggs on the point of hatching on the 7 th of April came under his notice. There are also other instances in which singularly early nests have been found in exceptionally mild seasons. Although four to five is the usual number of eggs, Mr. Baldwin Young states (in litt.) it only lays three to four in his district (Richmond Park, Sheffield), five very rarely. In the spring of 1886 a nest with three partly incubated eggs was found at Masham, the paucity of numbers being attributed to the inclement weather. Mr. J. Ranson (Zool. 1864, p. 9036), states that he took eighteen eggs from a Hedge Sparrow's nest, by one at a time, always leaving a nest egg, and then the nest was destroyed. An unusual locale for a colony, if it may be so termed, of Hedge Sparrows, is amongst stacks of pig-iron at Connel's Stores, Middlesbrough. There several pairs of birds are established and nest in security. Colourless examples of the eggs have occasionally been noticed.

Pale rufous varieties of the bird are on record, as observed or captured in the county (op. cit. 1865, p. 949I ; r866, p. 29 ; 1877, p. 256). In the Leeds Museum is included an albino specimen, found near that town in the winter of 1884 or 1885 , and the late J. Varley possessed an entirely black example obtained at Almondbury Bank, near Huddersfield, on I4th 
May I865. Cream coloured specimens are noted at Scarborough (op. cit. I883, p. 79), and Selby, on 3oth January I897; and white ones at Selby, I890, and Beverley, I900.

The Hedge Accentor is one of the best known foster parents of the Cuckoo, the colour of whose eggs is occasionally assimilated to that of the fosterer; and Mr. T. Stephenson, of Whitby, informed me that he once found a Hedge Sparrow's nest containing four of her own eggs and a cuckoo's, which latter was a little larger and nearly the same colour as the fosterer's.

I have observed that this bird will occasionally eat grain scattered in a garden for the feeding of poultry, and on these occasions is inclined to be very pugnacious, sometimes driving away a bantam which disputed its right to a meal.

Local names: Hedge Sparrow; Dunnock; Dicky Dunnock, general ; Cuddy, general among schoolboys ; Billy or Billy Hedge Sparrow, Doncaster ; Hedge Creeper, Thirsk and Cleveland; Shuffle Wings, Cleveland and Craven; it is also locally termed Hedge Warbler or Hedge Chanter; Cuddy Whooper is a name I have heard near Redcar, and Hempie is a term mentioned by Swainson as used in Yorkshire.

\section{ALPINE ACCENTOR.}

Accentor collaris (Scopoli).

Accidental visitant from Central or Southern Europe.

Like the Rock Thrush, this bird affects the mountainous districts of central and southern Europe, where it is, however, a resident and only to be considered migratory in so far as it passes the summer at considerable elevations and descends into the valleys for the winter. From some cause or another the Alpine Accentor occasionally finds its way into Western Europe, and has on several occasions occurred in the British Isles, and once in Yorkshire. 


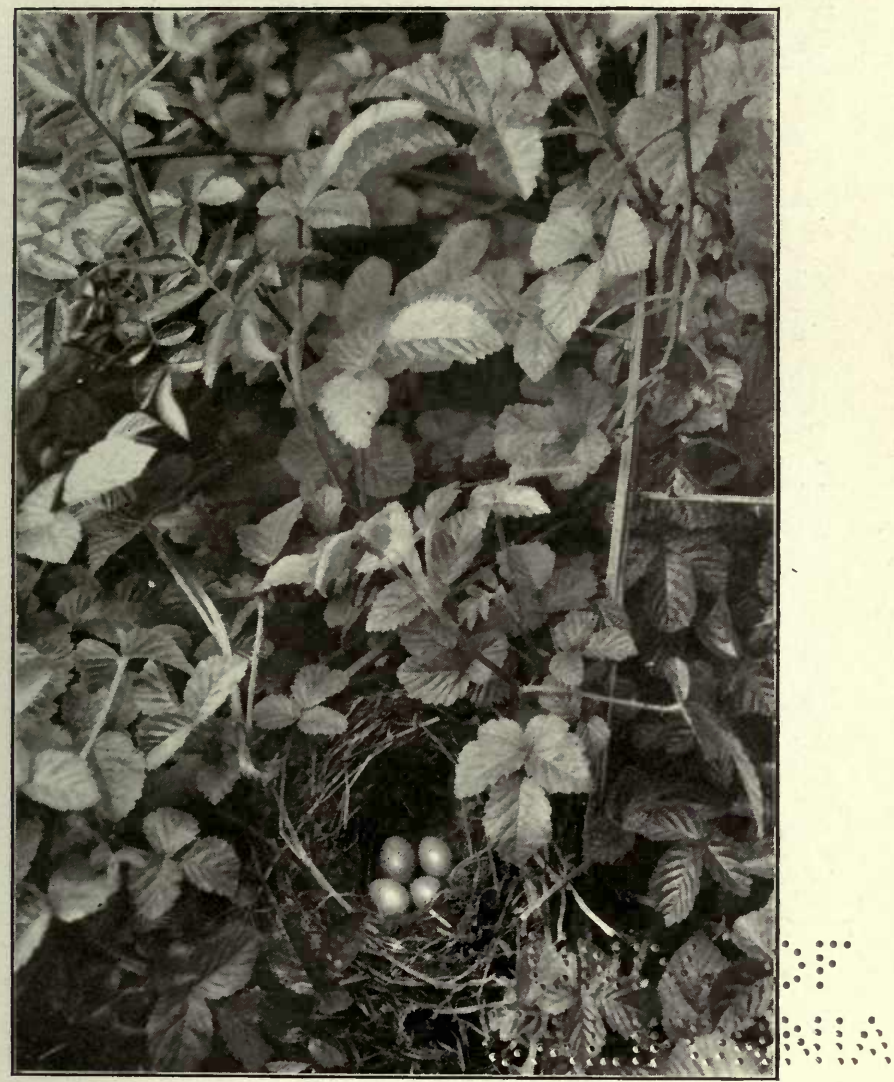

Nest of Hedge Accentor with a Cuckoo's Egg (top on left), near Harrogate.

R. Fortune.

See page 100. 
“ece

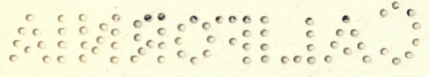


The claim of this species to our attention as a Yorkshire bird is in virtue of an occurrence at Scarborough, during the winter of $1862-3$. This specimen now forms part of the collection of Mr. J. H. Gurney of Keswick Hall, Norwich, where Mr. Wm. Eagle Clarke had the pleasure of seeing it.

It formerly had a place in the late W. W. Boulton's collection at Beverley; and that gentleman communicated the following account of it to the Zoologist (1863, p. 8766): "On the 22nd of August, at Mr. Roberts', bird stuffer, Scarborough, I saw a fine female specimen of the Alpine Accentor which had been shot near Scarborough. Last winter (r862-3) a poor man offered for sale to Mr. Roberts a string of larks and small birds he had shot. Mr. R. bought them and found this bird amongst the number. I purchased it and it is now in my collection."

I am informed by Mr. George Steels of Pocklington (I902), that he stuffed an Alpine Accentor "many years ago," for a gamekeeper named Wetherill, who had shot it at Waplington, but my informant could not ascertain where the specimen is now.

\section{DIPPER.}

Cinclus aquaticus (Bechst.).

Resident ; local ; common in the south-west and north-west, and also in Cleveland ; rare in the East Riding.

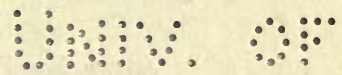

Historically, so far as we know, the:oldest:yorkstire: $\therefore$ Water Ouzel is the one described by Jolin "Ray;" which "was shot on the River Rivelin, near Sheffield (Will. "Orn." 1678 , p. I49).

Thomas Allis, in I844, wrote:-

Cinclus aquaticus.-Common Dipper-Rarely met with in the East Riding, frequently seen on the mountain streams of the North and West Ridings.

The Dipper is a common resident on the mountain becks and rivers which abound in or traverse the Fell district of 
north-western Yorkshire ; it also occurs, but less numerously, on the streams of the south-western moorlands, and is fairly common in suitable haunts among the hills of Cleveland. It breeds regularly by the side of streams near the coast between Loftus and Staithes, and in severe weather has. been seen among the rocks on the sea-shore. In these extensive habitats the three hundred feet contour line may be taken as defining the lower limit of the bird's distribution in any considerable abundance, while below this elevation it is sporadic down to as low as one hundred feet. It is a strictly sedentary species, but when frost of unusual severity and long duration render its subalpine home untenable, owing to the ice-bound streams no longer affording food, the Dipper descends to the lower reaches, and even then seldom indeed moves further than necessary, though it has once or twice been known to visit the polluted waters of the manufacturing districts.

In the East Riding it is a very scarce species and is known only in one or two localities ; it has bred at Stamford Bridge, and has been met with near Pocklington, while a pair have nested near Scampston annually for several years. The Rev. F. O. Morris shot a bird at Nunburnholme on the Ioth of January I856, which may have belonged to the Scandinavian form, next to be described, but it was not preserved.

Amongst curious facts in the nidification of this species the following is related by Mr. Henry Smurthwaite of Richmond "(Z60l. I 859; p: 655 I\%). "The nest was placed at the extreme end of a 'Sand Maritin's hole, which extended two feet in a $\therefore$ brink avierhianging a siream, and the old bird was captured on the nest, which contained five fresh eggs. Subsequently it was dug out and was found to resemble much in shape that of a Blackbird, but, as usual, was composed of moss thickly lined with oak leaves, the dome, however, being entirely wanting." Another remarkable case, where a pair of Sand Martins usurped the nest of a Dipper, is vouched for by Mr. Thomas Altham of Bashall Hall (see Sand Martin). A nest is described (Morris's Nat. I855, p. 268-9), which was placed under a small railway bridge. Here five nests were 


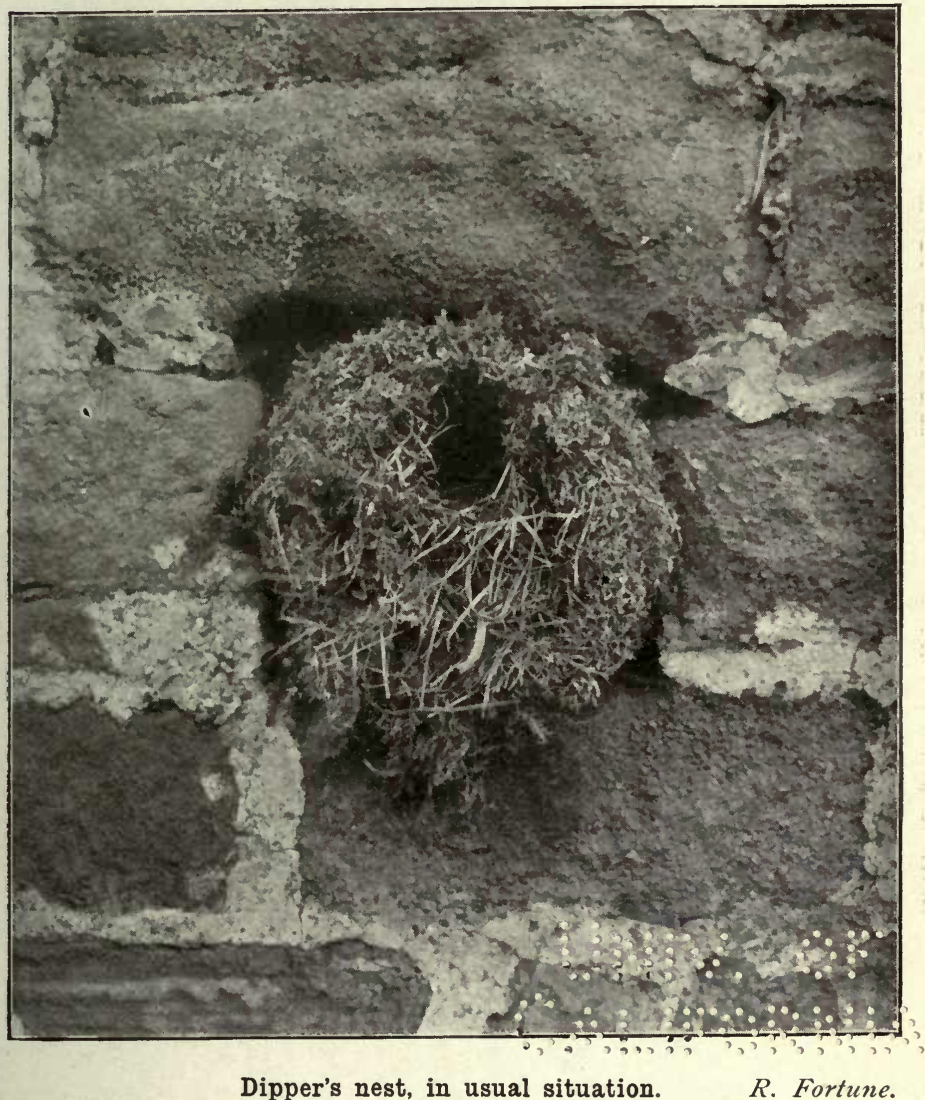

See page 102. 


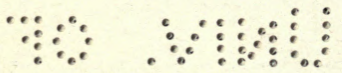

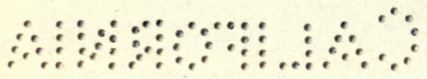


constructed by the same pair of birds in the spring of 1855 , from which no less than twenty-three eggs had been taken, and on May the I5th the old bird was sitting on two more eggs. A boulder in a stream has been utilised for a nesting site; another was between two beams of a sluice near Masham (Zool. I885, p. 25); and in IgoI a nest was built behind the Dropping Well at Knaresborough, where every time the old birds left or returned to their home they had to fly through the falling water. Mr. G. A. Widdas found a nest at Malham in 1903 placed in the centre of a small thorn bush about two or three yards from the water's edge. At Hartforth Hall, near Richmond, a Dipper was in the habit of roosting nightly for several weeks on a window sill (Field, 2oth October I900). A nest of this species at Sedbergh was ready for occupation on the 26 th of February; one at Richmond contained three eggs as early as March the I5th, and the earliest Yorkshire record for young birds is the 6th of April, on Hambleton.

There are various local vernacular names. In Teesdale it is Willy Fisher; at Harewood the Water Drill; at Settle it is called Douk (whence no doubt the use of the word in place-names) ; and at Loftus-in-Cleveland it is the Whitebreasted Ouzel, and Water Blacky. Water Crow is a term in general use, while Water Crake is the one used in Willughby's "Ornithology," p. I49.

\section{BLACK-BELLIED DIPPER.}

Cinclus melanogaster (C. L. Brehm).

It is not within the province of this work to debate the claims of this bird to specific rank. This much, however, must be said for it, that it is a well marked climatic raceone of those birds to which might be applied the trinomial system of nomenclature so usefully employed by American ornithologists for similar birds in North America, and by whom this form would be styled Cinclus aquaticus melanogaster. 
The Black-bellied Dipper is a common Scandinavian and North Russian bird, and seems occasionally to wander across the waters of the North Sea to eastern England. In our own county it has hitherto only, and perhaps, obviously, been noted in the vicinity of the coast, where in the East Riding it has been obtained on four occasions ; twice during the period of the autumn migration. Three of these birds have passed into the hands of ornithologists, and, it is worthy of note, have been examined by experts, and pronounced to be true melanogaster. The following are the particulars of the occurrences:-

One procured on a drain at Welwick on the 24th of October I874, was recorded by Mr. F. Boyes (Zool. I877, p. 53); this specimen is now in the York Museum.

In the same journal (I876, p. 487I), Mr. F. Boyes again records as a Black-bellied Dipper one obtained by a man named Priestman on the River Hull at Beverley, on the 29th of October 1875 .

The Rev. Julian G. Tuck mentions in the Field (January I876, p. 22) one taken at Flotmanby, near Filey, on the 8th of December I875.

In the collection of Mr. J. H. Gurney is a specimen which occurred near Bridlington, and was purchased by him of the late Mr. Jones, taxidermist, of Bridlington Quay.

\section{BEARDED TITMOUSE.}

\section{Panurus biarmicus (L.).}

Casual visitant; of very rare occurrence.

The Bearded Tit or Reedling, as it is usually designated, is resident on the broads of Norfolk, the nearest locality to Yorkshire where it is to be met with, and it is not uncommon on the reed-beds of Holland and other portions of the Continent, but as it is a sedentary species it is most likely that the stragglers, reported in parts of England other than 


$$
\int^{0}
$$

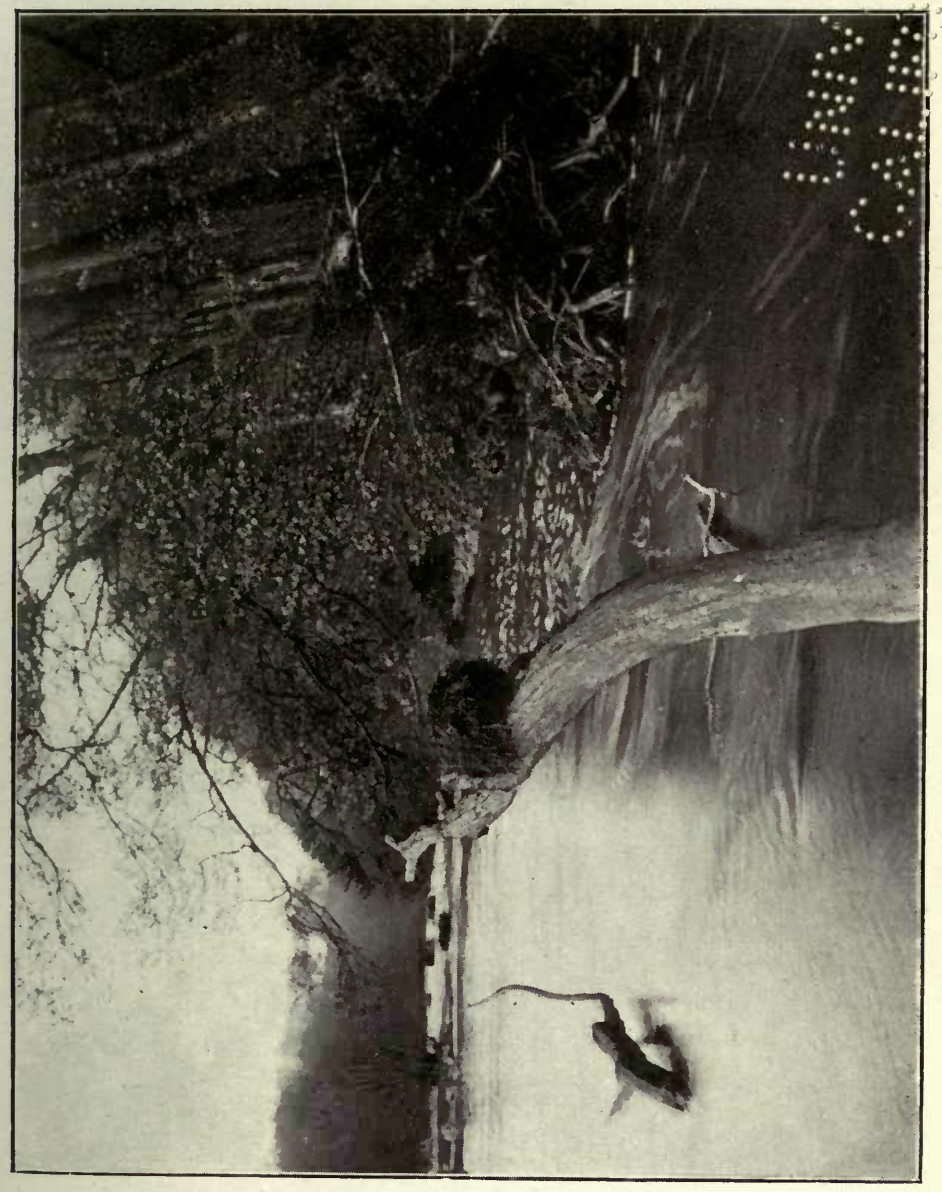

1

ஸ்

8

\& 


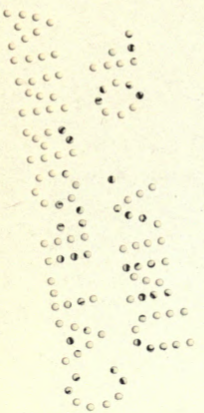


the neighbourhood of its nesting haunts, are native birds and not migrants. It is somewhat remarkable that of the earlier records of this species appertaining to Yorkshire no example has actually been obtained, and, owing to this unsatisfactory condition of affairs, its status is of a very uncertain character.

Thomas Allis, in 1844, wrote:-

Calamophilus biarmicus.-Bearded Tit-The only notice I have of this bird is from Wm. Eddison who says, 'It is not very common near Huddersfield. I do not recollect to have seen more than three or four living specimens. I had a dispute with a collector, who asserted they were common, but those he saw proved to be the long-tailed and not the bearded."

Mr. Mark Booth of Killerby recorded (Zool. I845, p. II35) that he "observed a fine male close to Kirkleatham Hospital, three or four years ago."

7 A more interesting statement was made by Charles Waterton, who informed Mr. A. J. More that a pair once built by the side of the lake at Walton Hall (Ibis, r865); and it is also reported to have occurred at Scarthingwell (J. Chaloner MS. I880).

Of these three occurrences Waterton's is the only one on which any reliance can be placed, and his residence, Walton Hall, is the most northerly point in the British Isles at which this species can with certainty be said to have occurred.

Mr. Kenneth McLean sends the following report to the Naturalist (rgor, p. 230):- "On 28th June I90r, by the side of Hornsea Mere, my attention was attracted by a soft musical 'tweet' amongst the rushes, which was new to me. .... Eventually I climbed into a stunted tree, and, after remaining perfectly still for some time, was rewarded by seeing a pair of old Bearded Reedlings and at least three young ones. ... I watched them for ten minutes or more, the soft rich colouring, especially of the old male, blending beautifully with the light green of the reeds and grasses by which they were surrounded. They were shy, retiring quickly down amongst the plants when alarmed, but still they did not seem to be particularly wild, as they came quite near to me." 


\section{LONG-TAILED TITMOUSE.}

Acredula caudata (L.).

Resident ; generally distributed; fairly common. More frequently in evidence in autumn and winter.

There can be no doubt that the nest described in 1713 by Dr. Richardson of North Bierley in Yorkshire, as that of the Goldcrest, was referable to the Long-tailed Tit, and consequently this may be taken as the first reference to this bird's connection with the county. ("Philosophical Transactions," Vol. xxviii., p. I67.)

Thomas Allis, in 1844, wrote:-

Parus caudatus.-Long-tailed Tit-Frequent in most parts of the county. R. Leyland observes that on the Ist January 1837 , a small flock was observed in one of the streets in Halifax, the weather being intensely cold.

During the breeding season, which lasts from March to July, the Long-tailed Titmouse is rather locally distributed, being then usually found in the old wooded districts; if the Marsh Tit be excepted, it is perhaps the rarest of the family which breeds with us, and it appears to be decreasing in the East Riding. Throughout the rest of the year it is more widely diffused, owing to its wandering proclivities, and may be met with in localities where it is unknown as a breeder, while there seems to be an influx of new comers from the north of our islands in October, which makes the species more common in the winter months. Although at times it may be seen among the roaming flocks of other Tits, Creepers, and small birds, in autumn and winter, most observers agree that they explore the woods in family parties, or sometimes in flocks; I noticed very large numbers while shooting in Grinkle Woods in January Igo2. The instance mentioned by Thomas Allis (see above), of a party of these birds being met with in the streets of Halifax is not unique, as, during the winter of $1854-55$, a flock of nine was seen flying through the streets of 


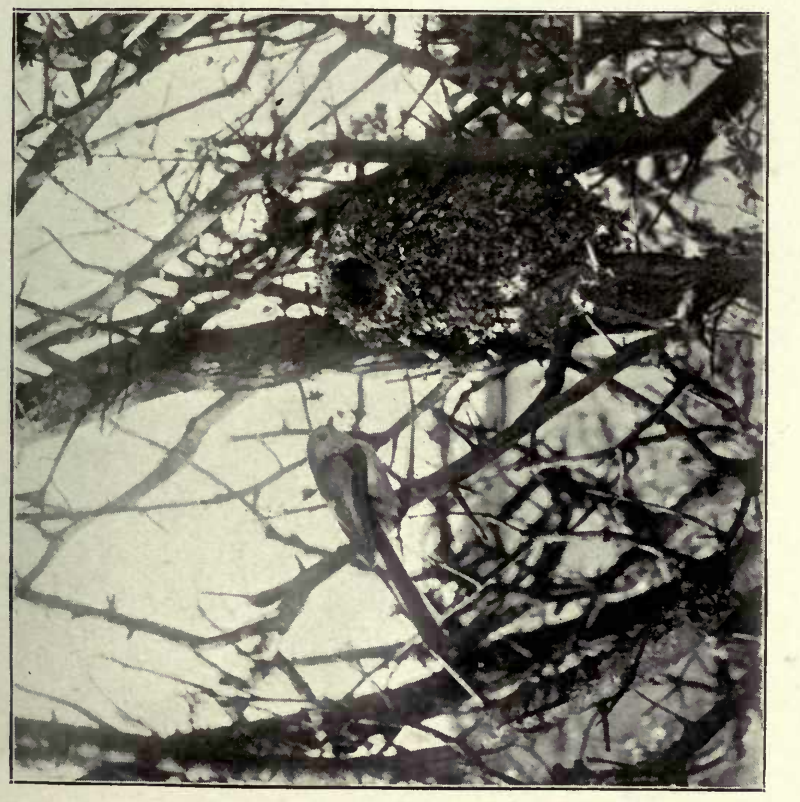

है

เं

远

을

م)

ฐี

总

a

$+$

蕰

?.] 

Middlesbrough, an event extremely unlikely to happen at the present time.

The earliest date on which nidification has commenced in the county is the I4th of March, when a nest ready for eggs was found at Hovingham in 1872. A nest at Roche Abbey in 1879 was placed inside an old home of a Magpie, which the Tits had lined with moss and lichens. The nesting eccentricities of the Paridæ are well known, and this bird's peculiarity lies in the direction of an occasional departure from the regular habit which apportions one pair of birds to one home. The late James Carter mentioned the finding of a nest at Masham, in April r876, containing three inmates, all old birds, which he had considerable difficulty in ejecting in order to count the eggs, fifteen in number. As early as I829 (Loudon's Magazine of Natural History, I830, p. 568), there is an account of a Long-tailed Tit's nest with young, near Clitheroe, which had no less than seven old birds in attendance; and in the Zoologist (1849, p. 2567), Mr. H. Horsfall mentioned a similar instance. In each case nearly all the birds were captured, and died in confinement, excepting one that was released and returned to rear the brood. Mr. Horsfall also recorded (tom. cit.) another occurrence where nine birds assisted to build a nest, while two used to sit upon the eggs.

The local names are: Bottle Tit, general; Bottle Jug, North and East Ridings; Miller's Thumb, Nidd Valley; Mealy Miller's Thumb, Lower Wharfe ; Long-tailed Tom and Long-tailed Pie, Loftus-in-Cleveland; Tom Piper, central Ryedale; Featherpoke, North and East Ridings; Feathersack, Northallerton; and Hedge Featherpoke, Doncaster, I848.

An example of the white-headed, or Continental form of the Long-tailed Tit is reported as having been seen, in company with birds of the ordinary British type, on March I8th I905, near Kirkham Abbey (op. cit. I906, p. I49). 


\section{GREAT TITMOUSE.}

\section{Parus major (L.).}

Resident ; commonly distributed. Autumn migrant, sometimes in considerable numbers.

The earliest published Yorkshire reference to the Great Tit is contained in Graves's "Cleveland," I808, where it is enumerated in the list of resident birds.

Thomas Allis wrote in 1844 :-

Parus major.-Great Titmouse-Common in most districts.

Second in numbers only to the Blue Tit, this species is one of the most abundant and familiar inhabitants of the woods and gardens; except in the bleak moorland districts it is found in every locality affording the requirements for its existence, and, consequently, does not require further notice as to its distribution.

As a migrant, however, it deserves more attention, for in the autumn there is occasionally a considerable arrival on the east coast, and this was noticeably the case during the latter part of October in 1878, at which time most unusual numbers appeared, and it was very abundant after a severe storm on October the 3oth, in company with Blue Tits and Wrens, both at Spurn and Teesmouth, this movement corresponding with a similar migration at Heligoland; a distinct increase on the coast line was observable also in 1883 , I884, I886, and 1889. In the Migration Reports there is only one entry relating to its appearance at the light stations, viz. :-I886, November Ist, "Spurn, P. major, very common" (p. 32). At Redcar I have often seen these little birds newly arrived; a large flight occurred in September 1889, and another on I4th September I90I, though not in such numbers as in 1878 . At Spurn they are frequently noted in autumn, usually in mid-September and October, and the birds seen then are cleaner and brighter looking than residents; both this and the Blue Tit have been known to alight on vessels in the North Sea during migration.

This species is insectivorous and a well-known enemy of 


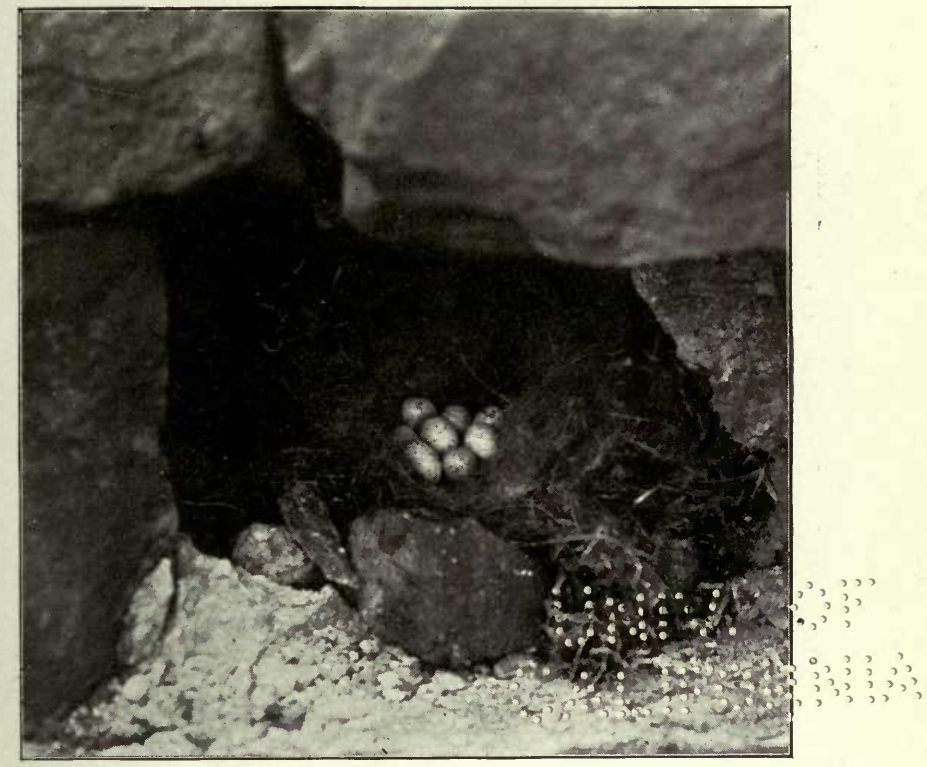

Great Tit's in old wall.

R. Fortune.

See page 108. 
“

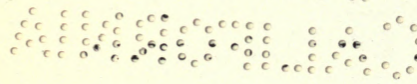


the apiculturalist; Mr. F. Boyes narrates a rather peculiar instance of one being killed by the bees whose hive it had visited once too often, on bee-murder intent; a trap being set, it was caught by the leg, and the infuriated inhabitants of the hive revenged themselves by stinging it to death before Mr. Boyes could effect its rescue. In the Rectory garden at Ripley, in I902, the Rev. W. T. Travis shewed me some hives where the Great Tits had actually broken their way in to feed on the inmates. These birds have been known also to attack wasps and destroy their nest. (Nat. I889, p. 333.)

Like its Blue cousin, this bird sometimes makes use of curious nesting sites, and of these one or two examples will suffice to illustrate this phase in its character. One, recorded by Mr. W. H. St. Quintin at Scampston, was in the cup of a deserted Blackbird's nest; another was found near York under a flower-pot on the carcases of a rat and a hedgehog (Zool. I882, p. 353); and I am enabled to figure one superposed on the nest of a Thrush built in a cluster of honeysuckle, at Bilton Banks, near Harrogate, in I902, and photographed by Mr. R. Fortune.

Local names: Greater Tit, Tom Tit, Billy Biter, Oxeye, and Blackcap are in general use; it is Black-capped Billy in the West Riding ; and Greater Billy Bluecap in Nidderdale ; Saw-whetter at Ackworth; and Saw-whet at Eavestone, near Ripon.

\section{COAL TITMOUSE. \\ Parus ater (L.).}

Resident; common, generally distributed in suitable localities, except in West Yorkshire, where it is local in summer.

The earliest allusion to the Coal Tit in connection with this county is found in a communication from Dr. Sherard, the eminent botanist, to Walter Moyle, a Cornishman and ornithologist of eminence. It is dated "London, May Io, I720," and runs as follows :- "Sir, .... Having received a letter from my old friend, Dr. Richardson of North Bierley 
in Yorkshire .... He sent me also Parus ater, as generally thought, tho' it does not agree with Gesner's short description." (The Works of Walter Moyle, Esq., I726.)

Thomas Allis, in $\mathrm{r} 844$, wrote :-

Parus ater.-Cole Tit-It is not infrequent in most woody districts.

Although not so numerous as the Great and Blue Tit, the present species is, on the whole, fairly common and generally met with, except in remote south-west and northwest portions of the West Riding, where it is to a certain extent local during the breeding season, though more generally distributed, or perhaps more in evidence, during the autumn and winter, when it consorts with other small birds which rove through the woods in search of food.

The favourite haunts of this bird are fir plantations, and in both summer and winter it is almost always to be found in these localities, even in the highest situations.

Owing to the scarcity of suitable nesting holes in the pine and fir woods in north-west Cleveland I have noticed that it occasionally excavates a hollow in the old nests of Magpies or Squirrels and, lining the inside with wool, hair, and other nesting materials, utilises the lofty site for its home. In woods at a lower elevation a hole in a tree, in a rotten stump, or in the ground, is usually selected, but this Tit, like the others of its family, often resorts to peculiar dwelling places.

The two extreme varieties of this bird have been accorded specific rank by some systematists of the present day; the olive-brown backed form being styled $P$. britannicus (Sharpe and Dresser), while the continental race, with slate-grey back, retains the name bestowed on the species by Linnæus, viz., $P$. ater; but, as gradations between these two forms occur in the British Isles, I consider the best course is to treat our bird as an insular form of the continental species.

The latter is said by the late J. Cordeaux to be an occasional straggler to our coast in autumn (Cordeaux MS. Nat. I896, p. 8 ; r899, p. 24), but I am not aware of any evidence in support of this statement.

Its local names are Blackcap, or Little Blackcap, and Tom Tit, in use in the North and West Ridings. 


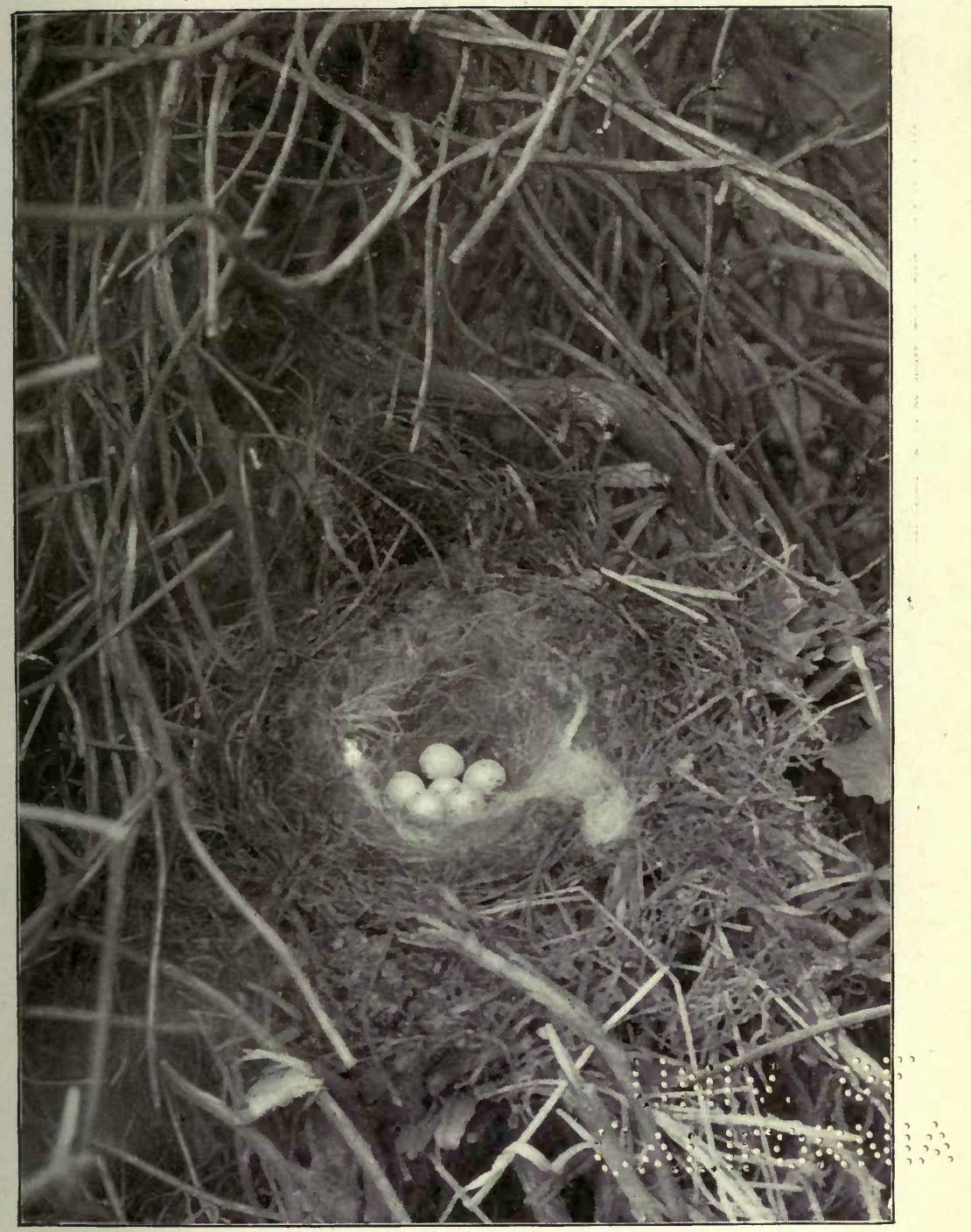

Open nest of Great Tit, built on an old Song Thrush's nest in a clump of woodbine.

R. Fortune. 


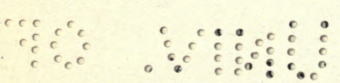
are 


\section{MARSH TITMOUSE.}

\section{Parus palustris (L.).}

Resident; fairly numerous, but rather locally distributed.

Probably the first mention of this bird in Yorkshire is contained in the appendix to Graves's " History of Cleveland " (I808), in which it is enumerated in the list of birds.

Thomas Allis, in I844, wrote:-

Parus palustris.-Marsh Tit. Wm. Eddison states this to be migratory near Huddersfield, and not very common; it is frequently met with in most parts of the county, though less common than the three preceding species (Great, Blue,* and Coal Tits).

Generally speaking the Marsh Titmouse is scarcer and more locally distributed than the preceding species. It is more retiring than its congeners in its habits during the nesting season, and seems partial to the combination of woodlands and water, particularly in river valleys and places where brushwood is found, and low growing trees afford suitable sites for the nest.

There does not appear to be any instance of the Marsh Titmouse as an immigrant at the coast, and the accession to its numbers, usually noted in the fall of the year, is probably caused by birds roaming further afield in search of food during the autumn and winter months.

Though generally speaking an insect feeder it has a "penchant" for Indian corn when obtainable. At Burton House, Masham, a bird of this species used to feed almost wholly on this grain, which was thrown out for the poultry during the winter of 1883 , and would fly down from a tree, select a piece and return to its perch, then, after biting out the softer centre of the corn, drop the remainder. In time the ground beneath the tree became quite strewn with the

* In the order observed by the B.O.U. list, and followed in this work, the Blue Tit is placed after the Marsh Tit, and does not precede it as in Allis's list. 
discarded fragments (James Carter MS.). At Kirkleatham, near Redcar, during the winter of I90I-2, three Marsh Tits used to feed with the Pheasants upon the corn thrown out in front of the keeper's lodge. (See also Mr. F. Boyes's remarks on a similar habit observed in connection with the Blue Tit, p. III.)

Local names are :-Blackcap and Tom Tit (general); and Blackcap Titmouse (Hinderwell's "Scarborough").

\section{BLUE TITMOUSE.}

\section{Parus cæruleus $(L$.).}

Resident; generally distributed; common. Regular autumn migrant.

The first allusion to this bird in Yorkshire is contained in the Tunstall MS. :- "We have plenty of the others (Titmice), particularly the Blue." (Fox's "Synopsis," p. 75.)

Thomas Allis, I844, wrote:-

Parus caruleus.-Blue Tit-Also common.

This familiar species, the commonest of its family, is generally distributed in the woodlands, fields, and hedgerows, and, as may be expected, is most abundant in the more wooded portions of the county, but even in the higher moorland districts it is by no means uncommon in the fall of the year, as the wandering parties of this and other small birds visit almost every hedge, wood, and town and city garden in the autumn and winter months, although they may be absent in the nesting season.

Great arrivals take place on the east coast in the autumn, generally accompanied by their larger relative, the Great Tit, and at the times of migration, from mid-September to midNovember, the hedgerows near the coast swarm with these little clean-coloured individuals. In 1878 there was a great influx during the last fortnight in October, which corresponded with a similar "rush" at Heligoland (Zool. 1879, p. 44); 


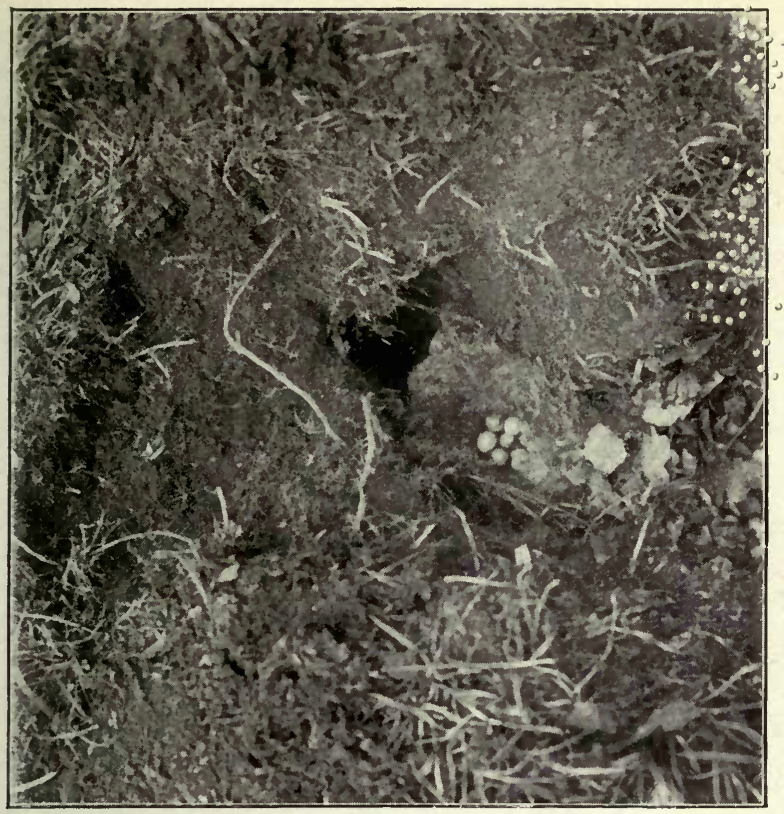

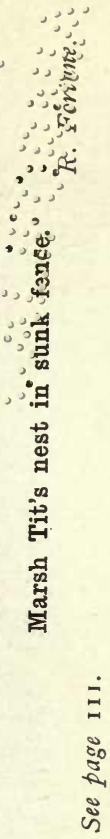

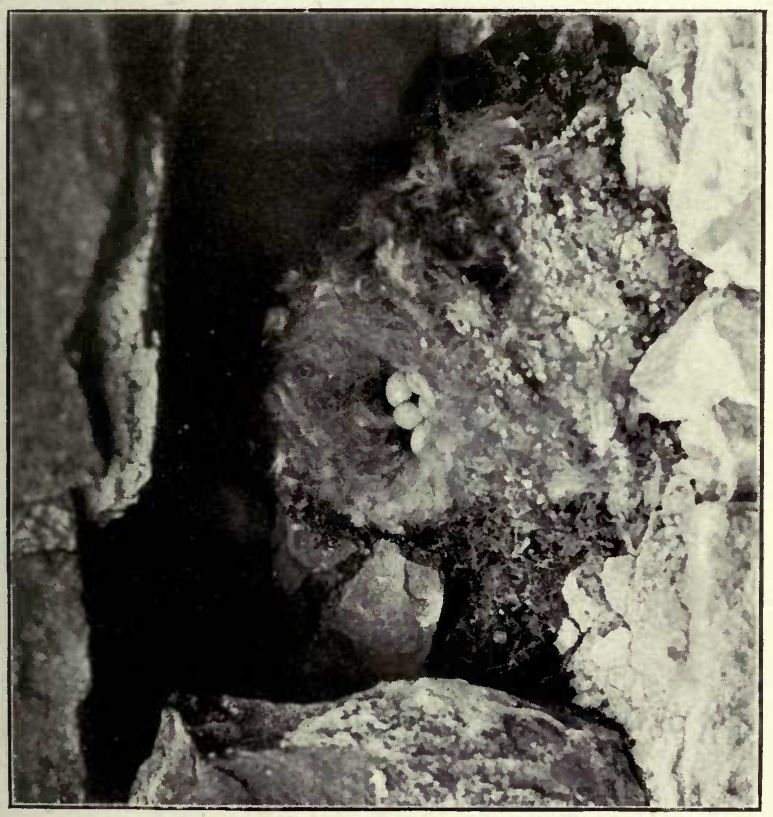

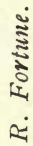

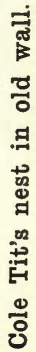

$\vdots$
$\vdots$
$\vdots$
$\vdots$ 

another heavy migration took place in I889; and on I4th September Igor, there was a great arrival at Redcar, where I have noticed it in most seasons in autumn, though not in such abundance as in 1878 .

The Migration Reports contain entries from Spurn, Flamborough, Whitby, and Teesmouth, relating to its occurrence in October, while in the Report for I883 (p. 40) one is noted as having struck the glass at Flamborough Lighthouse on April 3rd.

Inland the Blue Tit has been seen settled on such unusual places as house tops in the centre of large towns during the early mornings in October, which is significant of its being newly arrived, and at this period it may also be frequently observed in the trees right in the heart of our busiest towns.

This species is classed by fruit-growers among the " undesirables" in a garden at the time of harvest, and the damage caused by it, particularly to the best varieties of pears, is too often beyond computation. Mr. F. Boyes bears eloquent testimony to the destruction wrought by these little creatures to the choicest kinds of pears in his garden at Beverley, and the same observer, so long ago as 1877 , records the propensity of this bird for feeding on Indian corn in a similar manner to the Marsh Tit, described by the late James Carter under the heading of the latter species. (See Zool. I875, p. 4298.)

The peculiar situations chosen for nesting purposes have brought this bird into prominence in this respect, beyond any other British species; a hole in a tree trunk or branch is the most usual site, but often they make use of holes in walls, railings, or gate-posts, street lamps, pumps, and letterboxes, and the newspapers every year contain paragraphs recording "Tom Tits" nesting in these odd places. At Gunnergate, near Middlesbrough, a Blue Tit laid nine eggs in a Blackbird's nest placed high up in a spruce fir, in May Igor; the Blackbird's eggs had been taken a week or two previously, and the Tits had lined the nest with wool and hair before laying. At Kirkleatham, near Redcar, a nest was found in I902 containing twenty-four eggs, and in this instance vol. 1 . 
also the birds had utilised an old nest placed at the foot of a tree. Yet another strange site was a crevice in the jaw-bone of a whale used as a gate-post on the road leading from Bempton village to the cliffs, a road traversed by ornithologists from all over the country; here a brood was hatched in I90I, ere the nest was discovered, and in 1902 I found the owner of the gateway had sawn down the bone arch (Nat. I90I, p. 256).

An instance of three old birds feeding a brood of young at Boroughbridge is mentioned by Mr. Holtby (tom. cit. p. 282)

The only recorded example of a departure from the ordinary plumage was mentioned by the late Rev. J. Chaloner of Newton Kyme, who saw one in $\mathrm{I} 892$ " coloured as yellow as a canary" (op. cit. I892, p. 2I5).

Of local names Blue Cap, Tom Tit, Billy Biter, Billy Blue Cap, and Jacky Blue Cap are general; Little Billy Bluecap and Blue Bonnet are used in the West Riding; Bluey at Scarborough; Twitty Blue in Wharfedale; Jenny Wren in Craven; and Titinaup in the Aire Valley (fifty years ago).

\section{CRESTED TITMOUSE.}

Parus cristatus (L.).

Accidental visitant, of very rare occurrence.

In Great Britain the Crested Tit is confined to the woods on Speyside, Scotland ; it breeds in the low country of Holland and elsewhere on the Continent.

It is of very rare occurrence in this county, though an early reference is made to it by that old ornithologist, W. Lewin, who remarked so long ago as I797, "It has been killed in Scotland and also in Yorkshire." ("Brit. Birds," Vol. iv., p. 46.)

Thomas Allis thus alluded to it in $\mathrm{r} 844$ :-

Parus cristatus. - Crested Tit. My friend J. Heppenstall states that one was seen in a garden at Thorne.

In addition to the occurrences mentioned by Lewin and 


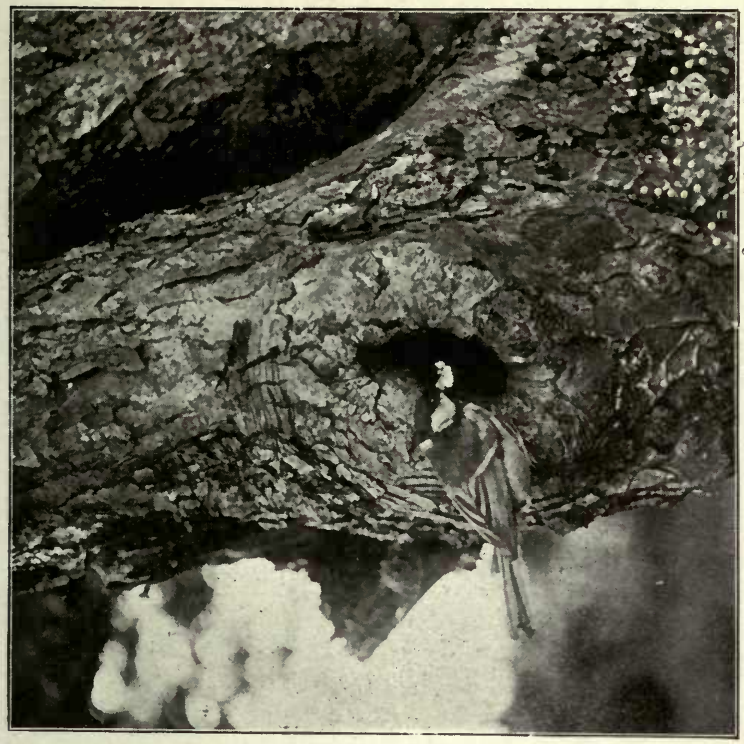

$\because \approx$

$\therefore \quad$

$\therefore$ : क , 웅 品 오 + 웅 4

8

竎 \$

E

$\stackrel{9}{\mathrm{~m}}$

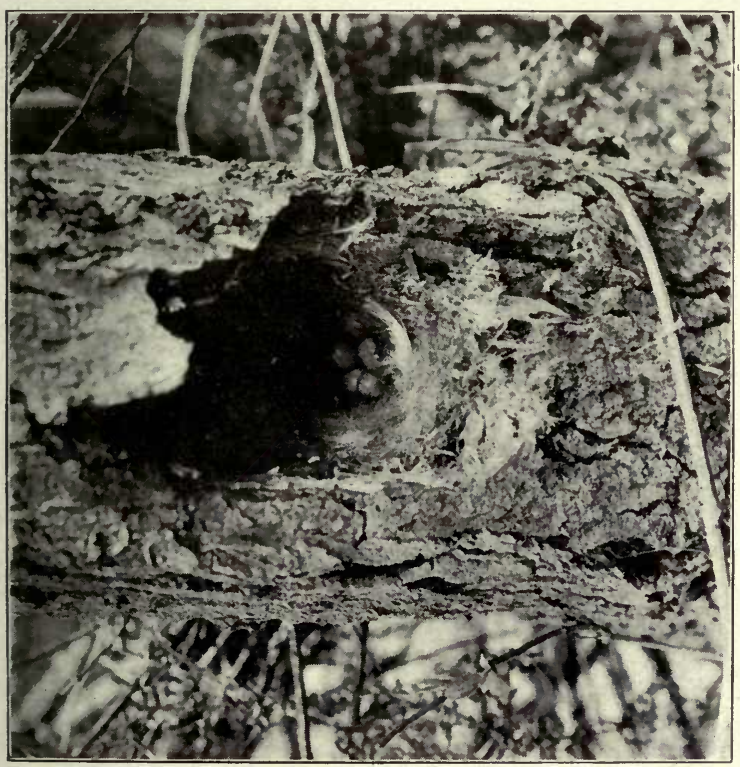

量

$\dot{3}$
$\Xi$
$\dot{8}$
$\dot{8}$ 

Allis (above), four examples are said to have been actually obtained, and if this be correct these birds must either have been wanderers from the Scottish forests, or, what is more probable, individuals which have straggled across the North Sea from the Continent, with other small migrants. The particulars relating to those which have been preserved, so far as it is possible to obtain details, are :-

Whitby, one, March 1872 , on the Newton House estate, and now in the Whitby local museum. Mr. T. Stephenson states that Parker (formerly the keeper at Newton House, where larch plantations are plentiful) saw the bird in both summer and winter. (Stephenson, MS. and Zool. I872, p. 302I).

Thirsk, one taken to Mr. Robert Lee, who preserved it " many years ago." (Lee, MS. I880.)

It is unfortunate that full details respecting these specimens are not available.

The reported occurrences of this bird in March 1870 , and August 1887, near Bradford and Keighley, mentioned in the "Vertebrate Fauna of Yorkshire" (p. 24), and in the Naturalist (I888, p. I5), are, as I am informed by Mr. E. P. Butterfield, not authenticated by subsequent investigation.*

\section{NUTHATCH.}

Sitta cæsia (Wolf).

Resident; local; not at all numerous; chiefly confined to old timbered parks.

The earliest reference to this bird in connection with Yorkshire is contained in a communication from Ralph Johnson of Brignall, near Greta Bridge, to John Ray, in 1678 , thus :-

"The Nuthatch or Nut-Jobber-Picus cinereus-She hath

* Those interested in the occasional appearance in England of the Crested Tit would do well to peruse Mr. J. H. Gurney's article on this subject in the Zoologist (1890, p. 210), and Naturalist (1891, p. 116). 
not a long tongue as the other [the Woodpecker kind] because she feeds not on Cossi as they do, but on other insects, and especially on nut-kernels. It is a pretty sight to see her fetch a nut out of her hoard, place it in a chink and then stand over it with her head downward, strike it with all her might, and breaking the shell, catch up the kernel. The feathers of her tail are not stiff and pointed, because her motion is rather down than up trees; nor hath she two hind toes, but the inner toe is separated a little from the middle, and falls somewhat across (as in the Owl kind) whereby she can support herself in any motion. Her voice is very shrill. Mr. Johnson." (Willughby "Orn." I678, p. 23.)

Thomas Allis, I844, wrote :-

Sitta europcea.-European Nuthatch-By no means common. $\mathrm{J}$. and W. Tuke report that it breeds at Castle Howard; scarce near Leeds, but is met with at Scarcroft and Harewood Bridge ; it is rare at Sheffield; it occurs near Doncaster, and is frequently met with in the Stainborough Woods at Wentworth Castle, the seat of Thos. T. V. Wentworth, Esq.

This interesting little bird is very local, somewhat irregular in its distribution, and nowhere very common. In the southern portions of the county it is a scarce species, though formerly abundant in Stainborough Park, near Barnsley, where it is still known. Near Sheffield, Doncaster, Ackworth, and several other localities it is occasionally met with and nests very sparingly. In the central districts it has undoubtedly increased in numbers and become more widely distributed in recent years; it nests in the neighbourhood of Leeds, and in the valleys of the Nidd and Lower Wharfe it is fairly numerous; it breeds annually at Plumpton, Newton Kyme, Allerton Park, Rudding Park, Ribston Park, Knaresborough, Harrogate, Ripley, Harewood, the Washburn valley, and other well timbered districts, where it can obtain suitable nesting trees; it is also found at Eavestone and at Studley Park. In the north-west it is extremely rare, though it has been noticed at Bolton-byBowland.

It occurs fairly regularly round York, as at Moreby and 


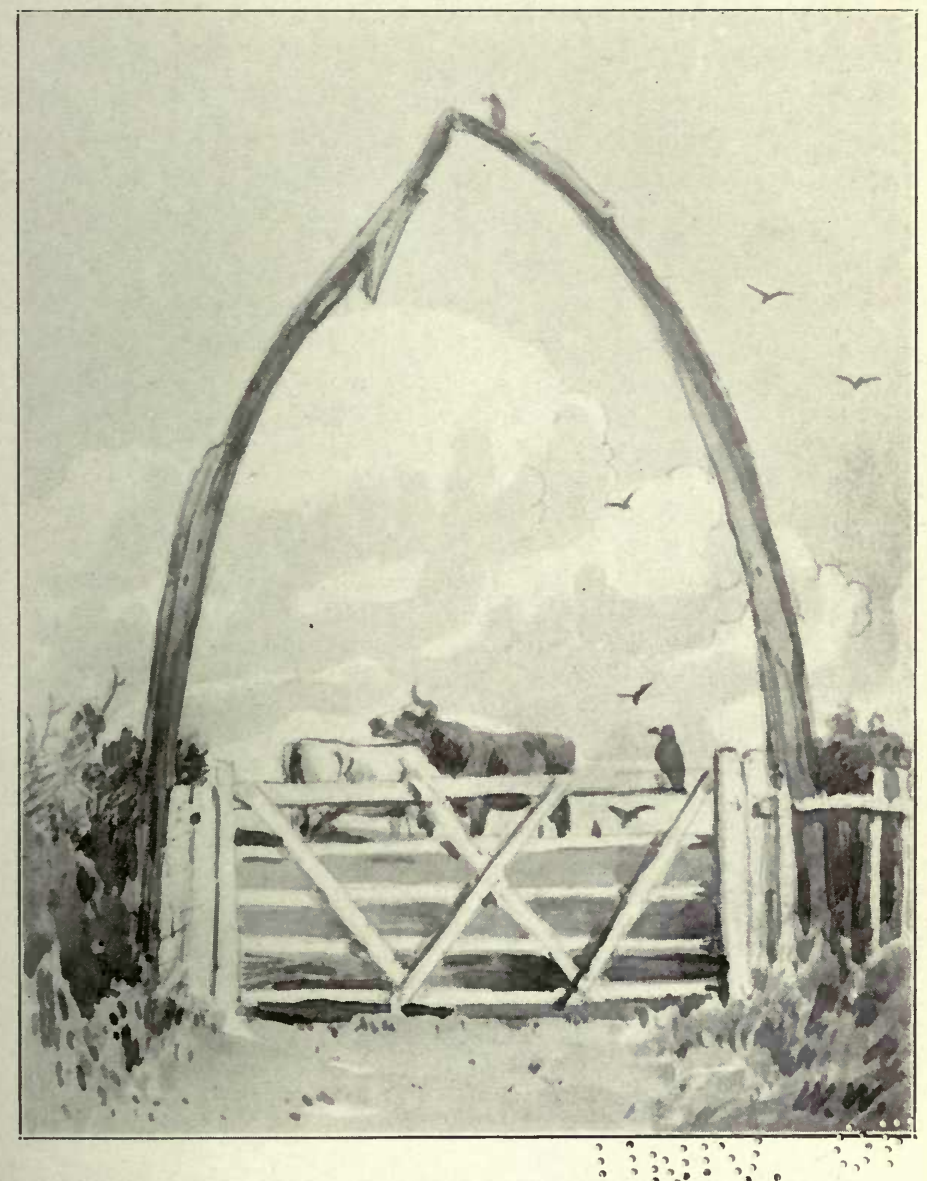

Whale's Jaw-bones near Bempton, nesting place of Blue Tit., ? ? After a Drawing by W. Woodhouse, from a'Phofa by E. ,$;, ?, \cdots, ?$

See page 114 . 
60 ato

and 
Skelton, breeding most years. At Creyke there were a few pairs ten or twelve years ago and probably are still. Mr. J. Backhouse has once observed it in the York nurseries. One of its headquarters in the North Riding used to be Castle Howard, where it was an abundant nester, though now it is not so common there; it is frequent at Hovingham, and in the valley of the Rye, near Helmsley, Rievaulx, and Hawnby, also at Leckby Carr and Masham, in Wensleydale, Bedale, Copgrove, and Bolton Woods, though scarce near Richmond, Thirsk, and Northallerton. In Cleveland it nests in several of the preserved woods and parks, notably at Wilton and Saltburn; a few years ago it was fairly numerous at Grinkle Park, but has greatly decreased in numbers. It has occurred at Whitby, and is a rare resident near Scarborough.

So long ago as 1780 Tunstall mentioned a specimen taken in a little wood near his house at Wycliffe-on-Tees, where he stated they were very frequent. (Tunst. MS. p. 6r.)

It is of very rare occurrence in the East Riding and is restricted to one or two localities. In Scampston Park there were six pairs until $1894-5$, and for several years two pairs breeding; until 1890 they nested in an elm tree, and the last time they were observed they were building in a beech tree on the lawn. At Kirby Underdale, near Pocklington, a pair bred a few years ago, the male bird being afterwards shot and preserved.

A very interesting reference to the Nuthatch is mentioned in a letter entitled " General Observations in Natural History, made at North Bierley in Yorkshire, by Dr. R. Richardson," as follows :- "The Nuthatch or Nut-jobber is not frequently to be met with in the South, yet is so common with us that I have sometimes seen six or seven of them in one day in my own woods. ... I I have with much pleasure often observed these Birds to crack nuts, which they do with very great dexterity. I ordered one of my servants that was with me in a wood last Christmas to observe from whence she fetched her provision; which he soon discovered in a hollow tree, and cutting the place open, brought from thence 
several pints of very choice nuts." (Phil. Trans. Vol. xxviii., I7I3, p. I67.)

The only names other than its ordinary appellation are Wood Cracker, at Doncaster, and Nut Jobber at North Bierley ( 6788$)$.

\section{WREN. \\ Troglodytes parvulus (Koch).}

Resident; common; generally distributed. Spring and autumn migrant.

The earliest published reference to this bird is in a letter from Dr. Richardson, about the year I7I3, entitled " Several Observations in Natural History, made at North Bierley in Yorkshire," which contains an allusion to the Common Wren. ("Phil. Trans." Vol. xxviii., p. I67.)

Thomas Allis, in $\mathrm{I} 844$, reported as follows :-

Troglodytes vulgaris. - The Wren-Common in most districts, though near Huddersfield Wm. Eddison states that it is not so frequent as in lower and warmer districts.

This familiar and favourite little bird is found more or less commonly in every locality where its simple requirements are met with, from the dwellings of civilized beings to the opposite extreme, in the high moorland districts, where it has been known to nest to an elevation of rroo feet, and its loud notes may even be heard right out on the bleak moors.

Although for the most part resident, considerable numbers migrate to our shores in autumn, especially at Spurn, where they were very abundant in October 1870 , and they usually arrive in that month with easterly winds, but in some years they are later and do not put in an appearance until November or December; in I88I the migration extended over eighty days, from July the $I 7$ th, at Flamborough, where several remained round the lantern during the night, to October the $4^{\text {th. }}$

At the Teesmouth they are sometimes seen on migration, 
though never in large numbers, with the exception of October 1899, when they swarmed on the sand-hills and sea-walls for a day or two, but, like other small migrants, they remain only a short time, being here one day and gone the next. (See Migration Reports.) At the light stations they are regular visitors in autumn, and on the vernal passage are observed from March until May, but with less frequency and in much smaller numbers at the latter period; their occurrence on vessels in the North Sea is by no means uncommon.

Although March to April is the usual time for nesting, the eggs have been found as early as February the 9 th, in I874, at Barnsley, and a late date is noted at Beverley, where newly hatched young were seen on October 9th I902. Very odd sites are often chosen for the nest: Charles Waterton in 1847 recorded one in the coils of a rope hung up against a tree in Walton Park ; one made within the nest of a Swallow is mentioned in Neville Wood's Naturalist, in 1837; and at Fewston in May I903, I saw a similar case of usurpation, a pair of Wrens having built for two years in succession and reared their young in a shed where they utilised a Swallow's nest which they domed over; but the most curious building place I have known of was in the carcass of a Crow, hung up on a keeper's museum near Winestead, in Holderness, where the parent bird was sitting on three eggs when discovered by Mr. Potter on Igth May Igo2.

The confiding nature of our little bird ensures its protection, as it does that of the equally well-known and homely Redbreast, and Yorkshire folk-lore associates the two in story and verse, as exemplified by the familiar couplets :-

\section{" The Robin and the Wren}

Are God Almighty's Cock and Hen,

Him that harries their nest

Never shall his soul have rest ;"

a similar idea of sacredness being felt for the species under notice as for her supposed mate.

It has been observed that the individuals seen on the coast in October appear to belong to a slightly larger race 
than the bird of our gardens, and Mr. E. P. Butterfield informs me that he has on one or two occasions observed this large form in autumn, on the moors near Bingly.

Its local names are somewhat numerous : Jenny Wren, Tom Tit, and Kitty are general; Jenner Hen is given as general by Johnson (Zool. I848); the name is pronounced Jenny Wa-ren about Doncaster (Hawley, op.cit. 1849); Jinties is used at Barnsley; Tommy Tit and Tricker at Thirsk ; Tommy in the Nidd Valley; Peggy about Huddersfield; Stump-tail about Staithes and Loftus-in-Cleveland; Chitty at Sedbergh ; and Runt at Skelmanthorpe, near Huddersfield.

\section{CREEPER.}

\section{Certhia familiaris (L.).}

Resident; generally distributed in woodland localities, parks, and orchards, but nowhere very numerous.

The first published mention of this bird in Yorkshire is contained in Graves's "Cleveland" (I808), where it is enumerated amongst the residents.

Thomas Allis, I844, wrote :-

Certhia familiaris. - The Common Creeper-Met with in most parts of the county, though not very numerous anywhere. R. Leyland remarks that the old walls so frequent in the neighbourhood of Halifax as fences form, in the absence of hollow trees, convenient building places for this species.

The above account of the Creeper as given by Allis in I844 holds good at the present time, and from every part of the county it is reported as being found in the wooded portions, but nowhere abundantly. Being a bird of the woodlands it is, of course, uncommon in the higher moorland districts, although it breeds in all the upper dales where suitable woods exist. After the nesting season, and during the winter months, it is more in evidence, as it commonly associates with the roaming bands of Titmice and Goldcrests in their search for food through hedgerow and wood, when its mouse-like appearance as it runs up the trees may be 


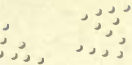

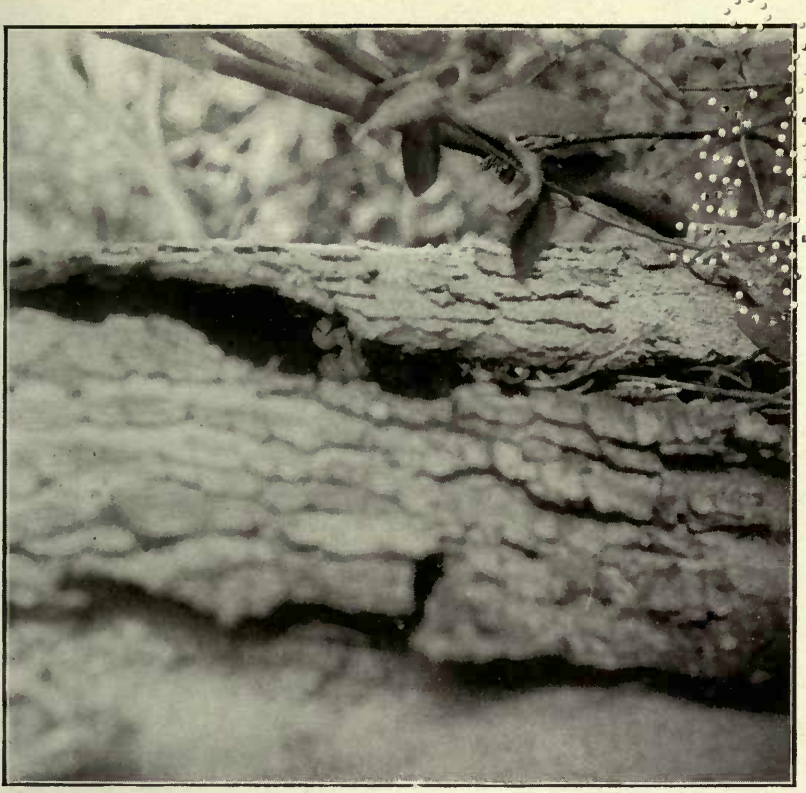

(2, כ2

$$
\begin{aligned}
& \frac{2}{\vdots} \\
& \vdots \\
& \vdots \\
& \Sigma
\end{aligned}
$$

芯

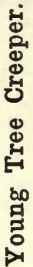



more conveniently observed than in the summer months when the foliage screens it from view.

Although not classed among the regular migrants it is not improbable that this species does occasionally cross the North Sea in autumn; an entry relating to its occurrence at Spurn on August I4th I885 appears in the Seventh Migration Report, p. 42, and on the Ist November I889, two examples, male and female, were shot at Easington Lane End, where it meets the coast line. (Nat. 189o, p. 10.)

Of local names, the book-name, Tree Creeper, is in general use ; at Barnsley it is recorded as being named Creepy-tree, and as Jinties (Nat. I853, p. 20I); at Marton-in-Cleveland it is called Little Woodpecker.

\section{PIED WAGTAIL. \\ Motacilla lugubris (Temminck.).}

Resident in small numbers, also summer visitant; generally distributed and common from March to September. Occurs in great numbers on the coast in spring and autumn.

The first allusion to this Wagtail as a Yorkshire bird is a quotation in Willughby's " Ornithology" from Ralph Johnson of Brignall, near Greta Bridge (a friend and correspondent of the celebrated John Ray), under the heading of "White Wagtail," but it is evident that the pied kind is meant :-

"Water Wagtails. The White, Motacilla alba. This comes every seed time and follows the plowman, and is therefore by him called the Seed Bird. Mr. Johnson." (Will. "Orn." I678, pp. 7, 237.) See also Montagu's Ornithological Dictionary, p. $36 \mathrm{r}$.

Thomas Allis, 1844, wrote:-

Motacilla yarrellii.-Common Wagtail-Common in most parts. Few remain during winter.

II It is somewhat difficult to avoid controversy in defining the faunistic status of this bird; perhaps it may be best described as a summer visitor, with the adjoinder that in the more sheltered parts a small proportion remain throughout 
winter. That accomplished ornithologist and Yorkshireman, Marmaduke Tunstall, made an early reference to its wintering in the county, thus:- "Have seen not unfrequently in the north of Yorkshire, in the middle of winter, as well as the Grey. Saw one this year January 8 th, in a very hard frost and snow." (Tunst. MS. I783, p. 7 r.)

During the summer months it is a common and generally distributed bird, being the most widely diffused of our Motacillidæ, but in the higher portions of the Shire, and particularly in the west and north-west, it is generally reported as being absent in winter. Even in the low-lying districts, and at the coast-line, the numbers met with between November and February are very few in comparison with the hosts which come in March and April, and depart in August and September. Very noticeable features of our coast migration are the vernal and autumnal movements of this bird; in late February or early March, the first arrivals take place,* in pairs or small parties, and up to the latter part of April the migration of Pied Wagtails is an ordinary event to be looked for in an early morning's walk along the shore. A large migratory flock was observed in Wharfedale in March I879. In August and September the return passage commences, and at the estuaries of the Tees and Humber large assemblies are daily to be seen in readiness to depart. Should the wind be favourable, by noon the greater portion have passed on. The Migration Reports contain frequent entries, too numerous for mention in detail, of its appearance, in both spring and autumn, at all the Yorkshire coast stations.

Nidification in the higher localities commences a little later than in the lowlands, and not infrequently the birds make choice of peculiar situations for the nest; amongst these may be mentioned a railway truck, a cowshed, and a hollow can, while a most curious instance is mentioned in the Zoologist (1863, p. 8844), of a pair near York usurping a nest in an unused chimney that had been occupied for

* So regular is their return in spring, when bean-sowing commences, as to give rise to a local proverb in North Yorkshire, "Sow beans when the Wagtail returns." 


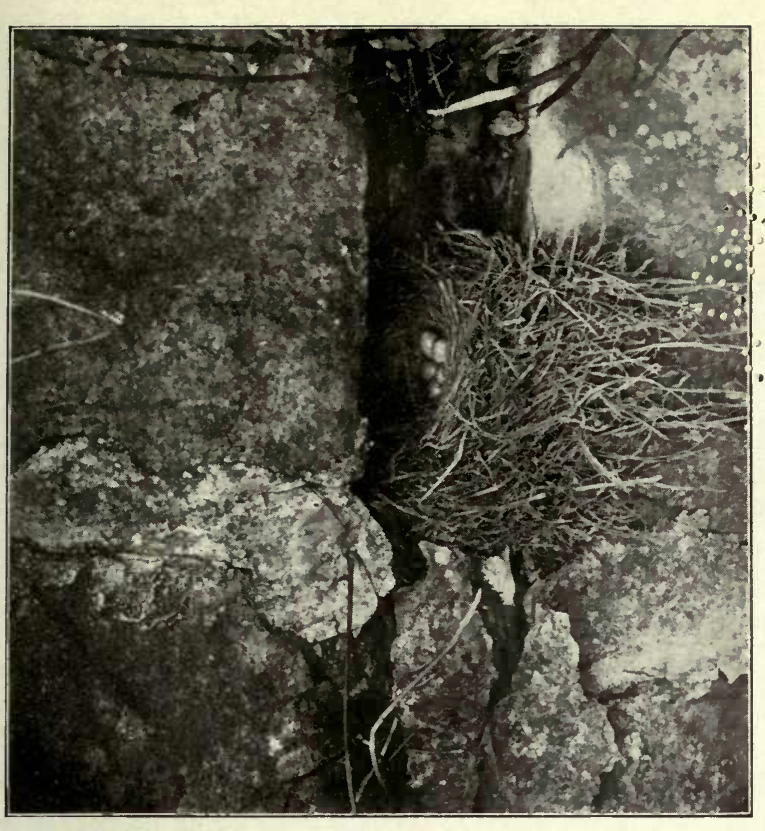

$$
\text { 年 }
$$

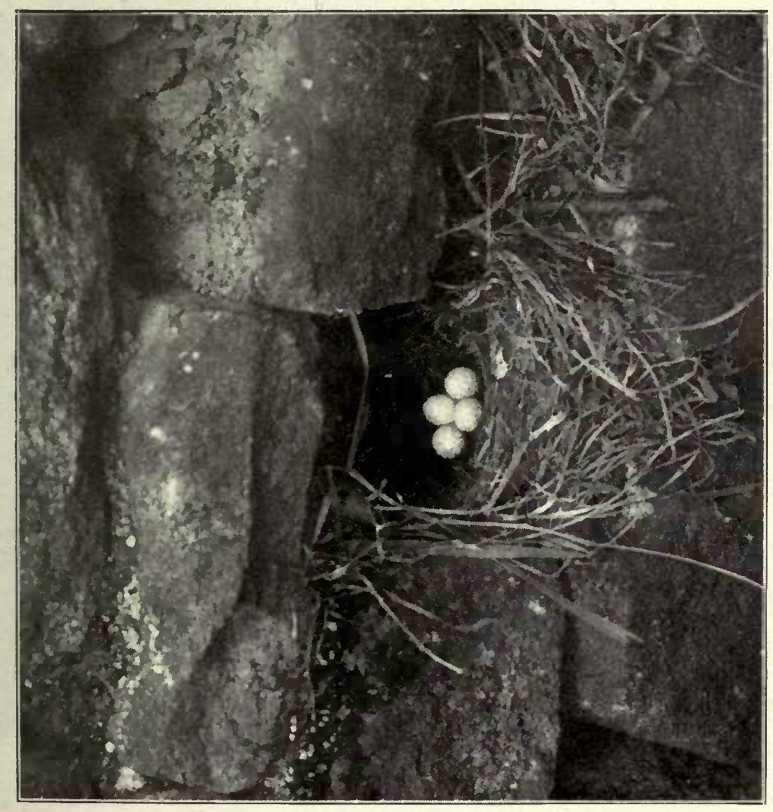

نं

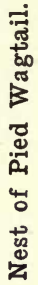





\section{WHITE WAGTAIL.}

some years by a pair of Swallows, and in spite of endeavours to dislodge them they retained possession and reared their young. On the Wolds of the East Riding a favourite site for nesting is in the chalk-pits.

Vernacular names are-Water Wagtail and Black and White Wagtail (general); Seed Bird (Willughby, I678; and in Wharfedale); Watterty or Watterty-wag (Huddersfield district); Willy Wagtail (Thirsk and East Riding); Water Waggy (Cleveland); Peggy Dish-wash (North Riding); Bessie Ducker (Huddersfield).

\section{WHITE WAGTAIL.}

\section{Motacilla alba $(L$.$) .$}

Bird of passage in spring, of uncommon occurrence.

The first published reference to the White Wagtail in Yorkshire is contained in the Zoologist (1848, p. 2229), where J. S. Webb recorded having seen a single bird close to York on July the I3th of that year.

Although there are comparatively few early records of this bird, which is the Continental form of our common Pied species, there is every reason to believe that it has been overlooked, and is a regular though scarce visitor on spring migration, its appearance usually coinciding with the arrival of the bulk of the Pied Wagtails in April. The first Yorkshire notice is that by J. S. Webb quoted above. Seven years subsequently the late Alfred Roberts (op. cit. I855, p. 463I) reported one shot at Deepdale near Scarborough on 23rd January I855, which, if correct, is the only winter occurrence that I am aware of. In I866 a pair were noticed in company with Pied Wagtails on the banks of the Calder, on March the 25 th, while a second pair were met with on Brierly Common where the nest is said to have been found ("Birds of Wakefield," I876) ; and Thos. Lister recorded an example in May 1874, near Huddersfield. On the river Wharfe, near Bolton Abbey, the White Wagtail was noted on I2th April I879, 
and in the Aire Valley on the 9 th of the same month in I905. One was caught near Leeds about $I 880$, and it is recorded from Gisburn on I8th April I88I (Vertebrate Fauna of Yorkshire, p. 25). In more recent years it has been met with near Pontefract on 3rd June I893; it is also reported to be a summer visitor in the Wakefield district. Near Huddersfield it has been noticed occasionally near the Kilner Bank; at Harrogate in the spring of Igoo; and several were observed in the Sedbergh neighbourhood. Mr. Wm. Morris informs me that a pair bred in a quarry in May, while the late James Carter noted it at Masham.

The neighbourhood of the coast is more favoured by the White Wagtail's appearance, and it is reported as a rare summer visitor (non-breeding) to the Humber and coast. At the Teesmouth it appears every spring, usually in April and May, the black cap contrasting strongly with the pearl grey back, and giving it a more delicate appearance than the Pied Wagtail, with which it is certainly attracted here on migration; the call note also seems different from our English bird, being softer in tone.

In I899 a male was seen on April the 27 th, near a slag heap by the Tees side, and a week later it was joined by a female. The pair were kept under observation up to the end of June, when they were accompanied by five young not long out of the nest. The slag heaps of Cleveland are strongholds of the Pied species, and there seems no reason why some of the White Wagtails which are noticed every year on migration should not remain to breed.

The date of its arrival at Teesmouth in Igoo was May the 6 th ; in IgoI April the 9 th ; and on the 3 rd of that month in I902, another bird was seen at Ingleby Greenhow in Cleveland on the 2oth of April ; and in I903 one was noted on the $7^{\text {th }}$ of May on the reclaimed land at Tod Point. Singular to relate, this bird has so far entirely escaped observation during the autumn southward movement.*

* Those interested in migration would do well to peruse $\mathrm{Mr}$. W. Eagle Clarke's very concise account of this bird's movements, contained in the Report of the British Association Bradford meeting, I900. 


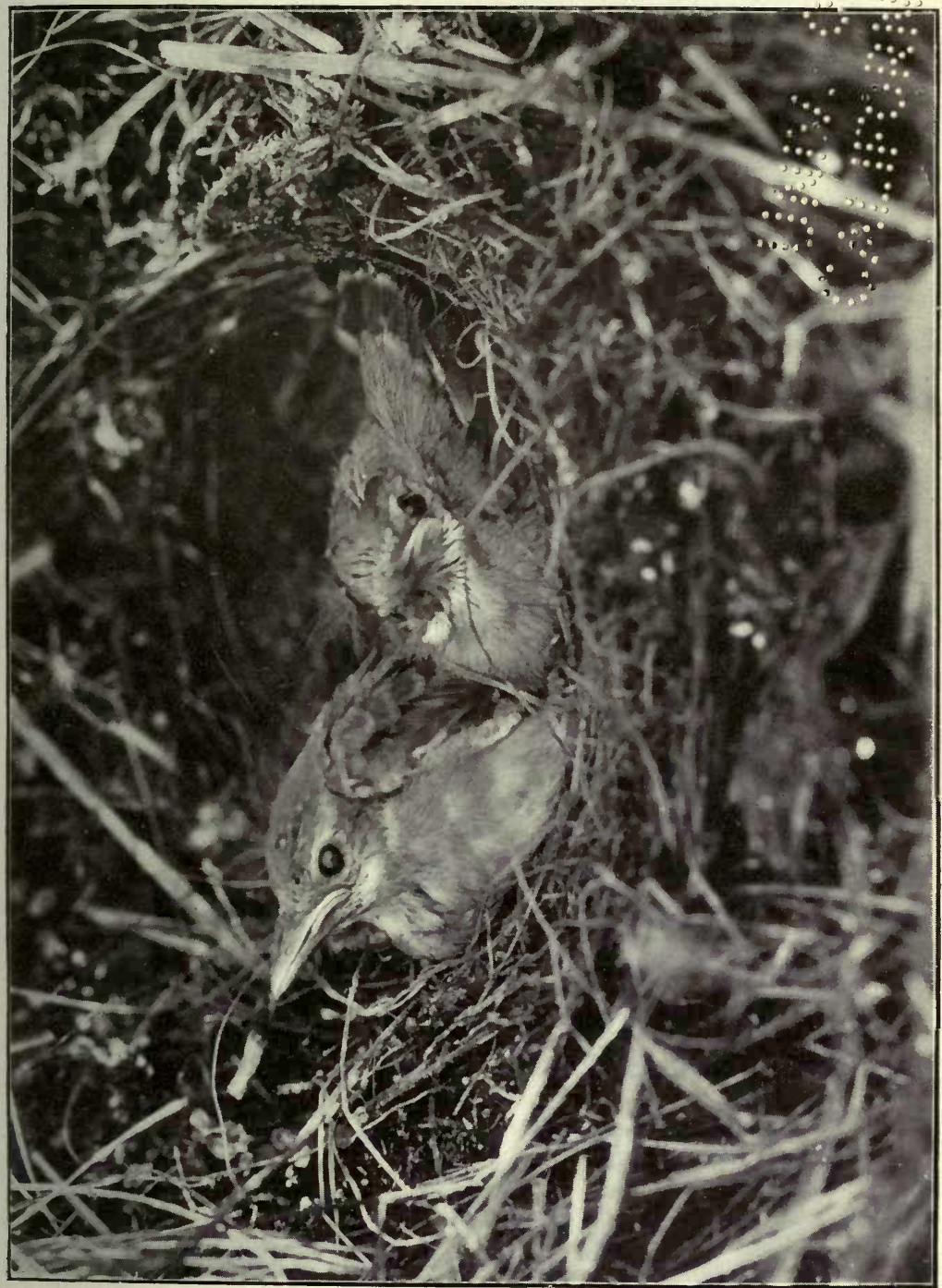

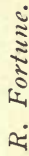

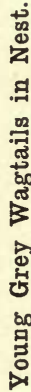

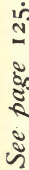





\section{GREY WAGTAIL. \\ Motacilla melanope (Pallas).}

Resident ; chiefly confined in summer to the moorland streams of the west, from Sheffield northward, and Cleveland ; autumnal migrant in small numbers; more generally distributed in winter.

Willughby, in 1676 , was the first to make reference to the Grey Wagtail as a British bird, thus :- " The Grey Wagtail -Motacilla cinerea, an flava altera Aldrov?... The description of this bird was communicated to us by $\mathrm{Mr}$. Johnson of Brignall, near Greta Bridge, in Yorkshire." (Will. "Orn." pp. 24, 238.)

Thomas Allis, 1844, wrote:-

Motacilla boarula.-Grey Wagtail-Frequently breeds on the moor streams near Sheffield, and visits the neighbourhood of the town in winter; the neighbourhood of Luddenden near Halifax has been a favourite breeding place of this species, but the same bird-stuffers that have persecuted the Pied Flycatcher make a point of shooting all the males. It is common in most parts, though not very frequent near Huddersfield.

A characteristic bird of the rocky and moorland streams of Yorkshire, the Grey Wagtail is, during the breeding season, practically confined to the upper reaches of our rivers from Sheffield northward, including the dales of the north-west and the Cleveland district, where, in the most elevated parts of the county, it is fairly abundant. In autumn the birds descend to the lower lands and become more general in their distribution, remaining until the following spring when they depart for their breeding places.

Although a sedentary species with us it is regularly noted as an autumnal immigrant on the coast in small numbers, and usually during the first fortnight in September; at the Teesmouth I have noticed that, although the call of this bird may frequently be heard among those of the hosts of migrants which are coming in before daybreak, very few are actually seen at the coast line. We always have a few " tired out" individuals on the beach in the early mornings 
during September, but the bulk move inland ere daybreak. At the Humber mouth, young birds, often in considerable numbers, pass through the district early in September, while the adults which spend the winter in the east coast districts do not arrive before October, leaving again in March. It is common around Beverley in winter, frequenting running streams and ditches, and seems especially fond of sewers and sewerage beds. At Flamborough the Grey Wagtail has been shot in autumn when taking its departure. The observations communicated to the British Association Migration Committee contain but two references to this bird, viz. :- "Spurn, September 7th, Grey Wagtail, several" (Fourth Report, p. 34); and "A few during September" (Sixth Report, p. 47).

Its local names are:-Winter Wagtail at Barnsley and Beverley; Yellow Wagtail along the Lower Wharfe and at Middlesbrough in winter; Yellow Water Waggy at Staithes and Loftus-in-Cleveland; Waggy Wagtail at Fewston, Washburndale; and Washtail at Sedbergh.

\section{BLUE-HEADED WAGTAIL.}

Motacilla flava $(L$.).

Casual visitant during the spring and autumn migrations, of rare occurrence.

When we consider that the Blue-headed Wagtail breeds at no greater distance from us than the opposite shores of the Continent from Norway to the Mediterranean, there is every reason to believe that the bird visits us in the spring and autumn much more frequently than the appended records would lead us to suppose. Careful observation of the flocks of newly arrived Yellow Wagtails in spring, especially at the coast, may shew that this darker, and slightly larger, Continental form occurs in their company from time to time.

The instances of its appearance, so far as I have been able to ascertain, are as follows :- 
In the spring of 1879 an example was obtained by the late James Cunningham, on the side of a small pond at Fern Hill, near Warley, in the Borough of Halifax; it was recorded at the time, but disputed, and sank into oblivion until re-discovered by Mr. A. Crabtree, F.L.S., who kindly submitted the specimen to Mr. W. Eagle Clarke and myself.

Another occurred on the 29th March 1892, on the banks of a small stream intersecting the sand-hills between Redcar and Marske; it was brought in the flesh to me, and is now in my possession.

Other reported occurrences are :-

At Ackworth, where one was observed on Ist May I89I, in a flock of Yellow Wagtails, by Mr. J. H. Fryer (Major Arundel MS.).

The late J. Cordeaux mentioned an example at Easington on I7th April I897, following the plough, "seen by a com. petent observer." (Nat. I898, p. 237.)

And on 6th May Igoo, three individuals were noted at the Teesmouth, consorting with a flock of Yellow Wagtails. (C. Milburn MS.)

\section{GREY-HEADED YELLOW WAGTAIL.}

\section{Motacilla borealis (Sundevall).}

Accidental visitant from northern Europe and Siberia, of extremely rare occurrence.

This species, which inhabits northern Europe and Siberia, migrating in winter to Africa and India, had not been recorded in Great Britain until the 2oth of May I903, when a Yorkshire example was exhibited on behalf of Mr. W. Eagle Clarke and myself at the meeting of the British Ornithologist' Club,* and the following details supplied by Mr. W. Eagle Clarke :-

"This specimen was submitted for determination by

* At the same meeting of the B.O.Club Mr. W. R. Butterfield exhibited two male examples of this bird procured on 13 th May 1903. near Willingdon, Sussex. 
my friend Mr. T. H. Nelson. It was captured in a lark-net at Halifax in the spring of I9or, and is now in the collection of Mr. Arthur Crabtree of that town, who obtained it from a friend who saw the specimen in the flesh. It is very surprising that this species is not somewhat more frequent in its visits to our shores, when on passage to and from its Scandinavian summer haunts, and yet I believe this to be the first really authentic record of its occurrence in the British Isles." (Bulletin of the Brit. Orn. Club. No. 98.)

I here beg to acknowledge my indebtedness to $\mathrm{Mr}$. Crabtree for his courtesy in forwarding the specimen and giving the information concerning its capture.

\section{YELLOW WAGTAIL.}

\section{Motacilla raii (Bonaparte).}

Summer visitant, generally distributed, but in varying numbers : arrives in mid-April, leaving again in September.

Historically, the earliest reference to this species in Yorkshire is found in Willughby's "Ornithology" (I678), thus:"The Common Yellow-Motacilla flava. The other Yellow $-M$. flava altera. This was observed in the north by $\mathrm{Mr}$. Johnson (of Brignall, near Greta Bridge), and the description thereof communicated to us."

Thomas Allis, I844, wrote :-

Motacilla rayi.-Yellow Wagtail-Common in sandy districts near York, and not abundant in the East Riding.

On the whole a fairly abundant summer visitor, the Yellow Wagtail, the most elegant and delicate looking of the genus, usually arrives about the middle of April, the approximate date in the south of the county being the I3th for the first comers. At the Humber mouth it may be expected in the middle of the month, but at the Tees the bulk do not appear till the third week, when at times the neighbourhood swarms 
with the newly arrived birds; in the higher lying districts it is a few days later in arriving. The first immigrants are generally male birds only; later both sexes are met with in about equal proportions. Although it has been stated that this species is found in the north of England in March, these early arrivals are extremely rare, and I am not aware of any authentic instance in this county.

As a breeding species it is rather local, and nowhere in Yorkshire is it so abundant as in the high moorland dales of the north-west; the upper valleys of the Tees, Swale, and Ure, and the lower reaches of the Nidd being favourite localities for its nesting quarters; and up to I300 feet elevation the bird commonly haunts the fields and pastures bordering the rivers and their tributaries. It is not uncommon in the central parts of the West Riding, but in the North and East Ridings it is more frequently seen on passage than as a nester, though in the Beverley district it is generally distributed.

In late July and August both old and young assemble in small flocks in readiness to depart, and by the third week in September the Yellow Wagtails almost to a bird have left us ; indeed I have no note of its being obtained in October. At the coast large numbers of migrating birds are to be met with during the latter half of August and the first fortnight of September, and at the Tees and Humber estuaries the fields, sand-hills, and beaches in the early mornings are often swarming with them, though by mid-day they have usually passed on. One extract from many, collected by the British Association Migration Committee, will serve as an illustration of this movement. "Spurn, August I4th, a few immature Yellow Wagtails ; 23rd, thousands, the whole district ablaze with them; 24th, less numbers." (Seventh Report (I885), p. 43.)

The Yellow Wagtail breeds commonly in clover, tare, and wheat fields, preferring thick herbage to conceal its nest, which is always very difficult to find; after the young can fly they are brought on to the mown meadows, fields, and commons to feed.

VOL. I. 
A white variety, having a faint tinge of yellow on the rump, was shot by Capt. Turton on the roth of September I827, at Rampton, in the North Riding.

Local names are Cow Bird at Sedbergh ; Ray's Wagtail at Ackworth; Water Wagtail at Doncaster (Zool. r849, p. 2325); Yellow Water Waggy at Staithes and Loftus-inCleveland; Spring Wagtail in south-west Yorkshire; and Barley Seed Bird in Craven (Carr's "Craven Dialect," I828).

\section{TREE PIPIT.}

\section{Anthus trivialis (L.).}

Summer visitant; generally distributed in wooded localities ; arrives in mid-April, and leaves in September.

The first published reference to the Tree Pipit is in Willughby's "Ornithology," under the heading of The Lesser Crested Lark, Alauda cristata minor. This last we have not yet seen. Mr. Johnson (of Brignall, near Greta Bridge) found and described it in the north of England." (Will. "Orn." r678, pp. 24 and 209.) According to Montagu's "Ornithological Dictionary" this is the Tree Pipit. See also Yarrell's "British Birds," 4th ed., Vol. i., p. 57I.

Thomas Allis, 1844, wrote:-

Anthus arboreus.-Tree Pipit-Common.

This species, which is our only true summer visitor of the Pipit family, usually arrives about the middle of April. From a long series of observations, extending over half a century, the average taken gives April the $15^{\text {th }}$ as the approximate date, while the earliest note of its appearance, so far as I am aware, is the I8th of March I894, when Mr. R. Fortune observed several near Harrogate.

During its sojourn with us it is generally diffused, commonly frequenting the outskirts of woods and plantations, and, in more open country, the scattered timber on the borders of fields and streams. Altitude does not seem to affect its 


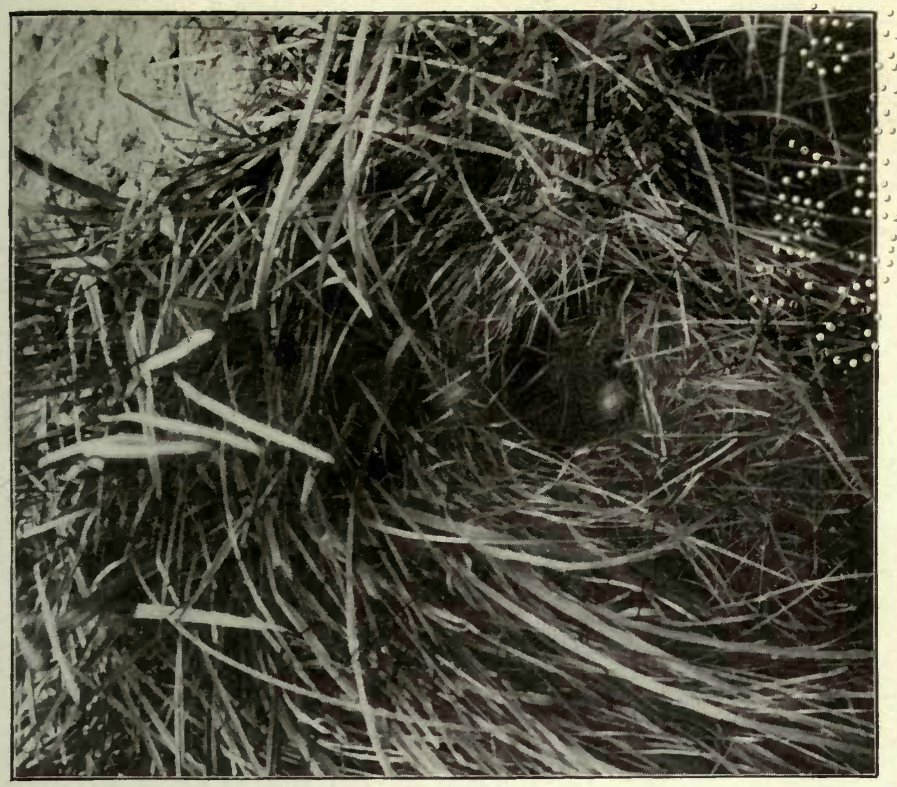

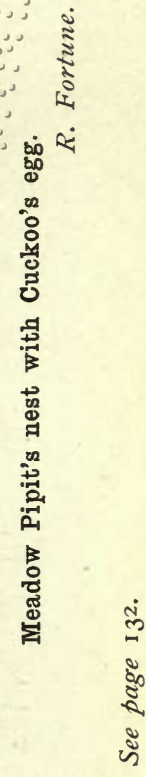

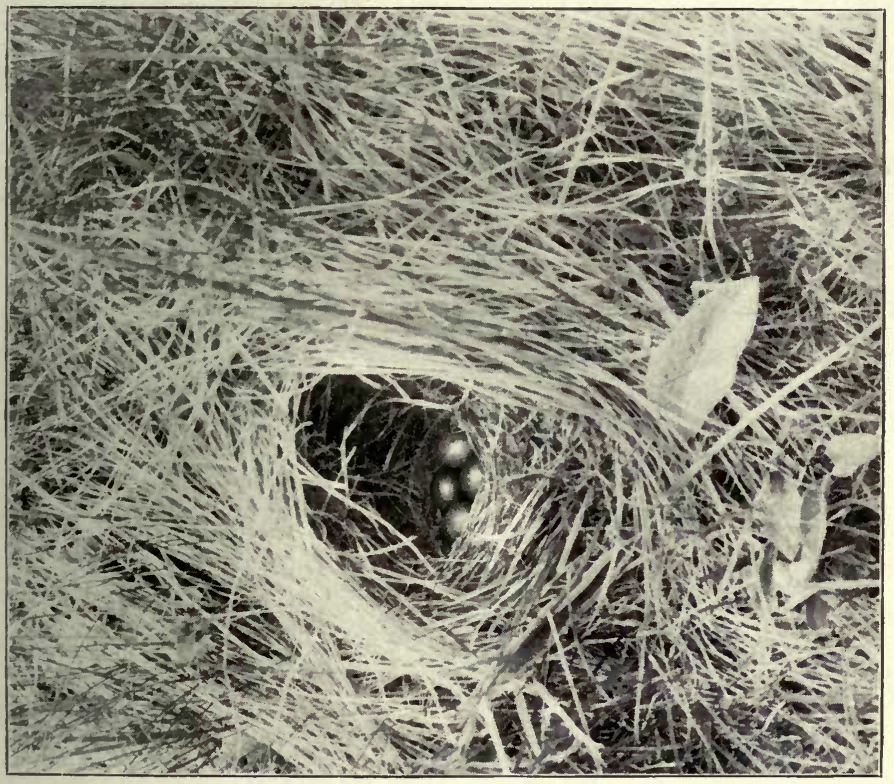



distribution, for in the higher dales affording the necessary woody environment it is quite as common as in the low cultivated districts.

The average date of its departure from south Yorkshire was calculated by the late Thomas Lister to be the 22nd of September, and the late J. Cordeaux stated (MS.), "After the nesting season they congregate into small flocks, leaving in August and September, occasionally migrating with Meadow Pipits." The observations communicated to the British Association Migration Committee do not afford much information as to this movement, which takes place quietly and unobtrusively, this bird being not easily distinguished by the light-keepers from others of its genus. The only entries relating to it are :- "Spurn, August 2oth to September roth, Common" (Sixth Report, p. 47); and " Spurn, September I4th, Tree Pipits, etc." (Seventh Report, p. 32). An unusually late date for its autumn passage was mentioned by Edward Blyth, who recorded in Rennie's "Field Naturalist" (1833, p. 466), the capture of Tree Pipits, among other species, on board a vessel when fourteen miles off Whitby, on the 7 th of October 1833 .

In reference to the great diversity of colouring in this bird's eggs, I have noticed that the red and pink types much outnumber the other variable colours met with, though the reverse is considered to be the case in Holderness. Instances of six eggs in a clutch are not uncommon, and Mr. F. Graves found one in the Sedbergh district containing the unusual number of seven.

This bird, as stated above, is the Lesser Crested Lark of Willughby. Local Yorkshire names are Tree Lark and Titlark, used generally. Bulking Lark is a term applied to it at Thirsk (Morris's Nat. I854, p. I05), while Wood Lark and Bank Lark are in use in Cleveland and Ribblesdale. It may, however, be observed that it is not usually distinguished from the Meadow Pipit which frequently alights on trees. 


\section{MEADOW PIPIT.}

\section{Anthus pratensis (L.).}

Resident; generally distributed ; abundant in summer, especially in moorland and marshy districts. A regular spring and autumn migrant.

Historically the earliest allusion to this bird in Yorkshire is made in a communication, dated 1678 , from Ralph Johnson, of Brignall, near Greta Bridge, a friend and correspondent of John Ray, in the following terms :-

"Honoured Sir,.... I have only observed this change from proper colours to white... to be very usual in 'Titlarks,' which I have seen on our moors." (Corres. of John Ray, p. 96, I848.)

Thomas Allis, I844, wrote :-

Anthus pratensis.-Titlark or Meadow Pipit-Frequent in most parts ; breeds abundantly on the moors.

One of our commonest birds, the Meadow Pipit is found breeding from the low-lying marshes near the coast up to the highest moorland districts, where at both extremes it is most abundant. In more highly cultivated parts, though by no means uncommon, it is not so much in evidence, for this species loves open uninclosed tracts; being a common and generally diffused bird of the fields, commons, moors, and marshes it requires no further notice as regards its distribution. During the winter months the Titlark, as it is best known to Yorkshiremen, is reported as being scarce or altogether absent from every part of the county above 300 feet elevation, while even in more congenial localities it is much scarcer at this season than in summer, and there can be little doubt that the bulk of our breeding birds are summer visitors.

The migration of the Meadow Pipit at the coast is a very noticeable feature of bird life and, as a rule, it makes its appearance a little earlier than the Pied Wagtail ; the first comers in the latter part of February, but the main body in the middle of March, and at this period, at the Tees and 


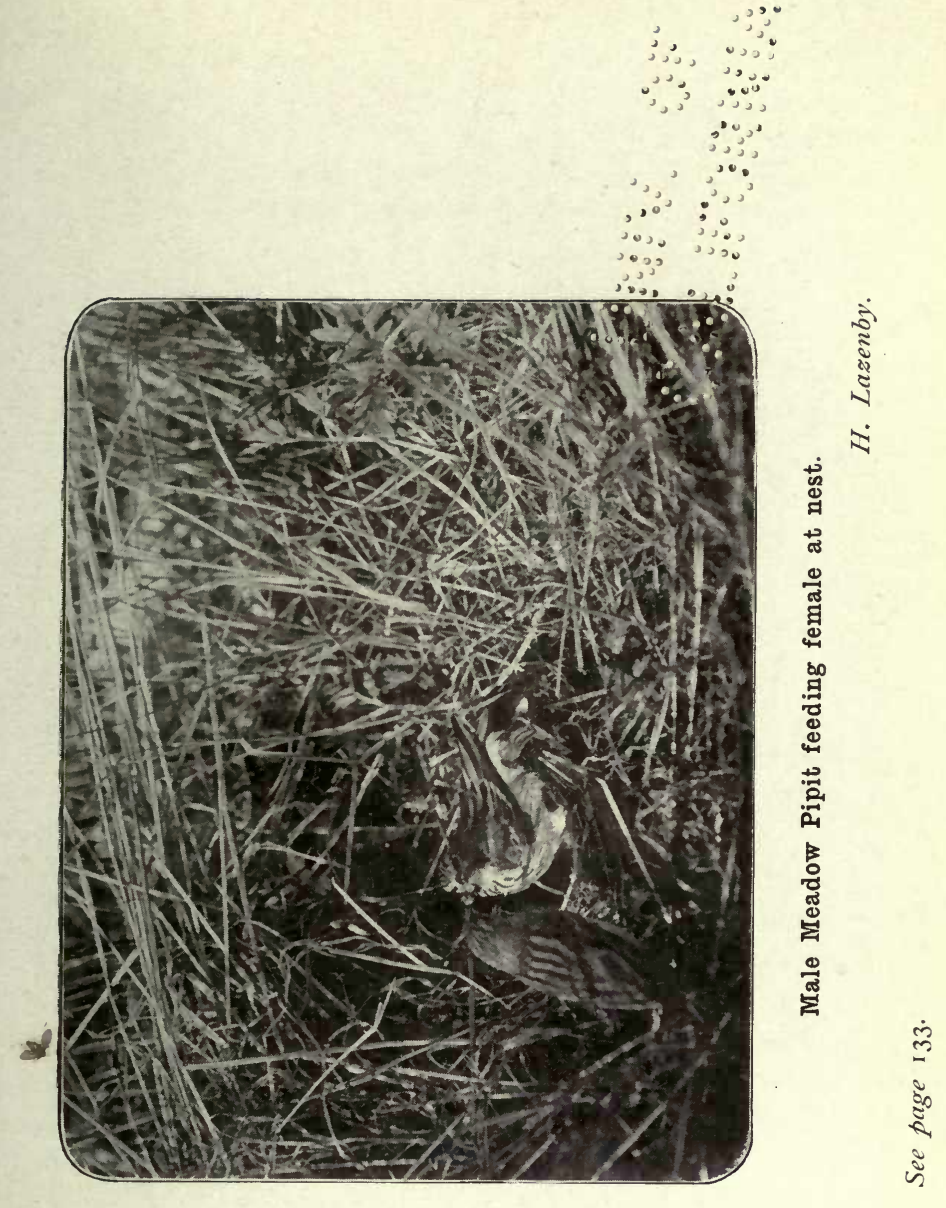



Humber estuaries particularly, the sand-hills, marshes, and fields are absolutely swarming with the light clean-coloured immigrants. An enormous influx took place at the Teesmouth during the third week in March I903, when I noted many crossing at Redcar, against a strong north-west gale, and apparently completely exhausted with their long journey. In the autumn immense flocks pass south from August to mid-October, our departing home-bred birds being augmented in numbers by individuals from higher latitudes. At the Tees and Humber there is frequently a great arrival of these Pipits coming in direct from seaward, the majority of which move on after a short stay. The British Association Migration Reports contain many entries, too voluminous for recapitulation, concerning this species, quantities of which are immolated against the lanterns of the coast beacons during the night in both spring and autumn.

In Yorkshire the nest of the Meadow Pipit is most frequently chosen by the Cuckoo for the deposition of its parasitic egg. A late date for nidification was noted at the Teesmouth in I902, when a nest with newly hatched young was discovered on the 3 rd of August.

White varieties are mentioned by Ray's correspondent so long ago as 1678 (see above), and a pied specimen is recorded at Dalton, near Huddersfield (S. L. Mosley MS.).

Local names: Titlark is in general use throughout the county; terms of more restricted use are Chit Lark at Skelmanthorpe ; Ground Lark at Loftus-in-Cleveland ; Ling Bird at Sedbergh; Ditch Lark near Skipton, where the eggs are reddish coloured; Ground Laverick in Upper Teesdale; Ling Tit and Titling in Nidderdale; Titty at the Teesmouth; Bank Lark in Cleveland; Heather Lintie in the North Riding; and Moor Tit in the Wilsden district. 


\section{TAWNY PIPIT.}

\section{Anthus campestris (L.).}

Accidental visitant from Continental Europe, of extremely rare occurrence.

The Tawny Pipit is found in the western and southern portions of the Continent, migrating in winter to Africa and Asia Minor.

The only Yorkshire example, a male, was found at Barmston in Holderness, on the 2oth of November I869, by Mr. Thomas Boynton, and is preserved in his collection at Bridlington, where I have had the pleasure of examining it. (See Zool. I870, pp. 202I, 2068, 2100.)

[A specimen of Richard's Pipit, Anthus richardi (Vieill.) is said, on the authority of the late David Graham of York, to have occurred on the coast in 1849 (Zool. I849, p. 2569), but the circumstances connected with its occurrence are not of a sufficiently reliable nature to warrant its inclusion in the Yorkshire list.]

\section{ROCK PIPIT.}

\section{Anthus obscurus (Latham).}

Resident, local; confined to, and generally distributed on, the coast. A regular spring and autumn migrant.

The first allusion to the Rock Pipit, as being a native of Yorkshire, is contained in Thomas Allis's oft-mentioned Report of 1844 , as follows :-

Anthus obscurus.-Rock Pipit. Arthur Strickland observes that the Pipit or Rock Lark is general all along the coast, confining itself to the sea shore and cliffs adjoining; this species, which frequents this country and the northern shores of Europe, is to be designated obscurus and is the "Dusky Lark" of Pennant and Lewin. The aquaticus is ascertained to be a distinct species, and frequents a more southern range than the last. 
As may be expected this bird is strictly limited to the coast line, and from no inland locality is there any report of its occurrence. As a nester it is more local than at any other time of the year, the cliffs at and near Flamborough being its chief breeding quarters. The nest has been found in the Scarborough and Whitby districts, and I have also seen considerable numbers of the birds, in pairs, on the Staithes, Boulby, and Saltburn cliffs in spring and summer, so that there can be little doubt that it breeds-sparingly, perhapsalong the whole line of cliffs on the coast. On the low-lying parts of the seaboard it is rare in the breeding season, although the late J. Cordeaux stated that at Spurn he noted old birds with young. I have no conclusive evidence as to its breeding at the mouth of the Tees, but the nest and eggs have been taken a few miles to the northward on the Durham coast.

In the autumn and winter, from September to April, it is frequently found along the seaboard from the Tees to the Humber, being most numerous during September and October. In the early part of the former month the autumn migration commences, usually continuing to the first half of November, and at this period the bird may be commonly met with; at the Teesmouth I have not infrequently seen small flocks consisting of from twelve to fourteen individuals. The spring migration takes place in March and April, but is not so pronounced as that of the autumn.

Concerning the nidification habits of the Rock Pipit, it may be of interest to state that near Scarborough on I2th June I88I, a nest was found containing a Cuckoo's egg besides those of the lawful owners; the only recorded Yorkshire instance of this bird acting as the Cuckoo's fosterer. At Whitby a pair of these birds have, since I902, chosen a crevice in the stone pier in which to build their nest, and there they annually succeed in bringing off their young in safety. Another unusual building site is reported from Bridlington, on I6th May I879, by Mr. Major Lawson, who discovered a nest amongst the herbage growing on the clay cliff, and within four feet of high-water mark. 
The food of an example shot at Hornsea consisted almost entirely of beetles, the particulars being communicated to the Field of 29th November I89o.

In mid-autumn a race, having a light brown back with rich buff or cinnamon-coloured breast, very lightly streaked with a darker hue, is found equally as common as the dark resident bird. These light coloured individuals do not stay with us, but pass on in their journey southward, and there can be no doubt that they belong to the Scandinavian race which has been named Anthus rupestris (Nillson), by some authors, but, in the opinion of other ornithologists, is not considered specifically distinct from the ordinary $A$. obscurus. No record occurs of the light-coloured form in large numbers on the return passage in spring.

The only local names are Sea-beach Pipit, mentioned by J. Hogg (Zool. I845, p. I06r), and Rock Lark and Sand Lark, used at Bridlington; though it is sometimes called Titlark, in the belief that it is the common Meadow Pipit.

\section{GOLDEN ORIOLE.}

Oriolus galbula $(L$.$) .$

Accidental visitant, of very rare occurrence during the spring and autumn migration.

This beautiful species, which nests on the European Continent and in north Africa, can only be regarded as a rare straggler in Yorkshire at the periods of its spring and autumn movements, when the few specimens observed have, doubtless, accidentally deviated from their accustomed line of migration.

The earliest Yorkshire reference to this bird is contained in Allis's report, 1844 , as follows :-

Oriolus galbula.-Golden Oriole-A fine female was killed in spring of 1834 near the Spurn Point lighthouse, and is in the possession 
of Arthur Strickland, Esq., which appears to be the only known Yorkshire specimen.

The specimen mentioned by Allis is now in the York Museum.

One which occurred at Boat Bottom near Wakefield during the first week of August I856, was seen in the flesh by the late Wm. Talbot and described as being in splendid plumage (Talbot MS.).

In May 1859, the late Alfred Roberts of Scarborough had brought to him for preservation a male in the finest adult plumage, which had been killed on Admiral Mitford's estate at Hunmanby (Zool. I859, p. 656r). Mr. Roberts further stated (MS.) that a specimen in the museum at Scarborough, and another in a private collection, are said to have been obtained near that town.

The late Rev. J. W. Chaloner of Newton Kyme observed on 28th April I870, a male Golden Oriole whilst driving on the North Road, a short distance out of Doncaster, the bird flying between the conveyance and the roadside hedge for a distance of two hundred yards. About the same date one was observed in Grimston Park near Tadcaster, by Hamer the keeper (Chaloner MS.).

At Swinton Park, Masham, one was seen in May 1870 (James Carter MS.).

Regarding the occurrence of an example near Bingley, about the end of August or the beginning of September I875, Mr. E. P. P. Butterfield writes that a gamekeeper, on whose veracity he can rely, gave him a description of a bird which was no doubt a Golden Oriole. It was flying in company with some Thrushes. (See also Zool. I875, p. 4623.)

The Hull Museum Guide (I860) informs us that "specimens have been seen near Hull," and the late J. Cordeaux, in his "Birds of the Humber District," (I872), mentioned that a pair in the collection of the late W. W. Boulton are said to have been shot on the east coast; Mr. Boulton considering the authority a fairly reliable one.

A female example was found dead, on 3 rd May I888, at Hob Green near Ripon, and was examined by the late J. 
Carter, who stated it was in good plumage (Field, Igth May 1888). And the latest notice of its occurrence was communicated to me by Mr. Thomas Machen of Bridlington, who had sent to him for identification a female specimen caught in June I903, near Boynton.

\section{GREAT GREY SHRIKE.}

\section{Lanius excubitor (L.).}

Winter visitant, in limited numbers, chiefly on the coast line; remains through winter, departing in spring.

Probably the first mention of this bird in connection with Yorkshire is contained in Ray's "Synopsis," I7I3, where it is referred to under the name of "The Greater Butcher Bird, or Mattagasse, Eboracensibus." The earliest known Yorkshire specimen that I am aware of is a female in the Burton Agnes collection, shot near Malton in 1836 .

Thomas Allis, I844, wrote:-

Lanius excubitor.-Great Grey Shrike-Is not uncommon near Doncaster in winter; several specimens have been obtained near Sheffield; it is occasionally met with near Huddersfield and York; it is rare in most other districts, one specimen only being known in the neighbourhood of Barnsley and of Burlington.

Allis's remarks as regards the scarcity of this species at Burlington (Bridlington) were probably due to the paucity of observers in his day. At the present time on the coast, and especially in Holderness, the Great Grey Shrike is observed almost annually as an autumn immigrant, arriving as a rule during the latter days of October; in some years it may almost be called common, such being the case in I880, as evidenced by the observations of the British Association Migration Committee, while in 1892 no less than twenty were seen near Kilnsea on the $15^{\text {th }}$ of October, and seven were noticed the next day. Off Scarborough one was taken on board a smack in October 1889 , and I have a specimen in my collection which was brought in on $25^{\text {th }}$ October $189 x$, 
by a pilot who captured it three miles out at sea while resting on the "sheet" of his coble; it lived for several days, feeding on small birds. The adult males with pure white under parts are seldom seen, the bulk of the immigrants being young birds or females; they linger near the coast for a few days, and then gradually spread over the country.

The occurrence of quite a young bird of the year at Kilnsea in the East Riding, on 26th August 1877 , recorded in the Field (1877, p. 28I), is unprecedentedly early. Remaining throughout the winter, it has at that season occurred in most parts of the county, but cannot be said to frequent any locality regularly, though the list of recorded occurrences is very voluminous. Taking its departure on the advent of spring, we must look upon the shooting of one at York, whilst in the pursuit of Fieldfares, on I8th April I849 (Zool. I849, p. 2452), as a late record. It has occurred on the coast on the return journey as late as the 3 rd of May, and six were noted as being seen near Spurn Lighthouse on I 7 th February I88I, doubtless preparing to brave the dangers of the North Sea passage.

As regards the habits of this bird the late J. Cordeaux remarked (MS.) "I have known one to hover in the air for a few minutes, Kestrel-like, as if uncertain whether to make a swoop on its quarry; the small immigrants on first arrival in autumn offer an easy prey to this marauder, and both the Redbreast and the Wren fall victims to the cunning Shrike, who will carry off one of these birds in his beak with the greatest ease. The Grey Shrike has great power of concealment, and if shot at and only wounded, where there is any cover as long as sea grass, is almost certain to escape detection, however carefully the ground is looked over." The same observer saw a Great Grey Shrike impale a Goldcrest on the spikes of a wire fence, and one was noticed at Flamborough that had three mice gibbeted on a thorn hedge.

A curious example, in the collection of Mr. P. Loten of Easington, that was procured at Spurn, had the upper parts dark-plumbeous, the head the darkest; it was first thought to be the southern L. meridionalis of Temminck, but sub- 
sequent examination, and comparison with skins in Mr. Dresser's collection, proved that it cannot be referred to that form, and that it is probably a melanism of $L$. excubitor, and as such is a most interesting variety.

The only vernacular appellation is the well-known one of Butcher Bird.

\section{LESSER GREY SHRIKE. \\ Lanius minor (f. F. Gmelin).}

Accidental visitant, of very rare occurrence.

The Lesser Grey Shrike is a summer visitor to southern and central Europe, wintering in South Africa, and is but a rare accidental straggler to the British Isles, the instances of its occurrence, as previously chronicled, being eight in number and all confined to the southern or south-eastern counties of England.

Mr. Thomas Stephenson of Whitby reports a ninth example, which is the first known for the North of England, and a new species to Yorkshire. The individual in question was shot at Sleights, near Whitby, on the 2oth September I905, and was forwarded to Mr. Stephenson for identification to Mr. W. Eagle Clarke, who pronounces it to be an immature bird, in first plumage, and a most interesting addition to the avi-fauna of the county (see Naturalist, March, I906, p. 70).

The specimen is now in the Whitby local museum.

\section{RED-BACKED SHRIKE.}

\section{Lanius collurio (L.).}

Bird of passage, of rare occurrence; has occasionally remained to nest.

Apparently the earliest local reference to the Redbacked Shrike is contained in the second book of Willughby's "Ornithology," 1678 , where it is stated that in Yorkshire it is called "Flusher." 


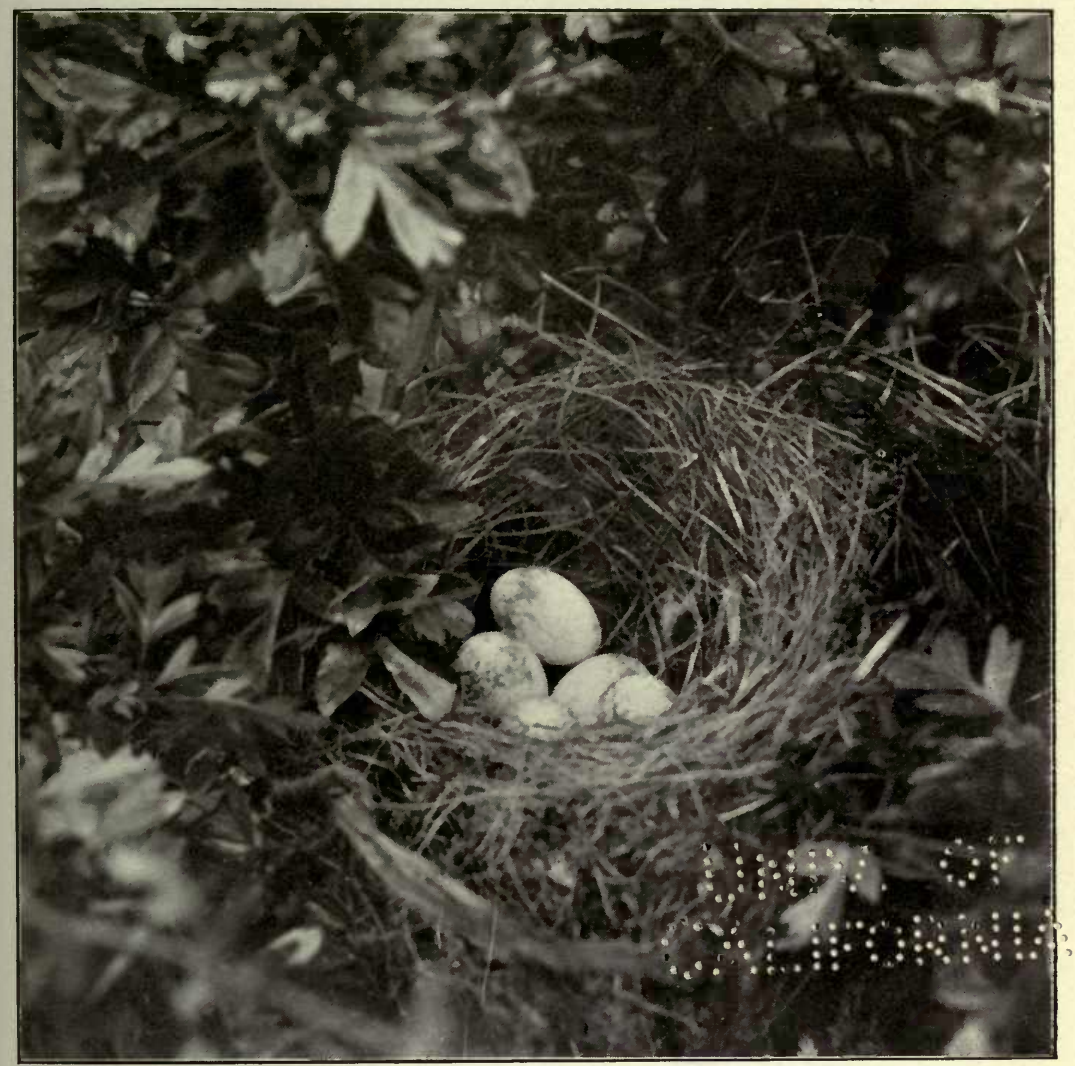

Nest of Red-backed Shrike in north-west Yorkshire.

F. Fortune.

See page 141 . 

Thomas Allis, in $\mathrm{I} 844$, wrote :-

Lanius collurio.-Red-backed Shrike-Not very uncommon near Sheffield and Doncaster; it breeds occasionally near Halifax, but is becoming scarce; it is met with occasionally near Huddersfield and York, but is not known in the East Riding.

This bird is of much less frequent occurrence in the county than the Great Grey Shrike. It has been chronicled as breeding in a few instances, but does not now, so far as my knowledge extends, repair annually to any locality, with the exception of Sedbergh, where it is a fairly regular nester, though formerly it seems to have ranked as a somewhat constant visitor, for the late Henry Denny, who was an excellent naturalist, in his Leeds Catalogue, 1840 , cited this species as not uncommon in several localities near Leeds. Allis's statement, quoted above, refers to its occurrence in the West Riding; though, as regards Huddersfield, the late $\mathrm{J}$. Varley stated he could well remember it as an almost annual visitor in that neighbourhood, where he had himself taken both the nest and eggs ; the remarks respecting East Yorkshire must, also, be modified. When on its migration it has been observed both in the spring and autumn, but its visits then are few and far between, and, generally speaking, it may now be ranked as a bird of passage, occasionally remaining to breed.

The following are the occasions on which it has nested in the county :-Dr. Farrar of Barnsley obtained a pair of old birds, which were snared on their nest, in Cliff Wood near that town in the year I826. Mr. H. Smurthwaite of Richmond, in Morris's "Naturalist" ( 1854, p. 8I), mentioned that eggs in the collection of his friend Mr. Wood were taken from a nest near that place. Dr. Hall communicated to the Field (r869, p. 435), a note that a nest with four young birds had been taken within a mile of the town of Sheffield in the early summer of 1868 .

Regarding the nesting of this bird at Beverley in 1876 , Mr. F. Boyes communicated the following particulars to the Zoologist (1877, p. I57):-“The Red-backed Shrike is a very rare bird here, and I cannot hear that one has been seen for fifteen years. On May the $27^{\text {th }}$ a hen bird of this 
species was shot, and on the following day a pair were obtained. A circumstance occurred in connection with the capture of these birds that is perhaps interesting; it appears the male and female were both sitting on a dead branch near each other when the female was shot. The person who shot it repaired to the same place early the following day to shoot the male, when he found a second female; this he shot, and later in the day shot the male. Is it possible that the male had two wives? It is scarcely reasonable that he could have picked up another mate in so short a time in a part of the country where these birds are so rare. I ought to mention that the first female was laying, and had an egg fully developed in the ovary. A search was afterwards made, and the nest, containing one egg, found near the spot where all three birds were shot. The second female was a younger bird, and showed no signs of breeding, the eggs in the ovary being very small."

At Swillington Hall a female and young one, thought to have been bred there, were obtained on 2nd July I88I, as communicated by the late J. Tennant. A nest and eggs were found on Oliver's Mount, Scarborough, 3rd July I889 (W. Gyngell MS.); in the north-west Mr. W. Morris states that he has taken the nest in a thick thorn bush, and I am aware of several instances of this bird breeding in Clevel nd; twice near Redcar, about 1870 , when both nest and young were found, and in June 1898 , when a nest and two eggs were discovered in a thorn bush at Gunnergate. Lastly, the late J. Cordeaux recorded (Nat. I895, p. I), the nesting of a pair at Winsetts, a farm between Skeffling and Easington, in the summer of 1894 ; five young got off in the third week of July, but unfortunately the parent birds and two young were killed, the latter having apparently just left the nest.

Concerning the reported nesting of this species at Silsden in Airedale ("Vertebrate Fauna of Yorkshire," p. 27), the evidence is not considered to be of a satisfactory character.

In addition to the above, the Red-backed Shrike has been observed on the undermentioned occasions. In some of these instances the dates would seem to indicate that the species 
had nested in the locality, but the majority of the occurrences. were doubtless birds on their spring or autumn migrations.

Prior to 1845 one occurred near Guisborough, and another was observed near Hull (Zool. I845, pp. I055, I023). One was taken in a trap baited with young Thrushes at Ackworth in the summer of 1856 (Morris's Nat. I857, p. I98). In April I864, one was obtained in Ribblesdale (Nat. I896, p. 39); on 26th September I866, a fine female was found at Flanshaw near Wakefield, and preserved by the late Wm. Talbot.

On Ist July I879, Mr. J. Lucas observed a Red-backed Shrike chattering and making a great noise in a dell known as Hole Bottom, in Nidderdale; adding that it is there a rare bird, and that he had no other record of its occurrence in that part of Yorkshire (Zool. I879, p. 404). On I8th May I872, one occurred at Clayton West, and about 1876 a mature bird was obtained near Richmond. Mr. M. Bailey of Flamborough has in his collection a fine male, which I have seen, that was brought to him in the flesh by a fisherman, who had captured it on the sheet of his boat when seven miles at sea off the headland, on 8th May 1877. An adult male was shot at Addingham in July I879, as mentioned by Mr. Stuart of Skipton (MS.). Near Scarborough the late A. Roberts reported it as rare, but he had known of one being killed while sticking caterpillars and humble bees on the thorns of an old hedge. A male was reported near Carperby, in Wensleydale, in 1872 , and a pair were seen near Eastholme Bridge in I882. Mr. G. Steels of Pocklington has once had an example brought to him. At Spurn Mr. W. Eagle Clarke saw a pair on 28th May I882, and he surmised that they were fresh arrivals from over-sea. On Igth August I884, an immature bird occurred in Holderness (Sixth Migration Report, p. 48), and in 1885 two or three were seen at Spurn in August and September (Seventh Migration Report, p. 43). One obtained near York is now in the Bluecoat Boys' School collection in that city (Nat. I886, p. 308). Mr. Harper records the occurrence of an individual near Scarborough in 1889 (Zool. I889, p. I50). At Whitby one was procured on Ioth September I8gI ; Messrs. Hewett and Potter saw 
one sitting on the telegraph wires at Spurn on 26th May 1895, and another at Everingham on 22nd May 1898. At Aldborough in South Holderness Mr. T. Petch noted one on 4th May I898; and lastly, in I899, an example was observed on the I5th of May, near Scarborough, by Mr. W. Roberts.

Vernacular names of this species are obviously few; Butcher Bird is generally applied to the genus. An old Yorkshire name now obsolete is "Weirangle" or "Wariangle" (Cf. "Würgengel," Germany) i.e., "Worrying or Destroying Angel " ; called also "Würger " or "Worrier," "Throttler." Another obsolete name is Flasher or Flusher (Yorkshire, Willughby), derived from the ruddy colour of its plumage, or perhaps from Flesher, i.e., Butcher Bird (Swainson).

\section{WOODCHAT SHRIKE.}

\section{Lanius pomeranus (Sparrman).}

Accidental summer visitant from central and southern Europe and northern Africa.

Thomas Allis, I844, wrote :-

Lanius rufus. - Woodchat Shrike-I find only one Yorkshire specimen recorded, which was in the possession of Mr. Leadbitter. See Yarrell's "British Birds."

This species, which breeds freely on the Continent, wintering in southern Africa, has occurred in Yorkshire-so far as I have been able to ascertain-on six occasions only, and I greatly regret my inability to give full particulars of them, for details respecting so rare a visitant to Britain, and so fine a species, would be most acceptable to all interested in Yorkshire ornithology.

W. Yarrell in the first edition of his "British Birds" (vol. i., p. I6I), published in 1843 , stated that " A few years ago Mr. Leadbitter received a specimen which had been killed in Yorkshire." Professor Newton in his edition of that work (I87I) mentions its having been met with in Yorkshire, no doubt referring to the same specimen.

According to the late A. Roberts of Scarborough, Mr. Alwin 
S. Bell obtained two young birds in the Castle Holmes, Scarborough, in the year 1860 or $186 \mathrm{I}$, but he (Mr. Bell) only succeeded in preserving one of them, owing to their being so very fat.

The late J. Varley, of Almondbury, near Huddersfield, reported in 1879 that when he was a bird-nester he saw two Woodchats brought in to be preserved by a bird-stuffer.

An adult male, shot at Hackness, near Scarborough, in June I88I, is in the collection of Mr. R. Chase of Birmingham (Zool. I892, p. 347).

The late J. Cordeaux mentioned (Nat. I897, p. 15), that the late H. B. Hewetson informed him that he saw two at Easington, near Spurn, on 8th September I896. Mr. Cordeaux added that his informant knew the bird well, having frequently seen it in Morocco.

And the latest information with reference to this species is imparted by Mr. C. G. Danford of Reighton Hall, who informed me on 28th May 1903, that on the 9th of that month, when on the middle cliff at Reighton, he distinctly saw a male Woodchat alight on a furze bush within a few yards of where he was sitting, and he watched it at close quarters for some minutes. Mr. Danford is familiar with the bird, and has often seen it in Hungary. (Nat. 1903, p. 262.)

\section{WAXWING.}

\section{Ampelis garrulus (L.).}

Accidental visitant, appearing at irregular intervals during winter ; absent some years, plentiful in others.

The first record of the appearance of the Waxwing in the British Isles was by the celebrated Dr. Martin Lister, F.R.S., who in a letter to John Ray ("Phil. Trans." I685, No. I75, p. Ir6r, fig. 9) said " One or two were shot at York in January I680 (or, to use the new style, I68I). His figure, though rude, sufficiently shews the species, to which he gave the English

$$
\text { vol. I. }
$$


name of Silk-tail." Other early notices were by Ralph Johnson, who, writing to Ray from Brignall, near Greta Bridge, May 7 th 1686 , described two which had been killed in the preceding March, saying "They came near us in great flocks, like Fieldfares, and fed upon haws as they do."

Thoresby, in a letter to Ray, dated Leeds, April 27th, I703, mentioned a third visitation, and said "I am tempted that the German Silk-tail is become natural to us, there being no less than three killed nigh this town the last winter."

Tunstall, according to Latham in Pennant's "British Zoology," recorded "Many seen in Yorkshire ( 1787 ), and a large flock at Wycliffe [on Tees]. Many taken alive, but they did not thrive. They fed on dog-berries." (See also Yarrell's "British Birds," 4th Ed., i., p. 525).

Thomas Allis's account, I844, is as follows :-

Bombycilla garrula.-Bohemian Waxwing-Obtained near Sheffield most seasons ; rare near Halifax and Hebden Bridge, though occasionally met with; a large flock was seen about Storrs Hall and in the neighbourhood of Kirkburton about ten years ago in the company of Fieldfares and Redwings; another large flock was seen in the same locality about four years back [i.e., 1840] from which Wm. Eddison obtained seven or eight specimens; it is only in severe winters that they resort there; they are occasionally met with in hard winters near Doncaster, York, and Bridlington. It is a very rare visitant near Barnsley; John Spencer Stanhope, Esq., of Cannon Hall, has a couple of specimens which his keeper shot in his immediate neighbourhood, and Dr. Farrar has a pair shot at Carr Green, July Ist 1832 ; several specimens have been shot near Thirsk.

This peculiar looking bird is an inhabitant of northern Europe, and an erratic, casual visitant to Yorkshire, as to the British Isles in general, being what may be termed a gypsy migrant; in some years appearing in considerable numbers, and scarce or altogether absent in others, whilst, between the years of plenty, odd flocks or occasional stragglers are met with at irregular intervals.

It was abundant in $1828-29$, according to writers in Loudon's Magazine of Natural History, and very numerous in the winters of $1834-5$ and $1849-50$, when it was noted in all the three Ridings, as evidenced by the records in the Zoologist for 1850 , the pages of which contain numerous 
references to its occurrence all over the county. Another visitation was in November 1863 and the early part of 1864 , large flights appearing, particularly near the coast; a flock of about forty was seen at Acklam near Middlesbrough, eleven being procured by G. Mussell, who ate the bodies, which he found to be excellent food. (See also Zool. I864.) The next great arrival took place in December 1866 , and January I867, the neighbourhood of the coast again being most favoured, though numbers were seen and shot inland. In Holderness, at Whitby, and at Scarborough a good many were obtained, one of those killed near the latter place having the waxen appendages on all the tail feathers as well as on the secondaries and tertiaries. From Sheffield Henry Seebohm mentioned meeting with a flock in Glossop Road, and recorded others shot in the county ("British Birds," Vol. ii., p. 4). Large parties were also noticed, and examples killed, in Arkengarthdale, Wensleydale, and other remote districts. In 1870 the West Riding was visited by several flocks, and sixteen were obtained near Doncaster. A few stragglers occurred in I872, I879, and I88I (Nat. I88r, p. 82), and in January 1883 some were noted in the North and East Ridings within short distance of the sea.

An interval of ten years then elapsed before any considerable flight again occurred, and in February I893, small parties were reported, chiefly on or near the sea-board; one obtained at Beverley had eight tips to each wing; a specimen shot at the Tessmouth in October, was sitting on a slag ball on the reclaiming wall. Another visitation was in 1897 , when many were killed, principally in the North Riding, in Cleveland, and near Scarborough; and the most recent flight occurred in the autumn and winter of 1903, when they appeared in small numbers in many parts of the county, but most frequently in the neighbourhood of the coast.

It will be observed that the time of arrival of the Waxwing is generally from October to February, but an unusually late date was mentioned by Allis, viz., July the Ist I832; an additional July record is given by Mr. Foster of Bridlington, who procured an example at Sewerby in that month in the 
year I89o; another specimen, one of two seen, was taken near Patrington in Holderness on April the 23rd I894.

There are, as might be expected in the case of a casual visitant, no vernacular names in use, but, in addition to its ordinary book-name, it has been mentioned by the names of Silk-tail (Thoresby and Hogg), Waxwing or Waxen Chatterer, and Bohemian Waxwing.

\section{SPOTTED FLYCATCHER.}

Muscicapa grisola (L.).

Summer visitant, common, and generally distributed.

The "Beam Bird" of Pennant (Vol. ii., p. 263, I766), quoted by that old writer as obtained by Willughby in I678, and " known in that county (Yorkshire) by the name of Beam Bird, because it nestles under the ends of beams on outbuildings, etc.," is probably to be referred to the species under notice, and as such is the earliest mention of its connection with the county.

Thomas Allis wrote as follows, in I844 :-

Muscicapa grisola.-Spotted Flycatcher-Less frequently met with than in the south of England, though obtained in most localities, and, like most of the migratory birds, returns to the same locality year after year; it is remarkable above all other birds for the exposed situations it frequently chooses for its nest.

The Spotted Flycatcher is a common and generally distributed species, annually arriving during the first fortnight in May. An unprecedentedly early record is the 9 th of April, at Skipton, where one perched close to the observer, who was perfectly satisfied as to its identity. It departs again in September, very few remaining beyond the third week in that month.

This is one of the few birds to be found in our town gardens, and has been alleged to be guilty of destroying honey bees (Nat. I886, p. 277), a practice, however, which does not appear to be general. It is well known for its habit of return- 


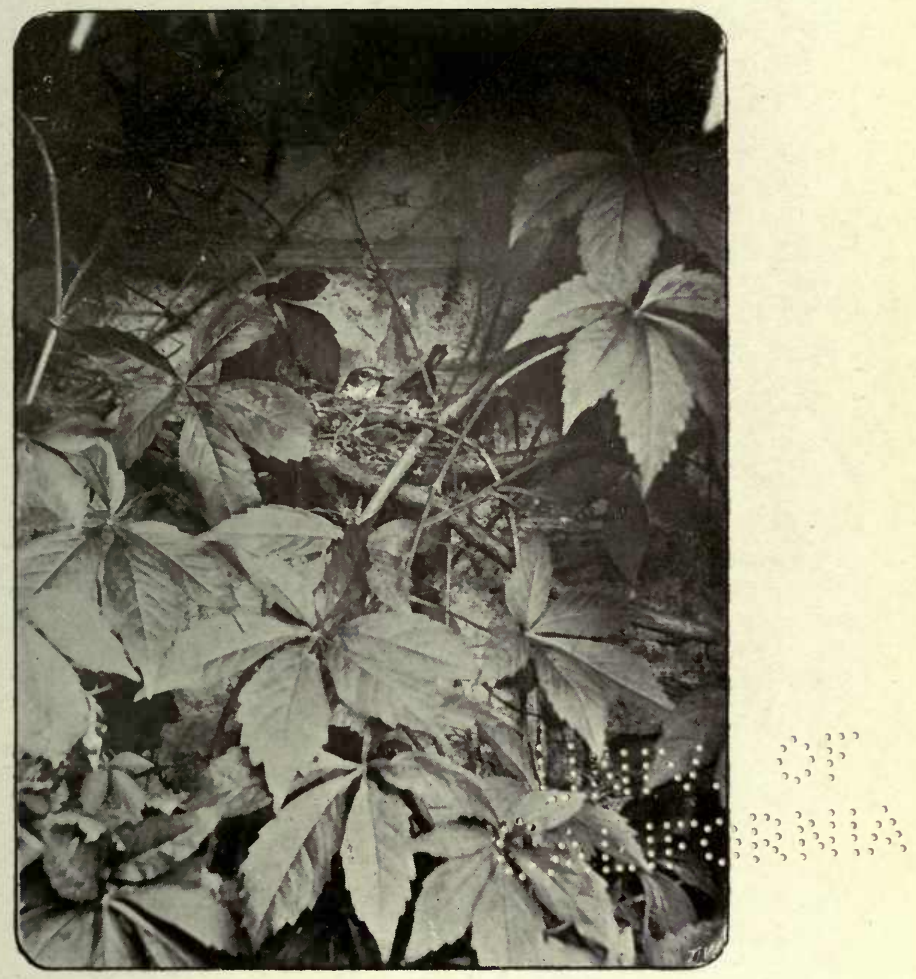

Spotted Flycatcher on Nest.

H. Lazenby.

See page 149. 

ing to its favourite breeding haunts, and for the frequency with which it makes choice of curious sites for its nest. The records of these are too voluminous for more than one or two instances to be cited, viz. :-one mentioned by John Atkinson ("Compendium of Ornithology," I820), built on the angle of a lamp-post in one of the streets in Leeds, where young were brought off; and in the spring of 1880 , a pair nested on the hinge of a door in constant use opening into a tenniscourt at Masham, but in spite of disturbance the birds contrived to hatch five eggs and rear their brood in safety. Near Harrogate a nest described by Mr. R. Fortune, was built of strips of paper, and lined in the usual manner.

A variety of this species obtained near Wath-upon-Dearne in August 1870, is described by Dr. H. Payne as having "the upper plumage and tail whitish fawn, the under parts nearly white." At Croft-on-Tees a clutch of unspotted eggs was found in 1890 .

The vernacular names at present in use are Grey Flycatcher, Bee-bird, and Wall-chat, the latter term known in north Yorkshire. The old and now obsolete names which were applied to it by old writers were Wall-bird or Beam-bird, and Rafter or Rafter-bird (Swainson).

\section{PIED FLYCATCHER. Muscicapa atricapilla $(L$.).}

Summer visitant; very local in its distribution; fairly numerous in some districts; is noticed on the coast on both the vernal and autumnal migrations.

Thomas Allis's Report, written in I844, contains the first allusion to this as a county species :-

Muscicapa arctuosa.-Pied Flycatcher-Dr. Farrar says this species is one of our latest summer visitants, and quite local in its habitat. The Stainborough Woods are a very favourite resort, especially frequenting the lofty oaks with which these woods abound, but I never saw it without the Park enclosure. It has bred at Danby near Middleham; 2, Wharncliffe, 3, Ovenden, Harewood, and Studley. W. Eddison says it bred at Dalton for several successive years, when 
it disappeared, probably destroyed by some collector; R. Leyland says that a few years ago it was frequently found breeding at Luddenden Dean in the Parish of Halifax, but that one or two bird-stuffers have nearly extirpated it ; it is very rarely seen in the East Riding or the immediate vicinity of York.

Of this conspicuous bird, whose distribution in Britain as a summer resident is exceedingly limited, Yorkshire is one of the chief headquarters, and perhaps the most southern county in which its occurrence in any numbers can be considered regular. Although single individuals are occasionally observed in April, yet the usual time for its appearance is from the first to the second week in May; the earliest record is the I2th of April I878, at Barnsley; at Masham one was seen in 1882 on the 22 nd of the same month; on the 24th of April I893, I watched a male bird for some time in Borrow Greens Wood, Easby-in-Cleveland, and five days subsequently one was caught asleep, soon after daylight, on a garden hedge behind Redcar sandhills. On their first arrival in spring I have noticed the birds in considerable numbers in the fishermen's garden plots, and on the roth of May I899, I saw one sitting on a post within a few yards of my smoke-room window. They only remain to rest for a few hours in the vicinity of the coast, soon dispersing inland to their breeding haunts.

The choice of localities in which this species annually breeds shows a strong predilection for the combination of woodland and water, preferring as it does either deeply wooded river valleys, or woods in close proximity to extensive sheets of water. In the North Riding it nests annually on the Yorkshire side of the Tees near Barnard Castle, and also higher up the dale; on the banks of the Lure near Sedbergh; by the river Wiske in the neighbourhcod of Northallerton; in the woods at Castle Howard; and at Duncombe Park, Helmsley, and Hovingham in Ryedale; near Easby and Ingleby in Cleveland; in the Esk valley and the small dales branching therefrom; Mulgrave Woods; and also at Haxby, Hambleton, Coxwold, Swainby, Loftusin-Cleveland, Whitby, and Scarborough. In Wensleydale it 


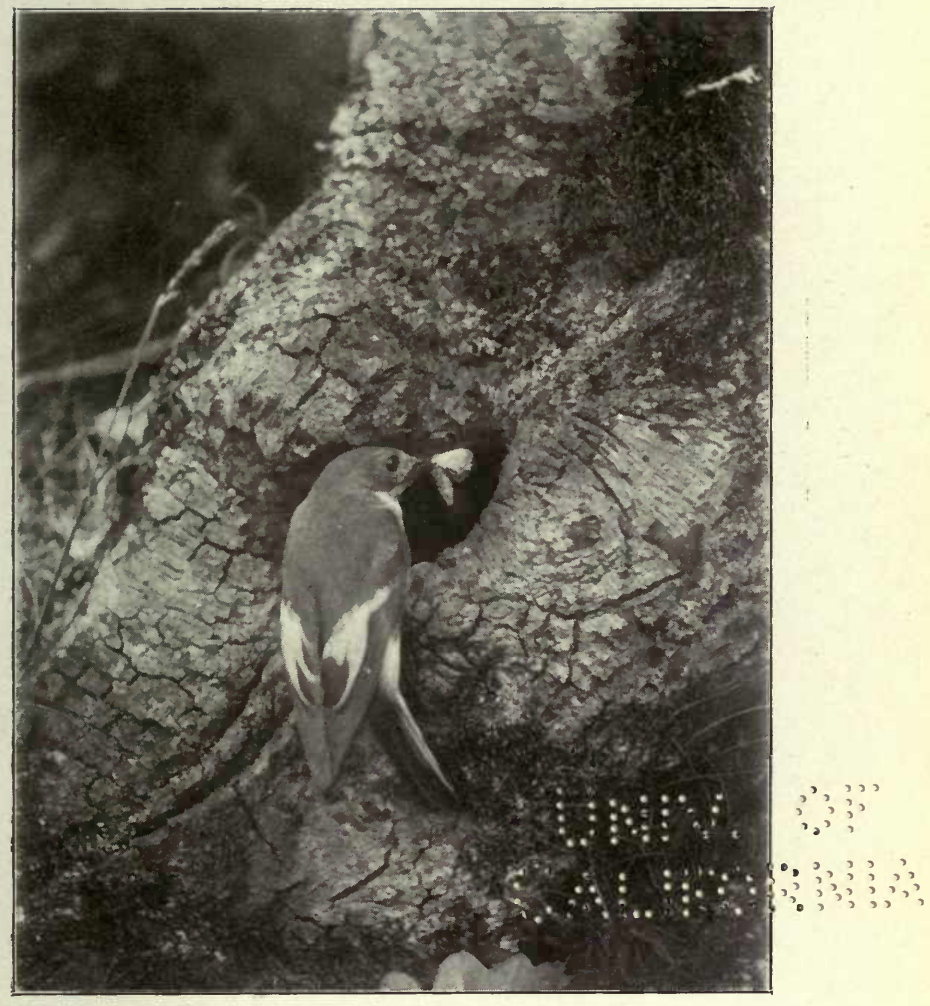

Pied Flycatcher taking food to young.

See page ${ }^{5}$ I.

T. A. Metcalfe. 

is known to breed on the banks of the Ure near Mashambut decreasing in numbers-at Danby, Hackfall, and Caperby.

The West Riding contains, perhaps, the chief resorts of this interesting species, which nests in Bolton Woods in Wharfedale; in Nidderdale it visits the woods near Harrogate, Knaresborough, Fewston, Brimham, Guyscliffe, Lofthouse, Bewerley, and Harefield, being scarcer near Pateley Bridge (in which locality two broods were hatched in I869, the second being on the I5th of July). Other localities annually resorted to in the West Riding are Stainborough Woods, and those at Cannon Hall, both near Barnsley. It has also been reported as breeding occasionally, and singly, near Halifax, Sheffield, Huddersfield, Hebden Bridge, Gisburn, Skelmanthorpe, Ripon, and in I904 Mr. James Moore of Morecambe informed me a pair nested near Bentham, close to the Westmorland border. In I8II the Rev. James Dalton, a noted naturalist in his time, found it breeding at Copgrove (near Boroughbridge); and in I844 Ovenden (near Halifax), Harewood, and Studley were quoted as breeding stations by Thomas Allis. I have no information of their now being frequented, with the exception of Studley, and there it only nests irregularly.

In the East Riding it is more frequently observed on passage than as a breeding species; the only districts from which its nest is recorded being Heslington, Pocklington, and in Holderness, where the late Colonel B. B. HaworthBooth informed me he found one in a yew tree in June I895.

On the coast it occurs regularly at the periods of the vernal and autumnal migrations, in some seasons in considerable numbers. An interesting and unusual occurrence took place at Flamborough on 3rd May I866, and the two following days, several specimens of both sexes in mature and immature plumage being shot out of a large flock by Mr. M. Bailey. Another very remarkable incident which occurred at the latter end of April, " about fifty years ago," has been communicated to me by Mr. J. Braim, formerly of Sleights, who discovered no fewer than four Pied Flycatchers, one male and three females, drowned in a rain-water tub, 
they having, presumably, fallen into the water in their efforts to procure flies. Mr. Braim has obligingly presented me with three of these specimens.

The greatest arrival yet known took place from the 3rd to 6th May I885, and was very pronounced at Spurn, Flamborough, and Redcar (Seventh Migration Report, p. 43). On the return passage in autumn they are reported at various stations on the seaboard, from mid-August to the end of September, and have been observed to alight on a vessel at sea on passage from Sweden to Hull (Nat. I893, p. 5).

The individuals which occur on the East Coast during the autumn immigration are invariably described as immature birds. It is very likely that observers are mistaken in this matter, as at this season the sexes, both mature and immature, are hardly distinguishable. The late J. Hancock ("Birds of North'd. and D'm." p. 79), pointed out the close resemblance in plumage of the sexes in young and old birds.

This species affects the tops of the highest trees as its hunting quarters, while its nesting holes are not far above the ground. Like its congener, the Spotted Flycatcher, it has been accused of killing honey bees, and at Whitby one was shot in flagrante delicto (Nat. I886, p. 277).

Mr. W. Eagle Clarke had examples, obtained at Spurn in autumn, which are an inch less in total length than the average measurement.

\section{RED-BREASTED FLYCATCHER.}

Muscicapa parva (Bechst.).

Accidental summer visitant from the European Continent, of extremely rare occurrence.

This species nests on the Continent of Europe and in Persia, migrating in winter to northern India and China. Its claim to be included in the Yorkshire avi-fauna rests on the occurrence of one immature example only, which is the seventh specimen recorded for Britain, and was obtained by Mr. John Morley, at Scarborough, on the 23rd of October 
I889, in a wood amongst beech trees. It was observed to fly from its perch at intervals after flies, the white feathers in its tail being then very conspicuous. The wood was swarming with Golden-crested Wrens, and also Woodcock, which had evidently just arrived.

The bird was sent to London for comparison, and its identity fully established, as Mr. J. H. Gurney exhibited it at the Zoological Society's meeting for that purpose; it was too heavily shot for the sex to be determined. (Gurney, Nat. I89o, p. I4 ; Field, I8th January I89o; Zool. I89I, pp. 362-3, 47I.)

The specimen is now in the collection of Sir Vauncey Crewe of Calke Abbey, Derbyshire.

\section{SWALLOW. Hirundo rustica (L.).}

Summer visitant, generally distributed, abundant. Arrives in mid-April and departs at the end of September, a few remaining until October.

In its connection with Yorkshire history, the earliest reference to the Swallow, of which I am aware, is contained in a letter from the erudite Dr. Martin Lister to the celebrated John Ray, and is dated York, February 8th I675, thus :-

"Dear Sir,.... One and the same Swallow [Hirundo rustica], I have known, by the abstracting daily of her eggs, to have laid nineteen successively, and then to have given over." ("Correspondence of John Ray," p. II7.)

Thomas Allis wrote, in I844, as follows :-

Hirundo rustica.-Chimney Swallow,-Common, Dr.Farrar remarks, respecting the whole tribe, that, probably the same cause, or causes, which have diminished the number of Cuckoos this season, may also have had their influence on these birds, as he seldom remembers having seen so few as up to the date of his communication, June 6th 1844

One of our familiar and most eagerly looked-for summer visitants is the Swallow, which usually arrives in Yorkshire from the Ioth to the middle or third week of April, varying slightly as the season is early or late; in the south of the 
county it may be noticed a few days earlier than in the middle and north; Neville Wood, in I837, mentioned the roth as the average date, and at Barnsley the same estimate was arrived at after an analysis of many years' notes. In the central and northern districts its appearance may be expected in mid-April, and so far back as 1784 that able Yorkshire ornithologist, Marmaduke Tunstall, writing from Wycliffe-on-Tees, calculated its arrival at this period, though it does not reach the higher dales and remote upland localities until the third week or even the end of the month. Two authentic instances of March Swallows are reported; one by Thomas Allis, who noticed two near Pontefract on 3oth March I830; and, in more recent years, Mr. J. J. Emerson of Easby-in-Cleveland, saw a pair on the 25th of the same month in I897. Solitary birds have not infrequently been recorded from various parts of the county in the first week in April, but the old adage " one Swallow does not make a summer" holds good in Yorkshire as elsewhere, and these first arrivals are merely the advance guards of the main hosts that follow at the end of April and early in May.

The departure of the main body takes place at the end of August and throughout September, a few sometimes remaining till mid-October, whilst exceptional cases have been known of odd birds being observed in the winter months. At Spurn some were seen on 8 th November I89I, at the time when our winter migrants, the Snow Buntings, were coming; at Redcar I have seen individuals as late as the 22nd of November in the year I89I, and two were noted there on 3 rd December I846 ( Zool. I846, p. I368); three were noticed at Huddersfield on I8th January I837; and one near Halifax on 4th February I862 (See J. E. Harting on "Belated Swallows," Field, 3oth January I892). These lingerers probably belong to late broods, or are from more northern regions. The first birds moving south are young ones, and in September they may be seen the whole day passing along the coast; on the 3 rd and 4 th September I898, there were continuous flights passing Redcar to the south-east; and at Flamborough they have been frequently observed in mid-September 
congregating about the Headland preparatory to their long journey.*

The Swallow is generally diffused in the county and ascends into the highest parts of the dales, being known to breed in Nidderdale to II5O feet, and to 2000 feet elevation in Teesdale ; in Arkengarthdale odd pairs nest in the shepherds' huts on the moors; I have also known a nest in the shooting house on Swainby Moor, and, while grouse shooting, have seen birds hawking for insects about the moors. In the Harrogate neighbourhood its numbers had considerably decreased a few years ago, but it appears to be regaining ground, though it is to be feared that, generally speaking, it is not so plentiful in the county as formerly. In some seasons, owing probably to severe weather, it is less abundant than in other years; this was the case in I90I, as testified by several writers, notably James Carter (Field, 25th May I90I), and on I2th and I3th May I886, after the bulk of the late comers had appeared, a spell of cold wintry weather, with heavy snow and gales of wind, caused terrible mortality amongst their ranks; thousands perished of cold and want of food, many being picked up in a famished and dying condition (Nat. I886, p. I82).

Swallows have often been observed hawking for insects several miles distant from land, both off the Cleveland coast and in the Humber district.

The ancient myth respecting birds of this family hibernating at the bottom of ponds and rivers dies hard in the remote dales, but Pennant (Vol. iv., pp. I3, I4), related an instance of probable hibernation, several bushels-full of birds in a torpid state being found in a cliff at Whitby while digging out a fox; and in mid-winter, about I850, some twenty Swallows were discovered inside an old tree, cracked with age, that was cut down on Lord Feversham's estate near

* In this connection the Migration Reports furnish plenteous evidence concerning Yorkshire, the entries being, however, too voluminous to be given in detail : and for a concise account of the migration of the Swallow the student is referred to Mr. W. Eagle Clarke's report, read at the British Association meeting at Glasgow, 190 r. 
Helmsley; only one of the birds showed signs of animation, and it soon collapsed.

During the whole of the winter of 1895 two of these birds took up their quarters in an old barn at Elton Wold, near Beverley, and remained until the new-comers in spring had appeared; but a most circumstantial statement is given, by the Rev. T. Powell, of two wintering at Healey Vicarage, near Masham, in I895-6, as follows :-

"They were members of a very late brood of four hatched in a nest under the slates inside our cowhouse. I may here mention that a pair of Swallows nest every year in the same place. The two Swallows in question were seen flying about by members of my family long after the other Swallows had disappeared. They finally lodged above the lintel of the cowhouse door, squeezing themselves into a small hole in the stonework, and thus escaping the draught. When I saw them the tail was the only part of their bodies that was at all conspicuous. My eldest son, then sixteen years old, had them both in his hand at the beginning of last Christmas holidays. They were in a drowsy condition and did not attempt to fly when he gave them the chance. On very fine days, as he informs me, he saw them flying for about two hours in the middle of the day from eleven to one o'clock. One of the Swallows died some time in the spring, the other left its winter quarters shortly before the return of the Swallows (in April), and was a conspicuous object among its fellows during spring and early summer through having lost one of the forks of its tail. It mated with another Swallow, and they attempted to nest in the pigsty, which joins the cowhouse, but this came to nothing - the lowness of the roof of the pigsty most likely causing them to desist from the attempt." (Field, 2nd January r897.)

The selection of breeding sites of this bird does not vary greatly, though at Campsall Hall a pair for several years successively attempted to build in the upper corner of the entrance hall (Neville Wood's Nat. I837) ; another pair built a nest, in June 1887 , and reared its brood, on the curtain pole overhanging a staircase window of a country house near 


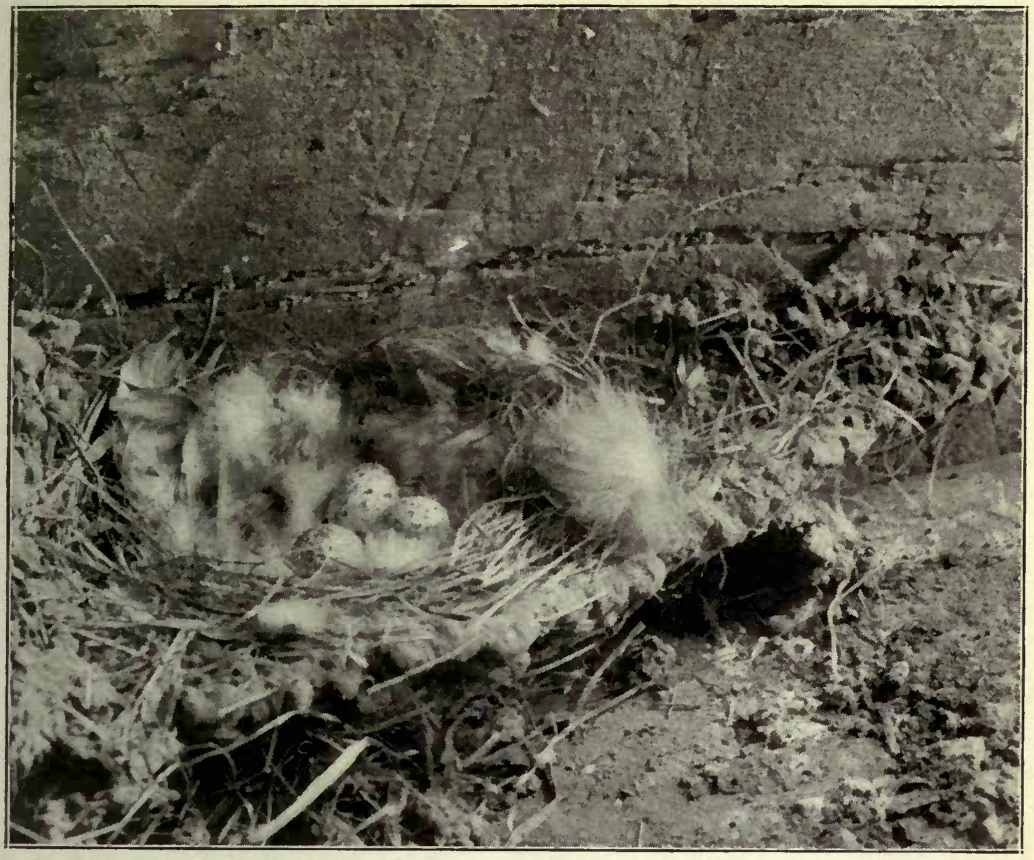

Swallow's Nest.

R. Fortune.

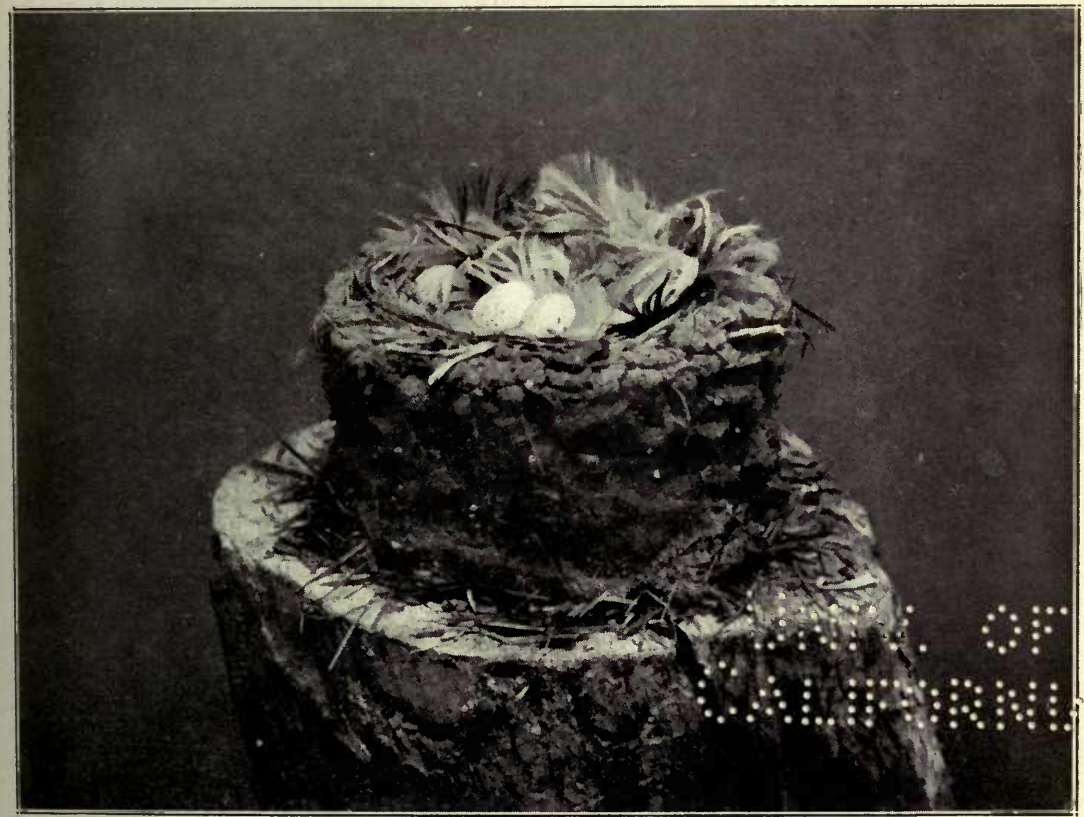

Cup-shaped Swallow's nest, near Harrogate..

R. Fortune.

See page ${ }_{5} 6$. 


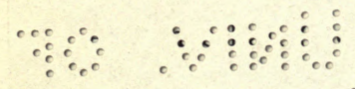

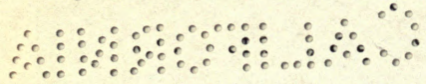


Cottingham (Field, 8th October I887); and at Wilstrop two nests were built under the eaves of an outhouse against a wall, and without any supporting ledge; whilst at the same place other two were in a shed built against the inner walls and about a foot below the angle of the roof (Nat. I89o, p. 258).

Late nests are not infrequent, therefore one or two instances only need be cited; one at Starbeck had young in October I884, the old birds being observed feeding them during a snowstorm at the end of that month; and in the following year several were reported, one, near Rotherham, having young as late as the roth of October.

White varieties occur almost every season; of Yorkshire examples the earliest and latest known may suffice:-One in the Tunstall collection was shot at Bradford-on-Tees (Tunst. MS. p. 76), and the latest was noted at Market Weighton in 1896 . A dun coloured specimen was observed at Beverley in I866, and at King's Mill, near Huddersfield, one of a pale drab plumage is recorded.

The folk lore of this county abounds with superstition connected with this favourite bird; it is deemed to be a very good omen if a pair take possession of a place and build a nest against it, while it is unpropitious for them to forsake a place they have once tenanted. Terrible penalties, we are told in the North Riding, are paid by the rash hand that destroys or robs a Swallow's nest; rain will continually descend on his crops for a month, or his cows will cease to give milk, or else give it mixed with blood. In the West and East Ridings punishment is considered certain to follow the ruthless act in one form or other, either death or some great calamity will fall upon the family. A farmer's wife near Hull told how some young men, sons of a banker in that town, pulled down some Swallows' nests about a little farm he possessed. "The bank broke soon after," she said, " and, poor things, the family have had nought but trouble since." (Henderson's Folk-lore.) The descent of a Swallow down a chimney, as in the case of a Jackdaw, portends the speedy decease of the inmates of the house.

A country rhyme runs:- 
"The Martin and the Swallow, Are God Almighty's bow and arrow."

The only vernacular names are Fork-tailed Swallow, Chimney Swallow, and Barn Swallow.

\section{HOUSE MARTIN.}

\section{Chelidon urbica $(L$.$) .$}

Summer visitant, abundant, generally distributed. Arrives late in April and leaves in September, stragglers occasionally remaining until November or December.

The first reference to this species as a county bird is contained in a letter from Mr. Bolton, near Halifax, dated 30th August I794, and runs as follows :-

"In the latter end of August 1779, some boys beat down a Martin's nest, with young. The birds built anew for another brood, which had but just learned the use of their wings, when their congeners took leave. Several times in the course of the winter I have seen sometimes one, sometimes two, flying about, the weather was mild, and the sun shined warm; and after the $25^{\text {th }}$ of March they were constantly to be seen on fine days." (Latham, "Gen. Hist. Birds," I823, vii., note to p. 278.)

Thomas Allis, I844, wrote :-

Hirundo urbica.-The Martin-Common in most districts, but Arthur Strickland remarks "There seem few birds less disturbed in their nidification than this, notwithstanding it appears to me to have greatly diminished in numbers of late years ; many houses I remember annually abounding with their nests now hardly possess more than two or three." I think the same remark applies to the neighbourhood of York.

The House Martin arrives a little later in spring than the Swallow and, as a general rule, in the third week of April ; in the south of the county it is somewhat earlier, the I $^{\text {th }}$ of April being the average date of its appearance, but in most 
parts of Yorkshire its presence does not become apparent until the third or last week of the month. In 1877 it was noted in Wensleydale on the 6th of March, which is remarkably early; in Cleveland the earliest arrival of which I have a note is the $4^{\text {th }}$ of April Igor, when one was seen at Marton.

During August and September most of the House Martins leave us, but a few linger until October almost every year, while some stay into November. Two records are known of its being seen in December: one at Whitby in $\mathbf{r 8 8}$, on the $4^{\text {th }}$ of the month, and another which came under my notice at Redcar in I900, on the I4th; the bird was afterwards repeatedly seen flying in front of my house until the 20 th, when from II a.m. until 2 p.m. I had it under observation for the last time. An instance of this species wintering in the county is given by Latham's correspondent, as mentioned above in the first Yorkshire reference to this bird.*

Though generally distributed, and common in most localities, the House Martin is, unfortunately, decreasing in numbers in the manufacturing districts and in the neighbourhood of many large towns, where whole colonies have deserted their breeding places owing to the prevalence of smoke and the destruction and usurpation of their nests by the ubiquitious House Sparrow. This decrease appears to be noticed also in many other parts, although in some places, and particularly at Harrogate, the reverse is happily the case. In the west and north-west portions of the county the bird is found up to II5o feet elevation, at which altitude it breeds in Teesdale and Nidderdale, and I have often met with it hawking for insects on the Cleveland moors in August, whilst grouse-driving operations were in progress. Great mortality amongst the Swallow tribe was caused by the severe weather in May I886, and this species suffered equally with its congeners (cf. Swallow, p. I55, and Nat. I886, p. I82).

Along the sea-cliffs a great number of Martins breed

" (cf. J. E. Harting on "Belated Swallows." Field, zoth January 892; and Nat. 1901, p. 74.) 
annually, placing their nests under the ledges, and colonies exist in these situations at Saltburn, Boulby, Whitby, Scarborough, and the famed Flamborough range. In a few inland localities it also breeds in cliffs, as at Malham Cove, where the nests are lower down than those of the Swifts; in a quarry between Kirkby-in-Cleveland and Bilsdale, and at Kilnsey Crag in Wharfedale. In some colonies many nests are found in close proximity to each other; in Nidderdale forty-six were built within a space of nine yards, and at Battersby-inCleveland I counted fifty-two on a small row of railway cottages. A curious site was chosen by a pair of these birds at Sedbergh in 1885 , where a nest was noticed fixed on the face of the station clock; at Malham Cove a nest was built on a wall instead of under the eaves, and was domed over, with the entrance at the side.

Mr. Wm. Storey of Fewston informs me that, in 1893 , he caught a pair of Martins, which had built under the eaves of his house, put a split ring on the leg of each and liberated them. Next year, on the 2oth of June, the birds returned with the rings on their legs. They again nested in I895, but the male was, unfortunately, killed by flying against the telegraph wires, the ring still remaining on its leg, and so proving its identity.

Late nesting with this species is noted almost annually; three instances were reported at Beverley in October I885, one with young still unfledged on the Igth of the month; and the late P. Inchbald mentioned, in the Field of 5 th November I887, a nest and young at Hornsea on the 7 th of October. A few days later he was told the nest had been taken down, in consequence of the warblings of the birds being considered tokens of ill omen at so late a period of the year. At High Harrogate, in the year I905, I saw Martins feeding their young in the nest as late as the IIth of October; on the I2th the young had flown, though it is doubtful whether they would be able to migrate, as a spell of severe cold weather immediately ensued.

White and parti-coloured varieties are not uncommon; Marmaduke Tunstall mentioned one of the former in August 


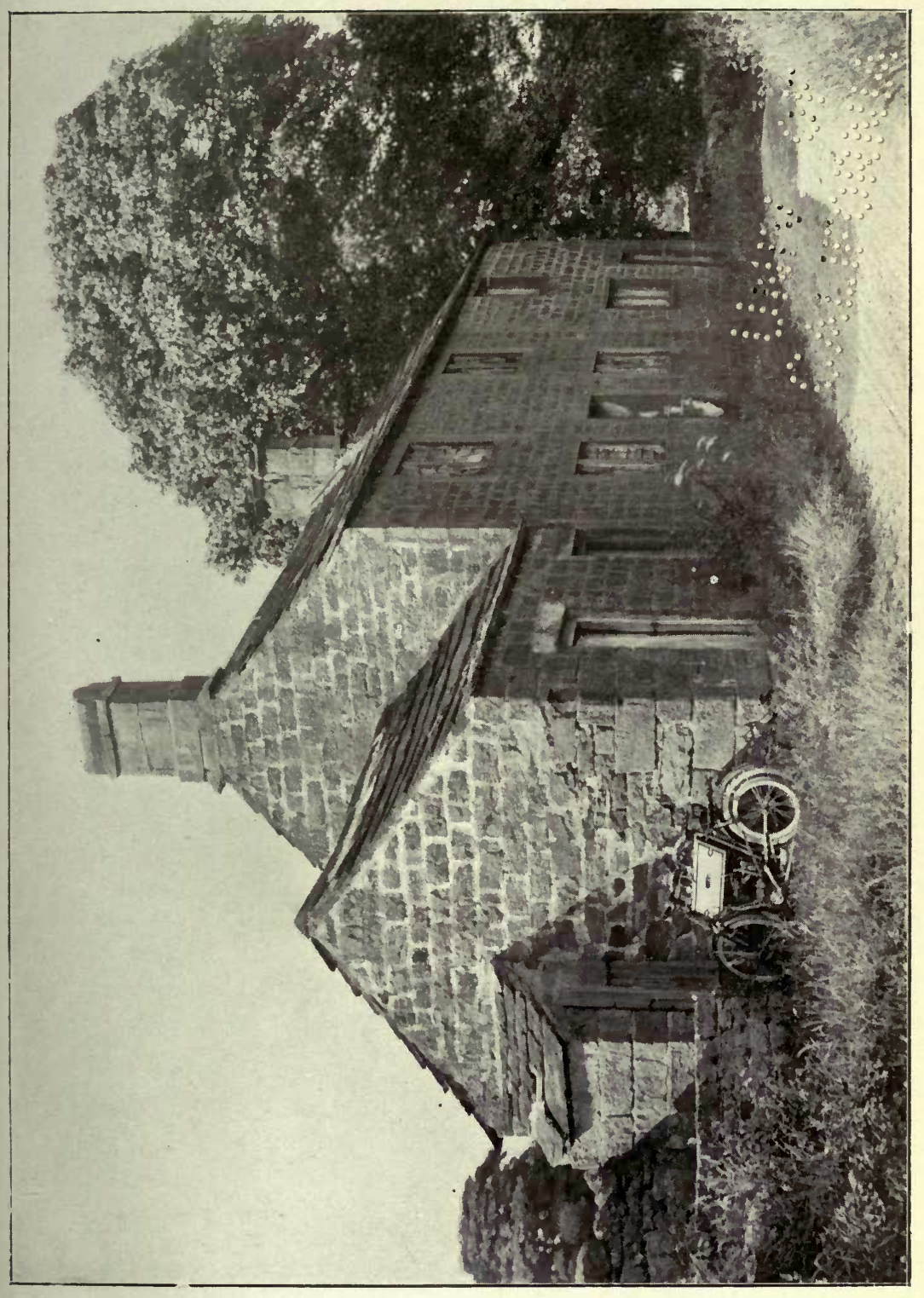

ปั

品 ن

高

:

$+$

7

。

우

\&

:

요

苟

i

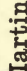

空

우

:

4

:

。

ฐ

용

.



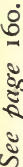




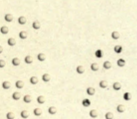


I78I (Tunst. MS. 1784, p. 76 ), and a pure albino, with pink eyes, was noted at Patrington on 26th September 1880 .

The local names in general use are: Swallow, House Swallow, Window Swallow, and Martin; while Eaves or Easin Swallow is a name applied to the bird in the Craven district.

[An American Purple Martin (Progne purpurea, L.) was shot at Colne Bridge near Huddersfield in 1854 (Hobkirk's Huddersfield, I859, p. I44), but, at this distance of time, it is not possible to investigate the circumstance, and the record is to be considered unreliable.]

\section{SAND MARTIN.}

Cotile riparia $(L$.$) .$

Summer visitant, abundant in suitable localities.

Probably the first notice of this species in the county is found in Graves's "History of Cleveland " (I808), where it is enumerated in the list of migrants.

Thomas Allis, in 1844 , referred to it thus :-

Hirundo riparia.-Sand Martin-Common near Doncaster: a few pairs are occasionally met with near Sheffield : pretty frequent in favourable localities in other districts.

The Sand Martin arrives from early in April to the middle of the month; in the south of the county, at Barnsley, the th $^{\text {th }}$ is computed, from an analysis of many years' records, to be the average date; in central and north Yorkshire it does not make its appearance till a few days later, though, as in the case of its congeners, stragglers are occasionally noted much earlier, as at Otley where one was recorded on 29th February r886 (Field, 3rd April I886), and at Ackworth a pair were seen on 28th March 1897. This species felt the ill-effects of the storm that proved so disastrous to the Swallow tribe on the I2th and I3th of May I886, many being picked up dead or starving (Nat. I886, p.I82; see also Swallow, p. I55).

vol. 1 . 
It departs a little earlier than the Swallow and House Martin, though small parties sometimes linger until late in October; the late Wm. Talbot, in his "Birds of Wakefield," I877, recorded one as late as the I4th, and on the 20 th of the same month, in 1880 , about twenty were observed in Flamborough village, hawking for insects.

This bird, the least of the genus, is abundant in those localities where suitable situations for its nesting galleries are met with, such as the sandy banksides of rivers, sand quarries, and the face of precipitous cliffs both inland and on the sea-coast. In some districts it is more numerous than the two preceding species, this being the case at Pateley Bridge; but it is necessarily a local bird, its numbers depending on the presence of available nesting quarters; on the east Wolds and in the higher reaches of some of the dales, such as Swaledale and Arkengarthdale, it is, for lack of them, rather rare. In Teesdale a colony is established about two miles above Middleton, and in Nidderdale it is met with to 1400 feet elevation, and is not infrequent in the neighbourhood of the large reservoirs in the West Riding dales. On the sea-cliffs of Boulby in the North Riding, and at Flamborough in the East, several large colonies are found, those at the latter place being in the sand veins in the upper cliff, between the chalk and the boulder clay on the south beach. Twenty or thirty years ago they were very common on the sandhills between Redcar and Saltburn, where they had nesting galleries in the steep sides of the banks facing the sea, but, erosion of the coast having destroyed the holes, they have deserted the place and are now quite scarce. At Thorne Waste, near Goole, the Sand Martins excavate holes, drilling the peaty sides of the trenches cut for the drainage of the moss; this is a departure from the ordinary habits of the birds, though a more unusual nesting place was utilised by several pairs, which bred in the markers' huts on Strensall Common, in $188 \mathrm{I}$; and a still more curious locality was mentioned by the late E. Tindall of Knapton, who found a pair nesting in the north end of an old haystack; the eggs were on the point of hatching when they. were, unfortunately, 
destroyed by some boys. Numbers of these birds nest in the heaps of rejected lime at the whiting works near Beverley.

A bird so weak and frail as this species is not considered to be of a quarrelsome nature, but a rather remarkable instance occurred in I90I, near Bashall Hall on the Lancashire border, where a pair of Sand Martins dispossessed a Dipper, which had reared a brood, and the Martins afterwards hatched two broods in the same nest (T. Altham, in litt. I3th February I902).

There are several Yorkshire records of white or particoloured specimens; one with silvery plumage is mentioned in Neville Wood's Naturalist, I837 ; the Rev. F. O. Morris noted one at Doncaster in the same year with a white breast and a white band round the nape of the neck; a white variety was seen near Wilsden, and one at the same place, in 1877 , with the upper plumage bluish white, and the lower parts glossy white. An example near Settle, in 1895 , had white wings; and, finally, an albino is recorded from Killinghall, near Harrogate, in 1898.

The local names are not very numerous, and have all reference to the situations in which it nests: Bank Martin is general; and Bank Swallow a West Riding term; it is Pit Martin in Craven; Sandy in Teesdale ; and Sand or River Swallow is given by Swainson, I886.

\section{GREENFINCH.}

Ligurinus chloris (L.).

Resident, common, generally and abundantly distributed. A great influx of migrants in autumn.

Probably the earliest Yorkshire reference to this species is given by Tunstall (MS. I783, p. 66) thus: " Loxia Chloris.Green Grosbeak. Heard from pretty good authority, that there had been a mongrel between this bird and the canary."

Thomas Allis, I844, wrote :- 
Coccothraustes chloris.-Green Finch-Abundant everywhere.

One of our commonest residents is the Greenfinch, which is found wherever it meets with suitable conditions for its existence, and in the dales it has occurred to an elevation of rooo feet. It congregates in vast numbers in autumn, at which period large flocks of immigrants cross the North Sea in October and November, and resort to the stubbles to feed in company with other Finches and Linnets; the old males migrate separately from the females and young. It has also been occasionally noticed during the vernal migration.

In the autumn and winter of $\mathrm{I} 88 \mathrm{I}$ an immense concourse of these birds gathered in the stubble fields near the coast, attracted by the grain that had been scattered by a storm during harvest time; the year 1883 witnessed another great arrival, with Linnets, in October, and in the same month of I887 many were seen at the Teesmouth. Several "rushes" are recorded in the Migration Reports, while in October Igor, a strong migration from the north took place at Redcar, accompanied by Linnets, Siskins, and other small birds. On the Cleveland coast the flocks generally arrive from about east or north-east, in foggy weather being often so greatly exhausted as to drop on the rocks, or on the sands, directly they " make the land." During the spring passage in rgor, there was a great influx at Redcar on the Ist of May, with Siskins; they came from due east, early in the morning, which was misty, with a light easterly breeze, and many were seen sitting on the hedgerows and in the gardens ; in all probability these birds were on their passage further northward.

An exceptionally late nest, containing young, was reported at Patrington on August 30th 1857. At Redcar, in 1902, a pair of Greenfinches built a nest, and reared their young brood in a garden, close to the entrance gate, and within three feet of the footpath.

An instance of variation from the ordinary plumage is that of a white example, seen near Bradford, on Irth April I890 ( $N$ at. I890, p. 335), while specimens almost as yellow as canaries have occurred at Beverley.

As regards varieties of the eggs, the late Canon Atkinson 


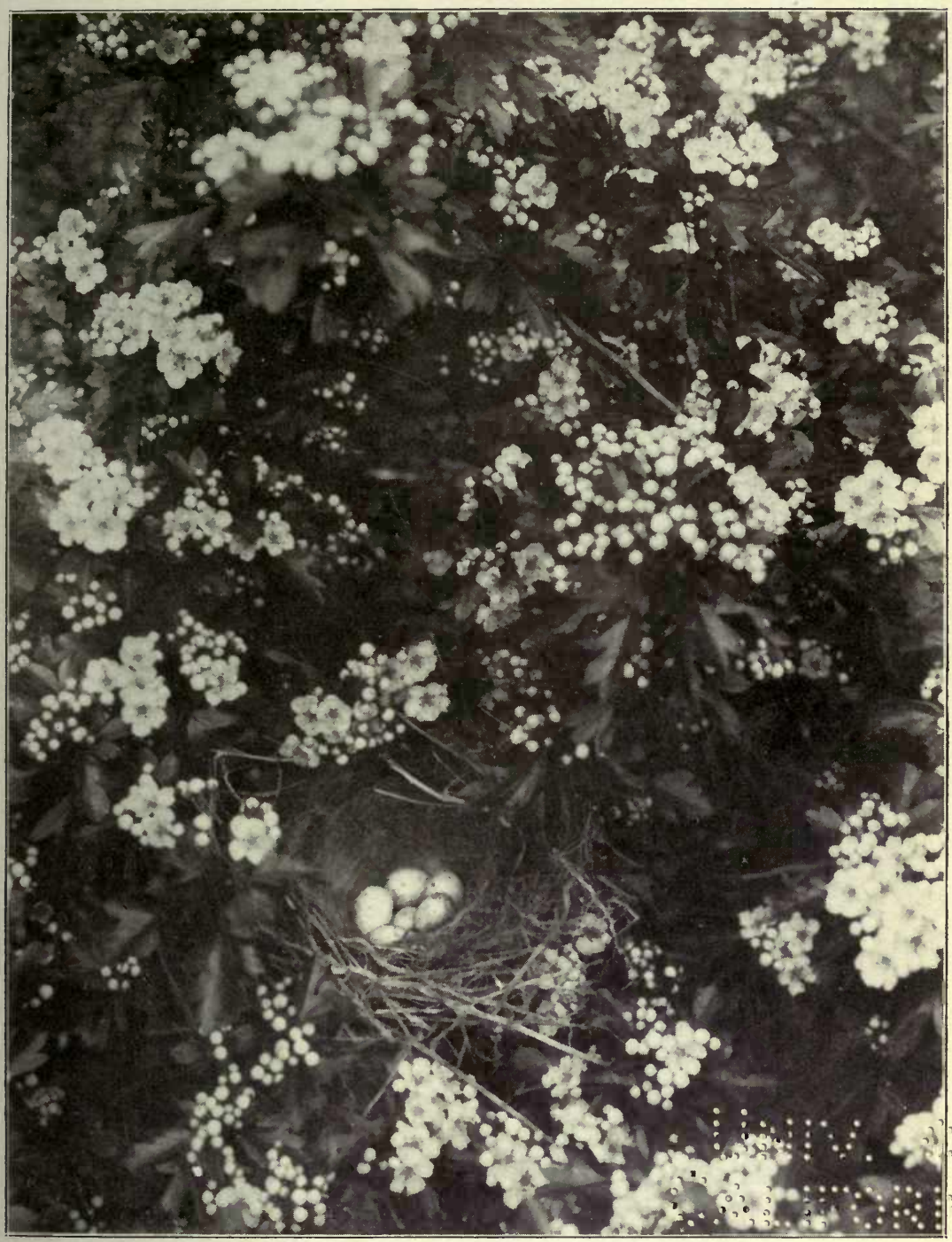

Greenfinch's Nest.

R. Fortune.

See page I64: 
46 $\because 4$

की 
mentioned a clutch at Danby, in I863, of a warm shade of white, resembling the hue of Dippers' or Sand Martins' eggs.

Of local names, Green Linnet and Green Lenny are general ; Greeny is in use in Cleveland and the East Riding; Green Grosbeak was the name used by Tunstall in 1783 ; Featherpoke has been noted at Newsome, near Huddersfield; and Bighead at Beverley.

\section{HAWFINCH. \\ Coccothraustes vulgaris (Pallas).}

Resident, local ; breeds regularly in some parts. Greatly increasing in numbers and extending its northward range.

The earliest Yorkshire reference to this species appears to be in Leyland's Halifax Catalogue, I828, where it is stated to be "very rare."

Thomas Allis, in 1844 , wrote of it thus :-

Coccothraustes vulgaris.-Hawfinch-Is a rare winter visitant near Sheffeld; one or two have been taken near Halifax; it occurs rarely at Killingbeck near Leeds, and near York, as well as in the neighbourhood of Barnsley, and is very rare about Huddersfield; eight specimens were shot near Doncaster in 1843 , and are now all in the possession of Hugh Reid, bird-stuffer of that place. Arthur Strickland observes that a few of these birds are generally killed every winter in the neighbourhood of Bridlington, but they have not been known to remain over the summer in that district.

Although formerly considered to be rather rare, the Hawfinch, while somewhat local, has vastly increased of late years and extended its range northward. Whatever may be the cause of this increase, whether it is to be attributed to the protection afforded by law, or due solely to natural causes, the fact remains that the bird is now resident in many places where it used to be merely a winter visitant, or perhaps its presence was unsuspected or overlooked, possibly the latter in some cases, for it is of a shy disposition, and may be existent in a locality, without being known, until close 
investigation reveals its loosely made nest, and it is more likely to be noticed in autumn, when the young are out and feeding in vegetable gardens.

In the south of the county it was rare up to the "sixties"; it now breeds regularly, yet not numerously, near Sheffield, Halifax, and Barnsley; it is fairly abundant and has greatly increased in the Aire Valley, where it was first noted as a nester in 1878 ; near Wakefield it bred in several places in 1876 and continues to do so annually; it has increased in the Huddersfield neighbourhood, where a few nests have been known of recent years; at Hebden Bridge the eggs were found in I883; it is rare near Selby and Askern; at Doncaster it is resident, though the fact of a nest being discovered in 1863 was considered worthy of record in the Ibis (I865); the young were found at Ackworth in I88I, and up to $\mathrm{I} 88 \mathrm{~g}$ it had nested regularly for several years in the Pontefract district, but it is still a rare species near Goole. In the Leeds area one or two localities are occasionally favoured, as also are Otley and Staveley; it is rather scarce in lower Wharfedale, though some breed near Boston Spa and other suitable places; it has also been recorded from Ben Rhydding in the upper portion of the valley, and at Fewston in the Washburn valley; Nidderdale claims it now as an annual breeder, yet it was only detected there in 1886 ; along the lower reaches of the stream it has increased, and breeds near Harrogate, Ripley, Rudding Park, Knaresborough, and Ribston Park. In the Ripon district it is fairly common and increasing as a nesting species near the city and at Studley Park; it has also occurred at North Stainley. It is rare generally in the north-west, but is now numerous at Bolton Abbey and Bolton-by-Bowland, where it has been caught in gardens and orchards when attacking the pea crops.

In East Yorkshire the Hawfinch is a fairly abundant species near Pocklington, Warter, and Nunburnholme; at Scampston it has only been identified within the past ten or twelve years, but nests annually, and the late Col. B. B. Haworth-Booth recorded nests at Hullbank House in 1893 and 1895 ; in the Beverley district, where it may be described as nesting in 
some numbers, it has been overlooked, having been common and an annual nester in the Public Pasture for the past forty years, and it has also occurred in flocks in the winter ; it breeds at Brough-on-Humber, and has been observed near Hedon in the nesting season.

Coming to the North Riding, where it was but a winter visitant, or an uncommon breeding species, it is noticeable that; within the past ten or fifteen years, it has become much more numerous; one or two pairs nest at Castle Howard; near Bedale several broods are reared every year, and at Richmond, Thirsk, and Helmsley its nest has been found. At Staithes, Whitby, and Scarborough it nests sparingly, and in upper Teesdale an odd pair or two have bred on the Yorkshire side of the river since 1897 ; near Sedbergh, in the extreme northwest, it is a scarce winter visitant, as also in Arkengarthdale and Swaledale. The increase of this bird in Cleveland is very remarkable; so recently as the year I89o it was considered rare, but at the present time it is not by any means uncommon; it occurs as a winter visitant in most places in the district, and nests more or less frequently all over the division, from Loftus on the south-east to Yarm on the north-west, at which latter place there has been a small colony for the past ten years; it also breeds in the dales on the south and south-west almost up to the moor edges, as at Danby and Swainby.

The Migration Reports do not contain any reference to the Hawfinch at the Yorkshire stations, though a striking feature in its increase is that, in I902, an example was reported from one of the Yorkshire lighthouses, and it would thus appear that it may now be looked for as a migrant on our coast.

The nest is usually in low situations, such as fruit trees in orchards, low growing oaks, or thorn bushes; in Wharfedale Mr. E. P. Butterfield states the birds are not at all shy and have to be frightened off their nests, but this is contrary to the general experience, which is that they are of the shyest nature and forsake their nests on the very slightest interference, though in a few instances I have known them exhibit the trait Mr. Butterfield refers to. 
Since 1897 there has been a large colony in Cleveland (the precise locality of which it would be unwise to indicate), where some twenty to thirty pairs breed in comparative security; the first year or two the nests were on low and easily accessible trees, some not more than five feet above the ground, but, after being disturbed, they changed their places of abode, and for the past three years most of the nests have been built on the extremities of branches of oak trees in a plantation, and are not discoverable until the fall of the leaves in autumn. The usual time for nesting is the third week in May, though a full clutch of eggs has been found on the $13^{\text {th }}$ of that month. In the early days of this colony the nests were mere platforms of twigs and a few roots ; afterwards more elaborate structures were built, with cupshaped nests on the platforms, made of roots or pieces of fibrous bark, and lined with grass and hair. In the year Ig02, although it was known that nearly thirty pairs were in the locality, only two nests were discovered, the remainder being hidden by the thick foliage on the trees; consequently a swarm of young birds made their appearance in the neighbouring gardens, and commenced an onslaught upon the pea crops as soon as the pods began to fill. The irate owners, whose property was thus destroyed, waged war on the plunderers, with the result that, up to the middle of September, no fewer than thirty-five, young and old, were killed by means of traps, guns, and bird-lime. On the 9 th of September I saw whole rows of peas that had been demolished by the powerful beaks of the Hawfinches, instruments well adapted for such purposes.

A departure from the usual type of egg is occasionally met with, and some of a bluish colour have been found in the Masham neighbourhood.

The local names are few :-Grosbeak is of general use, and Cherry Finch is applied to it at Upsall, Swaledale. 


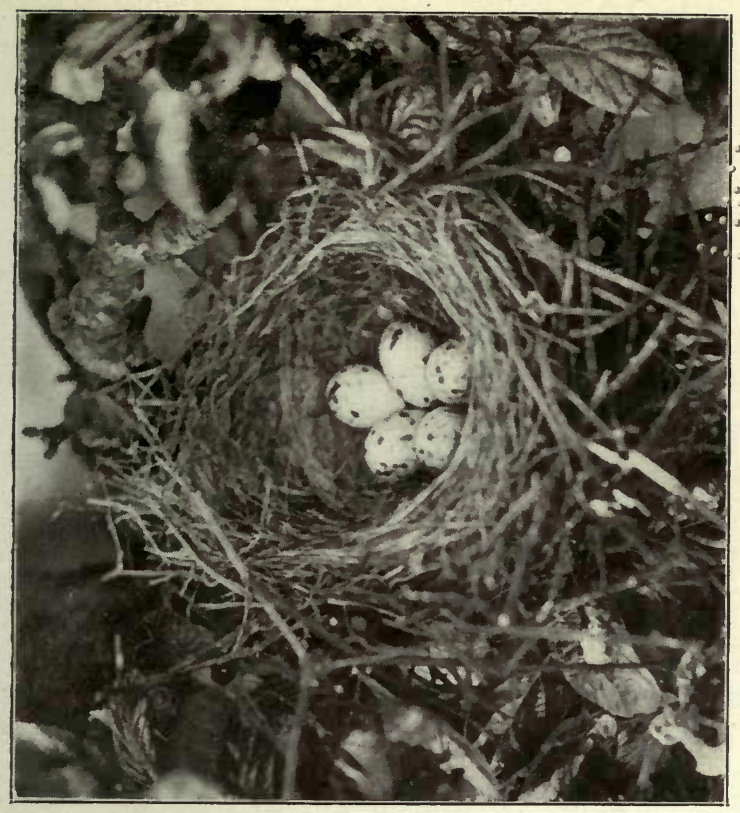

j, כj, כj,

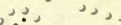

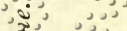

文,

, वे, , ग,

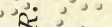

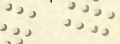

装

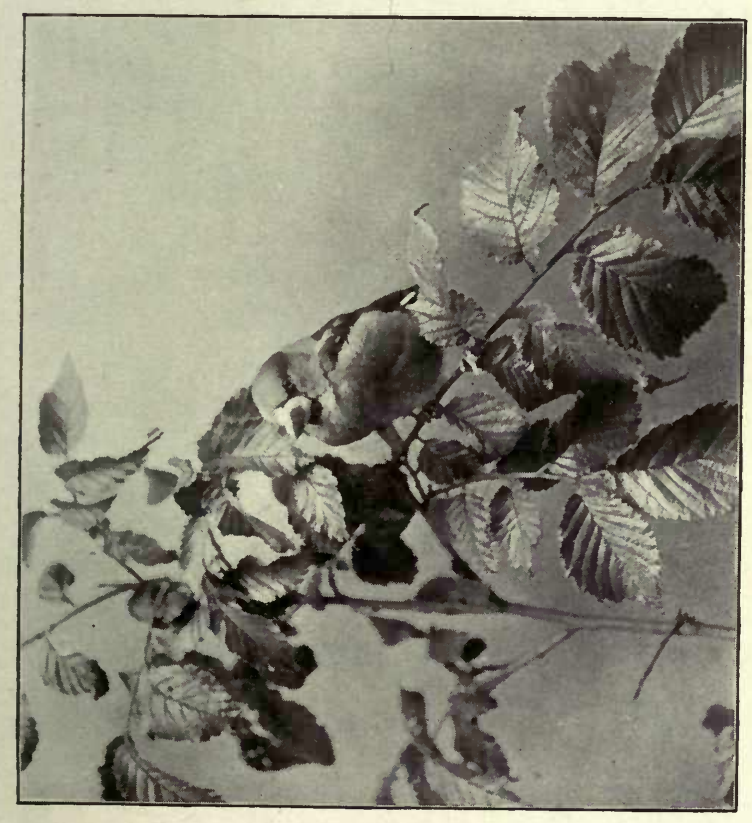

¿্

염 



\section{GOLDFINCH.}

\section{Carduelis elegans (Sleph.).}

Resident, local, not common, decreasing in numbers; a few migrants in autumn.

This species was first alluded to as a native of Yorkshire by Marmaduke Tunstall, in I783, thus :- "Goldfinch.Called in the north of England Redcap and Gold Linnet." (Tunst. MS. p. 68.)

Thomas Allis, in I844, wrote of it as follows:-

Carduelis elegans.-Goldfinch-Common at Doncaster and Hebden Bridge; formerly by no means uncommon near Halifax, now nearly extinct; it is met with near Leeds; is not very common about Huddersfield: it is very plentiful in the moorland districts near Barnsley; it is rarely seen in the immediate neighbourhood of York, though pretty abundant a few miles to the east of the city: it is obtained about Thirsk.

This charming little finch, which was formerly abundant in most cultivated districts, is becoming extremely rare, its decrease in highly farmed neighbourhoods being attributable to the destruction of those plants on whose seeds it usually feeds; in some places linseed and flax were extensively cultivated for manufacturing purposes, and in harvest time the birds were attracted to the ripening seeds; this industry has almost died out, and, with its decline, a corresponding decrease in the number of Goldfinches has taken place. The professional bird catchers are also partly responsible for their scarcity, as many used to be snared in autumn to sell for cage birds, and so recently as I904 no fewer than seventeen were captured near Knaresborough; the result is that in only few places can it, at the present time, be found nesting in a wild state. In the south, south-west, and southeast portions of the West Riding it is almost extinct as a nester, though it was formerly plentiful in suitable localities; odd pairs still breed near Wakefield, and about Ackworth it is slightly increasing. In the Leeds area it used to be frequent near Sherburn-in-Elmet when teazle was cultivated, 
and it fed on the seeds; in 1878 a small flock was observed in a market garden in Meanwood Road, the first reported from there. In Lower Wharfedale it was abundant when flax was extensively grown; Oglethorpe Whin cover, where it still nests sparingly, used to be a favourite haunt. In the. Nidd valley it continued to nest up to I882, as also in the Washburn valley near Fewston; at Staveley; near Ripon, and in the north-west of the county, though in most of these districts its present status, generally speaking, is that of a winter visitant in small numbers.

Many years ago Goldfinches were caught in the Castle Yard at York; as breeding birds they are now scarce near the city, except at Sandhutton, where some considerable numbers nest, though not so many as formerly; in the central valleys of the North Riding it is extremely scarce as a nesting species, but it bred in upper Teesdale in I87I. In the Scarborough district it was met with in the years I900 and I90I; and appears to be slightly increasing there, several nests being found in I905. It is a scarce resident near Whitby; at Loftus it is frequent in winter, though it rarely breeds there. It used to be plentiful in north-west Cleveland about the "sixties" when linseed was freely grown, now that the cultivation of that plant is discontinued it has become very rare; it is generally a winter visitant, only nesting sparingly in one or two localities.

In the East Riding it is not uncommon at Pocklington and within a radius of several miles in the surrounding district, where it nests annually; it is occasionally found at Market Weighton, but is scarce at Knapton and Scampston, and generally noticed only in winter. It bred formerly near Bridlington, but has greatly decreased in numbers, while near Flamborough and Spurn it is only a winter visitant on migration. In the Beverley neighbourhood it is scarce, and as soon as it makes its appearance it is eagerly sought after by the bird-catchers. It was formerly exceedingly numerous, and there is very good authority for stating that no less than four hundred were captured on the site of the present Union at Beverley in a few days; this small 

site, at that time being a waste covered with thistles, knapweed, etc.; these were caught by a famous bird-catcher called Greenhough, and large numbers were taken in other years by him and other well-known bird-snarers. More recently these birds have been regularly sought for in the autumn; the bird-catchers traverse the country in all directions with a Goldfinch in a small cage, which, on hearing its wild relatives, immediately gives warning; the men, from long experience, know all the likely localities, such as commons, where the knapweed is seeding freely, and bits of uncultivated, or waste, land, where thistles are allowed to seed. In the early autumn the old birds and their broods usually keep together, and the young are easily caught, the old birds falling victims later. It still nests in a few localities in Holderness, especially in plantations of old Scotch firs, and in spring it feeds on the seeds of the fir cones. It has also nested sparingly near Hedon and Aldborough.

As a migrant the Goldfinch occurs regularly on the coast in October, but never in large numbers, although it was fairly plentiful in 1880 . The returns from the light stations afford but slight information respecting its occurrence, and there is only one entry referring to its spring passage. The following items are extracted from the Migration Reports :-

"I88I. A few seen at Spurn on October 27th.

I882. At Spurn, on April 2oth, six from south, remaining all day.

At Spurn in autumn. Some in October.

I883. November 22nd. Tees L.V. One on board."

In the year 1898 there were several noted on the sanddunes at Spurn on the Igth of November, and in Igor I noticed an arrival at the Teesmouth on the $4^{\text {th }}$ of November.

There is a common belief amongst bird-fanciers in Yorkshire that the Goldfinches obtained from pear-trees and sloe-bushes are better singers than those reared from other trees; the former are synonymous with the "Cheverel " or "Chevil" ; in some parts this is termed the pear-tree Goldfinch, while the other so-called variety is the apple-tree Goldfinch, though, technically speaking, there is only one true 
species (See Yarrell's “ British Birds,” Ed. 4, Vol. ii., p. I24).

The provincial names by which the Goldfinch is known are:-Goldie and Gold Spink, given by Swainson as in general use, the latter term being dialectically modified in Craven to Gowd-Spink. Tunstall, in 1783 , mentioned it as known as Gold Linnet in the North of England, pronounced Gowd Linnet in the North Riding, and Gold Lenny in Cleveland. Redcap is another term in general use, and King Harry or King Harry Redcap, in the North and East Ridings; Thistle Finch is a North Riding name, and Captain a West Riding one; while Grey Kate or Grey Pate are, in the North and East Ridings, applied to the young.

\section{SISKIN.}

Carduelis spinus (L.).

Winter visitant, of uncertain appearance and in varying numbers.

The first notice of the Siskin appertaining to Yorkshire appears to be in the Allan MS., I79I, of the Tunstall Museum (p. 205 of Fox's "Synopsis)," where it is stated that this species "Visits us at uncertain times, but chiefly in winter, and never known to breed here."

Thomas Allis, in 1844, referred to it thus :-

Carduelis spinus.-Siskin-Rather common near Sheffield some winters. J. Heppenstall observes "Last year I received several which were shot feeding on the seeds of the alder; it visits our gardens most autumns along with Fringilla montefringilla, the attraction seems to be the seeds of the sycamore; I was informed in Hertfordshire that they had large flocks last winter feeding on the seeds of arbor-vitæ." It is common in flocks in winter near Bridlington; it is an irregular visitant near Halifax, but was very abundant in the winter of $1835-6$; it is not infrequently obtained near Doncaster, in April 1837 a large flock was seen in Sandall Beat; it is met with rarely near York and Barnsley; it is common near Hebden Bridge in some seasons.

Although reported to have bred in Yorkshire, the alleged instances of the discovery of its nest are so few that the Siskin cannot accurately be described as a resident species, and must rank as a winter visitant, irregular in numbers and 
varying greatly in different years. It is chiefly noted in situations where alders grow, those trees being favourable for the production of its favourite food. The nest is said to have been found near Halifax about I850 (F. G. S. Rawson), Walton Hall (A. G. More, Ibis, I865, p. I29), and at Haxby near York (Zool. I850, p. 2676), but it is doubtful if these reported discoveries are to be relied upon, except in the case of the Walton Hall occurrence which was vouched for by Charles Waterton, who gave the particulars to Mr. More. In more recent years, however, one or two pairs have nested near Pickering.

In the West Riding it was fairly abundant about fifty years ago, much more so than at the present time; it now only appears intermittently and in small numbers, though it was unusually numerous near Bingley, in Airedale, in the winters of $1902-3$ and $1905-6$; in the north-west it is very scarce and is only occasionally found in the dales. In the East Riding it is not a common visitant, but formerly it was frequent near Pocklington and was often brought in by bird-catchers; at Flamborough it is only seen on migration in autumn; it has occurred sparingly at Scampston, Market Weighton, and Beverley, and is reported at Spurn on its passage in most seasons. In north Yorkshire it is a fairly regular visitant, and when away from the coast is generally found by the margins of streams, and frequently in company with Redpolls; it is met with in most of the valleys in the central portion of the North Riding, is somewhat scarce in the north-west, and has been noted at High Force in upper Teesdale. As early as 1808 Graves mentioned it in his list of Cleveland birds, and in 1844 John Hogg stated he had seen a few ; it still occurs annually but is uncertain as to numbers.

As a migrant at the light stations it appears regularly in small parties between Spurn and Easington in autumn, haunting the lanes and drain banks, feeding on seeds of nettles and other plants, and generally so tame as to allow of a near approach. It was abundant in the autumn of I88I, in October, both at Spurn and at the Teesmouth, in flocks 
up to twenty, but more generally two or three together; they were mostly females and birds of the year, only very few being old males. In 1889 there were several at Spurn associated with Mealy Redpolls. At Flamborough it is also seen during the autumn migration, and on 2Ist November I893, three were reported in company with Snow Buntings. On the Cleveland coast it is observed on both the spring and autumn passages; at the former period very irregularly and only in small numbers, usually at the end of April or early in May; on Ist May Igor, several came with Greenfinches from due east (see Greenfinch). In the autumn migration it is in greater abundance and more regular in its appearance ; on 23rd September I9or, there was a large arrival at the Teesmouth, and many remained for several days feeding on the sand-dunes; they were also observed at inland localities, and on the 3 oth of October there was a great flight from due north, with Larks, Greenfinches, and Snow Buntings.

A variety of a light fawn colour was noted by Mr. W. Morris, near Sedbergh, in October I905.

The only local name given by Swainson is Aberdavine, which he interprets to mean Alder Finch; this is not now in use in Yorkshire, although the Siskin was well known to old bird-catchers about Beverley under the name of Aberdevine.

\section{SERIN.}

\section{Serinus hortulanus (Koch).}

Accidental visitant from the Continent, of extremely rare occurrence.

This Continental species, which is of very rare occurrence in England, was claimed as a Yorkshire bird by the late G. C. Swailes of Beverley, and as the circumstances are exceptional it may be desirable to give his account verbatim, as follows :-

"I have in a small aviary here a pair of Serin-finches which have this season nested and reared a brood of young. 
On the 26 th ult. I was surprised to see near the aviary a strange male Serin, which stayed close by for some time, and so far as one could possibly judge, it was not an escaped bird. During the afternoon I heard it singing merrily its trivial song in the top of some tall oaks a few hundred yards from the aviary." (G. C. Swailes, Field, 5th June 1897.)

Mr. F. Boyes confirms Mr. Swailes's statement, and remarks that he also saw and heard the wild bird.

\section{HOUSE SPARROW.}

Passer domesticus (L.).

Resident, general, very numerous ; partially migratory in autumn.

The first Yorkshire allusion to the Sparrow is in a communication from Ralph Johnson of Brignall, near Greta Bridge, to John Ray, bearing date 29th March I672 :-

"Honoured Sir, I have only observed this change from proper colours to white . . . and in Sparrows (P. domesticus) which is usual. ..." ("Correspondence of John Ray," p. 96.)

Thomas Allis, I844, wrote:-

Passer domesticus.-House Sparrow-Abundant everywhere.

The ubiquitous Sparrow, which is only too numerous in this as in other counties, flourishes exceedingly wherever there are human habitations, and even in the dales up to an elevation of rooo feet; in the latter situations it sometimes nests in rocks with Jackdaws and Starlings away from civilization.

Common as this bird is, however, it may not be generally known that it is a regular migrant, and of this fact there is abundant evidence in the returns sent in from the light stations on the coast, which show that both in spring and autumn considerable numbers cross the North Sea; in the latter season from the first week in September to the end of the year, and often in flocks of hundreds, some of which 
rest on light-vessels, and resume their course in the morning. At Spurn in I880 an immense flock, evidently freshly arrived, was noticed on the shore; there was a great " rush" from October I4th to I9th I884; another from 3 rd to 7 th October I886, and again from the 18 th to the $23 \mathrm{rd}$. Many also came in from 2nd to 6th November 1895. Large flocks of clean looking birds, which are undoubtedly migratory, are frequently noticed at the Teesmouth in winter, feeding on the reclaimed lands.

The damage caused by Sparrows to ripening corn has long been a subject of complaint and led to the customs, which formerly prevailed in many villages, of paying "Sparrow money" for their destruction. At Falsgrave, now part of Scarborough, in 1809 , the overseers were empowered to pay 3d. per dozen for all killed and brought to them, and Id. per dozen for their eggs. In some parishes the money paid formed an important amount, as at Worsborough, where in I820 488 sparrows were paid for at $\frac{1}{2} \mathrm{~d}$. each $-f_{\mathrm{I}}$ os. $4 \mathrm{~d}$. (Wilkinson's Worsborough). At Patrington the prices were for two Sparrows $\frac{1}{2} \mathrm{~d}$., four unfledged $\frac{1}{2} \mathrm{~d}$., six eggs $\frac{1}{2} \mathrm{~d}$. In various other Holderness villages similar amounts were paid, and this custom continued until about 1850 , the village boys thus obtaining a good supply of pocket money. In the parishes of Micklefield near Leeds, and Wakefield, a premium was offered for the killing of Sparrows, and was continued until I872: for every old or fully fledged bird $\frac{1}{2} \mathrm{~d}$., for two young ones $\frac{1}{2} \mathrm{~d}$., for four eggs $\frac{1}{2} \mathrm{~d}$. At Linton-on-Ouse the overseers paid Id. for males and $\frac{1}{2} \mathrm{~d}$. for females; the gunners used to shoot the male of a pair, the hen then got another mate, and no less than seven males have been killed in one place; that is, a hen has had seven mates before she was driven away (Zool. I865, p. 97II).

In connection with this bird there is a proverbial saying near Hatfield, "There are no Sparrows in Lindholme," which has arisen from the circumstance described as follows:“ Tom o' Lindholme, being left at home to protect the corn from Sparrows, to save trouble, got them all into the barn, put a harrow into the window to keep them in, and starved 
them to death." ("Hatfield Chase.") Lindholme is about three miles from Hatfield (Notes and Queries, Ser. i., Vol. viii., p. 532).

The choice of nesting sites is occasionally varied from the usual one; near Beverley eggs have been found in Sand Martins' burrows, and in Cleveland I have seen nests placed beneath those of Rooks in a rookery. Both birds and eggs are subject to great variation; of the latter a brown coloured clutch, resembling those of a Skylark, found at Kirkleatham on 8th June 1892 , is one of the most unusual. As regards varieties in plumage, there used to be a black breed at Leven near Beverley; the males were a deep blackish brown, so nearly black as to be only distinguishable from that colour when in the hand; the hens a shade lighter, and the young slaty black. The late W. W. Boulton had three sent in I865, which are now in the possession of Mr. F. Boyes (Zool. I865, p. 953I). Albino, white, pied, buff, and bluish coloured examples are also met with, and are rather common near Beverley; at Northallerton a female, perfectly white, had a white brood, one of which was captured.

Early and late nesting is not uncommon with such a prolific species, but one or two examples of each will suffice. Eggs were found on 27th January 1874, and young were recorded on 2Ist February I846, near Huddersfield; late in the year the eggs have been seen in November 1874, whilst on I2th December 1862 an egg was picked up on a pavement in Leeds.

Local vernacular names:-Spadge or Spadger are in general use ; Spuggy is a Cleveland term ; it is Tile Sparrow at Doncaster, and Collier at Skelmanthorpe, near Huddersfield. 


\section{TREE SPARROW.}

Passer montanus (L.).

Resident, local; large flocks of migrants arrive in autumn.

The first reference to this species is contained in a communication from Dr. Sherrard (the botanist and friend of John Ray) to Walter Moyle, and is dated London, May Ioth I720. It reads thus:-

"Having received a letter from my old friend Dr. Richardson of North Bierley in Yorkshire, with a bird he thinks new, I wou'd not neglect acquainting you of it and offering you it if you have it not. He calls it Passer domesticus minor, torquatus, vertice cupreo; 'tis the hen. The cock, he writes me, has a much fairer ring about his neck." (The works of Walter Moyle, Esq., I726. J. E. Harting, in introduction to Rodd's "Birds of Cornwall.") It is also referred to by G. Edwards, who had a specimen sent from Landesburg in Yorkshire. ("Gleanings of Natural History," I760, Part ii., p. I24.) Pennant, after giving a description of the bird, added: "We are obliged to Mr. Edwards for this description, who first discovered them to be natives of Yorkshire." (“Brit. Zool.," I766 Ed., p. Iog.)

Thomas Allis, in $\mathrm{I} 844$, wrote:-

Passer montana.-Tree Sparrow-Near Sheffield, Halifax, and Barnsley this bird is infrequent ; it is met with near Leeds and Doncaster, and is not uncommon in the vicinity of York. Arthur Strickland observes "It is well known that this bird usually builds in hollow trees, but, as a proof how circumstances alter their habits, or perhaps they return to their more natural ones, at Walton, where birds are protected from injury, it, for several years, built in a clipped hedge near the house, making a nest of sticks closed in on all sides like that of a Magpie; unfortunately the hedge was cut down and they forsook the place."

The Tree Sparrow is resident, local, and rather eccentric in its distribution, though during the past twenty years it has greatly increased and multiplied in numbers; in 
some districts it is now quite common and nests in large colonies. In the south of the West Riding it is somewhat rare, abundant in the south-west and towards the central portions, and very scarce in the north-west; it is not uncommon, though local still, in the lower portions of the valleys of the Nidd and Wharfe, and the northern parts of the Riding. In the North Riding, in the neighbourhood of York, it is a plentiful species, as also near Thirsk, Pickering, Bedale, Northallerton, and in Swaledale and Teesdale. In Cleveland it is not very plentiful, and the same remark applies to the Whitby and Scarborough localities. It is fairly numerous in some parts of the East Riding, as at Flamborough and Bempton, Lowthorpe, Beverley, and other places in Holderness.

Large flocks of immigrants arrive on the coast in autumn, at the time when the Greenfinches are migrating, but as a rule not often to the north of Flamborough. The Migration Reports contain only two references to its occurrence at this season, at stations north of that headland, viz., in I884, on the gth September, "One at Whitby L.H.," and in I887, on October the 2nd, "One at the Tees L.V." A return passage is sometimes observed in early spring.

In winter the Tree Sparrow often frequents the stackyards and feeds in company with Finches and other small passerine birds. Up to I86o great numbers were caught at these times in traps and sold to the constable at Linton-onOuse for a half-penny each (Zool. I86I, p. 78I8). In some localities it does not belie its name and builds in pollard and decayed trees and bushes, though it departs from this habit, in many instances adapting itself to its surroundings, and chooses other sites for its nest; in the Aire valley it selects crevices in canal bridges; near Wakefield, stone quarries; at Wilstrop it prefers holes in walls and in stacks; near Northallerton a colony nested in the thatched roof of a farm outbuilding; at Beverley the nest has been found in the burrows of Sand Martins, and commonly in chalk pits and pollard willows away from human habitations, where its sharp chirruping cry cannot be mistaken; and at 
Flamborough it breeds in the upper parts of the cliffs, and also in Lloyd's signal tower.

At Linton-on-Ouse, in $1860, \mathrm{~J}$. Ranson had upwards of a hundred eggs through his hands, and did not find so much dissimilarity amongst them as in the ordinary House Sparrow.

The local names recorded are:-Rock Sparrow at Halifax; and Red-headed Sparrow at Linton-on-Ouse. Mountain Sparrow is Pennant's name; and Cuddy was applied to it in the North Riding by Tunstall (but I do not find mention elsewhere of this name as referring to the Tree Sparrow.)

\section{CHAFFINCH.}

Fringilla colebs (L.).

Resident, generally distributed, common. A great influx of migrants takes place in autumn.

This species was first noticed as a Yorkshire bird by Marmaduke Tunstall, in 1784 , thus :- "The Chaffinch-Fringilla colebs. In the north of England called Spink from its cry, as is probably its French name Pinçon; also White Linnet and sometimes Flaxfinch." (Tunst. MS. I784, p. 67.)

Thomas Allis, I844, wrote:-

Fringilla calebs.-Chaffinch-Very common.

The well-known and favourite "Spink" of birds' nesting boys is abundantly distributed in all parts of the county, excepting the moorlands, ascending the dales to a height of I 100 feet, at which elevation it has nested in Teesdale where it replaces the House Sparrow.

During the autumn migration immense numbers arrive on the coast from mid-September to the end of November, often in company with Larks, Greenfinches, and other small migrants, the first flocks usually consisting of young birds ; the adult males, in comparatively small numbers, coming 
later. Sometimes they alight on board vessels at sea, and as early as $1833 \mathrm{Ed}$. Blyth recorded the fact of two female Chaffinches coming on to his ship off Whitby on October the 7 th (Rennie's Field Naturalist, I833). The Migration Reports contain frequent interesting entries concerning the passage of this bird; in 1879 migration extended over seventy days from the I 7 th of September to the Ist of December, and extensive flights are noted almost annually. There was a great "rush" at Redcar on 2oth November I884, but the heaviest migration ever chronicled was in I886, and was observed along the whole length of the east coast, the chief "rush" being between the 3 rd and the 6 th of October; on 23rd December I9or, several small flocks passed Redcar going southward. Late in spring the foreigners congregate on the lands bordering the coast, preparatory to the return journey northward.

The habit of separation of the sexes in winter need not be commented upon here further than by stating that the hens and young birds assemble in the low country, whilst old cocks, in smaller flocks, keep to higher ground.

Instances of the Chaffinch singing as early as January or February, and as late as October, have been known. An example of exceptionally early breeding took place in 1873 at Heckmondwike, where eggs were found on the 8 th of March ; and amongst the numerous cases of curious localities chosen for building sites the following may be mentioned: a nest built on an old Swallow's nest which had been placed on a beam, in a field shed at Scampston; two nests built together, one on top of the other, at Linton-on-Ouse in I866; and one at the foot of a large oak at Hebden Bridge. A nest at Northallerton was found on Ioth May I882, patched all over with pieces of newspaper in lieu of lichens. At Beverley the nest and eggs have been found built inside a deserted nest of the Mistle Thrush.

The cock bird has been occasionally noticed sitting on eggs, one such instance being recorded at Settle, though it may well be that this was in mistake for a hen in male plumage, an example of which was shot at Chapeltown near Leeds, 
on I6th May I887; in its ovary were two eggs, one of which had the shell partly formed and the yolk perfect (Ibis, I888, p. 228). Other varieties in plumage, albino, white, pied, and cinnamon coloured, have been met with, and Tunstall mentioned a light coloured specimen given to him "by the Hon. Fred Vane of Sellaby, brother of Lord Darlington, taken in this neighbourhood [Wycliffe-on-Tees]. It had much white, and some fine yellow feathers on the back and shoulders. If it had not been taken in a wild state, should have almost judged it to have been bred between a Chaffinch and a jonquil Canary Bird." (Tunst. MS., p. 67.)

Variations from the ordinary type of eggs, entirely of a light blue colour, like those of the Pied Flycatcher, are not uncommon; and the late Canon Atkinson mentioned a clutch of very pale buff, slightly tinged with vinous colour ("Moorland Parish," p. 342).

Its local names are numerous. Those in general use are Spink, White Linnet, Spinky, and Bullspink; Pink is used in the Nidd valley; Bully or Bullie in the North Riding and the Nidd valley; Shilfa, Sheelfa, or Sheelie, Wet Bird, and Scobby or Scobbie in the North Riding; Weetie in central Yorkshire to the coast; Wintie in the East Riding; Chaffy in Cleveland ; and French Linnet and Fleck Linnet in southern Holderness ; whilst Tunstall called it Flaxfinch.

\section{BRAMBLING.}

\section{Fringilla montifringilla (L.).}

Regular winter visitant, but varying in numbers.

The earliest reliable notice of this species in Yorkshire is contained in Atkinson's "Compendium of British Ornithology," I820, p. 68, where it is stated to be "pretty common in Yorkshire." 
The Brambling, or Lesser Mountain Finch, of Willughby is undoubtedly the Snow Bunting.

Thomas Allis, I844, wrote :-

Fringilla montifringilla.-Mountain Finch-A few met with in most districts every winter; occasionally more abundant.

This pretty Finch is a constant winter visitant, but irregular in numbers, being very abundant in some years and comparatively scarce in others. It may generally be expected in the first or second week of October, though an exceptionally early date is the 2nd of that month in the year Igor, when several were noted at the Teesmouth; it was also recorded at Wakefield on the same date in I883; the earliest arrival at Spurn was on the 26th September I896. It is fairly well distributed, and, as it is particularly partial to beech mast, the woods where this fruit is in greatest abundance are most favoured by its attentions.

In 1864 these birds were very numerous, and in $1898-9$ they were particularly abundant, thousands being seen in the beech woods, where they were very tame and allowed a close approach. In the dales it is sometimes met with almost on the edges of the moors and occasionally remains till late in spring; one or two were seen on Bluberhouse Moor on Ioth April 1887 , though it usually takes its departure before this time. The latest record for Spurn is the 9th of April, when a beautiful male in breeding plumage was observed.

In severe winters, when frost and snow cover up its ordinary feeding grounds, it betakes itself to the stack yards, and there consorts with Chaffinches and other small birds, returning to the fields and woods with milder weather. It was unusually plentiful in the farm-steads in Cleveland during the hard frost of January and February I895, and in November 1896, it was common in south Holderness. Seebohm stated ("Br. Birds," Vol. ii., p. 98), that in a "Brambling year" great numbers resort nightly to roost in Meersbrook Park near Sheffield, in company with Redwings.

The migration in autumn commences as a rule in October, and continues in some seasons until December or early in January of the following year. Late in autumn flocks, 
often of great size and entirely composed of old males, occur on the coast, and the stubble fields are on their arrival favourite localities for them. When migrating, or shifting their ground, they fly very close together like Knots and may thus be distinguished from other small birds at a distance. On I8th October I882, an immense flock, extending over two hundred yards in length, was observed at Spurn, and on the I2th and I $3^{\text {th }}$ of the same month there was a considerable arrival at the Teesmouth in company with Greenfinches, Snow Buntings, and Linnets; a great " rush" was also recorded in October 1895, at the Humber and Tees estuaries. The Brambling has been known to alight on vessels at sea, and as early as I855 three were brought into Middlesbrough, having been captured in an exhausted condition on board a ship, as it was taking the Tees, on the evening of the I4th of October.

The late Canon Atkinson wrote a circumstantial account of the supposed nesting of this species at Baldersby Park, near Thirsk, from particulars supplied by the late Hon. Guy Dawnay, who forwarded him the nest, which was constructed of moss, wool, and grass outwardly, and lined with hair and fine feathers, containing the full complement of eggs, and had been found on the side shoot of an oak about six feet above the ground (Zool. I864, p. 92Io; Ibis, I865; Field 23rd July I864).

Mr. Dresser, however, considers it extremely improbable that the nest and eggs were those of the Brambling ("Birds of Europe," Vol. iv., p. I6).

A white example was in the late James Carter's possession at Masham, obtained in I88I ; and a pied specimen has been seen at Harrogate.

The vernacular names are not numerous. Mountain Finch and Bramble Finch are in general use; French Linnet or French Lenny is used in the North Riding ; and Over-sea Lenny at Loftus and Staithes. 


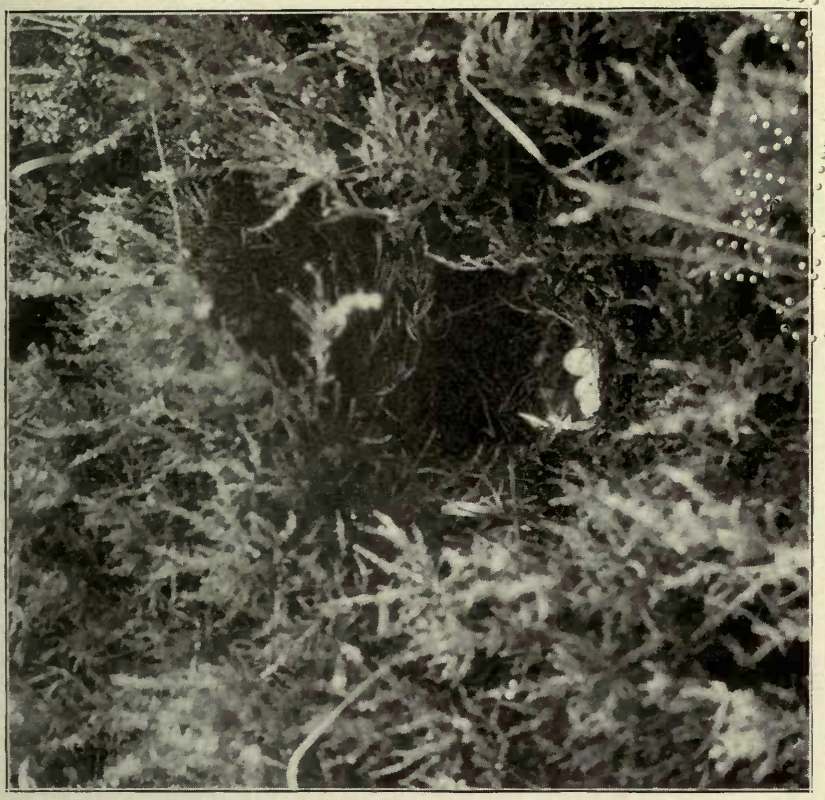

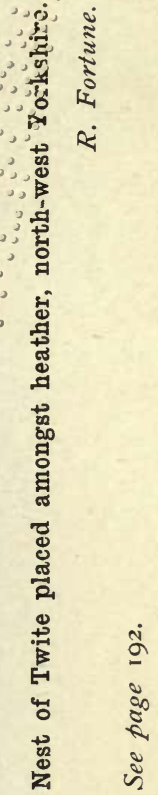

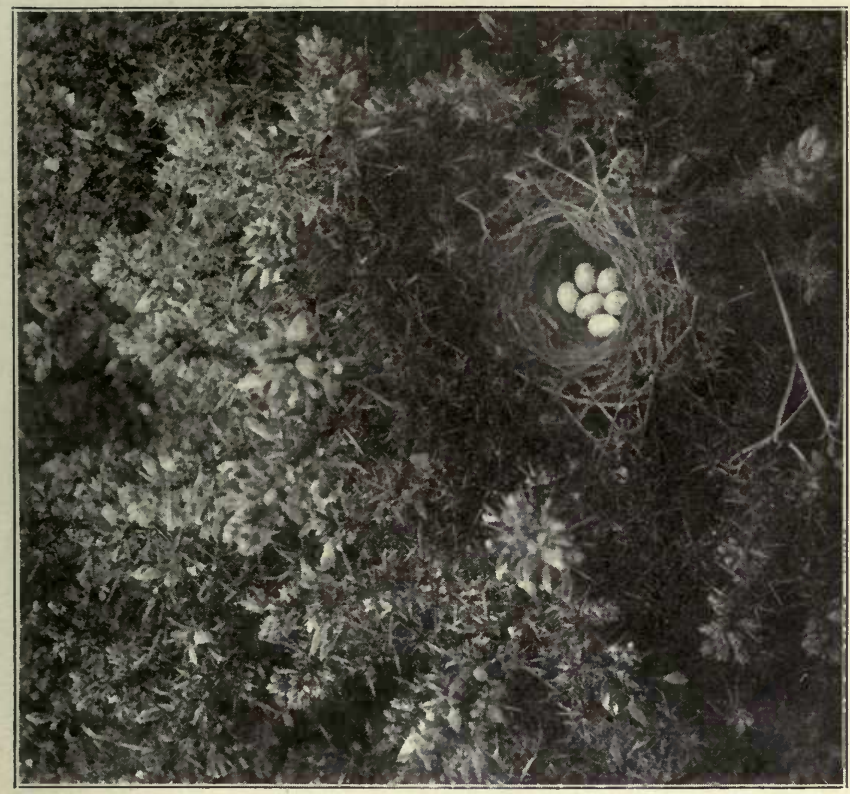

¿̇

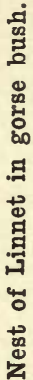

i்

క్ర

\&े 



\section{LINNET.}

\section{Linota cannabina $(L$.).}

Resident, common, and generally distributed. Large numbers of migrants arrive in autumn.

The earliest mention of the Linnet in connection with Yorkshire is found in the following communication from Mr. Jessop of Sheffield to the well-known John Ray, thus :"Sir, ... I have gotten a black-legged Linnet (L. cannabina). ... I am, . . . Fra. Jessop. Broomhall, November 25th I668." ("Correspondence of John Ray," p. 33.)

Thomas Allis, I844, wrote :-

Linota cannabina.-Common Linnet-Frequent in most districts, especially the moorlands.

The Common Linnet is resident and, as its name implies, common; it is generally distributed, particularly on moors or waste and uninhabited lands. Like its more handsome relative, the Goldfinch, its numbers have lessened during the past few years, and this is owing to the same causes which have led to the decrease of the former species, viz., high farming, the discontinuance of flax cultivation, and the wiles of the bird-catchers, who are ever on the look out to entrap them for cage birds. It is, however, still common where gorse abounds; on the cliff tops near Flamborough and Bempton it is particularly numerous in the nesting season amongst the whin covers and in the bye-lanes; in the Aire valley it frequently nests in whitethorn hedges ; and at Spurn, where it breeds regularly on the sand-dunes, the nests are sometimes lined with feathers of the Lesser Tern.

During the autumn large migratory flocks arrive from over-sea, in September and October, and occasionally on the return passage in spring. In $I 884$ from the 9 th of September to the end of October great numbers were reported, and also in 1887 from the 8 th of October to the 3 rd of November; these occurred at all the light stations between Teesmouth and Spurn, and on the I6th of April I887, many were seen at the Teesmouth going north-west. In the autumn of 
I898 thousands were noted on the coast between Easington and Kilnsea (see Migration Reports). On their arrival they often remain for some time on the sand-dunes and waste lands near the coast, afterwards resorting to the stubbles where they feed in company with Greenfinches and other small birds, and it is at these times that large numbers fall victims to the snares of the bird-catchers.

Instances of late nesting are occasionally met with. One such is reported from Kilnsea, where a nest with callow young was found on Ist September I886. Spotless eggs are occasionally reported; a clutch in my collection was found at Malton by Mr. S. H. Smith and others have been noted at Strensall and Great Ayton.

As regards variation in plumage, two examples of an isabelline type; one with white primaries and tail feathers, and another with a pure white head, have occurred at Beverley; one at Bawtry had a white ring round the neck (Neville Wood's Nat. I837), and an albino specimen is in the possession of Mr. Wm. Morris of Sedbergh.

Of local names, we have Brownie in the North Riding; Grey Linnet, Red Linnet, and Lemon Bird, applied according to the stage of plumage in which the bird appears; Red Lenn at Huddersfield; Robin Linnet in Nidderdale; Song Linnet at Ackworth; Goss [Gorse] Linnet near Doncaster; Whin Linnet at Sedbergh and in the East Riding; Thorn Linnet in Ribblesdale; and Bent Linnet at Spurn; while the term Brown Linnet, and Lennert or Linnet, are of general application.

\section{MEALY REDPOLL.}

Linota linaria (L.).

Winter visitant, of irregular occurrence.

Probably the earliest notice of this bird is contained in Thomas Allis's oft-quoted Report of I844:-

Linota canescens.-Mealy Redpoll-One specimen shot in the winter of 1839 at Sheffield is in the possession of John Heppenstall. 
Of the different races of Mealy Redpoll, as classified by modern ornithologists, three have occurred in Yorkshire, and these will be treated separately and in order.* The one to be first considered is L. linaria, what may be termed the typical form; this is an inhabitant of northern Europe and Asia, and an uncertain winter visitant to this county, some years being comparatively abundant, while perhaps several seasons may intervene between its visits.

It is very scarce in the West Riding, though a large number were observed in the Aire valley in the winter of $1877-8$, and a flock was seen at Kirkburton in 1876 ; it has also been met with sparingly in other localities; several were shot at Fewston in the winter of 1892 ; it has been once reported from Ackworth, and one with curved mandibles is recorded at Skipton (Zool. I883, p. 259).

In the East and North Ridings it has occurred rarely at a few inland places; there was a flight at Beverley some years ago ; and at Market Weighton, Pocklington, Richmond, and Thirsk it has been noticed, but only as a very scarce winter visitant.

On the coast line it appears at intervals in considerable flocks, as in $1855, \mathrm{I} 86 \mathrm{I}$, and I876, and then for years it may be absent altogether. A large arrival took place, in company with Siskins, in October I88I ; at Spurn a great flight arrived on the night of the 24th, and a beautiful adult male was caught at early morning of the 25 th, fourteen or fifteen more being seen in a garden. They were numerous in the vicinity of Spurn, Kilnsea, and Easington from the 25th to the 27th, in small parties of thirty or forty, but generally three or four on plants of Sea Starwort. Some were beautiful old birds, very mealy, and besides the patch of blood red on the forehead, had the breast and rump washed with delicate crimson rose. Out of twenty-four obtained from various flocks all but two were males, either old or young; the stomachs contained seeds. There was a marked difference in the length and depth of

* See Yarrell's “British Birds,' 4th Ed., Vol. ii., pp. 5-7; and Saunders' Manual, 2nd Ed., p. 189. 
the bills, and this in examples shot from the same flock, indicating probably that the migration was made up of birds coming from widely separated districts in Scandinavia. At Redcar, on the $24^{\text {th }}$ of October in the same year, five alighted on the road opposite my window, at Io a.m. ; two were seen in a garden, and several others came on to the Tees Breakwater; at Spurn in I889 some arrived with Siskins from October the 2oth to the 24th; they were also observed in the autumn of I89I; at both Spurn and Flamborough in I893, and a small flight appeared in 1895 .

\section{NORTHERN MEALY REDPOLL.}

\section{Linota exilipes (Coues).}

An extremely rare winter visitant from northern Europe, Siberia, and northern America.

The breeding range of Coues' Redpoll, which is the second of the three Yorkshire species, is confined to the north-eastern parts of the Old World, including northern Scandinavia and probably the Arctic parts of North America, so that the bird may be termed circumpolar during the nesting season, migrating south on the approach of winter.

The first instance of its occurrence in this county was made known by the late J. Cordeaux, who had an example from the late H. B. Hewetson at Easington in the winter of I893-4 (Nat. I894, p. 84). Two others were obtained at Skeffling on the 30th of December I898 (op. cit. I899, p. 80).

Mr. Cordeaux expressed his firm conviction that this bird occurs much oftener than is supposed, and he has occasionally obtained Redpolls which are referable neither to $L$. linaria nor to $L$. rufescens, but which resemble the former so far that they have the margin of the body feathers more or less edged with a grey fringe, a seasonable change which is never seen in the Redpoll of the British Isles. (See also Yarrell, 4th Ed., Vol.ii., pp. 5-7; Saunders' “Manual," 2nd Ed., p. I89; and Harting's "Handbook," 2nd Ed., p. 376.) 


\section{GREENLAND MEALY REDPOLL.}

\section{Linota hornemanni (Holboell).}

An extremely rare winter visitant from Greenland, Iceland, and Spitzbergen.

This, the third of the Yorkshire Mealy Redpolls, has its habitat within the Arctic circle.

Its claim to rank as a Yorkshire species is founded on the fact that two examples were obtained at Spurn, one in October I883, and another in October I893. It was the first of these specimens and not $L$. exilipes which was figured by Lord Lilford in his magnificent work, and it is now in the Royal Scottish Museum. (Lilford's ". Birds," Vol. iv., pl. 29; see also Saunders' "Manual," 2nd Ed., p. I89; and Harting's "Handbook," 2nd Ed., p. 376.)

\section{LESSER REDPOLL. \\ Linota rufescens (Vieillot).}

Resident, generally distributed, common. An influx of migrants in autumn.

Probably the first allusion to this bird in connection with the county of York is the statement in Montagu's "Ornithological Dictionary" (I802), to the effect that "A nest and eggs were sent by Dr. Latham from Yorkshire."

Thomas Allis, I844, wrote :-

Linota linaria.-Lesser Redpoll-Common in most districts, breeding near Halifax in nearly every shrubbery and plantation.

This, the smallest British Finch, is a fairly common resident, though somewhat local, and breeds in most districts where it can find conditions suitable for its requirements; it is met with sparingly in the dales to a considerable elevation, but of late years its numbers have decreased, and especially in the neighbourhood of large towns, where it is becoming scarce, 
yet it holds its own in localities where it is secure from molestation by the professional bird-catchers. In the East Riding it is rare as a resident, and best known as a spring migrant, retiring southward in autumn. The statement in Yarrell's "British Birds" (I849 Ed., Vol. i., p. 5I5) that Halifax is the limit of the Redpoll's southern range is inaccurate, as it is known to breed in the midland and southern counties of England.

Its ranks receive considerable additions in autumn and winter from more northern latitudes; at the migratory season large flocks of new arrivals may be observed on the Cleveland sea-board, also at Flamborough and Spurn, generally in October when the main stream of migration is flowing; it was especially numerous in October I882; and at Flamborough in December 1895 , and January 1896 , there were more than had been known altogether for the previous twenty years (Nat. I89o, p. 84).

An albino variety was reported by W. Illingworth, from Horbury near Wakefield on 2Ist September I872, and a white one, picked up at Kirkheaton, is now in Mr. Alfred Beaumont's collection at Lewisham.

Its local and vernacular names are :-Red Linnet in the West Riding; Rose Linnet about York; Chivey about Huddersfield ; Chippet Linnet at Doncaster (I849); and Redcap at Ackworth; while Chivey or Chevy Linnet and French Linnet are in general use.

\section{TWITE.}

\section{Linota flavirostris (L.).}

Resident; not uncommonly distributed on moorlands of the West Riding, more sparingly in the North Riding. An influx of migrants in autumn.

The earliest published reference to this bird as occurring in Yorkshire is a description of an example obtained near 


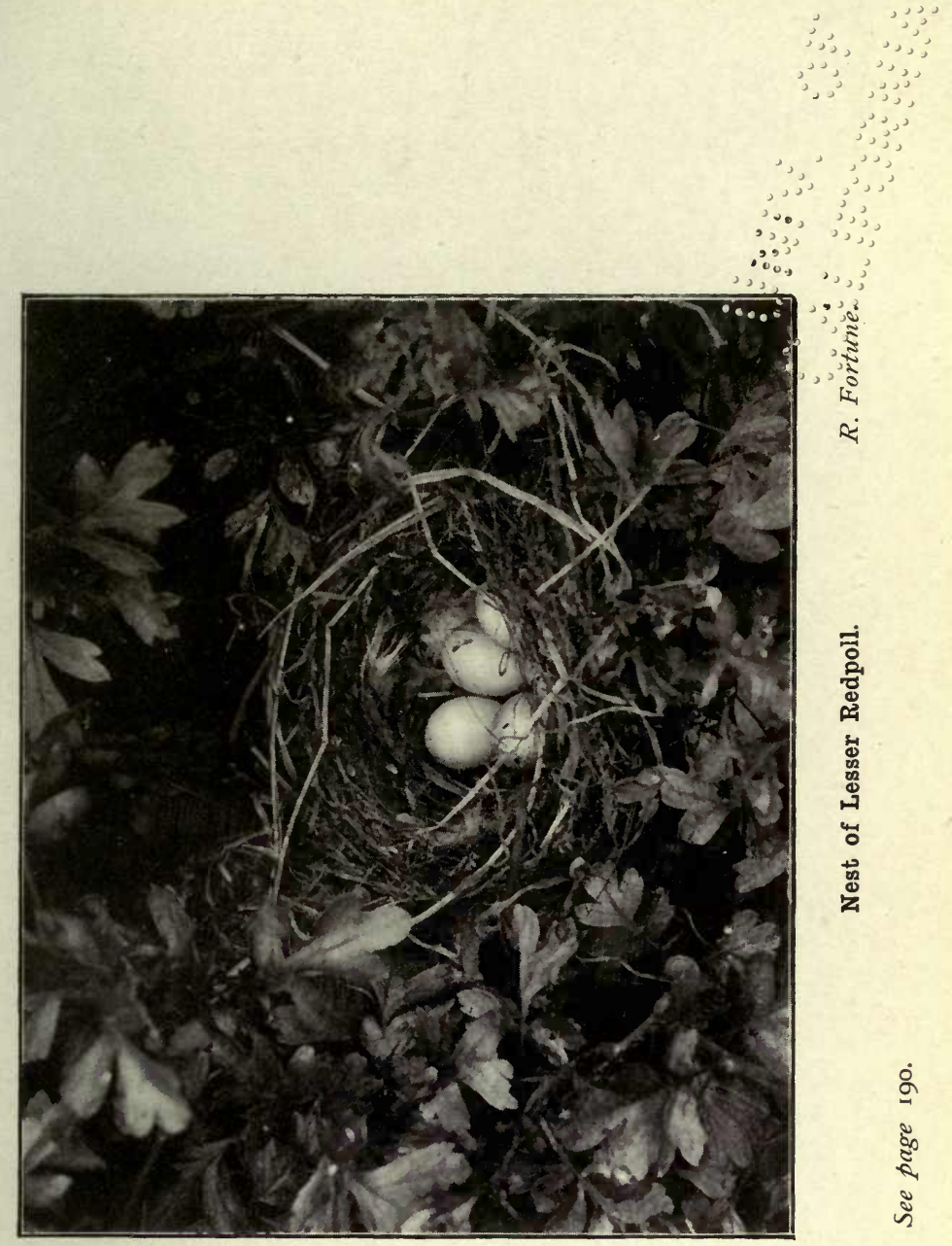




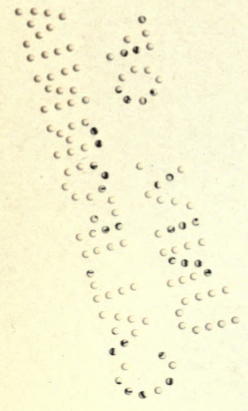


Sheffield and sent by Mr.F. Jessop, of that place, to Willughby. (Will. "Orn." I676).

Thomas Allis, 1844 , wrote :-

Linota montana.-The Mountain Linnet-Near Halifax it breeds in abundance on all the high moors; also at Thorne Moor; it is met with near Leeds, Doncaster, and York.

The Mountain Linnet, as it is called, is resident and not at all uncommon on some of the high moors in the West Riding ; near Sheffield it breeds occasionally, and in the higher reaches of the Aire Valley it is fairly common, though slightly decreasing of late years, as is the case near Halifax and Huddersfield ; in the vicinity of the latter place it has nested at the low end of Crossland Moor close to the town; near Wilsden a small colony was found, with several nests in close proximity built on the ground amongst bracken, and in a much frequented locality (E. P. Butterfield, in litt. I903). These were erroneously recorded as Lesser Redpolls (Zool. I902, p. I93). Round Keighley it is quite abundant, as many as thirty nests having been seen in a single season, and on Adel Moor its eggs have been found several times; in Upper Wharfedale and Nidderdale, and on the moors round Ripon, it also breeds sparingly; the fells of the north-west claim it as a nesting species in small numbers; there is a colony in Ribblesdale on Swarth Fell, and it nests in places near the Lancashire border. In the south-west it was noted on Thorne Waste in Allis's time, and his statement is confirmed by Mr. Thomas Bunker, who found the nest so recently as I884. It is scarcer in the North than in the West Riding, but breeds in limited numbers on the Cleveland Hills, on the moors in Arkengarthdale and Swaledale, commonly in Wensleydale, occasionally on the moors near Bedale, and it has also been once known at Romanby near Northallerton; Strensall Common used to be one of its breeding haunts, though it appears to have deserted that neighbourhood during the past decade, and a few pairs nest in Teesdale and near Sedbergh; in the Whitby district it nests sparingly on the moorlands south of the town and also towards the borders of Cleveland on Grinkle and Waupley. The Rev. H. H. Slater and the 
Rev. E. P. Knubley found several pairs breeding on Pilmoor (Nat. I882, p. I79), which is only eighty feet above the sea, though in this fact there is nothing extraordinary, as I have frequently found the nest in the Hebrides almost on the sea-level.

In autumn and winter the Twite descends to the valleys and low grounds and is then seen in greater numbers, more generally distributed, and is occasionally snared in the nets of the professional bird-catchers.

A considerable influx of migrants from the north takes place during October and November, associated with Linnets and other small birds; when they first arrive the Spurn and Kilnsea districts are their favourite haunts, and at this season they are also met with at most of the coast stations, Flamborough, Scarborough, and the Teesmouth ; they soon, however, distribute themselves over the county and are then met with at many inland localities, though not in such abundance as formerly. The return migration usually commences in March or April.

Some old males shot in October I88r, from a flock at Spurn, had the colour above the tail almost as rich as in the breeding season.

This bird nests earlier in Yorkshire than in Scotland, where May is the usual month for nidification; a nest and eggs were found at Romanby, near Northallerton, on the 2 th of April I882, and Messrs. Slater and Knubley discovered them on Pilmoor on the 27 th of the same month. Though the winter assemblages sometimes do not break up till late in spring, in Swaledale, in I888, they were still to be seen in flocks on the 20 th of May.

Several instances are chronicled of white varieties being procured : two at Bewerley near Pateley (Zool. 1850, p. 2953); one at Bedale (James Carter, Field, August I8th I877); one on the moors near Huddersfield (S. L. Mosley MS.).

Of local names, Swainson gives Twite Finch as used in the North Riding; Mountain Linnet is general; Twate or Twate Finch appears to be a variant of the usual name; Grey Linnet or Grey Lenny is used in Cleveland and in the 
Wilsden district, to distinguish it from the Brown Linnet; Little Peewit, used in north Yorkshire, is evidently adopted from its call note; and Ling Linnet, in Ribblesdale, from its frequenting the moorlands; while Thorny Linnet was stated by Pennant, I798, to be its name in Yorkshire.

\section{BULLFINCH.}

\section{Pyrrhula europœa (Vieillot).}

Resident ; locally distributed, and not very numerous. Migrants arrive in winter.

The first Yorkshire mention of the Bullfinch was made by Marmaduke Tunstall in I786, thus :- "Loxia pyrrhulaBullfinch. Have had many Bullfinches black, and all the intermediate colours between that, and the natural ones, being spotted with black, etc. .... They are very plenty in the north of Yorkshire." (Tunst. MS. p. 65.)

Thomas Allis, I844, wrote :-

Pyrrhula vulgaris.-Bullinch-Common in many parts; not at all common near Huddersfield ; R. Leyland says " Gardeners and bird fanciers alike persecute this beautiful bird, and near Halifax it is consequently becoming scarce."

This handsome species is resident and generally distributed where it it can find situations, such as gardens and woodland localities, containing food suitable for its habits, but it is becoming scarcer in most districts owing to the persecution of bird catchers and the animosity of gardeners who resent the damage done to fruit buds; in the churchwardens' accounts for the parish of Ecclesfield, near Sheffield, an entry occurs proving that it was in bad repute in the sixteenth century: "I590, Item for VIJ bulspynke heades, VJd.," and we learn by three old acts of Elizabeth's reign that power was given to churchwardens to pay "for the head of every bulfinsh or other bird that devoureth the blouthe of fruit-Id." In more recent times as many as three hundred were killed in the "eighties" in one year at Grinkle, and near Harrogate vol. 1 . 
fifty were taken by one man in a week, though, where any protection is afforded, it is inclined to increase in numbers. In autumn it is more frequently observed, as then the old and young wander about in search of food, and additions to their ranks are received from northern migrants; this was especially noticeable in 1880 when some were seen at Spurn late in November, and the Migration Reports contain entries in 1884,1886 , and 1887 concerning its appearance at the light stations in October and November. It has also been noted during the return passage in spring, in March and April, at the Tees Lighthouse (Sixth Report; see also Zool. I88I, p. I33, for particulars as to other places).

Melanic varieties of plumage frequently occur when in captivity, as mentioned by Tunstall (see above), and other observers, and some have been noticed in a wild state.

Mr. K. Maclean states (MS.) that in the Staithes and Loftus districts, when a boy, he frequently caught a larger form which went by the name of the "Russian Bullfinch." (See next species.)

The local names include Bullspink and Bully, which are in general use; Bullflinch at Thirsk; Bully Black Head or Black-headed Bully at Loftus-in-Cleveland; and Thickbill at Hebden Bridge. The name Bullfinch Grosbeak, given by M.P. in a Wensleydale list of birds (Loudon's Mag. I832) is merely an attempt to bestow a generic and specific term in English; and Coal Hood and Hedge Coal Hood, given in Doncaster records by Neville Wood, are not local names at all, but merely fanciful appellations given by that author, and used by no one else.

\section{NORTHERN BULLFINCH.}

\section{Pyrrhula major (Brehm)。}

Accidental visitant from Northern Europe; rare.

This large form of the Bullfinch, which is separated by Brehm as a distinct species, is found in Northern Europe 


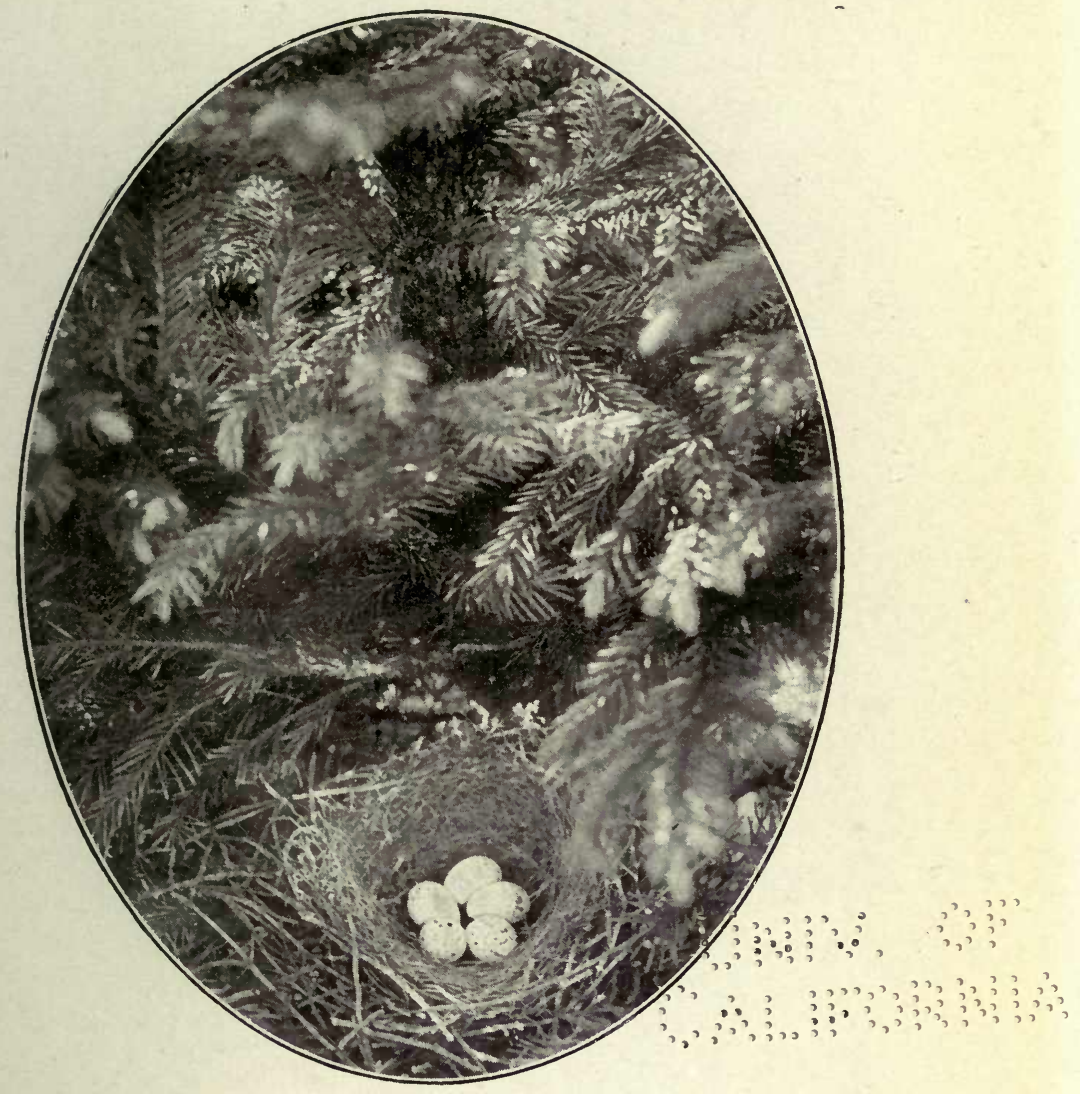

Nest of Bullfinch in fir tree. $\quad R$. Fortune.

See page 194. 
to

and 
and Northern Asia, and has occasionally occurred at Heligoland on migration.

As it has been imported into this country as a cage bird the task of discriminating between "escapes " and wild birds is difficult, but one shot by Mr. Craggs Clubley of Kilnsea, in November I894, is, in all probability, a genuine migrant ; this is rendered more likely from the fact that a second specimen was obtained in the same month and year at Hunmanby, and came into the possession of Mr. Brown of Filey.

These are the first British specimens, and were both exhibited by Col. Irby, F.Z.S., at the Zoological Society's meeting, November I895 (P.Z.S. I895, p. 68I ; and J. Cordeaux, Nat. I896, p. 4).

The Hunmanby bird, which is a male, was figured by Lord Lilford (Vol. iv. pl. 34), and is now in the Royal Scottish Museum. The Kilnsea specimen is in the British Museum of Natural History at South Kensington.*

\section{PINE GROSBEAK. \\ Pinicola enucleator $(L$.).}

Rare accidental visitant from Northern Europe and America.

The home of this species is among the pine forests near the Arctic circle, but sometimes it extends to the birch

* Until the present year these were the only recorded instances of this bird's appearance in Britain, but Mr. W. Eagle Clarke informs me of the recent occurrence of Bullfinches in Shetland, which he had no doubt belonged to the large northern form; a female specimen, obtained on the island of Fetlar on 4 th November 1905, was forwarded for his inspection, and proved to be an undoubted example of the race named, the wing measuring 3.67 inches. During the past autumn quite a number of these birds seem to have arrived in Shetland, and one or two visited Fair Isle in November. In the spring of 1905 several Bullfinches appeared in Unst, most probably on their return journey to their northern summer haunts. Strange to say they seem to have escaped detection elsewhere in the British Islands, for none have been recorded in the pages of the serial literature devoted to natural history subjects. ("Ann. Scot Nat. Hist." I906, pp. 50-5I.) 
woods as far as $70^{\circ} \mathrm{N}$. lat. Eastward it is plentiful in North Russia, Siberia to Kamchatka, and southward to Lake Baikal. In America it is found in the Arctic and sub-Arctic forests, migrating in winter to California, Colorado, and the Eastern States.

The Local Museum at Whitby contains a specimen of this rare Arctic visitor, shot from a flock at Littlebeck, four miles distant from Whitby, in the winter of (about) I86I, by G. Kitching, who at the same time procured four others ; these were made into skins, but have been lost sight of.

At the request of Mr. J. H. Gurney, Messrs. Stephenson and Wilson of Whitby compared the Whitby Museum example with a Swedish skin sent by Mr. Gurney, and, writing on I3th February I890, Mr. Stephenson pronounced the two to be the same species, though differing materially in colour; the Whitby specimen being of a dullish carmine red colour on the head, throat, breast, and back near the tail where the Swedish bird is tinged with darkish yellow, the lower mandible is lighter in colour than the upper, with greyish feathers at the base and cheeks, which are afterwards blended or mixed with carmine on the neck. The beak, which has not the least tendency to cross, and the legs are the same as the Swedish specimen. The secondary, etc., wing feathers edged with dirtyish coloured white, producing a barred appearance on the wings. Length, if stretched out, would be $7 \frac{3}{8}$ in. to $7 \frac{1}{2}$ in. He also observed that the red colour on the back near the tail of the Whitby specimen is slightly tinged with indistinct yellow towards the flanks, and that there are no traces of its being in confinement.

Two other Yorkshire examples are mentioned in the sale catalogue of Mr. Sealey of Cambridge, thus :- "Lot 59, Pine Grosbeaks, three in a case, one shot at Doncaster and the other at Sheffield." See J. H. Gurney, Zool. 1877, p. 242, and 1890 , p. 126 , as to the authenticity of British records of this bird. 


\section{COMMON CROSSBILL.}

\section{Loxia curvirostra (L.).}

Autumn and winter visitant; somewhat irregular. Has occasionally nested.

Its first connection with Yorkshire was made by Marmaduke Tunstall, thus :- " (Loxia curvirostra Linn \& Ges.). Crossbill-Common. A person who was here in July last and was well acquainted with their cry, was persuaded that at that time he heard some in my woods (Wycliffe-on-Tees). As they have never been known to breed here I much doubted; but as they breed very early it was possible." (Tunst. MS. I784.)

Thomas Allis, in 1844 , wrote :-

Loxia curvirostra.-Common Crossbill-Periodically common in fir plantations near Doncaster ; rare about Hebden Bridge ; it has been frequently obtained near Sheffield, and was numerous in the winter of $1837-8$; at Halifax an irregular visitant, frequenting the gardens and plantations; occasionally seen near Huddersfield; a large flock was seen about Whitley Hall a few years ago; sometimes met with near Barnsley in $1831-4$ and 5 , also in the vicinity of York. Arthur Strickland says " For many years back I have almost annually noted this bird in small flocks about August in the grounds about Boynton, apparently family groups returning after breeding, and busy feeding on the larch and fir cones; on one occasion I detected it breeding there, and the egg figured in Mr. Hewetson's work was from that locality; much doubt has existed as to the time and place of nidification of this species, but I believe the whole difficulty arises from making their nests in the tops of very high larch trees, where it is extremely difficult to detect them; I see it mentioned that in lately cutting down some very tall larch trees in Holt Forest this bird was found to have bred there, a circumstance not before suspected. We have, besides, occasionally had a large flock of them in winter, as was the case in 1829 , when between thirty and forty were killed, and some remained till spring." Near Leeds they have been met with at Killingbeck, and several nests were found in Bramham Park in 1840 ; it is also seen about Thirsk.

This un-English looking bird is a native of the pine forests of Europe, from Lapland to Spain and Greece, the mountain 
regions of north Africa, and the woods of Siberia and Kamchatka, wintering as far east as China.

It has nested at intervals in Yorkshire, and is of almost yearly occurrence in one district or another, but its appearances are so erratic and uncertain that the term "resident" or "annual visitant" cannot accurately be applied. It has been met with irregularly in the fir plantations of the south, the first being noticed near Sheffield in I834, and at Barnsley in I83I; at Storthes Hall, near Wakefield, there were many in $I 863$ and in $I 889$; in the valley of the Hodder a small flock was seen in $1878-9$, and a few in Ribblesdale in January I888; near Huddersfield it has occurred as a visitant in late autumn, and has been recorded in the neighbourhood of Doncaster, Selby, and Ackworth since 1835. In Upper Wharfedale it occurs in the fir woods in winter, sometimes in large flocks; a pair were observed at Grassington in the summer of I899; it bred near Fewston in I902, and has also nested at Birstwith; in Nidderdale it is a fairly regular visitant in winter to Pateley, near which place a pair nested and brought off four young in 1876 ; at Knaresborough they were numerous in 1838 , and a large flock was observed in 1846 ; it has also been occasionally noted near Ripon. Turning to the central districts, several nests were found at Bramham Park in I840 ; in the vicinity of York, at Kelfield, in I855, a young one was obtained which had the appearance of being bred there; sixty or seventy examples were noted, and a nest containing four eggs was found near Stockton-onthe-Forest in 1872 (Zool. 1880, pp. 403, 515); in various other localities of the North Riding it has occurred in autumn and winter, being abundant in Wensleydale in 1867 , when thirty were killed at one shot at Thornton Rust. It is an irregular visitant near Richmond, and is said to have bred near Gilling, where a keeper saw young birds following their parents. At Scarborough it has been met with on many occasions; ten were obtained in 1898 , and on 7 th April I900, Mr. Walter Gyngell heard one singing at the top of a Scotch fir at Seamer Carr. In the Whitby and Grinkle woods it used to be very abundant a few years ago, as many 
as two hundred being seen in a flock, and it is also reported to have nested near the former place. In the Cleveland division it is very irregular in its visits; several were procured near Swainby and Osmotherly in I869, and in I894 large parties were in the woods at Swainby, Ayton, and Easby in November and December; the Swainby keeper reported their appearance on the 26th of March following, though a diligent search through the woods, made by Mr. Emerson and myself, in hope of finding a nest, was fruitless ; in Teesdale and the extreme north-west it occurs, as a rare visitant only, in winter.

In the East Riding it breeds in some seasons near Scampston, where small flocks were observed in I864 and I888 ; the nest is also reported from Market Weighton, and in the summer of 1829 a pair bred in a large tree in Boynton Woods (see Allis). A flock of about twenty was seen in Mr. F. Boyes's garden, at Beverley, feeding in a Scotch fir tree, on 26th June 1903; large flocks have appeared on the estate of Sir Tatton Sykes at Sledmere, and it has probably bred in the larch and fir plantations there. It has also occurred irregularly at Waplington, Bridlington, Beverley, Flamborough, Spurn, and in various places near Hull, sometimes quite close to the town.

There were general visitations of these birds in 1855 , I863, I867-68, and, in I888, as the pages of the natural history journals testify, they were common in many counties, as again in I894, I898, and I903. Although the Crossbill does not come with the regularity of some of our over-sea migrants, yet it is frequently noticed on passage; in the autumn of 1875, when the Snow Buntings arrived at Flamborough, they were accompanied by Crossbills, a gale from the north-east blowing at the time and very cold; some were also reported there in August I889; at Spurn in I888 there was an arrival in summer, and on July the 14 th and 15 th a pair that were examined were found to have been feeding on the nymph of the "Cuckoo-spit"; one was also caught alive on the Bull Lightship. In August I894, they were observed both at Spurn and Flamborough; and in 1898 , 
also in August, a considerable number were seen at Spurn, several being brought in to Philip Loten to preserve; whilst on the 2oth of the same month a male in the red plumage came on board a fishing smack off Scarborough. Another extensive incursion took place in the autumn of I903, and many were observed in the woods in various parts of the county. These three last migrations extended to the Cleveland coast; in the year 1898 a red male was picked up on the 6 th of August, on Redcar sands, and in I894 large flocks frequented the woods in the north-western portion of the district. Again on I6th June 1903, another male in very fine red plumage was killed in a garden at Redcar, and considerable numbers were reported during July and August on the coast line southward to Spurn.

In connection with the I894 influx it may not be out of place to mention that, on the 9 th of November, when shooting with Mr. Emerson in Colemire Wood, Swainby, our attention was drawn to a peculiar noise, exactly similar to that made by Pheasants when rising in front of the beaters, but the frequency of which was so unusual as to preclude the idea that it was caused by those birds. My companion at last located the sound in a Scotch fir tree, and discovered that it was caused by some small birds; on shooting two of them they proved to be Crossbills, and the following day we saw two very large flocks feeding on the fir cones; they remained in the wood until the succeeding spring, but, so far as we could ascertain, did not nest there.

[In the woods of Scandinavia and north Russia a large, stout-billed race is found, formerly known as the Parrot Crossbill (Loxia pityopsittacus), now deemed to be unworthy of even sub-specific rank. A female example of this form was procured by Mr. M. Bailey of Flamborough, on $4^{\text {th }}$ August I866, and acquired by the late W. W. Boulton of Beverley (Zool. I867, p. 543)]. 


\section{TWO-BARRED CROSSBILL.}

\section{Loxia bifasciata (Brehm).}

Accidental visitant from Northern Europe, of very rare occurrence.

This species is a dweller in the forest region of north Russia, Siberia, Kamchatka, and on to the Pacific, in winter migrating to Sweden, Germany, and the west of Europe.

There are but few instances on record of its occurrence in the county, the first being from the neighbourhood of Knaresborough, where one was shot at Plompton in I826. This specimen was formerly in the collection of the late J. C. Garth of Knaresborough, and, at the dispersal of his effects in December I904, it was purchased by Mr. Riley Fortune of Harrogate.

On 27th December I845, at Cowick near Snaith, in Lord Downe's Park, a flock was seen from which two males and two females were procured, and passed into the possession of Hugh Reid of Doncaster.

At Easington near Spurn, an immature example was obtained on I2th August I889, by the Rev. H. H. Slater. (Nat. I889, p. 3I4 ; Lord Clifton, Field, 7 th December I889; Zool. r89r, p. 363.*)

At Flamborough a male, which I have seen in the collection of Mr. Forster of Bridlington, was obtained about I898.

\section{CORN BUNTING.}

\section{Emberiza miliaria (L.).}

Resident ; common, but rather locally distributed. A considerable influx of migrants in autumn.

The first allusion to this species as a Yorkshire bird is in a communication from the learned Dr. Martin Lister of

* It was reported to have occurred about the same time in some numbers on Heligoland, and others were recorded in different parts of the British Islands. 
York, to John Ray, bearing date 8th February 1675 , as follows:- "The Bunting breaks not oats, but hulls them dexterously, as I observe, having of them by me at the present time in cages." ("Correspondence of John Ray," p. II7.)

Thomas Allis, I844, wrote:-

Emberiza miliaria.-Common Bunting-Met with all over the county; common in most parts.

Although the Corn Bunting is on the whole a common species in Yorkshire, some districts are much more favoured than others with its presence, owing to its partiality to fields of high standing herbage, and particularly those in which grain, vetches, peas, beans, or clover are grown. In the more wild and moorland tracts the bird is rather scarce, though in the cultivated districts of the north-west it is not uncommon. The same remark applies to the majority of localities where crops of cereals afford the concealment for its nesting places which this bird loves, though the neighbourhood of the seaboard contains its chief strongholds, and in the fields adjoining the coast it is a common and generally diffused species. During the winter months, though not entirely absent from its summer haunts, it is much scarcer than in the breeding season, and is usually to be found frequenting the vicinity of stackyards, often in small flocks and consorting with other small birds; it also affects stubble fields, and congregates at dusk, roosting in flocks in damp, wet pastures.

As an immigrant the Corn Bunting is regularly met with on the coast in October and November, generally in little parties, and at this period it is very common ; it is, however, perhaps less frequently reported from the Lighthouses than any other of our grain eating birds. These immigrants appear to be overlooked by many coast observers, probably owing to their unobtrusive habits, which do not as a rule attract attention.

Two broods are usually reared, the second set of eggs being laid in August, and at times as late as September. An instance is recorded of two pure white eggs being found near Wakefield.

White, pied, and cream coloured varieties of the bird are occasionally met with.

The vernacular names are not numerous. Those used in 


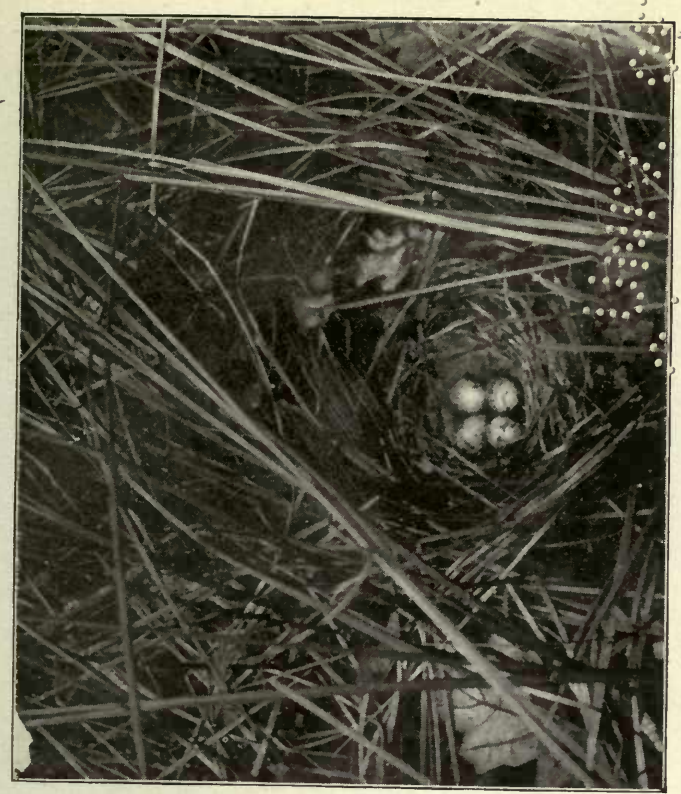

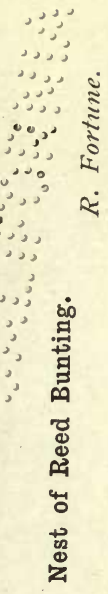

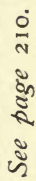

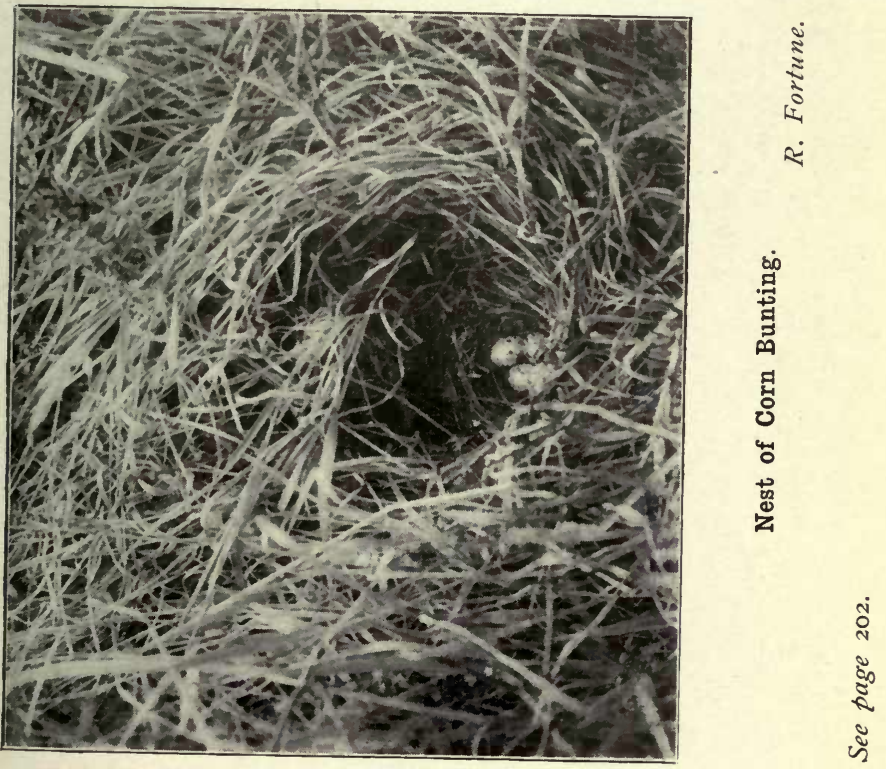



Yorkshire are :-Bunting, Common Bunting, Big Bunting, and Corn Bunting (general); Ground Lark at Doncaster ; Chub Lark along the Lower Wharfe and in the Western Ainsty ; and Titlark in Holderness.

\section{YELLOW BUNTING.}

Emberiza citrinella (L.).

Resident; generally distributed and abundant. A spring and autumn migrant.

The first mention of the Yellow Bunting as a Yorkshire bird was made by that accomplished naturalist and Yorkshireman, Marmaduke Tunstall, in I874, who referred to it as being “ called in the north 'Goldspink,' as also ' Yellow Yowley." (Tunst. MS. p. 68.)

Thomas Allis, I844, wrote:-

Emberiza citrinella.-Yellow Bunting-Rather common near Huddersfield; very common in other districts.

One of the most abundant birds of our hedgerows and fields, and generally familiar, as the various local names testify, the Yellow Bunting, or Yellow Ammer, is found commonly where its simple requirements exist, from the cultivated parts of the extreme north and west to the hedges near the seaboard. During the autumn and winter months the bird is very gregarious, and consorts in large numbers with finches and others of its genus, in their wanderings in search of food. It is also a common immigrant in the autumn in October and November, appearing generally at the same time and in the same manner as the preceding species; these newly arrived birds after a short rest soon make their way inland. In the spring a return movement is noticed, and at the Humber mouth considerable flocks may be noted moving leisurely northward, passing through the district.

In the Beverley district it frequently builds in spruce trees in young plantations. The latest nest of which I have 
had personal knowledge was noted on 2 Ist September I902, at Marton-in-Cleveland, and contained four much incubated eggs, although Mr. J. Ranson (Zool. I865, p. 97II), mentioned the finding of eggs and young in October in a hedge on the high moors of Yorkshire.

A variety of this species with white wing-bars was noted at Aldborough in Holderness (Nat. I894, p. 284); a pied specimen was obtained near Scarborough in August I905; and at Redcar on I6th June I903, I procured a clutch of three eggs which were perfectly colourless.

The vernacular local names are numerous. The terms in most general use are Yellow Hammer or Yellow Ammer ; Yellow Yowley, noted by Tunstall in 1784 , is also in general use, and Yeldrock is a Sedbergh name. A West Riding term is Yellow Youldring or Yoldring, with the variants Goldring and Youldring (Zool. I848, p. 2290), Yolering at Huddersfield, Yowlring and Yowley at Ackworth,,Yellow Yowring in Craven and Youldie in the Western Ainsty; of close affinity to these is the general term Goldie. In the North Riding this bird is Goldfinch, or as pronounced Gowdspink. In I784 Tunstall called it Goldspink, a name recorded also as used at Thirsk in 1854. In Upper Teesdale it is simply Spink; Bessy at Sedbergh; Scribbler in Cleveland; Writing Lark and Scribbling Lark at Harrogate and in Craven; Blakeling in Craven; and Gold Lenny or Yellow Lenny at Loftus-in-Cleveland.

\section{CIRL BUNTING.}

\section{Emberiza cirlus (L.).}

Resident; very limited both in numbers and distribution.

The first mention of the Cirl Bunting in Yorkshire was made by Neville Wood, who recorded that a fine female, in excellent condition, was shot at Campsall, seven miles to the north of Doncaster, on 25th April 1837 (Neville Wood's Nat. June I837). 


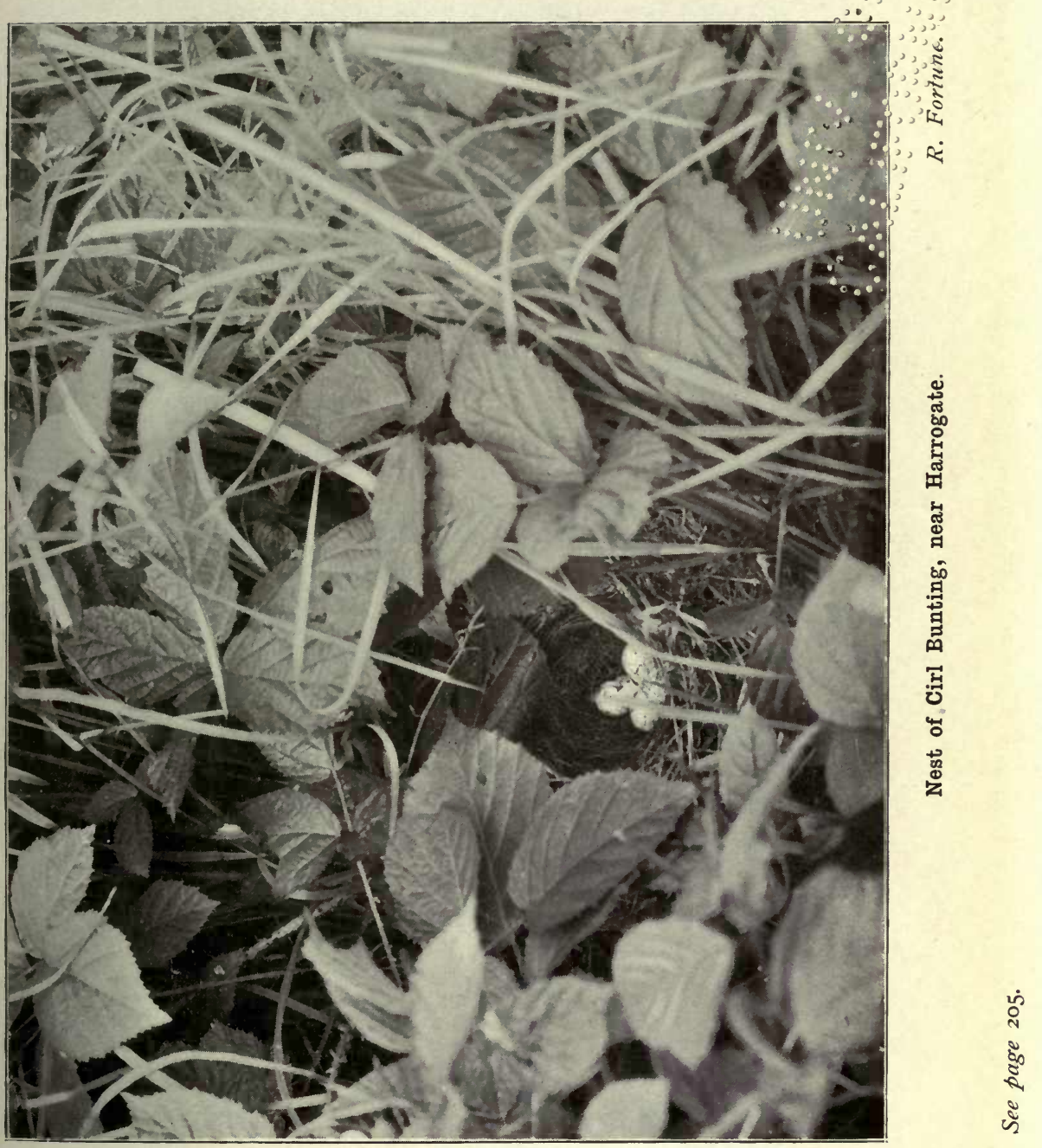



Thomas Allis, I844, wrote:-

Emberiza cirlus. - Cirl Bunting-Of the only two recorded Yorkshire specimens one was killed near Campsall Hall, Doncaster, in 1837 (F. O. Morris's list of Yorkshire Birds, " Doncaster Journal," December I 840) ; the other was shot near York.

This very distinct species has been usually considered as a casual visitant, but may now be described as a scarce resident, and has nested on several occasions, though very sparingly distributed.

One was taken at Bolton-on-Dearne on 8th January I88I ; near Huddersfield a pair nested at Woodsome in 1859 ; while at Lofthouse, near Wakefield, the nest and eggs have twice been found; in May I882 and I889 (J. Ward, Nat. I89o, pp. I48, 320). From Doncaster it was reported in 1837 (see above); two were noted at Norland in I864; in the Western Ainsty it has occurred at Wilstrop and at Newton Kyme (E. R. Waite, op. cit. I89I, p. 94); and, in the year I903, Mr. R. Fortune discovered a nest and four eggs near Harrogate; of which an illustration appears.

In the North Riding it is reported from the Richmond and Bedale districts in I840 and I850 (R. Strangwayes, Zool. I85 I, p. 3056); at Carperby, in Wensleydale, in I870 and in I883; and at Masham (where one was procured in I85I) the late James Carter turned out a pair in I886, they nested, and one was killed in the following year; in I89I a young bird was taken from a nest found on the 24th of August, in a plantation of fir and spruce trees near Mr. Carter's residence, and was forwarded to Mr. Wm. Eagle Clarke for identification ; and in July I9or, another young one was seen at the same place. On the coast the only record is from Whitby, where a female, one of three seen, was obtained at Fen Bog on 28th February 1882 , and is now in the local museum. 


\section{ORTOLAN BUNTING.}

\section{Emberiza hortulana $(L$.$) .$}

Accidental visitant, of extremely rare occurrence.

This Bunting, which in summer is found as far north as the Arctic Circle in Scandinavia, and breeds in France, Flanders, and Dutch Brabant, is only known in Yorkshire as a rare visitor on the spring and autumn migrations.

The first Yorkshire record is that of a male, now in the Newcastle Museum, which was caught on board a collier off the coast in May I822, and was figured by Bewick for his "British Birds" (Seebohm, "Brit. Birds," Vol. ii. p. I53; Jardine, "Brit. Birds," Vol. ii. p. 3II).

The late Canon J. C. Atkinson of Danby recorded in the Zoologist (1863, p. 8768), having seen a bird of this species near Guisbrough, in Cleveland, on I6th August I863, and, writing to Mr. W. Eagle Clarke in I880, he remarked, "I saw three specimens near Guisbrough in the spring fourteen or fifteen years ago."

Another Yorkshire specimen was obtained by the late H. B. Hewetson of Leeds, who, on IIth October I889, shot a young female in a field near Easington (Nat. I890, p. 8).

A skin of a male Ortolan, now in the possession of Mr. S. L. Mosley of Huddersfield, was purchased from the executors of the late J. Varley of that town, and is labelled "Bedale, Yorks., July 9th I882" (op. cit. I892, p. 3).

\section{SIBERIAN MEADOW BUNTING.}

Emberiza cioides (Brandt).

A straggler from Siberia, of extremely rare occurrence.

To Yorkshire belongs the honour of producing the only known European example of this rare inhabitant of Siberia 


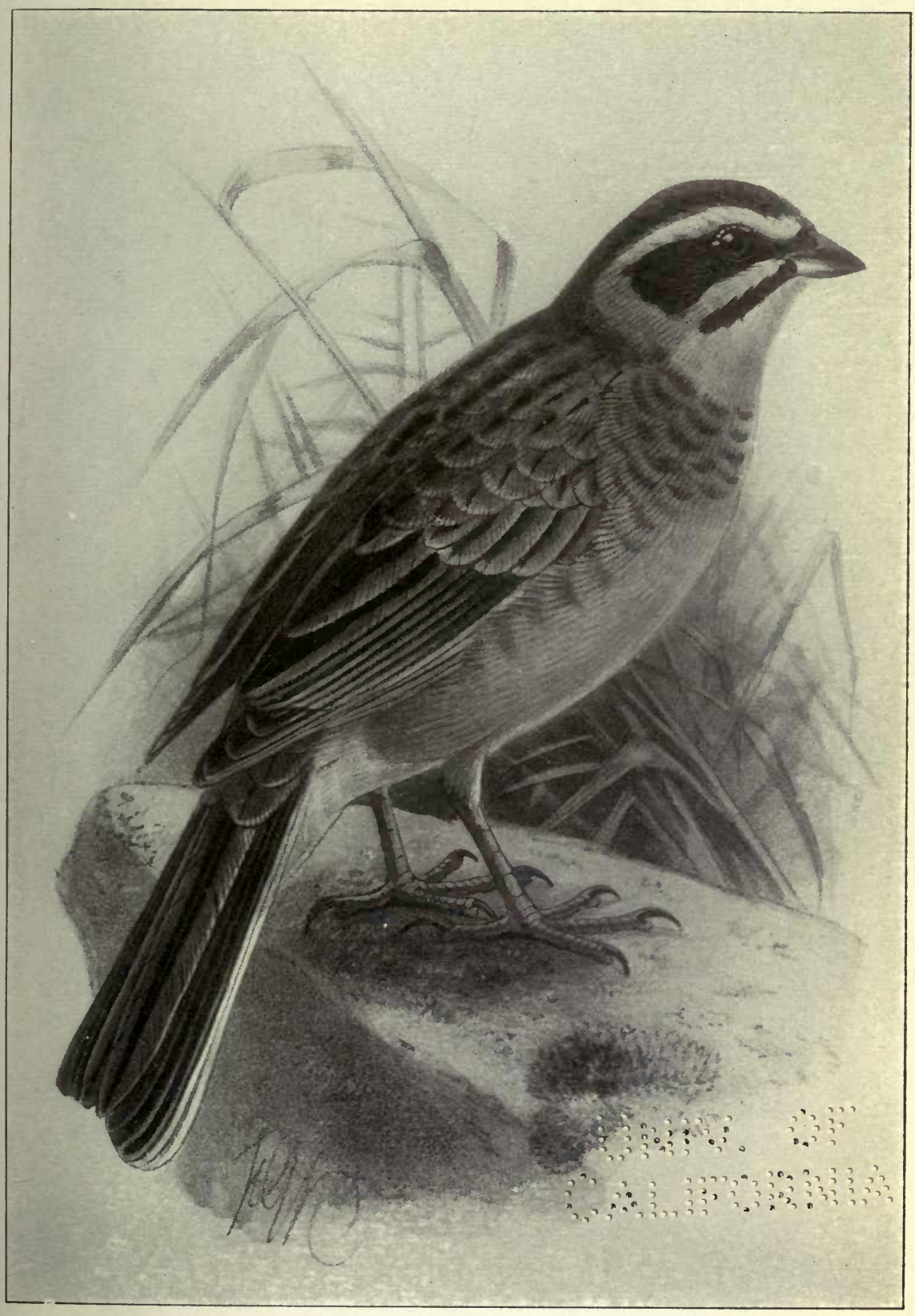

Siberian Meadow Bunting.

See page 207.

Reproduced by permission of the Editors of the Ibis, r 889 . 

and Mongolia. It was caught alive in November I886, during an easterly gale, at the foot of Flamborough cliffs, south of the headland, near to the lighthouse, by Wm. Gibbon, fisherman, from whom it was purchased by Mr. Matthew Bailey, the wellknown naturalist of Flamborough. In June I888, Mr. R. W. Chase of Birmingham saw the specimen at Mr. Bailey's house, bought it from him, and, not recognising it as any known British bird, forwarded it to the late Canon H. B. Tristram, who identified it as Emberiza cioides, a species new to Europe. It was afterwards exhibited by Canon Tristram at a meeting of the Zoological Society on I5th January I889, and was also seen by Prof. Newton.

Seebohm remarked that it resembles the Chinese sub-species E. cioides castaneiceps, more than the typical Siberian race. (See W. Eagle Clarke, Nat. I889, pp. 79, II3, 334, 356; Proc. Zool. Socy. I889, p. 6 ; and Ibis, I889 pp. 293, 295. The species was figured for the first time in the latter journal, plate $\mathrm{x}$.)

\section{RUSTIC BUNTING.}

\section{Emberiza rustica (Pallas).}

Accidental visitant, of extremely rare occurrence.

This eastern species, which in summer inhabits northern Europe and Asia from Archangel to Kamchatka, occurring annually as far west as Finland, and has a winter home in China, has only been known to occur four times in the British Islands, one of these being in Yorkshire, on I7th September I88I, at Easington in Holderness.

The bird when first observed was on the beach close to the sea, and on being followed up, took a short flight, alighting on some thistles for a moment, and then returned to the beach, where it was captured. It was given to $\mathrm{Mr}$. P. W. Loten of Easington, who set it up for his collection, but, not knowing the value of the capture, failed to note the sex, and it remained unnamed until Mr. W. Eagle Clarke identified it on the $7^{\text {th }}$ 
of October following. Professor Newton confirmed $\mathrm{Mr}$. Eagle Clarke's opinion, and exhibited the specimen at the meeting of the Zoological Society on I5th November I88I.

It is worthy of remark that on the same date that the Yorkshire Rustic Bunting, which is probably a young female, was procured, a fine young bird was obtained on Heligoland. The Yorkshire example is now in the York Museum. (P.Z.S. I88I, p. 827 ; Nat. I88I, p. 57 ; I888, p. I ; Zool. I88I, p. $465 ;$ Ibis, I882, p. I8I.)

[An alleged occurrence of the Little Bunting, Emberiza pusilla (Pallas), at Yarm on Ist January I900, proved on examination to be an error, the specimen being an immature example of the Reed Bunting (Field, 6th January and 3Ist March I900), and although it can scarcely be said, with strict accuracy, that this species, which is a native of northern Russia and Siberia, and a straggler to western Europe, has actually occurred in this county, yet the second recorded British example was met with on the Durham side of the Teesmouth under circumstances which call for notice at our hands. It was shot by the late C. Braithwaite on IIth October I902, near Seaton Snook, during an easterly wind which had prevailed for fully a week, and, as the river Tees is the boundary between Durham and this county, it is reasonable to assume that the Little Bunting may have come within the Yorkshire limits. The specimen in question was exhibited at the British Ornithologists' Club on 22nd October I902. (Nat. I902, p. 353; Zool. I902, p. 466 ; Ibis, I903, p. I39.)]

\section{REED BUNTING.}

\section{Emberiza schœniclus (L.).}

Resident ; common in most marshy districts. Migrates in autumn, being replaced by arrivals from the north; a return passage takes place early in April.

The earliest reference to the Reed Bunting as a Yorkshire 
species is contained in the Allan MS. of the Tunstall Museum, r79r (Fox's "Synopsis," p. 206), where it is alluded to as being called the "Nettle Monger."

Thomas Allis, 1844, wrote :-

Emberiza schøniclus.-Black-headed Bunting-Is met with occasionally along the sedgy margins of the canals and old brooks near Barnsley, and seldom more than a few pairs; breeds on the banks of the river near Halifax, but not very plentifully; it is met with near Leeds, and is pretty common near Doncaster, Sheffield, and York.

Owing to its partiality to the vicinity of water and lowgrowing vegetation on the banks of rivers, canals, and ponds, or the reedy growth on a marsh, the Reed Bunting, or Blackheaded Bunting as it is often termed, is local in its distribution. It is found in most parts of the county affording situations suitable for its requirements, and, as may be expected, the low-lying parts of the East Riding, and the inland "carrs," are most favoured by its presence; in the high reaches of the dales it is scarce or altogether absent. The individuals that breed with us leave in autumn, the sudden desertion of their favourite summer haunts being very noticeable, and their places are filled by immigrants, though numerically the bird is much scarcer during the cold season. About the end of March, or the beginning of April, the nesting pairs return to their breeding quarters. During the winter months Reed Buntings, in the dull winter dress, are generally found in the vicinity of stackyards or stubble fields, consorting at times with the common finches and buntings, or are to be seen in small flocks frequenting the rank vegetation near water.

In September and October numbers of immigrants appear on our coast, these movements usually corresponding with "rushes" at Heligoland. On 22nd September I88I, several were recorded on migration, in conjunction with Chiffchaffs and Whitethroats (Third Migration Report, p. 25).

The nests in the Holderness district of the East Riding are often built in the lower branches of hawthorn bushes, or, according to Mr. T. Petch, on the top of the drain banks, which latter is a departure from the bird's usual nidification habits; and Mr. James Backhouse records one at York

vol. 1 . 
built against the stem of an Austrian pine, and at least four feet from the ground (Nat. I884, p. 58).

The earliest date on which I have found the young is the I3th of May in the year I899, at the Teesmouth.

The Reed Bunting has quite a number of local names: the terms Black-headed Bunting and Blackcap are in pretty general use. At Ackworth, Sedbergh, and in the Nidd basin Reed Sparrow, and, at Doncaster and Filey, Carr Sparrow are in use. Seave-cap, used at Thirsk in I854, is intelligible when we note that Seave is a North Riding synonym for Rush. Water Sparrow and Ring Sparrow were in use at Linton-on-Ouse (J. Ranson, I866) ; and Willow Sparrow and Toad Snatcher presumably near Huddersfield (Zool. I848, p. 2290). Nettle Monger is a term given for North Yorkshire, in I79r, by George Allan (Fox's " Synopsis," p. 206).

\section{LAPLAND BUNTING.}

Calcarius lapponicus (L.).

Accidental visitant from northern Europe, Asia, and America, of rare occurrence.

Although the Lapland Bunting is one of the most abundant species in circumpolar Europe, Asia, and America during the breeding season, and very frequently occurs at Heligoland at the periods of the vernal and autumnal migrations, yet the scarcity of Yorkshire records seems to point out the probability of its being overlooked. The inconspicuous plumage of the old birds in the autumn dress, and the still duller hues of the young, render them very liable to be passed by among the swarms of Snow Buntings and other small immigrants which pour into our coast districts in October and November. That we are not entirely out of the line of this bird's migrations is proved by its occurrence in spring at Flamborough. Probably, like many other immigrants 
coming in autumn from north Scandinavia, its line of flight is more to the east of these islands, and it follows the European coast line southward; although its appearance in considerable numbers in Fair Isle, in autumn, would lead us to suppose it might be of more frequent occurrence on our shores.

The Yorkshire records are not numerous, and may be given in extenso:-

One was caught by J. Kitching, in Ruswarp Fields, about a mile from Whitby, in the spring of 1870 , or thereabouts, and is now in the Whitby Museum (T. Stephenson MS.).

At Scarborough one was netted with Skylarks, on 6th January I893 (W. J. Clarke MS.).

The famous headland of Flamborough appears to be more favoured than any other locality, there being no fewer than three successive years when the bird was noticed there. On IIth May I893, Messrs. M. Bailey and J. Cordeaux saw an adult male close to the edge of Bempton Cliffs, as recorded in the Zoologist (1893, p. 225), and in November of the same year Mr. Bailey sent word to Mr. Cordeaux that a large flock was near Flamborough village. Mr. Cordeaux proceeded to the place on the 2 Ist of the month, and found the birds on a barley stubble, associating with Snow Buntings, Redpolls, Siskins, and other small speçies. It was estimated that the flock comprised some one hundred and twenty individuals, and the observers had abundant opportunities of inspecting them at close quarters. They might be easily passed over for Tree Sparrows, having similar habits to those birds of crowding on a hedge-top and straggling down to feed, then flying up in a body when disturbed (Nat. I893, p. 356, and I894, p. 39 ; Zool. I894, p. I9).

Mr. Bailey afterwards gave me a version of this visitation confirming in every detail the account mentioned above. 


\section{SNOW BUNTING.}

\section{Plectrophanes nivalis (L.).}

Winter visitant, chiefly to the coast ; very numerous in most years. Irregular in its appearance inland.

The earliest reference to this bird in relation to Yorkshire is contained in Willughby's "Ornithology," under the heading of "The great pied Mountain Finch or Bramlin." . . . Mr. Johnson [of Brignall, near Greta Bridge] sent us the Bird itself, and the description of it out of the Northern part of Yorkshire." "The same Mr. Johnson sent also the description of another bird of this kind, by the name of The lesser Mountain Finch or Bramlin, together with the case of the Bird : which by the case I took to be only the female of the precedent, he from its difference in bigness, place, and other accidents rather judges it a distinct species." [Description follows.] (Will. "Orn." I676, p. 255.) These are the old female and young of the year of the Snow Bunting.

Thomas Allis, in I844, wrote of this species thus:-

Plectrophanes nivalis.-Snow Bunting-Occurs near Doncaster and Sheffield, where a beautiful specimen was shot in a garden close to the town; is met with near Halifax every winter, but sometimes occurs in immense flocks; is seen in hard winters about Huddersfield, and in great numbers about the high land near Pateley Bridge; it occurs on Hambleton and at Bradford in severe winters. Arthur Strickland reports that very large flocks every winter frequent some districts on the edge of the Wolds near Bridlington, but are so wary that they are very difficult of approach ; there are besides generally single birds or small flocks that do not seem to join the large ones and, from possessing more white and being more easily approached, appear to come from a more northern region.

This hardy little Arctic bird usually arrives about the middle or end of October or early in November; in 1879 the first appeared on the $23 \mathrm{rd}$ of October, and arrivals continued up to the 20 th of December; in I880 there was an intermittent stream from mid-October till the following January; and it was noted in I88I on the 6th of October. 
A few solitary adult birds are occasionally seen weeks before the main bodies put in an appearance; an early date is 26th August I888, when two or three were seen at Spurn; on I6th September I889, an old female was shot at the Teesmouth, and I saw an adult female on the 2oth of the same month in 1883 near Redcar, and procured it on the following day. The first flocks consist chiefly of young birds and a few females, rarely any old maes, though as the season advances the proportion of adult birds increases. Their departure takes place early in spring, a few sometimes remaining until April and occasionally even into May; one was seen on the 3 rd of that month in 1899 at Flamborough; and in I882 several lingered on the sand-banks near the Teesmouth as late as the I 7 th of May. As a rule they prefer the coast line, and are very common in most seasons on the dunes and reclaimed lands near the estuaries of the Humber and Tees, being also found in more or less numbers along most of the seaboard between those two places, particularly at Scarborough, Flamborough, Bridlington, and the sand-hills of Holderness.

The distribution of the Snow Bunting inland is very uncertain and irregular, and, contrary to what is the case on the coast, depends greatly on the character of the season; in severe winters it is found fairly frequently in several inland districts, in other years being extremely rare. It has occurred in the neighbourhood of some of the large towns in most unlikely places; in $1878-9$ a flock was seen within the borough of Leeds, in one of the busiest parts, and in I88I as many as a hundred were killed near Huddersfield. It is met with commonly on the Wolds in the East Riding, feeding on the stubbles; occasionally on the high moorlands of the north and north-west, and in the valleys of the central and northern parts of the county. An early record for the Tees valley is given by Tunstall, who stated that he had one in his possession " killed in this neighbourhood " [Wycliffeon-Tees] (Tunst. MS., I783).

This species figures annually in all the Migration Reports from the Yorkshire light-stations, in numbers varying greatly from year to year, and its appearance seems to be influenced 
by the severity of the weather in the regions whence it comes rather than by that in this country, although it is often noticed that a great influx precedes or follows gales from the north. It was very abundant. in $1860-61$, $1869-70$, and again in 1871 , a mild open season; in 1872,1873 , and $1877-78$. In $188 \mathrm{I}-82$ one of the heaviest migrations on record took place ; an enormous rush extending from the 14 th of November until the end of December. The great rush at the Teesmouth was from the 23rd to the $25^{\text {th }}$ of November, and again from the 6 th to the Ioth of December, many thousands remaining to feed on the adjoining corn stubbles. Another heavy rush occurred in $\mathrm{I} 882$ at the Teesmouth early in December, preceding the snowstorm on the 5 th of that month. I have frequently observed the "ower-sea bird" coming in from the east-south-east, and sometimes from north-east; and when off at sea have noticed flocks on migration. One of the latest dates was on 29th December I883, when about twenty passed the boat at I-30 p.m., flying west-south-west. In 1892 there were more recorded from Spurn and Easington than were ever before known, and the same winter an enormous flight came in on the $24^{\text {th }}$ of November at Redcar; they were plentiful also in I895-96. On 3Ist October Igor, an arrival from due north took place at Redcar, in company with Siskins, Finches, and other small birds, and on the 22nd of November, after a gale from the north, the sandhills at the Tees Breakwater were swarming with newcomers, mostly adults, nearly all of which left during the next few days.

On first arrival these Buntings feed on the seeds of saltloving plants, and are capable of withstanding more cold than most other small birds; even in the severest weather, long after our resident birds are starving and have betaken themselves to the stackyards, the cheery chirp of the Snow Bunting may be heard as it flits along the sand-banks or over the hard frozen foreshore; at these times it often resorts to the sands below high-water mark and feeds amongst the sea-coal and other débris washed up by the tide. Late in winter they take to the fields and stubbles, and are frequently found 
in the marshes bordering the coast. At the end of March I902, a flock of forty, some of which were adult males in very fine plumage, was feeding in the fishermen's gardens near Redcar on ground newly sown with oats.

There are several vernacular names: Snow-Flake is a general term, varied dialectically to Snow-Fleck in Nidderdale. In the North Riding it is called French Sparrow; White Lenny at Loftus and Staithes; Ower-sea Bird (over-sea-bird) at Redcar; and Over-the-sea Linnet at Kildale and Roxby. In Arkengarthdale it is called Sleightholme Throstle, doubtless by reason of making its appearance from that direction, N.E. Tawny Bunting, given by Tunstall in 1783 , was also formerly used in Cleveland. Mountain Bunting, used by Latham in I822, is probably only a book-name.

[An adult male example of the White-throated Bunting (Zonatrichia albicollis, Gmelin), a native of North America was observed by the late G. W. Jalland of Holderness House, Hull, feeding on the lawn with other birds, in the beginning of the year 1893. It was afterwards shot on the r $3^{\text {th }}$ of February, and was identified as the above species by the late J. Cordeaux (Zool. I893, p. I49; Nat. I893, p. II3).

This was probably an "escape" from some ship while being conveyed to this country as a cage bird.]

\section{STARLING.}

\section{Sturnus vulgaris (L.).}

Resident, very abundant, generally distributed. Immense flocks of migrants arrive in autumn, departing in spring.

The first Yorkshire reference to the Starling is a quotation from Ralph Johnson, of Brignall, near Greta Bridge, contained in Willughby's "Ornithology" :-

"The Stare, or Starling, which saith Mr. Johnson I never 
saw eat berries, whereas all the rest of this tribe, except perhaps the Water-Ouzel, are bacinivorous." (Will. "Orn." I678, p. 24.)

Thomas Allis, in 1844 , wrote :-

Sturnus vulgaris.-Common Starling-Universally common.

This favourite bird, one of our commonest and most generally distributed residents, has increased enormously within the past half-century, particularly in the valleys of the Wharfe, Nidd, and Washburn, and in Swaledale and Arkengarthdale, where at the present day it is quite an abundant species, being even found to an elevation of rooo feet, and known to nest at Malham. Mr. Ford, of Caistor, writing in the Field, 2oth October I888, remarks that a friend of his told him he recollected the first pair of Starlings that came to Swaledale, at Low Row; a few years after they made their way to Summerside, then to Muker, Keld, and the head of the dale.

An interesting remark in connection with Yorkshire is contained in a letter from the late Duke of Argyll to Mr. Harvie-Brown, as follows :-

"Inverary, January Igth I894.-Dear Mr. Harvie-Brown, I never saw a Starling till I went to England in 1836 . I still recollect the great interest with which I saw the bird for the first time at the Posting Inn at Northallerton in Yorkshire. Argyll."

The immunity from persecution which it enjoys, and its general usefulness and popularity have served it in good stead; Thomas Allis observed that it was universally common in I844, and its numbers have, subsequently to that period, multiplied almost beyond belief.

This species ranks numerically next to the Skylark on migration, and is often associated with it at that period, an early record connected with this phase of its history is dated 1834 , when a vast number were taken in an exhausted state below Scarborough Castle; while in Rennie's Field Naturalist, I833, mention is made of some alighting on board ship off the Yorkshire coast on 7 th October 1833 . Enormous flocks arrive from the Continent in autumn, and at 
this season, after stormy weather, they have been found killed beneath the lanterns of the Spurn and Flamborough lighthouses. At the latter place in October I869, a flock alighted during a foggy night on the dome of the lantern, where they kept up a continual chattering, and on I2th March 1877 , there were many at night round the lantern ; as also at Spurn in November I903. They arrive from mid-September to the end of October, and occasionally later in the year in November and December, sometimes congregating in thousands in the fields bordering the coast. In spring they reassemble into flocks previously to leaving this country. The vernal migration takes place about the first part, or the middle, of April and is probably carried on at night; one day great flocks may be seen and the next morning not a single migrant bird will be visible. In cold and backward seasons they remain until late in April, after our resident birds are nesting, and this was noticeably the case in 1902. On 20th April in that year an arrival took place, and large flocks were in evidence on the Tees Marshes as late as the end of the month, after which they disappeared.

The Migration Reports contain numerous references to the passage of this bird which occurs in "rushes" almost every autumn, and is reported from the Light Stations all along the east coast. On $4^{\text {th }}$ November I88I, an enormous flight, estimated to contain at least a million birds, came off the sea at Redcar, from the east, extending in a dense mass for over two miles, making a noise like thunder, and darkening the air. They all flew towards the north-west and went over the Teesmouth. During a "rush" on I3th October I902, at Kilnsea, many were killed against the telegraph wires. These immigrants generally belong to the north European form, having a purplish head and neck.*

The Starling is a well-known mimic of other birds' notes, amongst which are the Sparrow, Yellow Ammer, Chaffinch,

* An exhaustive account of the migration of the Starling, by Mr. W. Eagle Clarke, is published in the Report of the British Association Migration Committee, 1903. 
Robin, Curlew, Pheasant, Green Woodpecker, Jackdaw, and others, varying according to the birds of the locality, and in addition may be included a note not belonging to a feathered creature, viz., a dog whistle! A bird which bears the title of "Our Whistling Starling," has been, for several years, in the habit of saluting the dawn by a low melodious whistle on the roof of my house, and it sometimes gives a very good representation of a Peewit's call and the Golden Plover's note.

Starlings have of late years been observed to depart from their usual method of feeding and have developed a taste for insect food. One fine warm day in October Igor, Mr. E. B. Emerson saw about two hundred, hawking insects, in the same manner as Swallows do, over a field at Deighton, near Northallerton; and in the autumn of 1904 he witnessed a repetition of this habit in Bilsdale. I have observed the same trait in the flocks frequenting the flats near the sea; our "Whistling" bird constantly practises this mode of feeding in the autumn, and at Fewston these birds have been noticed feeding on ants. During hard frost and snow they often resort to the rocks to feed on the small mussels left bare at ebb-tide ; and in the Beverley district they have been detected devouring garden fruits.

On the sea coast of Cleveland and at Flamborough the Starling breeds in large numbers in the cliffs, and also resorts to holes in rocks in many inland localities. Amongst curious nesting situations the following have been noted:-the crevice in a crane at Bridlington station, in May IgOI; the balls of a water tank at Thirsk, where, in 1875 , a nest was built in each of the seven balls; and the cleft of an ivy-clad tree twenty feet from the ground. A nest is recorded at Nunappleton built of pampas grass and twigs, lined with feathers and placed in an "arborvitæ," and resembling the nest of a Bearded Tit (Field, 26th June i876). Though not its usual practice, instances are yet known when this bird has shared its nesting quarters with another species. In May I878, four eggs of the Starling were found, in the hole of a tree, with two belonging to the Stock Dove; these were taken, and about three weeks or a month later three more 
Starling's and two Stock Dove's eggs were in the nest. The I6th of February is given as an exceptionally early date for the discovery of eggs.

With reference to the vexed question of the Starling being double brooded, it is undoubtedly the fact that in some cases, perhaps exceptional ones, two broods are raised. In the year I902 a pair hatched off a brood in May, in the chimney adjoining my house at Redcar, and on 5 th July the same year they were busy attending to a second family.
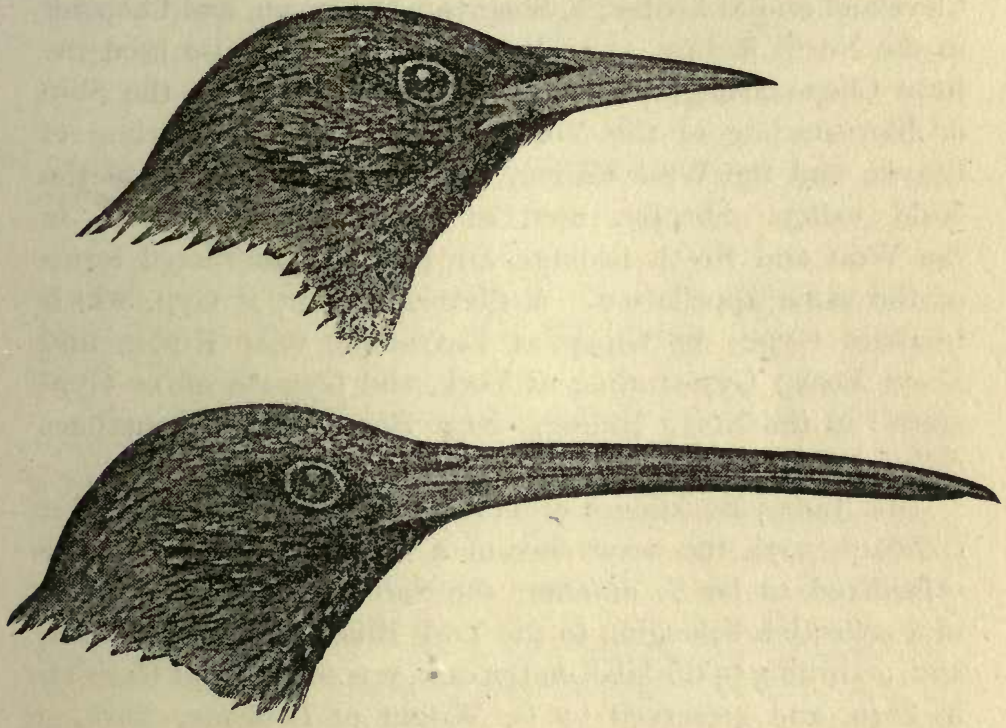

White and parti-coloured varieties are not uncommon. Mr. W. Morris, of Sedbergh, had an albino; another was shot on the Knavesmire, York, about I884; and examples of a cream, buff, and chestnut-brown have been met with. Two birds with curiously elongated mandibles were seen at Redcar in 1897 , one of which was shot and afterwards figured and described, in the Field of 27 th March I897, by Mr. W. B. Tegetmeier, by permission of whom I am enabled to produce Mr. Frowhawk's excellent drawing of the head of the abnormal specimen, and also, for comparison, a normal head. Another example, with elongated upper mandible, is recorded by 
Hugh Reid of Doncaster, in 1837 ; and a specimen with crossed mandibles was obtained about 1888 in the vicinity of Harrogate.

As to vernacular names, the word Starling is itself a diminutive of Stare, as used by Willughby in his "Ornithology," 1678 , and is sometimes transmuted into Starnil, as in the Flamborough district. From its connection with sheep it derives the name Shepster,* Shepstey, Sheep-stare, which are in general use, dialectically modified to Shipster in Cleveland and at Sedbergh, Shepstare in Craven, and Chepster in the North Riding, as spelt by Tunstall, who also used the form Chep-starling. These are the same terms as the Ship or Ship-starling of the North Riding, the Shep-starling of Craven and the West Riding, and the Sheep-starling of the Nidd valley. Sheppy, used at Ackworth, and Shep, in the West and North Ridings, are possibly contracted forms of the same appellation. A Cleveland term is Gyp, which becomes Gypey or Gipey at Eavestone, near Ripon, and about York; Gyp-starling at York, and Gyp-starnil or Gypstarn'l in the North Riding. Near Beverley it is sometimes called Jacob.

Mr. James Backhouse of York mentions in the Naturalist (I886, p. 307), the occurrence of a black Starling, which he considered to be $S$. unicolor, the Sardinian Starling. It is in a collection belonging to the York Blue Coat Boys' School, and, according to the label on the case, was procured at Howden in I840, and preserved by G. Wright of Fossgate, York.

A suggested explanation by Mr. J. H. Gurney (tom. cit. p. 340), is that the bird in question may be a melanic variety of the common Starling, but Mr. Backhouse assured me that Mr. H. E. Dresser has pronounced it to be the Sardinian species.

" "Shepster." An old clergyman who had never heard this name applied to birds, being in the vestry of the church, the clerk, who had noted the return of the Starlings to nesting operations, said to the Vicar. "Please, sir, the Shepsters have come." The old clergyman answered sharply, "Shew them into a pew ; shew them into a pew." (Nat. 1896, p. 254.) 
[The Red-winged Starling (Agelaus phoniceus L.), an inhabitant of America, has been so frequently introduced into this country that it is considered by many ornithologists to be unworthy of a place in the British list. A male example, found on 31st March 1877, under the telegraph wires by the wayside near Ardwick-le-Street, between Askern and Barnsley (Zool. 1887, p. 257 ; Nat. 1877, p. 53), was obviously an escaped bird.]

\section{ROSE COLOURED PASTOR.}

Pastor roseus (I.).

Accidental autumn visitant, of uncommon occurrence, chiefly near the coast.

The first reference to this species is in Denny's Leeds Catalogue of 1840 , which also appears in Allis's Report, dated 1844 :-

Pastor roseus.-Rose-coloured Pastor-Hugh Reid of Doncaster reports that two were shot by Mr. Beal near Bawtry, one is in the possession of Mr. Lawton of Tickhill, the other is in his own collection ; F. O. Morris mentions one from Skinningrove, and another from Thorne, probably the specimen next alluded to, viz. : John Heppenstall informs me that one was shot at Thorne about ten years ago, and was obtained for his father's cabinet; there were three or four individuals with this bird; another was killed but was unfortunately lost. H. Denny has mentioned two specimens, one being shot at Ripley, the other at Farnley Hall in 1828 ; one of these birds was killed near Beverley about four years ago; and Arthur Strickland mentions that one was killed while feeding on the ground near the house at Boynton in 1829 , and is now in his own collection; another was killed a few years ago at North Burton near that place.*

The Rose Coloured Pastor, or Rose Coloured Starling as it is sometimes termed, nests in south-east Europe and Asia Minor, migrating in winter eastward to India. It is a casual visitant to Yorkshire, chiefly in autumn, and at

* One of the specimens mentioned by Allis was sold at Steven's Rooms in London, in 1890 , and was purchased by Mr. J. Whitaker of Rainworth Lodge, Mansfield. 
very irregular intervals; one is recorded at Ripley, and another at Farnley Hall near Otley, in I828. These are mentioned in Allis's Report, as also are examples at :-

Boynton in 1829 , in A. Strickland's collection.

Thorne about I834, in Heppenstall's collection.

North Burton, near Boynton, a few years before 1844 .

Near Beverley about 1840 .

Near Bawtry, two, before I844. (One in the possession of M. Lawton of Tickhill, the other in H. Reid's collection.)

Skinningrove, before 1844 .

Additional occurrences are :-

Dunnington near York, one in 1850 , now in the York Museum (Nat. I886, p. 308).

Coatham Marsh, one, 28th August I85I(Zool. I85I, p. 3277).

Middlesbrough, one, I2th August I 855 (Morris's Nat. 1856).

Wetherby, one, about I855 (J. Tennant MS.).

York, one in 1856 (Zool. I856, p. 525). (Probably Ranson's record, op. cit. I868, p. II33, refers to this individual).

Huddersfield, one at Edgerton in I859 (Hobkirk's " Huddersfield," I859).

Easington, one in I860 (in the Hull Museum : see Museum Guide).

Withernwick, near Hull, one about I862-3; shot by J. Darley (MS. Igor).

Skinningrove, several in I862-3 (Kenneth McLean, MS.).

Scarborough, one, a fine old male, July 1863 (Alfred Roberts, MS.).

Ingleborough, one in I864; described; (Zool. I865, p. 9682).

Cottingham, East Yorks., a mature male, 26th August I865 (op. cit. I866, p. 29 ; and MS.) ; now in Mr. T. Boynton's collection.

Halifax, one in Warley Clough in I866; in the Halifax Museum (A. Crabtree, MS.).

Huddersfield, one, in Halifax Road, "some years ago" (J. Varley, MS., I88I).

Easington, one, a male, $4^{\text {th }}$ November 1877 (Zool. I878, p. 5I).

Spurn, one, an old female, 3oth August I884; the plumage 
was very dusky, like a Hooded Crow on the back; another was seen (Sixth Migration Report, p. 53).

Redcar, one, 23rd November I889 (Nat. I890, p. I00); in my collection.

Aldborough, one in I894.

Hull, Rolleston Hall, one seen, November I9or (Field, 23rd November Igor).

\section{CHOUGH.}

\section{Pyrrhocorax graculus (L.).}

Accidental visitant, of extremely rare occurrence.

The first notice of this species in Yorkshire is contained in Allis's Report, I844 :-

Fregilus graculus.-Chough-H. Reid informs me that one was killed by the gamekeeper of Mr. Randall Gossip at Hatfield, and went into the possession of Mr. Joseph Cook of Rotherham. F. O. Morris mentions one as being killed near Sheffield and preserved by H. Reid of Doncaster, probably the last mentioned bird, which I presume to be the same specimen also mentioned by my friend J. Heppenstall.

This striking looking bird is resident in some remote districts in the British Islands, one of its chief strongholds being on the wild west coast of Ireland; another colony is established on one of the islands of the Inner Hebrides, and a few pairs still breed on the Isle of Man and on the coast of Wales, but in Cornwall, whence it derives its best known name, the Cornish Chough has been reduced to very limited numbers.

In Yorkshire it is now only an extremely rare and casual wanderer, though the probability of its former existence as a resident is inferred from the discovery of an ulna in Kirkdale Cave preserved in the British Museum (R. Lydekker, Ibis, July I89r, p. 385). Further confirmatory evidence respecting its history in this county is supplied by Mr. K. McLean, who states that an old man who worked, in the 
early part of last century, in the alum works at Boulby, near Loftus-in-Cleveland, remembered what he called " Red-legged Daws" being on the cliffs, which at this place attain an altitude of upwards of 600 feet, the highest point on the English coast. This indicates the certainty of the Chough breeding there, and the locality would be a most suitable one for this bird, which loves high inaccessible sea-cliffs for its nesting quarters.

The late Canon Atkinson remarked ("Eggs and Nests," I86I, p. 85) that the Chough "was until lately (I86I) known to breed at Flamborough"; but neither Mr. M. Bailey nor any of the old residents of that neighbourhood can remember it, although their records, in some cases, extend as far back as 1837 .

One is recorded at Hatfield by Allis in 1844, and in the spring of 1875 another was observed near Sheffield (Charles Dixon, MS.).

The most recent authentic instance of its appearance was mentioned by the late James Carter of Masham, who observed that "In the winter of 1876 one was seen by Mr. Wm. Todd, taxidermist, feeding in the Marfield in company with some Rooks. Its red legs and bill shewed plainly against the snow." (Carter, in litt. and Nat. I886, p. 234.)

\section{NUTCRACKER.}

Nucifraga caryocatactes (L.).

Irregular visitant from northern Siberia, of extremely rare occurrence.

The opinions expressed by naturalists as to the form of this species which visits the British Islands is given in favour of the Eastern or slender-billed race. This bird, called the Siberian Nutcracker, is found from the $\mathrm{Ob}$ and Yenesei onwards. 
In this county it is a rare and irregular visitant, only five instances of its capture being chronicled.

At Campsall, near Doncaster, one is said to have occurred, on the authority of Neville Wood (Lancaster's "Askern," I842, p. 70).

At Wakefield one was obtained in the autumn of 1865 , and was purchased by Mr. J. E. Harting from G. Lumb, who had it in the flesh (Harting's "Handbook," 2nd Ed., p. 388).

Mr. T. Boynton of Bridlington has a specimen, which he informs me was procured in Boynton Woods, and was formerly in the Bessingby collection belonging to the late Harrington Hudson.

The Rev. G. D. Armitage possesses an example which was killed at Dungeon Wood, Huddersfield, in 1870 , and was purchased of Mr. S. L. Mosley who preserved it (Armitage, in litt.).

And finally, on 5 th January rgor, one was killed by a keeper at Ilkley, and was acquired by Mr. A. Page on the same day (Ibis, Igor, p. 737).

\section{JAY.}

Garrulus glandarius $(L$.).

Resident; not uncommon in some wooded districts, though decreasing owing to constant persecution; occasionally observed in autumn as an immigrant.

The earliest allusion to this species in Yorkshire appears to be in the appendix to Graves's "History of Cleveland," $\mathrm{I} 808$, where it is enumerated in the list of birds.

Thomas Allis, 1844, wrote:-

Garrulus glandarius.-Jay-Frequently met with in most parts ; rare near Hebden Bridge, and stated by $R$. Leyland to be nearly extirpated about Halifax.

This handsome woodland bird shares, with the hawk and crow families, the unenviable notoriety of figuring on the

vol. I. 
keeper's " Black List," and is consequently subject to incessant persecution whenever it ventures to show itself in a gamepreserving neighbourhood. A few years ago as many as twenty-four were procured in one day in Bramham Woods, and in addition to the enmity of the gamekeeper, the bird excites the anger of horticulturists by raiding the gardens when peas and cherries are ripe ; it is not surprising, therefore, to learn that it has become scarce in most parts of Yorkshire, especially near the large towns, in manufacturing districts, and where game is strictly preserved; though, in spite of its enemies, it continues to nest in many secluded woods and sparsely populated districts. In the higher dales and on the moorlands it is practically absent. It has now ceased to exist in some places where it was formerly a frequent species; at Lofthouse near Wakefield, and near Halifax it was numerous in the middle of last century, but George Roberts in 1876 says it was then extirpated at the former place. In 1836 Charles Waterton deplored the decrease of the Jay, even in his park, where all feathered creatures enjoyed complete immunity from harm, and there only two or three nests were annually produced. In the Grinkle Woods near Whitby it is still fairly common, though decreasing greatly of late years ; at Bolton-in-Bowland, in West Yorkshire, it altogether disappeared in I885, then reappeared ten years later and nested, but both old and young were ruthlessly destroyed. It is local in East Yorkshire, but has long been an annual breeder in the Market Weighton district, where it was formerly much more numerous than now. In 1865 and following years it was an autumn visitor in some numbers to the public common in Beverley, coming with the Woodcock, Redwings, and Blackbirds, and at Scampston Park it was only a winter visitor until recently, but is now a nesting species.

Though not usually classed among our immigrants, the Jay is known to cross the North Sea in autumn, as evidenced by the entries in the Third Migration Report (I883) p. 39, which refer to the great abundance of the bird in our English woodlands in the autumn of I882. This increase was very pronounced in most parts of this county bordering on the 
coast, and was very decided in Cleveland and the North Riding.* An influx of these birds, which could only be attributed to migration, was also observable in 1880,1890 , and 1892 (See Zool. I877, p. I3, and I883, p. I).

Of Yorkshire varieties there are several instances on record, the most numerous being white examples, and of these one at Woodlands, near Doncaster, in I837, was of a milk white plumage with the exception of one or two small feathers in the wings having a bluish tinge. An albino, with white legs, bill, and irides, near York in October 1876 , is recorded by R. M. Christy (op.cit. 1877, p. 25); another albino was reported near the city in July I900 (Nat. I90r, p. I2); and white, or nearly white, specimens have occurred at Osgoodby, near Selby (Field, 29th November I890), near York (Nat. I892, p. 308, and 1894, p. 368).

In some remote Cleveland dales it is thought by the country folk to be advisable to make the best terms possible in any dispute should the cry of the Jay be heard after sunset, which period is deemed to be synchronic with "after the first cry of the Owl." An old dalesman is reported to have remarked to a friend of the writer :- "Ah've heeard t'owld folk say, when Ah war a lad, that when t' Raven and t' Jay call after ' $t$ ' Ullot's abroad, them tweea be hodding crack wi' t' restless deead."

The vernacular names of the Jay in the North and West Ridings are Jenny Jay, or Jinny Jay ; at Scarcroft it is known as Blue Jay; near Loftus-in-Cleveland it is called Blue-wing; and at Sedbergh Jay Piet.

* Coincident with this was an immense migration at Heligoland from the 6 th to the 15 th of October 1882, when "thousands on thousands like a continual stream" were reported by Herr Gätke. 


\section{MAGPIE.}

\section{Pica rustica $(S c o p$.$) .$}

Resident, generally distributed, decreasing in numbers, but still fairly common in spite of persecution.

Probably the earliest Yorkshire mention of this bird is that made in $I 808$ by the Rev. J. Graves in his " History of Cleveland," where the Magpie is enumerated as a resident.

Thomas Allis, I844, wrote:-

Pica caudata.-Magpie-Common everywhere.

Notwithstanding much persecution at the hands of gamekeepers, this species continues to exist in the county, though its ranks are greatly reduced in comparison with its standing of thirty or forty years ago. At that period it was common in the southern portions, as many as fifty being seen in one day in New Spring Wood, near Barnsley, and at Charles Waterton's residence, Walton Hall, where all birds were strictly protected, no less than thirty-four nests of this bird, each with its complement of young, were known in 1835 ; at Stocksmoor, near Huddersfield, previous to 1859 , large assemblies were observed in severe weather; since that date they have been much reduced there (Zool. I862, p. 788I), though an extraordinary abundance was noted in I902. In Craven and Upper Wharfedale also it was an abundant species in the middle of the past (Igth) century. At the present time it is still generally, but sparingly, distributed where conditions favourable to its existence are found; woods or spinneys, and trees growing in hedgerows in thinly populated districts.

In most parts of the West Riding, removed from the neighbourhood of large manufacturing towns, the bird is met with, though its numbers are kept down to a low point ; in some places it nests to an elevation of upwards of 1000 feet, but in the highest dales and moorland districts it is very scarce. In the North Riding, where are many sparsely inhabited tracts and low-lying dales, it used to be fairly 
abundant; here again the attentions of the keepers have led to its decrease, still it holds its own in an astonishing manner considering the many enemies it has to contend against. A correspondent of the Field, February 28th I903, remarks that he had seen a flock, numbering twenty-seven individuals, that frequented a locality near York for some time previously to the date of his communication. It is pretty generally distributed in the East Riding, but becoming very scarce in those localities where it is still found, except perhaps on one or two estates whose owners still prefer to allow nature's ways to remain unchecked. One such sanctuary is Scampston Park, where the bird is slightly on the increase. It is moderately abundant at Market Weighton; formerly it nested quite close to the town of Beverley, though now it is decreasing in that district. In South Holderness, where if was formerly plentiful, it now breeds in small numbers only, convincing proof of the cause of its decadence being afforded by the sight of sixteen bodies suspended on a keeper's museum, on $5^{\text {th }}$ January I9or.

Although not included among the regular migrants, it would appear that the Magpie does in some seasons wander considerable distances from its ordinary haunts; many were noticed in Cleveland in 1883 , and several were seen in the Humber district after the gale of I4th October 1887 .

In addition to its reprehensible habit of plundering game birds' eggs, the Magpie has been detected in the act of destroying domesticated poultry; near Barnsley, in I892, one was found attacking a pigeon (Field, 5 th November I892).

As stated above, Charles Waterton protected these birds at Walton Park, where in 1833 he took the Pie's eggs out of a nest, substituting those of a Jackdaw, which the Magpie hatched. An instance of a female being induced, by repeated robberies, to lay four clutches of eggs, viz., five, seven, five, and six, is related by J. Ranson (Zool. I864, p. 9036). Eggs have been found in the North Riding as early as the 22nd of March.

Variation of plumage is not prevalent in this species to the same extent as in some others of the genus, and Yorkshire 
records are but few in number. Some white young ones were observed in Eskdale before I8I7 (Young's "Whitby," I8I7); one with pale grey on those parts which are usually black is mentioned by S. L. Mosley (Zool. I885, p. 437); another curious variety occurred near West Burton in Wensleydale, in I885, which had feathers of a faint rusty brown colour instead of black ; and an albino was captured at Kirbymoorside on 4 th June 1904 (op. cit. I904, p. 313).

Few birds are so intimately associated with folk-lore as the present species, which figures as one of the quarterings of " $t$ ' Yorksherman's coit of arms." These are-

"A flea, a fly,

A flitch of bacon,

And a chattering magpie" :

and to each quartering is attached a distich, the allusion to our subject running :-

"A Nanpie 'll chatter

Wi' owt er wi' nowt,"

or, according to another version :-

"A Magpie can talk for a terrible span,

$\mathrm{An}^{\prime}$ so an' all can a Yorksherman."

The following examples of familiar chants by village children are suggestive of the bird's chattering propensities :-

"Tell-pie-tit

Laid an egg an' couldn't sit."

or,

"Tell-pie-tit, thy tongue shall be split, An' every dog i' t' town shall get a bit."

Prognostications of misfortune attributed to the Magpie are indicated by some quaint couplets formerly heard in the Cleveland dales:-

"S'u'd ya hear a Cuckoo, then a Nanpie see,

Neea luck that day 'll come ti' thee."

and

"S'u'd a Dove thrice call, then thoo a Nanpie see,

Thoo mun watch thi' love wi' a jillous e'e."

The accomplished Yorkshire naturalist, Charles Waterton, wrote anent the superstitions connected with this bird : "The 
lower orders have an insurmountable prejudice against it, on the score of its supposed knowledge of their future destiny. They tell you that when four of these ominous birds are seen together, it is a sure sign that ere long there will be a funeral in the village; and that nine are quite a horrible sight. I have often heard countrymen say that they had rather see any bird than a Magpie, but, upon my asking them the cause of their antipathy to the bird, all the answer I could get was that they knew it to be unlucky, and that it always contrived to know what was going to take place."

A rhyme in vogue in country districts runs :-

\footnotetext{
"One for sorrow, two for mirth, Three a wedding, four a birth, Five heaven, six hell, Seven the deil's own sel'."
}

The indications vary in different districts : 'Four for death; five for rain,' being substituted in some places, though it appears to be a general custom to endeavour to avert the disaster thus liable to be brought by making as many crosses on the ground as there are birds seen. If a single bird crosses the path of anyone setting out on a journey it is a sure sign of ill-luck for the day, and persons have been known to turn back from a contemplated journey for this reason; but to counteract the evil influence it is the practice in North Riding country districts to make a cross in the air, or to take off the hat and make a polite bow; and in the West Riding the custom is to cross the thumbs, in addition to crossing oneself, repeating the lines:-

$$
\begin{aligned}
& \text { "I cross the Magpie, } \\
& \text { The Magpie crosses me, } \\
& \text { Bad luck to the Magpie, } \\
& \text { And good luck to me." }
\end{aligned}
$$

The vernacular names the bird is known by shew the "familiarity which breeds contempt" in the mind of the juvenile population. Mag, Maggie, and Nanpie are general ; Miggy in the north country (Swainson); Long-tailed Nan and Long-tailed Mag in Cleveland; Swainson gives Pie, Pianate, Pyenate as West Riding terms; they are used in 
Hallamshire; variants are Pinot at Skelmanthorpe, near Huddersfield; Pienet at Huddersfield, Pynot in the West Riding, Piannot in Craven, Pianet in Cleveland, Pyannot and Pyet in Swaledale, and Nan-piannot in Craven; other North Riding names are Tell-pie-tit, Tell-piet, Tell-pienot, Tell-pie, or Pie-nanny, as discussed in the folk-lore; while Pied Margaret is a Swaledale term.

\section{JACKDAW.}

Corvus monedula (L.).

Resident, common and generally distributed. An influx of migrants observed in autumn, in company with Rooks.

An early allusion to this bird in Yorkshire was made by Pennant in his account of Knaresborough in I773, thus :"Near this place (Knaresborough) the vaste precipitous cliffs, darkened with the ivy that spreads over their sides, exhibit a most magnificent scenery. Daws inhabit and caw far above on the face of it (the rocks)." (Pennant's "Tour from Alston Moor to Harrogate and Brimham Crags," I804, p. I04.)

Thomas Allis, in 1844 , wrote :-

Corvus monedula.-Jackdaw-Common in almost every district, but stated to be rare at Hebden Bridge and Huddersfield; the number of these birds is reported by A. Strickland to have increased considerably of late years about the rocks at Flamborough.

As a common resident, the "Jack" as it is usually known in Yorkshire, needs but little notice; it is generally diffused in the county where facilities for its nesting sites are found, and is absent only from the bleak moorlands.

As a migrant, however, the bird is not so well known, and deserves more attention in that connection, and here the Migration Reports may be consulted for evidence respecting its occurrence at the light stations. It is seen to cross the North Sea in autumn often in great numbers, and associated 
with Rooks, though not as a rule so plentifully north of Spurn as to the south of that point; it has, nevertheless, been recorded several times at Teesmouth and at Flamborough. On I7th October I889, a " rush " was noted at the latter place, and in I894, during the first week in November, an extraordinary arrival took place at Easington, in Holderness, flocks of fifty to sixty coming in for three or four days in succession.

Great numbers of Jackdaws nest on the sea-cliffs, especially on the Flamborough range, and between Staithes and Saltburn. At the former place they commit depredations on the Guillemots' eggs, their modus operandi being to roll the unprotected eggs off the ledges on to the rocks below, and then fly down to enjoy the feast; at other times they carry the eggs to the cliff tops and devour the contents on the grass. John Hodgson of Bempton says he has known a Daw deliberately roll several eggs from a ledge and then fly down to a lower projection to repeat the process, always keeping an eye on the descending egg to mark where it fell; the climbers accordingly consider them as inimical to their trade and wage war against them whenever possible. In addition to plundering eggs this species has been detected in the act of killing the chicks of Pheasants and Partridges near Ripley (Field, 23rd July I892).

Instances have been known where Jackdaws fought with other birds for the occupancy of a nesting hole in a tree; at Beverley an unsuccessful attempt was made on the part of a pair of Daws to oust Stock Doves from their nesting place ; and near Richmond, in I853, a Starling's egg was found in a nest with four eggs of a Jackdaw, an instance, evidently, of dual occupation. At Walton Hall, in 1835, Charles Waterton noted that Jackdaws, to obtain possession of a nesting site, drove away a pair of Tawny Owls which had bred for many years in a sycamore tree. The same naturalist induced a Jackdaw to hatch the substituted eggs of a Magpie. At Scampston, in I90I, several pairs built huge untidy nests in a clump of spruce firs, and similar nests have been observed at Escrick, Sedbergh, and other places, while at Beverley 
some have been reported built on the top of wirework fixed on chimney-pots with the object of preventing the birds building inside the chimneys. The Jackdaw's predilection for utilising church towers for nesting sites is proverbial, and at Calverley Church a spiral staircase in the befry tower was blocked up by an accumulation of sticks brought there for building materials. A similar case occurred in one of the hollow pinnacles of the Beverley Minster; inside this pinnacle were stone steps forming a ladder to the top, and the Jackdaws had built on the top step, but, as this did not form a sufficient base to support the nest, the birds had brought great quantities of sticks and filled up the ladder-way.

The Jackdaw, like other members of the Crow family, is liable to variation in plumage; pied examples are not infrequently met with, and the late J. C. Garth's collection contained a white specimen, probably obtained near Knaresborough; one which had a white crescent on each wing was seen at Flamborough in June I899; a curious brown coloured bird was observed near the Crimple, between Harrogate and Knaresborough, on I3th May I882; Mr. F. Boyes has seen several individuals with brown wings at Beverley, and one such specimen is in the possession of Mr. Stuart of that place. An example with curved mandibles was found near Burton Constable; it had mandibles closely resembling those of a Crossbill, but the upper was more curved and worn by use, the lower, which grew upwards, being pointed (Field, 7 th August I897).

Yorkshire folk-lore attributes the worst of ill-luck as likely to follow the flight of a Jackdaw down a chimney, the death of one of the inmates of the house being thus foretold.

Of its local names, Jack and Daw are general, becoming Jacky at Ackworth; and Caw Daw is given by Swainson as a north country appellation. 


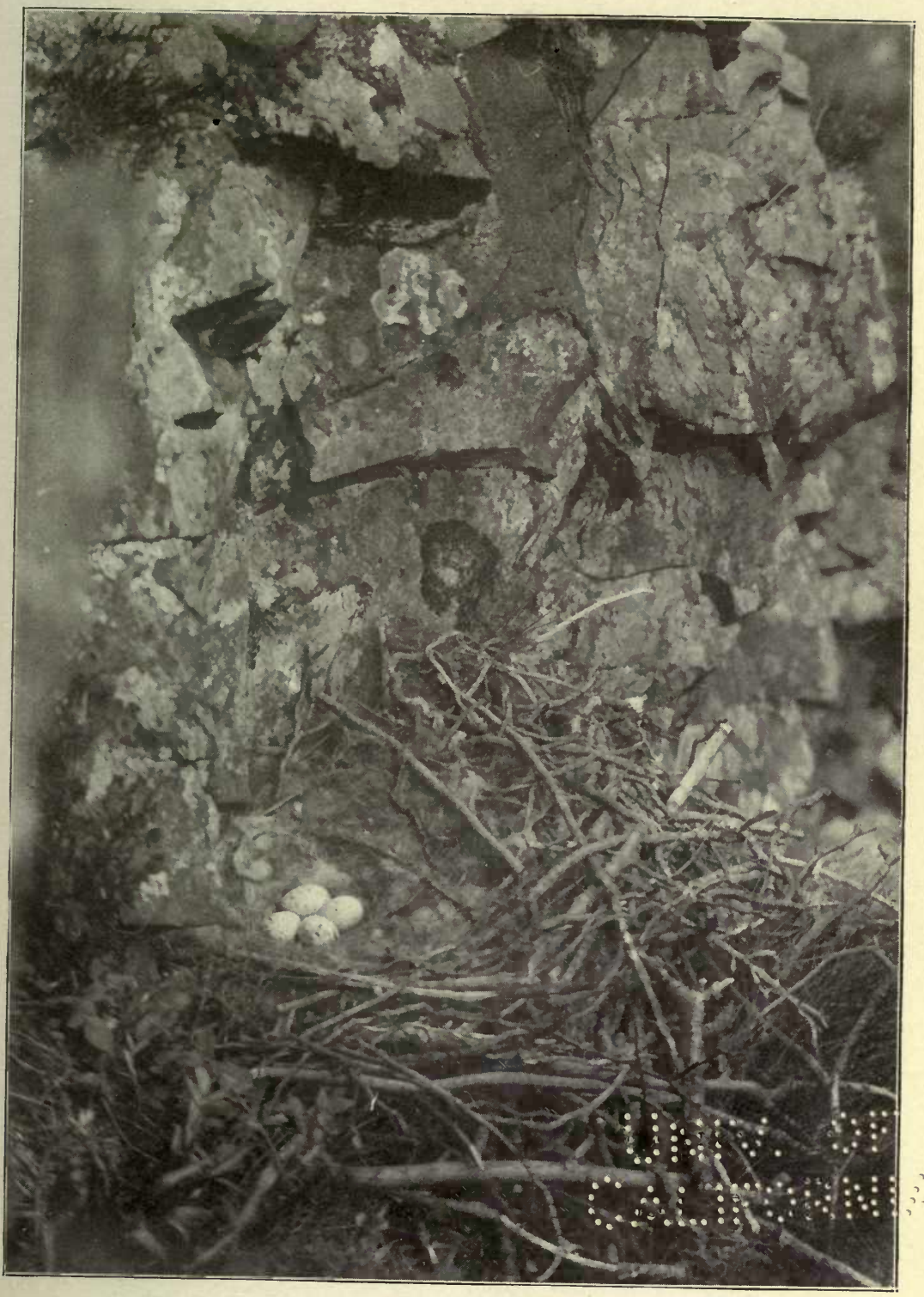

Raven's Nest, north-west Yorkshire.

R. Fortune.

See page 236. 
"द्ध

midnd 


\section{RAVEN. \\ Corvus corax (L.).}

Resident, but restricted now to one or two pairs in the northwestern fells.

The earliest recorded mention of this bird in connection with Yorkshire was made by Marmaduke Tunstall, of Wycliffeon-Tees, who remarked : "It is very rarely seen in these parts, yet one made its nest near my house some years ago." (Tunst. MS. 1783, p. 56 .)

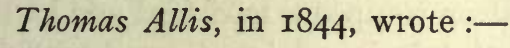

Corvus corax.-Raven-F. O. Morris observes that twenty-five years ago this bird was common in most parts, but has since been gradually getting scarce; R. Leyland says it is occasionally seen on the moors near Halifax; but does not breed there; H. Denny reports it as rare, though occasionally met with, at Walton Park; rare at Hebden Bridge; a pair breeds annually on a ledge of the building at the Mausoleum, Castle Howard; it occurs at Hambleton, and is met with rarely at Wharncliffe; it breeds annually on the rocks at Flamborough and some other places in the neighbourhood.

Rightly designated a citizen of the world, the Raven is resident in Yorkshire, though now reduced to small numbers and limited to very few localities in sparsely populated districts. Its occupation of the county in former times is proved by the discovery of remains in Kirkdale Cave, and the old records show that it not uncommonly built in trees and woods of the West Riding, though its history has become a tradition. The Rev. J. A. Haydyn of Dent Vicarage has obligingly supplied me with some important and interesting evidence, taken from the churchwardens' account-books, relating to the Raven in the early part of the eighteenth century, shewing that payments were made for the heads of these birds; thus in I7I3 for eight Ravens' heads the sum of Is. 4d. was paid, and for five Ravens' heads rod. was disbursed. Between I7I 3 and I750 there appears something of the kind every year, the normal price being $2 \mathrm{~d}$. per head, though in 1726 there is an entry thus:-For 8 Ravens' heads..3s. od.; and in I737: for 35 Ravens' heads...5s. Iod. 
At Walton Hall, the residence of Charles Waterton, the Raven bred in the park, where the last one was destroyed in I8I3, and the last nesting bird in the Aire valley was killed in Trowler's Gill in I837; near Selby a pair, taken from a nest in Bishop's Wood, were kept alive for many years. Other breeding situations were in the upper part of Nidderdale; Hackfall ; Raven's Gill near Pateley, the last nesting bird being shot by old Jack Sinclair, a celebrated Pateley character, who died in 1898 , aged ninety-two ; Gordale Scar ; and Eavestone near Ripon, where a nest was destroyed "some years ago " (Ingleby, MS., I902). In Lower Nidderdale, in I860, the late John Harrison of Wilstrop trapped a wild bird and had it for some time ; it afterwards left, found a mate, and brought off young in a fir tree in Allerton Park; but there, as at other of its old haunts, stragglers only are now seen at long intervals. So far as recent information can be relied upon, the only district in this Riding where it occasionally succeeds in nesting is on the wild fells of the north-west, the exact whereabouts of which it would be unwise to indicate; there a few survive and would breed if allowed to remain unmolested, but collectors are on the qui vive to secure the eggs as soon as laid, while keepers and shepherds combine to destroy the parent birds, which, like Ishmael of old, have every man's hand against them, and the wonder is that any contrive to escape.

Coming now to the North Riding, the history of the Raven is almost a memory of the past, though formerly there were numerous places which could claim it as a regular breeder; one of these was the Mausoleum at Castle Howard, where a pair occupied a conspicuous position up to the year 1856 ; in the Helmsley and Riveaulx district up to 1860 it bred on White Mare Cliff and Peake's Scar, and also in an ash tree in Gowerdale ; other sites were at Roulston Scar, Hood Hill, and in Bilsdale; at Danby it was extirpated in Atkinson's time ("Moorland Parish," p. 329), but in Newton Dale near Pickering there was always a brood, till about 1875 , in a crag known as Raven's Cliff. In Cleveland, until so recently as I866, a pair nested near Guisborough, sometimes in Cass Rock, and at others on Highcliff near the Raven's Well (now called 


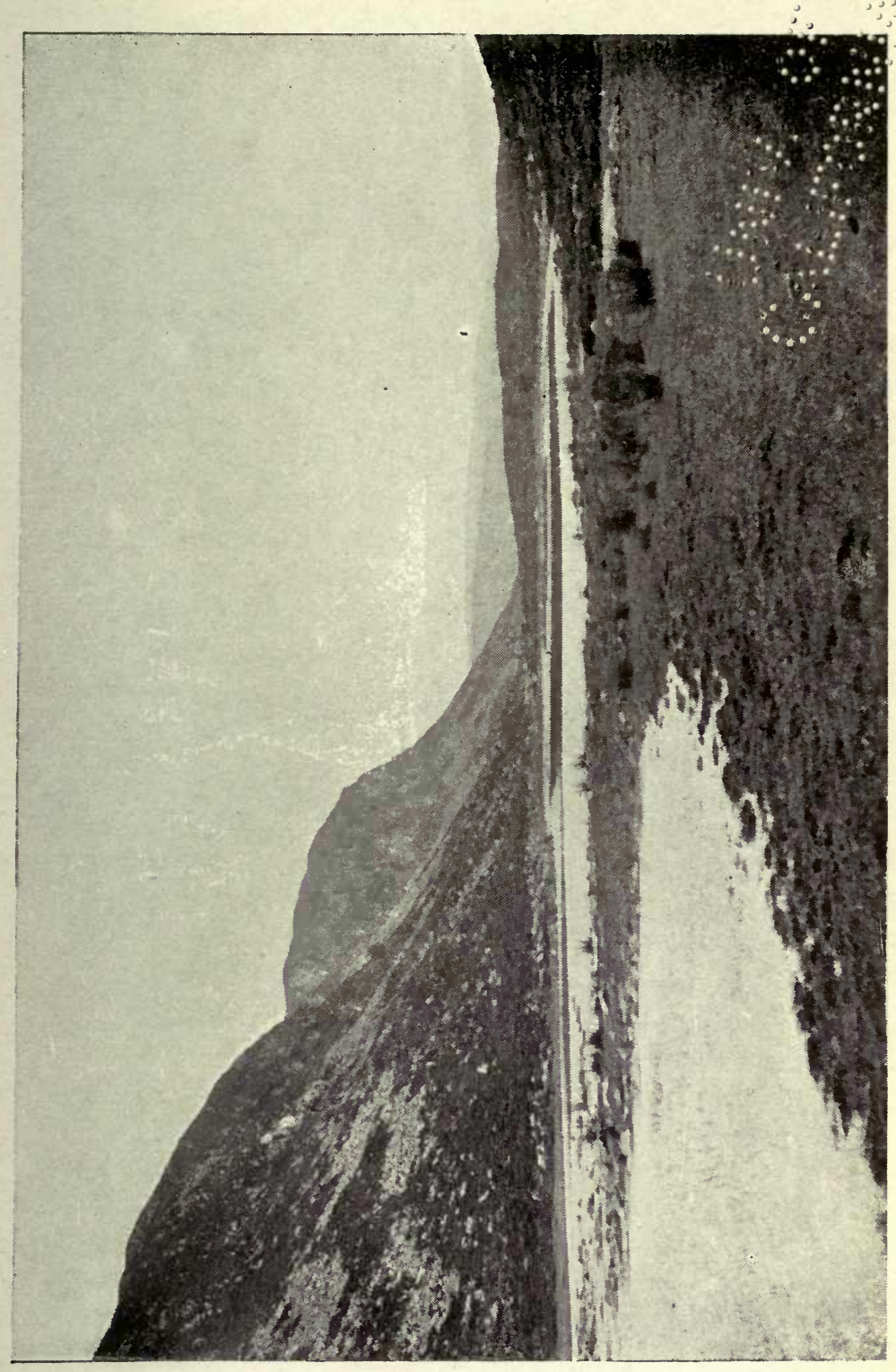

¿̊̃

घ'

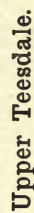

ซ్ ซ్లె

哭

is

\&

ڤ 

the Jackdaw's Well) ; five young were taken at the former place about $\mathrm{r} 860$, and a single bird was seen on Stape Moor in May I893. In Wensleydale it is known at Raven's Scar, Walden Head, Cover Head, Ellerton, and Askrigg, and, in the adjoining valley of the Swale, an old inhabitant, one Timothy Hutton, born in 1779 , and who died in 1863 , remembered Ravens breeding in Hudswell Scar; while up to 1880 there were breeding places in the upper dale at Swinnergill, Oxnop Scar, and Raven's Crag, which latter place is said to have been occupied in I884; two were seen at Keld in I88I, and a pair in Arkengarthdale in I882. The only parts of the North Riding where it still maintains a precarious footing are in the extreme north-west, in Upper Teesdale, and other two localities on the Westmorland border; at the first named place a pair nested on Cronkley Scar until quite recently; eggs were taken in 1899 and four birds were seen in the autumn of I902. In the year I880 eleven Ravens were killed on Bowes Moor, where I saw the remains of seven of them hanging on the walls of a keeper's cottage, the crime alleged against them being the raiding of lambs. On the borders of Westmorland in I88r a remarkable combat took place between a Peregrine and a Raven, in which the black bird was victorious, the Falcon being afterwards picked up dead on a moor. An odd pair of birds still build annually on the rocky sides of the fells in this locality, though, as they are generally robbed of their eggs, they change their dwelling places from year to year. In 1899 a clutch of four eggs was taken and the female found dead, egg-bound; the male got another mate, built a nest and reared a brood at the same place, while in I903 two pairs attempted to nest, but were driven away by the Peregrine Falcons, and in 1904 one pair nested and five eggs were produced.

In the East Riding a pair bred annually in Scampston deer-park in a Scotch fir ; the female was accidentally killed by the keeper, and the male left the place; this was sixty to seventy years ago as related by G. Petch of Lowthorpe, who used to come over each year to help take the young birds; Petch died in I886. Ravens nested on Beverley 
Minster up to $\mathrm{I} 840$, and the young were annually taken by an old mason named Gray; the nest was on the southernmost of the two west towers, and could be reached from a window near with a landing-net which Gray used to borrow from Mr. F. Boyes's father for the purpose ; the young were distributed to the hostelries in the town. It has been stated that a tree on an island of Hornsea Mere was formerly utilised as a nesting site.

On the sea-cliffs it was noted in Hinderwell's "Scarborough" (I830), at Flamborough and Speeton; two young were taken from there in 1844 and kept alive at Hedon (Zool. I845, p. 823). The site of the nest at Flamborough in I837 was on the cliff near the King and Queen Rocks. An interesting piece of evidence respecting its occupation of the Flamborough cliffs was supplied to me in the summer of I902 by Henry Marr, one of the "Climmers" at Bempton, who stated that his uncle, Richard Marr (who died in I90r " turned eighty "), was "top-man" with old George Londesborough, and remembered Ravens breeding on the cliffs; he started climbing at the age of thirty-five (about I855), and a pair of birds then nested between the Danes' Dyke and the "Dor" ; one was seen on the cliffs on I3th June I889.* Other breeding places were to the north of Filey Brigg before 1858 (E. Tindall, MS.); the Castle Cliff, Scarborough,where Alfred Roberts remembered a pair about I855; Peak, north of Scarborough (Hinderwell, 1830); and at Hawsker Bottoms, near Whitby, where it bred about I865, and is reported to have appeared there again in I880. On the Cleveland coast in the early part of the last century, and, as I am informed by Mr. W. Cook, ex-keeper of Grinkle, so recently as 1860 , the high crags of Boulby were resorted to; two of these birds were seen about I870 on the beach near there, on the dead body of a sailor washed ashore, while a single individual was noticed in the late spring of Ig02. It is enumerated in Graves's " History

- A tragic event is said to have occurred in connection with the disappearance of the last pair of Ravens on the East Riding cliffs, the unfortunate man who descended to the nest being killed by the breaking of the rope on his ascent. 


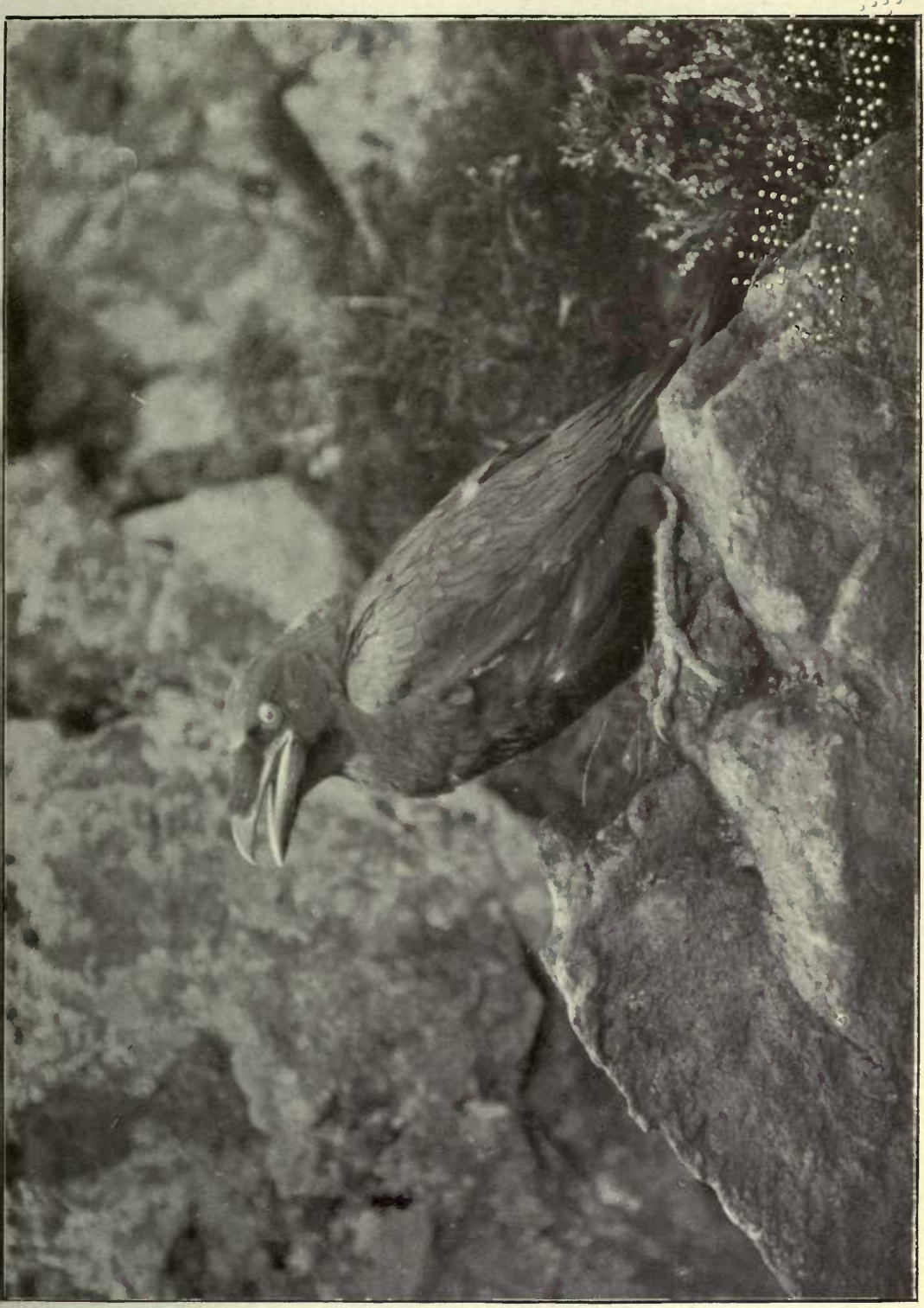

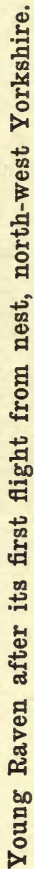



of Cleveland " ( 1808 ), and, according to J. Hogg (Zool x845, p. II06), it built on Huntcliffe near Saltburn.

Many pages might be filled with stories of the remarkable proclivities of this " uncanny bird," and anecdotes relating to Yorkshire are not wanting. A tame bird at Hedon would repeat the notes of the Cuckoo ; one at Skipton used to throw money out in exchange for meat, and the late John Harrison of Wilstrop had one at large near his house, which climbed into a tree near a rookery and terrified its neighbours by calling out " $\mathrm{Hi}, \mathrm{Hi}$ !" in a loud voice. A bird in my possession is an accomplished linguist and very expert at hiding anything which attracts its attention; in its first winter, when snow fell, it made a number of snowballs which it hid in various cachés of its own, but looked utterly woebegone when it went to unearth its treasures and the snow had melted.

Perhaps the earliest date for nidification is 26th February I902, when a female was observed sitting upon her nest in north-west Yorkshire, and on the 28 th of the same month in I895 a full clutch of eggs was taken in the same locality.

Of Yorkshire varieties there is a pied specimen, captured in Nidderdale several years ago, in Bewerley Hall collection; another, of similar plumage, occurred at Snailsworth; and one, partly pied, was observed on the beach near Loftusin-Cleveland, on the body of a drowned sailor.

The Raven figures largely in the folk-lore of Yorkshire, as in other counties, where it is usually considered to be the bird of ill-omen, and its presence or croaking is believed to prognosticate death; while several place-names indicate that it was familiar to the inhabitants in olden days; thus we find Raven's Roe, a rocky promontory near Ingleton; Raven's Scar, near Great Whernside; Raven's Crag or Ravenseat, in Swaledale; and Raven's Gill, Pateley. A relic of the connection between the Raven standard and the Danes seems to exist in the West Riding, where naughty children are told that a black Raven will come and fetch them; and Raven Hill, between Whitby and Sandsend, may indicate the spot where the Danes landed on their invasion of that part of the North Riding. At Guisbrough in Cleveland, 
there was a legend to the effect that a hidden box of treasure was guarded by a Raven, which assumed gigantic proportions if anyone attempted to rend its trust. Another item of Cleveland lore was that " When $t$ ' Raven and $t$ ' Jay call after t' Ullot's abroad, them tweea be ho'dding crack wi' $t$ ' restless deead." (See Jay.)

The only vernacular names are Corbie, used at Sedbergh and in north-west Yorkshire; and Croupy-Craw, which Swainson gives as used in the "North of England."

\section{CARRION CROW.}

Corvus corone $(L$.$) .$

Resident, generally but thinly distributed; scarce in the manufacturing districts, and decreasing generally. A few pairs nest on the sea cliffs.

The first mention of this species in connection with Yorkshire is an item in the Churchwardens' Accounts in the parish of Ecclesfield, near Sheffield, in payment of the expenses incurred in the destruction of vermin :- "I590. Item for vj crowe heades..jd." This, doubtless, is in accordance with the Act of 24 Henry VIII., which provided for the extirpation of Crows, Rooks, and Choughs. (Pennant, Vol. i., p. I68.)

Thomas Allis, in I844, wrote of it thus :-

Corvus corone.-Carrion Crow-Common near Sheffield; stated by $\mathrm{J}$. Heppenstall to be gregarious in severe weather; very scarce near Barnsley, and, when met with, almost always in solitary pairs. Common near Huddersfield, but seldom breeds there; not mentioned as occurring near Halifax, though common near Hebden Bridge ; common in most open and wooded districts.

The Carrion Crow is a generally, but thinly, distributed resident, being rare in the neighbourhood of large towns and in the manufacturing districts; on the fells of the northwest it is fairly common, as many as twenty-nine having been seen at one time, and in the dales of the West and North 


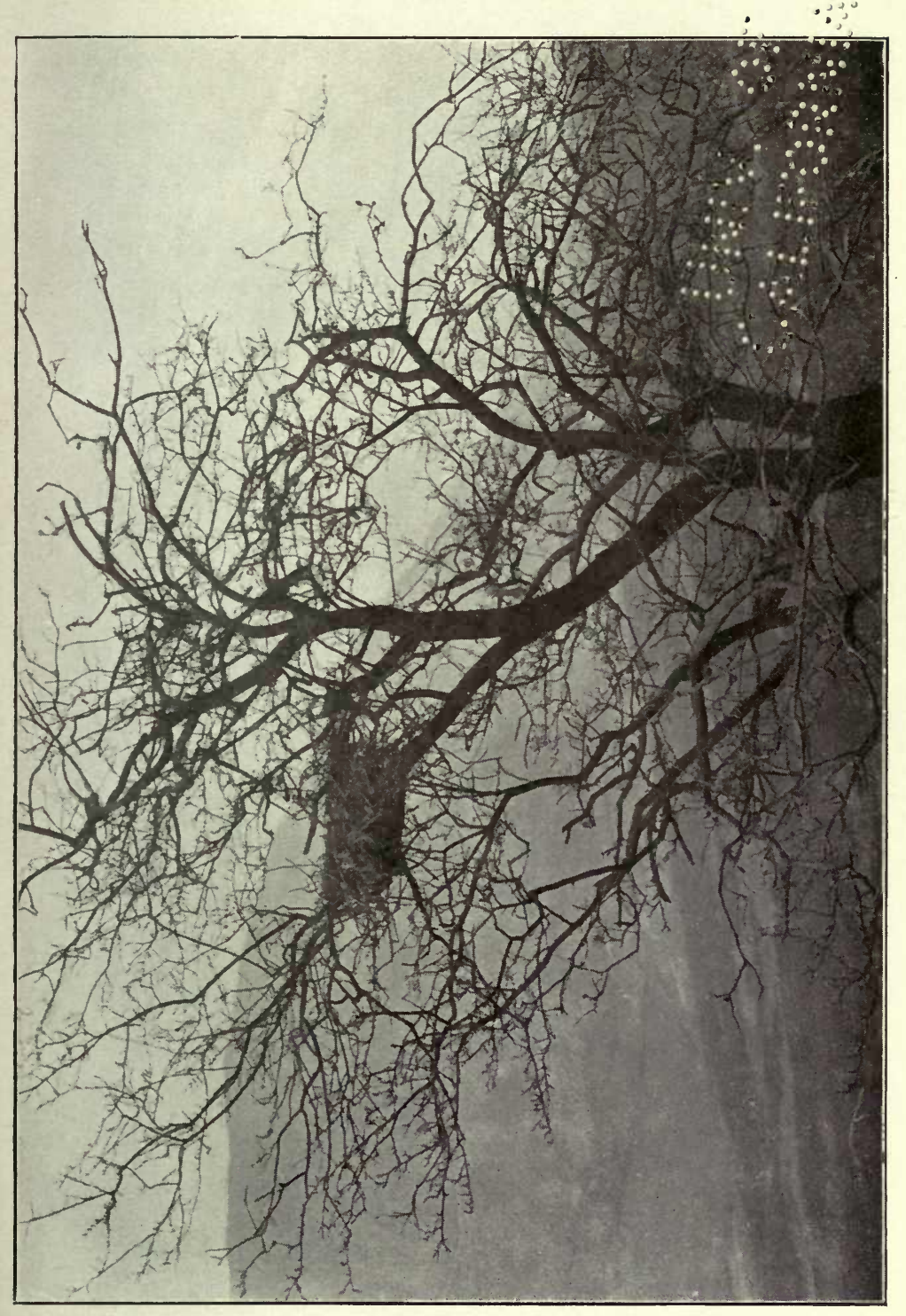

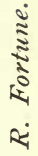

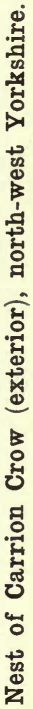

ते
हें
हूँ 

Ridings, the moorland districts where cliffs or precipitous mountain sides afford suitable nesting situations, and in the vicinity of large and secluded woods, it manages to survive, though its numbers have decreased, especially in the Wold district of the East Riding, but even in that division a few pairs build in isolated spinneys and trees in hedgerows, and one or two pairs nest annually on the high cliffs of Flamborough and Bempton. Owing to its predatory habits, inimical to the interests of game-preservers and poulty farmers, the Crow leads a precarious existence, being proscribed and persecuted without mercy by gamekeepers, who destroy the old birds, young, or eggs whenever an opportunity occurs. As illustrating the varied character of its menu, the particulars of a Crow's larder in Ribblesdale may be described : it contained remains of eggs of Partridge, Snipe, Lapwing, Sparrowhawk, Blackbird, Thrush, and domestic fowl, in addition to several rabbits' skulls. There is therefore no wonder that the bird is on the keeper's "Black List," and on the high moors it is a perfect pest to the shepherds in lambing time.

As an immigrant it is known at the light stations on the coast in autumn, coming in with Hooded Crows and Rooks, and occasionally in separate flocks, although it is not always possible to determine if this species is meant when entries referring to "Black Crows" occur in the Migration Reports, and, as a rule, but few are noted at the stations north of Spurn and Flamborough. One was killed at the latter place coming in off the sea, on 2nd October I894, with a piece of board tied round its neck, 4 in. by $I_{4}^{1}$ in., bearing an inscription, "Leading Star. O.R.," indicating that the bird had been caught on some vessel at sea, and set at liberty with the message fastened to it (Nat. I894, p. 326).

In winter both Carrion and Hooded Crows assemble on the Humber flats to feed on shell-fish and garbage cast up on the beach, and not only do they consort together at that season, but an instance is known of the two races inter-breeding at Scarborough, where a Carrion Crow mated with a female Hoodie ; the male was shot, and next year the Hoodie brought

VOL. 1 . 
another male Carrion Crow, when both it and the young were destroyed (Williamson's Scarborough list, 1836 ). At Langdon in Bowland and in Craven the nests are frequently built in low stunted bushes on the fells. The earliest reported eggs, a clutch of five, were found near Beverley on Ioth April I903.

Of interesting Yorkshire varieties the first known example was mentioned in a communication from Ralph Johnson, who, writing to John Ray, from Brignall, near Greta Bridge, under date 29th March I672, said: "Honoured Sir, I have only observed this change from proper colours to white.... in Crows (Corvus corone), whereof there is one now in Cliffe Wood, near Pierce Bridge" ("Correspondence of John Ray," p. 96). Another white variety is recorded in the Field, 3oth January I875; and one is reported, on the authority of Mr. Downs of Bolton Abbey, on Barden Fell in I906. A peculiarly plumaged bird was seen at Settle on 28th October I885; it was of a light silvery grey colour, with a slightly brindled appearance; the head and throat darker than the back and under surface, the tail and wings lighter, approaching a dove colour. Yet another "sport" of a pearl grey hue was observed in Ribblesdale in 1884 (Nat. I896, p. 4I).

Regarding the folk-lore connected with this species there will ever be an uncertainty as to whether the bird meant was a Crow or a Rook, these two names being often used indiscriminately, and the Rook superstitions may be read conjointly with this; but where the word "Daup" or "Daupee" is given there can be no doubt the Carrion Crow is meant. A saying illustrative of this is shewn in the Cleveland dialect: "Ther's bound for tae be a lot o' Rooks ti' year, $t$ ' Craws is building strang, an' wa's seean hae t' Daupees at wark." Here we see the distinction drawn; Rook and Crow apply to the same bird, but the Carrion Crow (Daupee) builds after the first-named have finished their nests. Like its larger relative, the Raven, it is deemed to be a bird of ill-omen, and the country children in some parts cry out at its appearance :-

"Crow, Crow, get out of my sight, Or else I'll eat thy liver and lights." 


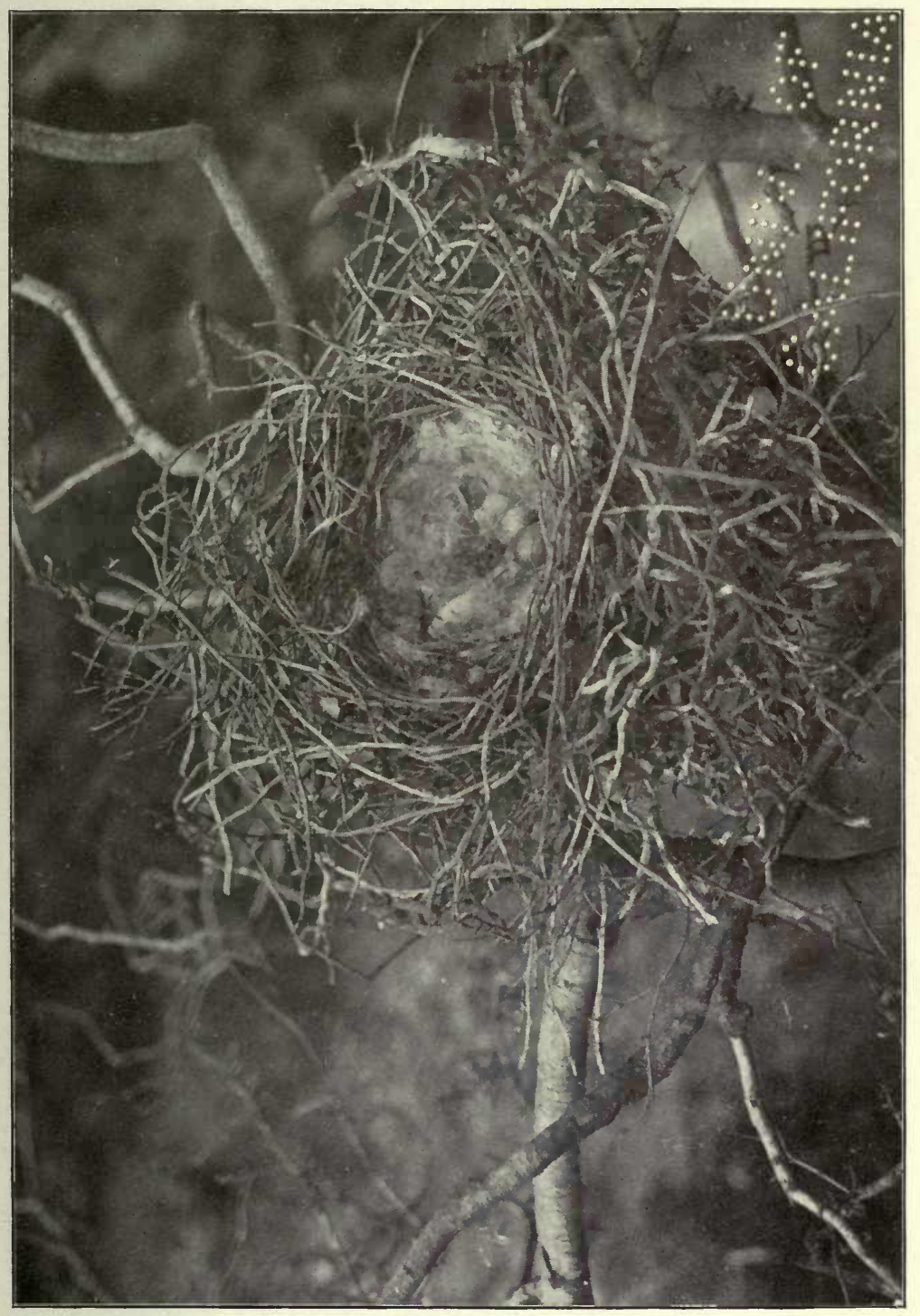

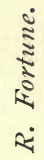

范

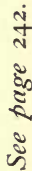



If a person falls asleep in the open it is said the "Craws will peck oot his een," and in the rhyme of "Lazy Jim" we have an exemplification of this supposition:-

Asleep, lazy Jim ligg'd,

Like an awd tup at's rigg'd ; (on its back.)

Bud ther cam' by what wakkens all sleepers,

An awd black Daupee,

Wheea seean oppen'd his e'e',

Fer he gav him a peck o' baith peepers.

Jim loup'd tiv his feet,

An' sairly did greet,

"If Ah catch tha, thoo gray-heeaded sinner,

Thoo'll nivver mair peck,

Fer Ah'll wring tha thy neck,

An' fling tha tea t' cat fer its dinner !"*

It is considered very unlucky for one of these birds to alight on outbuildings; the cattle are sure to die, and misfortune will inevitably follow. It is also supposed that if a Crow croaks an odd number of times in the morning it will be a wet day, if an even number it will be fine.

Of Yorkshire vernacular names the terms Craw, CarrionCraw, and Corbie-Craw are general; Car-Crow is used in Craven, and Ket-Crow in the West Riding, "ket" signifying carrion; at Sedbergh this bird is sometimes called the Flesh Crow; in Cleveland it is the Black-nebbed Crow, as distinguished from the White-nebbed Crow or Rook; Gor Crow is a West Riding term, Ger Crow a Craven one, and Cad Crow one used in the East Riding, while at Flamborough it is the Raven Crow. In the North and West Ridings are used the terms Dob, Doup, or Dowp, in Cleveland Daupee, and at Eavestone near Ripon, and Nunnington, the bird is Daup Crow. In Teesdale we have Dowk, and in Craven Midden Daup applied to this bird. In the Langdon Valley in Bowland the shepherds call it Raven; and in some of the remote Cleveland dales it is ironically termed "Black Pheasant."

"This song was known in 1790, and was sung at "Mell Suppers" so recently as 1838 . 


\section{HOODED CROW.}

Corvus cornix (L.).

Winter visitant, most abundant near the coast, where it arrives in October, leaving in March or April. Only of exceptional occurrence in some inland districts, whilst in others it is an annual visitor. Has occasionally remained to breed.

For the earliest local reference to this bird the observations of Ralph Johnson are quoted, and, although he wrote of the Durham side of the Tees, his remarks apply to both shores of the estuary:-

"The Royston Crow-Mr. Johnson [of Brignall, near Greta Bridge] calls it Sea-Crow, and saith it is frequent about Stockton in the Bishoprick of Durham, near the mouth of the River Tees." (Will. "Orn." I678, p. 22.)

Thomas Allis, I844, reported as follows:-

Corvus cornix.-Hooded Crow-Is rarely met with near York or Sheffield : more frequently near Doncaster; my friend Samuel Routh of Exthorpe has a single individual that has located itself on his premises for twenty winters past; it is more frequently met with at Thorne, and is very abundant in the lowlands not far from the coast ; it has been known to build near Scarborough. (See Yarrell's "British Birds," Vol. ii., p. 86.)

As one of our best known autumn migrants, the Hooded Crow makes its appearance on the coast with remarkable regularity in the first week of October; at Spurn, in the extreme south-eastern point of the county, it arrives on or about the 7 th of the month; my observations at the Teesmouth, on the opposite end of the seaboard, show that the average date of its arrival is October 6th, and the earliest noted was on roth September I880. Generally speaking, from the 3 rd to the 7 th of October it may be looked for, and, although odd birds are sometimes seen in September, the main migration does not take place until mid-October or November. In 1902 the earliest arrival was on the Ist of October, a single bird mobbed by Starlings; in I904 the first was noted on the $25^{\text {th }}$ of September.

The observations communicated to the British Association 
Migration Committee furnish abundant evidence respecting its appearance annually at all the Yorkshire Light stations, but the instances are too numerous to be given in detail, though it may be mentioned that "rushes" occurred in 1879 , after the "Skua gale," and each year afterwards in October, until I887, also in I889, I89I, I893, and I895. It sometimes begins to come from seaward at daylight and continues "dropping in " until noon, or occasionally later, giving rise to the opinion that it migrates by both day and night. Off Flamborough Head a long straggling flock was once noticed two miles off shore, passing over at a great height and descending on approaching the land; and when out at sea $I$ have often observed parties coming over in long, irregular lines, flying very slowly, and apparently tired out with the long journey. In October I88I, a Hooded Crow alighted on a fishing-coble, was brought ashore and put up for auction at the fish-market on the sands, but as soon as its captor placed it on the coble seat it spread its wings and flew off before a bid was offered, greatly to the amusement of the bystanders; another instance is recorded of one coming on board a ship on passage from Goteborg to Hull, and travelling by it to the Humber. Most of these immigrants (pauper aliens !) disperse over the country soon after arrival, although many remain in the neighbourhood of the coast, where they often come to the marshes, and at low tide associate with Carrion Crows to feed on any refuse or garbage thrown up on the shores of the estuaries. In severe winters they attack the weakly Thrushes, Redwings, and other small birds that are reduced to starvation point, and fall an easy prey to the marauding Crow. It is a rather scarce species in the West Riding, being more frequently found in the dales and moorland districts than in the flat open parts, but it is very common in the East and North Ridings after October. As spring approaches it receives a considerable degree of attention from the gamekeepers, especially on the moors, where it plunders the eggs of Grouse, or any other birds whose nests are accessible, and also works havoc amongst weakly lambs and ewes in the fell districts. 
The departure in spring usually takes place from March to April; on Irth April $x 870$, a flock was seen to leave the coast and take a course direct for the Naze ; odd birds sometimes remain until late in May, and on the 1 th th of that month in I902 I saw one on the Tees Marshes; at Spurn they have occasionally been observed in May and June, and near Pontefract a small flock was seen on 22nd May 1870. With reference to the return passage the Migration Reports contain much information; at Flamborough small bodies have been noticed hanging about the Headland, waiting for favourable winds before taking their departure; great numbers left on 30-3Ist March 1889, but on the 5th April many put back on account of stormy weather (M. Bailey, Nat. I889, p. I30). In this connection it is interesting to learn that important testimony, bearing on a similar occurrence which confirms Mr. Bailey's statement, is found in the Annual Register, I799, where under date of April 4th is the following:-

"Some hundreds of ... Royston Crows, Lapwings, etc., were cast on shore on the Holderness coast."

Yorkshire can lay claim to the Hooded Crow as a nesting species, irregular, perhaps, though in this respect the Cliffs of Flamborough have been more favoured than other localities. A pair bred there in $1858,187 \mathrm{r}, 1876$, and so recently as $188 \%$, when a brood was reared near the lighthouse (Zool. I858, p. 6I42, and M. Bailey MS.); odd birds have been seen in other years in the nesting season, both at Flamborough and in South Holderness, and a flock of sixteen "pensioners" remained at the former place all the summer of r8gr (Bailey, Nat. r8gr, p. 35I). Near Scarborough a female paired with a Carrion Crow at Hackness, where they brought off young in a large tree; the male bird was shot, and next year the Hoodie found another black mate, which, with the young brood, was again killed, and again the Hoodie, by the exercise of remarkable cunning, escaped; a third time she returned with a fresh partner, and on this occasion she shared the fate which had befallen her former companions; the young varied in plumage, some resembling the male bird, whilst others had the characteristics of the Hooded Crow. 
The female is now in the Scarborough Museum (Williamson's Scarborough Catalogue, 1836). Near Beverley a pair bred in 1876 , and a nest with young, near Easington in Holderness, was recorded by the late J. Cordeaux in the Naturalist $(1896$, p. 5). In the north of the county a pair nested on Hornby Castle estate, where the female was trapped in I865, and at Clifton Castle a pair was observed all the summer of the year 1880 (James Carter MS., and Field, 2oth November 1880).

The members of the Crow family are, proverbially, of a rapacious nature, and the species under notice is in this respect equally guilty with its relations; amongst its many crimes may be catalogued that of killing and eating salmon; the delinquents in this case were seen in the high reaches of the river Ure at Mickley, on 26th December 1888, in the act of devouring the fish which they had caught on the shallow spawning grounds; two Grey Crows were noticed chasing a Black-headed Gull near Beverley; and the late Canon Atkinson of Danby mentioned in the Zoologist (1875, p. 4420), two instances of these birds attacking Partridges on the wing.

It is not needful here to enter into the controversial question as to whether the Hooded and Carrion Crows are to be considered separate species; it is proved that they interbreed, and that the progeny are fertile, and partake of the characters of both parents. In the Newcastle Museum is a hybrid, taken near Richmond, whose plumage is all black, with the exception of a grey band across the breast (" Birds of Northd. and Dm." p. 35). The only other Yorkshire variety, at present recorded, is a light-coloured specimen at Coverhead, on 9 th October 1884 .

Folk lore connected with this species is not voluminous, though the remnant which is preserved proves that the migratory habit of the bird was known many years ago to dwellers in the Cleveland dales, who used to work a charm invoking the aid of the Hooded Crow. The account of this quaint ceremony was communicated by an old Cleveland woman, who remembered it being commonly resorted to in her grandmother's time, and who had herself worked it 
as a girl in the early years of the past century ; the only persons permitted to take part in it were " honest wed women and true maidens" who, with hand on God's word, declared themselves as such. According to the version given, those who had a wish needing the help of the fairies and other hidden powers, and who desired likewise to baffle the evil aims and spells of witchcraft, were required to keep a sharp look out for the coming of the Hooded Crows; on hearing the first cry of the birds, and immediately after seeing them, two women were to go indoors and prepare a dish of choice food, to be mixed and made into balls, the herbs and other ingredients for which were laid ready to hand, and the twain about to work the charm were to add in turn one thing at a time, both repeating an incantation, until all should be mixed ; the balls, to the number of nine, each tied in a separate cloth, were then to be dropped into a pan, ready boiling on the fire, the last to be dropped in as the last line of the incantation was repeated, both holding this last and ninth ball.

\section{THE INCANTATION.}

Hooded Craws frev ower $t^{\prime}$ sea,

Ah pray o' ye ti gracious be,

Sthrang o' wing, an' far o' fleeght,

Ah beg a favour fra yer might.

Byv t' blood o' $t$ ' hawks, 'at fouled yer nist,

Byv t' ullot's ${ }^{1}$ blood 'at brak yer rist,

Byv t' blood o' $t$ ' fox 'at teeak ${ }^{2}$ yer prey,

An' mair an' all t' egg suckin' jay,

Ah coss $^{3}$ nut yan, bud coss 'em all,

An' pray ill luck ti' on 'em fall.

Wi' wicken thauvel, ${ }^{4}$ siller speean, ${ }^{5}$

Wi' han's held cross'd; an' saut ${ }^{6}$ 'at $t^{\prime}$ meean 7

$E_{z}$ leeghted ${ }^{8}$ on three waning neeghts,

Fra wezzle's ${ }^{9}$ heart, an' wild cat's leeghts,

Fra nine white grubs fra fur an' rig, 10

Fra flat tailed wo'ms fra mou'd an' mig, 11

Fra chaffer ${ }^{12}$ grubs, an' deead lambs' een,

1 Owls. 2 took. 3 curse. 4 "Wicken thauvel "-a wooden implement used for turning flat cakes on a "girdle." ${ }^{5}$ silver spoon. ${ }^{6}$ salt. 7 moon. 8 lighted. 9 weazel's. 10 "fur an rig-furrow and ridge (of a field). 11 " mou'd an mig "-mould and manure heap. 12 cock-chafer. 
Sike teeasty food ez ne'er war seen, Ah beg ya sup at bre'k o' day, An' deea mah bidding, this $A h$ pray !

When cooked, the balls were laid over night on some midden, or well-known feeding place generally resorted to by Crows, and if consumed by the morning the charm had worked well, and the wish would be duly granted.

The vernacular names are many and varied, shewing the peculiar ideas respecting its country of origin. Hoodie, Royston Crow, and Norway Crow are general terms, as also are Grey Crow, Grey Back, or Grey-backed Crow ; in Craven it is the Northern Crow, or Dun Crow ; the Blue-backed Crow at Thirsk ; the Denmark Crow in the Humber district; Garton Greyback, or Wetwang Greyback, according to its haunts in the Wold district; Moor Crow in the Nidd Valley; Dutch Crow at Ackworth; Coatham Crow, and Woodcock Crow at Loftus and Staithes, and Black Neb in Teesdale.

\section{ROOK.}

\section{Corvus frugilegus (L.).}

Resident, generally distributed and very abundant. In autumn large numbers of immigrants arrive from the Continent.

Probably the earliest mention of the Rook in connection with Yorkshire dates back to about I730, and relates to an incident which occurred at Bilton near Knaresborough, as mentioned in the life of John Metcalf, where it is recorded that Metcalf [Blind Jack of Knaresborough] and a companion robbed a Rookery at dead of night, bringing away seven dozen and a half, excepting the heads which they left under the trees. This so incensed the owner that he sent the bellman round, offering a reward of two guineas for the detection of the offenders. (Yorkshire Magazine, I5th April I875, iv., p. 7I.)

Thomas Allis, 1844, wrote:-

Corvus frugilegus.-Rook-Common in most parts. R. Leyland 
remarks that a few small colonies still exist near Halifax in spite of steam engines and factories: Samuel Routh gives me the following information respecting the practice of the Rook in occasionally rejecting indigestible matter from the stomach like the Owls. "There are a number of fields under the plough opposite to my house, and nearly a quarter of a mile off, some of which are wheat in their regular course of cropping, and being in a retired part they are much infested by Rooks when the ear is filling. Just below these fields are some large grass closes where I can very frequently see the Rooks settle in large numbers ; it was, I think, in 1835 or 6 I had noticed them making sad havoc among the wheat just then filling in the ear, and on going over a part of a grass close, where I had the evening before observed the Rooks congregated, I was a good deal puzzled with a number (perhaps six or seven) of singularly shaped pellets about the thickness of a walnut and about two inches long, they were smaller considerably at one end than the other, and covered with a dry mucous coating, very thin. On breaking them I found them composed of the husks of wheat quite free from moisture or kernel, and intermixed throughout with small pieces of stone, chiefly lime, and one or two little bits of brick. It very soon occurred to me, from seeing the Rooks there previously in great numbers, and having seen them before upon the wheat, then in a milky state in the ear, that these pellets must be ejected by them, to which I was led also by their form. I mentioned the circumstance to my friend Thos. Gough of Kendal, who was much interested with the supposed fact, for I have no other proof that it is one. After a good deal of research I believe he has found the same kind of pellets. A year or two after I found the same things again in the same field, and exactly at the time when the wheat was in a milky state in the ear, but with this difference; the last I found, instead of the chaff being mixed all through the pellet with portions of lime or stone, it was mixed throughout with portions of a wing of a kind of beetle, the wing pieces appeared to me (not being an entomologist) all fo one kind and colour."

The Rook is, without doubt, the most abundant of our larger inland birds, and is not absent even from the desolate moorland tracts, for in the dales and on the high fells of the west and north-west it is met with in the most barren situations while on foraging expeditions. In timbered districts few country residences are complete without a "Rookery"; there is, therefore, no necessity to enter into details respecting the distribution of such a common species, which is one of the most familiar birds of the county.

As an immigrant from the Continent, however, it is not 


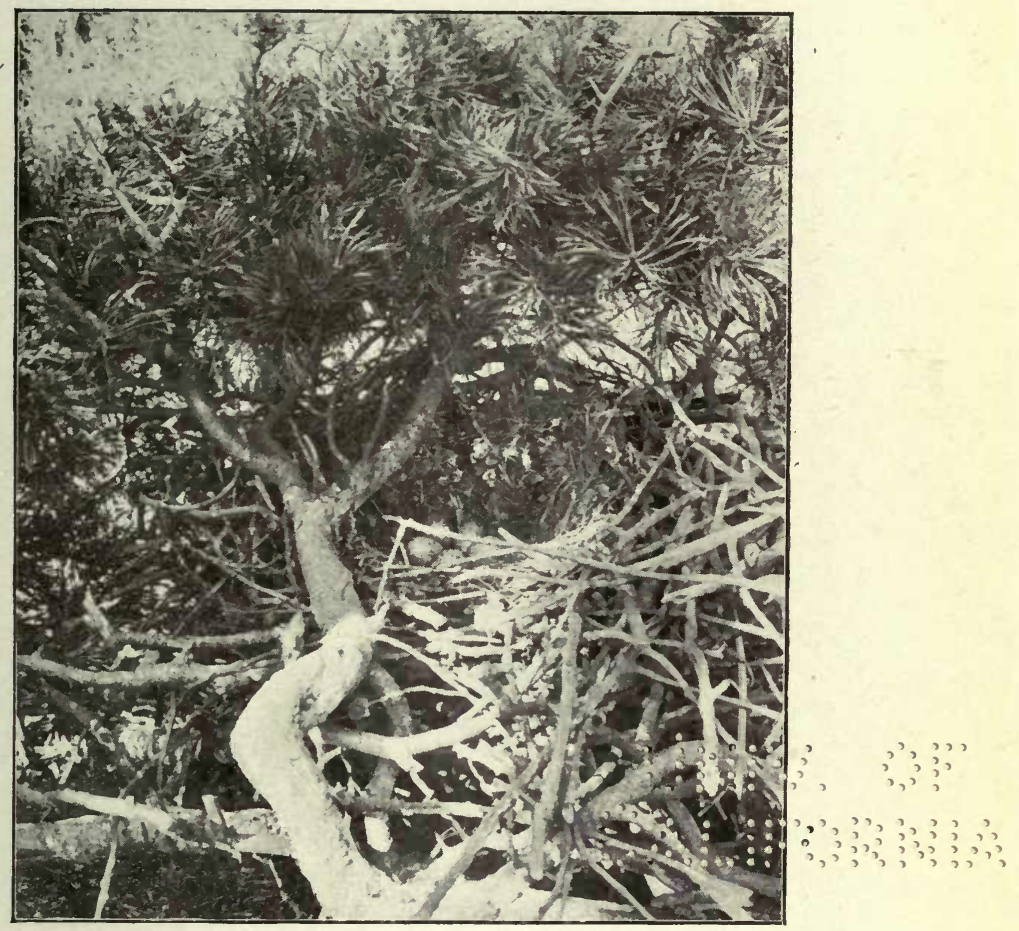

Nest of Rook.

R. Fortune.

See page 251. 
यद 646 ?

andrende 
so well known, and requires a little more notice at our hands. Immense numbers arrive on our shores every year, generally during October and November, when I have observed them coming in one steady stream, from early morning until late afternoon, and often in company with Hooded Crows, Lapwings, Starlings, and Skylarks. The Migration Reports contain many references to the autumnal migration of Rooks, but the greater portion appear to land from Spurn southward, though the Teesmouth is by no means neglected as a place of arrival for these immigrants, and "rushes" occur almost annually. In the autumn of 1902 there were more migrant Rooks noted than I have previously known, and similar reports are given from the Lincolnshire and Norfolk coasts. In March there is a gathering of large flocks at the coast, which seem to be emigrants about to depart on their return journey.*

After the breeding season both old and young collect in dense flocks, and in the late afternoon wing their flight to a chosen roosting place, not, as a ruke, a Rookery, although it may be near one. The members of several colonies often congregate, accompanied by a small proportion of Jackdaws, forming an immense swarm of birds, which on reaching the roost make a considerable commotion and breaking of twigs. Later in the year they are quieter in their demeanour, although I am not aware that any actual Rookery is resorted to as a roosting place in winter in like manner as in the nesting season. The late P. Inchbald, writing in the Zoologist (I872, p. 302I), recorded the dispersion of a Rookery by a small band of four or five Carrion Crows, at Hovingham Lodge near York, and at Ripon a colony was broken up in the spring of 1890 owing to its being harried by the same mischievous birds, while at Beverley a Rookery was abandoned from a similar cause.

It is now a well-established fact that Rooks do immense harm to eggs and young of game, poultry, and other birds,

* In the Report, issued in 1903, by the British Association Migration Committee, Mr. W. Eagle Clarke gives an exhaustive resumé of the migration of this species. 
particularly in dry seasons when their natural food is difficult to procure, and it is not improbable that this "petty larceny" habit has developed owing to the great increase of the birds, and the consequent comparative scarcity of food.

Nidification, as a rule, commences towards the end of February or early in March, and eggs are met with in the third week of the latter month, although they have been noted at Giggleswick as early as the gth. Some curious, indeed remarkable, situations have been chosen for the nests : the earliest noted being at Hull, where two pairs built and reared young between the chimney pots of two houses in George Street, the full particulars being set forth in the Zoologist (1846, p. 1366). At Heworth near York a remarkable instance occurred in 1887 , when a pair of Rooks built in a cage near the weathercock, at a height of 120 feet, on Heworth Church, but were not successful in rearing young that year nor the one following; in 1889 , however, two young were brought off, in 1890 three were reared, and the parents nested successfully since that time until the year 1903. Near Beverley nests have been built in a high hedge, also in poplar trees and willows, whilst some birds, whose nesting trees had been blown down, built in elder bushes within eight feet of the ground. A nest is also reported on the roof, close to the chimney, of a house in Scarborough. At Stokesley in Cleveland a colony of fifty pairs build in low saplings, and many nests were, in 1900 , not more than ten feet above terra firma.

There are numerous instances recorded in Yorkshire of variation in plumage of this species. Two examples shot at Pickering, on I3th May I896, had the black feathers of the dorsal plumage slightly margined with grey, giving the birds a chequered appearance of an unsuual character. White, albino, and pied varieties, also some of a dun or chocolate hue, are known, and so early as $x 805$ a white Rook was recorded at York, while Marmaduke Tunstall mentioned a pied individual, also a brown coloured bird with white eyes, at his brother's residence in Holderness (Tunst. MS., I783, p. 56).

The folk-lore connected with the Rook in Yorkshire is 


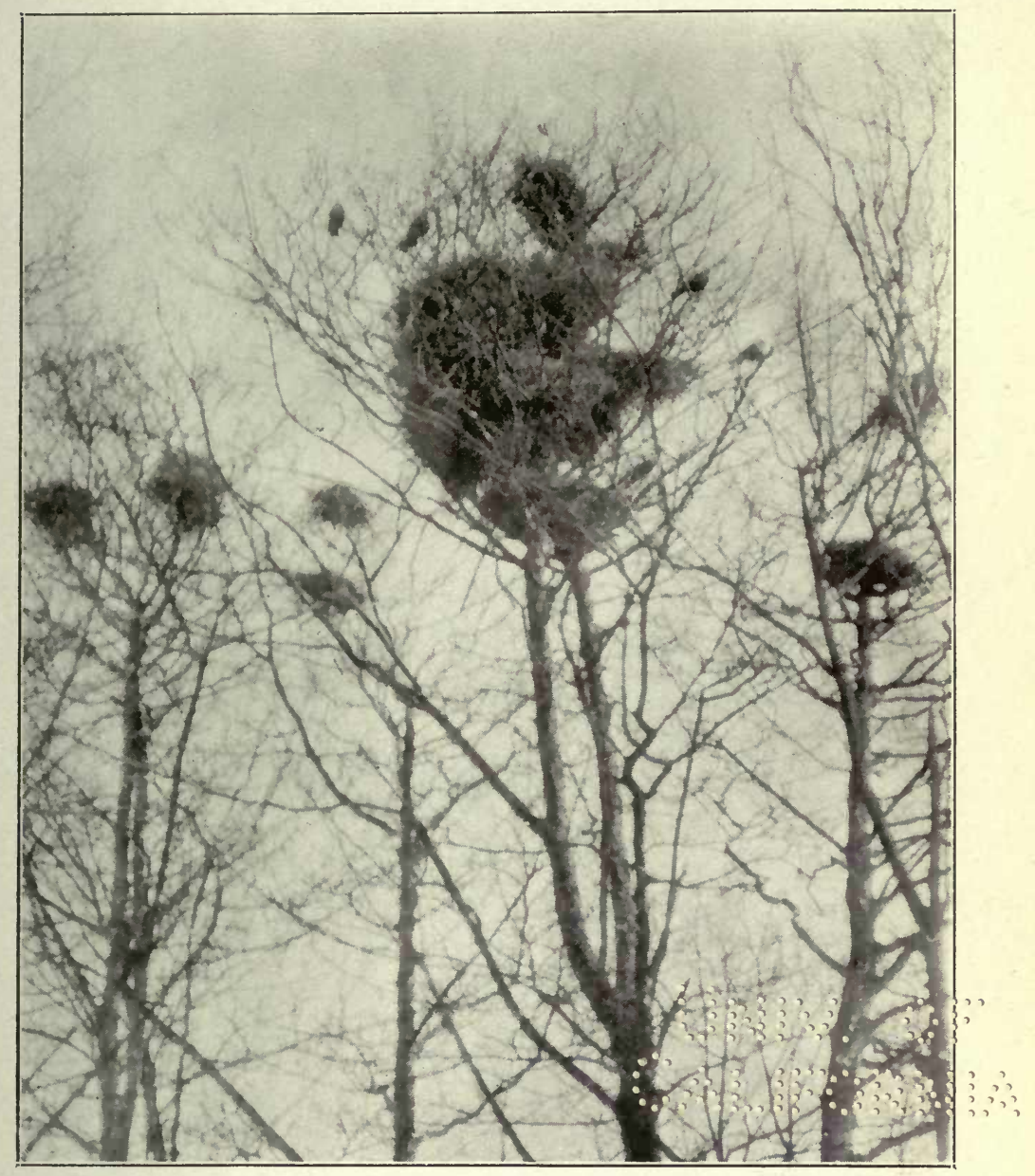

An Ancient Domicile. Rooks' nests near Panna:.

R. Fortune.

See page 252. 

very voluminous and interesting; regarding its nidification a rhyme runs:-

On the first of March, the Crows begin to search,

On the first of April, they are sitting still,

On the first of May, they're a' flown away ;

Croupin' greedy, back again, wi' October's wind and rain.

It is considered to be unlucky to disturb the nests, and in some parts the children believe that if they climbed the Rookery trees to rob the eggs the old birds would peck out their eyes, and if there were young in the nests the whole colony would attack the intruder. In Cleveland the village boys imagine that if they call out-

"Crow, Crow, thy nest's on fire!"

It'll burn the steeple, and burn the spire!"

any passing birds, on hearing the alarming news, fly homewards with increased speed; and in the Craven district, if it is desired to frighten away Rooks in the vicinity, the following couplet is shouted at them :-

"Crow, Crow, get out of my sight,

Or else I'll eat thy liver and lights."

In many districts in North Yorkshire it is a regular custom for country people to put on some new article of wearing apparel on Easter Sunday for fear of offending the "Crows," as is shewn in the following rhyme, written by "Florence Cleveland ":-

" On Easter Sunday .....

An' if ya've nowt ta put on new

There is a fine ta deea,

For $t^{\prime}$ craws is seear ta finnd it oot,

An' soil yer awd cleas mair."

Another Easter practice was to watch the flight of Rooks carefully. If they settled near home instead of flying far afield to feed, the farmer shook his head, believing that grub and other pests would afflict his crops that year. If a "Crow" settled on a house or outbuildings misfortune was sure to follow, death or sickness in the case of human beings, and disaster to stock and cattle; if the bird flew round the house and did not settle, any untoward event which happened 
was attributed to it, but to see a flock fly over was a sign of good luck. To find a dead "Crow" is unlucky. When Rooks congregate on the dead branches of trees it is certain to rain before night, but if they stand on the live boughs the effect is to the contrary ("Notes and Queries," I880).

At Norton Conyers near Ripon, the residence of Sir Reginald Graham, there is a curious legend connected with the Rookery, which, tradition says, was in existence 300 years ago. Some Seer or Witch, living near to Skipton Bridge, foretold that when the birds forsook their building-place then sad days and death would visit Norton Conyers. We are told that the year before the rebellion against Queen Elizabeth by the Earls of Northumberland and Westmorland, which Norton (the then owner) and his eight sons joined, and which lost them their heads and estate, the birds fled the Rookery. A like occurrence happened when Sir R. Graham died after Marston Moor; legend says but few birds built that year, and their cawing was so mournful to listen to, that all knew sad days were looming, and so it was, for, after having. received twenty-six wounds, and learning the battle was lost, the Cavalier baronet left the field, reached home that same night, and died an hour afterwards.

Local names : Crow or Craw are in general use. A common belief is that the Rook, after its first moult, becomes a " Crow" proper, and only a bird of the year can be correctly termed a Rook. Of this idea I had oral proof from the wife of a country gentleman in the North Riding, who remarked, in driving past a Rookery late in the year, "I suppose they will soon be growing into Crows." In the Craven neighbourhood the young birds before they can fly are called Pearkers, and Branchers is a general term for the fledglings. 


\section{SKYLARK.}

\section{Alauda arvensis (L.).}

Resident. Generally and abundantly distributed. Immense numbers of immigrants arrive from the Continent in autumn.

Historically, the Skylark, as a Yorkshire bird, can claim ancestry of great antiquity, for we find in the ordinances as to the price of food in the City of York, in I393, in the sixteenth year of the reign of King Richard II., that "the price for I2 larks be one penny" ; in the Northumberland Household Book, kept at the Castles of Wressill and Lekinfield, in I5I2, the value of "Larkys " was stated to be " I2 for 2 d." ; and in 1560 , at Hull, Larkes were quoted at $4 \mathrm{~d}$. per dozen.

Thomas Allis, in I844, wrote:-

Alauda arvensis.-Sky Lark-Very common. A bird of this species, in confinement at Halifax, has the mandibles greatly produced and crossed, as is sometimes met with in different species of birds in a state of nature; it takes its usual food with ease.

In addition to being a widely diffused and abundant resident species, enormous bodies of immigrant Skylarks arrive on the east coast in the autumn, individually far outnumbering any other migrant. After the breeding season the bulk of our home bred birds move towards the coast in readiness to leave, and by the end of August their departure has commenced. Throughout the two months following, this migration is at its height, and is usually carried on from daybreak to noon, when the succession of straggling flocks may be observed moving along the coast line in a southerly direction. This movement would be much more noticeable were it not for the tremendous swarms of new comers that pour in from the Continent, commencing about the end of August and continuing for several months, and even into the following year, during all hours of the day and night and in all weathers. When the atmosphere is foggy, or during heavy storms of rain and snow, Slkylarks are frequently killed against the lanterns of our sea marks, the 
casualities in one night often being very heavy.* Occasionally the two distinct movements of our departing birds and the immigrants may be observed simultaneously. It is remarkable, as shewn by the returns from Light-stations communicated to the Migration Committee, how frequently Larks are associated on migration with Starlings, either in separate flocks or together, the two species seem to be inseparable in the autumn passage, usually taking a course from east to west.

These migrants do not stay long with us, but pass inland, and probably move further southward in winter on the approach of severe weather; a day or two previous to any great change in temperature they may be observed to congregate and, on the outbreak of a storm, leave the district. The occurrence of "rushes" is noticed annually, generally during October or November; (on October 2I-23rd I88I, there was an incessant day and night rush at Redcar), but sometimes later, previous to the advent of sudden winter storms, in December, or even in January and February, and at times in astounding numbers. On December 9 th, and following days, in 1878 , with severe gales and snowstorms, great flights passed Redcar from eastward, in company with Redwings and Fieldfares; and on February 8th I902, I witnessed an extraordinary migration, preceding a fortnight's intensely hard frost. From early morning to dusk huge flocks were, with slight intermission of a few minutes, flying in a direction from almost due north, and, as there was no perceptible increase in the numbers of birds in the fields and marshes, they must have passed on without stopping.

About the end of February, or in the first half of March,

* On 6th November 1868, at Heligoland, 3400 Larks were captured at the lantern, and II,006 were taken in nets, making a total of I 5,000. Mr. W. Eagle Clarke states, in the British Association Report, 19or, that the Bell Rock Lighthouse, on 2nd December I882, was visited by the greatest multitude of Larks ever known : "they were striking hard for a couple of hours like a shower of hail." The student of migration is referred to this, the most admirable and complete history of the Skylark's movements which has ever been written. 


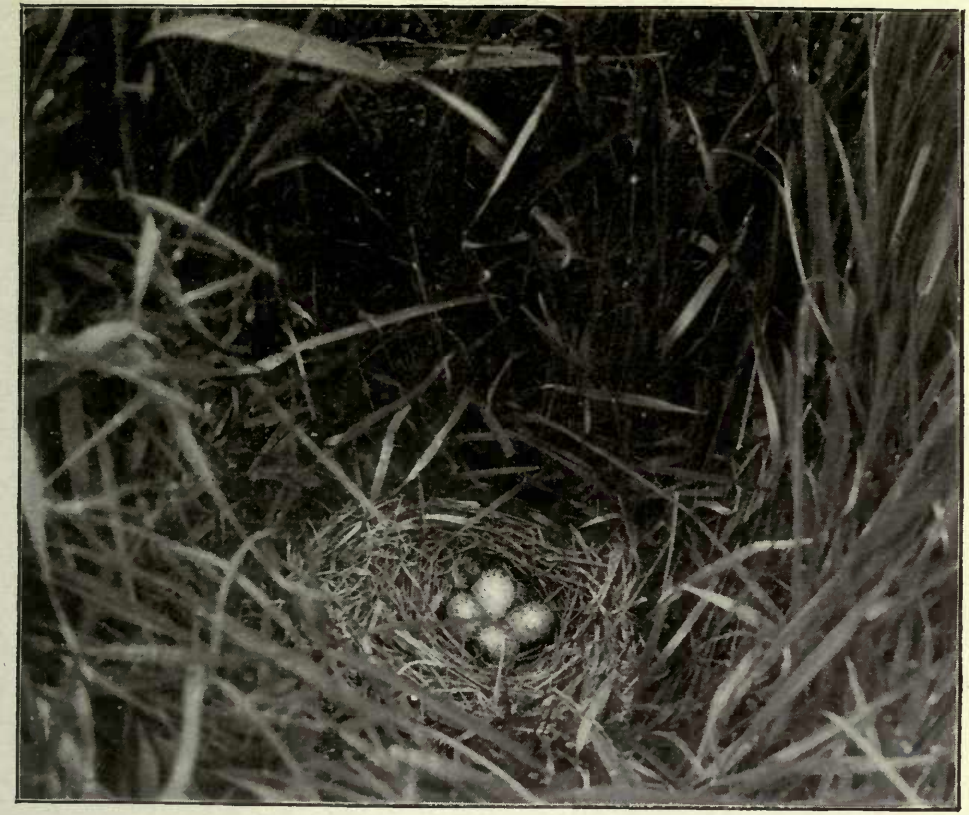

Skylark's Nest.

R. Fortune.

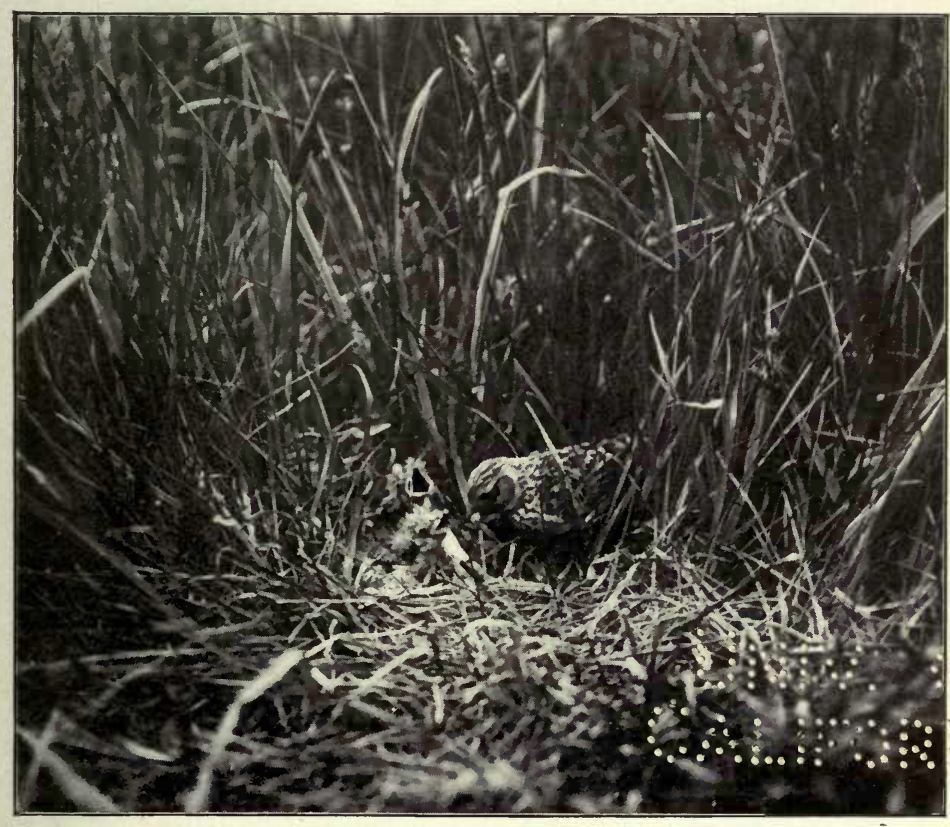



our resident birds appear in their old haunts and quickly make their return known by soaring skywards and pouring forth their full song, very different from the half-hearted trillings of those on the move.

Three or four eggs usually constitute a clutch, and when five are found they almost invariably belong to a second nest. At the Teesmouth there is a marked diversity of colouring in the eggs laid on the marshes, every variation being found, from an almost white ground clearly mottled with reddish brown, to a very dark or almost black type.

White and cream, or buff-coloured, varieties of the bird are not uncommon in Yorkshire; on 9th October I89o, I saw a white one in a migrating flock coming in from seaward, and a pied individual was secured at Scarborough, as mentioned in the Zoologist for I883, p. 79.

Of local names, Lark is the generally-used term, modified to Song-Lark at Ackworth; Sky alone is in use at the Teesmouth. In I827 Laverack was noted as used in Craven, and at Sedbergh this becomes Laverock.

\section{WOOD LARK.}

\section{Alauda arborea (L.).}

Resident; very limited both in numbers and distribution.

The first published record of this species in Yorkshire is in Graves's 'History of Cleveland," I808, where it is enumerated in the list of birds.

Thomas Allis, in his Report of I844, wrote :-

Alauda arborea.-Woodlark-Is met with near Doncaster; also occasionally at Killingbeck, near Leeds, and more rarely in the vicinities of York and Sheffield, and it is now very rarely seen about Barnsley; it breeds sparingly at Langwith, and Roans near York, as I am informed by $\mathrm{J}$. and $\mathrm{W}$. Tuke.

The Wood Lark is resident in limited numbers, and very sparingly distributed. It has been reported from the vicinity 
of Sheffield in End Cliff Woods ; near Wakefield, in the winter of 1856 , three were shot in company with Skylarks; one is noted at Luddenden in I899 (A. Crabtree, "Halifax Naturalist," I900); and from Doncaster it was recorded so long ago as I840, as also at Killingbeck near Leeds. At the same period it bred sparingly at Langwith and near York; in connection with the latter place, Audubon mentioned that, during his second visit to London in I828, he was presented with a pair of Wood Larks by Mr. Backhouse of York ("Audubon and his Journals," Vol. I. pp. 284-5). It has also occurred at Campsall, Maltby, and Roche Abbey ; and it is reported by Mr. R. Fortune to have nested on Harlow Moor, Harrogate, in $I 880$. In the north portion of the East Riding two examples have been met with at Pocklington; one in summer, which points to the probability of its having nested there. A female, that had been feeding on blades of grass, was noted in the North Riding, at Hornby, near Catterick, on 4th January 1864 , and is now in the museum at Newcastle-on-Tyne.

On the coast line it is a very rare migrant, known only in two or three places, though it is quite possible it may be overlooked amongst the numbers of Larks and Pipits frequenting the rough pastures and marshes in autumn and winter. In the Spurn district Mr. F. Boyes once saw several during hard weather; one was obtained in October I89I, and another was seen at Sproatley on 28th April I900. It is mentioned in Hinderwell's Scarborough list in I832, and also by the late Alfred Roberts in I880, but does not appear to have occurred there of late years. Near Redcar a small flock was feeding at high-water mark on the sands east of the town, during the severe weather in Jànuary I8gr, and on the I6th of that month I obtained four of them, one of which is now in the Royal Scottish Museum, whilst two more were procured by a fisherman on the following day (Zool. I89I, p. 253 ; Nat. I89r, p. 123). 


\section{SHORE LARK.}

\section{Otocorys alpestris $(L)$.}

Winter visitant to the coast line, irregular in numbers. Occurs annually at the estuary of the Tees.

The honour of introducing the Shore Lark to the Yorkshire avi-fauna is due to $\mathrm{Mr}$. Thomas Allis who, in a communication to the Zoologist (1854, p. 425 I), dated February I854, wrote :-

"I have a fine specimen of this rare bird, which was shot at Filey, on the Yorkshire coast, in the early part of March I853; a second was seen at the same time but was not obtained."

Thanks to the increased attention paid to ornithology, and the careful investigations made by a few latter day coast observers, amongst whom may be mentioned Messrs. Boyes, Cordeaux, and Eagle Clarke, the Shore Lark is now known to be a winter visitant to the Yorkshire coast on migration in October and November, and also later in the season; the numbers fluctuate in different years, but in its favourite haunts, which are the estuaries of the Tees and Humber, and Flamborough Head, the bird is found not infrequently, and at the Teesmouth it may be observed with unfailing regularity. At Filey, Scarborough, Whitby, and other parts of the seaboard, it is also reported, but it is not met with annually in these places excepting in the Staithes and Loftus district, where scores are sometimes seen after severe weather.

In I879-80 a large flock was noticed near Kilnsea, and twenty-three specimens were obtained during the winter; since then the Spurn district has been closely worked and the occurrences of Shore Larks have been recorded regularly in the columns of ornithological journals, with the result that that neighbourhood is regarded as the chief habitat of the bird in Yorkshire. In addition to the season mentioned - I879-80-it was abundant in $I 883, I 889, I 890, I 89 I, I 894-5$, and $1898-9$; and the time when it is most frequently noticed 
is at the period when the "rush" of winter immigrants takes place in October and November. The Teesmouth, however, is equally favoured by its visits, as my observations made during the past few years tend to prove, and it may be met with every winter in certain localities which provide it with suitable feeding grounds. In I9oo a party of twelve appeared on the I2th of October, and others continued to arrive until the 22nd of December, while a flock of fully two hundred individuals frequented a piece of reclaimed land from November until February of the following year.

The earliest date for the Shore Lark's arrival, of which I am aware, is I8th September I895, when two were killed in my presence on the rocks at the east end of Redcar. It has been known to prolong its stay until the 2oth of March, a flock numbering about twenty individuals being noted at Spurn on that date in $\mathrm{I} 880$.

There are, however, few species that are more overlooked by the sportsman and pseudo-naturalist than this under notice, and our earliest apprisals of its visits are chiefly due to speculative shots at small birds on the coast, which occasionally result in the Shore Lark falling to the gun, and being duly chronicled. My first acquaintance with it was on 2Ist November I877, when I procured one from a flock of, what I imagined to be, Skylarks crossing from seaward and flying overhead. At the Teesmouth it usually haunts the foot of the sandhills near high-water mark, where it feeds among the débris cast up by the tide, or on the short herbage at the edges of the tidal pools. In habits it is a very unobtrusive species and runs about silently, feeding with the assiduity of a Starling, but, on being approached, rises, uttering a peculiar "weet-you" call of alarm. Its appearance on the ground is rather deceptive, as the yellow and black markings of the head and throat are not conspicuous, and the bird appears to be of a warm brown hue on the back, and light coloured underneath, thus resembling the plumage of the majority of the Larks and Pipits. Its flight may best be described as intermediate between that of a Rock Pipit and a Skylark. 
Although many of the migratory flocks are seen to pass directly inland, the only note of its occurrence, except at the coast line, is from Harewood, near Leeds, where two were shot "many years ago" and were purchased by the late Capt. Turton for his collection at Upsall Castle (Turton MS., I880).

This species is not sufficiently well known to have any vernacular names, though Sea Lark is a term occasionally used in Cleveland.

\section{SWIFT.}

\section{Cypselus apus (L.).}

Summer visitant, generally distributed and fairly common, except in the manufacturing districts, where it is scarce. Arrives in the first week in May, departing in August and September, occasionally lingering as late as October.

An early allusion, perhaps the earliest, to this bird, is contained in the Allan MS. (I79I), where it is mentioned as " Black Martin or Swift. Largest of our Swallows, and more on the wing. ... Builds in high places, as church steeples, towers, etc." (Fox's "Synopsis of the Tunstall Museum," p. 76.)

Thomas Allis, I844, wrote:-

Cypselus apus.-Common Swift-Common about Doncaster. J. Heppenstall observes that it has been more common about the town of Sheffield this year than usual though evidently decreasing in the country. R. Leyland remarks that a few pairs still breed in the vicinity of Halifax, but that they have completely abandoned the streets where formerly they might be seen in considerable numbers: W. Eddison says it comes every summer with the latest visitants, and leaves early; it seems to be less numerous every year, which he attributes to the wantonly cruel pastime of shooting them for practice; there have been fewer near York this year than I have ever before known; in other districts their decrease is not mentioned.

This species arrives later than the Swallow and Martins, the usual time for its appearance being the first or second 
week of May, though occasional stragglers have been observed some days earlier; on 5th April I887, several arrived at Spurn and remained all night on the Lighthouse (Ninth Migration Report), nor does cold always retard their arrival, for on 7 th May I902, although a bitter east wind was blowing, with snow showers, I saw three Swifts at Redcar hawking for several hours over the breakers about twenty yards from the shore. About the middle or third week of August they leave for their winter quarters, some remaining until September, and late birds have been recorded in October or even in November; the latest date of which I have notice is I6th November I90I, when two were observed at Harrogate. An individual found in a dormant state in an old chimney at Bolton Hall, in mid-winter, was probably a weakly bird unable to migrate at the proper season.

It is generally, but somewhat locally, distributed, and decreasing in some localities, particularly in the neighbourhood of Beverley.

The information concerning the Swift supplied to the British Association Migration Committee indicates that, at the Light stations on the coast, it is noticed both in spring and autumn, being sometimes observed to flock round the lanterns and remain on the galleries and window-sills all night. Towards the end of June a north to south movement takes place along the coast line, reaching its height in the first half of July, and in most seasons gradually ceasing about the first week in August. At the Teesmouth the line of migration is most pronounced; the birds, coming from the direction of West Hartlepool, pass over, or close by, Seaton Carew, cross the river near the Snook and, striking the Yorkshire shore near Tod Point, take the direction of Wilton and Eston, missing Redcar entirely. Curiously enough this line of flight is also chosen by homing pigeons travelling south along the coast. A south, south-west, or south-east wind is invariably used by the migrating Swifts, and, after a continuance of adverse weather conditions at the period named, great "rushes" occur on the first favourable day. With steady winds in the right quarter the birds travel more leisurely, in small 
parties of from five to twenty, but during " rushes," such as that of 9th July I899, 6th July I90r, 6th July I902, and 30th June I904, flocks of from twenty to two hundred were noted passing continually from early morn to dark. Occasionally there is an arrival of Swifts from the south-east at the same time that the southward passage is in progress, two distinct migrations being observable at one time. The late $\mathrm{J}$. Cordeaux referred to this migratory movement in his "Birds of the Humber District," I899, p. I4. In the year 1879 an enormous concourse of Swifts was observable on the northeast coast ; at Redcar on the 2oth August there were many thousands between the Teesmouth and Saltburn, flying at various altitudes from 3 to 300 feet. At night numbers roosted on the window-sills of the houses on the sea front, and some entered in at bedroom windows which had been left open; next day all but two or three had departed; they then increased again until the 27 th, when they were more numerous than ever, swarming like gnats in the air, and exciting considerable interest in the town as they flew along the Esplanade and in the streets, where boys struck them down with whips and sticks. By the end of the month they had all disappeared excepting four individuals which remained two or three days after the bulk had left (Zool. 1879, p. 423; Field, 6th and I3th September I879).

In the upper portions of some of the dales of the West and North Ridings the Swift breeds at a considerable elevation ; at Malham Cove a colony have nesting holes in the higher parts of the cliff, as also at Kilnsey Crag in Wharfedale, and at Kettlewell, while eggs have been taken from a nest in an old shed on one of the high fells of the north-west. In some places the Swifts often have fierce battles with Starlings, ousting the latter birds from their breeding quarters. Several small colonies are found in the high sea-cliffs extending from Cleveland to Flamborough Head. In June I883, I discovered nests under the tiles in quite low outbuildings at Easterside in Ryedale. After the breeding season both old and young are frequently met with on the fell tops, and have been observed as high as Crossfell in Cumberland. 
A singular instance with reference to the roosting habits of this bird is related by Mr. W. Gyngell, who saw one near Scarborough clinging to a pendent branch in a tree about twenty feet above the ground, and then hanging suspended vertically, swaying like a scarecrow to and fro in the breeze, and evidently settled for the night (Nat. I897, p. 298; Zool. I897, p. 468).

The vernacular names are somewhat numerous and varied. Its cries give it the name of Screecher,-a term in general use,-Devil Screamer and Devil Squeaker in the North and West Ridings, and Devil Shrieker in the West Riding. These terms become Screw and Devil Screw at Ackworth, and the diabolic association is kept up in the West Riding term of Devil-bird, which at Skelmanthorpe, near Huddersfield, becomes Devil's Bitch. In many parts of the North and West Ridings it is known as Devilin or Dicky Devilling; in the East Riding it is Devilling, which at Thirsk is transmuted into Dibbling.* In Ryedale and Cleveland it is designated Collier. Swainson gives Whip as a West Riding term; at Loftus-in-Cleveland it is called the Tile Swallow; and the shepherds on Bowland Fells call it Longwings. In the Allan MS. (I79I) it is called Black Martin, which may possibly be merely a book name.

\section{WHITE-BELLIED SWIFT.}

Cypselus melba (L.).

Accidental visitant from Central and Southern Europe, of rare occurrence.

A summer immigrant to Central and Southern Europe, North Africa, and Asia Minor, wintering in India, Assam, and South Africa, this large Swift is but an accidental visitant to Yorkshire, having occurred on seven occasions only.

* A North Riding superstition carries the belief that to see two Devil-screamers fighting brings ill-luck. 
The first on record was obtained at Oughtybridge about the year I869, as I am informed, by Mr. A. E. Hutchinson, of Derby.

One was observed on 2nd June I870, at Hornsea in Holderness, by Mr. F. Boyes, who states that the bird came within ten yards of him.

At Ripponden, near Halifax, an example was caught by the late Mr. Priestley, in the autumn of 1872 , and is now in his widow's possession (F. G. S. Rawson MS.).

At Scarborough one was seen on I7th April I800, and afterwards at intervals for nearly a fortnight (L. West, Zool. I880, p. 407). Mr. West has so accurately described the bird to Mr. W. Eagle Clarke and myself as to leave no doubt as to its identification.

Mr. S. L. Mosley states (MS.), that at Kirkburton, near Huddersfield, a female specimen was picked up, in an exhausted condition, on and June I88I.

In the autumn of 1890 , one was observed at Scarborough, coming from seaward, and, as it reached the land, it dropped dead on the Parade near Mr. Marshall, of Stockton-on-Tees. It was taken by him to Mr. J. Morley, who identified it as the species under notice (Field, I8th October I890).

And, lastly, an immature male was taken on the moors at Langsett, near Penistone, in 1892 , and was purchased by Mr. W. E. Brady, and presented by him to the Barnsley Naturalists' Society on I5th May I893 (E. G. Bayford, in litt.).

\section{NIGHTJAR.}

\section{Caprimulgus europaus (L.).}

Summ I visitant, local in its distribution, not numerous, preferring the woodland, moorland, and fell districts.

The earliest mention of this species was made by Willughby, who stated that "It is found in the mountainous woods in .... Yorkshire." (Will. "Orn." I683, p. 22.) 
Thomas Allis, 1844, wrote as follows :-

Caprimulgus europous.-The Nightjar-This bird is noticed as becoming more rare near Halifax and Hebden Bridge; in other districts it is by no means rare in favourable localities; on two occasions I have attempted to rear the young, but, though I kept them alive for several weeks, feeding them on moths, beetles, and animal food, I could never get them to pick their food, but was always obliged to open their mouths and insert it, when the food was readily swallowed,-their habit being to take food on the wing, they seem to have no idea of picking it when at rest. W. Eddison says he has a nest of three eggs taken from a nest of four found near West $\mathrm{Nab}$; the usual number of eggs is considered to be two; I have never found the nest myself, but it never occurred to me to see more than a pair of young together.

The Nightjar or, as it is commonly called in Yorkshire, the Goatsucker, is one of our latest summer visitants, seldom making its appearance before the first or, more often, the second week of May. The date of the earliest arrival of which I am aware is I6th April I883, when one was reported by Mr. J. Lister on Langwith Moor in the south of the county. It leaves in September, some individuals remaining until October; the latest lingerers were a pair at Heslington Hall, near York, one of which was picked up in a starved condition in the third week of November I889.

The bird is nowhere very abundant, and is decidedly local in its choice of breeding quarters. The situations that it chiefly resorts to are the moor edges and the borders of woodlands near the moors, fir woods, and the fell sides of the North and West Ridings. It occurs in suitable places in the neighbourhood of Sheffield, Barnsley, Huddersfield, Wakefield, Doncaster, Otley, Ripon, and the upper portions of the river valleys running from the west and north-west of the county. It also nests annually in the dales, and in the vicinity of the North Riding moors, near Scarborough, Whitby, Pickering, Wensleydale, Teesdale, Arkengarthdale, Swaledale, and Sedbergh, the wastes and commons near York, and the Cleveland dales; favourite haunts, where I have found the eggs, being Scotch fir woods where the ground is overgrown with short heather. On 2oth August Igor, six were seen together on the border of the moor at Scarth Nick in 


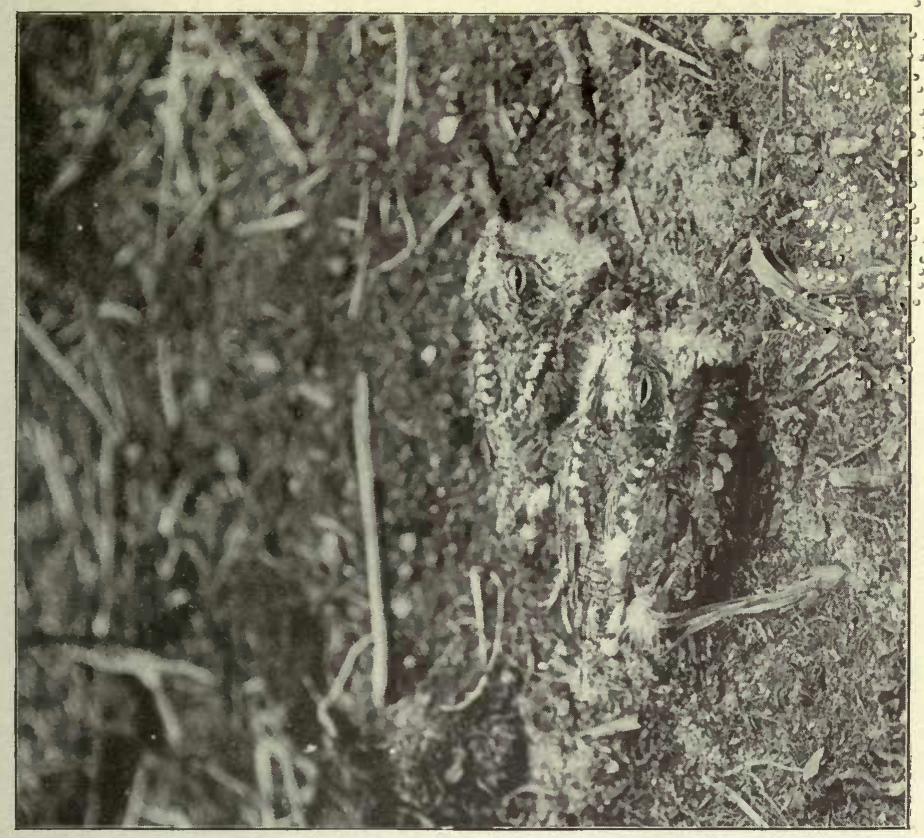

$, 3,2$

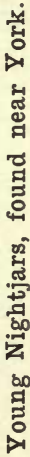

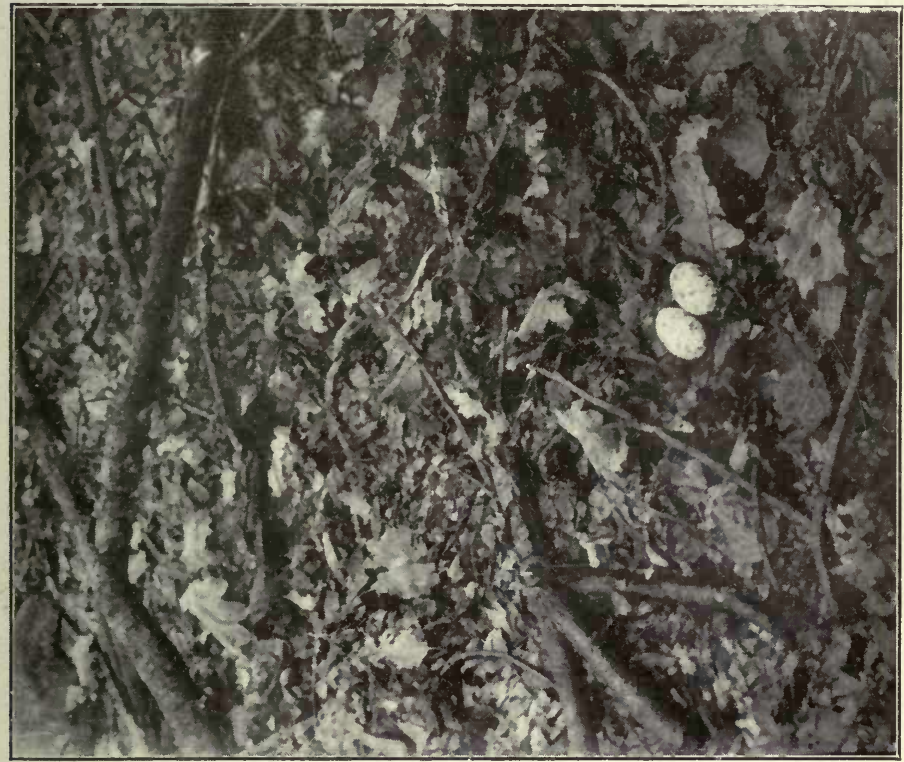

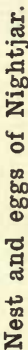

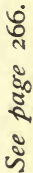



Cleveland. It is scarce as a nesting species in the East Riding, though it breeds annually near Market Weighton, Cliff Wood, Holme on Spalding Moor, and Scampston.

On the coast the Nightjar is observed on migration in spring and autumn, most frequently at the latter season, but individuals are met with annually at Spurn in May. I have noticed it on its first arrival at Redcar, generally during the prevalence of easterly winds, and on Ioth May Igor, at 7 a.m., one flew into the garden behind my house; it has also been seen in the streets of Redcar; one remained in the neighbourhood of the Teesmouth for several days in May I902. Two examples, noted at Spurn on 28th July 1897, may have been birds on the return passage unusually early.

A curious instance is related by Ed. Blyth in Rennie's "Field Naturalist," I833, of a Nightjar coming on board ship when fourteen miles off Whitby, on 7 th October : "The bird settled upon the bowsprit, panting with fatigue, and presented a very curious and interesting spectacle." The late J. Cordeaux has also recorded the occurrence of a female of this species alighting on a vessel in June I897, when Iro miles east of Spurn. During the autumnal or return passage southward, this bird is reported in September and October, at this period being not uncommon in the gardens about the town of Beverley; it has been seen assembling at Flamborough previous to migrating, and it is occasionally immolated against the glass of the lighthouses. The latest date recorded on the coast is 23 rd October 1878 , when one was observed at Easington near Spurn; while the latest record for unfledged young is 2nd September I889, at Thornthwaite (Nat. I889, p. 333).

Superstitions connected with this strange looking bird are very prevalent in the remote Yorkshire dales; one of these, which is perhaps of old Danish origin, and was believed in by the dalesfolk of Cleveland, describes it as a mysterious bird with large glowing eyes, hooked beak, and an awful shriek, which accompanies, or is heard by, the death-doomed. In Nidderdale the country people say that these birds embody 
the souls of unbaptized infants, doomed to wander for ever in the air, and call them " Gabble-ratchets," i.e. corpse hounds, a name which is equivalent to "Gabriel-hounds" of other localities, the unseen pack which is heard by night baying in the air.* This "Gabble-ratchet" in the Otley district is the only one by which the country folk know the bird, thus it appears the superstition is fairly rooted there; though a different version of the origin of the name is in vogue in Thirsk district. The bird is "Gabble-ratch" because it ratches (hoots) on the gables of houses. The jarring cry is supposed to be a harbinger of death, and we find this idea prominent in an old Cleveland dirge, known so long ago as I750, entitled "A Dree Neet," telling how " $t$ ' Squire lay a dying," then how " $t$ ' Gabriel ratchets yelp'd aboon, a gannin sowl ti chill." Mr. F. Lawton of Skelmanthorpe states that when he was a boy he has heard old women talk about "Gabbleratchers," and tell how they knew a certain person was going to die "because Gabbleratchers were heard over the house last night!" Mr. R. Blakeborough also informs me he has heard a similar tale told by a Cleveland dalesman, but in this instance the bird was seen and did not utter a sound. Except in very isolated districts, however, these ideas are fast dying out. In concluding the folk-lore of the Nightjar it may be interesting to quote a verse from another old Cleveland poem, "Signs o' t' Sea," bringing in the species under notice :-

"When a sad moan fra $t$ ' beach steals $t$ ' valley throu', An' t' neeght-jar wings its fleeght i' t' raven's track, Then stitch neea shrood byv t' rush leeght glow,

For t' greedy waves 'll claim what t' grave weeant tak'."

The vernacular names of this bird are many and varied. Goatsucker is a general and well-known one. Churn Owl and Fern Owl are used in Willughby's "Ornithology," I683, and the latter name is still occasionally heard in the Ripon neighbourhood; Night Crow a north-west Yorkshire and also a Market Weighton term, and Night Hawk one used in 
both the North and West Ridings. West Riding names are Wheel Bird and Dor Hawk. This last is said to be derived from an old word signifying buzzing, but may not this be merely at second hand, and the idea of the bird preying upon Dor Beetles be intended ? Eve-jar, used in Rennie's "Field Naturalist" in I833, appears to be merely a pedantic variant on Night-jar. Night Churr, Eve Churr, and Jar Owl are names given by Swainson without any indication of their place of use. Gabble-ratch, Gabriel-ratch, Gabbleratchet, Gaabr'l-ratchet, or Gabble-ratcher, said to be so called because it hoots on gables (Thirsk district), but in other localities the version is different and indicates a similar origin to Gabriel-hounds, as discussed above in connection with the folk-lore.

\section{WRYNECK. \\ Jynx torquilla (L.).}

Summer visitant, extremely local. Is occasionally observed near the coast during the spring and autumn migrations. Less frequent than formerly.

Probably the earliest published mention of this, as a county bird, is contained in the writings of the celebrated Marmaduke Tunstall, of Wycliffe-on-Tees, who stated:-

" Had once a nest of young Wrynecks brought me, which seemed to take food very readily, but frequently darted out their long tongues; they all died the next day. Sometimes called in the north the Cuckoo's Maiden ; as they are supposed to arrive here nearly at the same time and are often found together, probably as agreed in the same table of food, and coming in for a share." (Tunst. MS., I784).

Thomas Allis, I844, wrote :-

Yunx torquilla.-The Wryneck-Often met with near Doncaster; very scarce near Sheffield for the last eight or ten years; becoming very rare near Halifax; seldom met with near Hebden Bridge; Dr. Farrar has met with but one solitary specimen near Barnsley; it is 
occasionally, though very rarely, seen near York; I have never myself seen it in Yorkshire. Arthur Strickland observes "Being well acquainted with the note of this bird, I have once or twice detected it in this county, but it is evidently out of its usual range."

Although the Wryneck is not a common species, Yorkshire is not altogether out of its range, as stated by Allis's friend Strickland. The bird is a summer visitant, extremely local in its distribution, being restricted in the nesting season almost entirely to the south and south-east of the West Riding, and that portion of the East Riding which is adjacent, and in these districts it is very sparingly diffused, chiefly in old timbered parks or woods. It was formerly more numerous than it is at the present time, as Denny in his catalogue (I840) described it as fairly abundant in the neighbourhood of Leeds, and near Doncaster Allis stated it was common in I844. J. Heppenstall wrote of it (Zool. I843, p. 247), as an annual visitant in spring near Sheffield, arriving on I9th April of that year; and at the famous Charles Waterton's residence, Walton Hall, it is recorded yearly. One was shot at Honley, near Huddersfield, on 22nd May I864, while Talbot reported one in May 1875, in Cannon Hall Park, near Wakefield. Thus it is evident, from these old records, that the bird nested in the West Riding.

The present day information indicates that its numbers are much fewer, and probably the causes which have led to the decrease of the Woodpeckers are responsible for the scarcity of the Wryneck. At Fellbeck in Nidderdale it is recorded in spring (Nat. I886, p. I88); also at Harrogate, Dean Hall Wood, near Fewston, Newton Kyme, and Ackworth, but it is everywhere spoken of as being rare. Those old-time ornithologists, Marmaduke Tunstall of Wycliffe-on-Tees, and George Allan, wrote of this bird as being a regular visitant in the neighbourhood of their residences (Tunst. and Allan MS., I784); it is mentioned in Graves's " History of Cleveland" in I808; and, in his "Catalogue of Birds of Cleveland and S.E. Durham," I845, J. Hogg described it as migrating early in spring, and not uncommon in the district. Now, however, it is but rarely met with in north-east Yorkshire: I have 
information of its occurrence in the woods at Easby-inCleveland; one was noted at Danby in the breeding season, and another lower down the Esk valley, while, in the extreme north-west of the county, it has been reported from Sedbergh.

As a rare and occasional visitant on the spring and autumnal migrations, the Wryneck is known on the coast line, and has been announced as having bred near Market Weighton for two or three seasons, where Mr. F. Boyes took an egg from an old pollard willow, the Wrynecks being dispossessed by Starlings. On the Spurn promontory it has been met with on 25th August 1873 (Zool. 1873 , p. 378I), an adult female was procured by Mr. W. Eagle Clarke on 3Ist August r886, and at Easington it has occurred once in spring and on two occasions in autumn. In other parts of Holderness, and at Flamborough, it has been reported at these periods as a very rare migrant. In the Scarborough Philosophical Society's Report for I83I, is a record of one taken near the Castle that year. The Whitby Museum possesses a specimen obtained there; at Redcar a local example was in the collection of the late C. C. Oxley, and one was killed by coming in contact with the telegraph wires at Middlesbrough on and September I905.

The bird described by Mr. W. Eagle Clarke at Spurn, in 1886 , had been feeding on ants, with which its crop was filled, and amongst the common red species were several Wood Ants quite undigested, proving the bird had just arrived, since this insect does not occur near Spurn.

The vernacular names are peculiar, and well adapted to the bird's eccentricities. According to Swainson it is called Writhe Neck, Long Tongue or Tongue Bird, Emmet Hunter, Slab, and Cuckoo's Messenger. In I784 Tunstall called it Cuckoo's Maiden; while Cuckoo's Mate is a generally known appellation. 


\section{GREEN WOODPECKER.}

Gecinus viridis (L.).

Resident, local, but fairly common where it occurs.

Historically, the Green Woodpecker, as a Yorkshire bird, is of ancient standing, being referred to in the ballad of " Robin Hood and Guy of Gisborne" ; an early mention of it was also made by Willughby, thus :-

"This bird is by some called Hayhoe, which name is, I suppose, corrupted from Hewhole, as Turner saith it was called in English in his time, and Mr. Johnson (of Brignall, near Greta Bridge) now." (Will. "Orn." I680, p. 22.)

Thomas Allis, I844, wrote:-

Picus viridis.-Green Woodpecker-Common about Doncaster; occasionally seen near Leeds and York; not common near Sheffield; nearly extirpated in the vicinity of Halifax; rarely met with at Hebden Bridge ; very rare near Huddersfield, though formerly more plentiful ; frequently met with in the wooded districts near Barnsley; numerous near Thirsk.

This beautiful species is resident, very local in its distribution, and most numerous in the Vale of York (a name applied to the central plain of the county), and the north-east portion of the North Riding, which may be included between two lines, one drawn from York, by Malton, to Scarborough, and the other from the same starting point, due north along the western base of the Hambleton Hills. In these districts it prefers the woods bordering the highlands, and is more partial in its distribution than the Spotted species, though fairly numerous in the localities frequented by it. The Vale of Pickering is one of its chief strongholds; it is abundant also in the woods between Whitby and the Tees Valley; the old Yorkshire ornithologist, Marmaduke Tunstall, of Wycliffeon-Tees, referring to it in I784 as "passing the winter here in the north" (p. 6o), though, owing to the cutting down of timber and the persecution by collectors, it is not so abundant in the county as formerly. Outside the area indicated it occurs commonly in Wensleydale, Baldersby, Studley, and 


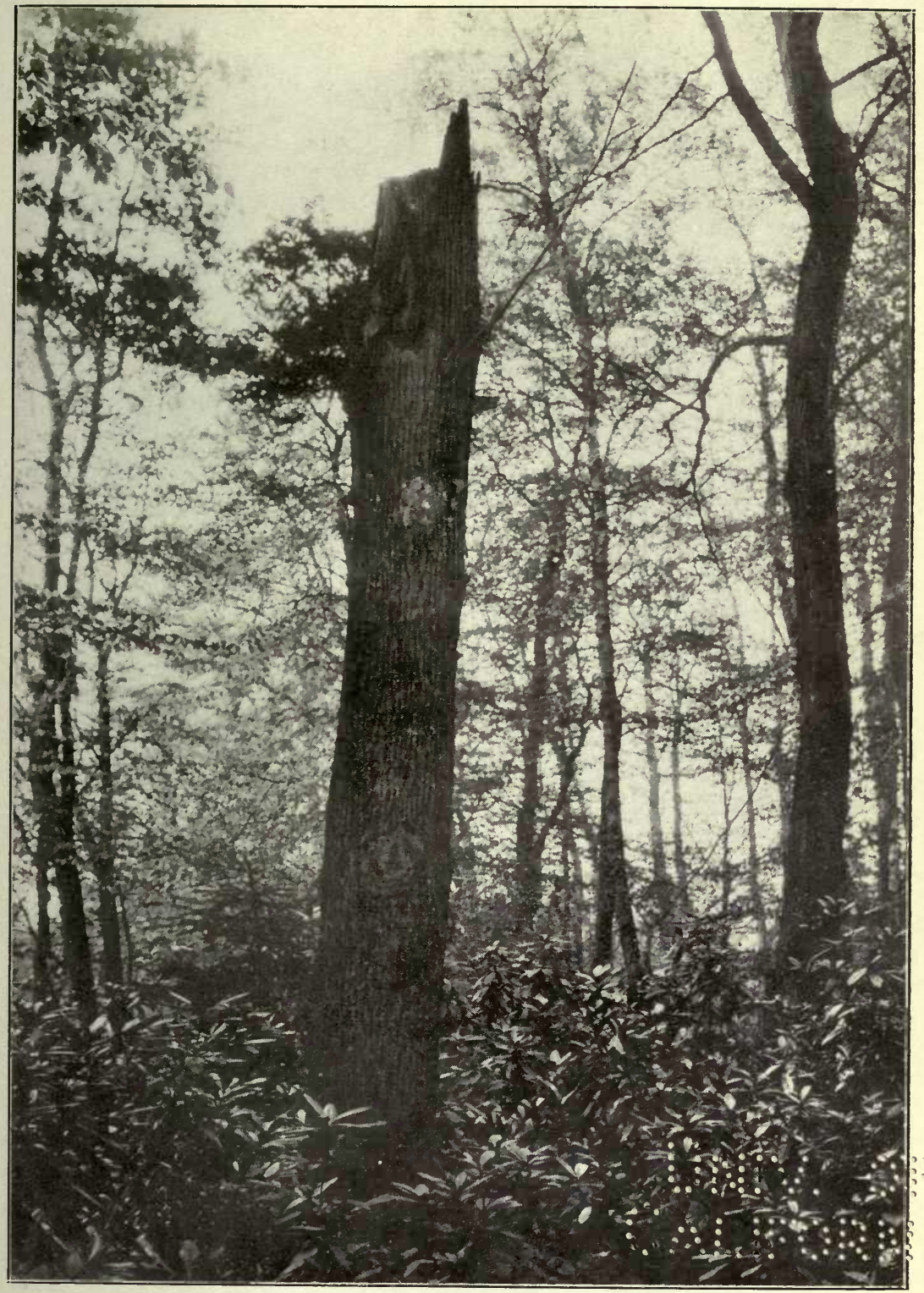

Home of Green Woodpecker.

$R$. Fortune.

See page 272. 
\% $\because 4$

and 
Swinton Parks, and in Nidderdale, especially in the vicinity of Harrogate. In other parts of the West Riding it is a scarce bird, and almost unknown in the extreme west and north-west divisions; though a pair nested at Bolton Abbey in 1906. In the remoter parts of the North Riding it has occurred rarely in Upper Teesdale and near Sedbergh. Perhaps the most singular feature in its distribution is its entire absence from Bishop Wood, near Selby, the oldest and largest wood in the county.

It is not found on the chalk Wolds or clays in the east, though it occurs on the west ridge of the Wolds, and is not uncommon in the drier sandy, or moory situations, where it also breeds; it is more local in the East Riding than elsewhere; it is somewhat rare near Beverley, but breeds rather commonly near Market Weighton, and not uncommonly at Scampston. It occurs at Pocklington, and has been noted once in November I882, at Rimswell, in South Holderness, while at Flamborough, where it has been met with on one or two occasions, an example was picked up in an exhausted state near the Lighthouse on I7th October 1894 , and another was found in the autumn of 1903 , which would seem to indicate that they were migrants.

In regard to the nidification of this bird a singular circumstance was brought to my notice in the spring of 1902 , in Harrogate, where a pair of Woodpeckers commenced building operations in a tree in the centre of the town, but, unfortunately, they were not allowed to continue their labours undisturbed. Another curious nesting incident took place in Cleveland in I902. On the I5th of May I went with a friend to examine a Woodpecker's nest in an ash tree; a hole was cut below the entrance, but the site was apparently deserted; however, a fortnight later we found the old birds were utilising the new aperture and were excavating the interior of the tree as vigorously as before. In some parts of the Cleveland dales I have known nesting trees close up to the edge of the moors, bordering on the Ring Ouzel's territory. This species is also frequently found out on the moors far from trees of any kind; it dislodges the moss on the boulders for grubs, and probably

vol. I. 
finds plenty of food in the shape of ants and other insects. Charles Waterton mentioned the fact of one roosting in one of the galleries of a bird tower at Walton Park.

The multiplicity of its vernacular names denotes that the bird must have been numerous in former days, when it was known as Wood Awl. It is alluded to, in the ballad of "Robin Hood and Guy of Gisborne," as Wood Weele ; and Hayhoe, or Hewhole, in Willughby's "Ornithology," r680. Other names are Cut Bill ; Heffald (Scatcherd's " History of Morley," I830); Hefful (Craven); Yaffle (North Riding); Yaffler (East Riding); Nickle (Zool. I848); Popinjay, Rain Pie, Rain Bird, Rain Fowl (Swainson); Wood Tapper, Wood Borer, and Tree Climber (East Cleveland).

\section{GREAT SPOTTED WOODPECKER.}

\section{Dendrocopus major (L.).}

Resident; local, thinly distributed, though more general than the other Yorkshire species. Observed as an autumn migrant on the coast.

Perhaps the first Yorkshire reference to this species is in the Rev. J. Graves's " History of Cleveland " (1808), where it is enumerated in the list of resident birds.

Thomas Allis, I844, wrote:-

Picus major.-Great Spotted Woodpecker-Not uncommon near Sheffield : very rare near Leeds ; it occurs at Plompton Woods near Harrogate ; is rare at Hebden Bridge ; not infrequent about Barnsley; rare near Huddersfield, but a nest and eggs were presented to W. Eddison a few years ago by Thos. Dunderdale, Esq., of Whitley Hall, for the Huddersfield Museum. Arthur Strickland has met with but one specimen which was from Boynton; J. and W. Tuke inform me that it is said to breed in the woods at Castle Howard.

In addition to being a generally distributed bird in Yorkshire, the Great Spotted Woodpecker is a spring and autumn migrant, and is perhaps deemed to be scarcer than really is the case, as, owing to its shy and retiring nature, its presence may not always be suspected in the localities that it haunts. 


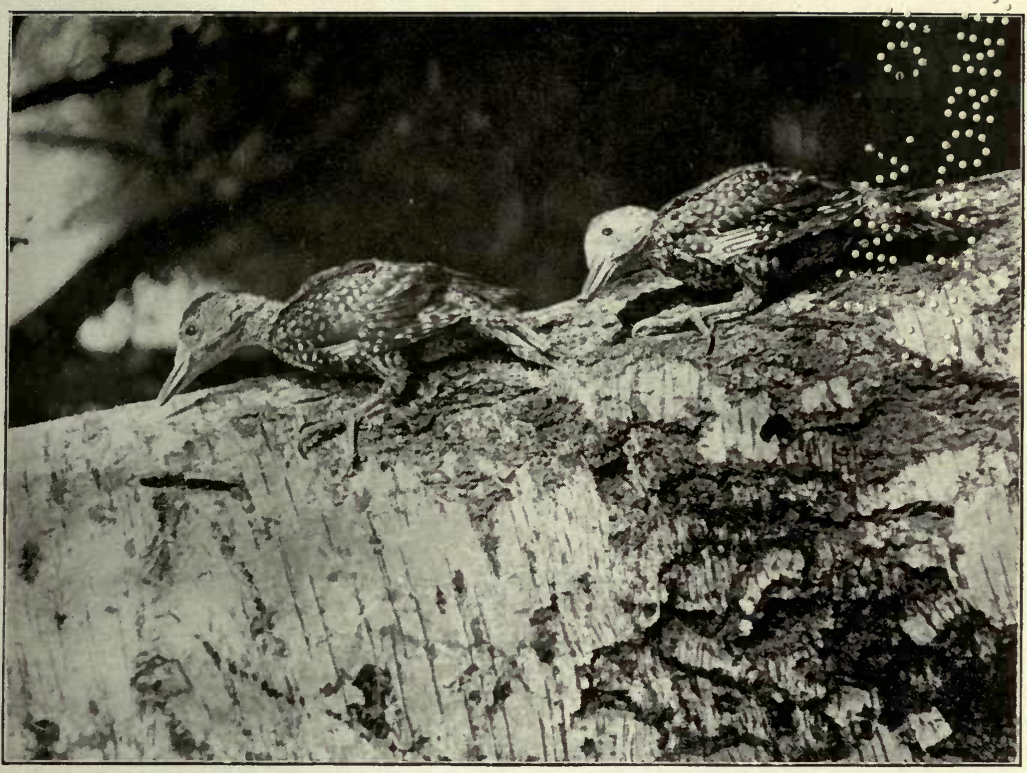

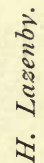

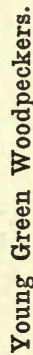

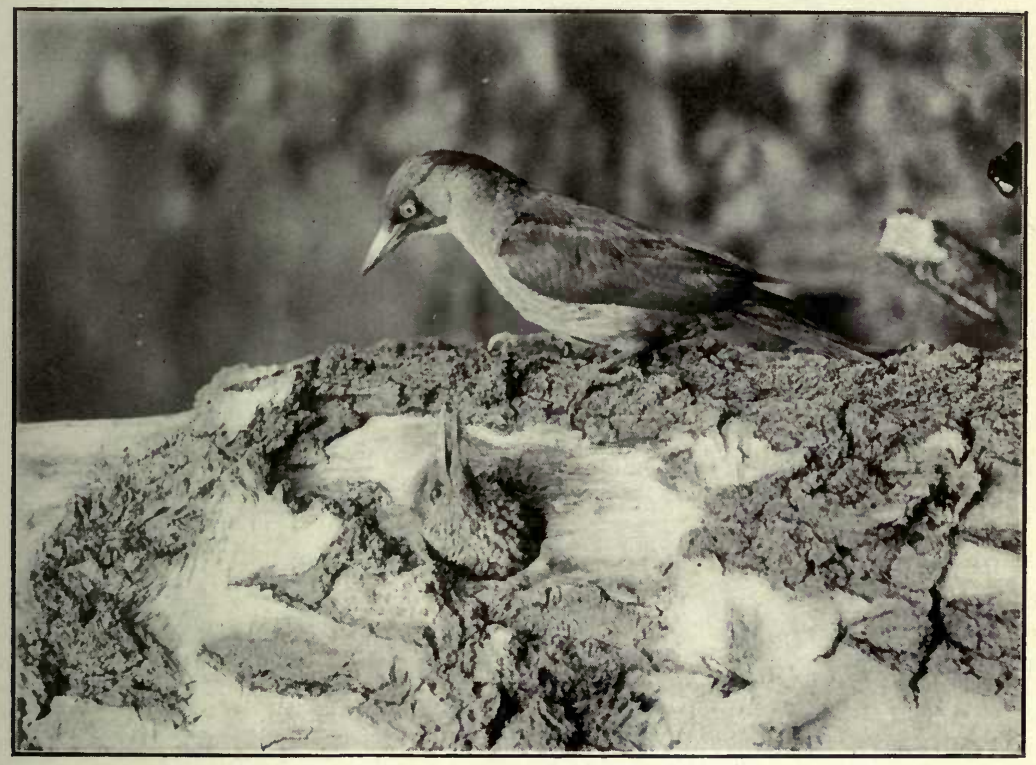

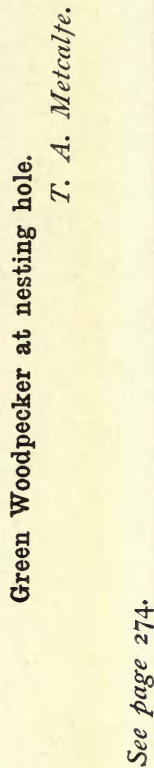




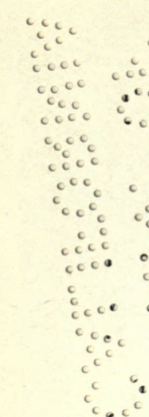


Though in no part an abundant species, it breeds in most districts where suitable conditions are found, except in the vicinity of the large manufacturing towns, the East Riding Wolds, and the moorland tracts. The bird is extremely partial to the woods of old parks and timber of ancient growth, and in some of the dales is met with at a considerable elevation, but does not remain after the nesting season. In the Central Plain, the Western Ainsty, and the Harrogate neighbourhood it is more frequently reported than from any other locality, though it is to be feared that the felling of old timber has led to its decrease in some parts where it was formerly not uncommon; it has increased within the past few years in the Wilsden district.

On the seaboard during the autumn migration this Woodpecker is of almost annual occurrence, and is observed from September to November. It is, however, referred to only once in the British Association Migration Reports, "At Spurn, 27th October I880" (Second Report). At that promontory they land on the sandhills, and, as there are no trees, they spend their short stay there in running up the pieces of drift wood used as fencing. They were numerous on the coast in I886, and also in 1889 ; in the latter year at most of the stations between Spurn and Teesmouth. Two were seen in October in the fishermen's gardens at Redcar, and this influx was coincident with a great migration over Heligoland, where, according to the late Herr Gätke, "more were seen than ever before." Near Beverley, in I898, the bird was more than usually common, upwards of a dozen being reported, and in the winter of I90I-2 a large migratory flight appeared in Cleveland; my taxidermist, G. Mussell, informed me he had more in to preserve during that winter than in all his past experience, extending over fifty years. Two examples were seen close to Middlesbrough Park, one of which was captured and brought to me for identification.

In the Beverley district the Great Spotted Woodpecker has been noticed to excavate holes in rotton trees in which to sleep, and it feeds on the larvæ of Sesia apiformis, the Poplar Clearwing Moth; below the poplar trees may often 
be seen strips which the bird has chipped way in its search for the grubs. Mr. Boyes saw one in his garden which was so tame that it allowed him to approach within fifteen yards, and watch it flying from branch to branch, exactly as a Thrush would do, and sit up in like manner across the branches, and not lengthwise, which is unusual.

[The HaIRy WoOdPecker, (Dendrocopus villosus, L.), a North American species, is reported as having occurred in two instances in Yorkshire, but the circumstances are not sufficiently trustworthy to justify my placing the bird in the county list.

Near Brighouse, a pair were obtained (upwards of a century ago), at Kirklees Hall, and passed into the collection of the Duchess of Portland (Latham, "Gen. Syn." II,. p. 578).

At Whitby, one was killed early in I849 (Higgins, Zool. I849, p. 2496 ; Bird, tom. cit. 2527; Newman, op. cit. I85I, p. 2985 ; Bird, tom. cit. p. 3034). This specimen is in the South Kensington Museum.]

\section{LESSER SPOTTED WOODPECKER.}

\section{Dendrocopus minor (L.).}

Resident, extremely local and confined to thickly wooded localities. in which it occurs in limited numbers.

Probably the earliest reference to this bird in Yorkshire is in Leyland's Halifax Catalogue, 1828, where it is described as very rare.

Thomas Allis, 1844, wrote:-

Picus minor.-Lesser Spotted Woodpecker-Met with near Doncaster; a few specimens have been obtained near Sheffield; it is rarely seen at Hebden Bridge ; a nest was taken, with several young, a few years ago by a son of Joseph Cooper, Botanical Gardener to Earl Fitzwilliam, in the woods at Wentworth; it is also met with in the woods at Thirkleby near Thirsk.

The Lesser Spotted Woodpecker is rarer in Yorkshire 


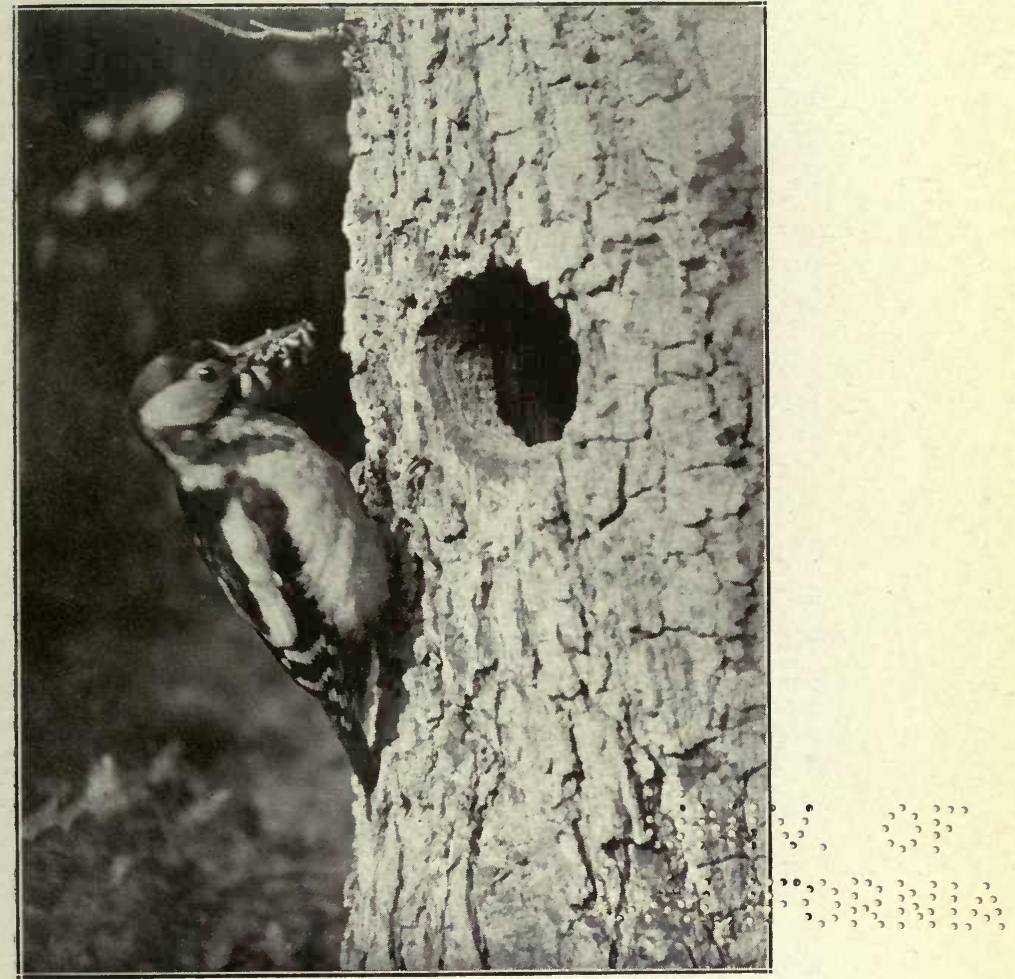

Lesser Spotted Woodpecker taking food to its young.

T. A. Metcalfe.

See page 277. 

then the preceding species, while its diminutive size adds to the difficulty of detecting it in its woodland haunts. Like its larger relative it loves the seclusion of old timbered parks, and has been recorded as nesting in various parts of the West Riding; at or near Wakefield, in 1858 ; Huddersfield, in I85I; Ackworth; once in Batley Wood (which is now a Leeds recreation ground); and at Eccup near Leeds; also in the lower Nidd Valley; in the Washburn Valley, near Fewston; and at Studley. After the breeding season the bird is more widely distributed, and more frequently observed, the occurrences being too numerous for mention in detail, though it may be remarked that, in the Wilsden district, several examples have been noticed recently, and it may probably be nesting there.

Other places from which the nest has been recorded are in the neighbourhood of York, Escrick, Allerthorpe Common, and Scampston Park. It is a rare bird near Beverley; one was taken in 1899 , a second in Igor, which I had an opportunity of examining; another example was seen in the winter of Igor-2, and a male was killed on the public common on 8th March 1903. In the Burton Agnes collection is a local specimen which was shot by Sir H. Boynton. This species is also announced to have nested in Mulgrave Woods near Whitby, in I893; another pair bred in Grinkle Woods in Igor, and they succeeded in getting the young away a few days only before the nesting tree was felled. It has been noted in Wensleydale; a single instance is reported of its breeding near Masham in I888; in Arncliffe Woods the bird occurs, but I have no information of its nesting there, and the same remark applies to localities in Cleveland, near Redcar, Marton, and Easby, where individuals are annually noticed. At one of these places four "Little Woodpeckers," as they are termed, frequented a wood in I898, a pair were noted in Igor, while another pair were seen in a spinney near Redcar during the winter of IgoI-2. Near Sedbergh the nest has been recorded on one occasion only.

In communicating an account of the nidification of this bird at Scampston Park, Mr. W. H. St. Quintin remarks 
that, when the young flew, a pair of the Great Spotted Woodpeckers took possession of, and reared a brood in, the same tree.

[Of the Great Black Woodpecker (Picus martius, L.), a Continental species, Thomas Allis wrote, in I844, as follows :-

Picus martius.-Great Black Woodpecker.-W. Yarrell reports that two specimens were killed in Yorkshire, but, falling into hands not aware of their ornithological interest, they were not preserved ("British Birds," Vol. II., p. I 28).

Examples are said to have occurred in the following instances (two of which were reported by Allis), but no reliance is to be placed on their authenticity :-

Yorkshire, once (Fothergill, "Ornith. Brit.," I799, p. 3).

Yorkshire, one (Yarrell, I843, II. p. I28).

Yarm, two seen (Zool. I845, p. Iro7).

Ripley, one killed, March I846 (op. cit. I846, p. I298).

Otley, one, on 8 th September I897, was probably one of the individuals liberated by the late Lord Lilford. (See also Harting's "Handbook," 2nd Ed. p. 396.)]

\section{K I NGF IS HER.}

\section{Alcedo ispida (L.).}

Resident, generally but sparsely distributed. Occurs in autumn as a migrant on the coast.

Probably the first Yorkshire reference to the Kingfisher is to be found in Miller's "History of Doncaster," in which it is stated that

"The Kingfisher conveys the small fish upon which it preys to a place, generally the deserted hole of a water rat, where it dissects the flesh from the bones of the fish, keeping them together to form its nest which consists of many thousand of these small bones." (Miller's "Doncaster," I804, p. I7.)

Thomas Allis, 1844, wrote:-

Alcedo ispida.-Common Kingfisher-W. Eddison says they breed near Huddersfield, and used to be very common, but the destructive 
plan of snaring them, or catching them with bird lime, will shortly place them in the list of rare birds ; Richard Leyland observes " An interesting circumstance connected with the history of this bird has fallen under my notice; in autumn an assemblage of them in some of the narrow glens (or cloughs as they are called about Halifax) takes place; probably the river swollen by the autumnal rains renders the acquisition of their food difficult, and consequently compels them to seek it in shallower water.-A bird stuffer, with whom I was well acquainted, procured in one season more than fifty specimens by placing a net across the bottom of the clough, and, commencing to beat the bushes from above, drove every bird into the net."

In spite of the persecution accorded to this lovely denizen of our river banks, whose brilliant plumage attracts the cupidity of collectors, the Kingfisher is still found on nearly every suitable stream in the county, and from most districts it is reported as either breeding, or being met with in winter, with more or less frequency. Owing to its conservative habits it is nowhere abundant during the nesting season, as each pair reserve a portion of their favourite stream or rivulet to themselves, and when the young are fully grown they are forthwith banished to seek fresh quarters, consequently the species is much less local in the non-breeding season, and at this period is frequently reported in the neighbourhood of the large towns-usually forming the subject of an obituary notice in the local press.

In regard to the West Riding it is gratifying to be able to state that, in the Lower Wharfe and Nidd Valleys, the bird is not uncommon, and is probably increasing and more abundant than in most parts of the Shire. Fairly common about Wilsden and Bingley in the Aire Valley, Skelmanthorpe, and in the valley of the Hodder, it also breeds in favourable places near Sheffield, Wakefield, Ackworth, Fewston, Bashall, Malham, Langstrothdale, and along the Ribble; in the vicinity of Liversedge, Huddersfield, Newsome, Leeds, and Eavestone it is only rarely met with, and has decreased in numbers of late years. Coming to the North Riding, the Kingfisher breeds regularly along the banks of the Ouse and its affluents in the neighbourhood of York, while in winter no fewer than sixteen have been reported in one season from 
a small stream within two miles of the city, no more than two birds being observed at any one time. Near Thirsk and Northallerton it breeds occasionally, while near Bedale it is not uncommon. In Cleveland it is found from Whitby almost to the source of the Esk, and in the flat plain from the foot of the Cleveland Hills to the coast line it breeds on every suitable beck, though not commonly. About Loftus and Staithes it nests sparingly, and in winter it has been observed in severe weather amongst the boulders strewn at the foot of the sea cliffs. Along the banks of the Tees it is found breeding up to Middleton-in-Teesdale and as far as High Force, while in Swaledale it is reported as a scarce resident from the extremity of the valley at Keld. In the East Riding, during the breeding season, a pair may be found on almost every stream and brooklet, which affords food enough and where the banks are sufficiently high for nesting purposes; it occasionally nests in a Sand Martin's hole in steep banks bordering a stream.

There is in autumn a considerable accession to the numbers of our resident birds, chiefly observable in August, September, and October in the coast districts; this was particularly apparent in $I 863-4, I 869, I 873, I 884, I 890$, and I894; the earliest date for an over-sea migrant is 4 th July I905, when one was observed, about two miles off Redcar, coming from the north-east and making direct for the land. At the Teesmouth odd birds annually appear near the tidal pools, on the marsh "stells," and along the sea-walls, from July to the following March, in which month the return migration takes place.

Broadly speaking, the breeding season lasts from April, or even earlier, until August, and as an instance of an early brood may be mentioned a nest with half grown young on 5 th May I897, near the Albert Park, Middlesbrough; while in the other extreme eggs were found near Keighly as late as August. This bird is very partial to its nesting quarters, and the late Alfred Roberts of Scarborough had three clutches of eggs from one nest in the bank of Scalby Beck, in the same season, I860; the first containing six eggs in May, the second, 

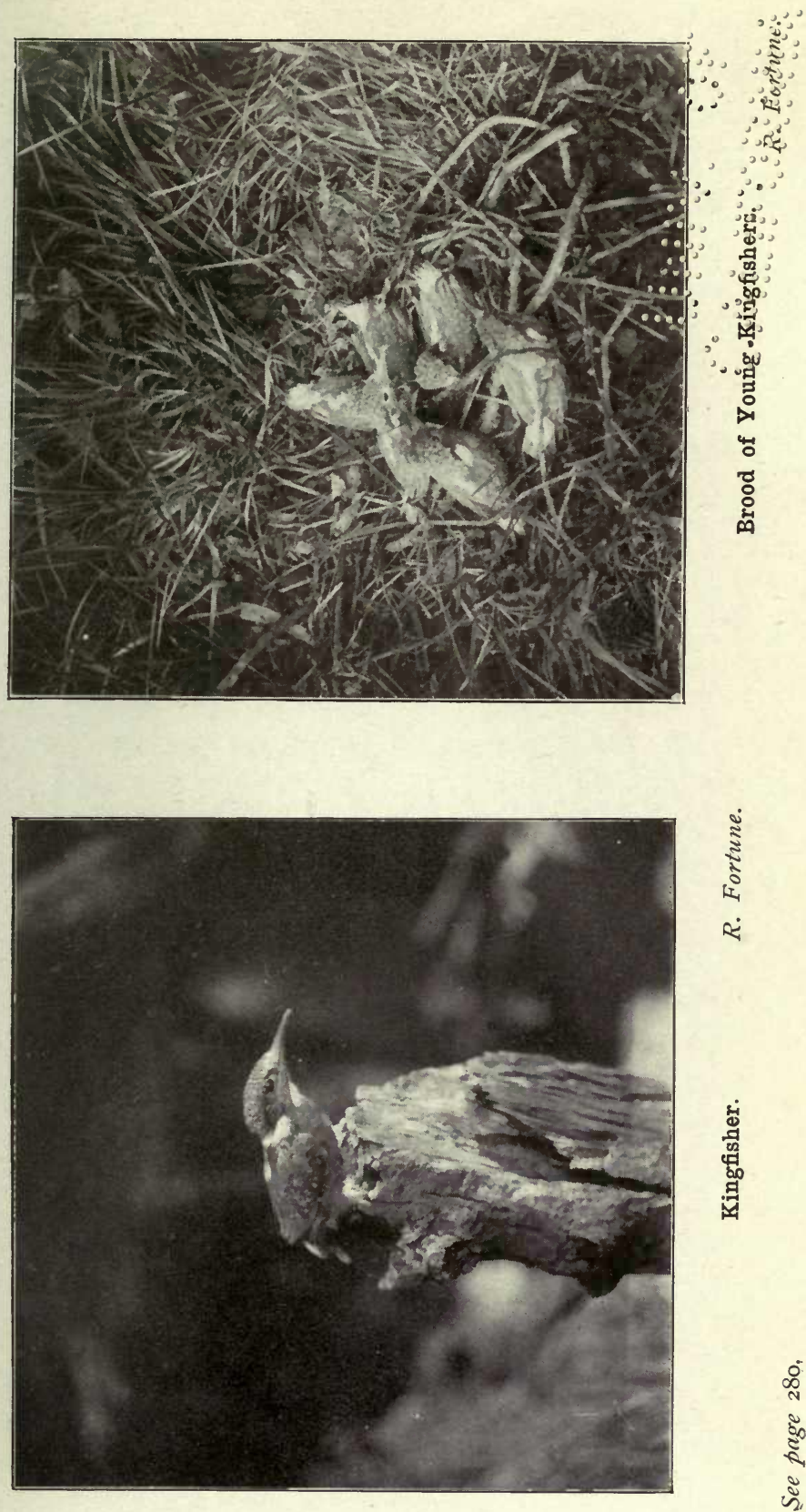

نं

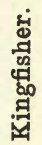



also numbering six, in early June, and the last, consisting of five eggs, in the following July. In the severe winter of 1878-79 a Kingfisher was found frozen to death at Wilstrop, on the iron frame of a sluice, its feet fixed and body leaning forward in the act of taking flight.

The folk-lore connected with this species is not very voluminous, the only item known to me being that the dalesfolk in some remote districts of Cleveland consider it to be unlucky to see a flight of three Kingfishers ; a sight, however, which is probably rarely witnessed.

The only vernacular name, other than its ordinary appellation, is Fisher, a term used in the West Riding.

\section{ROLLER,}

Coracias garrulus (L.).

Casual visitant, of uncommon occurrence in summer.

The first mention of this species occurs in R. Leyland's list of 1828 , whose remarks are also included in Allis's Report, as follows:-

Coracias garrulus. - Roller- R. Leyland informs me that a specimen shot in Fixby Park near Huddersfield, in 1824, is still in the possession of a gentleman at Littleborough; Hugh Reid reports one killed at Hatfield, which went into the possession of Mr. Joseph Cook of Rotherham. F. O. Morris mentions the Hatfield specimen, and says that one was shot near Halifax about the same time, and one near Scarborough in 1832 , now in the Museum there.

The wanderings of this brightly plumaged bird before reaching this country are many and devious. It migrates northward in spring, and, crossing the Mediterranean Sea, occasionally finds its way to the British Isles. It has been recorded in Yorkshire on eighteen different occasions, the particulars being as follows:-

The first is that mentioned by Leyland, and quoted above. At Seamer, near Scarborough, one, killed in 1832, was 
purchased for the Scarborough Museum (P. Hawkridge, in Neville Wood's Nat. 1838).

Another specimen, obtained at Scarborough in I833, is referred to in the P.Z.S. of that year.

Mr. E. R. Turton, writing under date of 6 th March I903, informs me that an example of this species, in his museum at Upsall Castle, was procured near Whitby in I839, and is probably the bird referred to in Ord's " History of Cleveland," "Shot near Kildale, by John Bell, Esq., M.P. In the collection at Kildale Hall." There is no collection at Kildale now, the late Capt. Turton having removed it to Upsall.

In Dr. Lankester's “ Askern,” p. 70, two Rollers are mentioned as being obtained in 1842 . The next instance is that of an example which flew on board the Hamburgh steamer in May I843, when forty miles off Flamborough Head (Denny, Ann. \& Mag. Nat. Hist.).

At Hatfield one was obtained about I844 (Allis), and about the same time Morris recorded one at Halifax ("British Birds").

In July I847, a pair was seen in a plantation called "Forty Pence" near Skelton-in-Cleveland, now belonging to Mr. W. H. Wharton, M.F.H. One of these was afterwards killed, and proved to be a female with eggs (Zool. I848, p. I968). This bird was eventually acquired by the late J. Hancock (see "Birds of Northd. and Dm." p. 28).

At Whitby a specimen was obtained in 1852 ; and in 1868 Mr. H. Machen of Bridlington shot one, but it was not found at the time, and, when picked up, was decomposed (Machen MS.).

Mr. T. Boynton of Bridlington has a specimen, formerly in the collection of the late W. W. Boulton of Beverley.

Mr. E. P. Butterfield possesses an example from near Bingley, in July I872 (Zool. I875, p. 4623).

At Grosmont one was taken by Mr. R. Hay, on " the Haggs," in June I874 (Turton MS.).

Near Richmond a specimen was reported at Marske Hall, "a few years ago" (Wade Dalton MS., I880).

At Boltby, near Thirsk, one, obtained on $5^{\text {th }}$ June 1880 , was preserved by Mr. R. Lee. Its last meal consisted of a mouse, swallowed whole, and several beetles (Lee MS.). 
The late H. T. Archer reported seeing a Roller on the banks of the Wharfe, near Ilkley, at the end of July I88I (Field, 6th August I88I, and MS.).

And lastly, an immature female, brought from Acklam-inCleveland on 2Ist September IgoI, was preserved by Mr. Geo. Mussell of Middlesbrough, to whom I am indebted for the information, and for an opportunity of examining the specimen.

\section{BEE-EATER. \\ Merops apiaster $(L$.$) .$}

Accidental visitant from Southern Europe and Northern Africa, of very rare occurrence.

This beautiful and rare visitant migrates northward in spring, from its winter home in North Western India and Africa, to the European Continent, whence a few stragglers have found their way to our country. In Yorkshire it is an accidental visitant, and has been met with on five occasions only :-

The first of these was at Sheffield about 1849 (Morris, "British Birds," Vol. I. p. 3I3).

Mr. T. Stephenson of Whitby states (MS. I880), "Wm. Lister of Glaisdale says, several years ago a stuffed one was in possession of the late Wm. Keld Agar in Fryup."

Near Beverley a male was captured on 5 th June 1880. Though in full plumage, it was in very poor condition, and it would seem that either the very cold weather, or its passage, had been too much for it (F. Boyes, Field, 3rd July I880).

On 9th June 1880 , the late R. Richardson, bird stuffer, Beverley, received a splendid male specimen from Filey, said to have been caught alive in an exhausted state (Richardson MS.).

And for an account of the most recent occurrence $I$ am indebted to Mr. G. W. Murdoch of Bentham, who, in a letter 
dated I $3^{\text {th }}$ September I905, kindly supplies the following particulars :-

"On the 9th inst. Mr. James Wilcock of Asperlands, High Bentham, informed me that he had been watching three small and very beautiful birds, which were quite new to him, and that they were very busy eating his bees. He described how one of the birds would take up its stand just at the mouth of the skep, and with its hard bill stab a bee as it emerged, and promptly swallow it. He saw one bird take eight bees in that way, and at least other two birds of a precisely similar build and colouration had been seen working in co-operation. Finally, he managed to secure one, caught in the very act of seizing and swallowing bees. That he brought to me, and it proved to be a male Beeeater."

The late date of the Bentham record, gth September, and the statement that three of these birds had been seen working together, are very interesting facts.

[The only European example on record of the BLUE-TAILED BeE-EATER (Merops phillipensis, L.), which is an inhabitant of India, Burmah, and the Islands of the East, is the one mentioned by the late John Hancock ("Birds of Northd. and Dm." I874, p. 28), as having occurred in August I862, near Seaton Snook, a place on the Durham side of the Teesmouth, by Thomas Hann of Byers Green. This passed into the possession of the Rev. T. M. Hick of Newburn. Whatever may be the facts relating to this episode, the occurrence is quite inexplicable. The locality where the bird was obtained is, however, actually on the Yorkshire side of the river, and therefore within the scope of the present work. Thomas Hann was well known to me, and to George Mussell, the Middlesbrough taxidermist. He called at Mussell's house in Middlesbrough on the day on which the bird was killed and detailed to him how he had been to the "Branch End," where he was sitting on a slag ball when the bird alighted near him and was shot. He subsequently told Mussell that he came by train from Eston, and that he was offered 
twelve shillings and sixpence for the specimen when he arrived at Middlesbrough station.

The mention of the slag proves the shooting to have been on the Yorkshire side, as that on the north side of the river is tipped from Messrs. Bell Bros.' Clarence Works, and I learn from Sir Hugh Bell that the tipping did not commence (except in the immediate vicinity of the works) until 1872 or 1873 , and there was no slag at all at Seaton Snook until well on into the "seventies." The "Branch End" is on the Yorkshire side, near Bolckow, Vaughan \& Co.'s works, where tipping was in progress before I862.]

\section{HOOPOE.}

\section{Upupa epops (L.).}

Casual visitant from Africa, of uncommon occurrence in sprin? : nd autumn, chiefly on the coast.

The earliest mention of the Hoopoe in Yorkshire was made by Marmaduke Tunstall, thus :-

"Many Hoopoes were seen in Yorkshire.... in the end of last summer ; one was sent me, shot within a few miles of this place (Wycliffe-on-Tees) in September; another, about the same time, from Holderness, where many were seen." (Tunst. MS. I784, p. 6r.)

Thomas Allis, I844, wrote:-

Upupa epops.-Hoopoe-F. O. Morris, in his Catalogue of Yorkshire Birds, says three have been killed near Doncaster, and one seen in 1836 in Sir W. Cooke's woods; also at Coatham, near Redcar, and near Scarborough.-Hugh Reid of Doncaster says one was killed at Armthorpe by Capt. Wilkinson, probably one of the before mentioned, and another at Pontefract by Mr. Hepworth; H. Denny reports one was shot by the Honble. Edwin Lascelles, 8th October 1830, at Eccup, a young specimen from a field of potatoes, and that another occurred at Low Moor. R. Leyland mentions one shot on Skircoat Moor, 3rd September 1840. Dr. Farrar says this bird is certainly one of our rarest visitants; I was informed by a friend, now deceased, that the keepers of Henry Wheat, Esq., of Norwood, near Sheffield, had seen 
a pair in 1832 , but did not obtain them ; my register of this bird informs me a specimen was killed at the Low Moor Iron Works near Bradford (before referred to), which is now in the possession of a gentleman at Leeds. Another was killed at Skircoat Moor, near Halifax, in 1840 (also before referred to), and I know another killed at Ecclesfield [Eccleshill (?)] near Bradford, by Mr. H. Greaves, 9th April 1840, the last a female specimen. Arthur Strickland says he has known several instances of this bird being killed in the east part of this county; of those two are in his collection, and there are others preserved in that neighbourhood; one was taken while alighting on a boat in the Bay (Bridlington Bay); he has no doubt this bird would breed in this county, but it is too conspicuous and attractive to escape persecution on arriving here.

This illustrious stranger is an inhabitant of Asia and northern Africa, migrating from the shores of the Mediterranean into Continental Europe, and wandering thence to this country. It has occurred in Yorkshire as a casual visitant in spring and autumn, the earliest records dating back to 1783 . From that period down to the present day it has appeared at irregular intervals, generally singly, and chiefly on the coast; one was mentioned by Allis as being taken on board a boat in Bridlington Bay, though numerous instances might be cited of its appearance in almost every district of the county.

The late J. Cordeaux stated, in his " Birds of the Humber District," I899, p. I6, that fifty years ago it was known to have occurred annually at Flamborough in spring.

On two occasions it would appear that a small flight had arrived on our shores, viz. in 1783 (Tunst. MS.) and, in 1836 , when a flock was noticed at Saltburn, and several were obtained, two of which are in the Upsall collection (Turton MS.).

The total number of occurrences as chronicled, or otherwise brought to my notice, amount to fifty-eight, representing, as nearly as can be estimated at this lapse of time, at least seventy individuals; too great a number to particularise.*

"In"the Zoologist (1850, p. 2768), J. Gray recorded " a considerable number of Hoopoes, during a winter storm at the Teesmouth, several being shot." This is, doubtless, a mistake, for in all probability the birds were Hoopers (Whoopers) or Wild Swans ; much more likely visitants, than Hoopoes, to the Teesmouth, during a winter storm. 


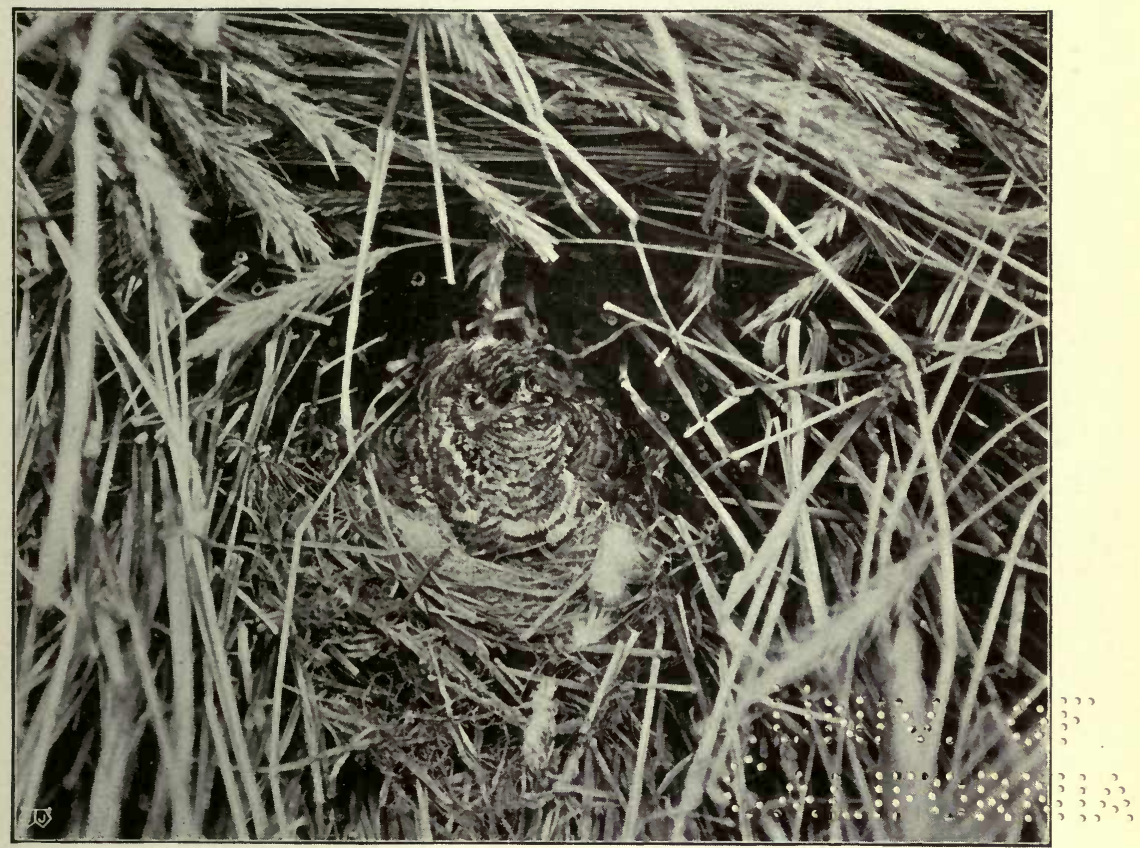

Young Cackoo in nest of Pied Wagtail, Sutton-on-Forest, York.

H. Lazenby.

See page 289. 
a

with at ? 
Mr. W. H. St. Quintin informs me (in litt.) that, on IIth January 1896 , he watched for some time a Hoopoe which had been a week or more on a farm of the East Riding Wolds. It was very tame and uttered a harsh churring call note, at the same time raising and depressing its crest.

\section{CUCKOO.}

\section{Cuculus canorus (L.).}

Summer visitant, generally distributed, common. Arrives about the third week in April, departing in August, young birds occasionally lingering to the end of September or even into October.

The earliest published reference to the Cuckoo, in connection with Yorkshire history, is contained in a communication from Ralph Johnson of Brignall, near Greta Bridge, to John Ray :-

"The Cuckoo, Cuculus. Who because he preys only upon the eggs of birds (and is therefore pursued, not attended, as is said, by the Moor Titling) or their young ones in the nest, hath small and weaker Beak and Talons, and therefore disappears in winter, when such food is not to be had. I have known one kept with all imaginable care, but (whether through alteration of food, or some other cause) before Winter she grew torpid, broke out in scabs, and died. The young one is curiously spotted. I have seen one in Harvest partly spotted, partly cinerous." (Will. "Orn." I683, p. 22.)

Thomas Allis, I844, wrote :-

Cuculus canorus.-Cuckoo-Common in most parts though I think less so near York than was formerly the case; Dr. Farrar says in I 843 most abundant, but this season, 1844, little heard, probably from the unusually long continued spring rendering its food less abundant; W. Eddison observes that it breeds very numerously on the moors near Huddersfield chiefly in the nest of Titlarks; its stomach often contains very curious specimens of very minute land shells. The instance before recorded, of a young Cuckoo being brought up in the nest of a Reed Warbler, in the possession of Arthur Strickland, adds a new 
Foster Mother to the long list before recorded. In the Museum of the Yorkshire Philosophical Society there is the egg of a Cuckoo appended to the skeleton of the bird from which it was extracted after death. (See Reed Warbler.)

So long ago as 1784 that accomplished Yorkshire ornithologist, Marmaduke Tunstall of Wycliffe-on-Tees, writing of this generally distributed and common summer visitant, which shares with the Swallow the title of "harbinger of spring," informed the naturalists of his day that its arrival in the county may be expected about the second or third week of April. True it is that earlier dates are recorded, one of these being the 4th April I904, when Mr. S. Elley, who is perfectly familiar with the bird, saw one, within a few yards' distance, near Saltburn; and on the same date Mr. E. B. Emerson distinctly saw one on the road, while driving between Swainby and Deighton; the earliest arrival I have had ocular proof of was on 8th April I88I, at Kirby-inCleveland; but, generally speaking, what was correct in Tunstall's time is equally so at the present day; the Yorkshire saying goes "In April come he will," and though March Cuckoos are reported from time to time, I am somewhat sceptical as to their authenticity.

As a common and generally distributed species, the Cuckoo requires little notice; it is found in all parts of the county from the sea-coast up to the high reaches of the dales, where it is met with at 1500 feet elevation.

Yorkshiremen say in regard to its departure, "In August go he must" ; this saying also holds good, for the majority leave in that month; a few remain until September, and late lingerers even into October; the latest date at Spurn is the $24^{\text {th }}$ of the latter month, I883, though a record is communicated (in litt.) by Mr. R. Butterfield, of an example being killed on 5 th November I902, at Horton, near Bradford.

The information collected by the British Association Migration Committee shews that, on the vernal and autumnal passages, it is frequently recorded at the Light stations on the coast, and is sometimes captured at the lanterns of our sea beacons. I have, on more than one occasion in spring, 


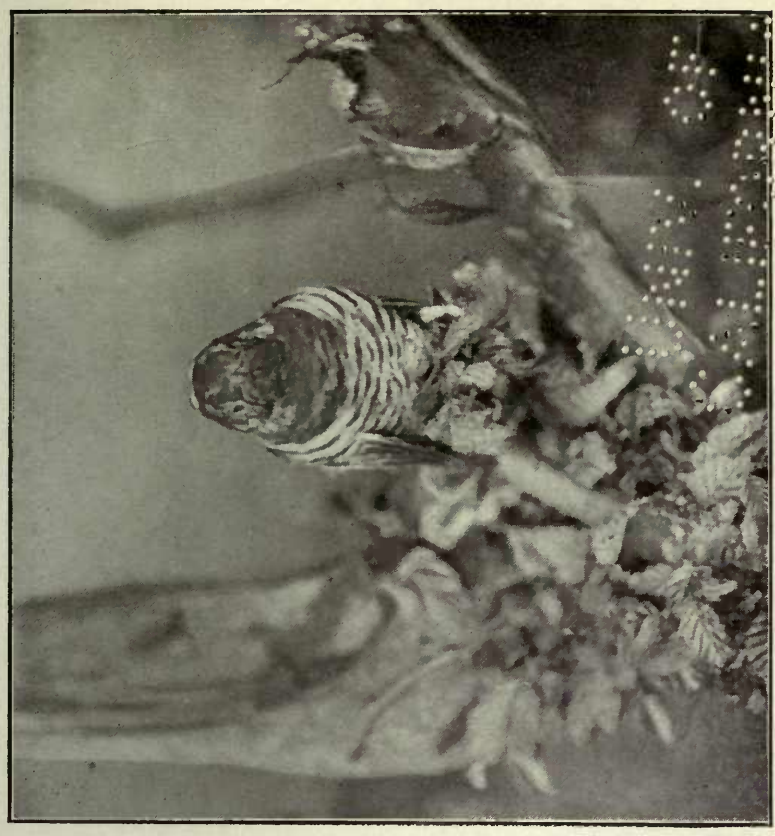

垔
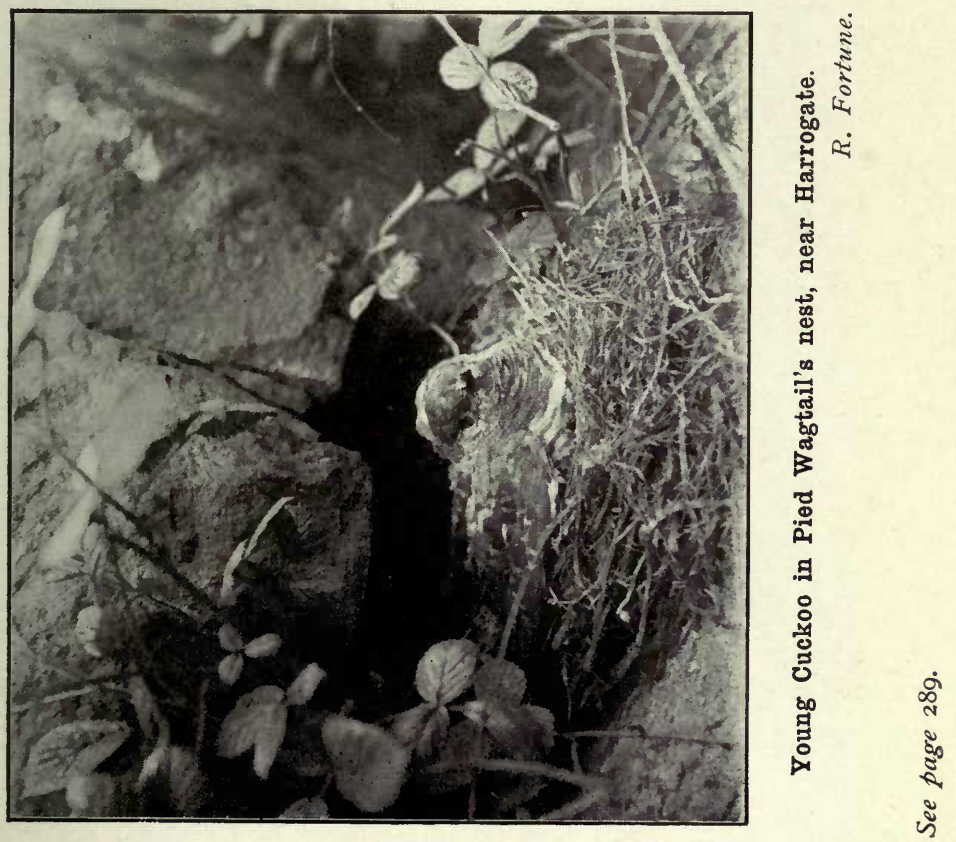


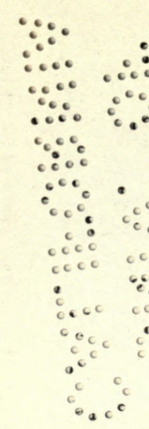


noticed an influx of these birds, which haunted the sandhills for a day or two and then dispersed inland; and they have been observed assembling at Flamborough in autumn prior to departure. The most important references to the autumn migration are :-

"I844. 28th August. Fifteen observed, apparently migrating" (Zool. I845, p. 82I).

" I88I. Many passed Spurn last fortnight in September" (Third Migration Report).

"I893. June 25-26th. Twenty seen near Kilnsea" (Cordeaux MS.).

The method by which the young Cuckoo ejects the young of its fosterers has been observed by Mr. Harper of Scarborough (Zool. I886, p. 245), and if proof were required of the old Cuckoo "sucking little birds' eggs to make her voice clear," a Yorkshire instance may be quoted from Goathland, where, in June Igor, a female bird was observed hunting the moor near a Titlark's nest containing one egg; a watch was kept on its movements; it was seen to hover in the vicinity for some time, to alight near the nest, and then fly away carrying some small object in its bill; on inspection of the nest a different egg to what it had contained was found, and a search near a hedge where the Cuckoo had flown revealed the broken pieces of shell of the Titlark's egg. The Cuckoo had carried off the Titlark's and substituted its own egg. The late J. Tennant of Boston Spa mentioned that he once saw a female Cuckoo killed, which had in its bill its own broken egg that it was apparently going to place in a Hedge Sparrow's nest near. A curious depository for a Cuckoo's egg was in a Wagtail's nest, built in a waggon of coals standing at York station, when the coal trade was greatly depressed. The egg was hatched and the young bird reared (York Herald, I2th July I876). Amongst the fosterer-Cuckoos found in Yorkshire are:-Meadow Pipit, Tree Pipit, Rock Pipit, Redstart, Whinchat, Whitethroat, Garden Warbler, Sedge Warbler, Reed Warbler (Allis), Hedge Accentor, Pied Wagtail, Yellow Wagtail, Yellow Bunting, Reed Bunting, Greenfinch, Twite (H. B. Booth MS.), Redbreast, Skylark, Song VOL. I. 
Thrush (Eds. Nat. I876), Swallow (young Cuckoo reared at Harswell Rectory, Field, IIth August I894), and Ring Ouzel (Butterfield MS.). The proportion of the fosterers in Wilsden district is estimated to be :-

$$
\begin{array}{lllllll}
\text { Meadow Pipit. } & \ldots & \ldots & \ldots & 80 & \text { per cent. } \\
\text { Whinchat } & \ldots & \ldots & \ldots & \ldots & 5 & \\
\text { Various } & . & \ldots & \ldots & \ldots & \ldots & \text { I }
\end{array}
$$

and occasionally two Cuckoo's eggs are laid in one nest. Tunstall, in 1784 , observed that he had kept Cuckoos in confinement, but they always died with the advent of frost. Mr. T. Whitwell, keeper, of Scugdale-in-Cleveland, informed me, in July Igor, that he had just seen a young Cuckoo sitting on a wall behind his house, which is on the edge of the moor, and an old Cuckoo came to feed it several times while it was under observation. On Strensall Common in the spring of I894 one was heard calling on the wing, and uttering a chuckling sound as well as the ordinary note. An instance of a female Cuckoo shot whilst calling on the wing is recounted by $\mathrm{Mr}$. Butterfield, thus proving that it is not only the male which utters its note while flying (Zool. r899, p. 322).

Yorkshire folk-lore connected with this favourite bird indicates the interest manifested by the country folk, many of whom aver that it changes into a hawk in winter. The rhyme respecting its arrival and departure runs :-

"In April come it will,

In May it sings all day,

In June it changes its tune,

In July it begins to fly,

In August go it must."

And in Craven district the proverb is :-

"In the month of Averil

The Gowk comes over the hill

In a shower of rain."

An almost universal belief prevails that, if a person has money in his pocket on first hearing the Cuckoo, he will never be in want of it throughout the year, but to be without money when he first hears the bird is unlucky. "When ya heer $t$ ' Cuckoo shoot, Torn yer money reet aboot." To send a person 
on a fruitless errand on the Ist of April, is called a "Gowk's errand." Sometimes the one sent is the bearer of a missive containing the following distich :-

"The first and second day of Averil

Hound (hunt) the Gowk another mile."

The reply of persons too experienced to be thus deceived is :

"April Gowks are past and gone,

You're a fool and I am none."

Another rhyme anent the bird's habits, which may serve as answer to queries sometimes asked in newspapers, is as follows :-

"The Cuckoo is a bonny bird, She sings as she flies,

She brings us good tidings, And tells us no lies;

She sucks little birds' eggs,

To make her voice clear, And always sings 'Cuckoo'

In the spring of the year."

Its frequent calling is said to prognosticate rain, and as its notes are less distinct before it migrates, the local saying runs : "Cuckoo'll seean be gannin; she chatters rarely."

A saying in the Yorkshire dales, "As scabbed as a Cuckoo," is in allusion to the great amount of scurf which comes from the young; and, in conclusion, I may refer to the tales told of the inhabitants of various villages, viz., Austwick, Cowlingin-Craven, Marsden near Huddersfield, Stanbury near Heworth, Slaithwaite, and others, who are the laughing stock of their neighbours because they attempted to "wall in the Cuckoo," under the supposition that, if they could keep it, they would be favoured with spring and summer weather all the year round.

This species is not subject to great variation in plumage, though Marmaduke Tunstall recorded one "with much white about the head and neck" (Tunst. MS. I784, p. 59). In July Ig03 I repeatedly saw one, with a considerable amount of white on the head, which visited a garden in Redcar, and came within a few feet of the onlookers. A specimen with 
white wings and tail was noted near Ripponden in 1784 , and one of a general dark cream colour, with distinct markings of a darker shade on the back, was in the collection of Hugh Reid of Doncaster.

The only vernacular name in use is Gowk or Gawk, which is applied generally in country districts.

Blue Pen is a term given to the young birds when first fledged.

\section{BARN OWL. \\ Strix flammea (L.).}

Resident, generally distributed, fairly common; most numerous in the south of the county.

Historically, the oldest reference to this species is in Willughby's "Ornithology" ( 1678, p. 2I), thus :- "This Mr. Johnson [of Brignall, near Greta Bridge], calls the Church Owl."

Thomas Allis, I844, wrote :-

Strix fammea.-Barn Owl-Becoming scarce in the neighbourhood of Halifax, Huddersfield, and Hebden Bridge, where factories and tall chimnies have driven them from their former haunts. It is plentifully met with in other parts of the county.

This, the most generally distributed of the Owls in Yorkshire, whilst found in a lesser or greater degree of abundance in all districts, appears to be more numerous in the southern portion of the county than elsewhere; it is rare in the high reaches of the western and north-western dales, and apparently these districts are not suitable to its requirements. Several pairs were turned out in the Hodder Valley a few years ago ; they bred, but soon disappeared and have not been seen since; near Eavestone this bird breeds in rocky cliffs. In Wensleydale, and in some.other localities, the decrease of this useful and interesting bird is to be deplored, though it is a pleasure to state that numerous correspondents allude to its receiving protection from the farmers; and now that this class of the community has learned to appreciate the services rendered by this bird, it is to be hoped that before many more years 
the game preserver may be as fully alive to the equally valuable services of the woodland species.*

Though not the most numerous, this is the best known of all the Owls, probably from the fact of its taking up its abode in close proximity to the haunts of man and frequenting the towers of churches, whence it has acquired a kind of ghostly fame.

The Barn Owl is occasionally observed as an immigrant on the coast in autumn from the Continent, but in limited numbers. It has been noticed at sea and several were seen, and two taken alive, tired out, at Easington, on $I 7$ th October I89I; whilst in the Migration Reports there are entries recording its appearance at east coast Light stations. I have noted its occurrence at Flamborough and Redcar in October and November, and in the latter month, in 1902 , one was captured alive in a house on the sea-front, which it had entered during the night. These migrants are usually of a much darker and redder plumage than our resident birds, and similar to the description given of Continental examples. In the collection of the late Edward Tindall of Knapton Hall is a fine variety obtained at Hackness, near Scarborough, in December I876. This specimen has the back and wings of a rich chestnut-brown, the wings shaded with mouse colour, the usual black spots being absent; the facial disks a light buff radiated with chestnut; the breast

* No apology is needed for introducing the following analysis of the castings of our three most abundant species, given at p. 148 of Newton's Yarrell. Such evidence cannot be too widely disseminated or too well known.

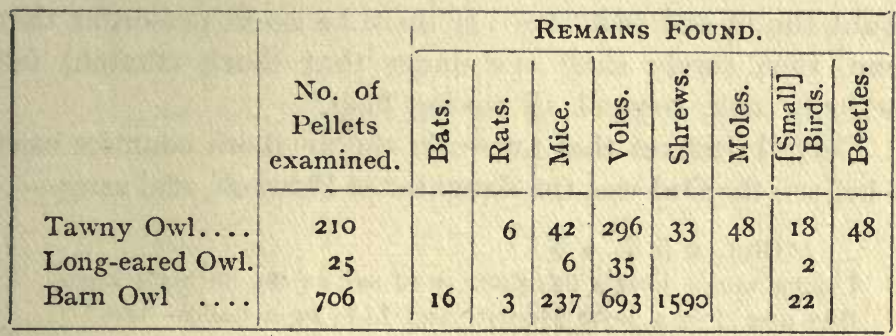


light buff and unspotted. Professor Newton (Yarrell's "Birds," 4th ed., Vol. I. p. I98), speaking of a similar variety, described by Mr. Stevenson, which occurred in Norfolk, considers it to be of foreign origin and probably an accidental visitor to this country, and remarks that Danish examples in particular have the facial disks of a dark rusty-red colour.

Charles Waterton induced the Barn Owl to nest in the old gateway tower at Walton Hall, and in other parts of his park; a late brood was noticed in November I828, and on Ist December I823, a half-fledged young one was in a nest in the old ruin on the island. We have it on the authority of Waterton himself that this species will occasionally catch fish, he having observed one in the act of taking perch from the lake ("Essays on Nat. Hist." pp. 270-277).

Yorkshire folk-lore connected with the Owl family embraces some curious superstitions formerly prevalent in the Cleveland dales, though at the present day these ideas are almost forgotten and exist only in the memories of the oldest dalespeople. The concoction called "Owl-broth" was at one time used medicinally in cases of palsy, but with what effect it would be impossible now to say. A quaint belief was to the effect that "Should an Ullot hoot whilst one crosses over a bridge, the moon then being at, or within three days of, full, and he or she be yet not half over the bridge, to such it be truly an ill sign. To break the spell, let such unlatch their shoon, toss baith beyond the brig-foot, so crossing over bare-foot." Another ill-omen was "An Ullot's cry thrice heard after rush-light, soon followed by a 'fire-flaught' (a hot cinder flying out of the fire), which dies before the one nearest the fire can cast their breath upon it, is a sure sign beyond all doubt the ill one shall die. If there be no ill person at that time, then surely shall one under that thack (thatch) fall suddenly sick, beyond all saving help."

Nuttall declares that nurses in the northern counties used to believe the Owl was the daughter of Pharaoh, and sang-

' Oh! ǒ ǒ ǒ o ō

I once was a king's daughter, and sat at my father's knee, But now I'm a poor Hoolet, and hide in a hollow tree.' 


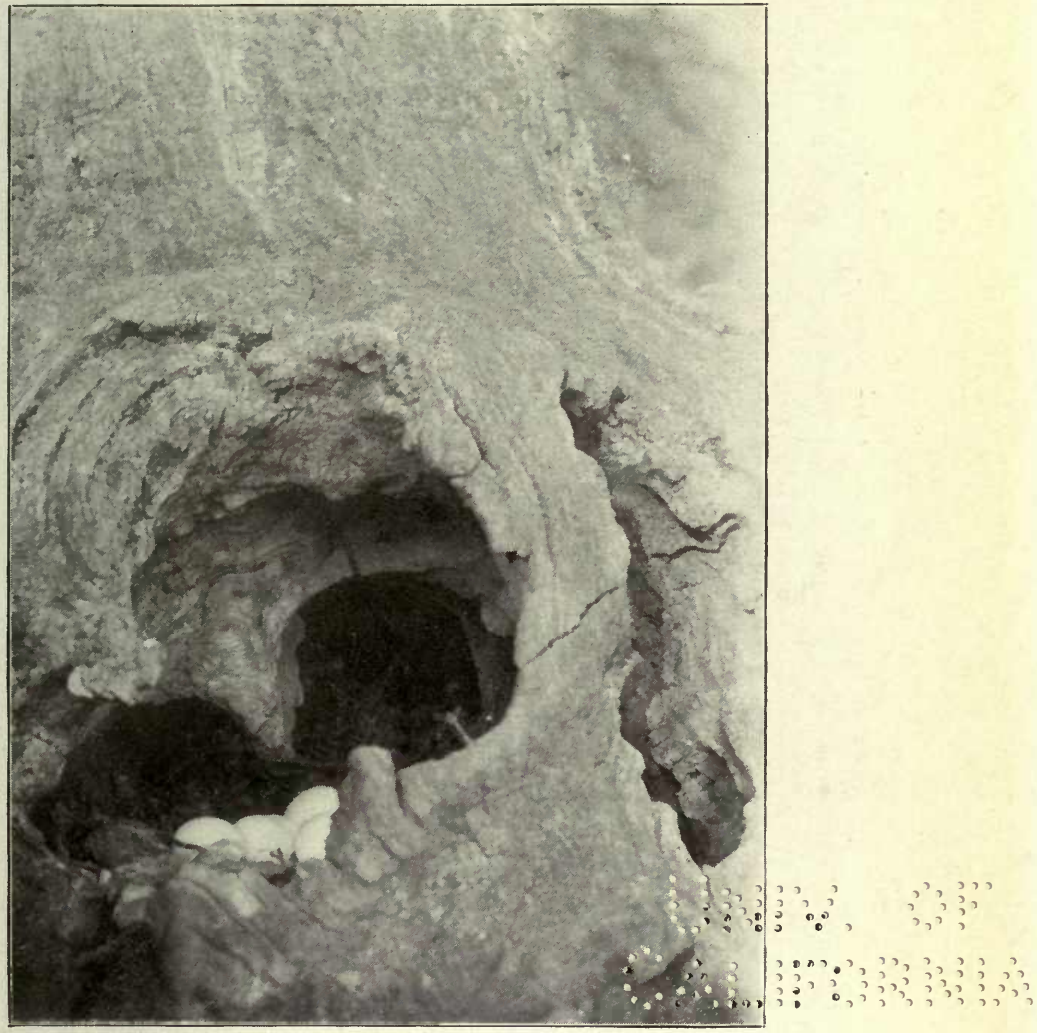

Barn Owl's nest in old oak tree. R. Fortune.

See page 294. 

A similar idea was prevalent at Charles Waterton's home, for in his remarks on the Barn Owl he gave two stanzas of an ode sung by the nursery-maid in his young days, as follows :

- Once I was a monarch's daughter, And sat on a lady's knee;

But am now a nightly rover,

Banish'd to the ivy-tree,

Crying hoo, hoo, hoo, hoo, hoo, hoo,

Hoo, hoo, hoo, my feet are cold!

Pity me, for here you see me,

Persecuted, poor and old.'

In Cleveland it was considered equally lucky to find a dead Owl, Hawk, Raven, or Carrion Crow.

The provincial names by which it is known are :-Ullot, Ullat, Jenny Howlet, Screech Owl, White Hoolet, White Owl, and Church Owl in general use; Yellow Owl in the western Ainsty; Screaming Owl at Loftus-in-Cleveland, and Hissing Owl.

\section{LONG-EARED OWL.}

\section{Asio otus (L.).}

Resident, local, confined to wooded districts; common where found. An autumn migrant in limited numbers.

Probably the earliest reference to this, as a Yorkshire species, is to be found in Willughby's "Ornithology" (I678, pp. I00-IOI), where that celebrated ornithologist stated that "Francis Jessop, Esq., sent it to us out of Yorkshire."

Thomas Allis, I844, wrote :-

Otus vulgaris.-Long-eared Owl-Common in most parts of the county, though reported to be rare in the district about Halifax, and now becoming scarce near Huddersfield. (W. Eddison, Esq., Rastrick, near Huddersfield).

This species is to be found in suitable localities, in varying numbers, but is local, inasmuch as it occurs only in wooded districts. In some parts of the West Riding it appears to 
be slightly on the increase, and in the East and North Ridings it is more numerous than the Tawny Owl. As an immigrant, it is observed annually on the coast in the vicinity of Spurn, and at the Teesmouth, but in very limited numbers, and arrives there later in the season than its congener, the Shorteared species, usually in the latter days of November or in December, although I have observed individuals in midOctober at Redcar; it is annually observed migrating across Heligoland.

The late A. Roberts of Scarborough reported the following curious incident in the nidification of this bird: "Some years ago, a friend of mine observed a Long-eared Owl leave an old Crow's nest and, on climbing the tree, found the nest empty. Three days afterwards he again saw the Owl leave the identical nest; he again ascended, and found three eggs just at hatching. The only way in which this can be accounted for is that, disturbed in other quarters, the Owls must have conveyed their eggs to this nest. Out of curiosity, the next time I had one of these birds in the flesh for preservation I found that the mouth was quite capable of containing its egg."

This Owl is gregarious in winter, and sometimes, when a wood is being beaten out for the shooters, several of these birds may be seen on the wing together, flying out into the open in an aimless manner, and quite dazed by the light.

The only local names are Horned Owl, which is a general term, and Long-horned Ullat.

\section{SHORT-EARED OWL.}

\section{Asio accipitrinus (Pallas).}

Winter visitant : fairly common in some seasons. Arrives usually in October and November. Occasionally nests in the county.

An early allusion, perhaps the first, to this species is found in the Allan MS. of the Tunstall or Wycliffe Museum, dated about I79I, where it is described as "A bird of passage; 


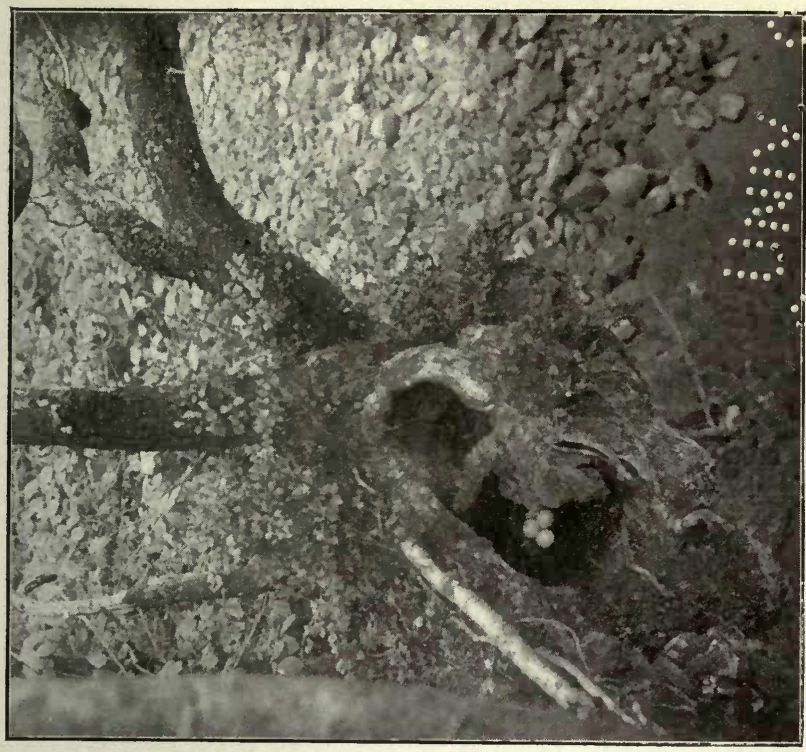

ह்

รั)

\&

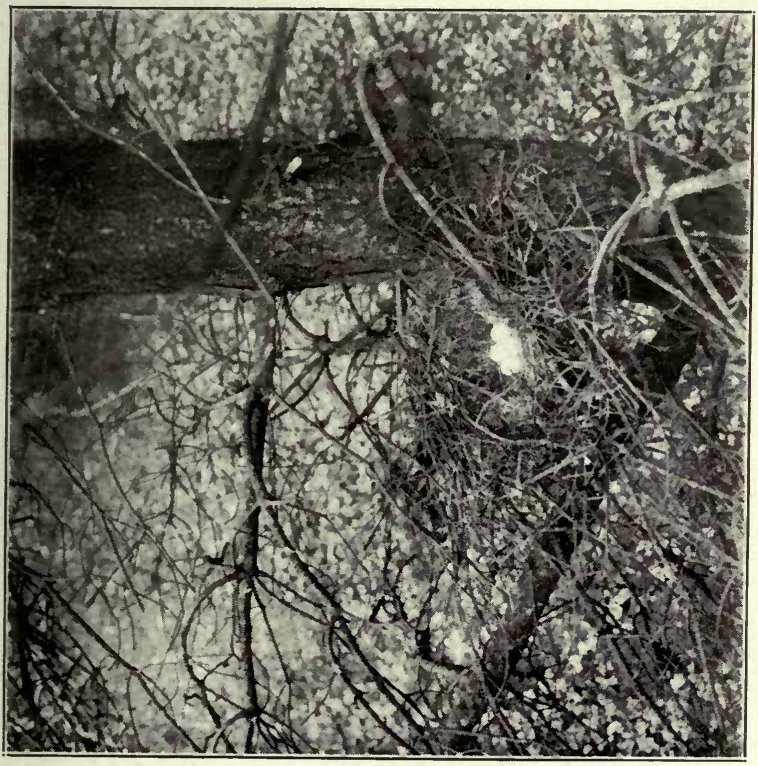

ह

ชั่

๙ั

๗ัँ 

visits us in October, and retires early in the spring, like the Woodcock. .... Known by the name of Mouse Hawk and Woodcock Owl." (Fox's "Synopsis," p. 54.)

Thomas Allis, I844, wrote:-

Otus brachyotus. - Short-eared Owl-By no means uncommon in the autumnal months, especially in cultivated fields ; but this species is also rare in the Halifax district. A. Strickland says he has several times met with this bird in considerable numbers when shooting among turnips in autumn, and that a few are shot every year at that season; from being met with in autumn, it is called Woodcock Owl, under the idea that it comes over with that bird, but, as they are found to breed on the moors to the north, and are not observed as a winter resident, he strongly suspects that the groups met with in autumn are in the act of leaving us, and not arriving, as is also observed with the Ring Ouzel.*

The Short-eared Owl is an annual immigrant from the north, arriving on our coast line from the first week in October to the middle of November in considerably varying numbers. The earliest recorded arrival was on 6th August I892, at Spurn ; at Redcar two appeared on 2Ist August I884. Occasionally individuals are known to occur in December, and even in January; on the I4th of the latter month, in the year 1879 , one was seen on the Tees Breakwater. These immigrants after a short rest proceed inland, distributing themselves generally over the county, where specimens are to be observed during the winter months.

The late J. Cordeaux contributed a most interesting article to the Zoologist ( 1877, p. 9), on the exceptionally large flight which visited these shores during the autumn of 1876 , which, whilst giving an accurate account of the habits of this species immediately after their arrival, also records some valuable observations on their habits during migration, as follows :-

"These birds arrived on the night of the 23rd of October, at least I first found them on the morning of the 24 th crouched amid patches of rough sea-grass on the embankment, as well as further inland on drain sides and amidst rough grass in

* Needless to remark Strickland's surmise was not the correct one, this Owl being a winter visitant. 
pastures. This autumn unprecedented numbers came, and I have heard of them in many localities on this coast. It is astonishing any are left to migrate, considering the number, year after year, destroyed on their first arrival, as well as many which figure afterwards amongst the "sundries" of the autumn and winter shootings. Mr. Lewis, the Principal of the Spurn Lighthouse, says he has never known them strike the glass like other birds, but during the period of migration they will fly round and round the lantern, apparently not incommoded by the blaze of light, and take off small birds that are fluttering and beating themselves to death against the glass. They arrived off Flamborough in flocks of from ten to twenty. The Principal has never known them strike the glass, but has twice observed them perched on the gallery rail on the outside of the lantern. North of Flamborough they appear to have been equally numerous along the coast." Great numbers also arrived at the same time at Redcar and the Teesmouth; I saw ten on the rocks at low tide on I7th October, and another on a chimney-stack in the town, while many were noted along the sand-banks.

In a letter received from Heligoland, H. Gätke stated :"The Short-eared Owls pick off the poor birds when they are dazzled by the glare of the lighthouse, but not those fluttering against the glass; but thrushes on the wingconstantly one hears their dying cries when clutched by the nude talons of an Owl that has just flitted like a phantom noiselessly past the light."

In the autumn of 1879 these birds arrived at Spurn at intervals during the last week in October, being most numerous on the morning of the 3 oth and all had departed by the next day. During the January of $\mathrm{I} 880$, when many migratory species were most erratic in their movements, a fresh immigration occurred at Spurn on the 30th. In I88I they were again abundant at the Teesmouth, as also in October I895, as many as twenty being seen together. In I 896 numbers were reported both at the Teesmouth and Spurn; and again over the whole of the north-east coast district, in 1903. At Redcar they are frequently observed coming directly off the sea, 
sometimes flying at a considerable elevation and on approaching the land lowering in their flight and alighting on the nearest terra firma. During a north-east wind in October I88I, while out wild-fowling, I noticed an Owl falling "out of space," like a collapsed baloon, over the sand-hillls. A sailor who had been to Norway told me that while his ship was in port, about the time of full moon, he saw one of these Owls fly high in the air at dusk and shape a course which would land it on the Yorkshire coast. Like the Woodcock, and many other migrants, these birds take advantage of the moon's light for their journey over-sea ; they arrive on our seaboard at all hours of the day from early morn till late afternoon. Two came over at 5-30 p.m. on 22nd September I88I, and other two at 6-30 p.m. on the following day; and they are met with, on first arrival, in most unlikely places. On 30 th October I902, my spaniel flushed one from underneath a boat standing on the road near my house, and within twenty yards of the front door, and it is by no means an unusual event in an east coast seaside town to see them in the cottage gardens, or on the premises adjoining fishermen's dwellings.

The Short-eared Owl is seldom reported on the return passage in spring; one is recorded on I6th May I843, on the sea banks near Redcar; the only instance of its occurrence at this period which has come under my observation was on the $I 7$ th of the same month, in I882, at the Tees Breakwater, though one was noted at Spurn as late as the 25th of May in $\mathrm{I} 88 \mathrm{r}$.

As a resident, this species is either overlooked, or rare. From the extensive moors of north-west Yorkshire, which offer every attraction as breeding haunts, it is reported as frequent near Carperby in Wensleydale, among the heather in the breeding season, but the nest has not been seen ( $N a t$. I886, p. I83) ; Mr. T. Whitwell, keeper, of Swainby, has told me that when he was keeper at Leyburn, about the year I890, he found three nests of the Short-eared Owl, one containing twelve eggs, and I have seen a pair of the birds which were killed there in the breeding season; in June I903, young ones were captured near Masham, having doubtless been bred 
on the moors there. In Arkengarthdale it is an occasional breeder (op. cit. 1892, p. 3I9), and in the Malham neighbourhood the nest and young have been taken, together with the parent birds, while I learn on good authority that in the spring of I894 a keeper in that district shot a "Moss Owl" as she rose from her nest, and afterwards destroyed the eggs. This bird is also reported as nesting on several of the moors in the extreme north-west of the county; one was shot near Bentham on I3th June I903, and in all probability would be nesting on the moors near that place. Mr. Thomas Bunker of Goole tells me that he is quite confident that a pair bred on the moors near that town in 1879 , for they were observed there during the summer, and some men employed in draining told him that on one occasion they must have been in close proximity to the nest, as the old birds swooped at them; while, in I898, Mr. Audas had a young Short-eared Owl brought from Thorne Waste, where he has frequently noticed the adult bird. Other localities in which it is said to have bred in the West Riding are on the Otley Moors and near Skipton.

In the North Riding it is mentioned in A. G. More's valuable paper on the distribution of birds during the breeding season (Ibis. I865), as frequenting the moors near Scarborough, on the authority of Mr. A. S. Bell, and I am indebted to Mr. More for a copy of Mr. Bell's letter to him, dated I8th November I862, in which he says:- "Another nest taken this year in the heath on the moors near Scarborough. The eggs were laid in a hole scratched in the ground, four in number. In the former case the eggs were in a hole in a bank side immediately under the root of a tree." So recently as June Igo4, the young, with down still adhering to their feathers, were taken on a moor near Scarborough, where as many as eleven old birds had been seen on the wing at one time in the previous April (J. Morley, in litt). In July of the same year Mr. Zimmerman of York discovered a nest, containing three young ones, at Strensall Common, his attention being drawn to the place by the peculiar clucking call of the parent birds which flew around him at close quarters.

The late William Lister saw the young birds taken from a 
nest on the Egton Moors, near Whitby, about the year I850, and had no doubt that, within recent years, they occasionally bred there. On the Danby Moors, also in Cleveland, Mr. W. H. Raw has found at least four nests, all of which contained young birds, and were placed among "old heather broken down and dead at the roots." The young did not in any instance exceed three in number. Mr. Raw found the last nest in $\mathbf{1 8 8 2}$, when both eggs and young birds were taken, and he thinks it is quite possible that they may still breed there.

An example examined by Mr. W. Eagle Clarke at Spurn in October 1879 , is in the Arctic form of plumage described by Seebohm ("Brit. Birds," Vol. I. p. 72).

The local names are Woodcock Owl in general use, so called from the fact that its arrival is coincident with that of the Woodcock; Moss Owl on the north-western fells; and Mouse Hawk is a term applied to it by G. Allan in I79I.

In concluding my account of this species, mention should be made of the fact that "Hawk Owl" is a name by which it is known in some parts of the county; and the result of my inquiries and the examination of specimens has been to prove that the "Hawk Owls" reported to have occurred in Yorkshire have in every instance been examples of the Shorteared Owl. The Hawk Owl (Surnia funerea), so far as I have been able to ascertain, has never occurred in this county.*

\section{TAWNY OWL. \\ Strix aluco $(L$.$) .$}

Resident, generally distributed and fairly common in well wooded districts.

Probably the earliest Yorkshire reference to this species is made by Graves in his "History of Cleveland" (I808),

* For particulars of an Owl carrying a Goldcrest on migration, see the latter species: and Zool. 1882, pp. 72-3, also Ficld, 3rd March and 7 th April 1888. 
wherein he enumerated it in his list under the name of "Brown or Wood Owl."

Thomas Allis, 1844, wrote:-

Syrnium aluco.-Tawny Owl-This also is becoming scarce near Halifax; is not met with at Huddersfield and Hebden Bridge, but not infrequently met with in other parts of the county.

This bird, perhaps the most abundant of the Yorkshire Strigidæ, is to be found in those portions of the county where there are woods, or small though dense fir plantations. It is included as a resident in most of the reports sent to me from various parts of the county, and whilst it seems to be especially abundant in the Cleveland district and the neighbourhood of Slingsby, it is mentioned as being only of occasional occurrence in the Halifax and Keighley districts, is rare around Sheffield and Huddersfield, not very common in Lower Wharfedale, and widely, although thinly, distributed in the East Riding, where it has increased considerably during the last few years, a fact which may be due to the Wild Birds Protection Act, coupled with a better knowledge of the bird's usefulness than was formerly entertained. Most of the reports express regret that so truly useful a species should be subject to persecution. It is satisfactory to know that that abominable instrument of torture, the pole trap, which was frequently the means of capturing the Tawny Owl, is now forbidden by statute.

The late J. Carter of Masham wrote (in litt. I902), that the Tawny Owls had become so abundant near his residence as to sometimes disturb the slumbers of his household by their incessant hooting; he also remarked that this bird can be induced to answer an imitation of its call at flight time.

This Owl nests in a variety of situations, hollow trees and ivy being perhaps the most generally selected, whilst the deserted nest of a Crow or Magpie is not uncommonly resorted to. Mention is made of a hole in a quarry being used near Scarborough, in which was found one young bird, one egg, and two dead rabbits. Mr. Eagle Clarke found the eggs of this species laid in a depression in the hay in a barn. In Swaledale it sometimes nests in holes in rocks, and Mr. C. J. Lee Warner, writing in the Field (I6th August I902), says 

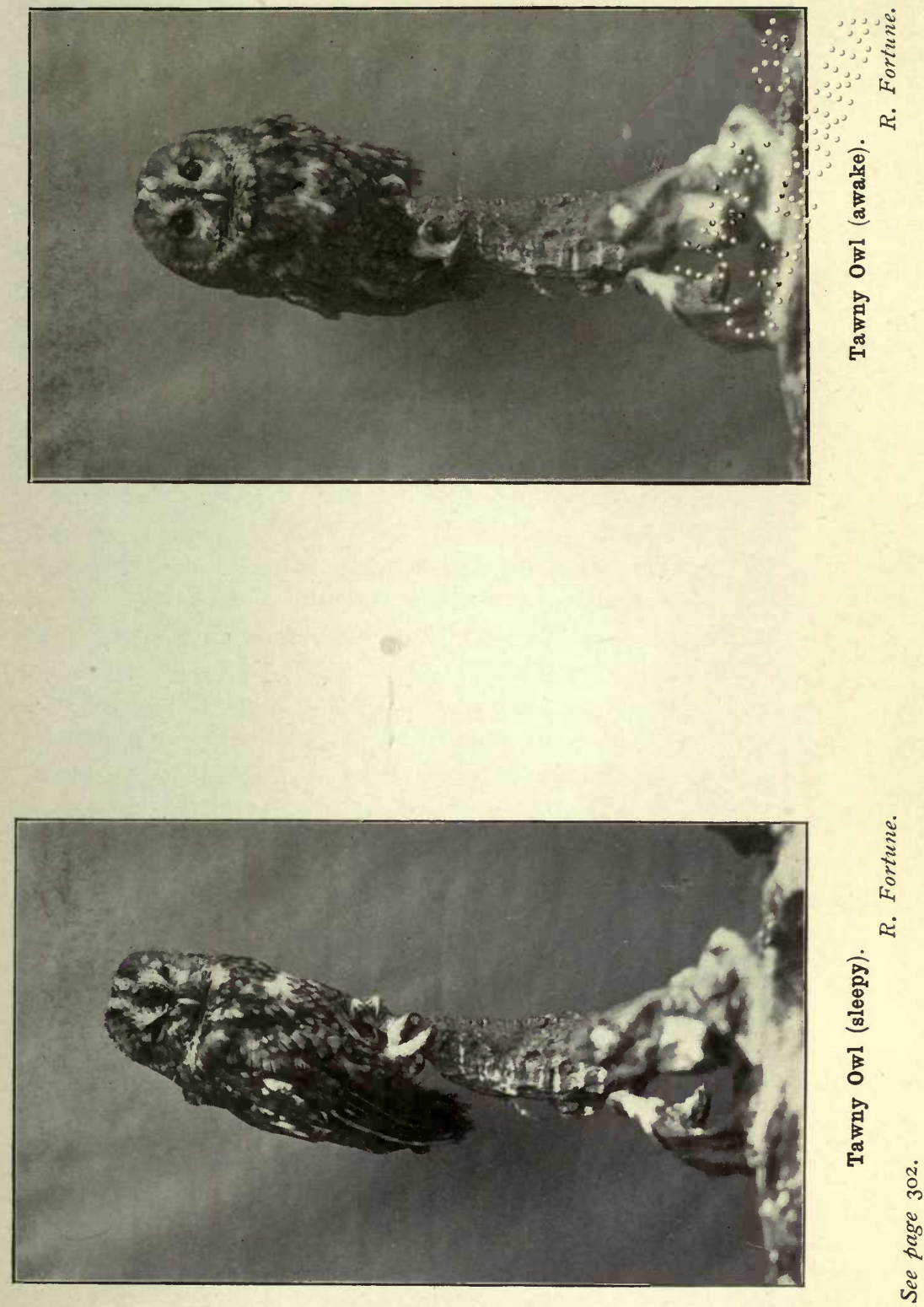

that in June 1897 , he found young birds on some hay in a barn close to Ulladale Force. On several occasions near Masham, and also at Sedbergh, clutches of five eggs have been found in a nest, which is an unusual number. Mr. S. Hannaford of Kiveton Park related that a pair of these birds kept their young well supplied with young rabbits, which they hung, one at a time, on a branch of a tree near the nest, so as to be within the reach of their young, and in an Owl's larder near a stackyard in the Masham district the remains of twelve rats were discovered.

A rather unusual circumstance in regard to the nidification of the Tawny Owl is reported in the Field, May I895, where mention is made of a Pheasant's nest at Hambleton containing five eggs of the rightful owner and two belonging to an Owl. A curious anecdote of one of these birds laying its first egg after being nearly twenty years in captivity is related in the Zoologist (1855, p. 476r), by Mr. Henry Spurr of Scarborough.

Both the ruddy and grey forms are met with in Yorkshire, and I am inclined to the opinion that the latter is an occasional immigrant from the Continent in autumn.

The north country vernacular names are applied indiscriminately to the Owl family; Hullot, Jinny Hullut, Howlet, Hoolet, Ullat, Jinny Yewlatt, Yoolat, and Jenny Howlet being in general use. Swainson gives the names Brown Owl or Brown Hoolet, Beech Owl and Ferny Hoolet. In Craven it is known as Hoot Owl. Wood Owl or Wood Ullat is a general name, and Ivy Owl is also sometimes used.

\section{TENGMALM'S OWL.}

Nyctala tengmalmi ( $\mathcal{F}, F$. Gmelin).

Accidental visitant from northern Europe, of extremely rare occurrence.

In his second edition of the "Manual of British Birds," I899, Mr. Howard Saunders mentions that there are about 
twenty instances of the visits of this little Owl to England; of these twelve belong to Yorkshire. The circumstances relating to the first occurrence of this species in the county were obligingly communicated by $\mathrm{Mr}$. Thos. Stephenson of Whitby, who states (MS.) that the late Martin Simpson, curator of the Whitby Museum, informed him that the late Thos. Richardson had a specimen from Sleights Moor, about I840, and presented it to the Museum, but, being imperfectly cured, it decayed.

About the year 1847 an Owl of this species was shot in the woods at Hunmanby, by Admiral Mitford's keeper, its occurrence remaining unknown until 1849, when it came under the notice of the late David Graham of York. The fact was afterwards recorded in the Zoologist (I849, p. 2649), by Dr. Morris.

A female example, killed at Lowthorpe in the year 1860 , is in the Burton Agnes collection, formed by the late Sir Henry Boynton.

The late W. W. Boulton of Beverley and Mr. M. Bailey of Flamborough kindly gave the information relating to the fourth Yorkshire occurrence, of which the following is a résumé:-On Ist October 1863 , after a severe gale from the north-east, a splendid specimen, in exquisite plumage, and supposed from its size to be a mature female, was captured at Flamborough in the day time by a man who ran it down in a field, the bird being dazzled by the light and rendered almost helpless. It was taken to Mr. Bailey for preservation, afterwards formed part of the collection of John Stephenson of Beverley, and is now in the possession of $\mathrm{Mr}$. Thomas Boynton of Bridlington.

An example of this interesting little Owl was in the possession of the late William Lister of Glaisdale, who obtained it at Egton, near Whitby, on Igth November I872. It is now in the Whitby Museum. Like the other specimens, this also occurred in the immediate vicinity of the coast, and I believe had been unrecorded until it was mentioned by Mr. W. Eagle Clarke in the "Handbook of the Vertebrate Fauna of Yorkshire." 
In January of the same year an Owl, trapped by Thos. Metcalf, a keeper in Handale Woods, near Loftus-in-Cleveland, is regarded by Mr. K. McLean as referable to this species (Nat. 1899, p. 139).

A third occurrence at Whitby, also comminicated by Mr. Thos. Stephenson, was on 3oth December 880 . The bird was taken at Normanby, above Hawsker, by a man named Ventriss, while rabbit shooting, and was flushed out of a patch of broom intermixed with furze. It is now in the possession of Mr. J. H. Wilson who preserved it, and who forwarded it to Mr. Eagle Clarke for identification (Zool. I882, p. I77).

In Holderness an adult female was killed at Holmpton on I8th October I884, and was preserved by Mr. P. Loten of Easington. This bird was recorded in the Naturalist (I884, p. II2), and Zoologist (I89I, p. 364).

Mr. R. P. Harper (op. cit. 1886, p. 214), reports that no fewer than three of these birds were procured near Scarborough during the three years previous. Unfortunately the dates were not observed. The first came on board a fishing smack at sea, and was identified by the late A. Roberts. Another was caught by some boys in an old quarry on Oliver's Mount and kept alive for nearly two years ; it was afterwards preserved by Mr. J. Morley. And the third was trapped at Ayton Moor, four miles from Scarborough, by a gamekeeper some time in 1885 , and is in the possession of Mr. D. Young of Irton. The record of Mr. J. Whitaker, however (op. cit. I885, p. 349), of two Little Owls at Scarborough, suggests the possibility of a mistake in the identity of these two individuals (see Little Owl, p. 304).

The particulars of the latest occurrence were obligingly supplied by Mr. R. Fortune of Harrogate, who informs me that a specimen in his possession was captured on a moor near Bickley, on 7 th November rgor.

[The only information obtainable relating to the supposed occurrence of the ACADIAN OwL (Nyctala acadica, Gmelin), VOL. I. 
a common North American species, in Europe* is contained in the subjoined communication to the Zoologist (I860, p. 7r04), from Sir Wm. M. E. Milner. It should be clearly understood that the mere fact of this and other species being included in this work is not in any way intended to claim for them a place on the British list; the information relating to such occurrences being simply given for what it may be worth.

Sir Wm. Milner's words are :- "I do not recollect ever mentioning to you for insertion in the Zoologist an account of my having received from a young clergyman, a son of Mr. Bury, who has the church at Osberton (my brother-in-law Mr. Foljambe's place) who, knowing I had a very fine collection of British birds, sent me a small Owl in a very curious case, which was shot in the East Riding of Yorkshire, not far from Beverley, by a keeper, a brother of Sir Thomas Whichcote's keeper, of Aswarbey, Lincolnshire. He sent this bird to his brother, who gave it to Mr. Bury, from whom I received it. I found out afterwards from looking at Audubon's "Birds of America," that it was the Sparrow Owl (Strix acadica), which is rather common in some parts of America, but totally unknown in this country."]

\section{LITTLE OWL. \\ Athene noctua (Scopoli).}

Accidental visitant from Continental Europe, of extremely rare occurrence.

Not merely is the whole of the information relating to the occurrence of this species very meagre, but unfortunately exceedingly vague, from the fact that in most instances there is an entire absence of details.

* Mr. H. E. Dresser, who considers that this Beverley occurrence is the only occasion on which the present species has been taken in Europe, does not feel justified in admitting it into his work on the Birds of Europe. 
The earliest reference to this, as a Yorkshire bird, is made in I768 in Pennant's "British Zoology" (i. p. I60), where it is said to be "very rare in England; it is sometimes found in Yorkshire." I suspect this is the authority from which Dr. John Berkenhout obtained the information for his "Synopsis of the Natural History of Great Britain" (I778), in which this species is described as having occurred in Yorkshire. Doubtless also Pennant's book is the source whence C. Fothergill derived the statement, given in his "Ornithologia Britannica" (I799), that it is " extremely rare in this kingdom, chiefly found in Yorkshire,"

In I828 R. Leyland of Halifax published a list of the birds occurring around that town, wherein he mentioned under the head of Strix passerina, Little Owl- "I have reason to believe that this species has been met with here; it has not however fallen under my own observation." The first edition of Yarrell's unrivalled work on British Birds, published in I843, contains a statement that the Little Owl has occurred in Yorkshire, and this is reiterated in Prof. Newton's fourth edition.

The "little earless owl" is included in a list of the birds which had been observed in Walton Park by the late Charles Waterton, and published in I866, after his death, by Dr. Hobson. With regard to this, it should be remembered that in the year 1842 Waterton purchased a dozen birds of this species at Rome; five of them survived the journey and were liberated in Walton Park.* In more recent years Mr. St. Quintin of Scampston Park, Rillington, has set at large several of these Little Owls, which have bred in the county,

* Under the heading of "Flight of 'Little Owls' in Yorkshire" the following doubtful record appeared in Neville Wood's Naturalist (1838, p. 168): "Mr. Rudston Read informs us that, some time since, from twenty to thirty ' Little Owls' were seen in a gorse cover belonging to P. Davies Cooke, Esq., of Owston Hall, near Doncaster. Mr. Read's informant was well acquainted with all the common British species of Owl, and stated positively that the Owston birds belonged to none of these. Unfortunately none of these 'Little Owls' were preserved.-ED." 
and others have been introduced into various parts of the kingdom, thus rendering the task of discrimination between liberated birds and genuine migrants an extremely difficult one.

The following occurrences suggest the probability of their being " migratories" :-

In the collection at Burton Agnes, formed by the late Sir Henry Boynton, is a female, obtained at Flamborough in I860, by R. Barkley, whose brother, Samuel Barkley of Bridlington, told me it was observed to fly into a thorn bush in a small ravine running up from the beach, whence it was flushed and killed.

Mr. J. Whitaker announced in the Naturalist (I884, p. 336), and Zoologist (1885, p. 349), that one was captured, on a fishing boat off Scarborough, in November I884, and taken to A. Roberts, who preserved it for Mr. Whitaker's collection. About six months later another was trapped at Seamer, near Scarborough, and the recorder appends the remark that probably they had come over together from the Continent.

The Little Owl has occurred on several other occasions in Yorkshire. One in Mr. T. Boynton's possession formerly formed part of the late W. W. Boulton's' collection at Beverley.

The late J. Carter of Masham informed me (in litt. I902), that one was taken near Kirby Malzeard " many years ago."

A specimen is mentioned by Mr. A. Crabtree in the "Halifax Naturalist" (Igoo, p. 86), as captured at Norland Moor, by J. Cunningham, but no date is given.

At Pocklington a specimen is reported by Mr. G. Steels (MS. I902), " ten years since."

And in the Naturalist (1897, p. 76), Mr. J. Backhouse mentions an adult female, procured at Escrick on 24th December 1896 , and preserved by Mr. Ed. Allan of York. 


\section{SNOWY OWL.}

\section{Nyctea scandiaca (L.).}

Accidental visitant from northern Europe and America, of extremely rare occurrence.

The earliest allusion to this as a Yorkshire bird is found in Thomas Allis's Report in 1844, thus :-

Surnia nyctea. - Snowy Owl-A pair were observed on Barlow Moor, near Selby, in 1837 ; the male was shot the 13th of that month [February], and is now in the possession of A. Clapham, Esq., of Potter Newton. (H. Denny's Sketch of the Natural History of Leeds and its vicinity for twenty miles. "Annals of Natural History," Vol. VII. p. 382, and Yarrell's "British Birds.")

In one instance only has a specimen of this fine species been obtained in Yorkshire, but there are several occasions on which it has been, or is supposed to have been, observed in the county.

Mr. A. Clapham of Scarborough stated that he has in his collection one which was taken on Barlow Moor (the example referred to by Allis). At that date the moor abounded in rabbits and furze, and was rented by his father for sporting purposes. The bird was first observed by the miller of an adjoining mill on the r2th and mistaken by him for a goose, but seeing it still there the next day he shot at it, just tipping the pinion. On an attempt being made to capture it, the bird threw itself on its back and offered so fierce a resistance that it was secured with difficulty and afterwards killed. This bird was exhibited during the year I837 at a meeting of the Zoological Society, by Mr. A. N. Vigors, F.R.S. Mr. Clapham said that the Rev. F. O. Morris's statement in his "British Birds" (I85I, i. I95), that this bird was accompanied by another of the same species, was incorrect.

Between the years 1849 and 1853 , during the winter or early spring months, Mr. Clapham, whilst walking at Scarborough, saw a large white bird flying towards the Castle, which, from its size, soft steady flight and broad wings, he concluded was $N$. scandiaca. This impression was confirmed 
on his hearing a day or two afterwards that a Snowy Ow had been shot at and missed from the Filey Rocks.

Regarding a possible occurrence of this species at Flamborough on I4th October I867, the late J. Cordeaux wrote as follows in the Zoologist (I868, p. I026):- "A large Owl chequered all over black and white, and, as the man said, ' as large as a great black-backed gull,' was seen in a turnip field. The man who saw it went home instantly for his gun; on his return, however, the bird had disappeared. Otherwise I might possibly have added Surnia nyctea to the avifauna of Flamborough."

In "Land and Water" for 27th December I879, Mr. Edward Thompson, in some Scarborough notes, mentions a Snowy Owl as having been seen near that town, and an unsuccessful attempt made to shoot it. Mr. Thompson afterwards stated that the bird frequented the New Park during the month of December and was frequently seen.

Mr. Stuart of Skipton (MS. I880), says that a specimen was obtained near the Lancashire border in the year named.

The following record is less satisfactory:-Messrs. J. Cordeaux and H. B. Hewetson had an opportunity of viewing a fully adult example in a field near Easington, Spurn, on 27th September I89I, Mr. Cordeaux afterwards reporting the incident (Field, 3rd October I89I ; Nat. I89I, p. 359 ; and Zool. I895, p. 59).

\section{SCOPS OWL.}

Scops giu (Scopoli).

Accidental visitant, from southern Europe and northern Africa, of extremely rare occurrence.

The first instances of the occurrence of this beautiful little Owl in Britain were announced from Yorkshire by Mr. Foljambe of Osberton, an accurate ornithologist, who assured Colonel Montagu that a specimen in his possession had, he 
believed, been shot in this county, and that Charles Fothergill of York had another, shot in the spring of 1805 near Wetherby.

Thomas Allis, I844, wrote :-

Scops aldrovandi.-Scops-eared Owl-F. O. Morris mentions this bird as having been met with at Womersley; two pairs have been shot at Ripley, near Harrogate, some years ago; the birds shot at Ripley were a pair of old and a pair of young birds; when shot they were nailed up to a house, and, after being there for a fortnight, and spoiled, were seen by Mr. Stubbs, animal preserver, of Ripon. The gamekeeper of Matthew Wilson, Esq., of Eshton Hall, in describing his exploits to a gentleman, said that some years ago he shot such a thing as he never saw before or since ; it was a regular formed Hullet not bigger than his fist, with horns above its eyes; this, it is almost certain, could be nothing else but the Scops. Another specimen was shot near Driffield about 1839 , and Arthur Strickland says “ A beautiful specimen of this little bird appeared in July 1832 , in the grounds at Boynton, and, from its loud and distinct note, attracted general attention; this note was like the sound of a single note on a musical instrument, repeated at about half a minute's interval, and was so loud that it could be distinctly heard in the house when all the doors and windows were shut, and the curtains drawn, and when the bird was in some tall trees some distance from the house; after some time it was shot by firing at the sound, as it was too dark to see the birdit is now in my collection." Another instance has been mentioned to me, and, from the description, I have no doubt of the species; it was in the grounds of Mr. Beaumont of Bossal, near Sand Hutton, and $I$ think it was stated to have been heard for more than one spring. Three other specimens are mentioned in Yarrell's "British Birds" as having been obtained in Yorkshire.*

Mr. Thomas Stephenson of Whitby writes that the late William Lister of Glaisdale had not the least doubt that this species was captured on the Egton estate in I865. The bird was described to him as being a little mottled Owl, only half the size of the Short-eared Owl, and having longer ears. Mr. Lister went to examine this bird, but unfortunately it had in the meantime come under the notice of a stranger, to whom it was sold.

A pair in the Hull Museum is stated to be well authenticated as having been obtained at Marton, near Bridlington.

* Two specimens in the York Museum are from the Allis and Strickland collections. 
[It is supposed that the Litrle Screech OwL (Scops asio, L.), which is, according to Audubon ("Orn. Biog."), a somewhat common North American species, has occurred on two occasions in England, in the counties of York and Norfolk (Stevenson's "Birds of Norfolk," Vol. I. p. 44); but the bird's claim to a place on the British list is not admitted, and Mr. H. E. Dresser, one of the best authorities we have on the avifauna of Europe, states that it has not been reported from any part of the Continent.

The information relating to the occurrence in which we are specially interested is, along with an etching of the bird, contained in the late Dr. Hobson's communication to the Naturalist of 1855 (p. I69), from which the following is abstracted :-

The Owl in question is in its grey plumage, and was shot by Joseph Owen in the breeding season of 1852 in Hawksworth Cover, the property of the Earl of Cardigan, half a mile above Kirkstall Abbey, and within the borough of Leeds. At that period there were a pair of Owls, and so far as Owen could judge by moonlight they appeared to be similar in size, colour, and flight. He at once saw that these birds differed materially from our Common Screech Owl, and was therefore extremely anxious to secure them; and, having shot one, he went to their haunt night after night to obtain the other, but this unfortunately he could never accomplish. Owen, ignorant of the value of his treasure, gave this Owl, in the flesh, to a bird-stuffer in Leeds, called Matthew Smith, who immediately put it up under the impression that it was a "Scops-eared Owl," and, under the same error in judgment, sold it to Dr. Hobson.]

\section{EAGLE OWL. \\ Bubo ignavus ( $T$. Forster).}

Accidental visitor, from Continental Europe, of extremely rare occurrence.

The earliest allusion to this species, as a Yorkshire bird, is made by Pennant in I768 ("British Zoology," i. p. I57), who stated that it had once been shot in the county. 
Thomas Allis, in I844, wrote:-

Bubo maximus.-Eagle Owl-One of these magnificent birds was shot at Horton, near Bradford, about 1824 (H. Denny's "Catalogue of Yorkshire Birds" in the "Annals of Natural History," Vol. VII. p. 388). Another was taken alive in a wood near Harrogate, in the summer of 1832, and was purchased by George Lane Fox, Esq., of Bramham, and is now at York in the Museum.

There are several other instances of this rare visitor to Britain having occurred in Yorkshire, and in the following enumeration of them, Prof. Newton's remark (Yarrell's "Birds," 4th Ed. p. I70), as to the probability of many of the British examples being escapes from captivity, is particularly applicable to those specimens which have occurred during the summer months; indeed grave doubts may be expressed as to the authenticity of most of these Yorkshire records.

One at Horton, near Bradford, about the year I824, is mentioned by the late Henry Denny in his "Catalogue of Yorkshire Birds" contributed in I840 to the "Annals of Natural History" (Vol. VII.), and is referred to by Allis, as is another taken near Harrogate in 1832.

Patrick Hawkridge of Scarborough communicated to Neville Wood's "Naturalist" ( 1838 , p. I55), a note of the capture of a specimen off Flamborough Head. The bird, after alighting upon the mast of a sloop sailing by, was with difficulty secured, after it had " actually pinned down with its powerful talons the cabin boy, who had been sent aloft to seize it."

The example mentioned by the Rev. F. O. Morris ("Brit. Birds," I85I, Vol. I. p. I84), as shot in the woods at Clifton Castle, near Bedale, in the month of March I845, provedas the result of inquiries made through my obliging correspondent the late James Carter of Masham-to be a bird escaped from Hornby Castle, the residence of the Duke of Leeds. A letter from Mr. Wilie, the Duke's agent, describes the bird as being from the forest at Mar Lodge, N.B.

Mr. C. C. Hanson of Greetland, near Halifax, stated that, on a very dark day in November 1845 , he snapped an old flint 
gun at an Eagle Owl, but the gun missing fire as usual, the Owl stared at him for a moment " with eyes like a leopard," then off it went. Mr. Hanson had approached quite close by the aid of an intervening stack.

Mr. Kenneth McLean has in his possession an example obtained by himself on 5 th November 1875 , on the banks at Hummersea, near Loftus-in-Cleveland (see Nat. I899, p. I38, where the specimen is figured).

In July 1876 , an Eagle Owl was captured on Rombalds Moor, above Ilkley, by two farm servants; it was probably an escape, the bird being quite unable to fly, owing to its plumage being "storm soaked." This bird was kept alive for some time in a small vivarium at Roundhay Park, Leeds, along with two specimens said to have been taken from a nest near Aberdeen!

The next occurrence was at Scarborough, on 3oth October I879, after a very heavy gale from the north-east. The late A. Roberts, who supplied the information, was on his way to the Museum at one o'clock p.m., when he was startled by seeing a very large Eagle Owl flying quite low in one of the back streets, which, on arriving within ten yards of him, rose with difficulty over the cottages and disappeared. The bird was also seen immediately afterwards by Mr. Robert Champley to alight in Lord Londesborough's grounds.

In the winter of $1879-80$, as recorded by the late J. Cordeaux in the Zoologist (I89r, p. 365), one was seen at Easington, near Spurn, where it remained all night in a tree in a cottage garden.

At Fixby, near Huddersfield, Mr. C. C. Hanson announced in the Naturalist (I886, p. II4), that a male was killed on Ist January I885, by Mr. Jos. Firth of Fixby. It measured two feet in extreme length, four feet four inches in expanse of wings, and weighed a little over four pounds. The specimen is now in the possession of Mr. Firth, Shepherd's Rest Inn, Cowcliffe.

With reference to a probable occurrence at Spurn the late J. Cordeaux wrote (op. cit. I889, p. 2) :- "An immense Owl, presumably of this species, said to be the largest ever 
observed at Spurn, was reported in October 1888, both on the sand-hills and in the warren at Kilnsea, either sitting in the bents or in flight. On the wing it was described as looking as big as one of the large gulls, and was said to have tufts of feathers on the head."

\section{MARSH HARRIER. \\ Circus æruginosus $(L$.).}

Casual visitant, of very rare occurrence. Formerly nested in one or two localities.

Under the old name of "Moor Buzzard" the following mention is made of this species in Miller's "History of Doncaster," published in I804:- "This bird is very common in our morasses, moors, etc., and is one of the most voracious of its tribe. It is a well attested fact that nine, nearly full grown, moor game (Tetrix and Rubra) were taken out of a nest one day and eight the next morning."

Thomas Allis, in 1844, wrote as follows:-

Circus rufus.-Marsh Harrier-Sometimes visits the moors near Sheffield; not uncommon near Doncaster. About forty years ago, H. Reid says that seven or eight were obtained in a season from Hatfield Moor and Carr side; rarely met with near Hebden Bridge. Arthur Strickland says that the total destruction of all the large beds of whins in his neighbourhood [Bridlington] has nearly banished this bird, before which it used occasionally to breed there. He says "Mr. Yarrell appears to me to be wrong in stating that the young bird is without the yellow caul on the head; all that I have seen, even from the nest, have had it strongly and distinctly marked, even more so than the old birds, as all the rest of the plumage is a dark brown and much more distinct from the yellow than in older ones; but this is a distinctly migratory species, and, as soon as the breeding season is over, they quit this country and totally lose the yellow on the head and other parts; in this state it is of very rare occurrence in this country; one specimen in my collection, killed some years ago in Cambridgeshire, being the only one I remember ever to have seen, but early in the spring, when they first come over, they may often be met with with the yellow caul only partly developed, which soon becomes perfect, and in old specimens extends over the breast, shoulders, and parts of the back. 
Formerly this bird bred on the "wastes" around Doncaster and in the East Riding, but-compelled to retreat before the steady march of agriculture and the misplaced zeal of the game-preserver-it has long since ceased to do so, and can now only be regarded as an extremely rare visitor to the county.

That it also bred on the moors of Cleveland is evidenced by J. Hogg, who in his "Birds of N.W. Cleveland and S.E. Durham" (Zool. I845, p. I053), remarked of this species :"Gamekeepers on some of our moors hunt this bird with pointers in the spring, for the purpose of finding its nest; having marked the spot, they afterwards shoot the old birds, and destroy their eggs or brood."

At first glance this appears doubtful, and more applicable to the Hen Harrier, but its probability seems to be greater when we remember that the late John Hancock stated that he took a nest and four eggs of this species on the Wemmergill Moors, which are in Yorkshire ("Birds of Northd. and Dm." p. I7), and I am informed by Mr. W. Walton of Middletonin-Teesdale that his grandfather used regularly to shoot Marsh Harriers on the moors on the Yorkshire side of the dale.

The late Alfred Roberts of Scarborough stated (MS.), that he had three eggs of the Marsh Harrier brought to him many years ago that had been taken by a person named Elliot on May Moss, a swampy place on the moors between Scarborough and Whitby; the nest being composed of heather, grass, and rushes.

In 1808 the species was cited by Graves as inhabiting Cleveland ; R. Leyland in 1828 mentioned it in his list of Halifax birds ; in 1844 Allis, in his Report, gave it as sometimes visiting the moors in the West Riding; and near Sheffield it has been reported from time to time.

In October I849, one was killed at Wassand, near Hornsea, by the keeper, in the presence of Sir Wm. Milner, Bart.; recorded by Dr. B. R. Morris in the Zoologist (1850, p. 2649).

One was obtained on Waupley Moors, in east Cleveland, in 1859 .

A fine female is said by Wm. Talbot, in his list of Wakefield 
birds, to have been found in a rabbit trap at Cudworth, near Barnsley, in April r869; this he saw in the flesh.

On I3th October I871, a young male was taken near Beverley, and recorded in the Zoologist (I87I, p. 2847), by Mr. F. Boyes, with the remark that it was "quite a rare and unlooked for occurrence."

Mr. A. Clapham of Scarborough stated that he possesses an almost black specimen, shot at Wassand in February or March 1872 , and that he saw another from the same place, a splendid bird, black with a rufous head.

Mr. A. Young of Blankney informs me he has an example killed at Seamer by his father, the late J. Young, keeper to Lord Londesborough.

In September 1877 one was reported near Pocklington (Nat. I878, p. II2).

An immature male obtained near York in 1875 , is now in the Hull Museum.

Near Barnsley a male, taken early in October 1883 , is recorded in the Field of Ist December for that year.

In 1880 one was trapped at Oakdale, in the Nidd Valley (J. Carter MS.). (This bird was erroneously recorded in the Field, 30th October I880, as a Hen Harrier.)

At Fewston an example was captured in autumn 1889 (W. Storey MS.).

And finally, in the Sheffield "Daily Telegraph" of Igth September I895, one is recorded from Thornsetts Moors, near Bradfield.

Provincial names for this species in the north of England, as mentioned by Swainson, are Marsh or Moor Hawk, and White-headed Harpy. Moor Buzzard was the name in general use, and J. Hogg gave Duck Hawk for the Teesmouth district. 


\section{HEN HARRIER.}

Circus cyaneus (L.).

Bird of passage, of rare occurrence. Formerly bred in the county.

Probably the earliest record for this bird in Yorkshire is in the year 1823, when the late John Hancock took the eggs, four in number, on the Wemmergill Moors.* ("Birds of Northd. and Dm." p. I9.)

Thomas Allis, I844, wrote:-

Circus cyaneus.-Hen Harrier-Not uncommon in the low grounds and carrs near Doncaster; now seldom met with in the East Riding. Rare near Sheffield and Leeds; still breeds, as I am informed by my friends J. and W. Tuke, on Hambleton, and in the neighbourhood of Pickering, and is not infrequently seen scouring the hedgerows in the vicinity of Huddersfield.

This species is now only an occasional visitor to our extensive moors and unenclosed lands; it will be observed that the majority of occurrences have been in autumn or winter, when the birds are migrating southward from their breeding haunts in Scotland or northern Europe, though it has been noted on rare occasions on the return passage in spring.

The Hen Harrier formerly bred annually on the extensive and wide spreading tracts of suitable country to be found in the North and West Ridings, yet it is to be regretted that the ornithological records of our county relating to that period are exceedingly meagre and scarce, the following being all the information I have been able to obtain on the nidification of the species.

As to its formerly nesting in north Yorkshire, see above. In the East Riding J. H. Anderson of Kilham, writing in I833, in Rennie's "Field Naturalist" (January 1834), stated :"The Hen Harrier breeds among our furze brakes, and a few years ago I shot the cock bird on a nest, and found six eggs under him ; I have also had young ones more than once."

P. Hawkridge of Scarborough, writing in Neville Wood's

* Wemmergill Moors are in Yorkshire. 
"Naturalist" ( 1838 , p. I06), under date of 7 th August I837, observed:- "Specimens are repeatedly shot on the moors near Scarborough. They also breed there." In I844 it still bred on Hambleton and in the neighbourhood of Pickering (see Allis's Report, and Nat. 1889, p. 330). Mr. Wm. H. Raw of Lealholm in Cleveland, in speaking of a pair in his possession, says :- "They were shot about thirty years since [about I850] by my father Robert Raw, near Danby Beacon, where they had a nest. I have heard my father say that at that time scarcely a year passed without a breed of these Harriers somewhere on the Danby Moors; but of late years they have been very scarce and rarely seen." These specimens, together with an egg taken from the nest, are now in the possession of Mr. W. Raw of Ruswarp. Mr. R. Standen, late of Goosnargh, near Preston (now of the Manchester Museum), states (MS.), that a nest supposed to have been of this species was found in Langden Fell, on the borders of Lancashire, by a shepherd lad; it contained three bluish-white eggs. The lad described both the nest and the bird pretty plainly. In Mr. J. C. Stevens' sale catalogue of 25th April I906, is a "lot " of four eggs, marked "Hen Harrier, Dentdale, Yorks., 28th April I888." From inquiries I afterwards made of the late owner of the eggs, the date appears to be perfectly reliable.

Writing in 1828 , R. Leyland mentioned it as rare in the Halifax district; and in I840 H. Denny of Leeds described it as rare, mentioning Halifax, Thorp Arch, and Selby as localities in which it had occurred.

In I844 T. Allis reported as to its status on the low grounds and carrs near Doncaster, in the East Riding, near Sheffield, and near Huddersfield.

On I4th August I834, one, now in Admiral Oxley's collection at Ripon, was shot in the High Street at Redcar.

Two fine males were killed near Bridlington in the winter of $1846-47$, as recorded by the Rev. F. O. Morris (Zool. I847, p. 1692$)$.

Mr. W. Walton of Middleton-in-Teesdale, writing in 1903 , says his grandfather used regularly to shoot the "Ringtail," on the moors on the Yorkshire side of the Tees. 
W. M. Morris mentioned in the Naturalist ( 1853, p. 60), one killed near Stockton-on-Tees on Irth October I852.

A pair was obtained at Grinkle in $\mathbf{1 8 6 5}$, and Mr. K. McLean has seen examples nailed up on the walls of keepers' cottages in that neighbourhood.

George Mussell, taxidermist, of Middlesbrough, informs me that he had several specimens sent for preservation from Ugthorpe in the "seventies," by the late Thomas Vaughan.

The late E. Chapman observed (Nat. I886, p. I83), that two females were noted in Wensleydale by Capt. Other; one in 1870 , at Bolton Gill, and the second about the same time in Howdah Wood, Bainbridge.

In the Western Ainsty, Mr. E. R. Waite mentions a specimen picked up dead in a rookery at Thorp Arch, in 1874, and another at Wetherby.

The late T. Lister of Barnsley informed Mr. W. Eagle Clarke that one was taken in December 1875 on the moors beyond Penistone.

On 30 th November 1876 , the late James Varley of Huddersfield saw a female at Hebden Bridge.

An immature specimen was obtained near Filey early in February 1877 , its capture being communicated to the Zoologist (I877, p. I79), by the Rev. J. G. Tuck.

Mr. James Backhouse of York mentions (Friends' "Nat. Hist. Journal," 1877, p. 56), that he saw one near that city about March I2th, and another at Askham Bog on the Igth of the same month, I877.

Mr. R. Standen states (MS.), that one was seen near the Sykes, Bowland, in May 1877 .

The Hull Museum contains a male from Rylston Fell, Skipton, in September I878, and a female killed on the river Hull.

A young male, in rich immature plumage, was captured on the warren at Kilnsea in Holderness on I6th October I879, and was forwarded to Mr. W. Eagle Clarke on the following day.

In addition to the above, Mr. R. Lee of Thirsk remarks that it has been reported at Knapton; and A. Roberts of Scarborough said it sometimes occurs on the moors near that town. Three pairs came under the notice of the late G. Page 
of Guisborough between I 865 and I880, all obtained within ten miles of that town. One, formerly in the possession of Wm. Lister, was procured on Egton Moor by Mr. Bennison. Mr. A. Crabtree, F.L.S., mentions in the "Halifax Naturalist" (I900, p. 86), one at Blackstone Edge in I879.

On I6th November I883, a female was taken on Snilesworth Moor, in the North Riding, and was recorded by Mr. R. Lee, in the Field of the $24^{\text {th }}$ of the same month.

At the latter end of April I887, I examined a female example which had been trapped at Egton Bridge, near Whitby, and sent to Geo. Mussell for preservation.

Mr. W. Eagle Clarke picked up a dead specimen during the Y.N.U. excursion at Hatfield Chase, in September I887.

Near Scarborough, in the autumn of 1888 , one was obtained, and was recorded by Mr. R. P. Harper in the Zoologist (1889, p. I50).

The late J. Cordeaux mentioned in the Naturalist (I892, p.3), one reported as seen by Mr. P. Loten on 22nd November I89I.

An occurrence at Scarborough in 1897 is referred to $\mathrm{Mr}$. J. Morley, in the Field, 8th June Igor.

Mr. Geo. Steels states (MS.), that he has preserved two examples procured near Pocklington, but he did not keep any records of the dates.

This species is known to keepers as the Ringtail, and in Ryedale it was formerly called the Blue Hawk.*

\section{MONTAGU'S HARRIER.}

\section{Circus cineraceus (Montagu).}

Casual visitant, of rare occurrence, during the spring and autumn migrations. Formerly bred in the county.

The first records of this species connected with Yorkshire are given by Thomas Allis in his oft-quoted Report, thus :-

* The record in the Field, 3oth October 1880 , of a female taken in a trap near Lofthouse-in-Nidderdale is, as the late J. Carter informed me (in litt. 1902), an error, the specimen being a Marsh Harrier.

vOL. 1. 
Circus ciheraceus.-Montagu's Harrier-Arthur Strickland has procured this and the foregoing species [Hen Harrier] in all stages from the nest, though now seldom met with. Jno. Heppenstall has a male from Thorne Moor, where it bred ; the nest was placed amongst the long heath (Calluna vulgaris), which grows to a considerable size on the borders of wet places. F. O. Morris reports two pairs being shot near Doncaster in 1835 ; and H. Reid says one was killed, by the late Mr. Brodrick's gamekeeper, about ten years ago, and is now in the possession of the Rev. R. Lucas of Edith Weston. H. Chapman also reports having had the bird, which,is, nevertheless, of rare occurrence.

This species appears formerly to have been more widely distributed in this county than either of its congeners, the Marsh and the Hen Harriers, and it also was the last of the genus to depart from its former haunts. Even yet it may occasionally breed on some of the less frequented moors, as, indeed, I have information of its doing, so recently as the present year, Ig06. The species can now, however, only be regarded as a casual visitor to the county, occurring most probably in the autumn, at which season it is observed in limited numbers as an annual migrant in the eastern counties.

The earliest notices are given in Allis's Report, and it is also reasonable to presume that the bird bred in the carrs near Doncaster, where two pairs were shot in I835.

Mr. John Braim records in Morris's "Naturalist " (I855, p. 2I4), that in July 1854 , a male was shot on the moors near Whitby, the female being seen, and three eggs taken from the nest. One of the eggs and the head of the bird are now in my possession.

Mr. A. Clapham of Scarborough observes that some years ngo-unfortunately he cannot give the year-Mr. Lloyd's keeper brought to him in June a pair of these Harriers in the flesh, along with their two young birds in down, and some addled eggs, obtained as Crosscliffe, Hackness, near Scarborough. The plumage of both the old birds was peculiar, being of a "dull slaty mixed colour." The two sexes were very similar in plumage and size; the female being so diminutive that were it not for the fact that she was procured at the same time as her mate and the young, she might have been mistaken for a male bird. 
I am indebted to Mr. E. P. Butterfield of Wilsden for information relating to a pair of Montagu's Harriers and their young, now in the possession of Mr. Dalton, which were obtained from a nest on Barden Moor, in Wharfedale, on 12th July 1860. The nest was placed somewhere on the site now occupied by the reservoir of the Bradford Corporation (see also Nat. I905, pp. 60-87).

Mr. J. H. Gurney reported, on the authority of Mr. Jones of Bridlington Quay, that a pair and their nestling young were captured near Bridlington in the year $187 \mathrm{I}$.

The nesting of this species at Stockton-on-the-Forest, near York, is announced in the Zoologist (I880, pp. 362, 445, 512). A bird, supposed to be a Montagu's Harrier, was flushed from some cover, where a nest containing one egg was found; the egg was compared with others and pronounced to be that of $C$. cineraceus.

The most recent instance of its attempting to breed in Yorkshire occurred in the present year (I906), when a nest with two eggs was discovered on a moor in the extreme south of the county; the female bird being, unfortunately, captured at the nest.

As a casual visitant and autumn migrant, I have been able to obtain very little information of its occurrence, the following being all that has been placed on record or communicated to me :-

J. Grey recorded in the Zoologist (1845, p. I054), a pair near Guisborough in I845, which passed into the collection of Mr. C. Newby of Stockton-on-Tees.

An adult male, in the collection of Mr. A. Clapham of Scarborough, was killed in a quarry near Garforth at Christmas I846; and he has had sent him several specimens by the gamekeeper at Skipwith Manor, near York.

One at Escrick, about the I5th October 1849, was recorded in the Zoologist (1850, p. 2649), by Dr. Morris.

A fine old male was taken near Brompton, Northallerton, in the year 1856 (op. cit. 1856, p. $525 \mathrm{r}$ ).

On Igth June 1867 , an adult female was obtained on Kilnsea Warren, by John Clubley, and preserved by Mr. 
Richardson of Beverley. Mr. F. Boyes examined this specimen, and observed that the appearance of the breast feathers seemed to imply that it had been sitting.

About the same year, one, procured at Littlebeck, was stuffed by Mr. Kitching of Whitby.

One, formerly in the possession of the late George Brook, was captured in Rash Gill, near the head of Swaledale, in the spring of 1870 .

In the Burton Agnes Museum, formed by the late Sir Hy. Boynton, is a specimen taken at Sunderlandwick, but the date is not given.

The late J. Cordeaux mentioned in his "Birds of the Humber District" that "Two immature females in Mr. Boulton's collection were killed of late years in Holderness."

On I4th May 1875, one was noted at Acaster Malbis, near York, and recorded in the Naturalist (1875, p. 80).

The late A. Roberts of Scarborough preserved a fine male, trapped on Seamer Moor in April I880, which is now in the possession of Mr. A. Young, keeper, of Blankney.

Mr. S. L. Mosley of Huddersfield informs me a young male was killed near Meltham, about I882.

A male was seen by the late J. Harrison at Wilstrop, on 3rd June I886, as recorded by Mr. E. R. Waite (op. cit. I89I, p. 98).

Mr. M. Bailey of Flamborough had a female specimen, obtained near that place, in the late autumn of 1896 . The outer web of the fifth primary was not notched, and the inner and outer notches on the first and second primaries were one inch below the coverts (op. cit. 1897, p. 237).

At Bickley, near Scarborough, a male was caught in a pole-trap on 26th April rgor, and is now in the possession of Mr. R. Fortune of Harrogate, who kindly supplied the particulars of its capture, and gave me an opportunity of examining the specimen.

The latest winter occurrence of which I am aware was at Mulgrave, near Whitby, in October 1902, and was inadvertently recorded (op. cit. I903, p. 29), as a "Black Kite." Through the courtesy of Mr. Thomas Stephenson 
and Mr. J. H. Wilson of Whitby, the specimen was submitted for examination to Mr. W. Eagle Clarke and myself, and proved to be a melanic male example of Montagu's Harrier. It is now in the possession of the Marquis of Normanby at Mulgrave Castle.

\section{COMMON BUZZARD.}

Buteo vulgaris (Leach.).

Resident; but confined to one or perhaps two pairs; also an irregular spring and autumn migrant.

The earliest reference to this bird in Yorkshire appears to have been made by Chas. Waterton of Walton Hall, the accomplished and celebrated ornithologist, who, writing in "Loudon's Magazine" (August I835, VIII. p. 453), stated :"In I8I3 I had my last sight of the Buzzard."

Thomas Allis, 1844, wrote:-

Buteo vulgaris.-Common Buzzard-Met with occasionally in most parts of the county; frequently near Doncaster, Huddersfield, and Sheffield.

This species, formerly one of the most abundant of the larger British birds, is now exceedingly rare, having gradually become scarcer since the gun came into general use.

About the year I850 it bred at Bishop's Wood, near Selby, three pairs frequenting the wood annually. This information was given by the late keeper, Mr. Wm. Harland, who used to procure the young birds when a boy. At about the same time it was abundant among the fells of Upper Wharfedale, where the young and eggs were by no means rare. It has nested near the summit of Great Whernside, from whence its eggs have been procured; and in 1863 two young birds were obtained from a nest in the vicinity of Kilnsey in the same valley. The late $\mathrm{J}$. Tennant, in a MS. list supplied in the year I880, remarked that he had seen a Buzzard's egg taken at Hebden Bridge, and, further, that the late J. Harrison of Wilstrop knew of four nests at Merton Farm in one year. 
Mr. E. R. Waite, in the Naturalist (r89r, p. 98 ), states that Mr. F. G. Binnie of Edinburgh University wrote :- "I find in my diary 27 th February 1868 , the following note: $\mathrm{Mr}$. Simpson, bird-stuffer, York, told me that some years since he had bought from some boys at Tadcaster a pair of young Hawks, which, on rearing, turned out to be of this species. The old birds had been seen several times afterwards." From this it seems probable the Buzzard has bred in the district.

Mr. H. Smurthwaite, writing in Morris's "Naturalist" (1853, p. I08), recorded its breeding near Sedbergh in the summer of 1852 ; and the same gentleman in the same journal mentions its nesting in Red Crag, Richmond, where five young were reared, a most unusual number, for, so far as my experience goes, two to three is the most frequent number of eggs, but I have known of a clutch of four taken in Westmorland in the spring of 1900 .

There is authentic evidence of a pair or two nesting in the unfrequented mountainous districts of north-west Yorkshire in 1878 , when the eggs were taken and the old birds shot at, in the belief that they were Golden Eagles, but I am not at liberty to mention the exact locality, as these birds continue to maintain a precarious existence in their fastnesses, where they are able to pass undetected and undisturbed, and, so recently as the year 1906 , succeeded in bringing off young ones. The late James Varley observed a pair flying in circles over Gordale Scar on 6th May I877; Mr. F. S. Mitchell, late of Clitheroe, states that it is noted almost every year on the Fells near Slaidburn, although he has never heard of its breeding ; and Captain Wade Dalton of Hauxwell Hall, near Bedale, remarks that it occurs in the winter on the moors but is by no means common. No doubt at this season it descends from the higher and more exposed fells lying to the westward.

Mr. J. E. Tinkler writes in the Naturalist (1892, p. 3I9), that up to 1870 it bred on Buzzard Scar in Swinnergill. Both Buzzards and Ravens used to breed in Swaledale, and fierce contests took place for possession of the nesting sites. It possibly nested in Arkengarthdale up to I850, and has been obtained in several localities in the high reaches of these dales, 


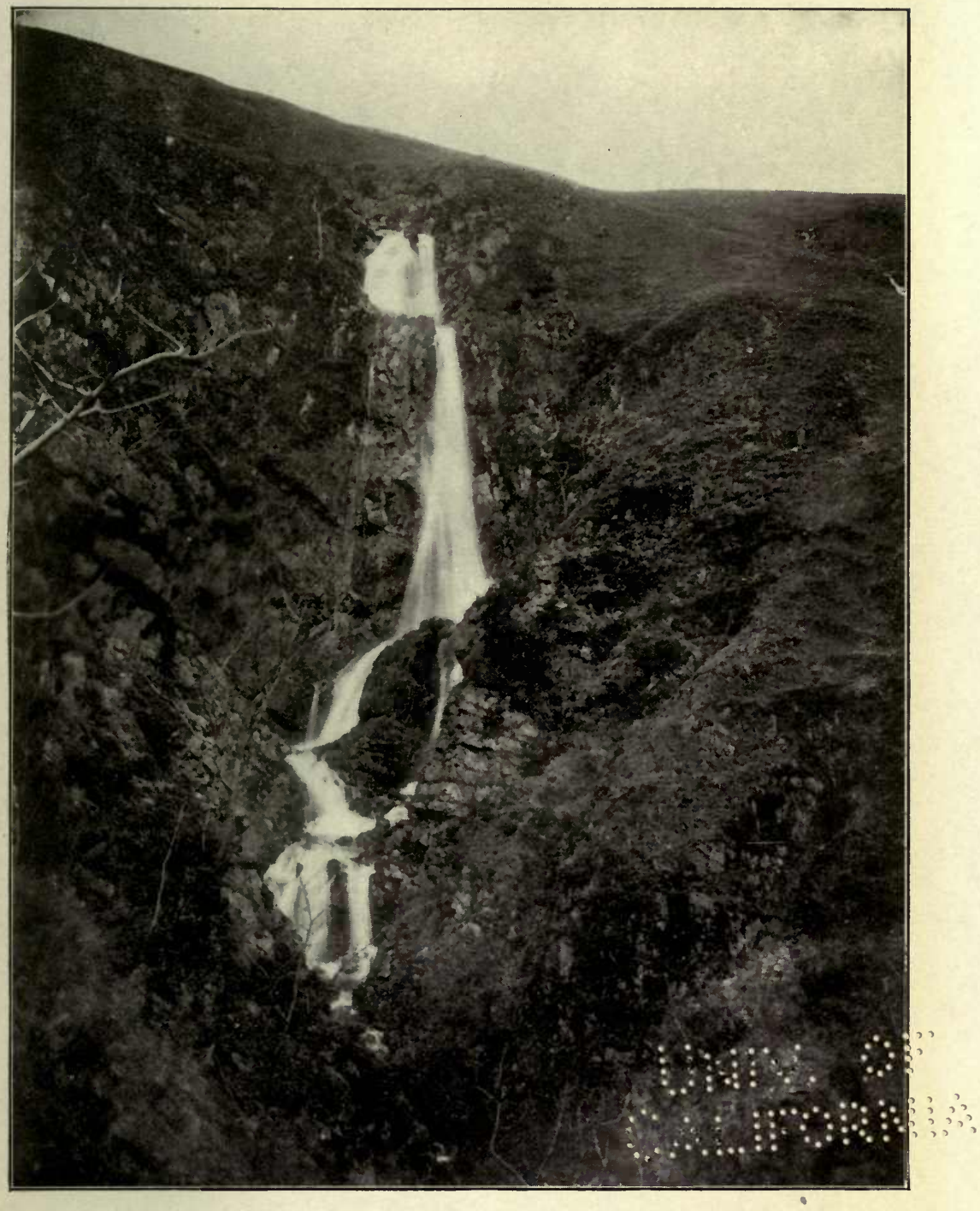

Ancient nesting place of Buzzard, in north-west $\mathbf{Y}$ orkshire.

R. Fortune.

See page 326. 
$\because 6 \quad \because 6$

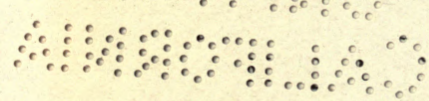


at Ellerton, Scollit, and Keld, and a pair were seen at Moss Farm, Muker, in 1898 . As the bird still nests over the Westmorland border it is not improbable that these individuals may have strayed from their breeding quarters. The late James Carter (MS. I902), stated that he had heard of them nesting on Ash Head Moor, near Masham, "several years ago"; and he had a specimen which was captured in that locality.

In Wensleydale, according to the late E. Chapman, the Common Buzzard did not belie its name about forty years ago, but it is now very rarely seen (MS. I886). It also occurs in Teesdale, though very seldom, and it appears to have ceased to nest in that district.

This fine bird formerly bred in Cleveland, on the high ridge between Waupley and Danby, and it also used to nest in Douthwaite Dale, near Whitby. It is still occasionally obtained in these districts, noticeably in the Grinkle and Mulgrave Woods, where specimens were trapped in 1886 , I887, and I895; as also at Ingleby-in-Cleveland, the latest record at that place being in 1887 , when an adult female was captured.

As a partial migrant the Buzzard is most frequently met with in the autumn, it is occasionally noted in spring, and although it has been frequently observed, especially near the coast, it is far from regular in its occurrence, more particularly during the last few years. Near Beverley it is stated to be now more rare than its congener the Rough-legged Buzzard, and this really appears to be the case. The communicated and recorded instances of its occurrence have, however, become too voluminous for particularization; suffice it to say that it has been noted in most parts of the county during the autumn and winter.

Mr. W. Walton of Middleton-in-Teesdale informs me that his grandfather kept a pet "Buzzard Hawk," and, cockfighting being then in vogue, he pitted it against gamecocks, when it came off victorious. He also remarks it had a very peculiar method of attacking its foe. The late J. Harrison of Wilstrop reported in the Field (29th May r886), 
an interesting instance of a Buzzard in his aviary nesting and laying two eggs.

This bird is now too rare to be known by any vernacular names, though in former days, when it was abundant, it was sometimes confounded with the Kite, and known by that name, as also Glead or Gled.

\section{ROUGH-LEGGED BUZZARD.}

Buteo lagopus (Gmelin).

Winter visitant, occurring occasionally in varying numbers, and chiefly near the coast. Rarely observed on the spring migration.

Apparently the earliest reference to this species in Yorkshire is contained in Thomas Allis's Report, I844:-

Buteo lagopus.-Rough-legged Buzzard-My friend John Heppenstall says that many were seen and obtained near Sheffield in the winter of $1839-40$; with this exception it appears to be a rare bird. H. Chapman informs me he has had it ; besides which, the recorded specimens are by Henry Denny, shot at Garforth in 1833 ; two by $\mathbf{A}$. Strickland who says that one of these came into his possession a few years ago ; it had been noticed on the Wolds for some time, and had the appearance and habit of an Owl upon the wing, and, from its low flights and small feet, he has no doubt but its principal food will be found to be insects; I differ from him in opinion on this head, as in 1839 my friend H. Doubleday sent me a live bird which was one out of more than fifty which had been trapped on a rabbit warren; this took animal food just like vulgaris. Dr. Farrar reports two taken in 1840 , one of them being shot at Clayton Heights, the other trapped at Hawksworth Hall; H. Reid reports one shot at Bilham, now possessed by the Rev. G. Wright. W. Eddison says it is scarce near Huddersfield, and $H$. Denny mentions it as being frequently met with at Black Hill, when a rabbit warren.

This bird occurs almost annually in Yorkshire as an autumn migrant, usually in the month of $\lambda$ ntober, and varies very considerably in its numbers; some years being very scarce or unnoticed, whilst in others great flights visit us; the first great migration of which mention is made took place in the winter of $1839-40$; others at intervals occurred 
until $1876-77$, again in $1879,1881,1892$, and the most recent in the autumn of 1903 , affording the most marked evidence of these irregular and inexplicable occurrences. That in I903 was observed along the north-east coast from Holy Island to Spurn, the first arrivals taking place on the Ioth of October, when I saw one which had been killed at Flamborough; and the latest reported example was seen on Swainby Moor in the middle of April following. So far as I have been able to ascertain they occurred at the following places:-

Flamborough, Ioth October, two seen, one of which was captured.

Bempton, same date, two seen in the neighbourhood, where they remained for several days.

Spurn promontory, same date, two occurred near Kilnsea, and several others noticed daily for a week or more afterwards, at various localities between Patrington and Spurn, where their appearance was a common topic of conversation amongst the inhabitants of the farms and villages.

Hull, about the end of October, one, taken near the borough.

Seamer Moors, near Scarborough, between the I3th October and the 7 th November, no fewer than twenty were reported, ten of which were trapped.

Whitby, I2th October, one, washed up on the beach.

Grosmont, I4th October, two seen, one being obtained.

Glaisdale, same date, seven observed.

Loftus-in-Cleveland, end of October, four seen on an adjacent moor; one was trapped and, through the courtesy of Mr. Claude Pease, it came into my possession.

Teesmouth, Ioth October, one seen.

Swainby, I6th November, two seen on the moor; one in April I904.

Bransdale, $27^{\text {th }}$ November, one caught, six or seven others seen.

Farndale Head, middle of October, one seen; Ist November, one trapped; another killed on I8th January I904, and a third on $15^{\text {th }}$ March. One seen in April, and others reported in the district. 
Boltby, near Thirsk, February 1904, three trapped.

Gatherly Moor, near Richmond, one caught alive in November.

Swaledale, one in November.

Wharfedale, November, several seen in various places; it was calculated that nine at least were observed, besides four others which were captured.

An examination of several specimens obtained during I876-77, and many of those killed in $1903-4$, resulted in the discovery that, with one exception in each case, they were all in immature plumage and light tawny-coloured birds with the upper parts mottled with lightish brown, whilst the breast, belly, and thighs were striped longitudinally with the same tint; the irides were pale straw colour. The exceptional bird was of a generally uniform dark brown colour.

On going through the numerous instances of winter occurrence in this county, I can only find mention made of two mature birds; one of these was taken at Patrington in January I877, and described as an old male. On 25th May 1877, I found on the sands at Redcar the remains of a Rough-legged Buzzard, which had apparently died while crossing the sea and had been washed ashore. This is the only instance of late spring migration which has come under my notice. The occurrence of this species in mature plumage in the British Isles is of the greatest rarity.

Its former breeding on the ground at Hackness, near Scarborough (A. G. More, Ibis, I865), is no longer regarded as worthy of consideration.

During the autumn, winter, and spring this species has occurred at one time or another in all parts of the county, being especially numerous in the vicinity of the coast. As the recorded and communicated instances are so very numerous, and the bird is regarded as an annual visitant, an enumeration of the localities is quite unnecessary.

Although in cultivated or low-lying country the Roughlegged Buzzard feeds largely on rats, voles, and such "small deer," it cannot be acquitted of the offence of killing game, and when opportunity offers it is an inveterate poacher; 
many of those which visited Yorkshire in the autumn and winter of rgo3-4 took up their abode on the moorlands, and on Seamer Moor they were observed quartering the ground and hovering like Kestrels; two that were captured had remains of voles and rabbits in their crops, but on some of the Cleveland Moors individuals were detected whilst in the act of killing and devouring Grouse. My taxidermist tells me that in the crop of a Buzzard which he preserved he found a quantity of flesh and feathers of this game-bird; others have been seem to capture and carry away game; in Farndale one was shot while killing a Grouse ; on Swainby Moor another was killed as it rose from its quarry, that proved to be a freshly killed and warm hen Grouse; yet another has been seen to carry off an old Grouse and clear every particle of flesh off its bones at one meal, whilst one bold robber ventured into the vicinity of a keeper's house on the edge of the moors, where it raided the domesticated pigeons.

\section{GOLDEN EAGLE.}

\section{Aquila chrysaëtus (L.).}

Casual visitant, of very rare occurrence.

The first mention of the Golden Eagle as connected with Yorkshire is in Dodsley's "Annual Register," I804, where it is stated that a bird of the Eagle kind was shot on 29th November 1804, at Stockfield [Stockeld (?)] Park, near Wetherby, by Mr. Cummins, gamekeeper to the Countess of Aberdeen, in the grounds near the house, and was secured alive. This specimen is also mentioned under the heading of Golden Eagle in the late Henry Denny's catalogue of the animals occurring near Leeds, published in 1840 .

Thomas Allis, in $\mathrm{r} 844$, wrote :-

Aquila chrysatus.-Golden Eagle-Arthur Strickland reports that one has been killed in the East Riding, and one specimen in the North Riding : it was shot near the Tees on 5 th November 1833 , by T. L. Rudd, Esq.. of Marston [Marton]-in-Cleveland: it weighed 12 $1 \mathrm{bs}$. 
its length was $3 \mathrm{ft}$. 4 ins.; expanse of wing $7 \mathrm{ft}$. 5 ins. : bill 3 ins. See Hogg's "Nat. Hist. of Stockton-on-Tees." [The following note is inserted in the opposite sheet of Allis's Report, and the paragraph referred to above is crossed out.]

The bird reported as the Golden Eagle in the "Natural History of Stockton-on-Tees," proved to be abicilla; there are, I believe, therefore, only two recorded Yorkshire specimens; the one reported by Arthur Strickland, and a subsequent specimen, shot by Admira Mitford's gamekeeper, and which is in the Scarborough Museum.-T.A.

The instances of the visits of this noble species, which is an inhabitant of the Scottish Highlands, to any part of England being extremely rare, as evidenced by its absence from most county lists, Yorkshire would seem to have been favoured by them to an unusual degree, no fewer than seven instances of its occurrence within the limits of the county being recorded; chiefly during the winter months.

From the fact that the White-tailed Eagle in the dark plumage of immaturity has been so frequently confounded with the present species, the most careful enquiries have been made as to the identification of the following, and many other supposed occurrences which were communicated.

The first Yorkshire instance is that referred to (above) in 1804. Efforts have been made to trace this specimen, but the authority is so good that there appears to be no reason for doubt.

The York "Courant" for January 1838 contained an account of an Eagle which was trapped during that month at Beningborough, near that city, in which neighbourhood it committed numerous depredations for a week before its capture. The expanse of wing in this specimen was given as 7 feet ro inches. Neville Wood, noticing the occurrence in his "Naturalist" ( 1838 , iii. p. 214 ), presumed from the dimensions given that the specimen was referable to this species.

One in the first year's plumage was taken at Hunmanby on 24th July 1844, on the estate of Admiral Mitford, who presented it to the Scarborough Museum. This information was communicated by the late Alfred Roberts, and is also mentioned by Allis. 
One instance of its occurrence in the East Riding was reported by Arthur Strickland to Thomas Allis, and is included in his Report at the head of this chapter.

Captain Edward H. Turton of Upsall Castle, Thirsk, states (MS.) that a specimen in his museum was obtained about Christmas I851, on Court Moor, Kildale, near Stokesley, in the North Riding, by his father's keeper.

A beautiful young female, in the first year's plumage, was captured in December I86I, at Skerne, near Driffield, in the East Riding, when in the act of eating a hare, by a man called Kemp, gamekeeper to Mr. A. Bannister. It was skinned and set up by Alfred Roberts of Scarborough, who said it weighed $8 \mathrm{lbs}$. 5ozs. This bird is now in the fine collection of the Norwich Museum, to which it was presented by Mr. Francis Hoare, formerly of Tranby Park, near Hull, to whom, the late W. W. Boulton and Mr. J. H. Gurney, I am indebted for the particulars.

In the winter of $1850-5 \mathrm{I}$, one was shot at, and wounded in one wing, by Mr. Tom Fewster at Helwath, Harwood Dale, about ten miles from Scarborough. It was captured alive, little the worse, and taken to Sir John Johnstone of Hackness Hall, who presented it to Squire Hill of Thornton. The bird recovered the use of its wing and lived in captivity until I864; when captured it was evidently immature, having black bars at the end of its tail and white at the base; the tail gradually darkened in colour, only becoming uniformly black in its last year. The specimen was preserved by Graham of York, and is now in the collection of Mr. Hill of Thornton, the son of its original owner (Prodham, Nat. 1887, p. 84). This is the example described by Mr. W. Eagle Clarke (" Birds of Yorkshire," Trans. Y.N.U.), as shot at Thornton in I864.

The latest Yorkshire Golden Eagle is an immature male bird killed at Kettlewell, near Starbotton, on the upper reaches of the Wharfe, on I7th November I902, by Mr. J. W. Mallinson, river-watcher, who informs me (in litt.), that, while in pursuance of his duties, his attention was attracted by a noise in a tree, afterwards found to have been caused by the Eagle knocking a steel rabbit trap, that was fastened to its 
left foot, against a branch while preparing for flight as its enemy, man, approached. The bird flew about two hundred yards and then settled on the ground, when Mr. Mallinson killed it with a stick. It proved to be in poor condition owing, doubtless, to the encumbrance of the trap, and is supposed to have been in the neighbourhood for some time, as the farmers had complained of trapped rabbits being torn to pieces in the snares. The dimensions of the specimen were: total length 3 feet $I$ inch, expanse of wings 8 feet $2 \frac{1}{2}$ inches, weight $9 \frac{1}{4}$ lbs. Mr. R. Butterfield of Wilsden supplied me with further particulars to the effect that the basal two-thirds of the tail is white, and the acuminated tips of the feathers in the cervical parts appear to indicate the tawny colour of the adult. The gizzard contained some hare's fur and sheep's wool. The specimen, which is supposed to be a third year's bird, was preserved by Mr. G. Widdas of Bradford, and is in the possession of its captor.

\section{WHITE-TAILE J EAGLE.}

Haliaëtus albicilla $(L$.).

Casual visitant, of rare occurrence, chiefly in winter, and near the coast, but not confined to that district.

The earliest published reference to this bird in Yorkshire is contained in the Tunstall MS. (I784), where it is stated, under the heading of "Cinereous Eagle," to have been " not unfrequently shot in Yorkshire," though as Tunstall did not himself see the specimens he could not determine the species. (Fox's "Synopsis," p. 47.)

Thomas Allis, in 1844, wrote :-

Haliatus albicilla.-White-tailed Eagle-Several specimens have been killed in the North and East Ridings. I have notice of only one in the West Riding, shot at Okeley, and which went into the possession of Mr. John Childers.

The White-tailed or Sea Eagle is but a very occasional 
visitor, occurring chiefly in the autumn and winter, on its passage southward from northern latitudes. Although most frequent on the coast, yet it is by no means confined to it, and visits our large inland woods and waters, where its size soon attracts the attention of the gamekeeper, to whose gun or snare it usually falls a victim. In Yorkshire, as in Norfolk, Durham, and Northumberland (" Birds of Northd. and Dm." 1874), the majority of specimens that have occurred are in immature plumage. Stevenson in his "Birds of Norfolk" attributed this to the well-known habit of the old birds of most of the Falconidæ of driving away their young from the nesting places as soon as they are able to provide for themselves. A specimen, formerly in the collection of Mr. A. Clapham of Scarborough, and now in the Leeds Museum, is interesting, inasmuch as only two or three feathers of the tail show black tips, having only these to cast to attain to maturity of plumage. This bird was taken at Castle Howard in the year $184 \mathrm{I}$.

In Graves's " History of Cleveland" one is mentioned as having been shot in December 1807 , at Staingate, near Danby Lodge, and is possibly the one referred to in the next paragraph.

Mr. Thomas Stephenson of Whitby obtained information of one killed in Stonegate Ghyll many years ago by a man named Pringles, whilst poaching by moonlight. This was formerly in the possession of the late G. Page of Guisborough, and was sold at the dispersal of his collection.

Mr. A. Woodruffe-Peacock announced (Nat. I895, p. 332), the discovery of a record of this species, obtained near Hessle between 1810 and $18 \mathrm{r} 8$, and which had been noted in an old copy of Bewick's "British Birds," formerly in the possession of Mr. Michael Woodcock, surgeon, of Hemsworth.

One was reported off the mouth of the Tees on 5 th November I823 (Zool. I845, p. I05I).

Admiral C. C. Oxley of Ripon has in his collection an individual, taken near Marske-by-the-Sea church in October 1836. This is the bird recorded by John Grey as a Golden Eagle, (tom. cit. p. I05I). 
The late Patrick Hawkridge recorded in Neville Wood's "Naturalist" (I837, p. 324), one at Haverah Park, which was presented to the Scarborough Museum by Sir W. A. Ingilby of Ripley Castle.

A specimen at Okeley is mentioned in Thomas Allis's Report, I844.

Mr. James Backhouse, writing in I880, states that an Eagle, probably of this species, was trapped at Cronkley Scar, Upper Teesdale, in 1844, by C. Dowson, whose son described the specimen.

Sterland in his "Birds of Sherwood Forest" mentioned an immature bird which was shot at Laughton-en-le-Morthen on I3th January I857, after a fortnight's sojourn in the neighbourhood.

An example was reported on the Cleveland coast between Skinningrove and Cattersty by G. Allison, in the year I860, as I am informed by Mr. Kenneth McLean.

In October I863 one was secured at Speeton Cliffs by Thomas Leng, after several unsuccessful attempts. It was preserved by Mr. Matthew Bailey of Flamborough, who has kindly given me this information, and further states that the bird measured thirty-nine inches from the tip of the bill to the end of the tail, and 7 feet 6 inches in expanse of wing. This bird passed into the collection of Captain Crowe of Speeton. Not very long before this (January I86I), Leng procured another, which is now in the possession of $\mathrm{Mr}$. M. Bailey. In both instances the age is given by $\mathrm{Mr}$. Bailey as about three years. The examples mentioned by Cordeaux ("Birds of Humber District," p. 2), are referable to these specimens, there being an error of date in Cordeaux's record.

The late Alfred Roberts of Scarborough stated (MS.), that one was obtained at Wykeham in I864; and another on Seamer Moor, which, when observed, was mobbed by hundreds of Rooks.

A fine male, trapped at Long Pain, Bedale Wood, near Scarborough, on I7th January I865, and sent to D. Graham of York, to stuff, by Lady Downe, was exhibited at a meeting 
of the Yorkshire Naturalists' Club. Graham remarked that it had been noticed in the neighbourhood for several winters. This information is, however, too vague to warrant any opinion as to the maturity or immaturity of the bird.

One in the Duke of Devonshire's possession at Chatsworth was killed by a keeper in the Forest Moors near Bolton Abbey, about the year 1871. It was unable to rise at the time, being gorged while feeding on the carcase of a sheep, and the keeper tried to capture it alive, but the bird fought so hard that he was compelled to kill it with his stick.

Mr. P. W. Loten of Easington informs me that in October I876 a White-tailed Eagle frequented Kilnsea, near Spurn, for some weeks, during which period it was often observed.

The late J. Cordeaux, writing in the Naturalist (I890, p. Io), recorded the occurrence of two, one of which, an immature female, measuring eight feet in extent of wings, was killed on 28 th October I889, by Mr. G. E. Clubley, with a charge of No. 8 shot in the head, while skimming over the bents at Spurn. (See also Zool. I8gI, p. 365.) At Scalby, near Scarborough, Mr. W. J. Clarke recorded (tom. cit. I891, p. 470), the capture of an immature specimen on 7 th November $189 \mathrm{r}$, a second bird being seen on the two following days.

In the Field of 7 th January I893, Mr. Stuart of Beverley described a bird, captured at Leven on the and of the same month, which was brought to him to preserve. It measured 6 feet ro $\frac{3}{4}$ inches in expanse of wings, and weighed $10 \frac{1}{2} \mathrm{fbs}$. Mr. F. Boyes, who examined the specimen, expresses the opinion that it was an adult.

In the same year a male example was taken to $\mathrm{Mr}$. T. Machen of Bridlington, who informed me that he also had an adult female, taken at Boynton, on Sir C. Strickland's estate; on 8th February I897, which may have been the individual reported by Mr. M. Bailey (Nat. I897, p. 80), as having been observed for some days in the vicinity of Flamborough.

An immature individual was killed on 8th December 1898 , at South Kirkby, near Burntwood Hall, Barnsley, and is now in the possession of Mr. J. Dymond of Burntwood Hall (Dymond, in litt. 1905).

vol. 1 . 
At various times and in different parts of the county, "Eagles" are announced to have been seen, though it is difficult to distinguish the species of the larger raptores without close examination. In the winter of 1876 no fewer than six large birds, described to me by the observer (who had a Golden Eagle in confinement) as "Sea-Eagles," came from seaward, in stormy weather, and flew over the Tees Breakwater towards the north side of the estuary. In 1886 , as I am informed by Dr. Snowdon of Hutton Rudby, an immense Eagle flew within a dozen feet as he was driving on his professional rounds near Crathorne-in-Cleveland; the tawny colour was distinctly visible. Another was seen on the moor at Scarth Nick, near Swainby, in I895. A fine adult, with white tail, was observed by Mr. G. E. Clubley, on 23rd January I8gr, on a block of ice, on the coast near Kilnsea, where he attempted to stalk it, as related in the Field of I4th February in that year. In the autumn of I89r Mr. M. Bailey of Flamborough noticed two Eagles, presumably of this species: and on 2nd May 1892 an example was seen at Easington by Mr. Pye. In the Field of 23rd April r892, Mr. R. Lee of Thirsk describes two individuals seen near that place on the I2th of the same month. And at Lowthorpe, in I899, Mr. W. H. St. Quintin saw an Eagle, flying close to the ground pursued by Rooks, and which passed within a hundred yards of a shooting party. Another example was seen on Swainby Moor, in February I904, by T. Whitwell, Mr. Emerson's keeper, who described it as being "twice as large as a Buzzard." As remarked above, these birds may have been Sea Eagles, but without further particulars it is impossible to name the species with accuracy. 


\section{GOSHAWK.}

\section{Astur palumbarius $(L$.).}

Casual visitant, in spring and autumn, of rare occurrence. Has been observed occasionally in winter, and is most frequent near the coast.

The earliest mention of the Goshawk in Yorkshire appears to be in Thomas Allis's Report, written in I844, thus :-

Astur palumharius.-Goshawk-The only Yorkshire specimen on record was shot at Cusworth by Mr. Wrightson's gamekeeper, in 1825 .

This fine Hawk, formerly one of the falconer's first favourites, has occurred at intervals in the county, generally in the vicinity of the coast, when on the spring and autumn passage. There are, however, instances on record of its being obtained in January and in June.

One, in the year 1825, at Cusworth, near Doncaster, as mentioned above.

Near Easington in Holderness, a male and female were killed on $I_{5}$ th October 1852 , by G. S. Gibbs, gamekeeper to Mr. H. Kirk of Stockton-on-Tees, as mentioned in Morris's "Naturalist" (I853, p. I9), by D. Graham of York.

At the meeting of the Yorkshire Naturalists' Club on and March I864, D. Graham exhibited a fine specimen taken near Oswaldkirk by Mr. J. Bower.

Mr. R. Lorrimer obtained a fine specimen whilst in pursuit of its prey on Filey Brigg in the first week October I864; the fact being communicated to the Sheffield "Daily Telegraph" (8th October I864), by Colonel Newman, mention being also made of it in the Zoologist (1864, p. 9327).

On 29th August 1875, one was reported at Ewecote, near Whitby, of which a note was included in the Rural Notes communicated to the "Yorkshire Post" (I4th March I876), by Geo. Roberts of Lofthouse.

About the year I877 a Goshawk was captured at Ewecote, near Whitby, by Mr. T. Crosby, for whom it was stuffed by Mr. Kitching of that town. Possibly these last two records relate to the same example. 
One in the possession of Admiral Oxley of Ripon is said to have been obtained in that neighbourhood, but no details are forthcoming as to the date of its occurrence, nor of that of a specimen stated by Mr. Thomas Bunker (MS.), to have been caught by the keeper at Ousefleet Grange.

Mr. Matthew Bailey of Flamborough has supplied the particulars of a specimen obtained near Flamborough; from this communication the following account is condensed:The bird, a fine old female, had frequented the neighbourhood for some weeks, baffling all attempts made to shoot it, until 23rd January 1877 , when it was observed by the gamekeeper of the Rev. Lloyd Greame, of Sewerby Hall, to kill a full-grown rabbit, which it had carried about twenty yards when he shot at but missed it. Concealing himself in an adjoining wood the keeper had not long to wait, as the bird soon returned and was killed. This bird, Mr. Bailey informs me, is now in the collection of Sir Vauncey Crewe, Bart.

In the collection of Mr. A. Clapham of Scarborough are four Yorkshire specimens, and I am indebted to the owner for the following information relating to them:-An adult female, brought to him in the flesh in the spring of I85-, which had been taken by Lady Downe's keeper at Wykeham. A young male in singular "cuckoo" plumage, trapped on the Lockton Moors, near Pickering, in June I864 (mistaken for an Iceland Falcon, Zool. I864, p. 9244). A mature female, obtained through D. Graham of York, in Mowbraydale above Malton; Mr. Clapham has unfortunately misplaced the memorandum of the date. An adult female trapped on a rabbit warren near Harrogate on 15 th April I87I.

In addition to these, Mr. Clapham has examined four or five others obtained in the neighbourhood of Scarborough, and remarks that, with one or two exceptions, these passed through the hands of the late A. Roberts, who stated that he had preserved, since the year I864, no fewer than five birds of this species, obtained principally from Seamer and Wykeham. Mr. A. Young, keeper, Blankney, formerly of Seamer, informs me (in litt. February 1904), that two of these specimens are in his possession. 
A specimen in the collection of Mr. Forster of Bridlington was, I am informed by that gentleman, procured in the West Riding, and purchased at the Rev. C. Hudson's sale, Marton Hall, East Riding.

Mr. E. R. Waite states (Nat. I89I, p. 99), that the late John Harrison saw a Goshawk at Wilstrop in I880; the bird was on the ground so near to him that he had no difficulty in recognising it.

About the year 1886 a single occurrence at Dee Side, in Dentdale, is mentioned by the Rev. Ed. Peake (op. cit. 1896, p. 42).

An adult male example was trapped by one of the keepers at Keldy Castle, near Levisham, on I4th February I889, and was recorded by Mr. Thos. Stephenson of Whitby (op. cit. 1889, p. 78 ).

The late J. Cordeaux stated ("Birds of the Humber District," I899, p. I8), that a pair were reported at Easington, near Spurn, by the late H. B. Hewetson, on 27th September I 896 .

I am informed, by Mr. W. Hewett of York, that a specimen, which had been captured at Escrick, in the winter of $1896-97$, was preserved by Mr. J. Pulleine of Selby.

And lastly, as Mr. Thos. Stephenson writes, an immature male of this species occurred at Wheeldale, near Whitby, in December 1897 , and is now in the possession of Mr. J. C. Walker of that town.

An instance is recorded of the Goshawk nesting in Yorkshire, but the authentication is so slender that no reliance can be placed on it. This appeared in the Zoologist (1863, p. 8678 ), the recorder being J. Ranson of Linton-on-Ouse, near York, and was as follows:- "This spring the nest of this rare bird was found in some ivy which surrounds an old oak tree which is situate in the boundary hedge of a plantation. I did not see the nest, but the three eggs were of a very pale blue. They were unfortunately broken by one of the possessor's children."

A second occurrence, however, is entitled to more consideration, the evidence connected with it, as communicated 
to the Zoologist (1899, p. 28), and later, in correspondence, by Mr. T. Southwell of Norwich, being satisfactory as regards the identification of the bird and eggs. The recorder writes:An adult female Goshawk was shot at the nest a few days before the I3th May I893, by Mr. W. M. Frank, keeper to Capt. Duncombe at Westerdale, in Cleveland. The nest, which contained four fresh eggs, was placed on the branch of a slender spruce fir, near the trunk, and about twenty feet from the ground. It was very large and flat, and the bird was wild and difficult to get a shot at; eventually she was enticed by imitation of her cry. Mr. Frank was under the impression she had a mate, but he did not see two birds together. Two eggs were sent to the Norwich Museum, along with the parent bird. A suggestion was put forward by Mr. Heatley Noble, who supplied the facts to Mr. Southwell, that the Hawk may have been an escaped trained bird, as only one was seen ; the eggs were fresh; and the bird was mutilated by the loss of a toe. Per contra Mr. Frank argued that though he did not see a male bird he thinks there was one, but it may have been scared away; the eggs were fresh because the female had not time given her to incubate. As to the inference that she was an escaped bird, Prof. Newton called attention to a passage in Gairdner's Edition of the "Paston Letters" (Lubbock's "Fauna of Norfolk," I879, p. 225), which shows that these trained Hawks were so far sedentary in their habits that, provided the locality were suitable, a liberated bird might be expected to remain and nest.

In confirmation of the "escape" theory it may be well to bear in mind that at Mulgrave Castle, near Whitby, which was, at the date of Mr. Southwell's communication, in the occupation of Lord Hillingdon, I have seen Goshawks used for rabbit hawking, which was a favourite sport of his lordship, though I am not aware of the loss of any of these trained birds. 


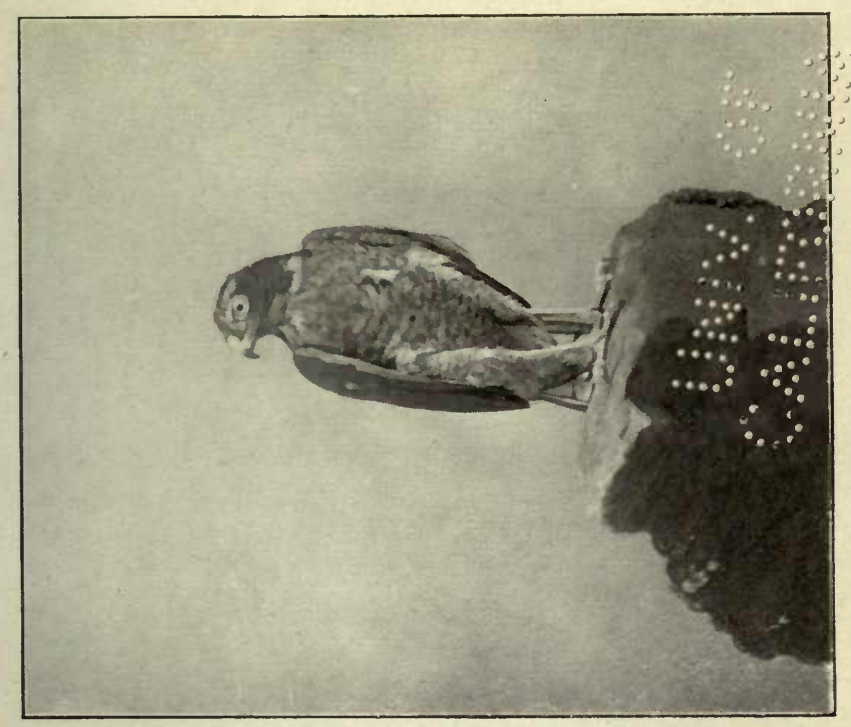

है

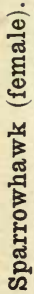

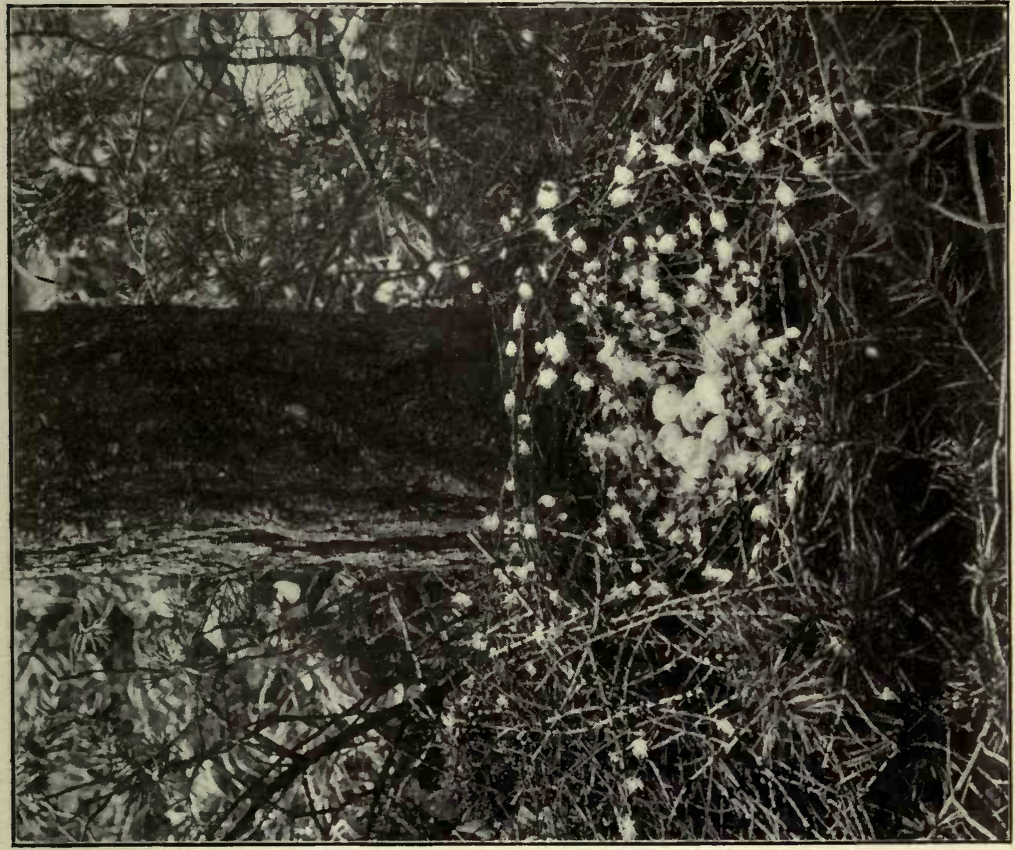

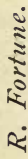

峦

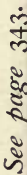


$\ldots$
$\vdots$
$\vdots$
$\cdots$
$\cdots$ 


\section{SPARROWHAWK.}

Accipiter nisus $(L$.$) .$

Common and generally distributed resident, also regular immigrant from the north in autumn.

Probably the first mention of the Sparrowhawk, as a county bird, is contained in Graves's " History of Cleveland" (I808), where it is enumerated in the list of resident birds.

Thomas Allis, 1844, wrote :-

Accipiter nisus.-Sparrowhawk-By no means uncommon.

Next to the Kestrel this is the most abundant of the Hawk tribe, being a generally distributed resident, breeding in almost every part of the county where there are suitable woodlands. It deposits its eggs in a nest of its own construction, contrary to the statements of some authorities, who aver that a deserted nest is usually selected; this is very rarely the case, and indeed when it happens is an exception to a very general rule. The nest made by this species may be described as a rather flat structure of dead twigs, slightly hollowed, the upper edge having generally a little down from the body of the bird adhering to it.

The evidence furnished to the British Association Migration Committee proves that the Sparrowhawk is a regular immigrant from the north in autumn on the coast; I have, on several occasions, observed individuals freshly arrived in the neighbourhood of the Teesmouth, and it sometimes appears in considerable numbers.

This species is becoming much scarcer, the result of the family grudge cherished by the gamekeeper, who allows the young to be hatched, and then, lying in wait, secures both parents without trouble, leaving the young to perish miserably in the nest.

The late J. Carter of Masham related an incident shewing the boldness of one of these birds which flew at, and struck, a Barn Owl, the latter falling to the ground, while the Hawk 
continued its flight, and the Owl, likewise little worse, rose and flew off before it could be picked up (Carter MS.).

In the collection of Mr. A. Clapham of Scarborough are many interesting varieties of the Sparrowhawk, thirty of which were obtained in Yorkshire.

A nest, containing the unusual number of seven eggs, was taken near York on 2Ist May I896.

In Cleveland it was formerly considered to be equally lucky to find either a dead Hawk, Raven, Owl, or Carrion Crow.

The old name for this Hawk, used by Falconers, was Musket ; vernacular names are Pigeon Hawk and Blue Hawk, in general use ; Gold Tip at Sedbergh, and Stannin (Standing) Hawk at Halifax.

\section{KITE.}

\section{Milvus ictinus (Savigny).}

Casual visitant, of very rare occurrence. Formerly nested in the county.

Historically, the earliest Yorkshire allusion to the Kite is contained in the "Gentleman's Magazine" (I747, p. 23), where it is mentioned by George Stovin, under date of 3Ist August 1727 , as a native of the country about Hatfield Chase.

Thomas Allis, 1844 , wrote :-

Milvus vulgaris. - The Kite-About twenty years ago one was caught in a trap at Edlington Wood, near Doncaster, and a pair of young taken from the nest, by $H$. Reid of Doncaster; none have been seen there since. One was obtained at Hornsea [Horsecar] Wood in 1833, and another in Lunn Wood in 1844, both near Barnsley, by Dr. Farrar ; and it is of very rare occurrence in the neighbourhood of Halifax. I have no notice of its being found in the North or East Riding. It has been observed by C. Waterton (see Yarrell's " British Birds") very near Huddersfield. W. Eddison has seen one specimen shot near Penistone.

There can be no doubt that this fine bird formerly bred in our county, but the necessarily old information on this point is difficult to procure, or at least I have not been fortunate 
enough to meet with it. A record is given by Thomas Allis (ante), and it may be as well to remark that Hugh Reid, who is quoted, was admittedly a first-rate and thoroughly reliable ornithologist. The Edlington specimen, as I am informed by Mr. Newstead, is now in the Chester Museum. In a MS. list supplied in I880, the late J. Tennant wrote of this species:- "One was shot early in the present century from the nest at Murton, near Hawnby, by the late Charles Harrison, who obtained both birds. A pair was obtained in Redhouse Wood by A. Christie, in spring, twenty to thirty years ago. A pair passed over Wilstrop in 1874 , and was noticed by the late $\mathrm{J}$. Harrison, his attention being directed to the long forked tails of the birds, which were being mobbed by a large party of Rooks."

The veteran naturalist, the late Charles Waterton of Walton, in Loudon's " Mag. Nat. Hist." (1835), remarked that " of all the large wild birds which formerly were so common in this part of Yorkshire, the Heron alone can now be seen. The Kite, the Buzzard, and the Raven have been exterminated long ago by our merciless gamekeepers..... Kites were frequent here in the days of my father; but I, myself, have never seen one near the place."

Dr. Farrar of Barnsley, in a MS. list of the birds of that district, dated 1844 , mentioned specimens at Horsecar Wood in I833, and at Lunn Wood in I844. The woods adjoin each other and are two miles from Barnsley on its eastern quarter. These records are referred to in Allis's Report, as also are occurrences at Halifax, Huddersfield, and Penistone.

In a list of birds prepared for this work by Wm. Lister of Glaisdale, in Cleveland, for which I am indebted to Mr. Thomas Stephenson of Whitby, that gentleman stated that he killed a Kite in Glaisdale in the year I843 or I844, and that one was also trapped by W. Bennison of Egton Bridge, and stuffed by the late Mr. Ruddock.

Admiral C. C. Oxley of Ripon informs me that a specimen in his collection was killed in Redcar in 1837.

A female occurred near Market Weighton on 5 th July 1850 , as recorded in the Zoologist (1850, p. 2952), by J. C. Garth. 
Near Ackworth, Major Arundel mentions a single occurrence in $\mathrm{r} 85 \mathrm{I}$.

The late James Varley of Almondbury, near Huddersfield, mentioned (MS.), that he saw one on the wing near that place in the summer of 1853 .

In the Zoologist (1859, p. 656r), the late A. Roberts of Scarborough recorded one, a male in fine plumage, near that town in the spring of 1859 .

Mr. Christy Horsfall of Horsforth Low Hall wrote ( $\alpha p$. cit. I863, p. 844I), that a specimen of the Kite had frequented the woods there for eighteen months previous to the date of his communication, and was still there on 2nd January 1863.

About $\mathrm{r} 864$ a Kite captured by Mr. R. Hill near Newholme was stuffed by J. Kitching of Whitby.

In the Loftus and Staithes district one is mentioned as having occurred in I868, at Highfields.

At Stainsacre, near Whitby, an example was caught about I877-78, by a person named Wedgewood.

An adult female, now in the Hull Museum, was taken near Ripon, in the spring of 1877 .

One of these birds was observed to fly in from seaward at the Teesmouth, on I5th September I883, and alight on the vane of an old lighthouse-which at that time stood on the Tees sands-where it was eventually captured. I had an opportunity of examining the specimen in the flesh at G. Mussell's, who preserved it for the Middlesbrough Museum.

The latest occurrence of which I have notice relates to a female example, measuring 2 feet 4 inches in length, secured at Flamborough, on $5_{5}$ th October I9or, and identified by Mr. T. Machen of Bridlington, who has kindly supplied me with the above facts.

The Kite has also been obtained or has occurred as follows, but unfortunately without any indication of date :-

The late $\mathbf{P}$. Inchbald mentioned it as occurring rarely near Halifax (Huddersfield Catalogue, I859).

The late A. Roberts of Scarborough stated that four specimens have passed through his hands for preservation, all obtained near Seamer; one of these was then in the 
collection of Mr. A. Clapham, and two are in that of Mr. Young, keeper, Blankney. The last was obtained three or four years before 1879 .

One was preserved by Mr. R. Lee which had been obtained near Thirkleby, about three miles from Thirsk. No date is given, but it was since 1867 .

A male example in the Burton Agnes collection was caught on the moors near Scarborough, but the date is not mentioned.

Included in a sale at Stevens's rooms on 2rst February r905, was a "Yorkshire-killed kite r880."

The reports of the occurrence of this bird should be received with caution, as my experience is that in the mountainous portions of the county the Buzzard is usually known by the names of Kite or Glead, and this is also the case in North Wales, where the former synonym applies. It is not improbable, therefore that the "Glead" mentioned in the Rev. Ed. Peake's "Avifauna of Ribblesdale" (Nat. 1896, p. 42), as "occurring in the memory of the old dalesfolk, especially near Wharfe and on Greygreth," is referable to the Buzzard. The old Yorkshire name for the Kite was Gled, Glead, or Greedy Gled, being derived from the Saxon " glidan " to glide, referring to the bird's sailing or gliding motions in the air. Forktail was another name formerly in use in the north country.

\section{[SWALLOW-TAILED KITE.}

Elanoides furcatus ( $L$. .).

The status of this American Kite, with regard to this country, is of such a doubtful character that I have deemed it advisable to merely quote the evidence respecting its occurrence.

Thomas Allis's Report, I844, contains the following allusion to this species :-

Nauclerus furcatus.-Swallow-tail Kite-The only British specimen of this elegant bird appears to have been taken alive at Shawgill, near Hawes, in Wensleydale, on 6th September 1805. (See Yarrell's "British Birds," Vol. I. p. 72.) 
Three specimens of this wanderer from the "Far West" are reported to have visited our county. One of these has passed into history, and the following are the particulars of it from Professor Newton's admirable edition of Yarrell's "British Birds" :-

"In the extracts from the Minute Book of the Linnean Society printed at the end of the Fourteenth Volume of its -Transactions" (p. 583), under date " 4 th November I823,' there is a notice of a communication by Dr. Sims mentioning, on the authority of the late Mr. Fothergill of Carr End, near Arkrigg [Askrigg] in Yorkshire, the occurrence of a Swallowtailed Kite near Hawes in Wensleydale in that county. The Editor has been favoured by a son of the gentleman last named-Mr. William Fothergill of Darlington, with a complete corroboration of this story in the shape of the original note in the handwriting of his father. This note states that " on the 6th September 1805 , during a tremendous thunderstorm a bird, of which a correct description follows, was observed flying about in Shaw Gill, near Simonstone, and alighting upon a tree was knocked down by a stick thrown at it, which however did not prove fatal, as I saw it alive and had an opportunity of carefully examining it four days after it was taken." A very accurate description of the specimen .... follows, and the note proceeds thus-the latter portion having to all appearance been written subsequently :- "The bird was kept to the 27 th, and then made its escape, by the door of the room being left open while showing [it] to some company. At first it arose high in the air, but being violently attacked by a party of Rooks, it alighted in the tree in which it was first taken. When its keeper approached, it took a lofty flight towards the south, as far as the eye could follow, and has not since been heard of.-[Signed] W. Fothergill. 3oth September I805." The Editor has further been kindly shown by his obliging correspondent a letter addressed to his father the following year by his nephew, the late Charles Fothergill of York, an ardent naturalist, who says, "I have also proved, what I expected would be the case, that the Falco taken at 
Hardrow Scarr was the Swallow-tailed Falcon or Falco furcatus of Linnæus." Unaccountable then as the fact may be, it rests on the evidence of perfectly competent witnesses, and there is accordingly no room for doubt in this case."

The second specimen is in the collection of Mr. A. Clapham of Scarborough, who stated that he purchased it from Mr. Graham of York, to whom it had been sold by Mr. Jonathan Taylor, a schoolmaster at Harome, near Helmsley. Mr. Clapham made careful enquiries before purchasing this bird and communicated with Mr. Taylor, the following being a copy of that person's reply :-

"Harum, r $3^{\text {th }}$ May 1872 . In referring to my old book of memoranda is the following :-25th May I859, Little George (the name by which this keeper was always known at Duncombe Park), brought me to-day a Swallow-tailed Kite, shot by himself in the Quarry Bank, near Helmsley, on the estate of the Earl of Feversham.-[Signed] Jonathan TAylor." Mr. Clapham had also other letters from Mr. Taylor bearing out his statements, and in one he greatly regrets having sold the bird to Mr. Graham for a few shillings, not knowing its value at that time. Confirmatory evidence bearing out this statement was received from a totally independent source. Mr. Thomas Stephenson of Whitby, who kindly interested himself in procuring information relating to north-eastern Yorkshire, reported that Wm. Lister and his brother observed about this same year a Swallow-tailed Kite at Glaisdale. Mr. Lister was an ornithologist and had no hesitation as to the identification of the bird, which he thus described : "black and white and the tail much more forked than that of the common Kite," which he knows well.

The third example of this rare bird attributed to Yorkshire is in the fine collection of Mr. Alfred Beaumont of Huddersfield, and is supposed to have been obtained in Bolton Woods some forty or fifty years ago. For many years it formed part of the collection of a Brighouse or Halifax gentleman, on whose death the collection came under the hammer, when the bird passed into the possession of its present owner, the price paid for it being $£$ Ir. This is all the information obtainable, 
but Mr. Beaumont was perfectly satisfied as to its validity as a Yorkshire specimen; a satisfaction in which I am unable to participate, from the extremely vague character of the evidence adduced.]

\section{HONEY BUZZARD.}

Pernis apivorus $(L$.$) .$

Bird of passage, of rare occurrence in spring and autumn; most frequently observed at the latter period, and near the coast.

The first mention of the Honey Buzzard in the county is probably that in Denny's Leeds Catalogue (I828), where one was said to have been obtained at Harewood, which passed into the collection of Dr. Leach.

Thomas Allis, I844, wrote :-

Pernis apivorus.-Honey Buzzard-Two or three specimens are mentioned as having occurred in the East Riding; in the West Riding it has been met with rarely by most of my correspondents, except in the neighbourhood of Doncaster, where it is met with not infrequently.

The late John Hancock in his catalogue of "Birds of Northumberland and Durham," considered this to be one of the commonest larger birds of prey, whilst the late J. Cordeaux in his "Birds of the Humber District" stated he had not met with a Lincolnshire-killed specimen. In Yorkshire it has been frequently recorded when on its migratory course.

It has no doubt bred in the county, for Dr. Farrar informed Thomas Allis that a pair fixed their quarters in Wharncliffe Wood in 1833 , one of them being shot; and the late W. W. Boulton of Beverley was of opinion that two young birds, which formerly constituted part of his fine collection, were bred amid the wooded margins of the Hornsea Mere. The specimens are now in the possession of Mr. F. Boyes who, however, observes that they are quite mature enough to have been migrants. Additional important evidence respecting the nesting of this species is furnished by an item 
in a catalogue of a sale at Stevens's Rooms on 22nd April I895, viz. :- " Two eggs of the Honey Buzzard taken at Hackness, near Scarborough, from the collection of Dr. Rooke of that town" ; and it seems not improbable that some of the individuals seen in spring and early summer may have intended to nest in the county if allowed to remain unmolested.

Although this species is not so regular in its appearance as some others of the Falconidæ, yet the published and communicated instances of its occurrence number nearly one hundred, and therefore it is undesirable, and would prove tedious, to give particulars of each individual. It has been observed most frequently in the spring on its passage to its breeding quarters in north-west Europe, and in the autumn when on its way back to its African winter resorts, and more often near to the coast-line than in inland localities.

The curious capture of one at Bridlington in 1849 was communicated to the Zoologist (1850, p. 2649), by Dr. C. R. Bree. It was flapping against a window at twelve o'clock at night, and making such a noise that the person got up, opened the window, and captured it.

At Whitby, J. Kitching of that town had, some time ago (1875), a fine living specimen of the Honey Buzzard in his possession, which had been caught at sea about four miles off Whitby, whilst in pursuit of a pigeon which took refuge on board a fishing coble. The Buzzard hovered round the coble, and was eventually knocked down into the water and captured. This must be regarded as a most unusual occurrence.

Mr. J. Backhouse has presented to the York Museum a specimen taken at I a.m. on I4th September I883, against the Spurn Lighthouse.

On 4th September I896, at about 7 a.m., an immature example was shot near the rocks below 'The Cliffe' at Redcar. The morning was fine but hazy, and three of these birds were noticed, amongst the usual concourse of Gulls near the water line, at low tide. The Gulls and two of the strangers flew off, but the third visitor remained until fired at and wounded. It then flew to Redcar Pier and perched on the rail at the head, 
where a fisherman, observing it fall dead on the deck, picked it up and brought it to me for identification.

In August I902 the gamekeeper at Aske, near Richmond, killed an immature individual while in the act of carrying off a Wood Pigeon. For this information I am indebted to the Marquis of Zetland, in whose possession the specimen now is. I may state that I have been at some pains to ascertain the correctness of this incident, and the identity of the specimen.

The stomach of one which occurred at Flamborough on and June I855, was found to be full of worms and slugs (Zool. I855, p. 476I), and the crop of an individual killed at Storthes Hall, near Huddersfield, on 28th May I874, contained a young bird and egg shells of the Mistle Thrush (op. cit. I874, p. 4I53). It will be observed that the Flamborough example, referred to above, was in pursuit of a Pigeon, and, in confirmation of this departure from the bird's usual habits, it may be repeated that the specimen obtained at Aske, near Richmond, in August I902, was in the act of carrying off a Wood Pigeon.

Almost every known phase of plumage in the Honey Buzzard has occurred in the county; melanic examples are recorded from Seamer in the spring of 1869 , and Bridlington in the "seventies"; the latter specimen was picked up on the shore, and is in the possession of Mr. Forster. A dovecoloured individual was obtained in 1869 at Scarborough, and another at Redcar on 3rd October I903.

\section{GREENLAND FALCON.}

Falco candicans ( $\mathcal{F}, F$. Gmelin).

Accidental visitant, from Iceland, Greenland, arctic North America, and northern Asia, of extremely rare occurrence.

The confusion that formerly prevailed among ornithologists with regard to the specific identification of the Northern Falcons is now a thing of the past, and has resulted in the 
recognition of three distinct species, one of which-the true Jer Falcon of the Scandinavian Peninsula-has been ascertained -to have occurred in the British Isles on two occasions.

Under the names of Gyr and Jer Falcon, I have records of ten occurrences in this county : four of them (three certainly and one probably) are referable to the species under consideration and the remaining six to the Iceland Falcon; and it is satisfactory to know that the specific names of some of them, which would otherwise have been open to grave doubt, have been determined by the highest authorities.

The first occurrence of this species of which we have any record was in 1837 , and was communicated to Neville Wood's "Naturalist" ( 1837, pp. 53 and I63), by Thomas Allis of York, of whose accounts the following is an abstract:-A fine adult specimen of the Jer Falcon was shot at Sutton-upon-Derwent, by a man named Storthwaite, on I3th March I837, and passed into Allis's possession. It was shot in each wing, but not wounded in the body. Like most birds of the family when in captivity, it sulked and entirely refused all food for the first four days; it was still alive on the 26th April, and seemed likely to do well. That this was a Greenland Falcon we have high authority in John Hancock, the author who was the first to point out the distinction between this and the Iceland Falcon. In a letter to Mr. Thompson ("Natural History of Ireland": Birds, i. p. 32), Hancock says, "I know of one instance of the capture of $F$. Granlandicus in this country; it was a mature bird, and was in the collection of Mr. Ellis [Allis] of York, up to the time of his collecticn being sold ; it was obtained in Yorkshire, and, to the best of my recollection, was shot about the year I836."

Thomas Allis's Report on Yorkshire Birds (1844), contains the following reference to this specimen:-

Falco islandicus.-Gyr Falcon-The only recorded Yorkshire specimen is a fine adult bird that was shot on I $3^{\text {th }}$ March 1837 , at Suttonon-Derwent, and came into my own possession. A shot had struck it at the extremity of each wing without injuring the body, and it lived with me for several months, entirely refusing food for the first three or four days.

vol. I. 
The second bird is now in the Scarborough Museum (where I have seen it) and is a fine mature female. It was obtained on $25^{\text {th }}$ November I854, by a person named Dixon, near Robin Hood's Bay, on the moors of Sir John Johnstone, Bart., and recorded in the Zoologist (1855, p. 4558), by the late A. Roberts of Scarborough, by whom it was preserved. The length from the point of the beak to the end of the tail was $20 \frac{3}{4}$ inches, full extent of the wings 3 feet ro inches, weight 3 tbs. 3 ozs.; the crop was overloaded with the entrails of some animal, the stomach with feathers and portions of a Grouse.

In the third instance the bird was not absolutely identified, but from the description may, I think, be referred to this species. It is recorded in Cordeaux's "Birds of the Humber District," under the head of Jer Falcon, as follows :- "Was reported at Flamborough several years since by Thomas Leng, fisherman. Leng was shooting Rock-pigeons at the time from the Speeton rocks, and says that at some distance the bird looked quite white, but on a nearer view he distinctly saw that its plumage was speckled with black, although it was altogether a very light bird. It fell to the bottom of the cliff; and he sent his son down, also descending himself to recover it, but was unsuccessful, as the rising tide had carried it out."

The fourth, and latest, occurrence was on the moors of north Yorkshire, in the autumn of 1892 , when a fine example was captured, and came into the possession of the late Mr. Foulds of Bradford; afterwards being acquired by $\mathrm{Mr}$. Joseph Morley of Scarborough, to whom I am indebted for the opportunity of examining the specimen.

Mr. J. E. Tinkler, in a communication to the Zoologist (I844, p. I3I), says that four instances of the occurrence of the Gyr Falcon ( $F$. candicans), have been noted in northwest Yorkshire. In 1879 or 1880 , near Roe Beck, in Arkengarthdale, one was seen to pounce upon and carry off a Grouse. Another, an immature specimen, was killed in the early spring of 1877 , or thereabouts, on the edge of Ellerton Moor, while pursuing a Woodcock. The other two occurred at the extreme 
head of Swaledale, near the Westmorland boundary; the recorder did not see the birds himself, but they were reported as "large white Hawks, spotted with brown." It may be well to remark that, while mentioning these supposed occurrences, the evidence adduced in support of their authenticity is not by any means satisfactory.

\section{ICELAND FALCON. \\ Falco islandus ( $\mathcal{F}, F$. Gmelin).}

Accidental visitant from Iceland and south Greenland, of extremely rare occurrence.

As stated in my remarks on the Greenland Falcon, there are six instances of this species having occurred in Yorkshire.

The first was shot about the middle of March in the year I837 on the moors between Guisborough and Normanby, as recorded by John Hogg, F.R.S., in his catalogue of the Birds of S.E. Durham and N.W. Cleveland (Zool. 1845, p. I052). It is there described as "a young bird, having all the upper parts of a brown ash-colour, the white occurring on the edges of the feathers. The under parts white, with large longitudinal brown spots." This specimen is referred to as being in its first year's plumage, and in the collection of John Hancock, in a letter addressed by him to Mr. Wm. Thompson ("Natural History of Ireland"; Birds, i. p. 32). It is now in the Hancock Collection in the Newcastle Museum, and in the official guide is described as " a male, in first plum: age, shot near Normanby" (which is about four miles from Guisborough). See also Hancock, "Ann. Nat. Hist." I838, ii. p. I59.

In the collection of Admiral Oxley of Ripon is a fine specimen of the Iceland Falcon, which is said to have been captured on Marston Moor, in December I826 or 1836 . This bird was purchased at the sale of the collection of the late Dr. Hobson of Leeds.

The third occurrence was in November I86r, when a fine 
young female was obtained at Upper Poppleton, as mentioned in the Zoologist (I86r, p. 73r2), by David Graham of York, who purchased the bird for five shillings. This bird is now in the collection of Mr. A. Clapham of Scarborough, who possesses not a few Yorkshire rarities, and who has also been at considerable trouble in furnishing valuable information and replying to numerous enquiries.

The fourth specimen is also in Mr. Clapham's collection : it was killed by Mr. Lorrimer on Filey Brigg, on 4th October I864, while in company with another of the same species, which escaped. This individual for some time proved a puzzle to Mr. Clapham's friends, who thought it to be a young Peregrine. At length it was submitted to Mr. H. E. Dresser, author of the "Birds of Europe," for his opinion ; in a letter from that ornithologist he states:- "The other bird is not a Jer Falcon but an Iceland Falcon, not in mature plumage and most probably, if not certainly, a male. It is a capital specimen."

Mr. Thomas Stephenson of Whitby states (MS.), that about the year $1865, \mathrm{Mr}$. Kitching, the bird preserver, of that town, found one nailed on a wall along with other "vermin" at Newton House near Whitby, by the gamekeeper Parker, who shot it. Mr. Kitching removed the bird, but it had been exposed too long to make a specimen of ; he retained portions and thinks they belong to this species.

The sixth, and until now unrecorded, instance is, chronologically speaking, the third. The specimen is in immature plumage and is one of two which occurred on the Wemmergill Moors in north Yorkshire, in the spring of 1846 , and was purchased in the flesh by the late Joseph Duff of Bishop Auckland, in whose collection it remained, labelled " Jer Falcon," until his decease, when it passed into the possession of his son, the late Theo. Duff. The collection was sold in I90r, and I purchased the example under consideration. (See also Zool. r851, p. 3036, where this bird is recorded in mistake as "Gyrfalcon, got at Wemer Gill, in Northumberland.")

The Jer Falcon supposed to have occurred on the Lockton Moors, near Pickering, and recorded in the Zoologist (I864, 
p. 9244), by J. Cordeaux - on the authority of Mr. Jones of Bridlington, who sold it to Mr. Clapham of Scarborough,proved to be a Goshawk, and is the one described under the head of that species as being in the singular "cuckoo" plumage.

\section{PEREGRINE FALCON. \\ Falco peregrinus (Tunstall).}

Resident, restricted now to a few pairs nesting on the north-western fells, an occasional pair on the sea-cliffs, and possibly another pair in Cleveland. Observed fairly regularly on migration at the coast.

Pennant appears to have first recorded this species in Yorkshire, under the head of "Grey Falcon," from a specimen shot near Halifax in I762 (" Brit. Zool." Vol. I. p. I37).

Thomas Allis, I844, wrote:-

Falco peregrinus.-Peregrine Falcon-Many birds have been shot at different periods; its occurrence is mentioned by most of my correspondents ; it still breeds near Pickering, but is becoming much more rare than formerly; it has also bred this year at Kilnsey Crag. and near Arncliff [Wharfedale].

In former years the records show that the Peregrine was far from uncommon as a resident in the county; and it seems probable that when the sport of falconry was in vogue, and this noble bird in high favour and enjoying a certain degree of protection, there would hardly be a locality suitable for its eyrie which was untenanted. But now all this is changed, the protection has long since been withdrawn, and the former favourite so far descended in the scale as to rank as "vermin" in the estimation of the descendants of its former protectors. Among the places where its eyries have been noted are Goathland, and Killingnab Scar, in Cleveland.* J. Hogg mentioned

* The farmers in Newton Dale were formerly obliged, by the ancient tenures of their land, to attend to the hawks which bred in Killingnab Scar, in order to secure them for the King's use. These hawks were said to be of large size (doubtless Peregrines), and in 1831, when Allen's "History of the County of York" was published, they continued to frequent their ancient place of resort. 
(Zool. I845, p. I052), on the authority of J. Grey, that it bred annually on Huntcliffe, in the early part of last century. It also bred on Black Hambleton, which was the only locality from which Colonel Thornton, as he assured Montagu, could procure a Tercel (a male) that would kill ducks, although he had tried many from other places.

It is an unmistakable pleasure to be able still to claim this noble bird as a resident. A pair or two bred almost annually until 1879 in the stupendous cliffs of our coast at Flamborough and Speeton, where its favourite prey, the Rock Pigeon, is numerous, and occasionally a pair or two also breed inland.

The late J. Cordeaux stated that there were two eyries at Flamborough in 1867 , one of which was robbed by the climbers. The other pair were more fortunate, and escaped unmolested, the young birds getting off.

On 3rd June 1876 , Mr. W. Eagle Clarke was at Buckton and Bempton, between Flamborough Head and Filey, and saw in the possession of the climbers three young in whitish down, which had been taken on 3oth May. They had come across them quite by accident in the highest portion of the cliff ; there was not the slightest sign of a nest, the young being simply on a ledge about four feet wide. On visiting the cliffs he saw both the old birds, the female leaving the ledge from which the young were taken and flying round uttering a very plaintive note. The climbers wished him to purchase these young birds, but this he declined to do, hoping, as he had heard them complain about the trouble of feeding them, and also some mention of putting them again on the eyrie, that they might yet be restored to the old birds; however, they eventually found their way to Barnsley. In the same year another brood was taken by. Edward Hodgson, and came into the possession of the Rev. G. D. Armitage, who at that period hawked with Major Brooksbank of Middleton. A pair of old birds returned to the cliffs in the spring of I879, when I regret to say one of them was ruthlessly killed and the eyrie consequently deserted. Occasional attempts to re-occupy it have been made at intervals, but without 


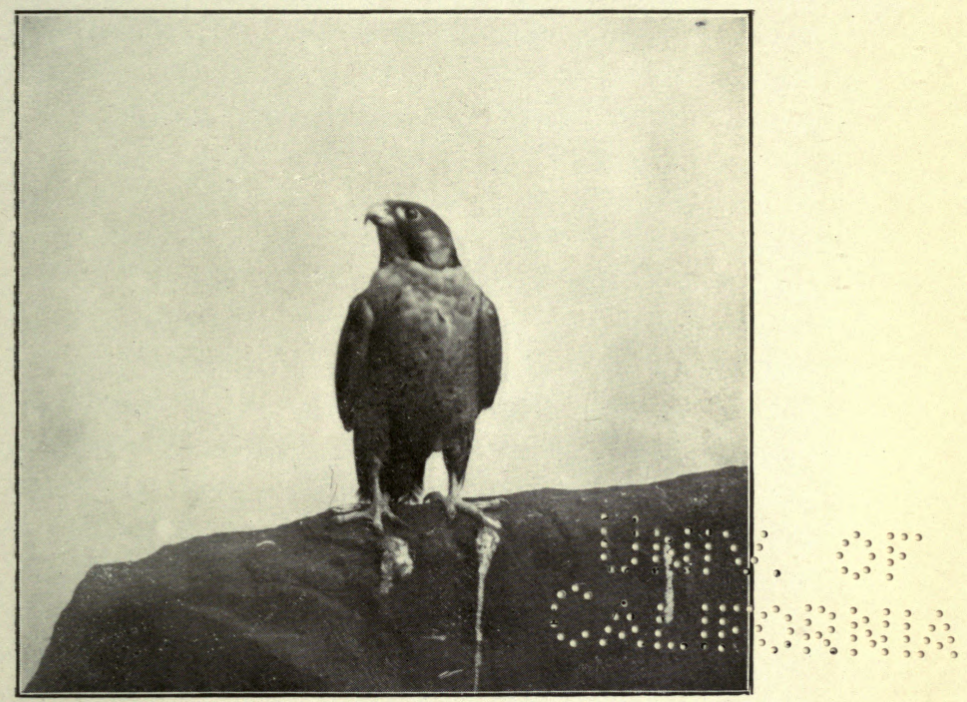

Telephoto picture of a wild Peregrine, taken in north-west Yorkshire. R. Fortune.

See page 360. 

success, until the present year (Ig06), when a pair took up their quarters between Dane's Dyke and the " Dor," and were only discovered when the climbers commenced work about the middle of May. I visited Bempton at the end of that month, and spent some considerable time at the cliffs, being repeatedly rewarded with a sight of one or other of the Falcons, and on some occasions both of them perched for fully half-anhour on a projecting point known as "Staple Neuk," where I watched them through powerful binoculars. On 6th June the climber went down purposely to locate the eyrie, which he found in a part of the cliff not visible from the top; the young, three in number, fledged about the 2Ist of the same month. All naturalists will echo the wish that these birds may continue to frequent their old-time haunts, thus imparting an additional interest to the cliffs of the Yorkshire coast. Near Scarborough a pair of Peregrines arrived in the winter of 1900 and nested in the following May, in a precipitous cliff a few miles distant from the town, where they successfully reared their young, which were frequently seen on the wing together with the parent birds. The male was killed in the autumn of rgor, but the female found another mate and nested again in the two following years. Odd individuals, chiefly in immature plumage, frequent the district between Scarborough and Flamborough almost every winter.

The late Geo. Brook of Huddersfield, stated (MS.), that in $187 \mathrm{x}$ a clutch of four eggs was taken from the Fells in Swaledale, and the old male shot. The eggs and bird were in his collection, but, as it is some years since he died, the collection may have been dispersed.

In the year 1879 a pair reared their young in safety in the Cleveland Hills, the information concerning them being supplied on condition that the locality be nameless.

In Upper Teesdale the Peregrine has bred intermittently on the Yorkshire side of the river, during the past twenty years, the nesting site being sometimes occupied by Ravens and in other years by the Falcons. Three eggs were taken there in I903, and the keepers trap the birds whenever opportunity occurs, no fewer than seven being killed in the year I900. 
At the head of the Swale Valley a pair annually attempt to breed, but with variable success, for here, as in other places, the gun and trap are employed against these noble birds. The Rev. Edward Peake says that in the Craven and Ribblesdale districts it still breeds on the crags if unmolested. Mr. W. Eagle Clarke visited an eyrie on the north-western fells in I880, where orders had been issued for the destruction of a pair of nesting Peregrines, whose doom was sealed owing to their penchant for Grouse. The Falcon was shot as she left her nest, which had four eggs, she being the sixteenth victim to the gun, all killed from eyries on this fell.

It is with great satisfaction, however, that I am able to state that this magnificent bird is known to nest in another north-western locality, one eyrie having been occupied regularly for a quarter of a century, though very rarely do the birds succeed in rearing a brood; four pairs nested in IgoI, and from the summit of a neighbouring hill six eyries may be pointed out on a clear day. The eggs are persistently taken, and from one spot three clutches were abstracted in a single season, there being an interval of about three weeks between each laying. In I899 three eggs were taken on IIth April, and a second clutch was completed on the 3oth; at the same place four eggs were taken on I6th April Ig02. Sometimes an old nest of the Raven is utilised as an eyrie, and in I896 a clutch of Raven's was found, while later in spring three Falcon's eggs were discovered in the same nest. On one occasion an experiment was tried with a fledgling Peregrine which was introduced into a Kestrel's nest, where it was reared.

As an autumn and winter visitant the Peregrine is most frequent on the coast, but it also occurs inland, visiting all parts of the county, so that an enumeration of the occurrences would be unnecessary and tedious.

These immigrants are mostly birds in immature plumage ; this species is a regular autumn and winter visitor, and three have been seen together in autumn, beating along the coast, and disturbing the shore birds. A few of these remain in the district during the winter, chiefly near the coast, though 


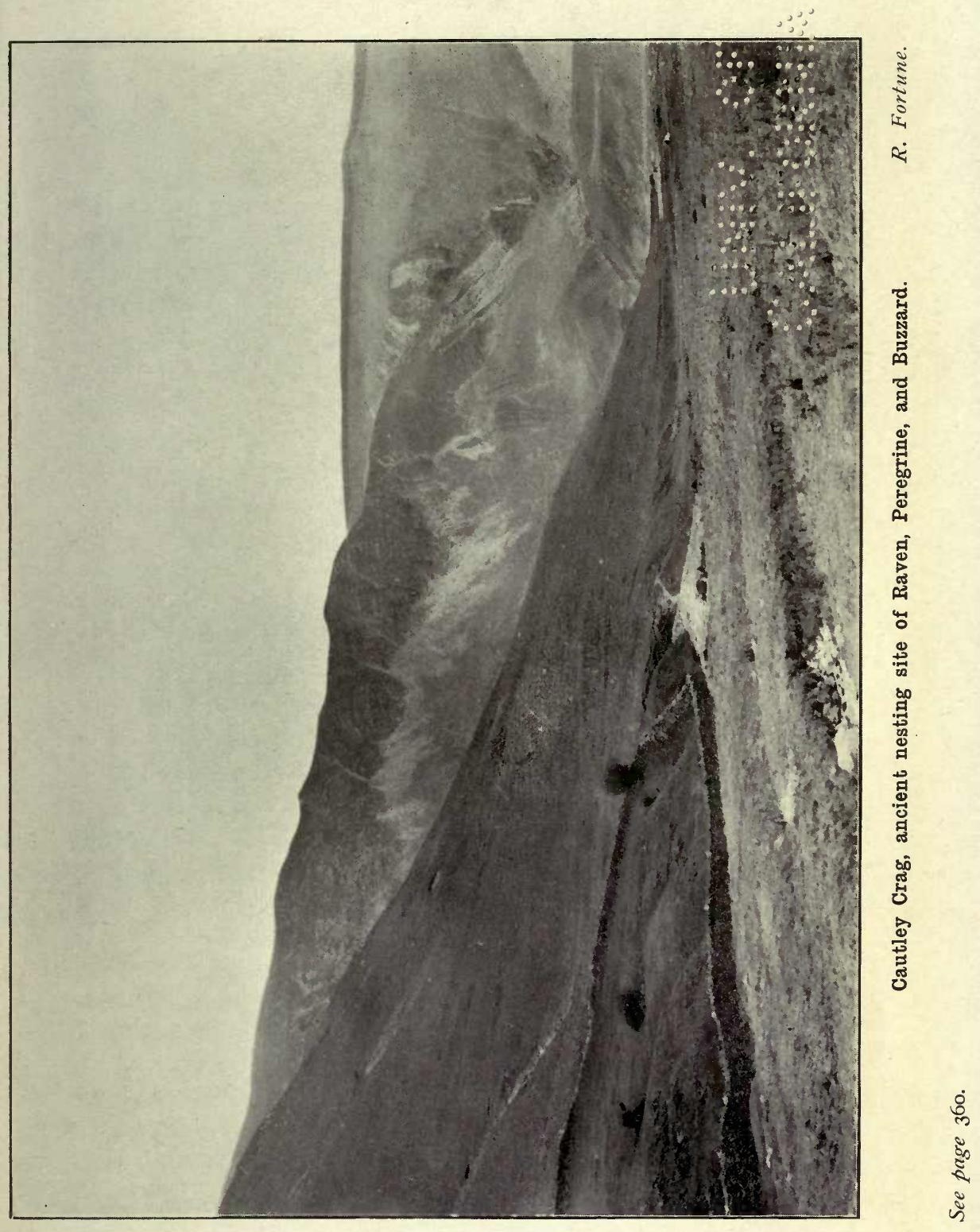




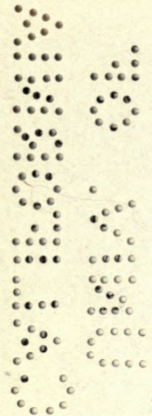


it is not very uncommon at this period on the higher Wolds, where it feeds on the Stock Doves which are very common there. In the majority of cases, however, these autumn immigrants amongst the Falconidæ leave the district (Holderness) before the advent of the winter season. Two were observed at Spurn on the return passage in the spring of 1898 .

An interesting anecdote is related of the Falcon at Flamborough by Mr. M. Bailey of that place. I quote Mr. Bailey's words :- "Being on a cruise at sea on 3Ist March, .... I saw something that might be interesting to you, that of a fine Peregrine Falcon hawking after sea birds. It was amusing to see him dart at the Guillemots as they sat or floated on the sea. The moment the Hawk made a dash at his prey, to his great disappointment, under water went the Guillemot. I watched him for fifteen or twenty minutes, but he never once appeared to touch the water. I was speaking of this to the master of a fishing yawl, who told me that, only a few days previously, when some miles distant from. land, he observed a Blackbird chased by a Peregrine Falcon. It was so closely pursued by the Falcon that it took shelter on board the yawl."

On 25 th October 1890 , I watched a Peregrine coming in off the sea at ro-30 a.m., and noticed it was carrying something in its talons. It dropped the object, a bird probably, near Redcar Pier, and flew past me within two hundred yards, going in a southward direction. Mr. W. H. St. Quintin states (MS.), that wild birds constantly come to his trained Hawks in winter. One remained at Scampston most of the winter of IgoI-2.

A very fine mature female, which the late W. W. Boulton dissected, contained the remains of a Rock Pigeon, including, amongst other portions, one entire foot and shank and a few feathers.

The local name on the north-west fells is Great Blue Hawk. In Ryedale it is called Perry Hawk; and Swainson gives the terms Blue-backed Falcon and Duck Hawk as used in the north of England. 


\section{HOBBY.}

Falco subbuteo (L.).

Casual visitant, of rare occurrence, chiefly in spring and summer, but occasionally in winter. Has nested in one or two localities.

Probably the earliest Yorkshire mention of this bird is in Willughby's "Ornithology" ( 1678, p. 2I), thus :- "This form persecuting of Larks (which are its chief and particular game) is not unfitly by Mr. Johnson [of Brignall, near Greta Bridge] entitled Accipiter alaudarius."

Thomas Allis, I844, wrote :-

Falco subbuteo.-Hobby-Frequently obtained in different parts of the West Riding; occasionally met with in the neighbourhood of York, but I have no mention of its capture in the East Riding."

The Hobby is only occasionally observed. The summer months are the usual time for its appearance, but instances are recorded of its having been obtained in the months of October (the 3Ist), December, and February, contrary to what might be expected of a species regarded as a summer visitor to Britain.

This bird is described by Hewitson in his " British Oology" (1838), as "more common in some parts of Yorkshire than elsewhere." J. Heppenstall of Sheffield in I843 mentioned it as pretty generally distributed in that district in the summer months (Zool. 1843, p. 247), and Dr. Farrar of Barnsley, writing in 1844 , said it is far from uncommon. Whatever may have been its abundance in former years in south Yorkshire, it is now, as far as I have been able to ascertain, only to be regarded as a rare casual visitor to that and all other parts of the county. As regards north Yorkshire, we find that in Cleveland, J. Hogg (op. cit. I845, p. I052), described it as being a rare species and migratory; and Mr. R. Lee of Thirsk states that he has only seen two in his experience.

A. G. More in his paper on the distribution of Birds in Britain during the breeding season (Ibis, I865), mentioned it

* More recent information than that possessed by Allis proves that the bird has occurred in the East Riding. 

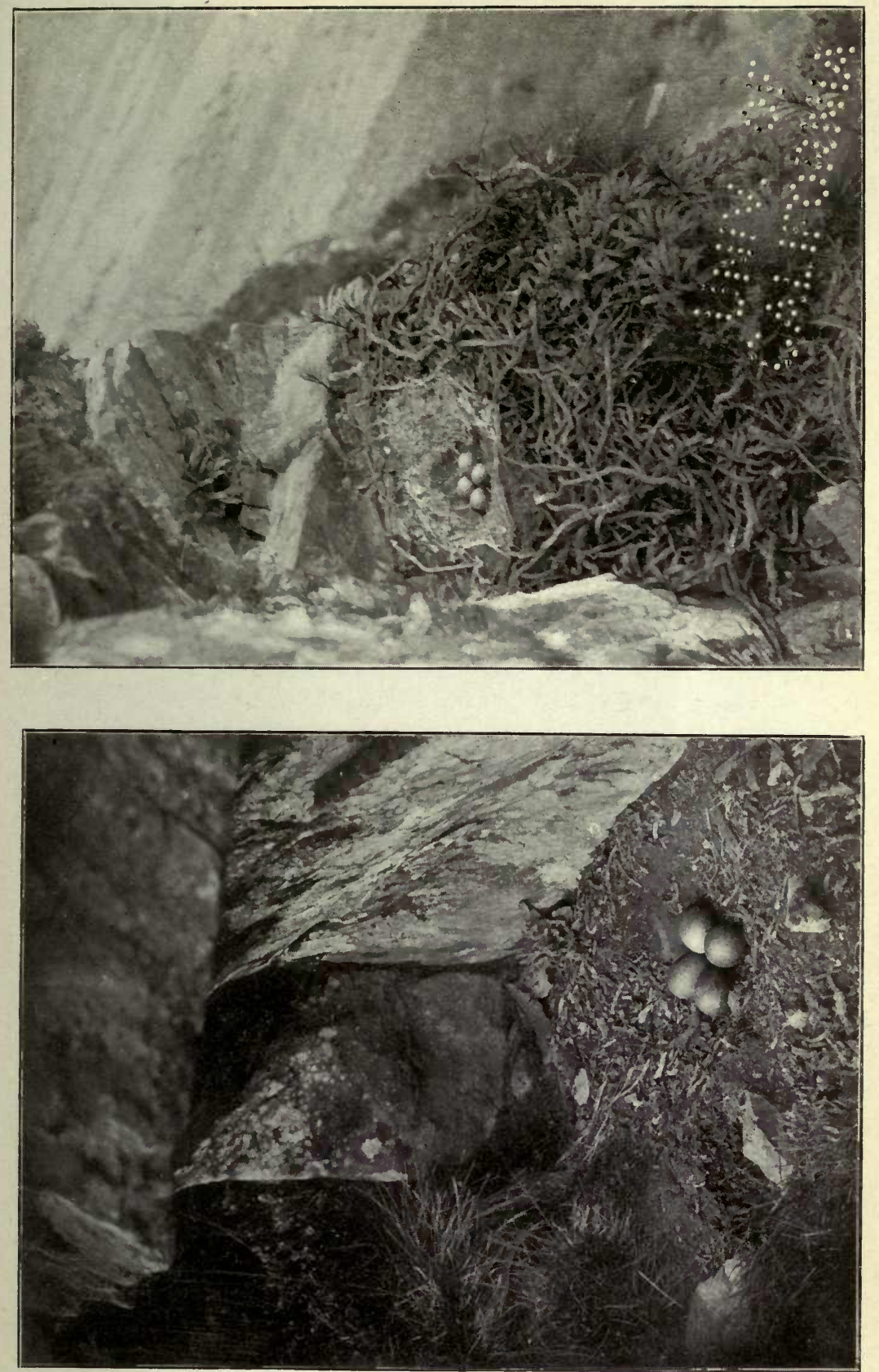


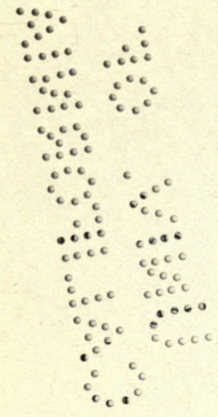


as breeding occasionally in Yorkshire. He has since stated, in reply to inquiries, that the only locality known to him was Rossington Wood, near Doncaster, and that his informant was the late Hugh Reid.

One instance of its having nested at Bishop Wood, near Selby, in the summer of 1869 (year not quite certain), was reported by the late keeper, Wm. Harland, who stated that its eggs were taken from a Crow's nest, and were in the possession of Mr. A. R. Kell of Barnsley. In the East Riding the nest has been reported at Everingham Park, near Market Weighton, in 1875 .

The following are the instances of its occurrence which have come under my notice :-

In Neville Wood's "Naturalist" (I837, p. 384), P. Hawkridge of Scarborough remarked:-This bird is very scarce in our neighbourhood. A specimen was once killed by a boy with a stick at Knapton, near Scarborough, and presented to the Scarborough museum by Mr. Tindall. When we consider the diminutive size of this Falcon, we may venture to pronounce it second to none of its family in point of courage. At the time the individual above mentioned was taken it had just seized a Rook.

The late Wm. Talbot in his "Birds of Wakefield" stated that he saw one in the flesh which had been taken at Bilham, near Doncaster, in February I845.

Near Bridlington, a male was killed in 1860 by $\mathrm{T}$. Ellotson, gamekeeper to Sir Henry Boynton, and is preserved in the Burton Agnes collection.

Mr. W. H. Raw of Lealholm, near Whitby, has a fine specimen which he obtained in Fryup, in the year I866.

The late J. Cordeaux in his "Birds of the Humber District" (I872), said that the late W. W. Boulton of Beverley informed him that it is not infrequently seen near there, and that he has had several during the last few years shot near the river Hull and at Spurn Point; though Mr. F. Boyes throws a doubt on this statement.

Mr. F. G. S. Rawson of Halifax reported one at Ovenden in 1873 . 
In I874 Mr. R. Richardson of Beverley had two females sent to him for preservation. One of these was captured at Kilnwick on 6th June, and is now in the possession of Mr. F. Boyes. The other, obtained at Flamborough on 3oth October, is in the collection of Mr. R. Crowe.

A male and female in the Hull Museum were procured in the West Riding, the male at Coniston, in $186 \%$, and the female at Flasby Hall, in July 1874.

At the meeting of the York and District Field Naturalists' Society on I4th November I877, Mr. Helstrip exhibited a fine adult example from near York. This specimen and another adult, also shot near York, are in the museum in that city.

Mr. R. Richardson of Beverley preserved a female for Mr. R. H. Barugh of Bridlington, which had been shot on 7 th June 1879 .

On 2Ist May I879, an immature example was preserved by Pearce Coupe of Marske-by-the-Sea, who obligingly gave me an opportunity of examining it.

Two examples, in the possession of Mr. T. Machen of Bridlington, were procured in the year I890, and about the same period a pair were killed near Thwing, in the East Riding.

An adult male was obtained at Danby, in February I894, and sent to Geo. Mussell of Middlesbrough, who shewed me the bird in the flesh. This specimen is now in my collection.

In Washburndale one was taken in Lindley Wood, in the spring of 1896 . On Ioth July in the same year one was noted near Scarborough, which had the "hatching spot" plainly visible (Zool. I896, p. 387).

Mr. W. H. St. Quintin has informed me of a specimen captured at Scampston in May I897.

An instance is recorded in the Field of IIth January I902, from near Kettering, on 7 th December Igor, when a male Hobby in adult plumage, evidently killed by a gun shot, was picked up by Mr. R. N. Stockburn.

Mr. W. Wilson states that a pair was noted near Flasby in I904, one bird being afterwards shot at Thorleby Springs.

And in October of the present year (I906) an example was killed near Thirsk, and was taken to Mr. R. Lee of that town. 
In addition to the above instances, the Hobby is reported to have occurred in the undermentioned localities, no precise information being given :-

Halifax (R. Leyland, I828) ; Barden and Bolton (H. Denny, 1840); Kirklees and Castle Hill, near Huddersfield (P. Inchbald, I859); Killingbeck, near Leeds (John Dixon, I853); Carlton and the moors west of Barnsley (T. Lister); Redcar, one in the collection of C. C. Oxley, late of The Cliffe, sold at his sale, now in the possession of Mr. T. Watson of Redcar ; one at Danby, about 1870 , shot by R. Raw; Bridlington (M. Lawson, I879); Stainland (C. C. Hanson, I879); a summer visitor to Scarborough but not plentiful (A. Roberts, I879); one in summer plumage, killed there, is in Mr. A. Young's possession at Blankney. Western Ainsty, occasionally seen, one shot near Wetherby, about 1860 (Nat. I89r, p. 99); two near Ulleskelf, about 1876 (Baynes MS.) ; Loftus-in-Cleveland, has been noted and shot (K. McLean MS.); Easington, near Spurn, one on Ist September (about) I880, now in the York Museum; Sedbergh, reported as a summer visitor, very rare (W. Morris MS. I902); at Colne Bridge, near Huddersfield, an example was killed some years ago, and is now in the possession of Mr. S. Calvert of Kirkheaton (S. L. Mosley MS.).

\section{MERLIN. \\ Falco æsalon (Tunstall).}

Resident, breeding on the high fells and moors of the west and north-east, over which it is thinly scattered. More generally distributed during autumn and winter, when it is occasionally observed on migration.

The first mention of the Merlin in Yorkshire is probably in the Allan MS., descriptive of the Tunstall or Wycliffe-onTees Museum, dated about I79r, where it is stated that "This bird .... migrates here in October." (Fox's "Synopsis," p. 53.)

Thomas Allis, 1844, wrote:-

Falco asilon.-Merlin-Mentioned as occurring by almost all my 
correspondents, and is of frequent occurrence in many parts of the West Riding.

This dashing little falcon breeds sparingly on most of our high moorlands, depositing its eggs among the heather and showing a strong predilection for the vicinity of boulders, on which it loves to rest. On 9th May I877 a nest was found on the Ilkley Moors ; the old male being first observed sitting on a stone post, which on approach he quitted, and flying low over the heather put the female off her nest. The nest, which contained four eggs, was merely a slight depression lined with and surrounded by burnt heather stems. H. Smurthwaite of Richmond mentioned in Morris's " Naturalist" ( 1854, p. 80), that he once heard of a nest being found in the centre of a field of young wheat-a most unusual occurrence.

As illustrating the partiality of these birds to certain nesting localities, Mr. W. Morris of Sedbergh writes that about I 890 a gamekeeper killed a pair of breeding Merlins, but did not destroy the eggs; these were found by my informant, the following year, in the nest together with a fresh clutch of four eggs.

In the year 1899 a pair of Merlins selected a very unusual position for their nest in a remote part of Scugdale, in Cleveland, the site chosen being in a tree, where both birds were 0 served.

The Merlin breeds in the following localities:-On the high moors of the Pennine Range it is reported from the neighbourhood of Sheffield (for an interesting and lengthy account of its breeding in this district, from the pen of Henry Seebohm, consult "Dresser's Birds of Europe," part 38), Penistone, Hebden Bridge, Halifax and Haworth, and from the Fells of Langden, Waddington, and Grindleton. In Craven and the district known as "The Dales," it nests on the moorlands above Ilkley, Barden, Pateley Bridge (now very rarely), Leyburn, Bedale, Masham, Ripon, Richmond, Barnard Castle, and Upper Teesdale. In the north-east it affects the Cleveland Hills and the moors above Whitby and Scarborough. The late Canon Atkinson stated in I880 that it used to be common on Danby Moor, but had then become very scarce. In Arkengarthdale and Swaledale, and on the Bowes and Scargill 


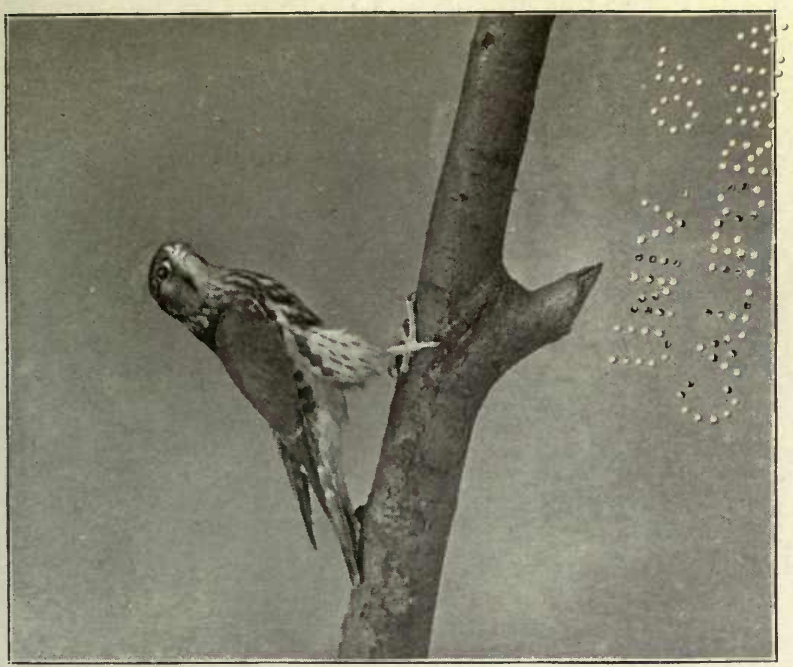

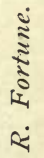

量

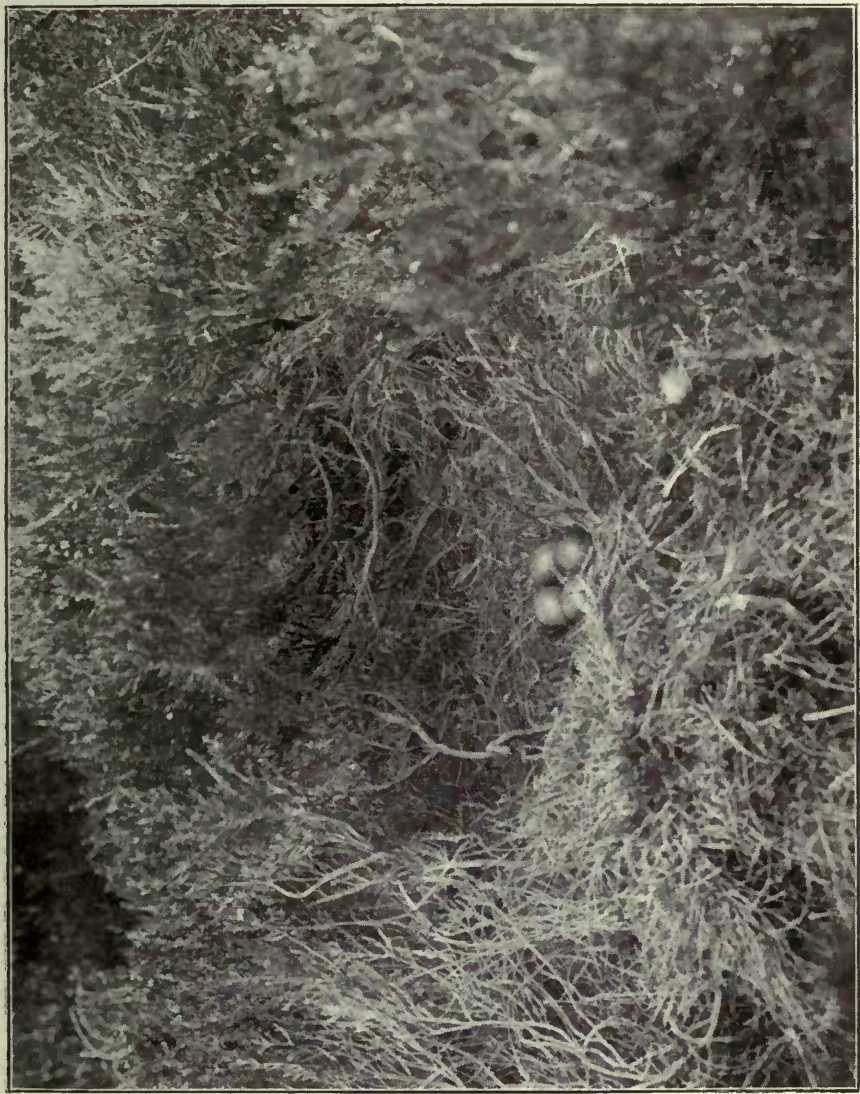

¿̇

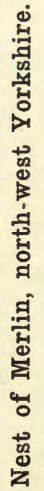

ڤె

ธั

ธัँ 


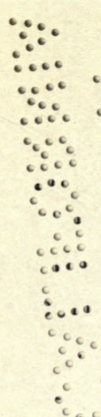


Moors adjoining, it nests regularly, but, as it figures in the keeper's vermin list, it is not allowed to remain unmolested. Between I88I and I890 sixteen nests with eggs or young were destroyed, and forty-four old birds were killed, the majority captured by that cruel abomination, the pole-trap. It may be mentioned that in most of these exposed localities its numbers were materially reduced by the instrument named, now forbidden by statute. (For details as to the persecution to which the poor birds are subject, see Nat. 1892, p. 320.)

It is occasionally observed as an immigrant in autumn at the coast; I have noted it at the Teesmouth in October, and on one occasion witnessed a newly arrived Merlin in full flight after a Dunlin. In the Humber district it usually appears during the first fortnight in October.

In inland districts it is more frequently observed in the autumn and winter months, when it is not so local, and instead of being confined to the moorlands descends from these elevated localities and visits the more enclosed country, and occasionally the close proximity of large towns. At this season it is met with quite commonly in the "Carrs" of east Yorkshire, where it is sometimes noticed chasing the Skylarks.

Local names are:--Little Blue Hawk, in general use; Little Hawk, in east Cleveland; Little Blue Pigeon-Hawk, at Wakefield; Stone Falcon, in north-west Yorkshire ; while Rock Hawk and Stone Hawk are given by Swainson as north country names.

\section{RED-FOOTED FALCON}

\section{Falco vespertinus $(L$.).}

Accidental visitant, from southern and eastern Europe, of extremely rare occurrence.

In the year 1830 this species, which appears to have been to this date an entire stranger to Britain, occurred almost simultaneously in this county and in Norfolk. The first of these occurrences took place in our county in the month of 
April, when a male was shot near Doncaster, which was reported to the Linnean Society at its meeting on Ist May I832 ("Transactions," xvii. p. 533), in a letter from Mr. H. S. Foljambe. Four specimens were shot in Norfolk during the following month.

Thomas Allis, I844, wrote:-

Falco rufipes.-Red-footed Falcon-I have notice of five instances of the capture of this bird; F. O. Morris says that a pair were shot near Doncaster, and a female at Rossington; the latter specimen is stated by Hugh Reid of Doncaster to be in the possession of W. R. Read, Esq., of York; a fourth, a female, was shot a few years back near Easingwold, and sent to $\mathrm{H}$. Chapman of York, with a message that " if it was a Cuckoo" he was to stuff it, and return it to the person who shot it, but, if it was not a Cuckoo, when stuffed he might keep it for his pains; the fifth specimen was shot on 6th May last, at Stainer Wood, near Selby, and is in the possession of Massey Hutchinson of Selby.

Since 1830 it is reported to have been obtained on the following different occasions. One in the Sheffield Museum, said to have been killed in that neighbourhood, is recorded in the Zoologist (I843, p. 247), by J. Heppenstall.

In May I844 a fine female was shot in Stainer Wood, near Selby, by a gamekeeper of the Right Hon. E. R. Petre. It passed into the possession of Mr. Massey Hutchinson of Selby (op. cit. I844, p. 654).

Thomas Allis, in his Report, recapitulated the foregoing, and added two other occurrences.

A female in mature plumage was shot from a ship entering the mouth of the Humber in November I864, as it hovered over the vessel. This specimen came into the possession of the late W. W. Boulton of Beverley, in the flesh, and was recorded by that gentleman in the Zoologist (I865, p. 94I5).

Mr. J. E. Harting in his "Handbook of British Birds" (2nd Ed. p. 324), mentions that a mature male occurred at Bempton Cliffs on 6th July I865. Mr. J. Whitaker of Rainworth Lodge, Mansfield, informs me that he purchased this specimen for his collection.

In the collection of Mr. T. Machen of Bridlington there is a mature male, obtained at Bempton by Mr. R. Morris on I8th June I869 (Cordeaux, "Birds of the Humber District "). 
A pair of adult birds in the Hull Museum was bought at the sale of Mr. Hall's Scorborough collection, I878. These birds are supposed to be local specimens.

William Lister of Glaisdale mentioned that one was captured at Egton Bridge, near Whitby, by the keeper of $\mathrm{Mr}$. Smith, in 1876 or 1877 .

Mr. A. Clapham of Scarborough states (MS.), that an adult in his collection was trapped by Lord Londesborough's keeper in the vicinity of Hackness, and that the keeper had another that was taken near Scarborough. The latter specimen is now in the possession of Mr. A. Young, keeper, Blankney, son of Lord Londesborough's late keeper.

Three specimens have been preserved by the late $A$. Roberts of Scarborough; these afterwards passed into the collections of Mr. A. Clapham, E. Tindall, and A. Young, gamekeeper. Mr. Roberts stated that all these birds had been feeding on the large common dew-worms. Two of these last mentioned birds are, no doubt, those recorded by Mr. Clapham.

A fine female was obtained in Wadworth Wood, near Doncaster, during the last week of April I884, and was preserved by the late A. Paterson of Doncaster, who kindly supplied the forezoing information.

In the spring of 1895 a pair was reported at Ackworth, and Major Arundel of that place has, at my request, prosecuted inquiries in reference to this occurrence, and communicated the result as follows:- "I7th March I903. For a fortnight or more during the spring of 1895 two (probably a pair), Red-footed Falcons were seen several times at Brook-o'-Dale and Stapleton, and one of them eventually fell to the gun of the gamekeeper, Savage, who shortly afterwards left the district and is now dead. I did not see the birds myself, but they were reported to me by Mr. G. P. Rhodes, a competent observer, who saw them on the wing, and examined the specimen that was shot, in the flesh." 


\section{KESTREL.}

\section{Falco tinnunculus ( $L$. $)$.}

Resident, common and generally distributed. An influx of migrants occurs in autumn.

The earliest mention of this Hawk in Yorkshire appears to be in Graves's "History of Cleveland" (I808), where it is enumerated among the resident birds.

Thomas Allis, I844, wrote :-

Falco tinnunculus. - Kestrel-Common in most parts of the county.

In Yorkshire, as in most other counties, the Kestrel is the most numerous and the best known species of the Falconidæ. It is generally distributed, being reported from every district in the county as occurring during some part of the year. As a breeder, it is found in all suitable localities, adapting itself to every variety of situation for the rearing of its progeny. In wooded districts it prefers the deserted nest of a Crow or Magpie; among the fells, a rocky ledge ; and on the coast the cliffs ; while in the open pastoral country, ruins and hollow trees are occasionally resorted to. All seem to be acceptable, and its absence from them can be accounted for by persecution or the immediate vicinity of some manufacturing centre. A pair bred in an unoccupied house on the main road between Ripon and Harrogate, and in Ribblesdale a nest was found in a barn. Amongst other curious nesting incidents are that of a Crow, Magpie, and Kestrel breeding in the same tree, near Worksop; and a Kestrel nesting in proximity to a Long-eared Owl, near York, in 1897 . There are certain portions of the densely populated districts of the West Riding in which this species is now only observed as a winter visitant, probably from elevated and more exposed localities, though formerly it bred there; and at Spurn Head it is annually noticed as an early autumn migrant.

With regard to the Kestrel's wintering in Yorkshire, Mr. J. E. Harting wrote as follows in the Field for 1872 :- "The Kestrel, which to a certain extent is migratory, has been 

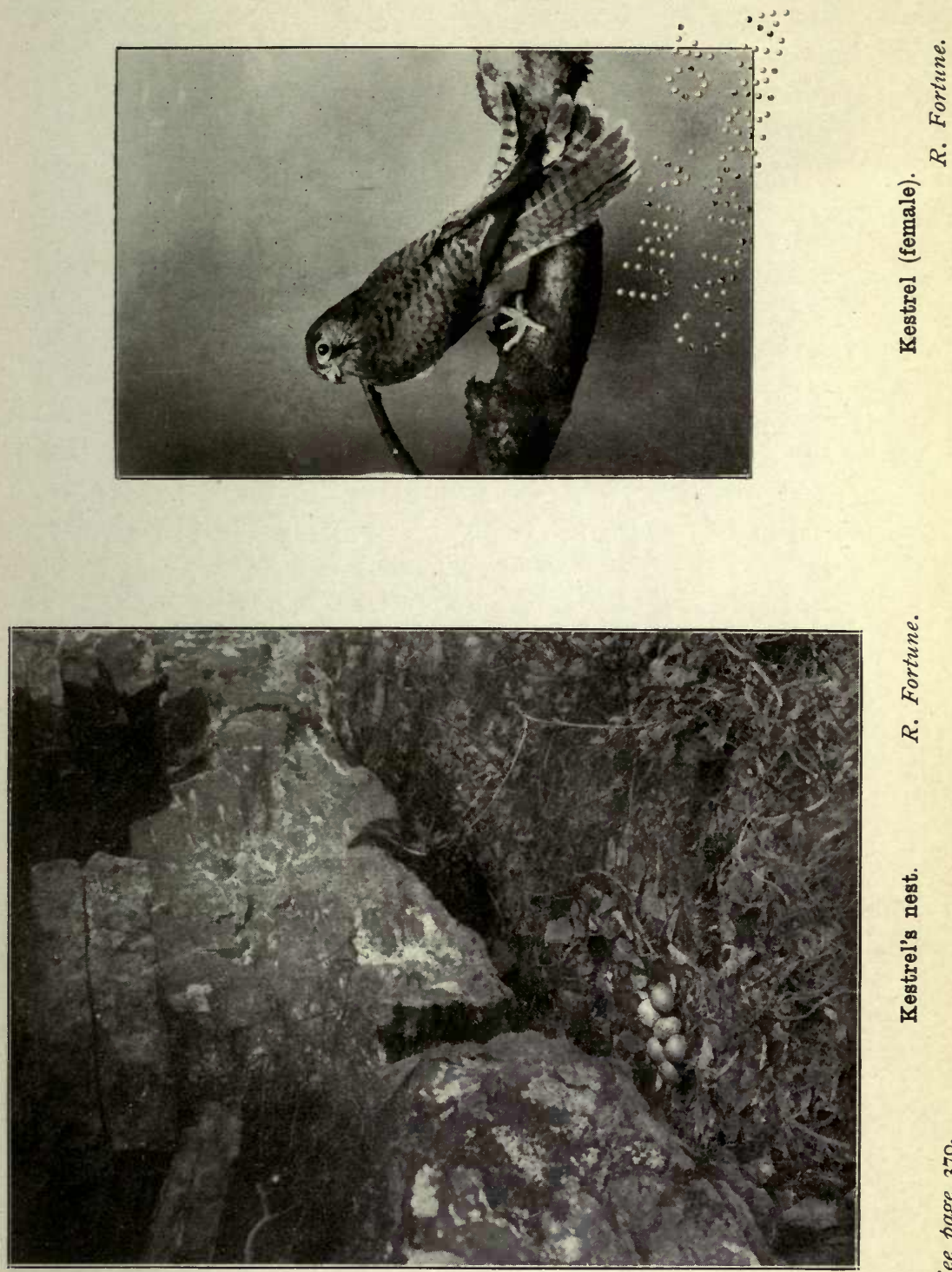

observed to be a resident in the neighbourhood of Barnsley throughout the year. This district may possibly be the northern limit of its winter haunts ; and if this is so, in all probability the Kestrels seen at Barnsley in the winter are not the same birds which spent the summer there, but are new comers from the north, taking the place of the others which have moved further south." As a resident throughout the year the Kestrel is by no means confined to south Yorkshire, as Mr. Harting suggests, but is generally distributed over the county. Mr. Robert Lee of Thirsk and Mr. James Brigham of Slingsby stated (MS.), that in those parts of the North Riding, the Kestrel may be found at all seasons. Further south it occurs commonly around Leeds in the winter. In high and exposed districts, the Kestrel is compelled in hard winters to seek more sheltered quarters, but in milder seasons remains in its old haunts. The evidence given above only tends to prove that the Kestrel is not confined in winter in its distribution, and does not preclude the possibility of such an exchange of birds taking place as Mr. Harting suggests. Indeed, the observations communicated to the British Association Migration Committee indicate that it receives a considerable accession to its numbers in autumn, chiefly during September and October. I have, almost yearly, noticed individuals flying in from the east or north-east, and have occasionally seen them crossing when at sea off the Cleveland coast. In some seasons they are very abundant in the neighbourhood of the Tees and Humber estuaries.

Mr. A. Clapham of Scarborough reported that he had a dwarf specimen of this species obtained on Strensall Common, and that about 1877 he saw a recently-killed male, in a York bird-stuffer's shop, that was almost black.

It is greatly to be lamented that such a useful bird should be subject to the rule of wholesale extermination which is applied to all the Hawks; a gamekeeper, when questioned on this point, quite admitted the harmless character of the bird, but added "it frightens the young Pheasants by its hovering" -a most grievous offence certainly.

Mr. W. Storey of Fewston relates an incident of one of 
these small Hawks pursuing a Pipit which alighted near a horse feeding in a field, when the Hawk immediately perched on the horse's back on the look out for its quarry. Near Masham a Kestrel was seen to capture a Starling.

The local names are :-Windhover in general use; Hover Hawk in the North and West Ridings; Stand Hawk in Cleveland; Standing Hawk at Skelmanthorpe; Steangall in Arkengarthdale and in the West Riding dales ; Jack Hawk, Little Red Hawk, and Yellow-backed Hawk in Arkengarthdale; Red Hawk and Mouse Hawk at Loftus-in-Cleveland and Beverley; and Brown Hawk in the Western Ainsty. Stannel, Stanchel, Stannel Hawk, Fleingall (i.e. Fly-in-gale), Vanner Hawk, and Wind-fanner are all old names mentioned by Swainson.

[An example of the American representative of our species (F. sparverius), now in the York Museum, was formerly in the possession of Mr. J. Backhouse of York, who states that it is one of a pair captured near Helmsley in May I882, and that he is convinced of its authenticity. Opinions differ, however, as to the reliance to be placed on the evidence connected with its occurrence, and I regret my ina ility to include it in the Yorkshire list. (See Zool. I883, p. I26 ; I884, pp. I76, 230 ; Nat. I884, p. I69 ; and Saunders' "Manual," and Ed. p. 356.)]

\section{LESSER KESTREL.}

Falco cenchris (Nauman).

Accidental visitant, from southern Europe, of extremely rare occurrence.

The first British example of this south European species was obtained by the late John Harrison of Wilstrop Hall, near Green Hammerton, who supplied the following particulars of the occurrence:-

About the middle of November 1867 , this bird was observed by him for some days flying about his farm, and, his curiosity 
having been aroused by its diminutive size, he at last shot it. Still thinking it to be only a small and curious variety of the common Kestrel, he took it to D. Graham of York for preservation. Mr. Graham afterwards identified the bird and he persuaded Mr. Harrison to present it to the York Museum, where I have seen it. Mr. W. S. Dallas, F.L.S., at that time curator of the Museum, informed Mr. Harrison that the specimen was a mature, though apparently not an old male, presenting all the distinctive characters of Tinnunculus cenchris, among which the yellowish-white claws were mentioned. Mr. Harrison greatly regretted his inability to supply the exact date, owing to his omission to make a note of it at the time. The bird being undoubtedly a Lesser Kestrel, and thus the authenticity of the occurrence resting on Mr. Harrison's word, it may be considered as quite beyond doubt.

Since the date of the first occurrence five others are placed on record, and a second Yorkshire specimen is reported by Mr. Robert Lee of Thirsk, who writes in the Field (23rd April I892), that, on the I2th of that month, an adult male in good plumage, and without any traces of being in confinement, was brought to him to preserve. The total length was $\mathrm{II}_{\frac{3}{4}}$ inches, expanse of wings 26 inches, and weight $4 \frac{1}{2} \mathrm{oz}$. The specimen is now in the possession of Mr. Foggit of Thirsk.

\section{OSPREY.}

\section{Pandion haliaëtus $(L$.).}

Bird of passage, of very rare occurrence in spring and autumn. Formerly observed regularly on its way to and from its northern breeding haunts.

The earliest reference to the Osprey, in connection with Yorkshire, is a quotation from R. Johnson [of Brignall, near Greta Bridge], who stated that "It preys often upon our rivers." (Willughby's "Ornithology," 1678, p. 2I.) 
Thomas Allis, I844, wrote as follows:-

Pandon haliatus. - Osprey-Numerous specimens have been killed.

In former years the Osprey was not infrequently observed in the spring, while on the passage to its breeding stations in the north, and again in the autumn while returning to its southern winter quarters. During these migrations the size of the bird and the habits peculiarly its own have caused it to be noticed by those not usually interested in ornithology. Latterly it has become much less frequent; this scarcity is in a great measure attributable to the fact that it no longer frequents its former favourite haunts in Scotland, and its association with the name of that country is now confined to perhaps a pair or two, if even that.

The instances of its appearance in this county, however, as chronicled during the past century, or otherwise brought under my notice, number upwards of seventy, and it seems hardly desirable to give the particulars of each case; the majority of these have been in the vicinity of the coast. It may suffice to state that the earliest spring record is 8th April 1883, when one was observed by the late H. B. Hewetson, soaring over the lake at Charles Waterton's residence, Walton Hall; others have been noted at various dates in the spring and summer up to the 28th July, when one was killed at Hebden Bridge in the year I878 (Crabtree, "Halifax Nat." December I900). The earliest record in the autumn is 29th August I899, at Pilmoor Farm, Hunmanby, and the latest at that season occurred at Cherry Burton, near Beverley, on 22nd November 1876 . The most recent occurrence was at Loftus-in-Cleveland, on 29th August I905.

Dr. Farrar (I844), mentioned that a female which occurred on Burnsall Moor, near Bolton Abbey, in April r844, was gorged with the remains of a Red Grouse.

The Osprey is too rare at the present time to be known by any vernacular names, though Swainson mentions Mullet Hawk, Eagle Fisher, and Bald Buzzard as used of old in the north country. 
PRINTED AT BROWNS' SAVILE PRESS, DOCK STREET, HULL 
RETURN TO the circulation desk of any University of California Library

$$
\text { or to the }
$$

NORTHERN REGIONAL LIBRARY FACILITY Bldg. 400, Richmond Field Station University of California

Richmond, CA 94804-4698

ALL BOOKS MAY BE RECALLED AFTER 7 DAYS 2 -month loans may be renewed by calling (510) 642-6753

1-year loans may be recharged by bringing books to NRLF

Renewals and recharges may be made 4 days prior to due date

\section{DUE AS STAMPED BELOW}

\section{A}

RETURNED

JUN $\mathrm{O}_{2} 1995$

Santa Gruz Jitnoy 


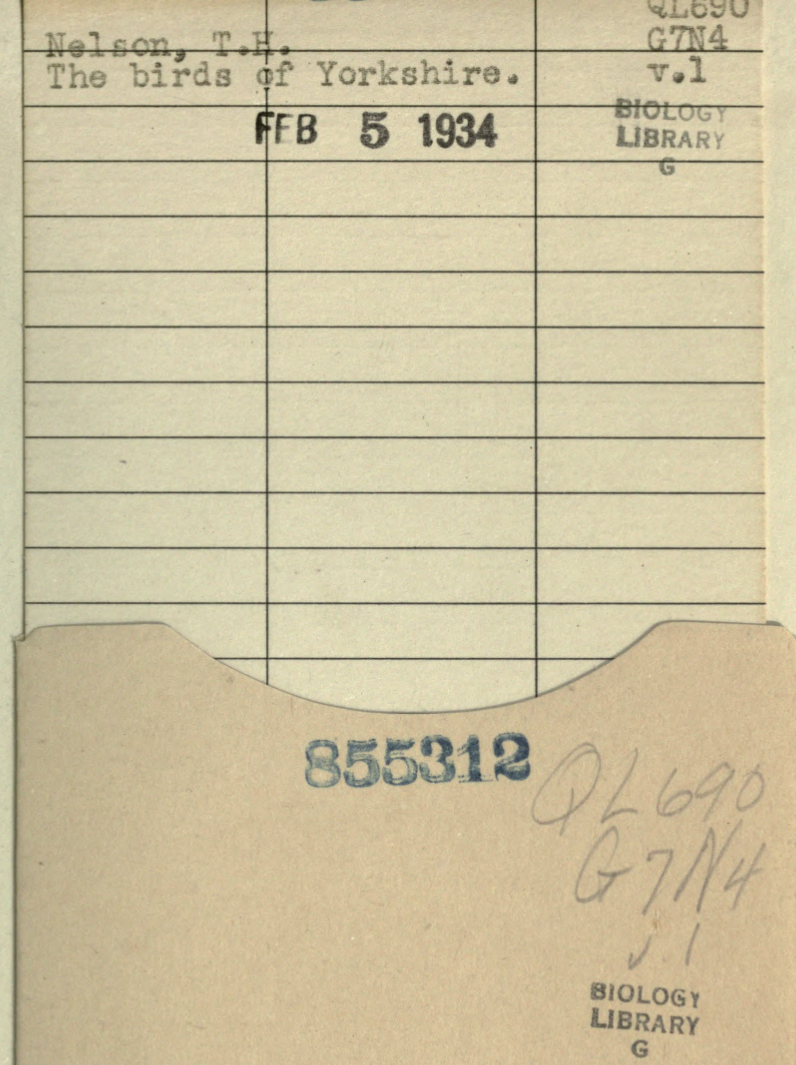

UNIVERSITY OF CALIFORNIA LIBRARY 
